DANIEL PENTEADO DE CASTRO

\title{
CONTRIBUIÇÕES AO ESTUDO DOS PODERES INSTRUTÓRIOS DO JUIZ NO PROCESSO CIVIL: \\ FUNDAMENTOS, INTERPRETAÇÃO E DINÂMICA
}

MESTRADO EM DIREITO

ORIENTADOR: PROFESSOR DOUTOR ANTONIO CARLOS MARCATO

FACULDADE DE DIREITO DA UNIVERSIDADE DE SÃO PAULO SÃO PAULO - 2010 


\section{CONTRIBUIÇÕES AO ESTUDO DOS PODERES INSTRUTÓRIOS DO JUIZ NO PROCESSO CIVIL: FUNDAMENTOS, INTERPRETAÇÃO E DINÂMICA}

Dissertação apresentada à Banca Examinadora da Faculdade de Direito da Universidade de São Paulo, como exigência parcial para obtenção do título de Mestre em Direito, sob a orientação do Professor Doutor Antonio Carlos Marcato. 
BANCA EXAMINADORA

Professor Doutor Antonio Carlos Marcato

Professor Doutor

Professor Doutor

São Paulo, de de 2010 
Aos meus queridos pais, pelo amor, dedicação e educação que pacientemente me foram dados. 


\section{AGRADECIMENTOS}

Mais difícil que elaborar uma dissertação de mestrado é exprimir com poucas palavras uma forma de agradecer a pessoas especiais que de algum modo contribuíram para a redação deste trabalho. Segue uma vã tentativa:

Agradeço ao professor Antonio Carlos Marcato, exemplo de professor para todas as áreas do saber e constante fonte de inspiração, pelo acolhimento, confiança e oportunidade depositadas que tornaram possível a confecção deste estudo. Aos professores Cândido Rangel Dinamarco, Ada Pellegrini Grinover, José Rogério Cruz e Tucci, Kazuo Watanabe, Carlos Alberto Carmona, Paulo Henrique dos Santos Lucon e Carlos Alberto de Salles, cujos preciosos ensinamentos lecionados nas disciplinas da pós-graduação foram fundamentais para o desenvolvimento do tema.

Agradeço também aos professores José Carlos Baptista Puoli e Ricardo de Barros Leonel, pelos sábios e valiosos conselhos tecidos no exame de qualificação. Aos professores Milton Paulo de Carvalho e José Roberto dos Santos Bedaque, pela paciência e receptividade para discutirem o tema e sanarem tormentosas dúvidas. Aos colegas de trabalho e, por todos, ao Doutor Carlos Miguel Castex Aidar, pelo incentivo e constante confiança nos desafios de trabalho que serviram de estímulo para aprofundamento dos estudos.

Devo externar meu agradecimento ao amigo e colega Heitor Vitor Mendonça Sica, pela paciente receptividade em muitas discussões, cujas sugestões foram fundamentais para traçar novos contornos a esta dissertação. Agradeço à colega Maria Carolina Beraldo, pelo companheirismo e compartilhamento das dificuldades enfrentadas.

Por fim, agradeço a todos os colegas da pós-graduação e professores que enriqueceram e estimularam a conclusão do trabalho, cada um na exata medida de suas virtudes, seja através de discussões, seja através de um gesto de incentivo. 


\section{RESUMO}

CASTRO, Daniel Penteado de. Contribuições ao estudo dos poderes instrutórios do juiz no processo civil: fundamentos, interpretação e dinâmica. 2010. 300 p. Dissertação (Mestrado em Direito) - Faculdade de Direito da Universidade de São Paulo, São Paulo, 2010 .

O presente trabalho procura trazer uma contribuição ao estudo dos poderes instrutórios do juiz no processo civil, revisitando as teorias acerca dos institutos fundamentais do processo, enfocando o papel do ativismo judicial na dinâmica da relação jurídica processual e estruturando diretrizes para utilização desses poderes, em consonância com a busca pela efetividade do processo.

A tônica da exposição é demonstrar a tendência cada vez mais acentuada de aumento dos poderes do juiz, como reflexo da influência do publicismo processual que impõe seja a tutela jurisdicional entregue de modo justo e efetivo. Seja no plano da evolução dos direitos constitucionais fundamentais, seja no aspecto do estudo do direito processual como ciência autônoma, atualmente em sua fase instrumentalista, seja ainda na perspectiva das ondas renovatórias traçadas por Mauro Cappelletti, uma das conclusões a que se chega é a convergência pela necessidade de uma justiça efetiva cujas vertentes reclamam o ativismo judicial, a fundamentar os poderes instrutórios do juiz. Sendo o processo uma relação jurídica de direito público, pertence ao Estado-juiz o interesse em conceder a tutela jurisdicional de forma a aplicar a vontade concreta da lei, motivo em que as iniciativas probatórias ganham relevância como técnica destinada a trazer elementos de convicção para alinhar o resultado do processo à aproximação de certeza em decidir.

Diante dessa perspectiva, foram analisadas questões ligadas à prova e à cognição judicial, para ao final estabelecer uma relação entre a necessidade da produção da prova e os fatos que devem ser conhecidos pelo juiz para lhe permitir decidir. A conclusão a que se chega é que a formação do livre convencimento motivado determina o grau de necessidade e relevância para a produção de determinada prova, cabendo ao juiz a direção formal e material do processo, a fim de determinar a produção de provas que lhe permitam decidir o mais próximo possível do escopo jurídico da jurisdição.

Após estudo e tentativa de definir o conceito, dimensão, momento e limites dos poderes instrutórios, restou confrontada a dinâmica das iniciativas probatórias em consonância com as diretrizes previstas nos princípios processuais constitucionais e infraconstitucionais que guardam maior proximidade com esses poderes. Finalmente, foram traçadas contribuições práticas que os impactos das iniciativas probatórias do juiz venham a produzir no sistema, baseadas nas conclusões deste trabalho e mediante análise da jurisprudência.

Palavras-chaves: Ativismo judicial - Poderes instrutórios - Efetividade do processo Iniciativas probatórias 


\section{RIASSUNTO}

CASTRO, Daniel Penteado de. Contributo per lo studio dei potteri istrutori del giudice nel processo civile: fondamenti, interpretazione e dinamica. 2010. 300 p. Tesi (Pos laurea) Faculdade de Direito da Universidade de São Paulo, São Paulo, 2010.

Il presente lavoro cerca di contribuire allo studio dei poteri di indagine del giudice nel processo civile, rivisitando le teorie circa l'istituto, ponendo l'accento sul ruolo del attivismo giudiziario nella dinamica del rapporto giuridico processuale, e strutturando l'uso di questi poteri, in linea con il bisogno do effiettività del processo.

Il testo cerca di dimostrare che la crescente tendenza di aumento dei poteri del giudice riflette l'influenza del pubblicismo procesale, Il quale impone che la tutela giurisdizionale sia consegnata in modo equo ed efficace. Sia sotto Il profilo dello sviluppo dei diritti fondamentali costituzionali, sia come conseguenza della autonomia scientifica del diritto processuale, attualmente nella fase di istrumentalità, sai ancora in vista del programma di acesso alla giustizia disegnato da Mauro Cappelletti, una delle conclusioni del lavoro è la convergenza con la necessità di una giustizia efficace, la quale esige l'attivismo giudiziario. Sicomme Il processo è rapporto giuridico di diritto pubblico, l'interesse del giudice di concedere tutela giuridica, al fine di far rispettare la volontà della legge, le iniziative probatorie del giudice diventano più importante come tecnica destinata a portare elementi di convinzione, avicinando Il risultato del processo e lasicureza decisória del magistrato.

Sotto questa prospettiva, abbiamo analizzato le questioni delle prove e cognizione giuridiale, al fine di elaborare un rapporto tra la necessità di prove e $\mathrm{i}$ fatti che devono essere conosciuti dal giudice per consentire a lui di decidere. La conclusione è che la formazione del libero convincimento motivato determina il grado di bisogno e di rilevanza per la produzione di determinate prove, lasciando al giudice il orientamento formale e materiale del processo per determinare la produzione di elementi di prova per consentirgli di decidere Il più vicino possibile alla meta giuridica della giurisdizione.

A seguito dell'analisi del concetto, della dimensione, del tempo e dei limiti dei potteri istrutorie del giudice, la dinâmica delle iniziative probatorie sono in linea con gli orientamenti definiti in principi processuali costituzionali infracostituzionali che si avicinano de tali poteri. Infine, abbiamo elaborato i contributi concreti che l'impatto delle iniziative probatorie del giudice portano al sistema, basato sui risultati di questo lavoro e attraverso l'esame delle decisioni dei tribunali.

Parole chiavi: Attivismo giudiziario - Potere di indagine - L'efficacia del processo Iniziative della prova. 


\section{SUMÁRIO}

INTRODUÇÃO 11

1 JURISDIÇÃO, PROCESSO, AÇÃO E DEFESA ......................................................... 13

1.1 Breves considerações acerca da evolução histórica da autotutela à jurisdição ... 13

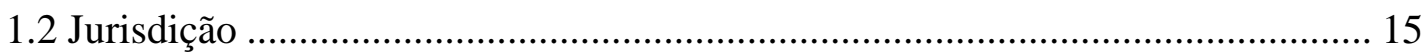

1.2.1 Os escopos sociais, políticos e jurídico da jurisdição ................................ 21



1.4 Notas sobre a evolução da natureza jurídica da ação..................................... 37

1.5 Breves comentários sobre a defesa .................................................................. 44

1.6 Conclusões parciais e projeção dos institutos fundamentais sobre os poderes instrutórios

2 PUBLICISMO PROCESSUAL E PODERES INSTRUTÓRIOS ........................................ 52

2.1 Linhas evolutivas: da fase sincrética à instrumental ....................................... 54

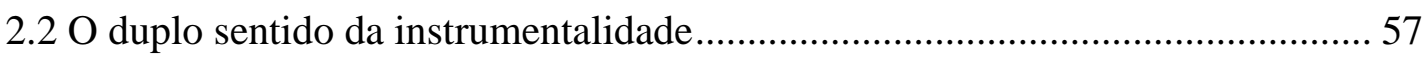

2.3 Da transição do liberalismo individualista para o Estado Social: reflexos



$2.4 \mathrm{O}$ direito processual constitucional e as ondas renovatórias de acesso à justiça 67

2.4.1 Projeção das ondas de acesso à justiça à luz das gerações dos direitos fundamentais constitucionais ................................................................. 70

2.5 Reflexos da tendência publicista sobre os poderes instrutórios .......................... 74

2.6 Conclusões parciais: os poderes instrutórios não beiram o autoritarismo ........... 78



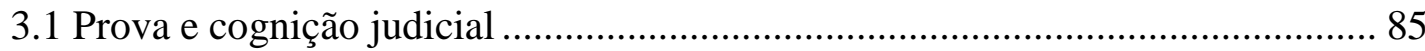

3.1.1 Breves apontamentos sobre a cognição judicial ........................................ 85

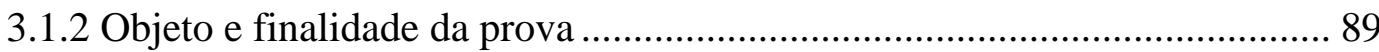

3.1.2.1 Valoração da prova e o mito da verdade absoluta nos autos ................ 93

3.1.2.2 Elementos de prova legal e interpretação sistemática......................... 100

3.1.2.2.1 Técnicas que podem dispensar a produção da prova: sistema de presunções e máximas de experiência 
3.1.3 Relação da prova com a cognição judicial

3.2 Ônus da prova, inversão do ônus da prova e carga dinâmica da prova ............ 116

3.2.1 O ônus da prova (ônus objetivo e ônus subjetivo) .................................... 116

3.2.2 A inversão do ônus da prova.............................................................. 120

3.2.3 A carga dinâmica da prova................................................................... 126

3.2.4 A distribuição do ônus da prova: reflexos nos poderes instrutórios .......... 130

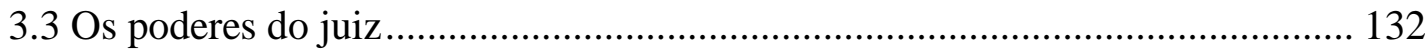

3.3.1 Os poderes instrutórios na classificação dos poderes do juiz: panorama no Código de Processo Civil .................................................... 135

3.3.1.1 Dimensão, conceito e momento das iniciativas probatórias ............... 139

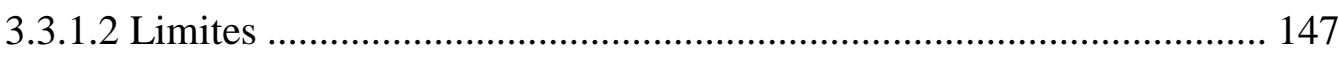

3.3.1.3 Legislação estrangeira: breves comentários ..................................... 152

3.3.1.4 Histórico do sistema brasileiro e da legislação contemporânea.......... 163

\section{CONFRONTO DAS INICIATIVAS PROBATÓRIAS DO JUIZ COM OS PRINCÍPIOS} PROCESSUAIS CONSTITUCIONAIS E INFRACONSTITUCIONAIS

4.1 Princípios constitucionais do processo civil e influência

da constitucionalização no processo .......................................................... 174

4.1.1 Princípio do devido processo legal ......................................................... 176

4.1.2 Princípio do contraditório (princípio da cooperação) e ampla defesa ....... 179



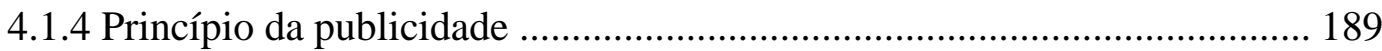

4.1.5 Princípio da motivação das decisões judiciais .......................................... 192

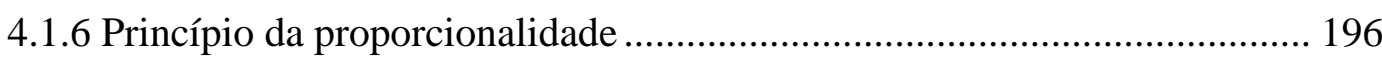

4.1.7 Princípio da vedação das provas ilícitas ou obtidas por meios ilícitos ...... 201

4.1.8 Princípio da duração razoável do processo ............................................... 206

4.2 Iniciativas probatórias do juiz e os princípios infraconstitucionais

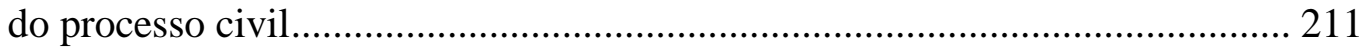



4.2.2 Princípio da disponibilidade e da indisponibilidade ................................ 216

4.2.3 Princípio da persuasão racional do juiz ou livre convencimento motivado227

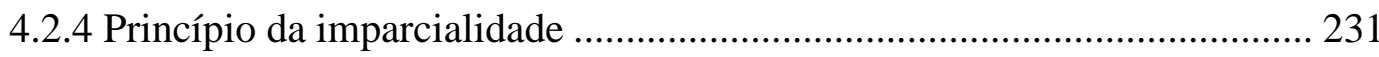


5.1 Julgamento antecipado da lide fundamentado na ausência de provas



5.2 Preclusão da prova - preclusão da parte e preclusão do juízo .......................... 242

5.3 Conversão do julgamento em diligência ........................................................ 245

5.4 Iniciativas probatórias para obtenção do resultado prático equivalente ........... 248

5.5 Aplicação de "medidas de apoio" e revisão da astreinte .................................. 252

5.6 Atualização do valor do bem penhorado e apresentação de novo quantum debeatur

5.7 Determinação da prova a ser produzida pela parte e inversão dinâmica do ônus da prova

5.8 Indisponibilidade das partes em arcar com o custo da produção da prova determinada pelo juiz

5.9 Outros julgados que podem servir de fundamento para o emprego das iniciativas probatórias do juiz 


\section{INTRODUÇÃO}

A preocupação por um processo civil de resultados tem sido objeto de amplos debates na doutrina processual, cuja escola precursora dessa perspectiva metodológica lastreia-se na visão instrumentalista do processo.

Em meio à visão instrumentalista, depreendem-se muitas premissas voltadas à obtenção da tutela jurídica justa, dentre elas uma mudança de paradigmas que imponha uma postura do Estado-juiz mais ativa e coordenadora das atividades exercidas pelas partes dentro do processo.

O aumento dos poderes do juiz é uma tendência que, de um lado, justifica-se (i) como medida destinada a tutelar direitos mediante uma visão pública do processo, com vistas a realizar o direito objetivo (escopo jurídico da jurisdição), para, (ii) uma vez atingido o escopo jurídico, serem atendidos os escopos políticos e sociais voltados à tutela jurídica justa, e, ainda, (iii) a tutela jurisdicional e o instrumento público que é o processo devem guardar estrita observância ao direito processual constitucional.

O desenvolvimento do processo passa a pertencer ao Estado, único titular da função jurisdicional, cujo instrumento destina-se a garantir efetividade e assegurar uma decisão équa. De igual sorte, ganha importância a atividade cognitiva exercida pelo magistrado, a reclamar postura mais ativa, mediante exercício dos poderes instrutórios voltados a propiciar uma decisão que seja justa e guarde fidelidade mais próxima com a realização concreta da lei.

O estudo dos poderes instrutórios tem sido objeto de acentuada polêmica e controvérsia difundida pela doutrina, ${ }^{1}$ embora já se encontre superada a aceitação da utilização desses poderes. ${ }^{2}$ Portanto, este estudo pretende trazer contribuições ligadas à dinâmica dos poderes instrutórios e compatibilizar sua utilização diante das regras e princípios sedimentados no sistema.

\footnotetext{
${ }^{1}$ A constatação é de José Luis Vázquez Sotelo (Iniciativas probatorias del juez en el proceso civil. Revista de Processo, São Paulo, Revista dos Tribunais, ano 34, n. 177, p. 94-152, nov. 2009).

2 BEDAQUE, José Roberto dos Santos. Poderes instrutórios do juiz. 4. ed. São Paulo: Revista dos Tribunais, 2009. p. 11.
} 
Para tanto, será realizada breve análise acerca dos institutos fundamentais do processo, partindo da evolução acadêmica e doutrinária, até as concepções atuais, para, ao final, se definir um conceito de cada instituto que caminhe em consonância com os fundamentos do modo de ser da função exercida pelo Estado-juiz, a acomodar-se com o exercício dos poderes instrutórios.

A seguir, serão examinadas premissas que se alinham à vertente publicista do processo, partindo-se das linhas evolutivas do estudo do processo como ciência (da fase sincrética à instrumental) e sua relação com a necessidade de interferência do próprio Estado na autonomia da vontade e evolução dos direitos fundamentais. Buscar-se-á estabelecer uma relação entre tais premissas e a perspectiva publicista, para ao final se atingir um terreno seguro e sólido que justifique a postura mais ativa do juiz na condução do processo.

Em seguida, será apresentada uma tentativa de definição de conceito, limites, dimensão e momento dos poderes instrutórios, cuja fixação impõe o confronto com os princípios processuais (gerais e constitucionais) existentes. Serão apontadas, ainda, contribuições da legislação estrangeira, seguidas de pesquisa histórica no ordenamento brasileiro.

Estabelecidas essas premissas, restará o confronto das iniciativas probatórias do juiz com os princípios existentes, de modo a se provar que elas, observadas as garantias constitucionais, em nada violam os princípios presentes no sistema.

Por fim, serão objeto de análise algumas situações práticas em que a definição do correto uso dos poderes instrutórios poderá, em dadas situações no processo, proporcionar uma atuação do Estado-juiz com equidade e efetividade, sem que esbarre ou viole garantias constitucionais e processuais. 


\section{JURISDIÇÃO, PROCESSO, AÇÃO E DEFESA}

\subsection{Breves considerações acerca da evolução histórica da autotutela à jurisdição}

Ubi jus ibi societas. Desde os primórdios, o homem habituou-se a viver em sociedade. E a vida cotidiana ganhou contornos de organização, mediante a observância de regras, preceitos e princípios a serem seguidos pelos integrantes da sociedade. ${ }^{3}$

Surgia assim uma ordem jurídica capaz de exercer função coordenadora dos interesses que se manifestassem na vida social, de modo a organizar a cooperação entre pessoas e compor os conflitos que se verificassem entre os seus membros. ${ }^{4}$

Isso não significa que os meios de solução de conflitos empregados nas fases primitivas da civilização dos povos fossem capazes de integrar uma ordem jurídica alicerçada na sujeição dos cidadãos ao Estado-juiz, conquanto, inicialmente, a resolução de conflitos se fazia através da autotutela, de modo a prevalecer a vitória do mais forte, mais astuto ou mais ágil sobre o mais fraco, caracterizada, portanto, pela ausência de juiz distinto das partes, bem como pela imposição de solução por uma parte à outra.

Paralelamente, surgiu o mecanismo da autocomposição, voltado à disposição de direitos pelas partes: a) desistência (renúncia à pretensão); b) submissão (renúncia à resistência oferecida à pretensão e c) transação (concessões recíprocas) ${ }^{5}$; na autocomposição, inexistia mecanismo apto a coagir uma das partes a cumprir o ato de disponibilidade previamente estabelecido.

\footnotetext{
${ }^{3}$ Nesse contexto, bem assevera André Franco Montoro que "não se pode conceber uma sociedade humana em que não haja ordem jurídica, mesmo em se tratando de um estado rudimentar. Isto se exprime em latim pelo adágio conhecido ubi societates, ibi jus (onde há sociedade, há direito)" (Introdução à ciência do direito. 24. ed. São Paulo: Revista dos Tribunais, 1997. p. 54).

${ }^{4}$ Nesse sentido: CINTRA, Antonio Carlos de Araújo; GRINOVER, Ada Pellegrini; DINAMARCO, Cândido Rangel. Teoria geral do processo. 24. ed. São Paulo: Malheiros, 2008. p. 25.

${ }^{5}$ Ibidem, p. 27.
} 
No entanto, a despeito da autocomposição constituir um meio de resolução de conflitos menos arbitrário que a imposição à força da autotutela, carecia da existência de um órgão destinado a imprimir força coercitiva, certeza e segurança ao ato de disponibilidade da parte. Logo, o cumprimento da autocomposição conduzia à imposição de solução violenta e parcial, nisso se assemelhando à autotutela.

Diante das falhas e incertezas trazidas por esses mecanismos de resolução de conflitos, surgiu a necessidade de afirmação do Estado como ente destinatário à pacificação social. Nessa fase precedente à jurisdição, houve três etapas distintas, a saber: a autotutela e a autocomposição, a arbitragem facultativa e a arbitragem obrigatória. ${ }^{6}$

A figura do legislador, imprimindo regras dotadas de critério objetivo e vinculativo, distintas do temor de julgamentos arbitrários e subjetivos, teve esteio na Lei das XII Tábuas (450 a.C.). Após o período arcaico e o clássico, iniciou-se no século III d.C. uma nova fase, conhecida por período da cognitio extra ordinem. Nos dizeres de Antonio Carlos de Araújo Cintra, Ada Pellegrini Grinover e Cândido Rangel Dinamarco:

"Com ela completou-se o ciclo histórico da evolução da chamada 'justiça privada' para a justiça pública: o Estado, já suficientemente fortalecido, impõe-se sobre os particulares e, prescindindo da voluntária submissão

\footnotetext{
${ }^{6}$ Cintra, Grinover e Dinamarco informam que antes da jurisdição houve três fases, a autotutela e a autocomposição, a arbitragem facultativa e a arbitragem obrigatória. Diante das deficiências apresentadas pela autotutela e a autocomposição, surgiu a figura do árbitro (sacerdotes, guiados por soluções ligadas à vontade de divindades, ou anciãos, experientes no conhecimento dos costumes do grupo social) como figura imparcial para a solução de conflitos. Gradativamente, o Estado foi se afirmando para se impor diante dos particulares, ao ditar a solução de conflitos: "A história nos mostra que, no direito romano arcaico (das origens do direito romano até o século II a.C., sendo dessa época a Lei das XII Tábuas), já o Estado participava, na medida da autoridade então conseguida perante os indivíduos, dessas atividades destinadas a indicar qual o preceito a preponderar no caso concreto de um conflito de interesses. Os cidadãos em conflito compareciam perante o pretor, comprometendo-se a aceitar o que viesse a ser decidido; e esse compromisso, necessário porque a mentalidade da época repudiava ainda qualquer ingerência do Estado (ou de quem quer que fosse) nos negócios de alguém contra a vontade do interessado recebia o nome de litiscontestatio. Em seguida, escolhiam um árbitro de sua confiança, o qual recebia do pretor o encargo de decidir a causa. O processo civil romano desenvolvia-se, assim, em dois estágios: perante o magistrado, ou pretor (in jure), e perante o árbitro, ou judex (apud judicem). Como se vê, já nesse período o Estado tinha alguma participação, pequena embora, na solução dos litígios; o sistema perdurou ainda durante todo o período clássico do direito romano (período formular, século II a.C. a século II d.C.), sendo que, correspondentemente ao fortalecimento do Estado, aumentou a participação através da conquista do poder de nomear o árbitro (o qual era de início nomeado pelas partes e apenas investido pelo magistrado). Vedada que era a autotutela, o sistema então implantado consistia numa arbitragem obrigatória, que substitui a anterior arbitragem facultativa. Além disso, para facilitar a sujeição das partes à decisões de terceiro, a autoridade pública começa a preestabelecer, em forma abstrata, regras destinadas a servir de critério objetivo e vinculativo para tais decisões, afastando assim os temores de julgamentos arbitrários e subjetivos. Surge, então, o legislador (a Lei das XII Tábuas, do ano 450 a.C. é um marco histórico fundamental dessa época).” (Teoria geral do processo, cit., p. 27-28).
} 
destes, impõe-lhes autoritativamente a sua solução para os conflitos de interesses. À atividade mediante a qual os juízes estatais examinam as pretensões e resolvem os conflitos dá-se o nome de "jurisdição"”.

Nesse contexto, a ciência processual foi construída sobre quatro pilares, que constituem os institutos fundamentais do direito processual: jurisdição, ação, defesa e processo. ${ }^{8}$ Esses institutos são unidades sistemáticas do direito processual, ${ }^{9}$ cuja análise guarda relevância, como ponto de partida apto a desenvolver qualquer tema ligado à ciência processual. Afinal, a revisitação desses institutos fundamentais e dos princípios processuais ${ }^{10}$ se destina a dar uma feição mais adaptada e harmoniosa à exigências da vida moderna. ${ }^{11}$

Serão, portanto, objeto de breve análise os institutos fundamentais do processo civil, na tentativa de pontuar seus reflexos diante da atividade do juiz como agente do Estado e traçar suas respectivas projeções no plano dos poderes instrutórios. ${ }^{12}$

\subsection{Jurisdição}

O conceito de jurisdição foi objeto de amplo debate, travado inicialmente pela doutrina italiana, mas que preocupou também os processualistas pátrios. Neste item serão

\footnotetext{
${ }^{7}$ CINTRA, Antonio Carlos de Araújo; GRINOVER, Ada Pellegrini; DINAMARCO, Cândido Rangel, Teoria geral do processo, cit., p. 29.

8 BEDAQUE, José Roberto dos Santos, Poderes instrutórios do juiz, cit., p. 26; e Direito e processo: influência do direito material sobre o processo. 4. ed. São Paulo: Malheiros, 2006, p. 32. Cândido Rangel Dinamarco equipara a ação, defesa, processo e jurisdição como institutos fundamentais da ciência do direito processual civil (núcleo central), assim como as normas e o conhecimento do direito civil giram em torno de certas categorias centrais (pessoas, bens, atos jurídicos). (Instituições de direito processual civil. 6. ed. São Paulo: Malheiros, 2009. v. 1, p. 302).

9 DINAMARCO, Cândido Rangel. Fundamentos do processo civil moderno. 5. ed. São Paulo: Malheiros, 2002. v. 1, p. 111. Ao tratar do tema "institutos fundamentais do direito processual”, Dinamarco assevera que uma visão teleológica unitária do sistema processual jamais será possível sem o exame conjunto da jurisdição, ação, defesa e processo, institutos que revelam as linhas convergentes de atuação dos princípios do direito processual e pelos quais adquirem sentido as regras fundamentais impostas pela Constituição ao sistema de administração da justiça (Ibidem, p. 114-115). O autor ainda afirma que "tudo que as normas processuais disciplinam enquadra-se em algum desses quatro setores do direito processual ou cumulativamente em mais de um deles. Nada, no direito processual ou em sua ciência, está fora desses setores" (Instituições de direito processual civil, cit., v. 1, p. 303).

${ }^{10}$ Vide Capítulo 4.

${ }^{11}$ É o que sustenta João Batista Lopes, ao definir como aggiornamento a tentativa de atualização com vistas a se atingir um modelo de processo mais moderno e ajustado aos anseios e reclamos da sociedade (Tutela antecipada no processo civil brasileiro. São Paulo: Saraiva, 2001. p. 14-15).

${ }^{12}$ A análise mais detida dos poderes instrutórios será realizada no Capítulo 3. Para a finalidade específica deste capítulo e do Capítulo 2, a menção aos poderes instrutórios está mais ligada ao aspecto do ativismo judicial em relação às iniciativas probatórias do juiz.
} 
apontados brevemente os conceitos de jurisdição difundidos pela doutrina, cuja definição guarda ligação com os escopos da jurisdição, ${ }^{13}$ assunto que será tratado no item seguinte. Inicialmente, a definição dualista de Giuseppe Chiovenda para jurisdição é: “(...) função do Estado que tem por escopo a atuação da vontade concreta da lei por meio da substituição, pela atividade de órgãos públicos, da atividade de particulares ou de outros órgãos públicos, já no afirmar a existência da vontade da lei, já no torná-la praticamente eficaz."14

Por sua vez, Ugo Rocco tratou de sintetizar o conceito de jurisdição, ${ }^{15}$ de modo a preponderar a uniformidade das ideias difundidas na doutrina italiana, verbis:

"Una seconda opinione sostiene che la giurisdizione è l'attività dello
Stato diretta all'attuazione del diritto obiettivo, mediante l'aplicazione
della norma generale al caso concreto e mediante la realizazione forzata
della norma generale stessa. (...) (Wach, Schmidt, Langheineken,
Chiovenda, Betti, Raselli, ecc.).".

A concepção supra de Chiovenda serviu para afastar a visão eminentemente privatista que adotava o conceito imanentista do direito de ação, ainda vinculado ao direito subjetivo, assunto que será melhor debatido adiante, no item 1.4. Em contrapartida, Carnelutti definiu a jurisdição como a "justa composição da lide"17. Para esse jurista italiano, a jurisdição pressupõe um conflito de interesses qualificado pela pretensão de alguém e a resistência de outrem. Esse conflito de interesses conceitua o que pode ser entendido por lide, e que sem lide não há atividade jurisdicional. Logo, a jurisdição é criada e organizada pelo Estado com a finalidade da justa composição dos conflitos.

\footnotetext{
${ }^{13}$ A preponderância de um dos escopos da jurisdição dentre os existentes (jurídico, social e político) se faz necessária para justificar a adoção de um dos conceitos de jurisdição como premissa deste estudo.

${ }^{14}$ CHIOVENDA, Giuseppe. Istituizione di diritto processuale civile. 2. ed. Napoli: Jovene, 1935. v. 2, p. 11.

${ }^{15}$ Cintra, Grinover e Dinamarco informam que no direito romano, a jurisdição (juris dictio) não abrangia o poder do juiz in executivis, restando na execução forçada o exercício de outro poder (imperium) alheio à jurisdição. Semelhante segregação também se verificou nos direitos intermédios francês, italiano e alemão (jurisdictio in sola natione consistit), ao passo que no direito ibérico, e posteriormente mediante evolução doutrinária nos demais países, restou pacificado que a execução é autêntica atividade jurisdicional (Teoria geral do processo, cit., p. 156). Leciona Sergio Bermudes que a etimologia da palavra jurisdictio já revela a essência da jurisdição, ou seja, "dizer o direito, no sentido de identificar a norma de direito objetivo preexistente (ou de elaborá-la), se inexistente) e de fazê-la atuar numa determinada situação" (Introdução ao processo civil. 2. ed. Rio de Janeiro: Forense, 1996. p. 17).

${ }^{16}$ ROCCO, Ugo. Trattato di diritto processuale civile. Torino: UTET, 1957. v. 1, p. 51-52.

17 CARNELUTTI, Francesco. Derecho y proceso. Traducción de Santiago Sentis Melendo. Buenos Aires: EJEA, 1971. p. 22-23.
} 
Enrico Tullio Liebman, para chegar a uma definição própria, analisou o conceito dualista de Chiovenda e o contrapôs ao esposado por Carnelutti, ${ }^{18}$ resultado de uma análise sociológica ao invés de jurídica, para, ao final, ministrar sua lição, também demonstrando sua preferência pela teoria unitária: "De nossa parte, resumindo, podemos considerar a jurisdição como a atividade dos órgãos do Estado destinada a formular e atuar praticamente a regra jurídica concreta que, segundo o direito vigente, disciplina determinada situação jurídica." 19

Na doutrina brasileira, Celso Neves utilizou a lição de Ugo Rocco para, depois, expor conceito próprio que atribuiu à jurisdição, mencionando sua preferência, com ressalvas, pelo ensinamento de Chiovenda:

\begin{abstract}
"A jurisdição pode ser considerada, como poder, no plano da soberania estatal, como função, nos lindes das atribuições que caracterizam o sistema orgânico do Estado; como atividade, no âmbito do processo. Poderíamos, pois, quanto à nossa disciplina, e no plano intermédio que explica os demais, entender por jurisdição civil a função estatal de caráter substitutivo do juízo e da vontade das partes, teleologicamente concebida para a realização imediata do direito objetivo não penal e consequente solução da lide civil que a ela corresponda, bem como a atuação da sanção que lhe seja própria, pela realização prática do comando emergente da decisão do órgão jurisdicional que a exaure, in casu. ${ }^{20}$
\end{abstract}

Sem buscar a função da jurisdição para defini-la, alguns autores colocam seu atributo de definitividade como elemento preponderante. $\mathrm{Na}$ Itália, Allorio $^{21}$ tem essa

\footnotetext{
18 "Muitas são as definições que têm sido dadas à jurisdição, mas lembremos apenas duas delas, as mais importantes, que constituíram o tecido dialético do debate científico na Itália por muitas décadas. A primeira delas define a jurisdição como a atuação da vontade concreta da lei mediante substituição da atividade alheia pelos órgãos públicos, seja afirmando a existência da vontade da lei, seja tornando-a efetiva na prática (Chiovenda). Nessa definição está esculpida a relação entre a lei e a jurisdição; e, com a ideia da substituição, torna-se evidente o fato de que o juiz é chamado a manifestar-se quando houver faltado da parte a observância do que a lei dispõe. Já a segunda prefere ver na jurisdição a justa composição das lides (Carnelutti), entendendo por lide qualquer conflito de interesses regulado por direito e por justa a composição feita nos termos deste. Essa definição considera a atuação do direito como meio para atingir o escopo final da composição do conflito de interesses, procurando assim captar a matéria a que a lei á aplicável e o resultado prático, do ponto de vista sociológico, a que a operação conduz." (LIEBMAN, Tullio Enrico. Manual de direito processual civil. 3. ed. Tradução e notas de Cândido Rangel Dinamarco. São Paulo: Método, 2005. v. 1, p. 22-23).

${ }^{19}$ LIEBMAN, Tullio Enrico, Manual de direito processual civil, cit., v. 1, p. 23.

${ }^{20}$ NEVES, Celso. Estrutura fundamental do processo civil. 2. ed., 2. tir. Rio de Janeiro: Forense, 1997. p. 28.

${ }^{21}$ ALlORIO, Enrico. Comentario del Codice di Procedura Civile: art. 1-68. Torino: Torinese, 1973. p. 4 e ss.
} 
visão, compartilhada por Eduardo Juan Couture. ${ }^{22}$ Para eles, caracteriza-se a atividade jurisdicional não por seu objetivo, mas por um de seus atributos, a coisa julgada.

Não que os demais autores não concordem que a coisa julgada é exclusividade da jurisdição, mas que se trata apenas de uma importante característica, não se prestando a defini-la. Nesse sentido Luigi Paolo Comoglio, Corrado Ferri e Michele Taruffo ${ }^{23}$ na Itália e Celso Neves, ${ }^{24}$ Cândido Rangel Dinamarco ${ }^{25}$ e Botelho de Mesquita ${ }^{26}$ no Brasil.

Dinamarco considera tal análise como puramente introspectiva, ${ }^{27}$ pois se a finalidade do processo fosse a produção da coisa julgada, estar-se-ia tratando o processo como um fim em si mesmo, o que deve ser evitado, por força de sua função instrumental.

No Brasil, não há uniformidade de opinião entre os doutrinadores sobre os conceitos de jurisdição adotados, mas percebe-se uma forte influência da doutrina italiana de Chiovenda, sem ignorar a enorme contribuição de Carnelutti para o estudo do instituto. Como exemplo, o magistério de Cintra, Grinover e Dinamarco, ${ }^{28}$ que tem grande aceitação

${ }^{22}$ Nesse sentido, Eduardo Juan Couture bem assevera que a imutabilidade e coercitividade são características da jurisdição, cujo atributo específico advém da coisa julgada (Fundamentos del derecho procesal civil. 2. ed. Buenos Aires: Depalma, 1951. p. 92-93).

23 "Definire una volta per sempre ogni possibiltà di contestazione costituisce senza dubbio un fine proprio dell'ordinamento e, d'altra parte, se si ammettono possibilità, anche se limitate, di riesame della controversia in un nuovo processo, e quindi in un diverso 'grado' di giurisdizione, si differisce inevitabilmente l'esito finale e definitivo della controversia. (...) L'attitività giurisdizionale di cognizione è caratterizzata quindi dal fatto che gli effetti prodotti dal provvedimento del giudice sono destinati ad assumere, in un certo tempo ben definito, ossia quando il processo sia concluso, una particolare qualità consistente nella loro assoluta immutabilità in futuro. Le parti non potranno più tornare a discutere delle questioni controverse e sono tenute ad osservare le statuizioni contenute nel provvedimento." COMOGLIO, Luigi Paulo; FERRI, Corrado; TARUFFO, Michele. Lezioni sul processo civile. 2. ed. Bologna: Il Mulino, 1998. p. 98-99).

${ }^{24}$ NEVES, Celso, Estrutura fundamental do processo civil, cit., p. 27.

${ }^{25}$ Para Cândido Rangel Dinamarco, a jurisdição é a única função do Estado dotada de definitividade, caracterizada pela imunização dos efeitos dos atos realizados (Instituições de direito processual civil, cit., v. 1, p. 319-320).

${ }^{26}$ José Ignácio Botelho de Mesquita sustenta que a imutabilidade deflui da própria ideia de processo, ligada ao seu fim último relativo à paz social e à certeza nas relações jurídicas. Para se atingir esse escopo, necessário estabelecer-se um limite à renovação dos litígios, o que se materializa mediante a imutabilidade da sentença (Coisa julgada. Rio de Janeiro: Forense, 2004. p. 118).

${ }^{27}$ DINAMARCO, Cândido Rangel. A instrumentalidade do processo. 13. ed. São Paulo: Malheiros, 2008. p. 212.

${ }^{28}$ Para Cintra, Grinover e Dinamarco, o que distingue a jurisdição das demais funções do Estado, num primeiro plano é a finalidade pacificadora com que o Estado a exerce. Aliada a essa diferença, acresça-se a capacidade do Estado de decidir imperativamente e impor decisões (Teoria geral do processo, cit., p. 30). Dinamarco, em opinião posterior, assim se expressou: "Conceitua-se a jurisdição através dessas duas premissas, como função do Estado, destinada à solução imperativa de conflitos e exercida mediante a atuação da vontade do direito em casos concretos." (Instituições de direito processual civil, cit., v. 1, p. 315). 
no meio acadêmico, sendo também de extrema relevância as opiniões de Botelho de Mesquita, ${ }^{29}$ Athos Gusmão Carneiro $^{30}$ e a peculiar visão de Celso Neves retrocitada.

Optamos por acolher o conceito mais amplo de jurisdição sustentado por Grinover, Cintra e Dinamarco, consistente na capacidade do Estado de dirimir os $\operatorname{conflitos}^{31}$ que envolvem as pessoas, decidindo sobre as pretensões apresentadas e impondo decisões. Trata-se de uma das funções do Estado, ${ }^{32}$ mediante a qual ele substitui os titulares dos interesses em conflito para, imparcialmente, buscar a pacificação do conflito que os envolve, com justiça. ${ }^{33}$

Esse conceito de jurisdição apresenta feição ampla dentro da teoria geral do processo, de sorte a afastar situações cuja natureza impõe uma jurisdição diferenciada, como a exercida no controle concentrado de constitucionalidade, por seus mais variados instrumentos - a ação declaratória de constitucionalidade, a ação direta de constitucionalidade, a ação direta interventiva e a ação de descumprimento de preceito fundamental. Nesses tipos de ação, não há um conflito de interesses, de modo a se formar

29 “Chama-se jurisdição esta atividade produtora de efeitos de fato e de direito, que o Estado exerce em favor dos destinatários da norma, em cumprimento a um dever para com eles, nascido do impedimento legal, em que se encontram, de produzir os mesmos efeitos por seus próprios meios." (MESQUITA, José Ignácio Botelho de. Da ação civil. In: Teses estudos e pareceres de processo civil. São Paulo: Revista dos Tribunais, 2005. v. 1, p. 99).

${ }^{30}$ Para Athos Gusmão Carneiro, ao direito subjetivo de ação corresponde a atividade estatal da jurisdição em que, mediante o exercício do devido processo legal, o Estado administra a justiça aos que a solicitaram. Assim: "A jurisdição é, com a administração e a legislação, forma de exercício da soberania estatal. (...) No conceituar de jurisdição, quero ater-me ao ensinamento do mestre Galeno Lacerda: É a atividade pela qual o Estado, com eficácia vinculativa plena, elimina a lide, declarando e/ou realizando o direito em concreto." (Jurisdição e competência. 8. ed. São Paulo: Saraiva, 1997. p. 34).

31 Vale lembrar que nas ações de jurisdição voluntária, inexiste conflito de interesses, mas sim a administração pública de interesses privados. Nesse contexto, a jurisdição voluntária não se encaixaria no conceito defendido por Eduardo Couture, em que na jurisdição é necessária a existência de coisa julgada, porquanto o art. 1.111 do Código de Processo Civil é claro em possibilitar a relativização da coisa julgada nos procedimentos de jurisdição voluntária previstos no Título I do Livro IV. Semelhante dificuldade em sistematizar um conceito abrangente de jurisdição é demonstrada por Liebman, ao analisar o conceito definido por Chiovenda (atuação da vontade da lei por parte dos órgãos públicos encarregados do seu exercício) e Carnelutti (a justa composição das lides). Embora complementares, e não antagônicas, Liebman esclarece que "Deve observar-se, por outra parte, que a definição de Carnelutti, aceitável para a jurisdição civil e para a administrativa, é o menos para o que concerne à jurisdição penal.” (Manual de direito processual civil, cit., v. 1, p. 5-6).

${ }^{32}$ Ao discorrer sobre o processo e o conceito de jurisdição, José Roberto dos Santos Bedaque bem assevera que "sendo autônomo, este tem fins distintos de seu conteúdo; fins esses que se confundem com os objetivos do próprio Estado, na medida em que a jurisdição é uma das funções com que ele procura cumprir seu papel, qual seja, o de assegurar o bem-estar da sociedade" (Poderes instrutórios do juiz, cit., p. 11).

${ }^{33}$ CINTRA, Antonio Carlos de Araújo; GRINOVER, Ada Pellegrini; DINAMARCO, Cândido Rangel, Teoria geral do processo, cit., p. 147. 
um processo de índole objetiva. Até o instituto da coisa julgada, nessa jurisdição constitucional, resta relativizado. ${ }^{34}$

De igual modo, também não se adequaria a concepção de Eduardo Couture, que acresceu que o exercício da jurisdição resulta em decisão suscetível de produzir coisa julgada e ter-se-á posta a ideia clássica em torno da função jurisdicional: "La cosa juzgada es, en este orden de elementos, la piedra de toque del acto jurisdicional. ${ }^{, 35}$

Por sua vez, a jurisdição revela três funções distintas, definidas por Celso Neves como "poder, no plano da soberania estatal; como função, nos lindes das atribuições que caracterizam o sistema orgânico do Estado; como atividade, no âmbito do processo". 36

E sob a égide dessas funções da jurisdição é que o Estado impõe suas decisões voltadas a trazer a pacificação de conflitos intersubjetivos, mediante a atuação do juiz. Portanto, o Estado atrai para si a atividade de pacificar conflitos trazidos à sua apreciação, ${ }^{37}$ corporificada na atuação de um juiz imparcial ao interesse das partes, e assim realizar as normas de direito substancial (direito objetivo). Na medida que na jurisdição o Estado substitui os titulares dos interesses em conflito para imparcialmente buscar a pacificação do conflito que os envolve com justiça, os poderes instrutórios exercidos pelo juiz guardam ampla ligação com o instituto fundamental da jurisdição, em sua concepção acima definida, ou seja, para tentar pacificar conflitos com justiça, necessária a participação ativa do magistrado, o que se reflete nas iniciativas probatórias, como forma de exercício dos poderes instrutórios. ${ }^{38}$

\footnotetext{
${ }^{34}$ Nesse sentido, Gilmar Ferreira Mendes, Inocêncio Mártires Coelho e Paulo Gustavo Gomes Branco sustentam a possibilidade de suscitar, perante o Supremo Tribunal Federal, "a inconstitucionalidade de norma já declarada constitucional, em ação direta ou em ação declaratória de constitucionalidade", em razão de "mudança nas circunstâncias fáticas ou de relevante alteração das concepções jurídicas dominantes" (Curso de direito constitucional. São Paulo: Saraiva, 2007. p. 1.215).

${ }^{35}$ COUTURE, Eduardo Juan, Fundamentos del derecho procesal civil, cit., p. 43.

${ }^{36}$ NEVES, Celso, Estrutura fundamental do processo civil, cit., p. 28. Semelhante sentido é lecionado por Cintra, Grinover e Dinamarco, ao conceituarem o poder como a capacidade de decidir imperativamente e impor decisões; a função, consistente no encargo que têm os órgãos estatais de promover a pacificação de conflitos mediante realização do direito justo e através do processo; e, por fim, a atividade ligada ao complexo dos atos do juiz no processo ao exercer o poder e cumprir a função que lhe compete (Teoria geral do processo, cit., p. 147).

${ }^{37}$ Existem algumas exceções de proibição à autotutela previstas no sistema como a exercida no direito de retenção (arts. 578, 664, 1.219, 1.433, II e 1.434 do CC), o desforço imediato (art. 1.210 , $\S 1^{\circ}$ do CC), o direito de cortar raízes e ramos de árvores limítrofes que ultrapassem a extrema do prédio (art. 1.283 do CC) e, de modo geral, a autoexecutoriedade administrativa, além das excludentes de ilicitude (legítima defesa ou estado de necessidade: arts. 24, 25 do CP e 188, 929 e 930 do CC).

${ }^{38}$ Voltaremos a tratar do tema com mais profundidade no Capítulo 3.
} 
Por outro lado, a atuação da jurisdição não se limita às funções acima citadas, de modo que ganhou espaço na doutrina moderna a maior preocupação com os escopos da jurisdição. A fim de trabalhar a premissa central deste estudo, voltada aos poderes instrutórios do juiz, necessária se faz a análise dos escopos da jurisdição.

\subsubsection{Os escopos sociais, políticos e jurídico da jurisdição}

A jurisdição reflete a realização dos fins do próprio Estado e, em face das cambiantes diretrizes políticas que a história exibe, os objetivos que a animam são também sujeitos a essas mesmas variações, no espaço e no tempo. ${ }^{39}$

A atividade do juiz como agente estatal revela os escopos da jurisdição, cuja atuação se materializa através do processo como instrumento. E, para que o instrumento produza resultados efetivos e traga a paz social, necessário, portanto, conhecer o contexto em que está inserido diante da atividade da jurisdição. Vale dizer, a observância dos escopos da jurisdição traçam diretrizes com vistas a se obter a pacificação social mediante atuação do Estado-juiz. ${ }^{40}$

Nesse contexto, serão analisados os escopos sociais, políticos e jurídico, através de breves definições, a fim de concluir-se a respectiva utilidade, sob a ótica dos poderes instrutórios do juiz.

Os escopos sociais depreendem a ideia de pacificação social. Sob essa premissa, a jurisdição deve proporcionar o resultado do processo que seja adequedo a uma finalidade social, de sorte que a justiça da decisão satisfaça aos litigantes. Com efeito, é certo que

\footnotetext{
${ }^{39}$ DINAMARCO, Cândido Rangel, A instrumentalidade do processo, cit., p. 178.

${ }^{40}$ Nesse sentido, Cândido Rangel Dinamarco aponta a importância dos escopos da jurisdição, diante da visão instrumentalista do processo de resultados. Ou seja, a instrumentalidade do sistema processual é alimentada pelos resultados que espera a nação: "A tomada de consciência teleológica tem, portanto, o valor de possibilitar o correto direcionamento do sistema e adequação do instrumental que o compõe, para melhor aptidão a produzir tais resultados. A começar da definição da magnitude do próprio poder exercido sub specie jurisdictionis, seu condicionamento e limitações, condutas exigidas, permitidas e reprimidas ao juiz e às partes, dimensão da via de acesso ao processo, tratamento a ser dispensado às pessoas litigantes e determinação do modo de ser do processo mesmo - tudo quanto se refira ao sistema processual e possa projetar reflexos no modo como ele atua na vida em sociedade há de ser coordenado com vista aos objetivos conhecidos e conscientemente delineados, a técnica jurídica a serviço dos objetivos políticos e sociais." (A instrumentalidade do processo, cit., p. 179).
} 
àquele que sucumbe na demanda é assegurada a prerrogativa de demonstrar seu inconformismo, mediante acesso à instância recursal. Todavia, isso não significa dizer que a decisão recorrida tenha sido injusta, embora passível de reforma.

De igual sorte, há situações em que a parte, ainda que tendo sucumbindo na demanda, se dá por satisfeita com a decisão a ela desfavorável. Essa satisfação pode ocorrer por inúmeras razões, mas normalmente está ligada ao fundamento e conteúdo da decisão a ela imposta, bem como a parte dispositiva, cujos alicerces foram suficientes e palatáveis para convencer o jurisdicionado, ainda que ele tenha sucumbido, o que revela a faceta da pacificação social com justiça. Sob a ótica dos escopos sociais, paira também o aspecto psicológico, porquanto a privação consumada é menos incômoda que o conflito pendente: eliminando este, desaparecem as angústias inerentes ao estado de insatisfação que, se perdurar, estará desativado de boa parte de sua potencialidade antissocial. ${ }^{41}$ Por fim, os escopos sociais também denotam sua faceta ligada à educação, consistente no papel desempenhado pelo Estado voltado à conscientização do jurisdicionado sobre seus direitos e obrigações, sem prejuízo de disponibilizar mecanismos voltados a facilitar o acesso à justiça. $^{42}$

Nessa seara, os escopos sociais da jurisdição reclamam a necessidade de pacificação social, de modo que ela se efetive com justiça. ${ }^{43}$ Ainda sob a ótica dos escopos sociais, merece destaque sua adequação à técnica processual, com a tendência de publicização e maior intervenção estatal no curso do processo. ${ }^{44}$ Essa premissa acaba por

${ }^{41}$ DINAMARCO, Cândido Rangel, A instrumentalidade do processo, cit., p. 191. Essa ideia também guarda ligação com o conceito de imperatividade e segurança jurídica trazidos por uma decisão já imunizada pelos efeitos da coisa julgada.

${ }^{42}$ Em relação à disponibilização de mecanismos voltados ao acesso à justiça, merecem aplausos o advento do Código de Defesa do Consumidor (Lei n. 8.078/90) e da Lei dos Juizados Especiais no âmbito estadual (Lei n. 8.099/95) e federal (Lei n. 10.259/2001), cujo papel relevante se prejeta através de meios de acesso do jurisdicionado à justiça, sem prejuízo da Lei de Assistência Judiciária (Lei n. 1.060/50).

${ }^{43}$ Nesse sentido, Cintra, Grinover e Dinamarco defendem a pacificação como escopo magno da jurisdição e de todo o sistema processual, na medida que este é definido como disciplina jurídica do exercício daquela. Ao final, complementam que: "É um escopo social, uma vez que se relaciona com o resultado do exercício da jurisdição perante a sociedade e sobre a vida gregária dos seus membros e felicidade pessoal de cada um." (Teoria geral do processo, cit., p. 30).

44 Cândido Rangel Dinamarco ainda ressalta a importância dos escopos políticos caminharem em consonância com o escopo jurídico. Partindo da premissa de intensas transformações sociais na sociedade contemporânea, de sorte a se formar manifesta "tensão entre a norma e a realidade", chega-se a um quadro de descompassos entre a aplicação da norma necessária à solução do caso concreto. Para aparar tais diferenças, propõe "que suceda o seu tratamento molecular. Constituem vigorosa afirmação dessa diretriz imposta ao direito processual pelo atual modo de ser da vida em sociedade, onde se multiplicam os problemas comuns, as quebras da ortoxia processual segundo a lei posta, que foram observados em pesquisa levada a efeito a partir de invasões urbanas ocorridas no Grande Recife: teve-se o Código de 
refletir no aumento dos poderes do juiz e impõe participação mais ativa no processo, ${ }^{45}$ notadamente mediante o exercício de iniciativas probatórias. Portanto, diante do contexto que se prima pela observância dos escopos da jurisdição em sua concepção atual, o aspecto destinado a atingir a pacificação social para se resolver conflitos com justiça impõe comportamento mais ativo do juiz na condução do processo, de modo a exercer, dentre outras condutas, o exercício dos poderes instrutórios.

Por sua vez, os escopos políticos da jurisdição sintetizam as vertentes do Estado e sua afirmação projetada através da jurisdição. Em síntese, divide-se em três aspectos: poder, liberdade e participação. Essa finalidade política da jurisdição implica em imperatividade (poder) que legitima o papel exercido pelo Estado-juiz, cunhado na liberdade, consistente em restringir e fazer observar os limites do poder e do seu exercício, a fim de preservar a dignidade do jurisdicionado, ao passo que, por fim, a participação se faz necessária para a legitimidade do processo político institucionalizado. ${ }^{46}$ Assim, as formas de influência sobre os centros de poder se lastreiam de modo participativo, para permitir e atribuir legitimidade ao exercício do próprio poder exercido pelo Estado-juiz de maneira democrática.

Sob a ótica da técnica processual, os escopos políticos depreendem a efetivação ao exercício das liberdades públicas, alocadas como direitos e garantias fundamentais na Constituição Federal de 1988, consistentes, em síntese, na técnica do habeas corpus, do

Processo Civil em questão, no sentido de que, para o tratamento molecular das gravíssimas situações sociais criadas, era preciso adaptar seus dispositivos de conformação individualista, aos fenômenos processuais coletivos que então surgiram" (A instrumentalidade do processo, cit., p. 256).

${ }_{45}$ É o que já preconizava Fritz Baur em 1982, ao refletir que naquela época já se impunha o papel ativo do juiz como reinvidicação de uma razoável aceleração do processo e sua função social, de sorte que essa atuação mais enérgica deveria impedir a prolongação injustificada e inútil do processo e, ao mesmo tempo, velar para que a parte mais fraca não sofresse desvantagens. Logo, a aceleração do processo e sua função social denotam contornos políticos alcançados mediante postura mais ativa do magistrado. Ao final, conclui que "em relação ao nosso assunto, há que se dizer que o juiz, simultaneamente, sai de seu papel passivo e assume de alguma maneira, a responsabilidade pela 'cura'de uma relação 'doente' entre o direito e a vida" (O papel ativo do juiz. Revista de Processo, São Paulo, Revista dos Tribunais, ano 7, n. 27, p. 187 e 194 , 1982).

46 “Poder (autoridade) e liberdade são dois polos de um equilíbrio que mediante o exercício da jurisdição o Estado procura manter; participação é um valor democrático, inalienável, para a legitimidade do processo político. Pois a função jurisdicional tem a missão institucionalizada de promover a efetividade desses três valores fundamentais no Estado e na democracia, para a estabilidade das instituições." (DINAMARCO, Cândido Rangel, A instrumentalidade do processo, cit., p. 199). 
habeas data, ${ }^{47}$ do mandado de injunção, do mandado de segurança e na instituição da ação popular.

O escopo jurídico da jurisdição, por sua vez, preleciona que a jurisdição deve ter como objetivo a atuação da vontade concreta da lei. Segundo a teoria dualista ou declarativa de Chiovenda, resta claro que a jurisdição está imbuída de um escopo eminentemente jurídico, voltado à aplicação do direito objetivo. ${ }^{48}$ Sob esse ponto de vista, o ativismo judicial também se impõe como condição necessária a aproximar o conhecimento do juiz com a fiel realidade dos fatos apresentados, mediante exercício dos poderes instrutórios, deixando, por sua vez, de limitar-se a analisar as provas trazidas aos autos pelas partes. Desse modo, se torna mais palatável a aproximação da verdade e, por sua vez, a correta aplicação do direito objetivo.

Discordando de Chiovenda, Carnelutti sustenta que a função da jurisdição é proporcionar à parte "a justa composição da lide", 49 através da observância de um aspecto sociológico. É a chamada teoria unitária ou constitutiva. Para os aprofundamentos necessários, imperioso conceituar alguns de seus argumentos.

As premissas utilizadas por Carnelutti para definir a função da jurisdição têm enfoque sociológico maior. Lide seria "il conflitto di interessi qualificato dalla pretesa di uno degli interessati e dalla resistenza dell'altro". ${ }^{50}$ Esse conflito decorre da escassez de bens e da consequente disputa sobre os mesmos. Logo, diante das necessidades individuais de cada um, os indivíduos teriam interesses privados sobre os bens que são conflitantes, em razão da escassez. Dessa forma, surge o conflito intersubjetivo de interesses. ${ }^{51}$

47 É o que Cândido Rangel Dinamarco denomina os remédios processuais constitucionais como a "consciência jurídico-substancial das liberdades públicas", instrumentalizadas pelo sistema processual com vistas a aperfeiçoar garantias da Constituição. (A instrumentalidade do processo, cit., p. 203).

${ }^{48}$ Essa posição assumida é puramente jurídica e voltada à efetivação do direito substancial, de sorte a compor a teoria dualista ou declarativa do ordenamento jurídico.

49 CARNELUTTI, Francesco. Trattato del processo civile. 2. ed. Napoli: Morano, 1958. p. 67. Em igual sentido, José Frederico Marques sustenta que "a jurisdição civil tem como causa finalis a composição do litígio, motivo pelo qual aplica as normas de direito objetivo reguladoras das relações intersubjetivas, que estão na substância do conflito de interesses" (Manual de direito processual civil. 2. ed., rev. atual. por Vilson Rodrigues Alves. Campinas: Millennium, 2000. v. 1, p. 150).

${ }^{50}$ CARNELUTTI, Francesco. Sistema di diritto processuale civile. Padova: Cedam, 1936. p. 40.

${ }^{51}$ Ibidem, p. 7-12. 
Esse conflito seria solucionado por uma regra de direito objetivo que, uma vez aplicada pelo juiz, se torna um comando. Dito comando materializa a forma de solução pacífica do conflito. A justa composição da lide deve se dar com a jurisdição, ou um de seus equivalentes (autocomposição).

Em decorrência disso, a atuação da jurisdição tem como objetivo proteger o interesse coletivo supremo que, para Carnelutti, era a paz social. ${ }^{52}$ A aplicação do direito regra interpretada em um comando - é cada vez menos necessária, com a progressão da civilidade do homem, que passa a compor-se espontaneamente. ${ }^{53}$

Portanto, o Estado não tem como finalidade legislar para o bem comum, mas legislar para regular os conflitos que surgem entre os homens, de modo a permitir que vivam pacificamente em sociedade.

Dinamarco entende que as definições de Chiovenda e Carnelutti são resultado de uma análise sob prismas diferentes e, em função, disso assevera que "o que realmente tem importância é a definição do escopo jurídico a partir da oposição entre a teoria dualista e a unitária, porque isso significa, afinal, revelar o exato ponto de inserção do processo no universo de direito".54

Embora seja possível contrapor as definições de forma excludente, entende-se que não são análises irreconciliáveis, mas sim complementares, ${ }^{55}$ apenas dotadas de premissas diversas, referentes ao escopo predominante da jurisdição que, exatamente por essa razão, chegam a conclusões diversas.

De outra banda, diversos autores hodiernamente atribuem à jurisdição objetivos maiores do que o jurídico. Cintra, Grinover e Dinamarco ${ }^{56}$ sobrepõem o escopo social ao jurídico (predominante na visão de Chiovenda) e ao político. Nesse pensamento, são acompanhados por muitos autores, como Kazuo Watanabe e Francesco P. Luiso. Em razão

\footnotetext{
${ }^{52}$ CARNELUTTI, Francesco, Sistema di diritto processuale civile, cit., p. 14.

${ }^{53}$ Ibidem, p. 14-15.

${ }^{54}$ DINAMARCO, Cândido Rangel, A instrumentalidade do processo, cit., p. 210.

${ }^{55}$ LIEBMAN, Tullio Enrico, Manual de direito processual civil, cit., v. 1, p. 23.

56 CINTRA, Antonio Carlos de Araújo; GRINOVER, Ada Pellegrini; DINAMARCO, Cândido Rangel, Teoria geral do processo, cit., p. 30.
} 
desse posicionamento, tais autores são fortes adeptos do incentivo à conciliação, em detrimento de uma decisão adjudicada.

A perspectiva chiovendiana é eminentemente jurídica, mas não despreza a existência dos outros escopos da jurisdição. O processo deve buscar a aplicação da lei por estar imbuído de um ideal de justiça. Logo, a solução do conflito entre as partes litigantes é antes uma consequência do que um objetivo e ocorre em razão da submissão das partes à jurisdição.

Dessa forma, a consecução dos demais escopos da jurisdição decorreria naturalmente. Na verdade, se o Estado exerce corretamente seu poder-dever jurisdicional, logo todos os escopos são atingidos. O Estado, segundo Dalmo de Abreu Dallari, tem como finalidade estabelecer uma ordem jurídica soberana, que deve buscar o bem comum, "o conjunto de todas as condições de vida social que consintam e favoreçam o desenvolvimento integral da personalidade humana". 57

Botelho de Mesquita aderiu à ideia de Chiovenda e aduz que, na busca do escopo jurídico da jurisdição, o Estado cumpre sua obrigação derivada do contrato social, propiciando o bem comum e, como consequência dessa atividade, atinge os demais fins: sociais (de pacificação e educação) e políticos (de preservação da liberdade, do ordenamento e de sua autoridade) ${ }^{58}$

Na mesma linha difundida por Botelho de Mesquita são os ensinamentos de José Roberto dos Santos Bedaque:

“Assim, para a caracterização da jurisdição, não é insuficiente considerar
apenas o escopo jurídico da jurisdição. Escopos sociais e políticos são
meras consequências daquele. Na medida que a lei representa a vontade
social, atuada ela no caso concreto haverá pacificação com justiça. Estará
afirmada a autoridade do Estado. Além do mais, colocar a participação e
a educação como escopo político e social da jurisdição significa

${ }^{57}$ DALLARI, Dalmo de Abreu. Elementos de teoria geral do estado. 20. ed. São Paulo: Saraiva, 1998. p. 24 e 118.

${ }^{58}$ MESQUITA, José Ignácio Botelho de, Da ação civil, in Teses estudos e pareceres de processo civil, cit., v. 1, p. 78-79. 
superdimensioná-las, em detrimento das funções legislativa e executiva a quem competem realmente tais atribuições." ${ }^{59}$

Também nesse sentido, Liebman afirma sobre a jurisdição que "o fim último de sua atividade é a justiça, e por meio dela, a paz social."

A ideia de Bedaque, no sentido de que cada escopo da jurisdição é atingido se o escopo jurídico for alcançado, merece aprofundamento. A pacificação inserida no escopo social é consequência da necessidade de submissão ao comando estatal e da formação da coisa julgada, que impede a rediscussão do conflito. A pacificação também é garantida pela proibição da autotutela. Mas importa lembrar que a pacificação decorre da conformidade das partes com a correta atuação do direito, conforme dito acima.

A educação, ainda no escopo social, resulta do fato que o Poder Judiciário julga aplicando o direito material ao caso concreto, incentivando os jurisdicionados à defesa de direitos próprios e o respeito aos direitos alheios. ${ }^{61}$ Esgota-se, portanto o escopo social, desde que cumprido o escopo jurídico, quando da atuação da jurisdição.

Com relação aos escopos políticos, trata-se de escopos lastreados em opção política do legislador, de sorte a se relacionar a atividade da jurisdição com as demais instituições jurídicas. Não se pretende diminuir a importância dos escopos políticos, mas é inegável que a jurisdição é forma de exercício de poder do Estado, que se afirma através de um sistema jurídico. Como lembra Celso Fernandes Campilongo, "não há sistema jurídico sem jurisdição". ${ }^{62}$ Trata-se, portanto, de elemento indispensável ao Estado para a manutenção de sua soberania e proteção da liberdade dos cidadãos. ${ }^{63}$

\footnotetext{
${ }^{59}$ BEDAQUE, José Roberto dos Santos, Poderes instrutórios do juiz, cit., p. 31. Em linhas conclusivas aos escopos da jurisdição, o autor sintetiza que "o processo jurisdicional é instrumento de uma função do Estado que, para manter a paz e a harmonia social, tem a atribuição específica de promover a atuação do ordenamento jurídico" (Ibidem, p. 71).

${ }^{60}$ LIEBMAN, Tullio Enrico, Manual de direito processual civil, cit., v. 1, p. 21.

${ }^{61}$ DINAMARCO, Cândido Rangel, Instituições de direito processual civil, cit., v. 1, p. 133.

${ }^{62}$ CAMPILONGO, Celso Fernandes. Política, sistema jurídico e decisão judicial. São Paulo: Max Limonad, 2002. p. 30.

${ }^{63}$ DINAMARCO, Cândido Rangel, A instrumentalidade do processo, cit., p. 201.
} 
Segundo Campilongo, ${ }^{64}$ o escopo político foi ampliado pelas modificações que a sociedade sofreu, de modo que a jurisdição passou a ser forma de atuação política na determinação dos rumos a serem tomados pelo Estado. $\mathrm{O}$ aumento teve início através do controle de constitucionalidade das leis e de legalidade do ato administrativo, a ponto de desenvolver-se para imprimir a garantia da eficácia das regras do processo eleitoral e garantia da eficácia de programas sociais do Estado. A participação na escolha de políticas públicas, que antes era totalmente relegada ao Poder Executivo, tem sido hoje redirecionada para o Poder Judiciário, embora tal redistribuição seja objeto de oposição. Essa participação é chamada de ativismo judicial ${ }^{65}$ e, segundo Mauro Cappelletti, o crescimento dessa atividade é resultado das mudanças as sociedades sofreram nos últimos anos. $^{66}$

Sem prejuízo desse grande avanço, desnecessário um aprofundamento maior dos escopos políticos da jurisdição, vez que há ainda muitos questionamentos que não se sedimentaram.

A real discussão, portanto, está entre a predominância do escopo jurídico ou do escopo social. Para os doutrinadores que sobrepõem o escopo social ao jurídico, deve haver uma busca pela conciliação, evitando, sempre que possível, a decisão imposta às partes, e essa conciliação seria uma forma mais apta de pacificação do que a adjudicação.

${ }^{64}$ CAMPILONGO, Celso Fernandes, Política, sistema jurídico e decisão judicial, cit., p. 108.

${ }^{65} \mathrm{O}$ fenômeno abarca questões que, para serem decididas pelo Poder Judiciário, acabam por esbarrar ou relativizar limitações impostas pelo sistema. Nesse contexto é a definição traçada por Elival da Silva Ramos: "Por ativismo judicial, deve-se entender o exercício da função jurisdicional para além dos limites impostos pelo próprio odenamento que incumbe, institucionalmente, ao Poder Judiciário fazer atuar, resolvendo litígios de feições subjetivas (conflitos de interesse) e controvérsias judiciais de natureza objetiva (conflitos normativos)." (Parâmetros dogmáticos do ativismo judicial em matéria constitucional. Tese (Professor Titular) - Faculdade de Direito da Universidade de São Paulo. São Paulo, 2009, p. 264).

66 "É manifesto o caráter acentuadamente criativo da atividade judiciária de interpretação e de atuação da legislação e dos direitos sociais. Deve reiterar-se, é certo, que a diferença em relação ao papel mais tradicional dos juízes é apenas de grau e não de conteúdo: mais uma vez impõe-se repetir que, em alguma medida, toda interpretação é criativa, e que sempre se mostra inevitável um mínimo de discricionariedade na atividade jurisdicional. Mas, obviamente, nessas novas áreas abertas à atividade dos juízes haverá, em regra, espaço para mais elevado grau de discricionariedade e, assim, de criatividade, pela simples razão de que quanto mais vaga a lei e mais imprecisos os elementos do direito, mais amplo se torna também o espaço deixado à discricionariedade nas decisões judiciárias.” (CAPPELLETTI, Mauro. Juízes legisladores. Tradução de Carlos Alvaro de Oliveira. Reimpr. Porto Alegre: Sergio Antonio Fabris, 1999. p. 42). 
Francesco P. Luiso explica a razão da preferência pelas soluções conciliatórias da seguinte forma:

\begin{abstract}
"L'idea comune è quella della priorita della giurisdizione, che è concetto diverso da quello della centralità della giurisdizione. Com quest'ultima espressione si indica un principio assolutamente ovvio, che trova il suo fondamento negli artt. 24 e 111 Costituizione: la tutela giurisdizionale dei diritti è un'attività costituzionalmente necessaria, che il legislatore ordinario non può circoscrevere o eliminare. Con l'altra espressione, invece, si indica quello stato psicologico istintivo, in base del quale - ove si presenti la necessità di tutelare um diritto - il ricorso alla giurisdizione viene invocato como il primo ed immediato rimedio. La parte lesa (o che ritiene di essere lesa nel suo diritto) pensa di dover ricorrere immediatamente al giudice per la tutela dello stesso".

(...)

Ebbene, in questa ottica la priorità della giurisdizione costituisce un antico retaggio che oggi mal si concilia con una realtà che si fonda essenzialmente sul principio di sussidiarietà, in base al quale l'intervento autoritativo gurisdizionale - che resta pur sempre possibile $e$ costituzionalmente dovuto - deve essere considerato come l'ultima delle chances a disposizione, alla quale si deve ricorrere quando le altre non riescono allo scopo." 67
\end{abstract}

Kazuo Watanabe também é grande entusiasta do incentivo à conciliação, sendo autor de projetos de lei nesse sentido, bem como responsável por estudos técnicos estatísticos relacionados à conciliação e os modos de torná-la mais eficaz, na qualidade de sucedâneo jurisdicional.

Esse autor critica o que chama de cultura da sentença, concluindo que ela será paulatinamente substituída pela cultura da pacificação. ${ }^{68}$ Ele ainda critica o baixo índice de conciliações realizadas nos juizados especiais brasileiros e enaltece o alto índice de transações obtidas pelas cortes americanas, mencionando que mais de $95 \%$ das ações ajuizadas no Estado da Califórnia são solucionados por ADR (alternative dispute resolution). Além do elogio aos californianos, Kazuo Watanabe menciona honrosamente

${ }^{67}$ LUISO, Francesco P. Presente e futuro della conciliazione in Italia. In: YARSHELL, Flávio Luiz; MORAES, Maurício Zanoide de (Coords.). Estudos em homenagem à professora Ada Pellegrini Grinover. São Paulo: DPJ, 2005. p. 575-576.

${ }^{68}$ WATANABE, Kazuo. Cultura da sentença e cultura da pacificação. In: YARSHELL, Flávio Luiz; MORAES, Maurício Zanoide de (Coord.). Estudos em homenagem à professora Ada Pellegrini Grinover. São Paulo: DPJ, 2005. p. 684-690. 
os resultados da conciliação em segundo grau criada pelo Tribunal de Justiça de São Paulo, e seus resultados de mais de $35 \%$ de obtenção de acordos. ${ }^{69}$

Mas esse sistema elogiado por Kazuo Watanabe é criticado por estudiosos norteamericanos $^{70}$. Em contraponto aos entusiastas da conciliação e alinhada às opiniões de José Ignácio Botelho de Mesquita e José Roberto dos Santos Bedaque, importante trazer a lume a análise feita por Owen M. Fiss.

Para o professor de Yale, o escopo jurídico se sobrepõe na solução do conflito e atua como forma educativa da população, incentivando o respeito às normas e aos pactos, enquanto o incentivo ao acordo atua em sentido exatamente oposto. $\mathrm{O}$ autor analisa introspectivamente o processo norte-americano, que parece estar contaminado pelos mesmos defeitos do processo brasileiro: alto custo e morosidade na solução adjudicada.

São exatamente esses defeitos que incentivam as partes a optarem por soluções das lides diversas do julgamento (considerando esse termo como o ato decisório posterior à cognição). Owen Fiss, analisando os resultados da conciliação, diminui a importância da função (meramente) pacificadora, diante da função judicial de aplicação da lei. ${ }^{71}$

Diante desses argumentos, é questionável a preferência pelas soluções conciliatórias, como preferem os defensores da predominância do escopo social sobre o escopo jurídico da jurisdição.

${ }^{69} \mathrm{O}$ alto índice de conciliações obtidas em $2^{\circ}$ grau não decorre somente do empenho e treinamento dos conciliadores, mas também do estágio processual e da quantidade de informações que as partes já possuem e de diversas outras como afirma Bryant Garth (Delay and settlement in civil litigation: notes toward a comparative and sociological perspective. In: STUDI in onore di Vittorio Denti: storia e metodologia garanzie e principi generali. Milano: Cedam, 1994, v. 1, p. 159).

${ }^{70}$ No Brasil, a crítica é de José Joaquim Calmon de Passos: "Convivemos, por muitos meses, na 'finada' ou assassinada Comissão Revisora do ministro Fernando Lyra, com esta admirável figura humana e não menos admirável jurista que é Kazuo Watanabe, um entusiasta contagiante dos méritos da conciliação. Embora brasileiro e dos de melhor quilate, vive nele, com grande força, ainda, a herança do povo de seus pais, que faz da conciliação quase que uma questão de honra. Candidamente ele acredita que poderemos chegar lá um dia, se insistirmos. Nós, que temos um 'fígado' pouco propício, somos céticos. Jamais acreditei que normas precedessem instituições ou pudessem efetivamente conformá-las." (Comentários ao Código de Processo Civil. 8. ed. Rio de Janeiro: Forense, 1998. v. 3, p. 452).

${ }^{71}$ Segundo Owen M. Fiss quando as partes celebram acordo, aceitam menos que o ideal. (Contra o acordo. In: Um novo processo civil: estudos norte-americanos sobre jurisdição, constituição e sociedade. Tradução de Carlos Alberto de Salles, coordenador; Daniel Porto Godinho da Silva; Melina de Medeiros Rós. São Paulo: Revista dos Tribunais, 2004. p. 139-142). 
Conclui-se portanto que, sendo os demais escopos da jurisdição atingidos em consequência da plena consecução do escopo jurídico, sugerir uma sobreposição do escopo social ou do político seria, nas já citadas palavras de Bedaque, "superdimensioná-los". 72

Em razão do exposto, evidencia-se necessária a adoção da teoria de Chiovenda no presente trabalho, no que toca à premissa de finalidade da jurisdição destinada à atuação concreta da lei, sobrepondo a aplicação da lei à pacificação, ${ }^{73}$ e considerando esta mera consequência da atuação correta da jurisdição. Esse pensar canaliza na atividade exercida pelo Estado-juiz o compromisso de realização do direito necessário à entrega da tutela jurisdicional. ${ }^{74} \mathrm{E}$, para a correta realização do escopo jurídico que se pretende a um provimento justo, impõe-se a atuação mais participativa do magistrado na formulação de seu livre convencimento.

Portanto, para atingir o escopo jurídico de modo adequado, deve o juiz estar imbuído de elementos suficientes à justa entrega da tutela jurisdicional, sejam os elementos trazidos aos autos mediante participação das partes, seja por conta do exercício dos poderes instrutórios, tema que voltará a ser tratado no Capítulo 3. Daí porque a presença de maiores elementos nos autos (mormente por iniciativa do juiz) irá refletir em mais acentuada aproximação da verdade e, por sua vez, em aplicação da vontade concreta da lei. Cumprido o escopo jurídico, por consequência o escopo social também será realizado, ao se propiciar uma decisão équa.

\footnotetext{
${ }^{72}$ BEDAQUE, José Roberto dos Santos, Poderes instrutórios do juiz, cit., p. 22.

${ }^{73}$ Ibidem, p. 12.

${ }^{74}$ Embora não seja objeto deste trabalho tratar de forma mais aprofundada as espécies de tutela jurisdicional, cumpre apenas citar as majoritariamente definidas pela doutrina e respectiva finalidade: nas ações de conhecimento, predominam as tutelas declaratória, condenatória e constitutiva, executiva lato sensu e mandamental, cada tipo voltada a atender a uma necessidade correspondente no plano de direito material. Em síntese, na tutela declaratória busca-se solucionar uma crise de certeza quanto a um direito, a uma relação jurídica, de modo a resolver a crise de certeza do direito material. Trata-se, como afirma Dinamarco, de "dúvidas objetivas criadas no meio social no tocante a direitos e obrigações ou à existência, inexistência ou modo-de-ser de relações jurídicas" (Instituições de direito processual civil, cit., v. 1, p. 153154). A tutela constitutiva se destina a alterar, criar, ou extinguir relações jurídicas voltadas ao direito material, porquanto assente a crise de situação jurídica do bem tutelado. Diferencia-se da tutela declaratória, pois não apenas reconhece a existência ou inexistência do direito, mas também provoca alterações no plano jurídico, criando, modificando ou extinguindo relações. A tutela condenatória, por sua vez, busca solucionar uma crise de inadimplemento, de sorte a obrigar o réu a cumprir ato comissivo ou omissivo. Dessa obrigação derivam categorias autônomas, a saber: a tutela mandamental (emissão do comando na própria sentença), a tutela executiva (em que determina a restituição de patrimônio alheio ao seu proprietário) e a tutela executiva lato sensu (em que a condenação e determinação de pagamento de quantia se materializará mediante transformação do patrimônio do devedor em dinheiro através de meios coercitivos).
} 
De igual modo que foram analisados os escopos da jurisdição para se tentar delinear sua influência nos poderes instrutórios, será examinada de forma breve a evolução das principais correntes conceituais dos demais institutos fundamentais, para assim permitir que se apresente uma conclusão parcial dos objetivos de cada instituto e seus reflexos nos poderes instrutórios do juiz.

\subsection{Processo}

A tutela jurisdicional é instrumentalizada pelo processo. Por sua vez, muitas teorias discorreram acerca da natureza jurídica do processo. ${ }^{75}$ Desenvolvida nos séculos XVIII e XIX e sob forte influência privatista e do liberalismo francês, Pothier defendia a ideia do processo visto como um contrato, colocado o pacto para o processo (litiscontestatio), valendo-se do mesmo raciocínio calcado na doutrina política do contrato social de Jean Jacques Rousseau. $^{76}$

Essa teoria, que partia do pressuposto do processo como um verdadeiro negócio jurídico de direito privado (litiscontestação), restou rechaçada diante da concepção atual, porquanto a jurisdição impõe a inevitável sujeição das partes, independentemente de voluntária aceitação. De igual modo, não se pode admitir a concepção do processo como quase contrato (Arnault de Guényvau e Savigny, no século XIX), na medida que resta omitida uma outra fonte de obrigações, à época já prevista no Código Napoleônico de 1804: a lei. ${ }^{77}$ Ou seja, a concepção do processo como quase contrato (o que por sua vez remete a determinada fonte de obrigação) não é adequada à melhor premissa metodológica, porquanto o processo em si já decorre de previsão legal. Ademais, conforme dito anteriormente, a inevitabilidade do jurisdição prescinde a manifestação volitiva das partes, o que afasta qualquer feição do processo como contrato ou quase contrato.

\footnotetext{
${ }^{75}$ Cintra, Grinover e Dinamarco informam que a noção de processo é esencialmente teleológica, por se caracterizar por sua finalidade de exercício do poder (jurisdiccional), ao passo em que a noção de procedimento é meramente formal, ligada aos atos que se sucedem, de sorte que em um proceso podem haver mais de um procedimento. Por sua vez, os autos são a materialidade dos documentos que se corporificam nos atos do procedimento. (Teoria geral do processo, cit., p. 297-298).

${ }^{76}$ CINTRA, Antonio Carlos de Araújo; GRINOVER, Ada Pellegrini; DINAMARCO, Cândido Rangel, Teoria geral do processo, cit., p. 299.

${ }^{77}$ Ibidem, p. 299-300.
} 
Oskar Von Bulow expôs em 1868 sua obra "Teoria dos pressupostos processuais e das exceções dilatórias", que constitui um divisor de águas e fio condutor de uma verdadeira escola sistemática processual civil. Bulow segmentou em planos distintos as relações de direito material e processual a serem discutidas no processo, distinguindo, esta última, em três aspectos: a) por seus sujeitos (autor, réu e Estado-juiz), ${ }^{78}$ b) por seu objeto (a prestação jurisdicional, declaração do direito), ${ }^{79} \mathrm{e}$, por fim, por seus pressupostos ${ }^{80}$. Dessas premissas nasceu a teoria do processo como relação jurídica, primeiramente formada entre autor e juiz, quando aquele exerce o direito de ação; a partir do conhecimento da demanda por parte do réu, este passará também a fazer parte da relação jurídica. A despeito dessa teoria ser aceita pela maioria da doutrina nacional, duas objeções pontuais, à guisa de contraponto, merecem ser comentadas: a teoria do processo como situação jurídica, de James Goldschmidt, e a teoria do processo como procedimento em contraditório, de Elio Fazzalari. ${ }^{81}$

78 "La relación jurídica procesal se distingue de las demás relaciones de derecho por outra singular característica, que puede haber contribuido, en gran parte, a desconocer su naturaleza de relación jurídica continua. El proceso es una relación jurídica que avanza gradualmente y que se desarrolla paso a paso. Mientras que las relaciones jurídicas privadas que constituyen la materia del debate judicial, se presentan como totalmente concluidas, la relación jurídica procesal se encuentra en embrión. Esta se prepara por medio de actos particulares. Solo se perfecciona com la litiscontestación, el contrato de derecho público, por el cual, de una parte, el tribunal asume la concreta obligación de decidir y realizar el derecho deducido en juicio, y de otra, las partes quedan obligadas, para ello, a prestar una colaboración indispensable y a someterse a los resultados de esta actividad común. Y también esta ulterior actividad discurre en una serie de actos separados, independientes y resultantes unos de otros. La relación jurídica procesal está en un constante movimiento y transformación." (BÜLOW, Oskar Von. La teoria de las excepciones procesales y los presupuestos procesales. Traducción de Miguel Angel Rosas Lichtschein. Buenos Aires: EJEA, 1964. p. 2).

${ }^{79}$ Para Oskar Von Bülow, o tribunal não deve decidir apenas sobre a existencia da pretensão jurídica, mas antes fazer o exame acerca da presença das condições de existencia do proceso, sendo a decisão daquela o direito da relação jurídica privada litigiosa (judicium deducta) (La teoria de las excepciones procesales y los presupuestos procesales, cit. p. 6-7).

${ }^{80}$ Os pressupostos apontados por Bülow estariam divididos, em síntese, na existência de um pedido, na capacidade de quem formula o pedido e na investidura do destinatário do pedido, o juiz: "Estos problemas deben plantearse también en la relación jurídica procesal y no se muestran a su respecto menos apropiados y fecundos que lo que se mostraron ya en las relaciones jurídicas privadas. También aqui ellos dirigen sua atención a una serie de importantes preceptos legales estrechamente unidos. En particular, a las prescripciones sobre: 1) la competencia, capacidad e insospechabilidad del tribunal; la capacidad procesal de las partes (persona legitima standi in iudicio (persona legítima para estar em juicio)) y la legitimación de su representante, 2) las cualidades proprias e imprescindibles de una materia litigiosa civil, 3) la redacción y comunicación (o notificación) de la demanda y la obligación del actor por las cauciones procesales, 4) el orden entre varios procesos. (...) En suma, en esos princípios están contenidos los elementos constitutivos de la relación jurídica procesal; idea tan poco tenida em cuenta hasta hoy, que ni uma vez há sido designada con un nombre definido. Proponemos, como tal, la expresión 'presupuestos procesales..” (La teoria de las excepciones procesales y los presupuestos procesales, cit., p. 5-6).

${ }^{81}$ Além das críticas que serão comentadas a seguir, outras merecem ser citadas e que se contrapõe à concepção do processo como relação jurídica. É o que sustentam Cintra, Grinover e Dinamarco ao criticarem: a) a divisão do processo em duas fases (in jure e apud judicem), a primeira, ligada à análise dos pressupostos processuais, ao passo em que na segunda se examina o mérito, o que nem seria verdadeiro para o direito romano; b) o juiz teria obrigações no processo, carecendo-lhe sanções por descumprimento; e c) as partes não têm obrigações no processo, mas sujeitam-se à autoridade do órgão juridicional. (Teoria geral do processo, cit., p. 301). 
James Goldschmidt critica a ideia de que o processo seja uma relação jurídica, ${ }^{82}$ afirmando que é uma situação jurídica. Para sua teoria, as partes do processo estão sujeitas à jurisdição e o juiz se apresenta no processo por dever funcional. Logo, o direito subjetivo do autor se converte em meras chances dentro do processo, que se desdobram em possibilidades (de praticar atos para que o direito seja reconhecido), ${ }^{83}$ expectativas (de obter esse reconhecimento), ${ }^{84}$ perspectivas (de uma sentença favorável) ${ }^{85}$ e ônus (encargo de praticar certos atos, cedendo a imperativos ou impulsos do próprio interesse, para evitar a sentença desfavorável). ${ }^{86}$ Os estudos de Goldschmidt merecem admiração por traçarem as primeiras definições de conceitos até então mal compreendidos, como o significado de sujeição, ônus e a relação funcional do juiz com o Estado. A teoria do processo como relação jurídica não passou incólume a diversas críticas, a saber: a) ela argumenta pela exceção, tomando como regras as deformações do processo; b) não se pode falar de uma situação, mas de um complexo de situações no processo; c) é exatamente o conjunto de situações jurídicas que recebe o nome de relação jurídica. Por fim, a crítica mais contundente é que toda a situação de incerteza expressa nos ônus, perspectivas, expectativas e possibilidades refere-se à res in judicium deducta, não ao judicium em si mesmo. Ou seja, o que se coloca em dúvida é o direito subjetivo material, não o processo. ${ }^{87}$

Por sua vez, Elio Fazzalari define o processo como procedimento em contraditório, repudiando a concepção de Oskar Von Bulow. Para Fazzalari, ${ }^{88}$ necessária a distinção entre processo e procedimento, de sorte que neste último se aperfeiçoe o contraditório entre as partes, calcado na oportunidade de informação e participação garantida pela Constituição. Isso porque, sendo o procedimento uma série de atos realizados no processo, imperiosa a observância do contraditório em todos os atos para que seja legítima a preparação do provimento final. Todavia, a concepção de Fazzalari em verdade não é incompatível com a definição de Bulow do processo como relação jurídica. É certo que, de um lado, as partes têm deveres, ônus, sujeição dentro do processo, o que constitui uma

${ }^{82}$ GOLDSCHMIDT, James. Teoria general del processo. Tradução de Leonardo Prieto Castro. Barcelona: Labor, 1936. p. 16-23.

${ }^{83}$ Ibidem, p. 189.

${ }_{85}^{84}$ Ibidem, p. 189-191.

${ }^{85}$ Ibidem, p. 192.

${ }^{86}$ Ibidem, p. 191.

${ }^{87}$ CINTRA, Antonio Carlos de Araújo; GRINOVER, Ada Pellegrini; DINAMARCO, Cândido Rangel, Teoria geral do processo, cit., p. 302.

${ }^{88}$ FAZZALARI, Elio. Processo (Teoria generale). In: NOVISSIMO digesto italiano. Turim: Utet, 1966. v. 13, p. 1.067-1.076. 
relação jurídica. De outra banda, o processo deve ser realizado em contraditório. Ambas as assertivas retrocitadas não se chocam, mas convergem à ideia de um processo como relação jurídica e, ao mesmo tempo, atento à observância de garantias constitucionais.

De todas as teorias acima expostas, soa interessante a concepção de Oskar Von Bulow, porquanto o processo, em linhas gerais, se afeiçoa a uma relação jurídica tripartite (autor, juiz e réu), ${ }^{89}$ em que as partes se imbuem poderes, faculdades, direitos, deveres, obrigações, sujeições e ônus, de sorte que a interligação constitui mera relação jurídica. ${ }^{90}$

Por outro lado, a ideia do processo como procedimento realizado em contraditório também não pode ser esquecida, de sorte que a legitimidade do provimento resultante do processo depende da efetiva participação das partes na sua formação, ou pelo menos na oportunidade de reação/participação, além de estender a ideia de processo para toda atividade realizada em contraditório, da qual resulte um provimento. ${ }^{91}$

E nessa relação jurídica entre autor, juiz e réu, é certo que o processo materializa o instrumento para alcance da tutela jurisdicional. Vale dizer, é através do processo como instrumento que se desenvolve toda a atividade voltada a atingir os escopos da jurisdição, notadamente o escopo jurídico. ${ }^{92}$

Nessa linha de raciocínio, Bedaque conclui:

“(...) a relação processual tem seu próprio objeto, que jamais é o mesmo da relação de direito material. Pode esta pertencer ao direito público ou privado, não importa. $\mathrm{O}$ processo, entendido como relação processual mais procedimento, ou como procedimento realizado em contraditório, tem sempre a mesma finalidade a ser atingida: a manutenção do ordenamento jurídico, do que advém a afirmação da autoridade do Estado

${ }^{89}$ Excluindo-se algumas hipóteses de jurisdição voluntária em que o Ministério Público não é parte que contrapõe o pedido do autor, mas tão-somente fiscal da lei em relação à viabilidade do provimento jurisdicional pretendido.

90 "São relações jurídicas, por exemplo, o nexo existente entre credor e devedor e também o que interliga os membros de uma sociedade. O processo também, como complexa ligação jurídica entre os sujeitos que nele desenvolvem atividades, é em si mesmo uma relação jurídica (relação jurídica processual), a qual, vista em seu conjunto, apresenta-se composta de inúmeras posições jurídicas ativas e passivas de cada um dos seus sujeitos: poderes, faculdades, deveres, sujeição, ônus.” (CINTRA, Antonio Carlos de Araújo; GRINOVER, Ada Pellegrini; DINAMARCO, Cândido Rangel, Teoria geral do processo, cit., p. 302).

${ }^{91}$ BEDAQUE, José Roberto dos Santos, Poderes instrutórios do juiz, cit., p. 67.

${ }^{92}$ O processo, na visão de Giuseppe Chiovenda, é instrumento necessário para atuação da jurisdição, com a função de "dare per quanto è possibile praticamente a chi ha um diritto tutto quello e proprio quello ch'egli há diritto di conseguire”. (Instituizioni di diritto processuale civile, v. 1. p. 42). 
e a paz social. A relação processual é, portanto, completamente independente da de direito material. O que existe é uma relação de instrumentalidade entre o processo e o direito objetivo material, pois aquele visa à atuação deste. E essa finalidade satisfaz não apenas o interesse das partes cujas relações são reguladas pelas normas de direito material, mas, principalmente, o interesse público na obediência à ordem jurídica estabelecida. Aliás, este último se sobrepõe ao primeiro. Concluise, portanto, que o processo jurisdicional é instrumento de uma função do Estado que, para manter a paz e a harmonia social, tem a atribuição específica de promover a atuação do ordenamento jurídico., ${ }^{, 93}$

Sendo o processo composto de uma relação tripartite e alinhado a servir como instrumento através do qual se atinge os escopos da jurisdição, resta clara a natureza pública da relação processual. O juiz não é parte no processo, mas agente, através do qual age o próprio Estado. Nesse contexto, a imparcialidade do juiz se sobrepõe ao interesse das partes, através de autoridade soberana, de modo a constituir o liame entre Estado-juiz e partes uma relação de direito público. No escólio de Grinover, Cintra e Dinamarco:

"A relação processual é de direito público, ainda que seja privada a
relação substancial controvertida: assim, tanto é pública a relação
processual penal como a trabalhista ou a civil, ainda que, com referência
particular a esta, a pretensão deduzida seja de caráter privado
(obrigações, coisas, etc.)." 94

Diante da conclusão de que o processo é a relação jurídica que serve como instrumento para um provimento justo ${ }^{95}$ é que serão analisados alguns aspectos ligados à atividade exercida pelo juiz (personificação do Estado), o qual exerce o poder em benefício geral e no cumprimento de sua função para pacificar os sujeitos em conflito e realizar a paz social. Ou seja, por ser relação processual de direito público, o interesse na prestação da tutela jurisdicional de forma justa consoante o escopo jurídico passa a pertencer ao Estadojuiz. Logo, a esse Estado-juiz são imbuídos poderes outorgados ao magistrado para a aproximação de um juízo de certeza que reflita a correta e adequada aplicação da lei, razão pela qual o ativismo judicial (notadamente mediante exercício dos poderes instrutórios) se

\footnotetext{
${ }^{93}$ BEDAQUE, José Roberto dos Santos, Poderes instrutórios do juiz, cit., p. 68-69.

94 CINTRA, Antonio Carlos de Araújo; GRINOVER, Ada Pellegrini; DINAMARCO, Cândido Rangel, Teoria geral do processo, cit., p. 311. No mesmo trecho, os autores complementam que o juiz não é sujeito em nome próprio, porém órgão através do qual age o Estado. Portanto, o Estado-juiz não guarda interesse algum sobre o bem da vida objeto do litígio entre as partes, mas exerce sua função soberana, passando, portanto, a guardar feição de uma relação de direito público. Dentre as principais características da relação processual, destacam-se a complexidade, progressividade, unidade, estrutura tríplice e a natureza pública (Ibidem, p. 310-311).

95 BEDAQUE, José Roberto dos Santos, ob. cit., p. 66.
} 
impõe para determinar iniciativas probatórias que conduzam a uma cognição mais profunda, que possibilite um julgamento mais acertado, próximo da verdade e revestido da devida aplicação da lei.

Antes de analisar em maior profundidade os fundamentos dos poderes instrutórios, necessário, contudo, traçar breves apontamentos sobre dois institutos fundamentais, que em muito se aproximam: a ação e a defesa.

\subsection{Notas sobre a evolução da natureza jurídica da ação}

Embora não seja o foco deste estudo, a evolução doutrinária da natureza jurídica da ação não pode passar despercebida, a fim de se traçarem comentários sobre esse instituto fundamental e a relação de sua concepção moderna com os poderes instrutórios. ${ }^{96} \mathrm{Na}$ concepção tradicional, calcada na teoria contemporânea, e à qual nos filiamos, a ação "é o direito ao exercício da atividade jurisdicional (ou o poder de exigir esse exercício). Mediante o exercício da ação provoca-se a jurisdição, que por sua vez se exerce através daquele complexo de atos que é o processo". ${ }^{97}$

Inicialmente, a teoria imanentista, privatista, civilista ou clássica, que contava entre seus adeptos Savigny ${ }^{98}$ e João Monteiro, ${ }^{99}$ preceituava que ação e processo eram simples

\footnotetext{
${ }^{96}$ Por se tratar de um dos institutos fundamentais do direito processual, juntamente com a jurisdição, defesa e processo (DINAMARCO, Cândido Rangel, Instituições de direito processual civil, v. 1, cit., p. 302), decidimos tratar brevemente da natureza jurídica da ação. Para um estudo completo sobre a história do direito de ação, ver: ORESTANO, Ricardo. Azione, diritti soggesttivi, persone giuridiche. Bologna: Il Mulino, 1978. p. 13 e ss.).

97 CINTRA, Antonio Carlos de Araújo; GRINOVER, Ada Pellegrini; DINAMARCO, Cândido Rangel, Teoria geral do processo, cit., p. 267.

${ }^{98} \mathrm{O}$ art. 75 do Código Civil de 1916 dispunha que "a todo direito corresponde uma ação, que o assegura". Esse dispositivo não encontra correspondência no Código Civil de 2002, o que corrobora a superação da tese de que o direito processual somente seria exercido se existente o direito material. Sobre o tema, esclarece Kazuo Watanabe que o antigo art. 75 do Código Civil de 1916 em verdade não tem o condão de projeções imanentistas, bastando interpretá-lo sob a ótica de que a toda afirmação de um direito (e não um direito efetivamente existente) corresponde uma ação que o assegura. Logo, direito afirmado deixa de ser o mesmo que direito existente, interpretação que deve ser observada quando da leitura do art. $5^{\circ}, \mathrm{XXXV}$, da Constituição Federal (Código brasileiro de defesa do consumidor comentado pelos autores do anteprojeto. 9. ed. Rio de Janeiro: Forense Universitária, 2007. p. 856). Em semelhante sentido, pondera Cândido Rangel, Dinamarco que "o Código Civil de 1916, fruto de uma cultura ainda sem conhecimento das conquistas científicas do direito processual operadas a partir do século XIX, adotava francamente a teoria civilista da ação, ao dizer que 'a todo direito corresponde uma ação, que o assegura' e ao inserir indevidamente no conceito de interesse de agir as qualificações de econômico ou moral. O Código Civil vigente não repete essas impropriedades" (A instrumentalidade do processo, cit., p. 214).

${ }^{99}$ MONTEIRO, João. Teoria do processo civil. 6. ed. atual. por J. M. Carvalho Santos. Rio de Janeiro: Borsoi, 1956. v. 1, p. 68-70.
} 
capítulos do direito substancial, não se diferenciando do direito subjetivo material. Portanto, a ação seria imanente ao direito material e não haveria ação sem direito, tampouco direito de ação, de sorte que a ação segue a natureza do direito. Essa teoria pode ser afastada mediante dois contrapontos fundamentais: o primeiro, no que diz respeito à ação declaratória negativa. Como é cediço, nesse tipo de demanda, o que se pretende é a declaração de inexistência de determinada relação jurídica, de sorte que o direito ao exercício da atividade jurisdicional prescinde um direito subjetivo material, mas se presta à declaração de sua inexistência. Outro argumento que rechaça a teoria imanentista é o decreto de improcedência da ação. Nessa hipótese, a pretensão do autor é afastada, ao passo que o exercício da ação existiu, ainda que repelido o direito material invocado.

Os romanistas Bernhard Windscheid e Theodor Muther, embora divergentes em alguns aspectos, ${ }^{100}$ desenvolveram no século XIX, na Alemanha, um novo conceito de ação, ${ }^{101}$ cujas ideias convergiram na distinção entre direito de ação e direito lesado, consistentes, respectivamente, no direito exercível contra o Estado e deste contra o devedor. Segundo essa concepção, direito material e direito de demandar se encontram dissociados, de modo que a ação é autônoma. ${ }^{102}$ A visão da ação como direito autônomo,

${ }^{100}$ Heitor Vitor Mendonça Sica traça breves apontamentos sobre a polêmica Windscheid e Muther, cujas divergências, em verdade, se complementaram. Embora Windcheid recusasse a ideia de que o direito de ação seria o direito à tutela de outro direito, bem como a faculdade de pedir a tutela em caso de lesão, concluiu que a ação não é algo derivado, mas sim originário e autônomo. Por sua vez, Muther afirmou que do direito subjetivo material lesado surgiam dois direitos: um contra o Estado (direito à tutela jurisdicional) e outro contra o ofendido (de reparar a lesão sofrida). Daí porque "apesar das divergências entre os dois estudiosos, os trabalhos se aproximam em torno do consenso de que a ação é um direito autônomo público em relação ao direito subjetivo material. O resultado dessa polêmica serviu de base para as chamadas teorias dualistas que, com algumas variações, colocam-se entre dois extremos: de um lado a concepção da ação como um direito concreto e de outro como direito abstrato" (Direito de defesa e tutela jurisdicional: estudo sobre a posição do réu no processo civil brasileiro. Tese (Doutoramento) - Faculdade de Direito da Universidade de São Paulo, São Paulo, 2009. p. 10-11). Ainda sobre a polêmica Windscheid-Muther, ver: WINDSCHEID, Bernhard; MUTHER, Theodor. Polémicas sobre la 'actio'. Tradução de Tomás A. Banzhaf. Buenos Aires: EJEA, 1974. Essa mesma polêmica, segundo José Roberto Bedaque, aliada às contribuições de Bülow, também influenciou os aperfeiçoamentos da doutrina no que tange à definição da jurisdição, por contribuírem para a existência do binômio direito-processo, distinguindo-se, portanto, o plano material do plano processual do ordenamento jurídico, o que desencadeou as concepções unitária e dualista, cuja divergência contrapõe-se sobre a natureza da atividdade jurisdicional em criar ou declarar direitos preexistentes (Direito e processo: influência do direito material sobre o processo, cit., p. 26).

${ }^{101}$ Para aprofundamento sobre o tema, ver os apontamentos de Enrico Tullio Liebman: "Esse problema foi suscitado por Windscheid, na monografia Die Actio des römischen Civilrechts, vom Standpunkte des heutigen Rechts, Dusseldorf, 1856, e depois discutido por ele em polêmica com Muther. Os escritos de ambos encontram-se traduzidos em língua italiana e reunidos no volume Windscheid-Muther, Polemica intorno all actio, Florença, 1954, com introdução de G. Pugliese (do qual v. ainda Actio e diritto subiettivo, Milão, 1939)." (Manual de direito processual civil, cit., v. 1, p. 197).

${ }^{102}$ A autonomia do direito de ação em relação ao direito material atualmente se mostra clara. Isso porque o sistema processual civil guarda tratamento exclusivo que difere o direito substancial do direito processual, cuja análise isolada de alguns aspectos processuais inclusive inviabiliza o julgamento de mérito, v.g., análise das condições da ação e pressupostos processuais. As condições da ação são a legitimidade de parte, 
por sua vez, apresenta desdobramentos que repercutiram em outras teorias, a seguir comentadas.

A teoria da ação como direito autônomo e concreto, inicialmente desenvolvida por Adolf Wach ${ }^{103}$ na Alemanha, preceitua, em linhas gerais, a ação como o direito a uma sentença favorável, também dirigida pelo Estado, e de igual sorte voltada também contra o réu na demanda. Em outras palavras, a ação seria um direito público, mas concreto, ligado às peculiaridades do direito subjetivo e correspondente a uma sentença de procedência. Esta linha também não completa o sistema existente. Se adotada a teoria concreta da ação, como acomodar nesse conceito as ações de improcedência? Como explicar os atos processuais praticados até a sentença que, ao final, foi desfavorável ao autor e, ao mesmo tempo, sustentar que não houve ação (sob a teoria concreta)?

Ainda em relação à teoria concreta, Giuseppe Chiovenda ${ }^{104}$ utilizou essa linha em 1903, mas derivou a definição de ação como um direito potestativo, ${ }^{105}$ ou seja, a despeito do direito de ação dissociar-se do direito material, não se tratava de obrigação de natureza pública do Estado, mas significava uma sujeição a ser exercida contra o réu. Sob essa ótica, a ação correspondia ao direito (poder de quem tem razão contra quem não tem) a uma sentença, mas não necessariamente que fosse favorável, ${ }^{106}$ ao resumir a existência do

interesse de agir e possibilidade jurídica do pedido. Já os pressupostos processuais classificam-se em objetivos que, por sua vez, se desdobram em: a) intrínsecos (regularidade processual, existência de citação); e b) extrínsecos (ausência de impedimentos, como coisa julgada, litispendência, compromisso). Os pressupostos subjetivos dizem respeito às partes na relação processual: a) referentes ao juiz (investidura, competência, imparcialidade); e b) referentes às partes (capacidade de ser parte, capacidade de estar em juízo, capacidade postulatória). Todavia, a reaproximação em alguns aspectos entre direito material e processual parece tender na chamada fase instrumentalista do processo, o que será melhor tratado no Capítulo 2.

${ }^{103}$ WACH, Adolf. Pretensióon de declaración. Tradução de Juan M. Semon., Buenos Aires: EJEA, 1962. p. 46.

${ }^{104}$ CHIOVENDA, Giuseppe. L'azione nel sistema dei diritti (1903). In: Saggi di diritto processuale civile. 2. ed. Roma: Foro Italiano, 1930. v. 1, p. 24-25.

105 "A característica principal dos direitos potestativos é a produção de um efeito jurídico a favor de uma pessoa e a cargo de outra, a qual nada deve fazer, ficando apenas sujeita à produção daquele efeito." (BEDAQUE, José Roberto dos Santos, Poderes instrutórios do juiz, cit., p. 35). O direito potestativo também não se confunde com o direito subjetivo, conforme leciona José Roberto Bedaque: "Tem direito subjetivo o titular de um interesse juridicamente protegido pela norma substancial. Enquanto este é um poder correlato a um dever, aquele constitui faculdade decorrente de relação jurídica preexistente, em que uma das partes tem o poder de transformá-la, extingui-la ou criar uma nova, submetendo a outra parte. O titular do direito potestativo prescinde de alguém, pois pode exercitá-lo unilateralmente, sujeitando outra pessoa a esse poder." (Direito e processo: influência do direito material sobre o processo, cit., p. 10).

${ }^{106} \mathrm{Na}$ doutrina brasileira, Celso Agrícola Barbi (Ação declaratória principal e incidente. Rio de Janeiro: Forense, 1977. p. 64) e José Ignácio Botelho de Mesquita (Da ação civil. São Paulo: Revista dos Tribunais, 1975, p. 57-76) adotam a teoria de Giuseppe Chiovenda. Em sua obra, Botelho de Mesquita parte do conceito de jurisdição para encontrar o de ação. Logo, a ação deflui da função da atividade jurisdicional, de 
direito de ação "apenas naqueles casos concretos em que também exista direito subjetivo, cuja proteção foi reclamada pelo autor". ${ }^{107}$

Precedeu a teoria de Chiovenda, a denominada teoria da ação como direito autônomo e abstrato, datada de 1877, por Degenkolb, na Alemanha. ${ }^{108}$ Para essa teoria, a ação é o direito à jurisdição, é o direito/poder de demandar. A ação é um direito público, subjetivo, autônomo e abstrato de exigir do Estado a jurisdição, prescindindo que o resultado seja favorável ou não. Necessário, contudo, que o autor demonstre um interesse seu, protegido em abstrato pelo direito material.

Alfredo Rocco foi mais além e difundiu que a teoria da ação como direito autônomo e abstrato se fragmenta em dois interesses: o interesse tutelado pelo direito, primário e concreto, protegido pelo direito material (interesse principal) e o interesse geral à sua tutela, abstrato e independente do primeiro, regido pelo direito processual de reclamar a atuação do Estado para defesa do interesse primário por parte do próprio Estado (interesse secundário abstrato), sendo o direito de ação dirigido contra o próprio Estado (é o interesse na intervenção do Estado para a realização dos próprios interesses tutelados). ${ }^{109}$ Francesco Carnelutti, por outro lado, configurou a ação como direito abstrato e de natureza pública, mas dirigida contra o juiz, e não contra o Estado, partindo como polo metodológico o conceito de lide, como o conflito intersubjetivo de interesses regulado ou composto pelo direito e qualificado como pretensão resistida. Por sua vez, a pretensão coaduna com a exigência de seu titular, fundada ou infundada, em subordinar ao seu

\footnotetext{
sorte que a ação, analisada sob a perspectiva do direito material lesado do autor, somente existirá se cumprida a finalidade da jurisdição. Piero Calamandrei, por sua vez, também perfilha a teoria concretista, com a ressalva de que o Estado, ao apresentar a prestação jurisdicional, não está sacrificando um interesse próprio para satisfazer a um interesse alheio. Em verdade, o Estado visa a atingir um de seus fins essencialmente público, de sorte a inexistir contraste entre o interesse particular do indivíduo e o interesse público do Estado, para assim ambos convergirem: "In realtà, quando lo Stato rende giustizia a chi gliela chiede, L'azione, com cui il privato si rivolge allo Stato per chiedere la tutela de suo interesse leso o minacciato, offre allo Stato per chiedere la tutela de suo interesse leso o minacciato, offre allo Stato l'occasione per riconfermare la sua autorità, manacciata dalla inosservanza della legge: in questo modo il privato, cercando la sodisfazione del suo interesse individuale, collabora all'atuazione del diritto oggettivo, mentre lo Stato, adoperandosi a restaurar ela legge, difende nelo stesso tempo il diritto soggetivo del privato." (La relatività del concetto d'azione. In: Studi sul processo civile. Padova: Cedam, 1947. v. 5, p. 12).

${ }^{107}$ MARCATO, Antonio Carlos. Procedimentos especiais. 12. ed. São Paulo: Atlas, 2006. p. 10.

108 Semelhante teoria restou formulada na mesma época, por Plósz, na Hungria. No Brasil, José Joaquim Calmon de Passos defende a teoria abstrata, para quem o direito de ação nem é direito a uma sentença favorável, nem é direito a uma sentença de mérito, mas sim um direito puro e simples a uma decisão (Ação no direito processual civil brasileiro. Salvador: Livraria Progresso, 1959. p. 146).

${ }^{109}$ ROCCO, Alfredo. La sentencia civil. Traducción de Mariano Ovejero. Buenos Aires: El Foro, 2003. p. 125 e ss.
} 
próprio interesse o interesse de outrem, bastando ser resistida para que ele leve seu reclamo ao conhecimento do Poder Judiciário. ${ }^{110}$

Por fim, ainda alinhados à teoria abstrata, Eduardo Juan Couture concebeu a ação integrada na categoria constitucional do direito de petição, ${ }^{111}$ definido como "poder jurídico, de titularidade de qualquer sujeito de direito, de acudir aos órgãos jurisdicionais para reclamar satisfação de uma pretensão", ${ }^{112}$ ao passo que José Joaquim Calmon de Passos definiu a ação como um direito do cidadão de obter uma decisão do Estado, seja ela de que conteúdo for. ${ }^{113}$

Embora a concepção da ação como direito autônomo e abstrato pareça mais acertada, essa definição soa exagerada, ao preceituar o exercício da ação exigido contra o próprio Estado, na medida que não é ele (corporificado no juiz como mero agente) o polo passivo da ação. Em relação à definição dada por Eduardo Juan Couture, ${ }^{114}$ o mero direito de petição não necessariamente atinge a finalidade da jurisdição, de sorte que o poder de acesso ao Judiciário não se confunde com o direito de ver examinada uma pretensão. Se, mediante a ação, a jurisdição atinge sua finalidade, realizando efetivamente o direito, ela só existe quando a situação material for realmente apreciada.

Por sua vez, a chamada teoria eclética da ação, ${ }^{115}$ inicialmente concebida por Pekelis, ${ }^{116}$ acentua o direito subjetivo contido na ação - direito de fazer agir o Estado e não direito de agir - e considera os outros direitos como mero reflexo desse único e verdadeiro direito subjetivo. Houve também quem afirmasse constituirr a ação o exercício de uma

110 CARNELUTTI, Francesco. Instituciones del proceso civil. Traducción de Santiago Sentis Melendo. Buenos Aires: El Foro, 1997. v. 1, p. 28.

111 Nesse sentido: CINTRA, Antonio Carlos de Araújo; GRINOVER, Ada Pellegrini; DINAMARCO, Cândido Rangel, Teoria geral do processo, cit., p. 270.

${ }^{112}$ COUTURE, Eduardo Juan, Fundamentos del derecho procesal civil, cit., p. 16.

${ }_{113}$ CALMON DE PASSOS, José Joaquim, A ação no direito processual civil brasileiro, cit., p. 145-146.

${ }^{114}$ COUTURE, Eduardo Juan, Fundamentos del derecho procesal civil, cit., p. 22-23.

115 Diz-se "eclética" por situar-se no meio termo entre a teoria concreta e a abstrata. Para Antonio Carlos Marcato, a teoria eclética é um das vertentes da teoria abstrata (Procedimentos especiais, cit., p. 11). Conforme sintetiza Kazuo Watanabe: "Por 'Teoria Eclética' se entende, basicamente, aquela que, na apuração das condições da ação, determina seja o nexo de instrumentalidade entre a ação e a situação de fato contrária ao direito, apurado através do exame das provas, e não apenas pela afirmativa do autor." ( $D a$ cognição no processo civil. 2. ed. São Paulo: Central de Publicações Jurídicas; Centro Brasileiro de Estudos e Pesquisas Judiciais, 1999, p. 88).

116 CINTRA, Antonio Carlos de Araújo; GRINOVER, Ada Pellegrini; DINAMARCO, Cândido Rangel, Teoria geral do processo, cit., p. 271. 
função pública; e também quem não a enquadrasse como direito ou poder, mas dever, configurando a obrigação de dirigir-se ao órgão jurisdicional para a solução dos conflitos. ${ }^{117}$ Por essa teoria, em linhas gerais, a ação é o direito a uma sentença de mérito. Todavia, para que exista o direito de ação, determinados requisitos devem ser preenchidos, quais sejam a presença das condições da ação. ${ }^{118}$ Ausentes as condições da ação, não existiria a ação e, consequentemente, não haveria o exercício da jurisdição. ${ }^{119}$

Em que pese a contribuição dada por Pekelis à ação como um dever, tal argumento não soa o mais acertado, porquanto a ação, quando muito, seria um ônus (a faculdade cujo exercício é posto como condição para se obter vantagem) que integra o direito subjetivo, poder ou faculdade, mas não um dever. ${ }^{120}$

Ainda no plano da teoria eclética, ${ }^{121}$ Enrico Tullio Liebman concebeu a ação como a provocação de uma atividade dos órgãos judiciários, um poder dirigido ao Estado, e por

117 CINTRA, Antonio Carlos de Araújo; GRINOVER, Ada Pellegrini; DINAMARCO, Cândido Rangel, Teoria geral do processo, cit., p. 271.

${ }^{118}$ Embora não seja o foco deste trabalho abordar as condições da ação (legitimidade de parte, interesse de agir e possibilidade jurídica do pedido), a doutrina moderna diverge quanto à ausência das condições da ação conduzirem necessariamente ao julgamento sem resolução de mérito. Em dado caso concreto, as condições da ação podem confundir-se com o mérito. Nesse sentido, sustentam Ovídio A. Baptista da Silva (Curso de processo civil: processo de conhecimento. 4. ed. São Paulo: Revista dos Tribunais, 1998, p. 107), Luiz Guilherme Marinoni e Sérgio Cruz Arenhart (Manual do processo de conhecimento. 3. ed. São Paulo: Revista dos Tribunais, 2004. p. 70-71) e José Roberto dos Santos Bedaque (Código de Processo Civil interpretado. In: MARCATO, Antonio Carlos (Coord.). Código de Processo Civil interpretado. 3. ed. São Paulo: Atlas, 2008. p. 9).

${ }^{119}$ Em sentido contrário, sustentam que as condições da ação são requisitos para o exercício regular da ação, de sorte que não representam a inexistência da ação e reflexamente haveria jurisdição: José Manoel de Arruda Alvim (Manual de direito processual civil. 12. ed. São Paulo: Revista dos Tribunais, 2008. v. 1. p. 442) e Humberto Theodoro Júnior (Curso de direito processual civil. 50. ed. Rio de janeiro: Forense, 2009. v. 1, p. 59).

120 CINTRA, Antonio Carlos de Araújo; GRINOVER, Ada Pellegrini; DINAMARCO, Cândido Rangel, Teoria geral do processo, cit., p. 272.

${ }^{121}$ Kazuo Watanabe bem delineia as distinções entre a teoria eclética e a teoria abstrata, no que toca à aferição das condições da ação e possibilidade de sentença de mérito: "Alguns exemplos poderiam evidenciar a sensível diferença teórica e prática entre esse modo de impostar as condições da ação, que é o único compatível com a teoria do direito abstrato de agir, e a colocação sustentada pela teoria eclética da ação que, como vimos, liga as condições da ação à situação de fato, afirmada e comprovada no processo, após a instrução e a avaliação das provas, e não in statu assertionis. A diferença é aferível fundamentalmente pelo exame do objeto da cognição." (Da cognição no processo civil, cit., p. 87-89). De forma didática, Kazuo Watanabe esboça algumas diferenças de reflexos práticos: numa ação de cobrança em que o autor afirma na inicial a natureza do crédito proveniente de dívida de jogo o juiz pode liminarmente indeferir a petição inicial por ausência de possibilidade jurídica (art. 295, parágrafo único, III, do CPC). Conclusão diversa pode ser aferida, todavia, no mesmo exemplo retrocitado, mas em situação que o autor alega que a dívida decorre de contrato de mútuo. Após a apresentação de contestação, fica provado que o crédito em tela provém de dívida de jogo. Nessa hipótese, pela teoria abstratista, a ação deverá ser julgada improcedente, de sorte a já restar analisado o próprio mérito da demanda e respectivo objeto litigioso (a afirmativa contida na inicial, aliada à constatação colhida na instrução de que a dívida provém de jogo, por si só já traz elementos suficientes ao magistrado para repelir o direito do autor, por reputar-se 
isso de natureza sempre pública e de conteúdo uniforme, este lastreado no pedido de tutela jurisdicional a um direito próprio. ${ }^{122} \mathrm{O}$ exercício do direito de ação se materializa quando o processo terminar com um provimento sobre o mérito da demanda, ainda que contrário ao autor. O direito a uma decisão deriva do poder de acesso ao Poder Judiciário constitucionalmente garantido. ${ }^{123}$

A definição de Liebman é adotada pela maioria da doutrina brasileira. ${ }^{124}$ Sendo um direito (ou poder) de natureza pública, que tem por conteúdo o exercício da jurisdição (existindo, portanto, antes do processo), assegurando às partes não somente a resposta do Estado, mas ainda o direito de sustentar as suas razões, o direito ao contraditório, o direito de influir sobre a formação do convencimento do juiz - tudo através daquilo que se denomina tradicionalmente devido processo legal (art. $5^{\circ}$, inc. LIV) ${ }^{125}-$, o direito de ação não resulta de uma concepção genérica, mas guarda laços de natureza constitucional (emanação do status civitatis).

Filiamo-nos a essa corrente, consistente no direito ${ }^{126}$ autônomo (prescinde a existência do direito subjetivo material ${ }^{127}$ ), abstrato (direito ao provimento jurisdicional,

inexistente). Por outro lado, a corrente defensora da teoria eclética irá concluir que a hipótese é de carência da ação, por sustentar que a dívida decorre de jogo de azar, e assim o pedido é juridicamente impossível.

122 LIEBMAN, Tullio Enrico, Manual de direito processual civil, cit., v. 1, p. 197-203. Interpretando essa doutrina, Cintra, Grinover e Dinamarco esclarecem que Liebman define o direito de ação como um direito subjetivo e instrumental e, mais que um direito, um poder correspondente à obrigação do Estado interessado na distribuição de justiça e correlato a uma pretensão material. Esse direito apresenta natureza constitucional, cuja função jurisdicional somente se exaure mediante sentença de mérito, favorável ou não ao autor. (Teoria geral do processo, cit., p. 271). Ao final, concluem: "Essa doutrina, que desfruta de notável interesse no Brasil, dá especial destaque às condições da ação (possibilidade jurídica do pedido, interesse de agir e legitimidade ad causam), colocadas como verdadeiro ponto de contato entre a ação e a situação de direito material.” (Ibidem, mesma página).

${ }^{123}$ LIEBMAN, Tullio Enrico, Manual de direito processual civil, cit., v. 1, p. 203.

${ }^{124}$ Nesse sentido: BUZAID, Alfredo. A ação declaratória no direito brasileiro. 2. ed. rev. e ampl., São Paulo: Saraiva, 1986, p. 111 e ss.; MARQUES, José Frederico. Instituições de direito processual civil. 2. ed. ed. Rio de Janeiro: Forense, 1962. v. 2, p. 16 e ss.; DINAMARCO, Cândido Rangel, Instituições de direito processual civil, cit., v. 3, p. 129 e ss.; GRINOVER, Ada Pellegrini. Ação (direito de) - II. In: ENCICLOPÉDIA Saraiva do direito. São Paulo: Saraiva, 1977. v. 2, p. 170-180; WATANABE, Kazuo, Da cognição no processo civil, cit., p. 76 e ss.

125 CINTRA, Antonio Carlos de Araújo; GRINOVER, Ada Pellegrini; DINAMARCO, Cândido Rangel, Teoria geral do processo, cit., p. 273.

${ }^{126}$ Direito autônomo ou poder? Essa distinção presente na doutrina parece não apresentar relevância prática e se limita a discussões doutrinárias, sendo aceitas ambas as acepções. Nesse sentido: "A doutrina dominante, mesmo no Brasil, conceitua a ação como um direito subjetivo. Os que entendem ser ela um poder, e não direito, partem da premissa de serem o direito subjetivo e a obrigação duas situações jurídicas necessariamente opostas (de vantagem e de desvantagem), presente um conflito de interesses; e, existindo conflito de interesses entre o autor e o Estado, não se poderá falar em direito subjetivo, senão em poder. Os que sustentam o contrário (ação com direito subjetivo) admitem que também o Estado tem interesse no exercício da função jurisdicional, mas não vêem nisso qualquer incoerência com a afirmação de existir uma verdadeira obrigação de exercê-la. Não aceitam que a configuração do conflito de interesses seja essencial à 
qualquer que seja sua natureza) e instrumental (no sentido de dar solução à pretensão de direito material) ao provimento jurisdicional (favorável ou não).

Nessa linha de raciocínio, o direito de ação, adotando-se a definição retrocitada, permite que o Estado-juiz conceda tutela jurisdicional àquele que realmente tenha direito, cuja realização da norma de direito material de forma justa somente será possível mediante a participação ativa das partes e do próprio juiz. Esse pensar, alinhado o direito de ação às vertentes citadas, converge para uma postura mais ativa do magistrado, o que se mostra relevante mediante o exercício dos poderes instrutórios, cujo ativismo calcado nas iniciativas probatórias terá por escopo analisar e conceder o provimento jurisdicional (favorável ou não). Vale dizer, para se atender ao direito constitucional de ação, deve o magistrado fazer uso de seus poderes instrutórios, com o condão de aproximar a tutela jurisdicional da forma mais próxima da verdade e respectiva aplicação do direito material. Somente assim esse direito constitucional de ação será exercido e respeitado em consonância com os princípios processuais e constitucionais previstos no sistema, tema esse que examinaremos em maior profundidade no Capítulo 4.

\subsection{Breves comentários sobre a defesa}

Em virtude do sentido contrário dos interesses dos litigantes, a bilateralidade da ação $^{128}$ e da defesa desenvolve-se como contradição recíproca. O réu também tem uma pretensão em face dos órgãos jurisdicionais (a pretensão de que o pedido do autor seja

noção de obrigação. O ordenamento jurídico, ao atribuir direitos e obrigações, tutela determinados interesses, estabelecendo previamente qual será o subordinante na hipótese de surgir o conflito. Mas entendem ser o conflito irrelevante para consubstanciar a obrigação. O obrigado pode ter interesse em cumprir sua obrigação e nem por isso ficará isento dela." (CINTRA, Antonio Carlos de Araújo; GRINOVER, Ada Pellegrini; DINAMARCO, Cândido Rangel, Teoria geral do processo, cit., p. 273). Sobre a concepção da ação como poder, ver: BEDAQUE, José Roberto dos Santos, Poderes instrutórios do juiz, cit., p. 53 e ss.

${ }^{127}$ A ideia de autonomia diz respeito ao exercício de direito de ação propriamente dito, e não ao provimento jurisdicional. A este, será necessária a presença do direito substancial. Nesse sentido, José Roberto Bedaque sustenta que: "A autonomia do direito de ação é relativa. Não se pode falar em absoluta independência de um instituto processual, com relação ao direito material, pois o direito processual não tem um fim em si mesmo. Sua finalidade é promover a realização prática do direito substancial. Embora o poder de provocar a jurisdição esteja previsto na Constituição e seja atribuído a todos, sua relevância para o direito processual existe somente quando ele funciona como um instrumento de atuação do direito material". Ao final, define a ação como "o poder de fazer com que o ordenamento jurídico seja atuado" ou poder de estimular essa atividade (jurisdição) e fazer com que ela atinja objetivo (Poderes instrutórios do juiz, cit., p. 56).

${ }^{128}$ A ideia de bilateralidade abrange as ações de jurisdição contenciosa. 
rejeitado), a qual assume uma forma antitética à pretensão do autor. ${ }^{129}$ A defesa reclama o exercício da garantia constitucional do contraditório e ampla defesa prevista no art. $5^{\circ}, \mathrm{LV}$, da Constituição Federal, de sorte que seja assegurado ao réu a possibilidade de contraditar o pedido do autor, bem como a oportunidade de informação, participação e reação a todos os atos processuais, e assim garantir o acesso à justiça, sob a ótica do réu em impugnar a pretensão do autor.

Nesse processo dialético, é pontuado de modo genérico o termo exceção como o poder jurídico que possibilita ao réu opor-se à ação movida pelo autor. ${ }^{130}$ Vale dizer, ao passo que a ação se funda na norma de direito objetivo, de igual sorte a exceção se presta ao direito de pleitear que a tutela jurisdicional do autor seja repelida, por não se adequar ao direito material. Trata-se, portanto, de direito de defesa, que por sua vez, também pode ser entendido como o ônus de defender-se. ${ }^{131}$

Assim como na pretensão do autor devem estar presentes as condições da ação e pressupostos processuais, de igual modo a exceção processual se destina a demonstrar a carência desses elementos. Paralelamente, ao passo que o autor deve fazer prova de seu direito, a exceção substancial se presta a atacar a própria pretensão do autor e o fundamento de seu pedido (exceção substancial direta), opondo fatos impeditivos, modificativos ou extintivos do direito alegado pelo autor, deixando de elidir propriamente a pretensão por ele deduzida (exceção substancial indireta, v.g., prescrição, novação, compensação). ${ }^{132}$

${ }^{129}$ CINTRA, Antonio Carlos de Araújo; GRINOVER, Ada Pellegrini; DINAMARCO, Cândido Rangel, Teoria geral do processo, cit., p. 290.

${ }^{130}$ Ibidem, p. 291.

${ }^{131}$ MARCATO, Antonio Carlos, Procedimentos especiais, p. 23.

${ }^{132}$ Embora não constitua objeto principal deste trabalho, vale trazer à colação as variações doutrinárias quanto a acepção do termo exceção. Cintra, Grinover e Dinamarco asseveram que alguns doutrinadores preferem reservar o nome exceção substancial apenas à defesa indireta de mérito, ao passo que a contestação materializa a defesa direta de mérito. Outros atribuem à exceção substancial a característica de preliminar de mérito. Há também classificação ligada aos efeitos das exceções, as quais denominam-se dilatórias (v.g. exceção de incompetência ou de suspeição) ou peremptórias (destinadas à extinção do processo, v.g., exceção de coisa julgada, de litispendência). A objeção é o conhecimento da defesa de ofício pelo juiz (v.g., incompetência absoluta, coisa julgada, pagamento), ao passo em que a exceção em sentido estrito diz respeito à defesa que só pode ser conhecida quando alegada pela parte (v.g., incompetência relativa, suspeição, vícios da vontade - art. 128 do CPC, parte final). Ao final, concluem que: "Na sistemática da legislação processual brasileira usa-se o nome exceção para indicar algumas exceções processuais, cuja arguição obedece a determinado rito (CPC, art. 304; CPP, art. 95; CLT, art. 799). Chamase de contestação, no processo civil, toda e qualquer outra defesa, de rito ou de mérito, direta ou indireta, contendo também preliminares (CPC, arts. 300 e 301).” (Teoria geral do processo, cit., p. 293). 
Por constituir instituto fundamental do direito processual paralelo ao direito de ação, a defesa também está sujeita a uma perspectiva publicista, de sorte que o direito de defesa não pode ser concebido apenas no interesse da parte, mas seu pleno exercício deverá garantir uma sentença justa, que resulte de processo no qual se proporcione ao julgador uma visão completa dos fatos e todos os elementos probatórios coligidos na demanda, a fim de lhe possibilitar a análise concreta de ambos os lados da questão. ${ }^{133}$

Logo, o exercício do direito de defesa não deve limitar-se à análise restrita das provas trazidas pelo réu, mas deverá o juiz valer-se de todos os elementos trazidos aos autos, a fim de permitir a formação de seu livre convencimento, que pode se tornar mais célere mediante o manejo dos poderes instrutórios. ${ }^{134}$ Assim, a defesa se assemelha ao exercício do direito de ação quanto às prerrogativas dos litigantes ligadas à produção de provas destinadas ao esclarecimento de pontos controvertidos na demanda. Na medida que a Constituição Federal de 1988 sedimentou como cláusula pétrea o exercício do direito de ação, ${ }^{135}$ ela também não olvidou a garantia fundamental do exercício do direito de defesa, ambos corolários da cláusula do devido processo legal.

Portanto, concluímos que a exceção se equipara ao direito de ação, como direito público subjetivo (ou poder) contraposto à pretensão do autor, prerrogativa também constitucionalmente garantida como consequência de devido processo legal e dos postulados que revestem o sistema contraditório do processo. Daí porque as mesmas teorias aplicáveis à natureza jurídica da ação se assemelham às que tratam da natureza jurídica da exceção, cuja pretensão se limita em rejeitar o pleito autoral. ${ }^{136}$ Nesse contexto,

\footnotetext{
${ }^{133}$ BEDAQUE, José Roberto dos Santos, Poderes instrutórios do juiz, cit., p. 57.

${ }^{134}$ Vide Capítulo 3.

${ }^{135} \mathrm{O}$ art. $5^{\circ}$, XXXV da Constituição Federal reza o princípio da inafastabilidade do Poder Judiciário.

136 Estas são as sínteses de Heitor Victor Mendonça Sica: "Desse caminho evolutivo extraem-se duas importantes consequências: a primeira é o reconhecimento de que o processo é instrumento público de solução de conflitos, não se prestando unicamente para satisfazer pretensões, mas sim a outorgar tutela jurisdicional a ambos os litigantes, em especial àquele que tem razão; a segunda é a de que o direito de ação não se exaure no ato de iniciativa processual (demanda inicial), mas se desdobra em um feixe de posições jurídicas exercitáveis ao longo de todo o processo com o objetivo de obter a tutela jurisdicional. Situados os contornos do direito de ação dentro dessas novas fronteiras, é evidente que ele se aproxima e se confunde com o direito de defesa, pois, por imperativo da garantia de tratamento isonômico e paritário, ambos se materializam num conjunto (quase) igual de poderes exercitáveis ao longo do processo, para obtenção da tutela jurisdicional. As únicas diferenças entre ação e defesa toleradas pela ordem constitucional são aquelas que sejam inerentes à posição de iniciativa tomada pelo autor. Assim, ação e defesa, como categorias fundamentais do direito processual civil, acabam se fundindo e se diluindo em torno do conceito de tutela jurisdicional. Sem prejuízo dessas seguras conclusões, não abandonamos a terminologia tradicional, que denomina o autor titular da ação e o réu titular da defesa. Todavia, não há mais como qualificá-los como 'aquele que pede e aquele em face de quem é pedido', respectivamente, mas sim abraçar
} 
a dinâmica da relação processual apresenta prerrogativas semelhantes entre as partes litigantes, envoltas numa série de poderes, faculdades e ônus pretéritos à efetiva entrega da tutela jurisdicional. ${ }^{137}$

De igual sorte, são uniformes os conteúdos do exercício das prerrogativas das partes dentro do processo, notadamente no que tange à distribuição do ônus da prova prevista no art. 333 do Código de Processo Civil. Sendo o direito de defesa de natureza constitucional, o exercício dessa garantia deve ser permitido de modo amplo e abrangente, a fim de contrapor-se ao próprio direito de ação. Essa assertiva é adequada à pacificação social pretendida pelo Estado-juiz, a fim de que o contraditório e a ampla defesa permitam atingir o escopo da jurisdição.

Embora não seja objeto deste trabalho esmiuçar o conceito de defesa, as breves considerações retrocitadas permitem concluir que as prerrogativa das partes destinadas à produção de provas dentro do processo se assemelham para autor e réu, e assim se institui um processo dialético, no qual a atividade do juiz ligada à avaliação da prova e exercício dos poderes instrutórios terá reflexos semelhantes quanto à posição dos litigantes, no que toca à oportunidade franqueada a cada um para a produção de provas de suas alegações e respectiva participação em contraditório.

\subsection{Conclusões parciais e projeção dos institutos fundamentais sobre os poderes instrutórios}

A jurisdição, definida como a capacidade do Estado de dirimir os conflitos que envolvem as pessoas, decidir sobre as pretensões apresentadas e impor decisões revela uma das funções do Estado, mediante a qual ele se substitui aos titulares dos interesses em

a concepção de que autor e réu são os 'sujeitos do contraditório'." (Direito de defesa e tutela jurisdicional: estudo sobre a posição do réu no processo civil brasileiro, cit., p. 313).

137 “Tomada nesse sentido, da exceção é lícito afirmar que configura um direito análogo e correlato à ação, mais parecendo um particular aspecto desta: aspecto esse que resulta exatamente da diversa posição que assumem no processo os sujeitos da relação processual. Tanto o direito de ação como o de defesa compreendem uma série de poderes, faculdades e ônus, que visam à preparação da prestação jurisdicional". (CINTRA, Antonio Carlos de Araújo; GRINOVER, Ada Pellegrini; DINAMARCO, Cândido Rangel, Teoria geral do processo, cit., p. 292). Aliás, a ideia de bilateralidade torna-se mais latente na medida que a própria desistência da demanda, após citação do réu, somente é possível mediante sua participação e consentimento, conforme impõe o $§ 4^{\circ}$ do art. 267 do Código de Processo Civil. 
conflito para, imparcialmente, ${ }^{138}$ buscar a pacificação do conflito que os envolve, com justiça.

Por sua vez, através do escopo jurídico, se depreende a concretização dos escopos sociais e políticos quanto à pacificação de conflitos. Ou seja, na vontade concreta da lei, encontra-se a pacificação social, mediante atuação imperativa do Estado-juiz. Necessária, portanto, a existência da lei e sua aplicação, cuja subsunção e imposição ganham contornos de flexibilidade necessários à correta entrega do bem da vida. ${ }^{139}$

O processo pode ser definido como uma relação jurídica processual de direito público (ainda que privado o interesse das partes, é público o interesse do Estado-juiz quanto a pacificação de conflitos de modo justo - escopo social) em que se desenvolve a ação e a defesa, e que se impõe como instrumento necessário à aplicação da regra concreta com justiça.

A ação é o direito autônomo constitucional, abstrato e instrumental ao provimento jurisdicional, de sorte que a defesa reflete igual direito público, contraposto à pretensão do autor e constitucionalmente garantida como corolário do devido processo legal e dos postulados que revestem o sistema contraditório do processo.

Portanto, através da breve análise feita dos institutos fundamentais, podem-se extrair algumas conclusões preliminares. Todas as teorias eleitas na tentativa de melhor

\footnotetext{
138 Cassio Scarpinella Bueno bem delineia as características da jurisdição, a saber: substitutividade, consistente na substituição, pelo Estado, da vontade dos litigantes, porquanto a decisão a se proferida pelo Estado-juiz é imperativa a eles e compulsória; imperatividade, calcada no "poder-dever" do Estado à luz do modelo de Estado adotado que a Constituição Federal de 1988 impôs no sistema brasileiro, de sorte que a substitutividade leva à compreensão da imperatividade. Há, ainda, a característica da imutabilidade necessária a imunizar e impedir que seja rediscutido, inclusive pelo próprio Estado-juiz, determinadas decisões por ele proferidas no âmbito da função jurisdicional, o que materializa a coisa julgada material expressa no art. 5, XXXVI da Constituição Federal. A inafastabilidade reside, em síntese, no "poderdever" do Estado, quando provocado, dar uma resposta ao jurisdicionado, a fim de atender a garantia constitucional prevista no art. $5^{\circ}, \mathrm{XXXV}$, da Constituição Federal. Ainda, a indelegabilidade revela que os órgãos que podem exercer a função jurisdicional, atuar jurisdicionalmente, são única e exclusivamente aqueles que a Constituição Federal cria e autoriza, de sorte que é vedada a delegação de função jurisdicional sem que haja prévia previsão constitucional, sendo ela exercida nos limites delineados pela Carta Magna. Por fim, a inércia pressupõe a provocação do interessado para o exercício da função jurisdicional e, uma vez provocado, o Estado-juiz atua de ofício e por impulso oficial. (Curso sistematizado de direito processual civil: teoria geral do direito processual civil. São Paulo: Saraiva, 2007. v. 1, p. $243-$ 248).

139 Sob essa premissa, para cada flexibilização, interpretação ou aplicação da lei de modo mais amplo, imperiosa a fundamentação e justificativa dessa exceção à regra, a fim de se evitarem decisões teratológicas e inócuas.
} 
delinear a concepção de jurisdição, defesa, ação e processo desaguam numa visão publicista do direito processual civil, que exige maior participação do juiz, no ensejo de tentar ao máximo aproximar-se da entrega da tutela jurisdicional justa.

A jurisdição, sendo atividade do Estado-juiz, deve ser exercida mediante o poderdever de pacificar conflitos com justiça. Portanto, o interesse do Estado se sobrepõe ao direito dos litigantes e tem como finalidade fazer atuar o direito objetivo, revestida a finalidade de se decidir de forma équa. Um dos caminhos seguros para o correto exercício desse poder-dever se materializa mediante "uma dose de poder investigatório que o juiz há de ter no processo (limitações ao poder dispositivo das partes)". ${ }^{140}$ A concepção mais ampla da jurisdição em realizar a vontade concreta da lei (escopo jurídico) e do modo mais équo possível reclama postura mais ativa do magistrado que, por sua vez, demanda o exercício dos poderes instrutórios voltados a se apurar um juízo próximo da certeza dos fatos para a entrega da tutela jurisdicional. E uma decisão calcada na aproximação da verdade (diante de maiores elementos probatórios trazidos aos autos) conduz ao melhor acerto na aplicação da vontade concreta da lei (escopo jurídico), realizando-se, por via reflexa, um dos aspectos do escopo social, ao se pacificar conflitos com justiça.

Já o processo atua como instrumento, ${ }^{141}$ como meio necessário para o desenvolvimento da relação jurídica processual havida entre autor e réu, sendo assegurado a eles as garantias constitucionalmente previstas para o exercício do direito de ação, do contraditório e ampla defesa. Nessa relação processual conduzida pelo Estado-juiz, em que se desenvolvem a ação e a defesa, caberá a ele, mediante atuação do magistrado, materializar e coordenar os atos processuais, a fim de atingir a finalidade do instrumento de atuação da lei. Conforme pondera Bedaque, ${ }^{142}$ sendo o processo uma relação jurídica voltada à atuação da vontade da lei, inadmissível qualquer confusão entre a relação processual e a de direito material, porquanto a atividade dos que integram a relação processual se destina à realização da lei, não aos bens da vida, objeto das relações substanciais. Logo, pouco importa ser a relação material de direito público ou privado,

\footnotetext{
${ }^{140}$ DINAMARCO, Cândido Rangel, Fundamentos do processo civil moderno, cit., v. 1, p. 116-117.

141 "Sendo o processo instrumento da jurisdição, deve ser entendido em função desta, ou seja, como o instrumento de atuação da lei no caso concreto, como o instrumento de garantia do ordenamento jurídico, da autoridade do Estado. É mediante o processo que o Estado prestigia a ordem jurídica vigente, impondo as normas de direito material às situações da vida real.” (BEDAQUE, José Roberto dos Santos, Poderes instrutórios do juiz, cit., p. 67).

${ }^{142}$ Ibidem, p. 70.
} 
deve ser lembrado que o processo sempre terá a finalidade de manutenção do ordenamento jurídico, do que advém a afirmação da autoridade do Estado e a paz social. Essa relação processual é, portanto, independente da relação de direito material, de sorte a remanecer a relação de instrumentalidade entre o processo e o direito objetivo material, pois aquele visa à atuação deste. Daí porque soa acertada a conclusão de que essa finalidade do processo "satisfaz não apenas o interesse das partes cujas relações são reguladas pelas normas de direito material, mas, principalmente, o interesse público na obediência à ordem jurídica estabelecida. Aliás, este último se sobrepõe ao primeiro". ${ }^{143}$

E, para pacificar conflitos mediante a atuação concreta da lei, através do processo como instrumento, materializada a ação e a defesa como meios de manifestação dos litigantes e garantia dos princípios constitucionais e processuais, os poderes instrutórios guardam fundamental importância na consecução de se resolver o conflito com justiça mediante a correta atuação do direito. Assim, a concepção moderna dos institutos fundamentais do processo civil conduz a uma postura mais ativa do magistrado, paralela a contornos publicistas, o que implica, por conseguinte, a importância que merece o tema dos poderes instrutórios. Vale dizer, mediante o ativismo judicial ligado ao exercício dos poderes instrutórios, observadas as garantias e princípios que regulam o sistema, tem-se um julgamento que se aproxima ao máximo de um juízo de certeza, cujo reflexo resulta na entrega da tutela jurisdicional de forma justa e alinhada à atuação concreta da lei. Isso ocorre porque interessa ao próprio Estado-juiz decidir os conflitos da forma mais próxima à certeza, mediante a correta aplicação do direito material, razão pela qual o exercício dos poderes instrutórios é a manifestação da vontade concreta da lei, tendo o processo como instrumento.

Portanto, inegável que o direito processual civil moderno guarda feições de transcendência do interesse público sobre o privado, ${ }^{144}$ servindo os poderes instrutórios

\footnotetext{
${ }^{143}$ BEDAQUE, José Roberto dos Santos, Poderes instrutórios do juiz, cit., p. 69.

144 "Superada hoje a corrente que considera como objeto do processo a defesa de direitos subjetivos, pois resulta de uma análise privatista do fenômeno. Sua finalidade é a atuação do direito objetivo, sendo a proteção de direitos, subjetivos uma consequência natural. (...) Com o desenvolvimento da ciência processual, todavia, não mais se admite tal enfoque, resultado de uma visão eminentemente privatista do processo. O interesse público na correta atuação da lei deve prevalecer sobre o interesse particular das partes em ver reconhecido seus direitos. A nova escola processual transformou a maneira de considerar o processo e sua finalidade. Melhor explicando: o Estado tem interesse na integridade do ordenamento jurídico e na pacificação social. Por isso, institui uma função voltada especificamente para esse fim (jurisdição). Para fazer com que os órgãos jurisdicionais atuem e alcancem o seu objetivo de aplicação do direito, os destinatários da norma de direito material devem manifestar-se (ação e defesa). Da dialética
} 
como mecanismo destinado à obtenção da tutela jurisdicional justa e mais próxima do direito objetivo. Ou seja, a concepção moderna dos institutos processuais fundamentais se encontra entrelaçada ao ativismo judicial, ${ }^{145}$ notadamente para atender à ordem jurídica justa. Esse pensar deflui como consequência da chamada publicização do processo civil, tema cujos contornos estão assentados não só por força da evolução das garantias constitucionais, mas também da própria ciência processual.

A seguir, analisaremos a evolução das influências publicistas (seja no plano processual, seja no plano constitucional) que se aproximam de uma postura mais ativa do juiz em relação às iniciativas probatórias.

desenvolvida pelas partes e coordenada pelo juiz, surge o instrumento que possibilitará a formulação e atuação da regra jurídica para o caso concreto (processo). Esse fenômeno, analisado por um ângulo publicista, está voltado para um só objetivo: a atuação do direito, com o que estará garantida a paz social." (BEDAQUE, José Roberto dos Santos, Poderes instrutórios do juiz, cit., p. 69 e 71).

${ }^{145}$ BEDAQUE, José Roberto dos Santos, Direio e processo: influência do direito material sobre o processo, cit., p. 53. 


\section{PUBLICISMO PROCESSUAL E PODERES INSTRUTÓRIOS}

O fenômeno da publicização do processo reside, em síntese, na tendência ao desapego do sincretismo do direito privado para assim tornar o processo civil um ramo do direito público, ${ }^{146}$ ou seja, o Estado-juiz passa, de mero espectador passivo do acompanhamento do exercício de faculdades, ônus e prerrogativas das partes dentro do processo, a assumir feição mais ativa, destinada a realizar um bem maior, calcado na aproximação de certeza dos fatos necessária à aplicação concreta da lei destinada a trazer a pacificação social. Conforme leciona Bedaque:

"O juiz é o Estado administrando a justiça: não é um registro passivo e mecânico dos fatos, em relação aos quais não o anima nenhum interesse de natureza vital. Não lhe pode ser indiferente o interesse da justiça. Este é o interesse da comunidade, do povo, do Estado, e é no juiz que um tal interesse se representa e personifica." 147

Semelhante definição é dada por Juan Montero Aroca:

"Estos postulados llevan a la necesidad de resolver de modo rápido el conflicto entre las partes, y para ello el mejor sistema es que el juez no se limite a juzgar sino que se convierta en verdadero gestor del proceso, dotado de grandes podres discrecionales, que han de estar al servicio de garantizar, no sólo los derechos de las partes, sino principalmente los valores e intereses de la sociedad." 148

\footnotetext{
146 Já em 1858, Oskar Von Bülow sustentava a idéia do direito processual como pertencente ao direito público: "Se acostumbra a hablar, tan solo, de relaciones de derecho privado. A éstas, sin embargo, no puede ser referido el proceso. Desde que los derechos y las obligaciones procesales se dan entre los funcionários del Estado y los ciudadanos, desde que se trata en el proceso de la función de los oficiales públicos y desde que, también, a las partes se las toma en cuenta unicamente en el aspecto de su vinculación y cooperación con la actividad judicial, esa relación pertence, con toda evidencia, al derecho público y el proceso resulta, por lo tanto, una relación jurídica pública." (La teoria de las excepciones procesales y los presupuestos procesales, cit., p. 1-2). Por sua vez, Cândido Rangel Dinamarco, ao tecer comentários acerca dos institutos fundamentais da ação, defesa e processo, bem assevera haver uma "relação jurídica pública" em que gravitam esses institutos em torno da jurisdição, cuja coordenação assenta sobre uma relação jurídica de direito público ( $A$ instrumentalidade do processo, cit., p. 91). Entendendo o direito processual civil como ramo do direito público, ver também: NERY JUNIOR, Nelson. Princípios do processo civil na Constituição Federal. 9. ed. São Paulo: Revista dos Tribunais, 2009, p. 41; THEODORO JÚNIOR, Humberto, Curso de direito processual civil, cit., v. 1, p. 2; BUENO, Cassio Scarpinella, Curso sistematizado de direito processual civil, cit., v. 1, p. 26; SANTOS, Moacyr Amaral. Primeiras linhas de direito processual civil. 17. ed. São Paulo: Saraiva, 1994. v. 1, p. 17; MARQUES, José Frederico, Manual de direito processual civil, cit., v. 1, p. 41; e SILVA, Ovídio A. Baptista; GOMES, Fábio Luiz. Teoria geral do processo civil. 4. ed. São Paulo: Revista dos Tribunais, 2006. p. 41-43; dentre outros.

${ }^{147}$ BEDAQUE, José Roberto dos Santos, Poderes instrutórios do juiz, cit., p. 77

${ }^{148}$ MONTERO AROCA, Juan. El derecho procesal em el siglo XX. Valencia: Tirant lo blanch. 2000, p. 71.
} 
Essa feição mais ativa, exteriorizada mediante a atuação do Estado-juiz, transcende o interesse particular das partes na obtenção do resultado do processo, para assim realizarse a correta aplicação da lei com justiça. A pacificação que se realiza pela aplicação da lei reclama uma série de atos, em verdade poderes do juiz destinados a amealhar elementos necessários à entrega da justa tutela jurisdicional. Assim, caberá ao magistrado, mediante utilização dos poderes que lhe são conferidos pelo Estado, coordenar a realização dos atos processuais, notadamente o campo da produção probatória necessária à formação de seu livre convencimento para, ao final, proferir sentença fundamentada em argumentos e elementos probatórios carreados ao bojo dos autos.

Portanto, o fenômeno da publicização do processo civil reclama maior intervenção do juiz no processo. ${ }^{149}$ Essa intervenção estatal, materializada na atuação do magistrado de maneira mais ativa no curso do processo, despreza a visão liberal de conceber o processo como relação jurídica privada das partes. Vale dizer, o Estado-juiz deixa de ser mero aplicador das normas de direito material na entrega da tutela jurisdicional, para atender ao interesse público na distribuição da justiça de forma justa e efetiva.

Em contrapartida, deve-se ter em mente que o ativismo judicial não significa poderes ilimitados e absolutos conferidos ao Estado-juiz. Não se devem coroar decisões arbitrárias e teratológicas sob o manto de uma hipertrofia dos poderes do juiz. Por essa razão, a todo poder outorgado no Estado Democrático de Direito corresponde à existência de travas e regras limitadoras e de controle, sob pena de permitir-se o autoritarismo. As premissas que serão tratadas neste capítulo refletem fundamentos a desaguar na justificativa do aumento dos poderes do juiz, entre os quais os poderes instrutórios.

\footnotetext{
149 “A necessidade de o juiz assumir a efetiva posição de condutor do processo, com ampla participação no contraditório desenvolvido pelas partes, corresponde à tendência unânime da moderna ciência processual. Amplia-se, dessa forma, a noção de contraditório, para incluir também a efetiva atuação do juiz no desenvolvimento da relação processual. A tendência de maior participação do juiz no processo é consequência de profundas alterações verificadas na fisionomia individualista do modelo processual clássico." (BEDAQUE, José Roberto dos Santos, Direito e processo: influência do direito material sobre o processo, cit., p. 53). A publicização, em suma, racionaliza a ideia de uma relação jurídica de direito público entre juiz e as partes no processo. Sobre o tema e sua linha precursora, ver o original: Bülow, Oskar Von. Die lehre von den Prozesseinreden und die prozessvoraussetzungen. Gissen, Ed. Roth, 1868 (Traducción: La teoria de las excepciones procesales y los presupuestos procesales, cit.).
} 
Nos Capítulo 3 e 4, trataremos dos poderes instrutórios do juiz, sua dimensão, limites e aplicação, enquanto os tópicos abaixo visam a aprofundar, primeiramente, as premissas retrocitadas.

\subsection{Linhas evolutivas: da fase sincrética à instrumental}

No decorrer da evolução do direito processual como ciência, houve três fases distintas, a saber: a fase sincrética, a fase autonomista e a fase instrumentalista. ${ }^{150}$

O direito processual ainda não era reconhecido como ciência autônoma até meados do século XIX. A fase sincrética, também conhecida por imanentista ou civilista, caracterizou-se pela confusão entre os planos substancial e processual do ordenamento jurídico, sendo o processo tratado como mero apêndice do direito material. Os civilistas ou imanentistas consideravam fundamental o direito material, tanto que o denominaram direito substantivo, de sorte que o processo, visto como simples conjunto de formalidades (mero procedimento) para sua atuação prática, era chamado de direito adjetivo, inexistindo, portanto, noção alguma do próprio direito processual como ramo autônomo, sobretudo carentes elementos para a sua autonomia científica.

Tal definição começou a se fragilizar por conta das inquietações levantadas em torno do instituto da ação, ressaltando sua autonomia em relação ao direito material, e não mais como algo agregado ao direito substancial. Essas afirmações inovadoras provocaram reações em cadeia, que chegaram até a plena consciência da autonomia, não só da ação, mas também dos demais institutos processuais.

Foi então formulada a teoria da autonomia da relação jurídica processual em face da relação jurídica de natureza substancial, eventualmente ligando os sujeitos do processo, e houve uma nova conceituação do direito de ação pelos alemães, sob influência do direito italiano, que foram decisivas para a dissociação do direito processual frente ao direito material ou substancial.

\footnotetext{
${ }^{150}$ CINTRA, Antonio Carlos de Araújo; GRINOVER, Ada Pellegrini; DINAMARCO, Cândido Rangel, Teoria geral do processo, cit., p. 48-51. No mesmo sentido: DINAMARCO, Cândido Rangel, $A$ instrumentalidade do processo, cit., p. 17 e ss.
} 
O ano de 1868 simbolizou o marco de início da autonomia científica ${ }^{151}$ do direito processual, com a publicação da obra do jurista alemão Oskar Von Bulow denominada Die Lehre von den Prozesseinreden und die Prozessvoraussetzungen (Teoria das exceções e dos pressupostos processuais), quando se iniciou o desenvolvimento da teoria do processo como relação jurídica. $\mathrm{O}$ estudo desse processualista traçou os princípios fundamentais que deram contornos de ciência ao direito processual, criando bases sólidas para a fase autônoma do processo. Em síntese, houve a segmentação dos dois planos do ordenamento jurídico, a partir da visão da relação processual e da relação de direito privado como duas realidades distintas, conforme já comentado no item 1.3.

Durante a fase autonomista, não obstante afirmar-se a existência de uma relação jurídica deduzida no processo distinta da travada pelos indivíduos no plano material, inovou-se, outrossim, pela enumeração das premissas metodológicas do processo como ciência, de sorte a desenvolver a definição das grandes teorias processuais, notadamente sobre a natureza jurídica da ação e do processo, as condições daquela e os pressupostos processuais, para assim sedimentar raízes que serviram como base para a afirmação do direito processual como ciência autônoma, ${ }^{152}$ cujo período perdurou por praticamente um século. $^{153}$

Nesse contexto, merece destaque a crítica tecida por Grinover, Cintra e Dinamarco:

"Faltou, na segunda fase, uma postura crítica. O sistema processual era estudado mediante uma visão puramente introspectiva, no exame de seus institutos, de suas categorias e conceitos fundamentais; e visto o processo costumeiramente como mero instrumento técnico predisposto à realização da ordem jurídica material, sem o reconhecimento de suas conotações

\footnotetext{
${ }^{151}$ Dinamarco bem assevera que o sincretismo que misturava os planos substancial e processual principiou a ruir no século XIX. A começar pela crítica ao tradicional conceito civilista da ação, de sorte a diferenciá-la como instituto de direito processual dirigido ao juiz, em que se reclama a prestação jurisdicional Ao final, conclui que: "A celeuma provocada por essas afirmações revolucionárias (hoje, tão naturais aos olhos do jurista moderno) acabou gerando reações em cadeia, que chegaram até à plena consciência da autonomia não só da ação, mas dela e dos demais institutos processuais." (A instrumentalidade do processo, cit., p. 1819).

${ }^{152}$ A autonomia da ação e do processo, segundo Dinamarco, trouxe a renovação dos estudos de direito processual, para consagrá-lo como ciência em si mesmo, revestido de objeto próprio e definido em seu próprio método (A instrumentalidade do processo, cit., p. 19-20).

${ }^{153}$ CINTRA, Antonio Carlos de Araújo; GRINOVER, Ada Pellegrini; DINAMARCO, Cândido Rangel, Teoria geral do processo, cit., p. 48. Este trabalho não tem o condão de analisar, tampouco confrontar todas as teorias que circundam a fase autonomista. O que se pretende neste tópico é tão somente apresentar breves contribuições sobre as três fases metodológicas fundamentais do direito processual, cujo resultado da pesquisa se presta a delimitar e desenvolver estudos voltados à perspectiva instrumentalista do processo.
} 
deontológicas e sem a análise dos seus resultados na vida das pessoas ou preocupação pela justiça que ele fosse capaz de fazer."154

Essa preocupação com um processo de resultados desencadeou novos estudos ligados à fase instrumentalista do processo, ou seja, ao desenvolvimento da ciência processual voltada à busca de um processo que traga resultados céleres, práticos e efetivos, quanto à obtenção da tutela jurisdicional. ${ }^{155}$

Portanto, o processo passou a ser visto a partir de ângulos externos, visando a cumprir seus escopos sociais, políticos e jurídicos supracitados, ou seja, deve-se levar em conta os resultados que ele proporciona para os destinatários dos provimentos jurisdicionais.

Assim, a realidade sociojurídica não é compatível com a preocupação voltada ao estudo do tecnicismo exacerbado que imperou durante a fase científica, época que teve por intuito caracterizar o direito processual, criando institutos solenes, de forma a ratificar sua autonomia. Superada a afirmação do direito processual como ciência autônoma e definidos seus institutos fundamentais, voltou-se o processualista moderno ao estudo dos resultados do processo perante os consumidores do serviço processual.

E esses resultados destinados a trazer efetividade na prestação da tutela jurisdicional se aproximam do interesse do próprio Estado-juiz, cujo ambiente, dessa perspectiva metodológica, também está ligado com a visão publicista do processo, na medida que para se atingir o escopo maior voltado à ordem jurídica justa, ${ }^{156}$ necessária a

${ }^{154}$ CINTRA, Antonio Carlos de Araújo; GRINOVER, Ada Pellegrini; DINAMARCO, Cândido Rangel, Teoria geral do processo, cit., p. 48-49.

${ }^{155}$ Referências legislativas não faltam quanto à tentativa de se buscar um processo mais justo e de resultados, a exemplo da Lei dos Juizados Especiais (Lei n. 9.099/95), da Lei da Ação Civil Pública (Lei n. 7.347/85), do Código de Defesa do Consumidor (Lei n. 8.078/90) e do Estatuto da Criança e do Adolescente (Lei n. 8.069/90). Todas essas leis, na maioria de seu conteúdo, se destinavam à oferta de tutela jurisdicional coletiva.

${ }^{156}$ Na definição de Ada Pellegrini Grinover, “(...) o acesso à ordem jurídica justa pressupõe um corpo adequado de juízes, com sensibilidade para captar a realidade social e suas vertiginosas transformações. E que isso postula exigência da mudança da mentalidade do juiz, inserido que há de ser no corpo social e comprometido com o objetivo de realização da justiça material. A aderência do juiz à realidade demanda, por sua vez, um constante aprimoramento, inclusive por intermédio de estudos interdisciplinares permanentes e, antes ainda, exige critérios de seleção e métodos de recrutamento que transcendam a avaliação de conhecimentos puramente técnicos" (Processo em evolução. Rio de Janeiro: Forense, 1996. p. 25). 
intervenção e participação mais ativa do juiz. Daí porque José Carlos Baptista Puoli, após analisar as tendências instrumentalistas difundidas pela doutrina, conclui que:

\begin{abstract}
“(...) se por um lado é certo que a tendência para incremento dos poderes do juiz não pode ser definida como um processo novo de restauração de nossa ciência, por outro pode-se afirmar, sem medo, que ela agora tomou novo rumo e uma mais alta relevância, na medida que, seja por intermédio do estudo da doutrina que vem sendo produzida neste final de século, seja pelo exame das alterações legislativas recentemente introduzidas em nosso sistema legal, tudo tem colocado o aumento dos poderes do juiz em lugar de destaque entre as várias propostas de alternativas para obtenção dos resultados queridos pelo sistema instrumental do processo." 157
\end{abstract}

Portanto, a atual preocupação do estudo da ciência processual apresenta contornos voltados à visão do processo como um instrumento público. ${ }^{158}$ Sob a ótica do processo como instrumento público e ainda restrita à análise dos poderes instrutórios como meio de participação ativa do juiz, com vistas a atender o interesse do Estado na pacificação de conflitos com justiça, será examinado o duplo sentido da instrumentalidade.

\title{
2.2 O duplo sentido da instrumentalidade
}

Inicialmente, cumpre esclarecer que a instrumentalidade do processo aqui tratada não se confunde com o princípio da instrumentalidade das formas. A primeira constitui o próprio sistema processual, sob uma perspectiva exterior, de sorte que esse complexo é examinado sob uma ótica ampla, mediante sua inserção na ordem jurídica, política e social. Já a instrumentalidade das formas apresenta menos abrangência dentro da

\footnotetext{
157 PUOLI, José Carlos Baptista. Os poderes do juiz e as reformas do processo civil. São Paulo: Juarez de Oliveira, 2002, p. 54.

${ }^{158}$ As premissas tratadas neste tópico seguem sintetizadas por Dinamarco, ao concluir que o direito judiciário civil viveu desde suas origens, e por muitos séculos, arraigado ao direito privado e como seu apêndice ( $A$ instrumentalidade do processo, cit., p. 49-50). Somente no século XIX o processo civil passou a ser afirmado como relação jurídica processual, adstrita, portanto, ao direito privado, com que a visão sincrética restou abolida. Com isso, abriram-se caminhos para o progresso da ideia publicista do direito processual, que inclusive está ligada com o desenvolvimento da própria teoria do Estado, no que toca à sua inevitabilidade e imposição de poder. Após discorrer sobre a evolução das diversas teorias acerca da ação e primeira abertura favorável ao reconhecimento da natureza pública da relação processual, da ação e de todo o sistema processual, Dinamarco conclui: "Presencia-se, pois, a uma ciência processual construída mediante afirmações e pressupostos publicistas, mas revelando surpreendentes posicionamentos sobrevivos ao sincretismo privatista já superado. Seguramente, concorreu para essa predisposição psicológica a origem do direito processual civil, que hoje unanimemente se reconhece ser ramo do direito público, nos compartimentos do direito privado." (Ibidem, p. 53).
} 
instrumentalidade e diz respeito a princípio relacionado a possíveis vícios ligados aos atos processuais, porquanto as formas constituem um instrumento a serviço dos objetivos, não sendo racional nem legítima a anulação do ato viciado, quando o objetivo tiver sido atingido. $^{159}$

Assim, o aspecto negativo da instrumentalidade como sistema está ligado ao princípio da instrumentalidade das formas, cuja conquista metodológica reza, em linhas gerais, o repúdio ao excesso de formalismo, porquanto as regras do processo não devem ter valor absoluto que sobrepuje as do direito substancial e as exigências sociais de pacificação de conflitos. Vale dizer, deve-se negar o processo como valor em si mesmo e rejeitar os excessos de forma quando atingida a finalidade de pacificação social. $\mathrm{O}$ apego exagerado à técnica retira do processualista a consciência de que o processo não vale pelo que ele é, mas pelos resultados que ele visa a atingir. É a valorização dos fins a serem atingidos que se impõe sobre os meios. ${ }^{160}$

Nesse contexto, é corrente o emprego da técnica processual destinada a repudiar formalismos exacerbados. Não se resume à técnica voltada apenas ao campo das nulidades, porquanto o ato supostamente anulável poderá convalecer quando prejudica somente a parte vencedora na demanda (art. $249, \S \S 1^{\circ}$ e $2^{\circ}$, do CPC), ${ }^{161}$ mas contém aptidão mais ampla, ligada ao próprio julgamento da demanda. Nesse contexto, Dinamarco cita como exemplo a dissociação dos efeitos da revelia com o julgamento antecipado da lide. ${ }^{162}$ Sendo o réu revel (art. 219 do CPC), não deverá o juiz necessariamente julgar com antecipação a lide com base nas provas e elementos até então carreados nos autos, ${ }^{163}$ sob pena de assim o fazendo apegar-se ao rigor da norma, ignorando por inteiro sua função primordial, consistente em pacificar conflitos com justiça. Conforme leciona Dinamarco:

\footnotetext{
${ }^{159}$ DINAMARCO, Cândido Rangel, A instrumentalidade do processo, cit., p. 314.

${ }^{160}$ Sobre o tema, ver: BEDAQUE, José Roberto dos Santos. Efetividade do processo e técnica processual. São Paulo: Malheiros, 2006; e OLIVEIRA, Carlos Alberto Alvaro de. Do formalismo no processo civil. 3. ed. São Paulo: Saraiva, 2009.

${ }^{161}$ Daí porque Bedaque sustenta que, mediante interpretação sistemática e teleológica, deve-se verificar qual a razão de determinada exigência legal quanto à forma. Uma vez identificada essa ratio legis, deve-se examinar se eventual atipicidade infere nos objetivos do ato, se implica violação ao devido processo legal ou causa prejuízo às partes. Inexistindo tais gravames, permite-se a ignorância do vício, de sorte que se coroe o alcance do valor mais importante: a entrega da tutela jurisdicional definitiva (Efetividade do processo e técnica processual, cit., p. 105).

${ }^{162}$ DINAMARCO, Cândido Rangel, A instrumentalidade do processo, cit., p. 317.

${ }^{163}$ Essa assertiva será melhor desenvolvida no item 3.1.2.2.
} 
"Sem transformar as regras formais do processo "num sistema orgânico de armadilhas ardilosamente preparadas pela parte mais astuciosa e estrategicamente dissimuladas no caminho do mais incauto', mas também sem renegar o valor que têm, o que se postula é, portanto, a colocação do processo em seu devido lugar de instrumento que não pretenda ir além de suas funções; 'instrumento cheio de dignidade e autonomia científica, mas nada mais do que instrumento'.,164

Essa visão teleológica evidencia maior observância ao princípio da instrumentalidade das formas, com vistas a minimizar desvios formais, de maneira que, por maior que seja o vício, a parte prejudicada no processo seja vencedora no mérito. Logo, esse reclamo decorrente de suposta nulidade mostra-se serôdio e desnecessário, porquanto a parte que o reclama já seria beneficiada com uma sentença de mérito, o que torna irrelevante eventual gravame suportado pela parte vencedora dentro do processo.

Sob esta premissa, o aspecto negativo da instrumentalidade é diametralmente oposto ao aspecto positivo que, por sua vez, está ligado à efetividade do processo, consistente no proveito que ele seja potencialmente apto a "exaurir os objetivos que o legitimam no contexto jurídico-social e político". ${ }^{165}$ Essa tendência metodológica resume a observância aos escopos da jurisdição já delineados neste trabalho. Reflete, em linhas gerais, a máxima de que o processo "deve proporcionar a quem tem um direito tudo aquilo e precisamente aquilo que ele tem o direito de obter". ${ }^{166}$ Assim, soa mais lógica a realização do escopo jurídico da jurisdição num primeiro plano, para então atingirem-se os escopos sociais e políticos. Uma vez realizada a correta subsunção do fato à norma, mediante utilização da norma de direito material, busca-se, através do provimento jurisdicional, acomodar os escopos políticos e sociais.

\footnotetext{
${ }^{164}$ Discurso de posse no cargo de juiz no $1^{\circ}$ Tribunal de Alçada Cível de São Paulo (DINAMARCO, Cândido Rangel, A instrumentalidade do processo, cit, p. 318).

${ }^{165}$ DINAMARCO, Cândido Rangel, A instrumentalidade do processo, cit., p. 315.

${ }^{166}$ No original: "Il processo deve dare per quanto è possibile praticamente a chi há um diritto tutto quello e proprio quello ch'egli há diritto di conseguire." (CHIOVENDA, Giuseppe. Dell'azione nascente dal contratto preliminare. In. Saggi di diritto processuale civile. 2. ed. Roma: Foro Italiano, 1930. v. 1, n. 3, esp. p. 110). Nesse contexto, Cândido Rangel Dinamarco discorre sobre o aspecto positivo da instrumentalidade, desdobrando-o em quatro vertentes, a saber: admissão em juízo, ligada, em síntese, à universalidade da tutela jurisdicional e disponibilização de meios de acesso à justiça; o modo de ser do processo, consistente na dialética entre autor e réu, que deve observar o contraditório, a inquisitividade, a prova e o procedimento; a justiça nas decisões, que apregoa o valor justiça como objetivo síntese da jurisdição no plano social; e a efetividade das decisões, ligada ao real resultado que o processo deve produzir quando da entrega do bem da vida pretendido, ou seja, de nada adianta um comando previsto na sentença sem que ele guarde efeitos que transcenda o que restou estabelecido no decisum ( $A$ instrumentalidade do processo, cit., p. 323 e ss.).
} 
Nesse contexto, Dinamarco bem adverte sobre a necessidade de maior relativização do binômio direito-processo, com vistas a superar a mentalidade da antiga e já superada fase autonomista ou privatista, a fim de que o processo sirva como instrumento do qual se possa extrair maior proveito. ${ }^{167}$

Portanto, seja no aspecto negativo, seja no aspecto positivo da instrumentalidade, evidenciam-se contornos publicistas. A relação do duplo sentido da instrumentalidade com os poderes instrutórios se acentua, na medida que ao Estado-juiz não caberá seguir as regras processuais de modo rígido e incontrastável. Ou seja, a despeito da existência de ônus, deveres e sujeições conferidas às partes dentro do processo, por vezes a função pública do processo (mormente por ser o juiz o destinatário da prova) ${ }^{168}$ reclama a relativização de formalismos não seguidos (aspecto negativo), para assim se obter a tutela jurisdicional justa (aspecto positivo). Assim, o tema poderes instrutórios volta a acenderse, com vistas a se atender a um processo instrumental, cujo resultado efetivo e justo, por vezes, reclama maior ativismo judicial. Daí porque os poderes instrutórios podem servir como técnica destinada ao resultado que irá propiciar ao processo, resultado que deverá pautar-se na obtenção mais próxima da verdade e que reflita a melhor aproximação da vontade concreta da lei, quando do julgamento de um conflito de interesses.

Mais uma vez, esse reclamo a obtenção da tutela jurisdicional justa visa a preservar o alinhamento da moderna visão teleológica do processo pautada no interesse do Estadojuiz em pacificar conflitos com equidade e efetividade, o que, por sua vez, demanda, em dadas situações, de um lado, a relativização de determinadas regras internas do processo (aspecto negativo) e, de outro, uma postura mais ativa do magistrado, necessária para se atingir a efetividade e justiça das decisões (aspecto positivo).

\footnotetext{
167 "Na mentalidade dos juízes, é preciso que, além de todas essas alterações, esteja presente o empenho muito vivo pelo efetivo comando do processo. Sua obcecada preocupação pelo compromisso que têm com a justiça será o melhor fator para uma participação mais efetiva, dando cumprimento aos ditames do processo civil como instrumento do Estado, empregado na persecução de objetivos que são seus. Tal é a postura publicista que se preconiza, com alteração das tradicionais fórmulas do equilíbrio ente o princípio dispositivo e o inquisitivo." (DINAMARCO, Cândido Rangel, A instrumentalidade do processo, cit., p. 61).

${ }^{168}$ Esse tema será melhor tratado no item 2.5.
} 


\subsection{Da transição do liberalismo individualista para o Estado Social: reflexos no aumento dos poderes do juiz}

Inúmeras premissas históricas, cujos reflexos abarcaram a transição do Estado Liberal (privatista) para o chamado Estado Social (intervencionista) se prestam a justificar os desdobramentos e necessidades aptos a impor maior intervenção do juiz no curso do processo, dotando-o de maiores poderes e atributos destinados à busca da entrega da tutela jurisdicional justa. Seria tarefa árdua e mergulhada em terreno pantanoso a tentativa de explorar todos os aspectos que desaguaram no contemporâneo modelo de intervenção estatal. Considerando o estudo central deste estudo, restringiremos, pois, a metodologia de estudo desse tema sob a ótica do direito privado, na medida que o direito material é tutelado pelo direito processual. ${ }^{169}$

O chamado Código Napoleônico (Código Civil francês de 1804) introduziu o modelo clássico e liberal da autonomia da vontade. A vontade das partes era vista como expressão suprema, materializado o contrato como justo e equitativo por sua própria natureza, porquanto os contratantes tinham o livre consentimento de autorregulamentar seus interesses.

Ao Estado-juiz cabia tão somente a aplicação da norma a cada caso concreto, ficando limitada a atuação do magistrado ao positivismo previsto no comando da lei, cabendo a ele enquadrar o fato à norma, restringindo-se, desse modo, à ótica de um sistema fechado. ${ }^{170}$

\footnotetext{
${ }^{169}$ Bedaque bem delineia as diferenças entre o direito processual e o direito substancial, de sorte que este último serve como instrumento para tutela do primeiro: "A partir dessas noções de direito substancial, é possível distingui-lo do direito processual. Enquanto aquele é constituído por um conjunto de normas destinadas a regular os conflitos de interesses, de natureza individual ou coletiva, determinando o que deve prevalecer, o direito processual é formado por regras cuja finalidade é garantir que a norma substancial seja atuada, mesmo quando o destinatário não o faça espontaneamente." (Direito e processo: influência do direito material sobre o processo, cit., p. 11).

${ }^{170}$ Significa dizer que a vontade dos entes contratantes, numa concepção voluntarista e individualista, cujo ápice de afirmação teve esteio no modelo clássico do contrato (Estado Liberal), era a expressão suprema justa e equitativa por sua própria natureza, porquanto as próprias partes dispunham de autonomia para contratar e autorregulamentar seus interesses. A única limitação era a afronta à ordem pública e aos bons costumes, restrição ainda modesta, conquanto aplicada somente nas hipóteses imperativas previstas em lei, v.g., as regras sobre a capacidade das partes.
} 
Porém, a partir do final do século XIX, ${ }^{171}$ e principalmente no período pós-guerra do século XX, desenvolveu-se a massificação das relações jurídicas, com os chamados contratos estandartizados ou de adesão, que influenciaram a erradicação do modelo clássico e liberal da autonomia da vontade em relação a um dos polos da relação contratual, na medida que cabe à parte aderir ou não às cláusulas predispostas no contrato.

Como reflexo dessa transição, foi necessária maior intervenção estatal ${ }^{172}$ no regime dos contratos, de modo a trazer à tona a ideia de socialização do direito. É o chamado dirigismo contratual ou ordem pública de direção. No âmbito da ordem pública de direção, Claudia Lima Marques bem assevera que:

“(..) na Europa, antes da Segunda Guerra Mundial, a socialização
iniciada do Direito foi incapaz de conter o fortalecimento do poder do
Estado. Estado e Direito tornaram-se sinônimos. O Estado refortalecido
começa um processo estatizante, passa a dirigir e a intervir na atividade
econômica, transforma-se em grande parceiro contratual. Deste processo
resulta o fortalecimento do direito administrativo e do direito de trabalho,
mas, também, refletirá na chamada publicização do Direito Civil."

Assim, a concepção clássica da autonomia da vontade não mais se amolda à nova realidade contratual, ou seja, a vontade do indivíduo como manifestação suprema vai encontrar limitações nas normas de ordem pública e na finalidade de atender também ao

\footnotetext{
${ }^{171} \mathrm{Na}$ verdade, os reflexos do fenômeno da revolução industrial foram o marco para uma nova concepção na sinergia das relações econômicas. Por sua vez, o final do século XIX foi marcado pelo aumento da circulação de riquezas e o dinamismo da troca de produtos, que irão intensificar-se com o modelo capitalista predominante no período pós-guerra, de modo a aumentar vertiginosamente as relações contratuais. Em igual sentido complementa José Carlos Baptista Puoli, ao discorrerr que o desenvolvimento da economia de massa fez com que os conflitos perdessem sua característica individual para dar lugar a uma conotação coletiva, seja em razão de se tratar de direitos disponíveis que ganham gravidade socialmente relevante por força do elevado número de conflitos subjacentes (relações de consumo), seja em razão da natureza desses direitos apresentar feição indisponível, como o direito ao meio ambiente (Os poderes do juiz e as reformas do processo civil, cit., p. 11).

${ }^{172}$ Deveras, a antiga concepção do modelo clássico do contrato como afirmação suprema da vontade das partes (autonomia da vontade) trazida pelo Estado Liberal não mais se adequava à conjuntura econômica contemporânea da sociedade. Isso porque o contrato como elemento de circulação de riquezas, a fim de proporcionar sua massificação e atender aos anseios da sociedade, reclama a presença de um Estado interventor no regime dos contratos, o chamado Estado Social intervencionista.

${ }^{173}$ MARQUES, Cláudia Lima. Contratos no Código de Defesa do Consumidor. São Paulo: Revista dos Tribunais, 1995. p. 72. Ainda sobre as diferenças entre as correntes privatista e publicista, José Roberto dos Santos Bedaque exemplifica: “O que varia é o ângulo pelo qual a jurisdição é analisada. Com inteira razão anotou Calamandrei que a razão do contraste é de caráter político e histórico. A concepção de jurisdição como atividade destinada à defesa de direitos subjetivos é originária do individual-liberalismo, onde a função do direito é, principalmente, a conciliação dos interesses individuais contrapostos. A corrente oposta coloca em primeiro plano o interesse público da manutenção do ordenamento." (Poderes instrutórios do juiz, cit., p. 30).
} 
interesse social. Tem-se, portanto, a transição do liberalismo individualista para o "Estado social de direito", mediante incremento da participação dos órgãos públicos na vida da sociedade. $^{174}$

Sob a ótica do direito processual, algumas transformações puderam ser sentidas, mediante a superação da linha de legitimação individual corrente na maioria das demandas, correspondente a um tratamento atômico tradicional dos conflitos, que cedeu, para determinadas hipóteses em que o bem tutelado afeiçoa-se a natureza supraindividual, cujo resultado da demanda impõe a molecularização do direito e do processo para tratar o litígio, a partir de uma ótica solidarista que se evidencia mediante soluções destinadas também a grupos de indivíduos, e não somente a indivíduos enquanto tais. ${ }^{175}$ Trata-se da tutela de direitos difusos e coletivos, que se alinham às chamadas "ondas de acesso à justiça", que serão tratadas no item seguinte. De todo modo, essa molecularização evidencia um dos aspectos da transição do Estado Liberal para o Estado Social, mediante a

\footnotetext{
${ }^{174}$ Essa é também a explicação empregada por Cândido Rangel Dinamarco, cujos reflexos do fenômeno não deixaram de atingir a ciência processual: "As transformações políticas e sociais havidas na Europa desde o século anterior tinham sido capazes de alterar a fórmula das relações entre o Estado e o indivíduo, com a ruptura de velhas estruturas - e isso foi responsável pelas primeiras preocupações em definir os fenômenos do processo, onde assoma a figura do juiz como agente estatal, a partir de premissas e conceitos antes não revelados à ciência dos estudiosos que se debruçavam sobre o direito judiciário civil (mera procédure). Tinha-se, até então a remansosa tranquilidade de uma visão plana do ordenamento jurídico, onde a ação era definida como o direito subjetivo lesado (ou: o resultado da lesão ao direito subjetivo), a jurisdição como sistema de tutela aos direitos, o processo como mera sucessão de atos (procedimento); incluíam a ação no sistema de exercício de direitos (jus quod sihi debeatur, judicio persequendi) e o processo era tido como conjunto de formas para esse exercício, sob a condução pouco participativa do juiz. Era o campo mais aberto, como se sabe, à prevalência do princípio dispositivo e ao da plena disponibilidade das situações jurídico-processuais - que são direitos descendentes jurídicos do liberalismo político então vigente (laissez faire, laissez passer et le monde va de lui même)." (A instrumentalidade do processo, cit., p. 17-18). Por outro lado, Cassio Scarpinella Bueno elucida duas vertentes que trazem à evidência os reflexos da transição do Estado Liberal ao Estado Social Democrático. A primeira delas é a própria interferência do Estado em suas diversas órbitas - União, Estados membros, Municípios, Distrito Federal, suas autarquias e fundações públicas no cotidiano da vida dos particulares, cujo extenção não se limita ao âmbito público, mas também exerce influência sobre as relações privadas. A segunda vertente deriva da anterior, de sorte a limitar a atuação do Estado quanto a conservação do exercício das liberdades públicas, assim entendidos os direitos civis, políticos e sociais constitucionalmente assegurados (Curso sistematizado de direito processual civil, cit., v. 1, p. 33-34).

${ }^{175}$ Para Dinamarco, a necessidade de "molecularização" também pode ser sentida sob a ótica do processo atingir o escopo social, de modo a tornar uniforme as decisões de conflitos de massa. Assim, para se fazer atuar a vontade concreta do direito diante da realidade dos problemas contemporâneos, tem-se manifesta tensão entre as normas e a realidade, o que reclama a chamada "molecularização" (A instrumentalidade do processo, cit., p. 329 e 255 ).
} 
previsão legal da tutela de interesses difusos, coletivos e individuais homogêneos, cuja natureza do bem da vida objeto do litígio reclama tutela jurisdicional diferenciada. ${ }^{176}$

Por sua vez, Marcelo Abelha Rodrigues também fundamenta a intervenção estatal, materializada na ampliação dos poderes instrutórios do juiz, sob a assertiva de busca do resultado de justiça, de entrega da ordem jurídica justa somente se houver igualdade e armas e de chances no manuseio dos instrumentos processuais, principalmente os probatórios. Assim, denota maior comprometimento com a verdade real. ${ }^{177}$

De igual modo, conforme leciona Barbosa Moreira, essa maior participação do Estado-juiz se destina a abolir a imagem do magistrado como arquétipo do observador distante e impassível da luta entre as partes, simples fiscal incumbido de vigiar-lhes o comportamento, para assegurar a observância das "regras do jogo" e, no fim, proclamar o vencedor. Já em 1985, Barbosa Moreira escrevia sobre os reflexos dessa intervenção estatal, materializada não só através da ampliação dos poderes do juiz em busca da verdade real, mas também mediante a utilização de técnicas destinadas a equacionar a isonomia de tratamento das partes dentro do processo (paridade de armas). ${ }^{178}$ Em 2005, semelhante ideia foi lembrada com vistas a exigir função mais participativa do órgão jurisdicional:

\footnotetext{
${ }^{176}$ Embora não seja objeto deste trabalho o aprofundarmento em alguns aspectos das ações coletivas, em linhas gerais, as inovações legislativas voltadas à tutela de interesses difusos, coletivos e individuais homogêneos estão previstas na Lei n. 7.347/85 (Lei da Ação Civil Pública), na Lei n. 4.717/65 (Lei da Ação Popular), no Título III da Lei n. 8.078/90 (Código de Defesa do Consumidor) e no art. 5º LXXIII, da Constituição Federal de 1988. Tais inovações, decorrentes da natureza do bem jurídico tutelado, dizem respeito, em síntese, ao regime da coisa julgada e legitimidade ativa para representação de interesses difusos, coletivos e individuais homogêneos em juízo. Conforme leciona Rodolfo de Camargo Mancuso, "a parte processual do Código de Defesa do Consumidor traslada-se para o âmbito da ação civil pública (art. 21 da Lei n. 7.347/85, acrescentado pelo art. 117 do CDC), sendo verdadeira a recíproca, ou seja, a parte processual relativa à ação civil pública, naquilo que não for incompatível, também se aplica às ações coletivas previstas no Código de Defesa do Consumidor. Ainda, o art. $1^{\circ}$ da Lei da Ação Civil Pública (Lei n. 7.347/85) invoca, expressamente, a ação popular, assim completando o circuito de interação e complementariedade na normação que rege o vasto campo dessas ações coletivas, em sentido largo" (Ação popular, proteção do patrimônio público, da moralidade administrativa e do meio ambiente. 5. ed. São Paulo: Revista dos Tribunais, 2003. p. 38). Por outro lado, o art. 5º LXXII, da Constituição Federal, além de conferir legitimidade ao cidadão para o exercício da ação popular, ainda delimita suas hipóteses de incidência destinada a evitar a ocorrência de atos lesivos ao patrimônio público, histórico, cultura e paisagístico, além de zelar pela proteção da moralidade administrativa, o que corrobora a subsistência dessa espécie de demanda por força do comando constitucional.

${ }^{177}$ RODRIGUES, Marcelo Abelha. A distribuição do ônus da prova no anteprojeto do Código Brasileiro de Processos Coletivos. In. GRINOVER, Ada Pellegrini; MENDES, Aluisio Gonçalves de Castro; WATANABE, Kazuo. (Coord.). Direito processual coletivo e o anteprojeto de Código Brasileiro de Processos Coletivos. São Paulo: Revista dos Tribunais, 2007. p. 245-253.

178 BARBOSA MOREIRA, José Carlos. A função social do processo civil moderno e o papel do juiz e das partes na direção e na instrução do processo. Revista de Processo, São Paulo, Revista dos Tribunais, ano 10, n. 37, p. 140-150, jan./mar. 1985.
} 


\begin{abstract}
"A ideia subjacente a essas reformas, ocioso ressaltar, é a de que o processo deve chegar a um resultado justo, de preferência com dispêndio mínimo de tempo e energias. Ora, o que normalmente quer cada uma das partes é sair vitoriosa, tenha ou não razão: pouco lhe importa, em regra, que se mostre justo o resultado, desde que lhe seja favorável; e, quando não tem razão, importa-lhe de ordinário retardar o desfecho do pleito. Há de existir alguém que atue imparcialmente no sentido de que o processo tenha marcha regular e venham aos autos todos os elementos necessários para que o julgamento corresponda, na medida do possível à realidade. Esse alguém não pode ser outro senão o órgão judicial." 179
\end{abstract}

Destarte, a visão privatista do processo em que a disponibilidade das provas compete exclusivamente às partes ganha novos contornos, materializados em postura mais ativa do magistrado quanto à produção de provas. Essa nova perspectiva também irá trazer novos questionamentos, notadamente o confronto de valores entre o princípio dispositivo e busca de uma tutela jurisdicional justa, conforme pondera Cappelletti:

\begin{abstract}
"Bien puede decirse, en verdad, que el clamoroso conflicto que resurge entre un sistema dispositivo-contencioso ('adversarial') y un sistema inquisitorio de procedimiento, no es outra cosa que un aspecto del gran desafío de nuestra época: el de conciliar la libertad privada individual con la justicia social."
\end{abstract}

${ }^{179}$ BARBOSA MOREIRA, José Carlos. O neoprivatismo no processo civil. Revista de Processo, São Paulo, Revista dos Tribunais, ano 30, n. 122, p. 9, abr. 2005. Nesse texto é bem lembrado que, em diversos sistemas jurídicos, as principais manobras legislativas que deram margem ao aumento dos poderes instrutórios do juiz ocorreram em regimes democráticos, o que retira qualquer cogitação de autoritarismo, a exemplo da reforma do ZPO alemão, em 2001 (§ 142, $1^{\text {a }}$ e $2^{\mathrm{a}}$ alíneas), o Codice di Procedura Civile de 1940 na Itália, a lei federal suíça que regula o processo civil federal, de 04.12.1947 (notadamente o art. 37: “Le juge n'est pas lié par les offres de preuve des parties; il ne retient que les preuves nécessaires. Il peut ordonner des preuves que les parties n'ont pas offertes"), o Code de Procédure Civil francês de 1975 (arts. 16 e 143), inúmeras alterações legislativas introduzidas a partir de 1998 na Civil Procedure Rules da Inglaterra (Rule 32.1, rule 18.1, rules 35.7, 35.8 (3) (b) e rule 35.15) a Lei n. 9.099/95, ao estatuir em seu art. $5^{\circ}$ que "o juiz dirigirá o processo com liberdade para determinar as provas a serem produzidas, para apreciá-las e para dar especial valor às regras de experiência comum ou técnica”, sem prejuízo do art. 130 do Código de Processo Civil. Portanto, ao contrário do que sustentam vozes que se opõem ao aumento dos poderes do juiz, os poderes instrutórios tiveram sementes legislativas arraigadas em cenários democráticos, de sorte que a experiência demonstra que nos regimes autoritários, o que prevaleceu foi supressão dos poderes dos juízes e fortalecimento do Poder Executivo. Semelhante ideia também é tratada na série Temas de Direito Processual: “A ciência do direito processual nasceu e desenvolveu-se no ambiente cultural do liberalismo individualista. Era natural que o Zeitgeist impregnasse a doutrina e maioria das grandes codificações oitocentistas. Naquelas e nestas avultava como traço característico o papel passivo atribuído ao juiz, assim como se queria o Estado tanto quanto possível alheio, na economia, ao livre jogo das forças do mercado (laisser faire), também se propugnava, para o órgão judicial, posição de distanciamento em face da luta entre as partes, reservadas a estas, com exclusividade, não só a iniciativa do processo, mas a introdução de elementos probatórios e, em boa medida, a própria condução do feito." (BARBOSA MOREIRA, José Carlos. Os novos rumos do processo civil brasileiro. In: Temas de direito processual: sexta série. São Paulo: Saraiva, 1997. p. 6-7).

${ }^{180}$ CAPPELLETTI, Mauro. Proceso, ideologias, sociedad. Traducción de Santiago Sentis Melendo e Tomás A. Banzhaf. Buenos Aires; EJEA, 1974, p. 86. A fim de justificar essa conclusão, Cappelletti aponta o cerne de um código de processo mais "social", como o foi o código austríaco de 1895: "Esta evolución marcó el comienzo de la legislación social en las naciones más adelantadas, acontecimiento fielmente reflejado, por ejemplo, en el código de procedimiento civil austriaco de 1895 com su concepción del 
Logo, os escopos do processo como meio de pacificação social e de realização da ordem jurídica justa ${ }^{181}$ afastam o interesse exclusivo das partes na condução do processo, cabendo ao Estado-juiz, investido em seu poder de jurisdição, buscar ao máximo aproximar-se da verdade dentro do processo. ${ }^{182} \mathrm{E}$, para tanto, o exercício dos poderes instrutórios servem como efetivo mecanismo destinado à aproximação de um juízo de certeza, cujo resultado se reflete na entrega da tutela jurisdicional, ao realizar a vontade concreta da lei. Vale dizer, se a prova se presta a convencer o juiz sobre a existência ou não de um fato, sua restrição contraria a própria lógica do processo que é destinada a realizar a vontade concreta da lei. Ausentes os elementos probatórios necessários para decidir, a tutela jurisdicional deixará de coroar o escopo jurídico e, por sua vez, deixará de ser justa.

Assim, sendo o processo instrumento de função pública, prevalece o interesse do Estado na busca da tutela jurisdicional justa. ${ }^{183}$ Isso não significa, todavia, que o juiz deva a todo custo determinar a produção de provas no processo de forma indistinta e desprovida de fundamentação. Conforme será analisado nos Capítulos 3 e 4, a limitação dos poderes instrutório reside na observância dos princípios constitucionais e processuais, sem prejuízo da correlação de investigação probatória com o pedido do autor. O aumento dos poderes do

procedimiento como instrumento para la educación y el bien estar social una idea que pronto revelaria gran fuerza de expansión en las legislaciones de otros países. Además, mientras el individualismo del ochocientos estaba fielmente reflejado en la concepción del procedimiento civil como 'asunto privado de las partes' - 'Privatsache der Partein' -, el movimiento hacia la afirmación de um papel más activo del juez en la dirección del proceso refleja en cambio la creciente exigencia de intervenciones públicas en la economia y en general en la vida privada, lo que es justamente un típico elemento de la época contemporanea." (Ibidem, mesma página).

${ }^{181}$ Conforme leciona Cândido Rangel Dinamarco, o acesso à justiça é o acesso à ordem jurídica justa, que por sua vez é a obtenção da justiça substancial. Daí conclui que: "Não obtém justiça substancial quem não consegue sequer o exame de suas pretensões pelo Poder Judiciário e também quem recebe soluções atrasadas ou mal formuladas para suas pretensões, ou soluções que não lhe melhorem efetivamente a vida em relação ao bem pretendido. Todas as garantias integrantes da tutela constitucional do processo convergem a essa promessa-síntese que é a garantia do acesso à justiça assim compreendido." (Instituições de direito processual civil, v. 1, cit., p. 118).

${ }^{182}$ Por essa razão a maior intervenção do Estado também se reflete no processo, através da atuação mais ampla do magistrado no curso do processo, para conferir caráter mais publicista. Semelhante ideia também é pontuada por José Carlos Baptista Puoli, inclusive sob a premissa de atuação mais participativa do juiz alinhada ao repúdio à já ultrapassada concepção do Estado Liberal: "Esta concepção, hoje ultrapassada, de repúdio ao juiz ativo e participativo era corolário da (já referida) filosofia preponderantemente liberal e individualista que dominava o pensamento do século passado e baseava sua visão de mundo nos conceitos de liberdade, igualdade formal e propriedade, os quais eram estudados sob o enfoque do indivíduo, ou seja, sem que houvesse uma maior preocupação com a repercussão que o exercício de tais direitos pudesse ter em relação à coletividade. Neste contexto, era deixada para o Estado uma função secundária que vinha sintetizada pelo ideal do 'Estado mínimo'." (Os poderes do juiz e as reformas do processo civil, cit., p. 22).

${ }^{183}$ Nesse sentido, Bedaque conclui: "Os estudos mais recentes estão voltados para a publicização do processo civil, ainda que os interesses discutidos sejam privados. O processo é o instrumento mediante o qual se exerce uma função pública, havendo predominante interesse do Estado em seu desenvolvimento. Assim, não pode o juiz ser reduzido a mero espectador do debate travado pelas partes." (Poderes instrutórios do juiz, cit., p. 132). 
juiz guarda ligação com a própria evolução das garantias constitucionais norteadoras do sistema, conforme demonstraremos a seguir.

\subsection{O direito processual constitucional e as ondas renovatórias de acesso à justiça}

O direito processual, como ramo do direito público, possui linhas fundamentais sedimentadas pelo direito constitucional, de modo a ligar a relação entre institutos processuais e seus pressupostos políticos e constitucionais. Essas linhas mestras evidenciam-se mediante princípios ou comandos previstos na Constituição, cujos aspectos delineiam não só vertentes do processo como instrumento técnico, mas também impõem a observância de preceitos éticos, pautados em fatores históricos, sociológicos e políticos. Assim, a Constituição se presta a equilibrar forças políticas assentes na sociedade em dada projeção histórica, de modo a servir como instrumento jurídico a ser utilizado pelo processualista para o completo entendimento do fenômeno do processo e seus princípios. $^{184}$

Ao estudo do direito processual civil a partir da Constituição Federal (que se baseia no modelo constitucional do direito processual civil brasileiro ${ }^{185}$ ), dá-se o nome de direito processual constitucional, ${ }^{186}$ que, por sua vez, subdivide-se em tutela constitucional dos princípios fundamentais da organização judiciária e do processo (voltada ao estudo das normas constitucionais sobre os órgãos da jurisdição, sua competência e garantias consistente no direito de acesso à justiça ou direito de ação e de defesa, e, por outro lado, direito ao processo ou garantia do devido processo legal, no sentido Constituição $\rightarrow$ processo) ${ }^{187}$ e jurisdição constitucional (consistente no controle judiciário de constititucionalidade das leis e dos atos da Administração, sem prejuízo da denominada jurisdição constitucional das liberdades, mediante uso dos remédios constitucionais

\footnotetext{
${ }^{184}$ CINTRA, Antonio Carlos de Araújo; GRINOVER, Ada Pellegrini; DINAMARCO, Cândido Rangel, Teoria geral do processo, cit., p. 84-85.

${ }^{185}$ BUENO, Cassio Scarpinella, Curso sistematizado de direito processual civil, cit., v. 1, p. 92. O "modelo constitucional do processo civil" está mais ligado à observância dos "princípios constitucionais do direito processual civil”, tema que será tratado no Capítulo 4.

${ }^{186}$ DINAMARCO, Cândido Rangel, Instituições de direito processual civil, v. 1, cit., p. 55.

${ }^{187}$ Essas garantias serão melhor analisadas no Capítulo 4.
} 
processuais, v.g., habeas corpus, habeas data, mandado de segurança, mandado de injunção e ação popular, no sentido processo $\rightarrow$ Constituição). ${ }^{188}$

De igual modo que a evolução da ciência processual sofreu influências publicistas (vide item 2.1), o direito constitucional, em sua atual e maior proximidade com o direito processual, ${ }^{189}$ também não ficou imune à linha de pensamento voltada ao ativismo estatal.

Destarte, embora não siga à risca a mesma ordem cronológica relativa à evolução do direito constitucional (assunto que será tratado mais adiante), vale trazer à colação as ideias traçadas por Mauro Cappelletti e Bryan Garth. ${ }^{190}$ Em meio à vertente da educação (escopos de pacificação social tratada no item 1.2.1.) e aos escopos políticos, encontra-se a questão relacionada às ondas de acesso à justiça voltadas a um processo que sirva mais como instrumento (meio) do que um fim.

188 CINTRA, Antonio Carlos de Araújo; GRINOVER, Ada Pellegrini; DINAMARCO, Cândido Rangel, Teoria geral do processo, cit., p. 86. Cassio Scarpinella Bueno sustenta que alheia ao "direito processual constitucional se encontra a tutela constitucional do processo ou direito constitucional processual", este voltado ao estudo amplo do conjunto das normas de direito processual previstas na Constituição Federal (Curso sistematizado de direito processual civil, cit., v. 1, p. 35-36). Em igual sentido: NERY JUNIOR, Nelson, Princípios do processo civil na Constituição Federal, cit., p. 41. Conforme apontamentos e conclusão deste autor, é irrelevante discutir se a escolha metodológica mais apurada seria tutela constitucional do processo ou direito constitucional processual. O que se pretende e guarda importância é a adoção do método de trabalho que coloque a Constituição Federal como elo indispensável para compreender o processo civil e a sua técnica na atualidade.

189 A posição enciclopédica do direito processual está inserida como ramo do direito público, porquanto governa a atividade jurisdicional do Estado. De igual sorte, é indubitável sua ligação com o direito constitucional, na medida que a Constituição traça os contornos e bases do direito processual, conforme lecionam Cintra, Grinover e Dinamarco: "O direito constitucional estabelece as bases do direito processual ao instituir o Poder Judiciário, criar os órgãos (jurisdicionais) que o compõem, assegurar as garantias da Magistratura e fixar aqueles princípios de ordem política e ética que consubstanciam o acesso à justiça (acesso à ordem jurídica justa) e a garantia do devido processo legal (due process of law). $\mathrm{O}$ direito processual, por sua vez, inclusive por meio de disposições contidas no próprio texto constitucional, cria e regula o exercício dos remédios jurídicos que tornam efetivo todo o ordenamento jurídico, em todos os seus ramos, com o objetivo precípuo de dirimir conflitos interindividuais, pacificando e fazendo justiça em casos concretos." (Teoria geral do processo, cit., p. 53). Em semelhante sentido, José Carlos Baptista Puoli cita exemplos de intervenção estatal na autorregulamentação de interesses, de sorte que a influência do Estado Social a partir de novos modelos constitucionais se estendeu também em outros ramos do direito, seja em razão da concepção de uma sociedade mais solidária, seja por conta da indicação de novos deveres relacionados aos setores da vida que não mais deixam ao exclusivo alvedrio dos particulares a autorregulamentação de seus respectivos interesses, o que se verifica nas diretrizes do Código Civil, ao editar normas de caráter cogente. (Os poderes do juiz e as reformas do processo civil, cit., p. 58).

${ }^{190}$ CAPPELLETTI, Mauro; GARTH, Bryant. Acesso à justiça. Reimpr. Tradução de Ellen Gracie Northfleet. Porto Alegre: Sergio Antonio Fabris, 1988. 
Em síntese, são três as ondas de acesso à justiça. A primeira onda, iniciada em 1965, consiste na assistência judiciária gratuita, ${ }^{191}$ especialmente voltada aos pobres e destinada a erradicar inúmeros óbices ao acesso à justiça, tais como o custo elevado das custas processuais e falta de representação por advogado, aliados à própria carência de informação sobre os direitos do jurisdicionado. O que se busca tutelar é a criação de mecanismos destinados a representar direitos de pessoas excluídas ou marginalizadas da proteção jurisdicional. $^{192}$

A segunda onda enfatiza a representação dos interesses coletivos ou metaindividuais, ${ }^{193}$ de sorte a quebrar a ideia individualista do processo e permitir maior intervenção do Ministério Público, de grupos e até mesmo indivíduos na representação em juízo, quanto à tutela de direitos difusos, coletivos e individuais homogêneos, interesses esses que não se encontram "subjetivados" ou "individualizados" na esfera do particular. A noção individualista do processo deve ceder a uma ideia coletiva e "molecularizada".

\footnotetext{
191 Assim entendida como a democratização, orientação e publicidade de direitos, bem como mecanismos para a defesa desses direitos em juízo.

${ }^{192}$ CAPPELLETTI, Mauro; GARTH, Bryant, Acesso à justiça, cit., p. 31-48. É nesse contexto que surgiram as Defensorias Públicas (arts. 134 e art. 5 , LXXIV, ambos da CF, regulamentados pelas LC ns. 80/94 e 98/99, e, no âmbito do Estado de São Paulo, a criação da Defensoria Pública, através da LC n. 988/2006), dispositivos que deram assento constitucional à assistência judiciária gratuita (art. $5^{\circ}, \mathrm{LXXIV}$, da CF) e sua previsão em determinados procedimentos, assim como no processo (art. $5^{\circ}$, LXXVII, da CF e Lei n. 1.060/50). A assistência judiciária adquiriu o status de garantia constitucional expressa com o advento da Constituição de 1934 (que estabeleceu em seu art. 113, item 32: “A União e os Estados concederão aos necessitados assistência judiciária, criando, para esse efeito, órgãos especiais, e assegurando a isenção de emolumentos, custas, taxas e selos.") Posteriormente, essa garantia individual restou suprimida na Constituição de 1937, mas retornou nas Constituições de 1946 e 1967 (assim como na Emenda Constitucional n. 1/69). A garantia prevista na Constituição de 1946 previa em seu art. 141, § 35, que: "O Poder Público, na forma que a lei estabelecer, concederá assistência judiciária aos necessitados". A Constituição de 1967 e posterior alteração pela Emenda n. 1/69 não tiveram alterações significativas (arts 150, § 32 - Constituição de 1967 e art. 153, § 32 - Constituição de 1967, após a EC n. 1/69), mas omitiram a menção de que o serviço seria prestado pelo Poder Público ("Será concedida assistência judiciária aos necessitados, na forma da lei”). Essa possibilidade de limitação - "na forma da lei" - não estava prevista na Constituição de 1934, conforme teor acima transcrito. Somente em 1988 a Constituição Federal aperfeiçoou a regra, com a redação do inciso LXXIV do art. $5^{\circ}$, ao prever indistintamente que "o Estado prestará assistência jurídica integral e gratuita aos que comprovarem insuficiência de recursos".

${ }^{193}$ CAPPELLETTI, Mauro; GARTH, Bryant, Acesso à justiça, cit., p. 49-66. Em linhas gerais, os direitos metaindividuais ou coletivos stricto sensu são o gênero, do qual deflui a espécie em direitos difusos, coletivos ou individuais homogêneos previstos no art. 81 do Código de Defesa do Consumidor (Lei n. 8.078/90): “Art. 81 - A defesa dos interesses e direitos dos consumidores e das vítimas poderá ser exercida em juízo individualmente, ou a título coletivo. Parágrafo único - A defesa coletiva será exercida quando se tratar de: I - interesses ou direitos difusos, assim entendidos, para efeitos deste código, os transindividuais, de natureza indivisível, de que sejam titulares pessoas indeterminadas e ligadas por circunstâncias de fato; II - interesses ou direitos coletivos, assim entendidos, para efeitos deste código, os transindividuais, de natureza indivisível de que seja titular grupo, categoria ou classe de pessoas ligadas entre si ou com a parte contrária por uma relação jurídica base; III - interesses ou direitos individuais homogêneos, assim entendidos os decorrentes de origem comum."
} 
A terceira onda prioriza uma reforma interna do processo, na busca da efetividade da tutela jurisdicional, levando em conta o enfoque das duas ondas de acesso à justiça supracitadas. Essa última onda resume-se, em síntese, na finalidade de efetiva obtenção do direito material, mediante: a) a implantação de procedimentos mais acessíveis, simples e racionais, mais céleres, econômicos, eficazes e adequados a determinados conflitos; b) criação de formas de justiça mais acessíveis e participativas, ${ }^{194}$ de sorte a atrair os membros dos grupos sociais, e com vistas a superar a excessiva burocratização; e, c) promoção de uma espécie de justiça coexistencial, voltada à conciliação e com critério de equidade social distributiva. Conforme leciona Cassio Scarpinella Bueno:

\begin{abstract}
"Não se trata, pois, de apenas criar condições de acesso à justiça no sentido de fazer que um determinado direito ou interesse seja levado para apreciação do Estado-juiz mas, muito além disto, de uma concepção que admite não ser suficiente a representação judicial de um direito. É mister também que a atuação jurisdicional possa tutelá-lo adequada e eficazmente, realizando-o no plano exterior ao processo, no plano material." 195
\end{abstract}

Por sua vez, é certo que os direitos fundamentais previstos na Constituição Federal experimentaram quatro "gerações" ou "dimensões", cuja evolução entrelaça e complementa as etapas e características de cada uma no plano constitucional, ${ }^{196}$ bem como aproximam-se das ondas de acesso à justiça expostas por Cappelletti, conforme será analisado a seguir.

\title{
2.4.1 Projeção das ondas de acesso à justiça à luz das gerações dos direitos fundamentais constitucionais
}

Os direitos fundamentais de primeira geração, concebidos no século XVIII como resposta do Estado Liberal ${ }^{197}$ ao Estado Absolutista, constituem as liberdades individuais

\footnotetext{
${ }^{194}$ CAPPELLETTI, Mauro; GARTH, Bryant, Acesso à justiça, cit., p. 67-73. Essa forma de justiça pode ser entendida em seu sentido amplo como mecanismos alternativos de resolução de conflitos, a exemplo do que tivemos com a Lei de Arbitragem (Lei n. 9.307/96). Como facilitação à solução de controvérsias e mecanismos mais céleres, tivemos a Lei dos Juizados Especiais (Lei n. 9.099/95). Sobre o tema arbitragem, ver: CARMONA, Carlos Alberto. Arbitragem e processo: um comentário à Lei n. 9.307/96. São Paulo: Atlas, 2004.

${ }^{195}$ BUENO, Cassio Scarpinella, Curso sistematizado de direito processual civil, cit., v. 1, p. 53.

${ }^{196}$ Para melhor aprofundamento sobre o tema, ver: BONAVIDES, Paulo. Curso de direito constitucional. 7. ed. São Paulo: Malheiros, 1998; CANOTILHO, José Joaquim. Direito constitucional. 6. ed. Coimbra: Almedina, 1993.

${ }^{197}$ O modelo do constitucionalismo liberal preocupou-se em proteger o indivíduo da ingerência do Estado.
} 
públicas em sentido amplo, oponíveis ao Estado. Trata-se da imposição de limites e abstenções à atuação do próprio Estado (v.g., limitações ao poder de legislar e de tributar, direito à vida, à liberdade, à propriedade, à liberdade de expressão, etc., enquadrando-se, portanto, como liberdades negativas ou direito de defesa do indivíduo contra o Estado), gerando a ele deveres e obrigações de abstenção, de sorte a proteger o indivíduo inserido no grupo social.

Os direitos fundamentais de segunda geração refletem a preocupação que teve maior ênfase no século XX. Dizem respeito aos direitos sociais em sentido amplo, ${ }^{198}$ voltados a compreender a sociedade como um todo, abolindo-se, portanto, uma visão meramente individualista. Esses direitos sociais estão evidenciados nas modernas Constituições democráticas ${ }^{199}$ como resposta ao individualismo do Estado Liberal e impõem ao Estado uma postura interventora ${ }^{200}$ para a sua realização, de forma a conferir as feições de Estado Social mediante políticas mais ativas do Poder Público (v.g., direitos sociais e do trabalho, culturais, econômicos, direito à saúde, à habitação, etc., conhecidos portanto, como direitos positivos, no sentido de delinearem um fazer do Estado).

Esses comandos previstos na Carta Magna certamente se alinham à vertente da primeira onda de acesso à justiça idealizada por Cappelletti ${ }^{201}$, de sorte que a previsão constitucional de defensorias públicas e meios gratuitos de acesso ao Poder Judiciário

\footnotetext{
${ }^{198}$ Essa transição do Estado Liberal para o Estado Social teve início a partir da Revolução Industrial iniciada na Inglaterra no século XVIII. Por sua vez, as ideias voltadas à defesa de direitos sociais ganharam melhores contornos no final do século XIX e início do século XX, quando as massas operárias assumiram relevância social e política, aparecendo no cenário institucional o primeiro corpo intermediário, porta-voz de suas reivindicações: o sindicato.

199 Conforme leciona Paulo Bonavides: "Com o Estado social, o Estado-inimigo cedeu lugar ao Estadoamigo, o Estado-medo ao Estado-confiança, o Estado-hostilidade ao Estado-segurança. As Constituições tendem assim a se transformar num pacto de garantia social, num seguro com que o Estado administra a Sociedade." (Curso de direito constitucional, cit., p. 345).

${ }^{200} \mathrm{O}$ dever de abstenção do Estado (direitos fundamentais de primeira geração, voltados à preservação das liberdades do indivíduo) substitui-se a um dare, facere, praestare, por intermédio de uma atuação positiva, que realmente permita a fruição dos direitos sociais de segunda geração.

201 Para Mauro Cappelletti, os direitos garantidos nas Constituições modernas (v.g., trabalho, saúde, segurança material e educação) se impõem mediante atuação positiva do Estado necessária a assegurar o gozo de tais direitos sociais básicos. De igual modo, o direito ao acesso efetivo à justiça também materializa as reformas do welfare state. Por fim, conclui que: "De fato, o direito ao acesso efetivo tem sido progressivamente reconhecido como sendo de importância capital entre os novos direitos individuais e sociais, uma vez que titularidade de direitos é destituída de sentido, na ausência de mecanismos para sua efetiva reivindicação. $\mathrm{O}$ direito à justiça pode, portanto, ser encarado como o requisito fundamental - o mais básico dos direitos humanos - de um sistema jurídico moderno e igualitário que pretenda garantir e não apenas proclamar os direitos de todos." (CAPPELLETTI, Mauro; GARTH, Bryant, Acesso à justiça, cit., p. 10-12).
} 
reflete uma atuação estatal destinada a viabilizar o acesso à justiça das classes menos favorecidas $^{202}$ (ativismo estatal voltado a viabilizar o acesso à justiça), cuja conotação se enquadra nos direitos sociais de segunda geração.

Já os chamados direitos fundamentais de terceira geração condizem a tutelar o bem da vida que não se assemelha ao indivíduo ou determinada coletividade como tal, mas transcende essa esfera para assegurar prerrogativas passíveis de proteção a todo o gênero humano de modo irrestrito, incondicionado, solidário e fraternal. Decorrem da própria organização social, de sorte que é a partir dessa geração que surge a concepção voltada a identificar a existência de valores que dizem respeito a uma categoria de pessoas consideradas em sua unidade, e não na fragmentação individual de seus componentes isoladamente considerados. São os chamados direitos difusos ou metaindividuais e coletivos (v.g., a tutela ao meio ambiente, a comunicação, ao patrimônio histórico, cultural e paisagístico). ${ }^{203}$

De igual modo, a concepção dos direitos fundamentais de terceira geração ${ }^{204}$ caminha em consonância com a segunda onda de acesso à justiça supracitada, que reclama a tutela de interesses que não apenas vão além da esfera individual, mas se impõem mediante contornos coletivos. Nos dizeres de Dinamarco:

"Na concessão dessa tutela, está presente o reconhecimento de que
existem bens não incluídos na esfera jurídica de qualquer pessoa, mas
representativos de valores que pertencem à própria comunidade, por ela
são fruídos e em benefício dela e de cada um dos seus membros também
merecem preservação por via judiciária. Reconhecer a relevância jurídica
de tais valores e a existência de interesse de todos sobre eles, interesses
que são difusos porque refogem à clássica estrutura da pertinência

202 Nesse sentido são as conclusões de Cleber Francisco Alves, ao aduzir que na medida que o Estado assumiu o monopólio da prestação jurisdicional e passou a desempenhar essa função, de igual modo deve proporcionar mecanismos de acesso e defesa dos direitos do jurisdicionado em juízo, independentemente da classe econômica ou social daquele que busca o acesso à justiça. (Justiça para todos!: assistência jurídica gratuita nos Estados Unidos, na França e no Brasil. Rio de Janeiro: Lumen Juris, 2006. p. 38).

${ }^{203} \mathrm{Em}$ linhas gerais, o núcleo de proteção dos direitos fundamentais de primeira, segunda e terceira gerações correspondem, respectivamente, ao lema da Revolução Francesa - liberdade, igualdade e fraternidade idealizado pelos pensadores franceses do século XVIII e institucionalizados historicamente, obedecendo-se à ordem dessa tríade ideológica.

204 Aliás, Paulo Bonavides conclui que a Constituição Federal de 1988 situa-se no contexto dos direitos fundamentais de terceira geração, de sorte que a Carta Magna trouxe mecanismos destinados a juridicizar o Estado social e assim viabilizar instrumentos para garantir os direitos sociais básicos e torná-los efetivos, a exemplo dos remédios constitucionais. Ao final, conclui que: "O Estado social brasileiro é portanto de terceira geração, em face desses aperfeiçoamentos: um Estado que não concede apenas direitos sociais básicos, mas os garante." (Curso de direito constitucional, cit., p. 338). 
individualizada de cada interesse a determinada pessoa, é um enorme passo dado no sentido de maior abertura da via de admissão em juízo e, consequentemente, de acesso à justiça." ${ }^{205}$

Por fim, os denominados direitos fundamentais de quarta geração decorrem dos reflexos da globalização e alinhamento de prerrogativas universalmente conceituadas, como o direito à democracia, à informação e ao pluralismo. Condizem também com as preocupações globais da sociedade e debates éticos necessários a estabelecer os alicerces jurídicos dos avanços tecnológicos e seus limites constitucionais. Esta geração se ocupa do redimensionamento de conceitos e limites biotecnológicos, rompendo paradigmas a cada nova incursão científica e, por fim, operando mudanças significativas no modo de vida de toda a humanidade.

O modelo constitucional presente na Carta de 1988 é manifesto quanto aos seus aspectos publicistas, seja no âmbito do direito processual constitucional, seja na tutela constitucional do processo, o que aproxima ainda mais a relação entre direito processual e direito constitucional. Portanto, no direito processual constitucional ${ }^{206}$ contemporâneo voltado a viabilizar o acesso à justiça e a tutelar a ordem jurídica justa, repousam também

${ }^{205}$ DINAMARCO, Candido Rangel, A instrumentalidade do processo, cit., p. 331 Dinamarco cita os reflexos desses direitos no plano constitucional, o que o faz concluir que a tutela dos direitos supraindividuais vem aumentando no direito brasileiro, mediante o manejo do mandado de segurança coletivo e das ações coletivas (semelhante à class actions do sistema norte-americano), o que denota a tutela de interesses sob o mando do solidariasmo, com a ruptura de conceitos individualistas. Essas inovações, portanto, caminham paralelamente a uma visão instrumentalista, arraigada a técnicas capazes de dotar o processo de maior carga e utilidade social e política (Ibidem, mesma página).

206 Também estão assentadas na Carta Magna garantias constitucionais voltadas ao processo. Nessa seara, interessantes são as observações de Dinamarco quanto à necessidade de princípios e estruturas prevalecerem em todo o direito processual, especialmente o jurisdicional, calcada na observância das garantias constitucionais: "No tocante ao processo jurisdicional, têm-se esses compromissos e limitações assim distribuídos e coordenados com a ideia central: a) o Estado promete proceder ao exame em via jurisdicional, de toda lamentação que lhe seja trazida com a alegação de moléstia causada a direitos ou interesses juridicamente protegidos (garantia da inafastabilidade do controle jurisdicional em matéria não penal); b) promete abster-se da autotutela, submetendo-se também ele próprio à ordem processual (seja em matéria repressiva, seja para satisfação de interesses próprios não protegidos pelo princípio da autoexecutoriedade); c) considera-se condicionado ao ajuizamento de uma demanda do interessado, para poder dar início ao exercício da jurisdição em cada caso (daí o valor da ação, como instituto processual); d) no exercício da jurisdição, reprime a si próprio a emissão de atos imperativos (provimentos) sem ter dado suficientes oportunidades de defesa ao demandado, para equilíbrio entre a situação deste e a do autor da demanda; e) institui e observa normas para o exercício da jurisdição e, com isso, dá realce ao valor processo, ao procedimento e ao contraditório que legitima os atos imperativos impostos." (A instrumentalidade do processo, cit., p. 96). 
influências publicistas, ${ }^{207}$ cuja realidade é uma tendência. ${ }^{208} \mathrm{E}$, por reclamar um interesse estatal no resultado do processo como instrumento, novamente se justifica a atenção aos poderes do juiz, exatamente com o condão de propiciar a entrega da justa e efetiva tutela jurisdicional. Em suma, a moderna concepção estatal voltada a um ativismo solidarista ${ }^{209} \mathrm{e}$ social reflete, no plano processual, uma postura do juiz mais ativa para se aproximar da entrega da tutela jurisdicional justa, sendo o exercício dos poderes instrutórios, notadamente as iniciativas probatórias do magistrado, uma via efetiva para a consecução desse interesse público. Assim, o interesse estatal, alinhado à vertente constitucional do ativismo que emana do próprio Estado, também guarda reflexos na figura do Estado-juiz, materializado no ativismo judicial, ativismo que pode se manifestar através dos poderes instrutórios, com vistas à entrega da tutela jurisdicional justa e efetiva, a atender também o escopo da terceira onda renovatória de acesso à justiça.

\subsection{Reflexos da tendência publicista sobre os poderes instrutórios}

Conforme sustenta Cappelletti, todas as decisões emanadas do órgão estatal têm função pública, verbis:

“(...) o processo civil, mesmo sendo um instrumento dirigido à tutela de
direitos (normalmente) privados, representa, contudo, ao mesmo tempo,
também uma função pública do Estado. Tratando-se de uma função
pública - da mesma forma que as funções legislativas e administrativas -
tem de ser considerar que o próprio Estado, não apenas as partes

207 Para Dinamarco, constituem características publicistas as garantias constitucionalmente outorgadas a princípios inerentes à ordem processual, tais como o contraditório e ampla defesa, o devido processo legal, o juiz natural, a publicidade, a motivação das decisões judiciais e a isonomia. Todos esses princípios se entrelaçam com vistas a proporcionar um processo justo e democrático, o que reveste com caráter público a função estatal da jurisdição (A instrumentalidade do processo, cit., p. 64-65).

208 DINAMARCO, Candido Rangel, A instrumentalidade do processo, cit., p. 58-59. Para o autor, essa tendência é universal e restou alimentada por influência do constitucionalismo que se projeta sobre os processualistas contemporâneos (Ibidem, p. 65-66).

${ }^{209}$ Essa é a síntese traçada por Carlos Alberto Alvaro de Oliveira, ao constatar que a mudança de paradigma decorrente da passagem do normativismo legalista para o direito fundamental principiológico afeta a segurança jurídica, o que traz a lume a convivência de um direito mais flexível e menos rígido. Tal assertiva deflui no declínio da concepção inerte do Estado Liberal, que passa a ser substituída pela postura do aplicador do direito que deva ficar atento às peculiaridades do caso, “(...) pois, às vezes, mesmo atendido o formalismo estabelecido pelo sistema, em face das circunstâncias da espécie, o processo pode se apresentar injusto ou conduzir a um resultado injusto" (Os direitos fundamentais à efetividade e à segurança em perspectiva dinâmica. In: SALLES, Carlos Alberto de (Coord.). As grandes transformações do processo civil brasileiro: homenagem ao professor Kazuo Watanabe. São Paulo: Quartier Latin, 2009. p. 43). 
privadas, está interessado em um ordenamento, rápido, orgânico e imparcial, exercício daquela função; que está interessado, em suma, em realizar o melhor possível entre os modos de levar a termo aquela função." ${ }^{, 10}$

Sendo o processo concebido como função pública do Estado, a esse interesse público são assegurados poderes do juiz necessários a garantir o seu legítimo exercício. Dinamarco elucida diversos pontos consistentes na preponderância do interesse público sobre o privado que, por vezes, se confundem com princípios constitucionais ${ }^{211}$ do processo, concluindo, ao final, que:

\begin{abstract}
“A publicização do direito processual é, pois, forte tendência metodológica da atualidade, alimentada pelo constitucionalismo que se implantou a fundo entre os processualistas contemporâneos; tanto quanto esse método, que em si constitui também uma tendência universal, ela remonta à firme tendência central no sentido de entender e tratar o processo como instrumento a serviço dos valores que são objeto das atenções da ordem jurídico-substancial." ${ }^{212}$
\end{abstract}

Nesse contexto, no que toca aos poderes instrutórios, as iniciativas probatórias de ofício pelo magistrado bem refletem a perspectiva publicista, porquanto ao juiz contemporâneo cabe a busca da verdade necessária à formação do livre convencimento. ${ }^{213}$ Dinamarco tece as advertências necessárias no que tange ao juiz "Pilatos" que "em face de uma instrução mal feita, resigna-se a fazer injustiça atribuindo a falha aos litigantes". ${ }^{214}$

${ }^{210}$ CAPPELLETTI, Mauro. O processo civil no direito comparado. Tradução de Hiltomar Martins Oliveira. Belo Horizonte; Líder, 2001. p. 38.

${ }^{211}$ Nesse sentido, Cândido Rangel Dinamarco elucida diversas situações em que a ordem pública prepondera sobre interesses privados no plano processual, tais como a inafastabilidade do controle jurisdicional, a garantia do juiz natural, o impulso oficial, a livre investigação das provas e liberdade de convencimento, o dever de fundamentação das sentenças, conhecimento de ofício de determinadas matérias, as nulidades absolutas, o contraditório, a ampla defesa e a tutela penal do processo (A instrumentalidade do processo, cit., p. 59). Ao final, conclui que: "Esses e outros sinais tornam sem dúvida que o sistema processual da atualidade é voltado à tutela de uma ordem superior de princípios e valores que se situam fora e acima do âmbito estrito dos interesses controvertidos entre as partes (ordem pública) e que, em seu conjunto, dirigem-se ao bem comum, como objetivo-síntese do Estado moderno.” (Ibidem, p. 59).

${ }^{212}$ DINAMARCO, Candido Rangel, A instrumentalidade do processo, cit., p. 65.

${ }^{213}$ Dinamarco bem assevera as razões que impõe maior intervenção do juiz na iniciativa da produção das provas, de sorte que deve repelir-se a ideia de que "só as partes provariam e o juiz permaneceria sempre $a u$ dessus de la mêlée, simplesmente recebendo as provas que elas trouxessem, para ao final examiná-las e valorá-las. A vocação solidarista do Estado moderno, no entanto, que não permanece naquele laissez faire, laissez passer da filosofia liberal, exige que o juiz seja personagem participativa e responsável, não mero figurante de uma comédia. Afinal, o processo é hoje encarado como um instrumento público que não pode ser regido exclusivamente pelos interesses, condutas e omissões dos litigantes - ele é uma instituição do Estado, não um negócio em família (Liebman). (Fundamentos do processo civil moderno, cit., v. 1, p. 133). Portanto, hoje prevalece forte tendência de mitigação do princípio dispositivo para assim o juiz suprir deficiências probatórias no processo.

${ }^{214}$ DINAMARCO, Cândido Rangel, Instituições de direito processual civil, cit., v.1, p. 229. 
Assim, o julgador moderno pode determinar a produção das provas que julgar necessárias à formação de seu livre convencimento, ${ }^{215}$ porquanto o que se busca é atender à finalidade pública da jurisdição, dentre as inúmeras funções estatais.

Vale dizer, como reflexo de uma visão publicista, a iniciativa probatória do magistrado perfilha-se inerente à função do órgão judicial, de modo que, consoante adverte Barbosa Moreira: "Confiar ao juiz papel mais ativo na direção e na instrução do feito, ao contrário do que parecem recear alguns, não implica forçosamente instaurar no processo civil o domínio do 'autoritarismo' ou do 'paternalismo'.,216

Portanto, a publicização do processo se impõe, em determinadas circunstâncias, à indisponibilidade de direitos, cuja premissa fundamental reside, em síntese, na supremacia do interesse estatal e da sociedade, conforme pondera Dinamarco:

\begin{abstract}
"A nota de publicidade do processo tem como causa imediata, resumidamente, a indisponibilidade de direitos; e, como reflexo funcional no processo, a sua inquisitividade. $\mathrm{O}$ interesse público transcendente aos limites objetivos e subjetivos do litígio é que fada à ineficácia a inércia das partes ou ato dispositivo de situações jurídico-processuais, pois do contrário esses comportamentos conduziriam indiretamente ao sacrifício da sociedade interessada no resultado do pleito."217
\end{abstract}

E esse interesse estatal goza de contornos de inquisitividade do Estado-juiz destinados à certeza relativa à obtenção da verdade dos fatos necessária à entrega da tutela jurisdicional justa. Se assim não fosse, esvair-se-ia por inteiro a ideologia lastreada na pacificação social, nos contornos arduamente defendidos pela doutrina contemporânea de que a jurisdição, acima de tudo, deve resolver conflitos com justiça e, nas palavras de Chiovenda retrocitadas, "dare per quanto è possibile praticamente a chi há um diritto tutto quello e proprio quello ch 'egli há diritto di conseguire". ${ }^{218}$

\footnotetext{
${ }^{215} \mathrm{O}$ tema será tratado com maior profundidade no Capítulo 3.

${ }^{216}$ BARBOSA MOREIRA, José Carlos. A função social do processo civil moderno e o papel do juiz e das partes na direção e na instrução do processo, cit., p. 147. O autor ainda complementa: “A ampliação dos poderes do órgão judicial não tem como contrapartida necessária o amesquinhamento do papel das partes, nem a eliminação, ou sequer a redução, das garantidas a que fazem juiz, e tampouco da responsabilidade que sobre elas pesa." (Ibidem, mesma página).

${ }^{217}$ DINAMARCO, Candido Rangel, A instrumentalidade do processo, cit., p. 65.

${ }^{218}$ CHIOVENDA, Giuzeppe, Instituizioni di diritto processuale civile, cit., v. 1. p. 42.
} 
Afinal, se o juiz é o destinatário da prova, ${ }^{219}$ a sua correta análise e esgotamento de todos os elementos probatórios necessários à formação do livre convencimento do magistrado se fazem imperiosos para pacificar conflitos com justiça. Sem a aproximação de certeza da verdade não se pode aplicar o direito material pretendido. E para se obter essa certeza, ou aproximar-se ao máximo dela, necessária uma postura mais ativa do juiz, que se alinhe a contornos publicistas que não se prendam exclusivamente à vontade das partes dentro do processo. Logo, a própria entrega da tutela jurisdicional se materializa mediante a atuação do Estado-juiz, cujo interesse maior é o de aplicar a lei com justiça. Nesse contexto são os ensinamentos de Bedaque:

"Se o objetivo da atividade jurisdicional é a manutenção da integridade
do ordenamento jurídico, deve o magistrado desenvolver todos os
esforços para alcançá-lo, pois somente se tal ocorrer, a jurisdição terá
cumprido sua função social. E, como o resultado da prova é, na grande
maioria dos casos, fator decisivo para a conclusão do órgão jurisdicional,
deve ele assumir posição ativa na fase investigatória, não se limitando a
analisar os elementos fornecidos pelas partes, mas procurá-los, quando
entender necessário. Ninguém melhor do que o juiz, a quem está afeto o
julgamento, para decidir sobre a necessidade de produzir determinada
prova. A colheita de elementos probatórios é ato privativo do
julgador."

Essa iniciativa probatória pode ser ampla, até a formação do convencimento do juízo. Caberá ao magistrado, portanto, ponderar a dosimetria de suas iniciativas quanto à produção de provas, de sorte a amealhar elementos aos autos que lhe permitam proferir uma sentença segura e fundamentada, seja no campo probatório, seja justificando os alicerces de seu convencimento, quando se tratar de matéria exclusivamente de direito.

\footnotetext{
${ }^{219}$ BEDAQUE, José Roberto dos Santos, Poderes instrutórios do juiz, cit., p. 15. Em igual sentido: BUENO, Cassio Scarpinella. Curso sistematizado de direito processual civil: procedimento comum, ordinário e sumário. São Paulo: Saraiva, 2007, v. 2, t. 1. p. 103 e 234 e ss.; e SANTOS, Moacyr Amaral. Primeiras linhas de direito processual civil. 17. ed. São Paulo: Saraiva, 2004. v. 2, p. 338. Semelhante entendimento também já restou sedimentado pelo Superior Tribunal de Justiça (AgR AI n. 771.335/SC, rel. Min. Sidnei Beneti, $3^{\text {a }}$ Turma, DJe, de 23.09.2008; REsp n. 670.126/RS, rel. Min. Humberto Martins, $2^{\text {a }}$ Turma, DJe, de 08.08.2008; AgR AI n. 1.009.348/SP, rel. Min. Massami Uyeda, $3^{\mathrm{a}}$ Turma, DJe, de 01.08.2008; AgR REsp n. 809.788/RS, rel. Humberto Gomes de Barros, $3^{\mathrm{a}}$ Turma, DJe, de 12.12.2007).

${ }^{220}$ BEDAQUE, José Roberto dos Santos, Poderes instrutórios do juiz, cit., p. 14-15.
} 


\subsection{Conclusões parciais: os poderes instrutórios não beiram o autoritarismo}

Sob a perspectiva publicista, o processo passa a ser visto a partir de uma ótica externa, com vistas a cumprir seus escopos sociais, políticos e jurídicos citados no Capítulo anterior. Vale dizer, deve-se levar em conta os resultados que ele proporciona para os destinatários dos provimentos jurisdicionais e que devem fazer do processo instrumento de atuação da própria Constituição. ${ }^{221}$ Portanto, a ideia de um processo provido de contornos publicistas reflete uma postura mais ativa do juiz. Pela análise dos itens discorridos neste capítulo, notadamente a terceira onda renovatória de acesso à justiça, os direitos fundamentais de segunda e terceira geração e a evolução do processo como ciência, em sua atual fase instrumentalista, podem-se depreender projeções que se manifestam na busca de um processo civil de resultados, cuja decisão seja justa.

Assim, a realidade sociojurídica não é compatível com a preocupação destinada ao estudo do tecnicismo exacerbado que imperou durante a fase científica, época que teve por intuito caracterizar o direito processual, criando institutos solenes de forma a ratificar sua autonomia. Superada a afirmação do direito processual como ciência autônoma e definido seus institutos fundamentais, volta-se o processualista moderno ao estudo dos resultados do processo perante os consumidores do serviço processual. Desta feita, a finalidade do processo é a atuação do direito objetivo, sendo a proteção de direitos subjetivos uma consequência decorrente do resultado do próprio processo. Em igual sentido, Orestano relembra a doutrina de Chiovenda:

“(...) atraverso il processo lo Stato assicurebbe lósservanza Del diritto
oggetivo nella vita sociale, sichè anche Del diritto processuale civile
viene revendicata l'appartenanza al diritto pubblico. Ed è appunto su
uma concezione pubblicistica della giustizia che si impernierà il sistema

${ }^{221}$ Essas são as conclusões de José Roberto dos Santos Bedaque: "Hoje, para o processo, como instituto fundamental do direito processual, em primeiro lugar está o interesse da coletividade, já que sua finalidade é a realização do direito e da paz social. O titular de um interesse pode ocupar o tempo e as energias dos tribunais estatais, desde que para ele exista a necessidade da tutela jurídica. Aliás, não só as normas ordinárias são atuadas mediante o processo. Ele é um instrumento de atuação da própria Constituição, cujas regras, abstratamente formuladas e que representam direitos e garantias fundamentais, se concretizam processualmente." (Poderes instrutórios do juiz, cit., p. 68). 
del Chiovenda, uno dei fundatori della moderna processualística civile e italiana."222

Esse é um dos principais argumentos que alicerceia a escola instrumentalista, cujas preocupações trazidas por Dinamarco como proposições metodológicas evidenciam os sentidos negativo e positivo da instrumentalidade, ambos arraigados em contornos publicistas. A relação do duplo sentido da instrumentalidade com os poderes instrutórios se acentua, na medida que ao Estado-juiz não caberá seguir as regras processuais de modo rígido e incontrastável. Ou seja, a despeito da existência de ônus, deveres e sujeições conferidas às partes dentro do processo, por vezes a função pública do processo (mormente por ser o juiz o destinatário da prova) reclama a relativização de formalismos não seguidos (aspecto negativo), para assim se obter a tutela jurisdicional justa (aspecto positivo).

Novamente, esse reclamo da obtenção da tutela jurisdicional destinada à aplicação da vontade concreta da lei tem por escopo preservar o alinhamento da moderna visão teleológica do processo com vistas a proporcionar resultados justos, pautados no interesse do Estado-juiz em pacificar conflitos com equidade e efetividade, o que, por sua vez impõe, em dadas situações, a relativização de determinadas regras internas do processo.

Como cada uma das partes pretende normalmente sair vitoriosa, pouco lhe valendo contentar-se com a justiça da decisão, e, quando não tem razão, importa-lhe de ordinário retardar a conclusão do pleito, ao juiz cabe atuar imparcialmente para que o processo tenha marcha regular, de sorte que venham aos autos todos os elementos necessários para que o julgamento corresponda, na medida do possível, à realidade. ${ }^{223}$

A linha instrumentalista, voltada a uma perspectiva publicista, também caminha em consonância com a própria transição do liberalismo individualista, aos reclamos de um

\footnotetext{
${ }^{222}$ ORESTANO, Ricardo, Azione, diritti soggesttivi, persone giuridiche, cit., p. 51-52. Em igual sentido são as conclusões de Mauro Cappelletti: “Es verdad que el proceso es un 'instrumento' y que, como tal, debe adecuarse, como se há dicho, al objeto respecto al cual opera. Pero también es verdad que todo instrumento impone a sua vez, en la técnica de su operar, algunas reglas de esa técnica, reglas que deberán por cierto ser siempre respetuosas de los fines a los cuales el instrumento há de servir, pero que sin embargo asumirán en si mismas, prescindiéndose del objeto a cuyo servicio está el instrumento, uma validez própria, uma propia racionalidad o necesidad (aunque ésta sea relativa). Es este uno de los aspectos de la llamada autonomia del derecho procesal, en cuyo ámbito son efectivamente individualizables ciertas normas o derechamente ciertos institutos, que podrían valer sea cual fuere la naturaleza del derecho sustancial." (Proceso, ideologias, sociedad, cit., p. 24-25).

${ }^{223}$ GRECO, Leonardo. Publicismo e privatismo no processo civil. Revista de Processo, São Paulo, Revista dos Tribunais, ano 33, n. 164, p. 49, out. 2008.
} 
Estado Social intervencionista. ${ }^{224}$ Conforme exposto, no direito processual constitucional contemporâneo, voltado a viabilizar o acesso à justiça e a tutelar a ordem jurídica justa, as influências publicistas são uma tendência. ${ }^{225} \mathrm{E}$ por reclamar um interesse estatal no resultado do processo como instrumento ${ }^{226}$, novamente se justifica a atenção aos poderes do juiz, notadamente os poderes instrutórios necessários à entrega da justa e efetiva tutela jurisdicional, através de um juízo que se aproxime da certeza em decidir.

Assim, a jurisdição estatal é um serviço público. A partir do momento que as partes submetem a esta submetem a resolução de seus litígios, sujeitam-se à decisão do órgão jurisdicional, cujos contornos metodológicos, arraigados às premissas retroexpostas, impõem o dever do Estado-juiz de assegurar o seu bom funcionamento, com a finalidade de se obter a aproximação de verdade e trazer efetividade e justiça nas decisões. Sidnei Amendoeira Jr., ao discorrer sobre a evolução dos poderes instrutórios do juiz, conclui:

\begin{abstract}
"Ora, mesmo diante de uma legislação altamente permissiva a uma atuação mais ativa do juiz, pode este, por opção ou inércia, restar passivo diante do jogo do processo e vice-versa. Assim, o que a história parece ensinar é que o juiz pouco a pouco vem se tornando mais ativo, não só porque a lei tem permitido essa tomada de postura, mas porque a conjuntura social e política assim exige.,227
\end{abstract}

De igual modo, José Carlos Barbosa Moreira já constatava em 1989 que o ativismo judicial na produção da prova era tema superado pela doutrina:

“(...) embora ainda insuficientemente exercitada na prática, a atuação do juiz nesse campo já superou, na doutrina predominante e na maioria das legislações modernas, os preconceitos que lhe costumavam impugnar a legitimidade; e velhas contraposições entre 'princípio dispositivo' e

\footnotetext{
${ }^{224}$ DINAMARCO, Candido Rangel, A instrumentalidade do processo, cit., p. 95.

225 “Creo que la idea en la cual esse reflejo es más evidente es la de la llamada publicización del proceso, de la cual desde hace tantos años habla toda la doctrina procesalista civil, incluso la italiana. Dicha publicización puede ciertamente ser la consecuencia pura y simple de la abolición del ius privatum y por ela consecuencia de la radical publicización o socialistización del objeto mismo del proceso (como em los sistemas orientales); pero puede también prescindir de esta publicización ulterior y más revolucionaria: puede limitar-se en suma, a aquella acentuación, por un lado, de la función supletoria y de dirección procesal del juez, y por outro, de los deberes de lealtad, de probidad, y de verdad (veridicidad) de las partes, a los cuales nos hemos referido al hablar, a título de ejemplo del código austríaco de 1895, que luego sirvió de modelo a las legislaciones de varios otros paises." (CAPPELLETTI, Mauro, Proceso, ideologias, sociedad, cit., p. 23).

${ }^{226}$ Cintra, Grinover e Dinamarco sintetizam os principais aspectos da influência publicista, de sorte que o juiz não deve mais se portar como espectador da batalha judicial, mas sim exercer a função jurisdicional que reúne interesses do próprio Estado, com finalidade sociopolítica em realizar a vontade concreta da lei (Teoria geral do processo, cit., p. 70).

${ }^{227}$ AMENDOEIRA JUNIOR, Sidnei. Poderes do juiz e tutela jurisdicional. São Paulo: Atlas, 2006. p. 48.
} 
'princípio inquisitivo' - rótulos não raro empregados sem grande preocupação de rigor, à maneira de slogans mais aptos a dissimular ideias do que propriamente a expressá-las - parecem fadadas a diluir-se no reconhecimento de autêntico truísmo: o de que a reconstituição dos fatos deve ser tarefa de colaboração, e não tem sentido fazer dela território de disputas e rivalidades entre um pretenso monopólio das partes e uma fantasiosa opressão destas pela atribuição exclusiva de poderes instrutórios ao órgão judicial. ${ }^{, 228}$

Por sua vez, não se pode confundir iniciativa probatória do juiz com autoritarismo judicial, tampouco relacionar que ideologias de cunho liberal, em contraste com ideologias que primam por uma postura mais ativa do juiz, estejam necessariamente ligadas ao campo do autoritarismo. A advertência é traçada por Michele Taruffo, para quem a diferença não reside num embate entre "ideologia liberal" e "ideologia autoritária”, mas sim na discussão acerca de qual ideologia deve prevalecer a coroar a finalidade a que se presta o processo. ${ }^{229}$

Um sistema que preserve o monopólio das partes na determinação das provas a serem produzidas, restando ao juiz mera postura passiva para decidir consoante as provas trazidas exclusivamente pelos litigantes, reflete nas mais desastrosas consequências: em primeiro lugar, compromete a própria qualidade da decisão a ser proferida, pois, havendo dúvida sobre como decidir, não poderá o magistrado produzir prova alguma, vendo-se forçado a proferir uma decisão sem sequer haver formado seu livre convencimento; ademais, essa decisão deficiente no campo probatório dificilmente refletirá uma sentença justa, porquanto duvidosa a aplicação da lei ao caso concreto, em relação aos fatos da causa, tampouco será possível aferir se tais fatos correspondem ou aproximam-se da verdade necessária para decidir e aplicar a lei de forma justa. Portanto, tem-se uma ideologia, cuja preocupação com a qualidade da decisão mostra-se irrelevante, na medida

${ }^{228}$ BARBOSA MOREIRA, José Carlos. Alguns problemas atuais da prova civil. Revista de Processo, São Paulo, Revista dos Tribunais, ano 14, n. 53, p. 124, jan./mar. 1989. Semelhantes conclusões são traçadas também por Giovanni Verde (Las ideologías del proceso en un reciente ensayo. In: MONTERO AROUCA (Coord.). Proceso civil e ideología: un prefacio, una sentencia, dos cartas y quince ensayos. Valencia: Tirant Lo Blanch, 2006. p. 77).

${ }^{229}$ TARUFFO, Michele. Poteri probatori delle parti e del giudice in Europa. Revista de Processo, São Paulo, Revista dos Tribunais, ano 31, n. 133, p. 255, mar. 2006. José Carlos Barbosa Moreira deixa claro a falsa premissa de que todas as leis aprovadas em regimes autoritários sejam necessariamente antidemocráticas, a exemplo da Lei da Ação Popular (Lei n. 4.717/65) e da Lei da Ação Civil Pública (Lei n. 7.347/85), ambas editadas em regimes militares, contudo de cunho manifestamente democrático. Embora não seja objeto deste trabalho a investigação comparada da legislação estrangeira, esse autor desmistifica outros equívocos consistentes na crença de que o aumento dos poderes do juiz e a edição de leis que conferiram ao magistrado poderes instrutórios ocorreram sob a égide de regimes políticos autoritários, o que evidencia que poderes do juiz não se confundem com autoritarismo, tampouco guardam influência de regimes políticos autoritários ( $\mathrm{O}$ neoprivatismo no processo civil, cit., p. 10). 
que a inquietação maior reside em preservar o monopólio das partes na produção da prova e vedar qualquer iniciativa do magistrado nesse sentido. ${ }^{230}$ Logo, preserva-se a exclusividade probatória das partes para, ao final, buscar-se uma decisão deficiente na análise dos fatos e, portanto, fadada a injustiças:

\begin{abstract}
"Essendo notorio, e storicamente confermato, che il modo meno efficiente per scoprire la verità dei fatti in giudizio è quello di rimettersi esclusivamente alle iniziative probatorie delle parti, risulta ovvio che chi assume uma posizione di assoluta indifferenza rispetto all'accertamento della verità sai anche incline ad adottare um sistema in cui le parti dispongano in via esclusiva di tutte le iniziative instruttorie, senza che al giudice sai attribuito alcun potere."231
\end{abstract}

Assim, a ideia de um processo exclusivamente privado, em respeito ao monopólio das partes na produção da prova, resulta no desprezo do acertamento da verdade dos fatos e despreocupação em se ter uma decisão que prime pela realização concreta da lei. ${ }^{232}$ Buscase tão somente legitimar uma decisão judicial com a aparência de ser um resultado correto e acertado, quando, em verdade, sequer restaram trazidos aos autos elementos de prova necessários a decidir qual parte tinha razão, de modo a desempenhar-se função marginal e simbólica. ${ }^{233}$ Portanto, diante da visão teleológica tratada neste capítulo, nos parece mais acertado o entendimento contrário, de que sendo o processo instrumento para a realização concreta da lei, de igual modo os poderes instrutórios se prestam a atingir essa finalidade, com vistas à obtenção da tutela jurisdicional justa.

Todavia, o ativismo judicial não significa conceder ao juiz margem de atuação indiscriminada e indistinta, mas deve, em contrapartida, limitar-se às garantias processuais e constitucionais que densificam e estruturam o sistema, tema esse que será melhor debatido no Capítulo 4. Na medida que exista um sistema democrático e que proporcione

\footnotetext{
${ }^{230}$ TARUFFO, Michele, Poteri probatori delle parti e del giudice in Europa, cit., p. 256.

${ }^{231}$ Ibidem, p. 257.

${ }^{232}$ Joan Picó I Junoy sustenta que a justiça é um ideal que emanda da comunidade, razão pela qual deve o Estado disponibilizar a serviço dos juízes todos os meios e poderes necessários para que essa finalidade seja alcançada (El derecho procesal entre el garantismo y la eficacia: un debate mal planteado. In: MONTERO AROUCA (Coord.). Proceso civil e ideología: un prefacio, una sentencia, dos cartas y quince ensayos. Valencia: Tirant Lo Blanch, 2006. p. 102-126).

233 Nesse sentido, Michele Taruffo complementa: “(...) non sarebbero altro che uma sorta di reppresentazione rituale che viene celebrata non perchè si tratta di uno strumento istituzionale finalizzato ad amministare la giustizia, ma perché serve a far credere, alle parti e alla società in genere, che giustizia viene fatta, nella speranza che in tal modo le parti si inducano chiudere la controversia e la pace sociale venga ricostituita." (Poteri probatori delle parti e del giudice in Europa, cit., p. 258).
} 
aos litigantes garantias processuais constitucionais, dificilmente haverá margem para atuação do temido autoritarismo. ${ }^{234}$

Definidas algumas premissas que reclamam no processo civil moderno postura mais ativa e participativa do magistrado na condução do processo, passemos, pois, à análise mais detida dos poderes instrutórios, sua definição, dimensão, limites, bem como breves menções ao direito alienígena e evolução no panorama nacional.

\footnotetext{
${ }^{234}$ Há vozes na doutrina que revelam uma preocupação mais acentuada em relação aos poderes instrutórios e que defendem o monopólio das partes na produção probatória, sob o fundamento de um processo garantístico, a exemplo de Franco Cipriani (na Itália) e Juan Montero Aroca (na Espanha). Os pontos de vista desses autores podem ser confirmados em: MONTERO AROUCA (Coord.). Proceso civil $e$ ideología: un prefacio, una sentencia, dos cartas y quince ensayos. Valencia: Tirant Lo Blanch, 2006. p. 51 66, p. 130-168, p. 265-279. Nesta mesma obra, o contraponto a estes dois autores é sustentado por Barbosa Moreira, Giovanni Verde e Joan Picò I Junoy, p. 199-216, 67-81 e 109-129, respectivamente. Por uma opção metodológica deste trabalho, pretendemos entrelaçar os principais contrapontos sustentados por esses autores no curso desta dissertação, a justificar a opção e defesa dos poderes instrutórios.
} 


\title{
3 OS PODERES INSTRUTÓRIOS DO JUIZ
}

Para prestar a tutela jurisdicional, o juiz precisa antes exercer cognição, para assim poder conceder o bem da vida pleiteado pelas partes. ${ }^{235}$ Significa dizer que sem uma prévia noção dos fatos e do direito, não há como analisar, para depois prestar a tutela jurisdicional pretendida.

Sob uma perspectiva metodológica instrumentalista e influenciada por contornos publicistas, os poderes concedidos ao Estado-juiz se destinam à realização do direito objetivo com vistas a proporcionar a pacificação social. Portanto, sendo esse o escopo a ser atingido (escopo jurídico, para atingir-se o escopo social), os poderes instrutórios se prestam à busca pela aproximação da vontade do direito substancial, cuja realização se efetiva através do processo como instrumento. Sem prejuízo das premissas tratadas nos capítulos anteriores, a realização do direito objetivo dentro do processo somente se aperfeiçoará mediante a aproximação do juízo de certeza quanto à correta constatação dos elementos probatórios trazidos para apreciação do Estado-juiz. Segundo Bedaque:

\begin{abstract}
"Quanto mais o provimento jurisdicional se aproximar da vontade do direito substancial, mais perto se estará da verdadeira paz social. Nessa medida, não se pode aceitar que o juiz, por respeito a dogmas inaceitáveis, aplique normas de direito substancial sobre fatos não suficientemente demonstrados. ${ }^{236}$ Trata-se de função social do processo, que depende sem dúvida, da efetividade deste. Já que o Estado, além de criar a ordem jurídica, assumiu também a sua manutenção, tem ele interesse em tornar realidade a disciplina das reações intersubjetivas previstas nas normas por ele mesmo editadas.,237
\end{abstract}

Essa perspectiva publicista do processo, notadamente no que diz respeito aos poderes instrutórios, a despeito de voltar-se à realização do direito objetivo, deve seguir obediência a princípios processuais e constitucionais que alicerçam o sistema, sob pena de ignorar própria segurança jurídica prevista no ordenamento.

\footnotetext{
${ }^{235}$ Kazuo Watanabe bem ilustra que o juiz, para conceder a prestação jurisdicional, necessita, na condição de terceiro que se interpõe entre as partes, num primeiro momento, conhecer das razões (em profundidade, superficialmente, parcialmente, definitivamente ou em caráter provisório, conforme a técnica da cognição empregada), para depois adotar as providências destinadas à realização prática do direito da parte ( $D a$ cognição no processo civil, cit., p. 47).

${ }^{236}$ MOLINA, Hernando Morales. La prueba em el derecho colombiano y los poderes del juez em el proceso civil. In: Nuevas orientaciones de la prueba. Santiago: Editorial Jurídica de Chile, 1981, apud BEDAQUE, José Roberto dos Santos, Poderes instrutórios, cit., p. 13).

${ }^{237}$ BEDAQUE, José Roberto dos Santos, Poderes instrutórios, cit., p. 13.
} 
Por sua vez, cognição e instrução são temas umbilicalmente ligados na teoria do processo de conhecimento. ${ }^{238} \mathrm{O}$ juiz necessita primeiro conhecer, para depois decidir. Nesse processo de cognição, com a definição dos pontos controvertidos alegados pelas partes, cabe ao magistrado amealhar elementos necessários a lhe franquearem fundamentos para decidir o objeto litigioso. Logo, na atividade de colheita de provas que os poderes instrutórios se manifestam na pessoa do julgador, com vistas a formar seu livre convencimento, para ao final decidir.

Antes de analisarmos as principais características dos poderes instrutórios, necessário primeiramente sedimentar algumas premissas acerca da cognição e da prova. Não pretendemos adentrar no vasto campo da teoria geral da prova - tarefa que foge da premissa central deste trabalho - mas buscar alguns elementos insertos nessa teoria que de alguma forma venham contribuir para a tentativa de extrair definições ligadas aos principais aspectos dos poderes instrutórios.

Buscar-se-á neste capítulo, num primeiro momento, traçar breves apontamentos sobre a cognição judicial, a prova e a relação entre ambas, seguidos de considerações acerca de temas que gravitam em torno do ônus da prova, para após apontar as principais classificações dos poderes do juiz disseminadas pela doutrina e, em seguida, tentar definir um conceito, extensão e limites dos poderes instrutórios, acompanhados de sua menção no direito comparado e evolução legislativa nacional.

\subsection{Prova e cognição judicial}

\subsubsection{Breves apontamentos sobre a cognição judicial}

A cognição judicial consiste em considerar, analisar e valorar as alegações e as provas produzidas, cujo resultado repercuta no julgamento do objeto litigioso. ${ }^{239}$ Nesse exercício intelectivo, cabe ao magistrado a melhor adequação da aplicação da norma ao

\footnotetext{
${ }^{238}$ DINAMARCO, Cândido Rangel, Instituições de direito processual civil, cit., v. 3, p. 32.

${ }^{239}$ WATANABE, Kazuo, Da cognição no processo civil, cit., p. 59. Em igual sentido: CÂMARA, Alexandre Freitas. O objeto da cognição no processo civil. Rio de Janeiro: Instituto de Estudos Jurídicos (IEP), 1995. p. 207. (Livro de Estudos Jurídicos, n. 11).
} 
caso concreto, de sorte que o processo se materializa como instrumento em que as provas são produzidas, para assim formar o campo probatório que auxiliará o julgador na formação de seu livre convencimento necessário a decidir.

No processo cognitivo, é permitida réu, após ter sido trazido a juízo pela citação, a possibilidade de opor-se à pretensão do autor e valer-se de todos os meios de defesa em direito admitidos, podendo, mediante exercício do contraditório, negar o que restou afirmado na petição inicial e assim implantar dúvidas de fato ou de direito (questões) a serem dirimidas pelo juiz. ${ }^{240}$ Portanto, a cognição se destina à canalização de atividades voltadas à resolução de questões ${ }^{241}$ postas dentro do processo, para ao final permitir o proferimento de uma decisão por parte do julgador, de modo que "o demandar-contestarconhecer-julgar constitui o caminho a ser percorrido para obtenção da tutela jurisdicional., 242

Kazuo Watanabe ${ }^{243}$ sistematizou os diversos planos que se projetam a cognição judicial. Em linhas gerais, a cognição é vertical, quando realizada uma análise da matéria em profundidade, que pode ser exauriente (completa) ou sumária (incompleta). Trata-se da variação da intensidade na aproximação da verdade e de seu esclarecimento convincente e completo. Por isso que a cognição sumária, em linhas gerais, compreende uma cognitio superficial, baseada em juízo de probabilidade e verossimilhança, a exemplo das medidas cautelares (arts. 800 e ss. do CPC), do mandado de segurança (Lei n. 12.016/2009) e do instituto da antecipação de tutela (arts. 461, 461-A, 273 e ss. do CPC). Portanto, na cognição sumária, há restrição no plano da cognição vertical, porquanto a profundidade de conhecimento da matéria se limita a mera demonstração superficial da probabilidade do direito. Daí porque Dinamarco ${ }^{244}$ cita determinadas hipóteses em que a cognição é sumária

\footnotetext{
${ }^{240}$ DINAMARCO, Cândido Rangel, Instituições de direito processual civil, cit., v. 3, p. 28.

${ }^{241}$ Conforme leciona Dinamarco, pontos não se confundem com questões. Os primeiros são fundamentos ou elementos capazes de influir no julgamento, ao passo que questões são os próprios pontos, quando sobre eles existe alguma dúvida, de onde se extrai a expressão lecionada por Carnelutti ponto controvertido de fato ou de direito. Por sua vez, os pontos ou questões de mérito constituem a existência dos direitos alegados pelas partes, daí subdividindo-se em constitutivos, impeditivos, extintivos e modificativos (Instituições de direito processual civil, cit., v. 3, cit., p. 35). O que difere essas categorias, assevera Dinamarco, é a eficácia que cada uma delas exerce sobre a vida dos direitos, "mas todos eles são de algum modo juridicamente relevantes e, na medida que o sejam para o julgamento de determinada causa, ali eles serão objeto do conhecimento judicial" (Ibidem, p. 36).

${ }^{242}$ DINAMARCO, Cândido Rangel, Instituições de direito processual civil, cit., v. 3, p. 29.

${ }^{243}$ WATANABE, Kazuo, Da cognição no processo civil, cit., p. 111-112.

${ }^{244}$ DINAMARCO, Cândido Rangel, ob. cit., v. 3, p. 39.
} 
(superficial) e, por coerência, a lei nega autoridade de coisa julgada aos julgamentos proferidos por falta de prova suficiente (haja vista a tomada de decisão sem elevado grau de certeza), conforme se verificava no art. 15 da Lei n. 1.533/51 ${ }^{245}$ (ao tratar da ausência de coisa julgada no mandado de segurança quando fundamentada na falta de direito líquido e certo - certeza quanto aos fatos) e no art. 810 do Código de Processo Civil, ${ }^{246}$ ao afastar a coisa julgada quando a sentença nega a tutela cautelar.Ainda no plano da cognição vertical, a cognição exauriente, por sua vez, não reflete um juízo de certeza, mas tão somente sua aproximação da certeza em decidir, tema que voltaremos a tratar no item. 3.1.2.1.

Por sua vez, a cognição horizontal está ligada ao exame da amplitude (extensão) de todas as questões trazidas em juízo (cognição plena), ${ }^{247}$ ou seja, o juiz analisará somente as questões controvertidas necessárias para julgar o pedido e consoante as limitações definidas pela norma de direito material ou processual para seu respectivo conhecimento. Portanto, esse exame guarda relevância conforme o pedido e a fattispecie trazida em juízo e o respectivo preceito previsto na norma de direito material. ${ }^{248}$ Ainda, a cognição no plano horizontal também pode se limitar pela norma de direito processual, de sorte a restringir determinada matéria de defesa, a exemplo da ação de desapropriação, em que o art. 20 do Decreto-Lei n. 3.365/41 ${ }^{249}$ impõe a discussão somente em torno do preço ou pontos inerentes ao processo, sendo vedada qualquer discussão, nessa espécie de demanda, relativa a outros pontos ligados ao ato expropriatório. Outras hipóteses existem, a exemplo do procedimento sumário, em que o legislador expressamente vetou a admissibilidade da reconvenção, da ação declaratória incidental ou qualquer modalidade de intervenção de terceiros por iniciativa da parte (arts. $278, \S 1^{\circ}$ e 280 do CPC), assim como, no âmbito dos

\footnotetext{
245 “Art. 15 - A decisão do mandado de segurança não impedirá que o requerente, por ação própria, pleiteie os seus direitos e os respectivos efeitos patrimoniais". A Lei n. 12.016/2009 revogou expressamente a Lei n. 1.533/51. Por outro lado, semelhante redação do art. 15 da Lei n. 1.533/51 restou preservada no novel art. 19 da Lei n. 12.016/2006, restringindo, contudo, a ausência de coisa julgada em situações que não decidam pelo mérito do mandamus: "Art. 19 - A sentença ou o acórdão que denegar mandado de segurança, sem decidir o mérito, não impedirá que o requerente, por ação própria, pleiteie os seus direitos e os respectivos efeitos patrimoniais."

246 “Art. 810 - O indeferimento da medida não obsta a que a parte intente a ação, nem influi no julgamento desta, salvo se o juiz, no procedimento cautelar, acolher a alegação de decadência ou de prescrição do direito do autor."

${ }^{247}$ WATANABE, kazuo, Da cognição no processo civil, cit., p. 113-114.

${ }^{248}$ Valer-nos-emos dos exemplos Dinamarco ao asseverar que em ação de anulação de casamento, não se conhece de fatos desonrosos praticados depois da celebração, porque reputam-se irrelevantes para tal fim. De igual modo, em ação de indenização fundada em responsabilidade civil objetiva, uma vez constatada essa relação jurídica de direito material, desnecessária se torna qualquer investigação voltada à aferição de culpa por parte do causador do dano (Instituições de direito processual civil, cit., v. 3, p. 35).

249 “Art. 20 - A contestação só poderá versar sobre vício do processo judicial ou impugnação do preço; qualquer outra questão deverá ser decidida por ação direta."
} 
Juizados Especiais, o ajuizamento da reconvenção também é vetado, restando tão somente o exercício do pedido contraposto ${ }^{250}$ (art. 31 e parágrafo único da Lei n. 9.099/95).

Estabelecida uma distinção entre os planos da cognição judicial e seus graus de profundidade (plano vertical) e extensão (plano horizontal), ${ }^{251}$ vale lembrar que a cognição também evidencia atos de conhecimento do juiz que não necessariamente se materializam no processo de conhecimento e precedem a sentença, mas podem aperfeiçoar-se após o julgamento da demanda, a exemplo do pedido de antecipação de tutela recursal formulado em grau de apelação, das medidas cautelares destinadas à obtenção ou exclusão de efeito suspensivo à apelação, ${ }^{252}$ para vedar ou permitir a execução provisória, bem como na medida cautelar típica de arresto e de sequestro interposta antes ou durante a execução do julgado.

Por isso que os atos judiciais cognitivos não se limitam ao processo de conhecimento, mas, em dadas situações, ocorrem no terreno da execução (cujo conhecimento de determinada matéria pode preceder uma decisão voltada a atos de expropriação patrimonial do devedor), ${ }^{253}$ para assim complementar essa cognição destinada à preparação de um ato expropriatório. Logo, ao juiz é conferido o poder de solicitar esclarecimentos e informações adicionais às partes, determinar a expedição de ofícios, enfim, realizar atos e diligências cuja finalidade se destina a obter elementos

\footnotetext{
${ }^{250}$ Algumas diferenças podem ser pontuadas entre reconvenção e pedido contraposto. A primeira é ação autônoma, cuja extinção da ação principal não implica na extinção da reconvenção (art. 317 do CPC); no pedido contraposto, há uma relação jurídica processual; ele é formulado na própria contestação, ao passo que o ajuizamento da reconvenção implica em duas relações jurídicas autônomas. Na reconvenção, é possível pleitear pedido diverso (porém conexo) ao pedido da ação principal.

${ }^{251}$ Em resumo, a cognição horizontal pode ser plena (completa) ou limitada, conforme o caso, e, no plano vertical, exauriente ou sumária (DINAMARCO, Cândido Rangel, Instituições de direito processual civil, cit., v. 3, p. 37).

${ }^{252} \mathrm{O}$ manejo das medidas cautelares também se presta à finalidade de suspender a execução provisória, quando presentes o requisitos do periculum in mora e do fumus boni iuris. As Súmulas ns. 634 e 635 do STF pacificaram o entendimento de que enquanto não houver juízo de admissibilidade do recurso extraordinário pelo tribunal a quo, cabe a esse tribunal a competência para julgamento da medida cautelar. Semelhante entendimento também já restou perfilhado pelo Superior Tribunal de Justiça (MC n. 10.388/SP, $1^{\text {a }}$ Turma, rel. Min. Luiz Fux, j. 02.02.2006, DJ, de 20.02.2006, p. 203; e MC n. 11.004/SP, $3^{\text {a }}$ Turma, rel. Min. Humberto Gomes de Barros, j. 07.02.2006, DJ, de 13.03.2006, p. 315).

${ }^{253}$ Cândido Rangel Dinamarco bem assevera que o termo "instrução", assim definido como "preparar", compreende tanto o processo de conhecimento quanto a execução: "No processo de conhecimento preparase o provimento jurisdicional, que é a sentença de mérito, propiciando-se 'conhecimento ao juiz'. Na execução, em que inexiste julgamento do mérito, prepara-se o ato final de entrega do bem mediante constrições judiciais (penhora), avaliações, alienações em hasta pública etc.; preparam-se também os julgamentos interlocutórios que o juiz deve pronunciar ao longo do procedimento executivo. Não há na doutrina brasileira o hábito de atribuir toda essa extensão ao vocábulo 'instrução' e ao verbo 'instruir', mas na italiana tais conceitos são corriqueiros." (Instituições de direito processual civil, cit., v. 3, p. 33-34).
} 
suficientes à apreciação de um pedido (que não necessariamente reflita em uma sentença), ainda que ele reclame cognição limitada no plano horizontal. Ou seja, é necessário captar informações, recursos e dados que reflitam a aproximação da justa representação da realidade, para ao final decidir. E essa atividade, que será melhor delineada nos itens $3.3 \mathrm{e}$ seguintes, integra os poderes instrutórios, cuja manifestação não necessariamente se aperfeiçoa antes da sentença e durante a fase instrutória.

Portanto a cognição, seja no plano vertical, seja no plano horizontal, integra atividade intelectiva do magistrado que, por sua vez, pode valer-se de seus poderes instrutórios na busca de elementos necessários a decidir, respeitadas as garantias e princípios constitucionais e processuais previstos no sistema. Apresentado um breve panorama sobre a cognição judicial e suas dimensões, cumpre examinar o objeto, finalidade e desdobramentos acerca da prova para, ao final, estabelecer sua relação com a cognição judicial.

\subsubsection{Objeto e finalidade da prova}

Segundo Moacyr Amaral Santos, a prova tem por finalidade a formação da convicção de alguém, de sorte a convencer quanto à existência dos fatos da causa. Logo, a prova se presta a verificar se os fatos afirmados são certos, ou seja, a criar a proximidade de certeza da sua existência. Com base nessa proximidade, tornada inabalável pela exclusão de todos os motivos contrários ou divergentes, se faz a convicção. ${ }^{254} \mathrm{E}$ o destinatário desse resultado da prova é o próprio juiz, que é o mesmo receptor das afirmações de fatos feitas pelos litigantes. ${ }^{255}$ Conforme trataremos no item 3.3.1.1, para

\footnotetext{
${ }^{254}$ SANTOS, Moacyr Amaral, Primeiras linhas de direito processual civil, cit., v. 2, p. 337-338.

255 SANTOS, Moacyr Amaral, Primeiras linhas de direito processual civil, cit., v. 2, p. 338. Por fim: “A prova tem por finalidade convencer o juiz quanto à existência ou inexistência dos fatos sobre que versa a lide. Estes, portanto, constituem o seu objeto." (Ibidem., p. 343). Moacyr Amaral Santos adota a mesma classificação difundida por Malatesta e, no Brasil, seguida por Aureliano de Gusmão e Gabriel de Rezende Filho, consistente em três critérios: objeto, sujeito e forma. O objeto da prova é o fato por provar-se, que se divide no próprio fato (prova direta) ou a outro do qual, por trabalho do raciocínio, se chega àquele (prova indireta). Como exemplos de provas indiretas destacam-se as presunções e os indícios. Assim, "enquanto na prova direta a conclusão objetiva é consequente da afirmação da testemunha ou da atestação da coisa ou documento, sem necessidade maior de raciocínio, na indireta o raciocínio reclama a formulação de hipóteses, sua apreciação, exclusão de umas, aceitação de outras, enfim trabalhos indutivos maiores ou menores, para se atingir a verdade relativa ao fato probando." (Ibidem p. 340). O sujeito é a pessoa ou coisa de quem ou de onde emana a prova, sendo a primeira considerada prova pessoal e a segunda prova real. Por fim, a forma delimita a maneira pela qual a prova é trazida em juízo, daí dividindo-se em testemunhal, cuja afirmação é oral (oitiva de testemunhas, depoimento pessoal etc.) e documental, consisteme em prova escrita ou gravada.
} 
esse autor, o poder instrutório do juiz tem caráter supletivo ao da iniciativa das partes, ou seja, deve ser utilizado somente nos casos em que houver necessidade de melhor esclarecimento da verdade, sem o que não é possível ao juiz, de consciência tranquila, proferir sentença.

Semelhante constatação em relação à finalidade da prova é feita por Cassio Scarpinella Bueno, para quem a prova compreende tudo o que puder influenciar, de algum modo, a formação da convicção do magistrado para decidir de uma forma ou de outra, acolhendo, no todo ou em parte, ou rejeitando o pedido do autor. ${ }^{256} \mathrm{O}$ objeto da prova são os fatos relevantes ou pertinentes àquilo que deve ser enfrentado pelo juiz, seja no plano processual, seja no material. E, para se ter conhecimento do objeto da prova, tem-se os meios de prova, cuja classificação os divide quanto ao sujeito, quanto à forma e quanto ao momento. ${ }^{257}$ No que importa a esta investigação, em relação ao momento do meio de prova, "eles podem, para essa terceira classe, ser apresentados dentro ou fora da 'fase instrutória' dos mais diversos procedimentos". ${ }^{258}$

Cândido Rangel Dinamarco define a prova, na dinâmica do processo e dos procedimentos, como "um conjunto de atividades de verificação e demonstração, mediante as quais se procura chegar à verdade quanto aos fatos relevantes para julgamento", de sorte que o vocábulo prova designa também o próprio resultado das atividades consistentes em provar. ${ }^{259}$ Sendo o objeto da prova "o conjunto das alegações controvertidas das partes em relação a fatos relevantes ${ }^{260}$ para o julgamento da causa, não sendo estes notórios nem

\footnotetext{
${ }^{256}$ BUENO, Cassio Scarpinella, Curso sistematizado de direito processual civil, cit., v. 2, t. 1, p. 233. Em igual sentido: MARINONI, Luiz Guilherme; ARENHART, Sérgio Cruz, Manual do processo de conhecimento, cit., p. 314-315. Para Humberto Theodoro Júnior, o objeto da prova são os fatos deduzidos pelas partes em juízo (Curso de direito processual civil, cit., v. 1, p .412).

${ }^{257}$ BUENO, Cassio Scarpinella, Curso sistematizado de direito processual civil, cit., v. 2, t. 1, p. 234. Em relação ao sujeito, os meios de prova podem ser pessoais (declaração ou afirmação feita por alguém) ou reais (exame de uma pessoa ou de uma coisa). Quanto à forma, os meios de prova podem ser orais ou escritos (Ibidem, mesma página).

${ }^{258}$ BUENO, Cassio Scarpinella, Curso sistematizado de direito processual civil, cit., v. 2, t. 1, p. 234.

${ }^{259}$ DINAMARCO, Cândido Rangel, Instituições de direito processual civil, cit., v. 3, p. 41-44.

${ }^{260}$ Para Dinamarco, fatos irrelevantes são aqueles que, com ou sem eles, a decisão final será a mesma. Por sua vez, os fatos relevantes são aqueles cujo reconhecimento seja capaz de influir nos julgamentos a proferir no processo, de modo que se materializam em "condutas ou acontecimentos que, havendo sido alegados na demanda inicial ou na defesa do réu, tenham em tese a desejada eficácia constitutiva, impeditiva, modificativa ou extintiva pretendida por aquele que os alegou" (Instituições de direito processual civil, cit., v. 3, p. 64). Em igual sentido, Ovídio A. Baptista da Silva sustenta que são objeto de prova apenas os fatos relevantes em que se funda a ação ou defesa e que sejam necessários se conhecer para o julgamento da controvérsia (Curso de processo civil: processo de conhecimento, cit., p. 342).
} 
presumidos", 261 pode-se concluir que a finalidade da prova é o esclarecimento da verdade ou sua proximidade em relação ao próprio objeto da prova.

Por sua vez, João Batista Lopes aproxima a prova das alegações sobre os fatos, de sorte que a prova judiciária constitui o termo empregado como sinônimo de demonstração dos fatos alegados no processo. ${ }^{262}$ Por fim, Aclibes Burgarelli define que a prova tem por finalidade a condução de elementos necessários à estrutura intelectual do julgador, ${ }^{263}$ sendo a convicação do juiz o objeto imediato da prova. ${ }^{264}$

Assim, sendo os fatos relevantes ${ }^{265}$ para julgamento da causa o objeto da prova, de igual sorte ela se destina a angariar elementos, cuja finalidade será formar o convencimento do julgador. Nesse contexto, o art. 451 do Código de Processo Civil determina que, no procedimento ordinário, “ao iniciar a instrução, o juiz, ouvidas as partes, fixará os pontos controvertidos sobre que incidirá a prova”. Portanto, uma vez delimitados os pontos relevantes ou controvertidos para os quais deve haver produção da prova, ela terá por finalidade o esclarecimento de tais pontos, mediante o resultado da própria prova produzida. $^{266}$

Por essa razão, na desenvoltura da cognição, a produção probatória acaba por ter finalidade, em sua maioria, ${ }^{267}$ de esclarecer questões controvertidas ligadas aos fatos que o

${ }^{261}$ DINAMARCO, Cândido Rangel, Instituições de direito processual civil, cit., v. 3, p. 58.

${ }^{262}$ LOPES, João Batista. A prova no direito processual civil. 3. ed. São Paulo: Revista dos Tribunais, 2007. p. 25-26. Em igual sentido: THEODORO JÚNIOR, Humberto, Curso de direito processual civil, cit., v. 1, p. 411.

263 "A natureza jurídica da prova, em conclusão, é estrutural, relativa e intelectual. Forma-se um arcabouço, em relação ao fato material e à norma hipotética de incidência fática, de sorte a despertar, na inteligência do julgador, um processo de conhecimento técnico, inerente à sua atividade." (BURGARELLI, Aclibes. Tratado das provas cíveis. São Paulo: Juarez de Oliveira, 2000. p. 114-115).

${ }^{264}$ Ibidem, p. 133. Semelhante entendimento quanto à finalidade da prova também é defendido por Leonardo Greco (O conceito de prova. In: Estudos de direito processual. Campos dos Goytacazes, RJ: Editora da Faculdade de Direito de Campos, 2005. p. 440).

${ }^{265}$ Bento Herculano Duarte discorre acerca do fato notório como aquele relacionado a acontecimento ou situação de conhecimento geral, a exemplo de datas, gestão política ou acontecimentos públicos e de conhecimento geral. Por sua vez, fato confessado é o que prejudica aquele que o declara, ao passo que o fato incontroverso é o alegado por uma parte e silenciado pela parte adversa (Elementos de teoria geral da prova. In: DUARTE, Bento Herculano; DUARTE, Ronnie Preuss (Coords.). Processo civil: aspectos relevantes. São Paulo: Método, 2006. p. 19).

266 “Art. 332 - Todos os meios legais, bem como os moralmente legítimos, ainda que não especificados neste Código, são hábeis para provar a verdade dos fatos, em que se funda a ação ou a defesa."

267 A ressalva é feita por Bento Herculano Duarte, para quem o objeto da prova deve versar sobre o esclarecimento dos fatos, exceção ao disposto no art. 337 do Código de Processo Civil: "O direito, ordinariamente, não se prova, facultada a exigência quanto ao direito municipal, estatual, estrangeiro ou consuetudinário." (Elementos de teoria geral da prova, in Processo civil: aspectos relevantes, cit., p. 16-39). 
juiz deva ter conhecimento, para ao final decidir. Tem-se portanto na convicação do julgador a formulação de critérios subjetivos ligados à formação de seu livre convencimento, diante de elementos objetivos. Nesse contexto, o que ao juiz pode se aproximar da verdade, certamente não soa de acordo com o entendimento sustentado pela parte sucumbente na demanda. O aproveitamento de determinado argumento alegado por uma das partes e utilizado para a fundamentação da sentença certamente despreza as colocações em sentido contrário formuladas pela outra parte.

Portanto, se é o próprio juiz quem fixa os pontos controvertidos e decide acerca dos fatos relevantes e necessários para a produção da prova, mais lógico que lhe seja franqueado o exercício dos poderes instrutórios, com vistas a atingir a finalidade da prova, consistente na formação de seu livre convencimento, motivado com base nos elementos probatórios trazidos aos autos. Afinal, se é interesse do Estado-juiz pacificar conflitos de forma justa e realizar a vontade concreta da lei, de igual modo os poderes instrutórios se manifestam para atingir a aproximação da certeza em decidir. Por essa razão, Hernando Devis Echandia discorre acerca do princípio do interesse público da função da prova, apontanto o contraste que representa um processo que confere o monopólio das partes na produção da prova, em contradição com o interesse público do Estado juiz na realização da justiça:

"Siendo el fin de la prueba llevar la certeza a la mente del jue para que
pueda fallar conforme a justicia, hay un interés público indudable y
manifesto en la función que desempenã en el proceso, como lo hay en
éste, en la acción y en la jurisdicción, a pesar de que cada parte persiga
con ella su proprio beneficio y la defensa de su pretensión o excepción.
(...) Sostener que la prueba es de exclusivo interés privado de quien la
pide o aporta, y que, asimismo, en esa circunstancia reside el interés
primordial y el fin principal de ella, equivale en el fondo a decidir que el
interés y el fin primordiales del proceso son privados, puesto que aquélla
es el instrumento que permite a éste cumplir su función, y, en
consecuencia, se caería en el mismo doble eror respecto del interés que
protege y el fin que persigue la jurisdicción.".68

Destarte, a definição do objeto da prova revela-se insuficiente para a concessão da tutela jurisdicional, restando ainda, para se atingir a finalidade da prova, uma terceira etapa

\footnotetext{
${ }^{268}$ DEVIS ECHANDIA, Hernando. Teoria general de la prueba judicial. 5. ed. Buenos Aires: Víctor P. de Zavalía, 1981. v. 1, p. 119.
} 
de atividade cognitiva a ser exercida pelo juiz, qual seja, a valoração da prova, tema que será tratado a seguir.

\subsubsection{Valoração da prova e o mito da verdade absoluta nos autos}

Tendo a prova o condão de esclarecer as alegações controvertidas sucitadas pelas partes, ou ainda aproximar da certeza em decidir quanto aos fatos relevantes para julgamento, resta perquerir a forma com que a prova é valorada, com vistas à formação do livre convencimento do julgador. Ou seja, uma vez trazidos aos autos os elementos de prova do direito das partes, cabe ao juiz o poder-dever de valorar tais provas e assim formar seu convencimento necessário para decidir. ${ }^{269}$ Cumpre, portanto, verificar a intensidade com que é feito esse exercício subsuntivo por parte do magistrado e o critério adotado para a formação do convencimento judicial que se produz de forma subjetiva nos autos.

Moacyr Amaral Santos, ao definir o conceito de prova judiciária em seu aspecto objetivo (meios destinados a fornecer ao juiz o conhecimento da verdade dos fatos deduzidos em juízo), também o faz em seu aspecto subjetivo (a que se forma no espírito do juiz, seu principal destinatário quanto à verdade dos fatos). ${ }^{270}$

No sistema brasileiro, impera o princípio da persuasão racional ou livre convencimento motivado (art. 131 do CPC), tema que voltaremos a tratar no item 4.2.3. Ao juiz é assegurado formar livremente a sua convicção (persuasão racional), de sorte que o convencimento esteja vastamente fundamentado (livre convencimento motivado). Portanto, o juiz pode apreciar as provas produzidas nos autos para assim formar seu livre convencimento, que deve ser motivado.

\footnotetext{
${ }^{269}$ Nesse sentido, Hernando Devis Echandia discorre que "por valoración o apreciación de la prueba judicial se entiende la operación mental que tiene por fin conocer el mérito o valor de convicción que pueda deducirse de su contenido" (DEVIS ECHANDIA, Hernando. Teoria general de la prueba judicial, cit., p. 287).

${ }^{270}$ SANTOS, Moacyr Amaral, Primeiras linhas de direito processual civil, cit., v. 2, p. 339. Em igual sentido: LOPES, João Batista, A prova no direito processual civil, cit., p. 25-26; e THEODORO JÚNIOR, Humberto, Curso de direito processual civil, cit., v. 1, p. 411.
} 
Todavia, nessa avaliação subjetiva do julgador (salvo algumas exceções de "prova legal" que serão tratadas no item seguinte), a lei é omissa quanto a um critério de avaliação e valoração da prova, deixando ao arbítrio do juiz tão somente elucidar as razões de seu livre convencimento em relação ao resultado do conjunto probatório amealhado nos autos, elucidação que deve ser motivada e fundamentada. Nesse contexto, a motivação assume um papel de racionalização das provas, de modo que a conclusão do julgador guarde coerência lógica com o resultado da prova produzida.

Daí porque a iniciativa probatória do magistrado não deve encontrar óbice relativo à disponibilidade da produção das provas pretendidas pelas partes. Vale dizer, sendo o juiz o destinatário da prova e cabendo unicamente a ele o mister de analisar e valorar os fatos relevantes para o julgamento da causa, para ao final decidir, é certo que qualquer diligência iniciada pelo magistrado tem o condão de alcançar a própria finalidade da prova comentada no item anterior. Ou seja, a iniciativa probatória deriva da própria necessidade de angariar elementos que sejam suficientes para a formação do livre convencimento motivado do julgador.

Logo, a iniciativa probatória do juiz também se fundamenta no sistema do livre convencimento motivado, porquanto a formação do conjunto probatório se faz necessária até o momento em que o julgador tenha condições de decidir a demanda. E a reunião dessas condições necessárias para propiciar a formação do livre convencimento motivado irá variar consoante o grau de cognição a ser exercido pelo magistrado, aliado às questões que sejam passíveis de confirmação mediante a produção da prova. ${ }^{271}$ Portanto, sendo o juiz o destinatário da prova, deve angariar elementos nos autos que sejam suficientes para poder decidir.

Conforme trataremos no item 4.2.2., o juiz não se sujeita à disponibilidade das provas requeridas pelas partes para julgar, mas deve, no intuito de formar seu livre convencimento necessário para decidir (nesse caso, as provas amelhadas pelas partes podem ou não ser suficientes para a formação do livre convencimento), também chegar o mais perto da verdade nos autos, quando insuficientes as provas para o convencer. Ou seja,

${ }^{271}$ Ver itens 3.1 .1 e 3.1 .2 e 4.2.3. 
em relação a esse último aspecto, deve decidir a demanda consoante a constatação de elementos que reflitam a aproximação da verdade necessária para aplicar o direito material.

Essa aproximação da verdade suficiente para convencer o julgador pode se materializar em variadas circunstâncias: (i) pelo resultado do conjunto das provas postuladas pelas partes e produzidas nos autos; (ii) pelo resultado das provas produzidas por iniciativa do juiz (nessa hipótese, considerando ser indiferente as partes haverem postulado ou renunciado a produção de determinada prova); ou, ainda, (iii) o juiz não vislumbra no resultado das provas amealhadas condições suficientes para a formação de seu livre convencimento, de sorte a aplicar as regras de julgamento. Portanto, cuidaremos de discorrer se nas hipóteses citadas nas alíneas (i) e (ii) deve o magistrado preocupar-se em formar seu livre convencimento de modo a tentar refletir a fiel realidade dos fatos, porquanto na situação elencada na alínea (iii), por óbvio, já se esgotaram todos os meios de aproximação da verdade, restando ao magistrado a aplicação de regra de julgamento. ${ }^{272}$

Para Michele Taruffo, as decisões justas devem se fundar em uma determinação verdadeira dos direitos controvertidos, porquanto as provas produzidas nos autos pelas partes se destinam exclusivamente a atender ao interesse de cada litigante. ${ }^{273}$ Por outro lado, tanto no processo quanto fora dele, a verdade é a melhor aproximação possível da realidade histórica e empírica dos fatos que precisam ser apurados. ${ }^{274}$

Em contrapartida, a ideia de busca da verdade absoluta e irrefutável soa algo intangível e de difícil constatação da própria certeza. Há limites do próprio saber humano que impedem uma visão completa da realidade. $\mathrm{O}$ conhecimento científico mostra como algo considerado correto atualmente pode ser definido como errôneo no futuro, ao passo que já se afirmou que a característica marcante de uma tese científica é a possibilidade de testabilidade, e não de seu acerto absoluto. ${ }^{275} \mathrm{O}$ juiz, ao ter a iniciativa probatória, deve tomar a cautela de tornar-se um juiz inquisidor que tente a todo custo obter a certeza absoluta como condição necessária para decidir a demanda. Portanto, acertada a

\footnotetext{
272 Trataremos do tema no item 3.2.4.

${ }^{273}$ TARUFFO, Michele. La prueba científica en el proceso civil. In: FERRER BELTRÁN, Jordi et al. Estudios sobre la prueba. México: Universidad Nacional Autónoma de México, 2006. p. 135.

${ }^{274}$ TARUFFO, Michele. Verità e probabilità nella prova dei fatti. Revista de Processo, São Paulo, Revista dos Tribunais, ano 32, n. 154, p. 213, dez. 2007.

${ }^{275}$ PAULA JUNIOR, Aloysio Libano de. A experiência probatória no direito americano e no brasileiro. Dissertação (Mestrado) - Faculdade de Direito da Universidade do Estado do Rio de Janeiro, 2008. p. 35.
} 
preocupação para se evitar a postura do juiz que se comporte como um inquisidor e tente de forma desenfreada descobrir a verdade nos autos na ânsia de fazer justiça, até porque tal medida pode vir a protelar excessivamente a entrega da tutela jurisdicional. ${ }^{276}$

O que torna mais acentuado o problema é a disposição dos litigantes em postularem o reconhecimento do próprio interesse nos autos, na tentativa de convencer o magistrado acerca das respectivas versões dos fatos que melhor lhes convêm. Por essa razão, Piero Calamandrei assevera:

\begin{abstract}
"A querela entre os advogados e a verdade é tão antiga quanto a que existe entre o diabo e a água benta. E, entre as facécias costumeiras que circulam sobre a mentira profissional dos advogados, ouve-se fazer seriamente esta espécie de raciocínio: em todo o processo há dois advogados, um que diz branco e outro que diz preto. Verdadeiros, os dois não podem ser, já que sustentam teses contrárias; logo, um deles sustenta a mentira. Isso autorizaria considerar que cinquenta por cento dos advogados são uns mentirosos; mas, como o mesmo advogado que tem razão numa causa não tem em outra, isso quer dizer que não há um que não esteja disposto a sustentar no momento oportuno causas infundadas, ou seja, ora um ora outro, todos são mentirosos. Esse raciocínio ignora que a verdade tem três dimensões e que ela poderá mostrar-se diferente a quem a observar de diferentes ângulos visuais. No processo, os dois advogados, embora sustentando teses opostas, podem estar, e quase sempre estão, de boa-fé, pois cada um representa a verdade como a vê, colocando-se no lugar do seu cliente.,"277
\end{abstract}

Na medida em que recai sobre o juiz o mister de procurar aplicar com fidelidade o direito material que reflita a aproximação de verdade, por outro lado, deve filtrar a tentativa das partes em limitarem a demonstrar somente a verdade que conduza à tutela de seus exclusivos direitos, não obstante o art. 339 do Código de Processo Civil seja claro ao determinar que ninguém se exime do dever de colaborar com o Poder Judiciário para descobrimento da verdade.

Dinamarco acresce que a certeza proporcionada pelo exercício consumado da jurisdição coincide com a segurança jurídica, que é fator de paz social e constitui importante escopo do processo. Por outro lado, é certo que nem sempre os julgados apoiarse-ão em absoluta certeza e, por vezes, essa exigência se torna uma ilusão, valendo-se a

\footnotetext{
${ }^{276}$ Essa preocupação revela a ponderação de princípios entre justiça efetiva e pacificação social, de um lado e, em contrapartida, o princípio da celeridade. Voltaremos a tratar desse tema nos itens 4.1.6 e 4.1.8.

${ }^{277}$ CALAMANDREI, Piero. Eles, os juízes, vistos por um advogado. Tradução de Eduardo Brandão. São Paulo: Martins Fontes, 1998. p. 121-122.
} 
decisão de mero juízo de probabilidade. ${ }^{278}$ Portanto, a certeza é um dogma guardado e cultivado entre os juristas e na teoria do processo, porquanto está ligada com a verdade, da qual constitui manifestação subjetiva, de modo que a exigência de certeza é "uma ilusão, talvez uma generosa quimera". ${ }^{279}$ Logo, essa manifestação subjetiva do julgador se baseia na supremacia dos motivos convergentes e afastamento dos divergentes, sempre de modo racional e calculando haver algum risco, o que é inevitável. ${ }^{280}$ Possíveis errores in judicando podem ser netralizados através dos recursos e de ações rescisórias, num sistema que está sujeito a falhas humanas, cujos riscos podem ser minimizados mediante a participação efetiva das partes (contraditório), do juiz (temperamentos inquisitivos ao sistema dispositivo) e pelo efetivo respeito às garantias constitucionais. ${ }^{281}$

Semelhante constação é feita por Francisco Rosito que, ao comparar a diferença entre verossimilhança e probabilidade, conclui que probabilidade é o resultado obtido pela produção dos meios de prova (a presença de elementos cognoscitivos que confirma a hipótese a ele relativa), de modo a indicar aquilo que foi objeto de prova, sendo o convencimento resultado de um juízo de probabilidade dos fatos, ao passo que a verossimilhança se trata da valoração que o juiz realiza prescindindo a produção de meios de prova, de modo a constituir um juízo independente da prova produzida. ${ }^{282}$

Por sua vez, Piero Calamandrei estabelece uma gradação crescente da aproximação da verdade a partir daquilo que é possível, verossímil e provável: um fato possível (que pode ser verdadeiro) será menos reconhecido que um fato verossímil (que tem aparência de

\footnotetext{
${ }^{278}$ DINAMARCO, Cândido Rangel, A instrumentalidade do processo, cit., p. 280. Sobre a diferença entre certeza e probabilidade, Dinamarco acresce que: "Probabilidade é a situação decorrente da preponderância dos motivos convergentes à aceitação de determinada posição, sobre os motivos divergentes. A probabilidade é menos que a certeza, porque, lá, os motivos divergentes não ficam afastados, mas somente suplantados, e é mais que a credibilidade, ou verossimilhança, em que na mente do observador os motivos convergem e os divergentes comparecem em situação de equivalência e, se o espírito não se anima a afirmar, também não ousa negar." (Ibidem, p. 282). Em igual sentido: Instituições de direito processual civil, cit., v. 1, p. 147.

${ }^{279}$ DINAMARCO, Cândido Rangel, A instrumentalidade do processo, cit., p. 279 e 281.

${ }^{280}$ DINAMARCO, Cândido Rangel, A instrumentalidade do processo, cit., p. 282.

${ }^{281}$ DINAMARCO, Cândido Rangel, A instrumentalidade do processo, cit., p. 286. Em igual sentido, Flávio Luiz Yarshell sustenta que a existência de uma prova ou de outra não constitui a certeza de uma sentença com este ou aquele conteúdo, até porque a sentença, ainda que transitada em julgado, pode não ser apta a estabelecer a certeza, razão pela qual a própria prova, que é meio instrumental que deve ser considerado para que se chegue a uma decisão, pode ser mal avaliada, a ponto de conduzir a uma sentença equivocada (Antecipação de prova sem o requisito da urgência e direito autônomo à prova. São Paulo: Malheiros, 2009. p. 250-251). No mesmo sentido: ARRUDA ALVIM, José Manoel de, Manual de direito processual civil, cit., v. 2, p. 470.

${ }^{282}$ ROSITO, Francisco. Direito probatório: as máximas de experiência em juízo. Porto Alegre: Livraria do advogado, 2007. p. 47-48.
} 
ser verdadeiro), ao passo que um fato provável (que se pode provar como verdadeiro) corresponde a uma maior aproximação de certeza que o fato verossímil, porquanto transcende a aparência e há argumentos que fazem crer representar a realidade. ${ }^{283}$

Portanto, a conclusão a que se chega é que existe um juízo de probabilidade no convencimento do julgador, até porque a atividade jurisdicional é passível de erros, bem como o julgador possui valores pessoais e uma vontade inconsciente que, na maioria das vezes, o próprio magistrado não consegue desvendar. ${ }^{284}$

Por essa razão, em que pese defender-se a postura de um juiz que prime pela verdade real, é certo que a verdade real é relativa, senão eivada de um juízo de probabilidades, sujeitando-se, portanto, a erros ou acertos. Deveras, conforme trataremos no item 4.2.2, o magistrado deve primar pelo princípio da verdade real, de sorte a evitar a postura de um julgador que seja obrigado a decidir ainda sem formar o livre convencimento e consoante a disponibilidade exclusiva das provas pelas partes. Para evitar a concessão de tutela jurisdicional sem que se dê razão a quem tem direito ou deixe de aplicar o direito material, se justifica a observância da verdade real, que não é absoluta, mas prima pela aproximação mediante juízo de probabilidade. Moacyr Amaral Santos assevera que:

“'A verdade é a conformidade da noção ideológica com a realidade ${ }^{285}$
Conceito da verdade relativa, não da verdade absoluta, sempre procurada,
nunca alcançada. Se a verdade sòmente pode ser procurada e se
apresentar através dos sentidos e da inteligência, compreende-se logo,
precários como são aquêles, insuficiente como é esta, a relatividade que
deve presidir à conformidade da noção ideológica com a realidade. (...)
Por isso mesmo, a verdade, que se busca, quase sempre, não se apresenta,
ou nunca se apresenta com a brancura da verdade abasoluta, mas apenas
com as cores da realidade sensível e inteligível. Contudo, é a verdade."

Esse temperamento beira o critério de razoabilidade, cujo juízo deflui da sapiência do próprio julgador. Taruffo bem adverte que os poderes de iniciativa probatória por parte

${ }^{283}$ CALAMANDREI, Piero. Estudios sobre el proceso civil. Tradução de Santiago Sentis Melendo. Buenos Aires: EJEA, 1962. p. 325-326.

${ }^{284}$ MARINONI, Luiz Guilherme. Novas linhas do processo civil. 4. ed. São Paulo: Malheiros, 2000. p. 43.

${ }^{285}$ MALATESTA, Nicola Framarino Dei. A lógica das provas em matéria criminal. Tradução de J. Alves de Sá, 1911, v. 1, cap. I, apud SANTOS, Moacyr Amaral. Prova judiciária no cível e comercial. São Paulo: Max Limonad, 1949. v. 1, p. 4.

${ }^{286}$ SANTOS, Moacyr Amaral, Prova judiciária no cível e comercial, cit., v. 1, p. 4-5. 
do juiz devem ser utilizados sempre que algum meio de prova ao seu alcance possa ser empregado para melhor conhecimento dos fatos necessários a decidir o conflito, ainda que tal prova não tenha sido postulada pelos litigantes. ${ }^{287}$ Em igual sentido, leciona Humberto Theodoro Júnior, para quem, nessa última hipótese, o compromisso do juiz "não é com a posição de nenhuma das partes, mas com a verdade, sem a qual não se consegue fazer a justiça, para cuja realização se idelizou a tutela jurisdicional no Estado Democrático de Direito". 288

Assim, a verdade real atua como diretriz axiológica para o magistrado, na formação de seu livre convencimento motivado que, conforme tratado neste item, pode sujeitar-se a desacertos e imprecisões que decorrem de erros humanos, seja (i) na avaliação da prova, seja (ii) na interpretação e aplicação do direito, ${ }^{289}$ o que leva a concluir que a entrega da tutela jurisdicional se resume a juízo de probabilidade de acertos lógico-dedutivos, o que não se confunde com certeza absoluta. Afinal, a verdade não é um fim em si mesma no processo, mas um meio para se atingirem outros fins, dentre eles o escopo jurídico e social da jurisdição.

Por outro lado, esse mesmo ímpeto de aproximação da verdade deve encontrar freios previstos no sistema, exatamente para que o processo não se torne uma via crucis destinada à busca desenfreada da verdade que, como visto acima, não é absoluta e ainda pode conduzir a um desgaste temporal e material que prejudica ambos os litigantes. Daí porque, para se balizarem os poderes instrutórios, sem prejuízo das premissas que serão traçadas no item 3.3.1.2, devem ser observado ainda o respeito aos princípios processuais e constitucionais que integram o sistema, sendo difícil definir, de uma forma objetiva e rígida, critérios estaques que devam ser aplicados de forma ostensiva. Se, de um lado, a verdade trazida aos autos é relativa, máxime a trazer mais consistência para a aplicação de regras rígidas e inflexíveis num sistema de freios e contrapesos, de outra banda, o magistrado não pode simplesmente obrigar-se a decidir consoante a sorte das provas trazidas aos autos de forma exclusiva pelas partes, tampouco sujeitar-se a julgar de olhos vendados e sem saber qual parte tinha razão.

\footnotetext{
${ }^{287}$ TARUFFO, Michele, Poteri probatori delle parti e del giudice in Europa, cit., p. 257.

288 THEODORO JÚNIOR, Humberto, Curso de direito processual civil, cit., v. 1, p. 419.

289 Para Dinamarco, pode haver erros na admissão ou inadmissão da prova, na sua produção, em sua avaliação e na interpretação do direito. Ainda pode haver erros decorrentes de disposições legais mal formuladas ou de más colocações do juiz, o que torna impossível reduzir a zero a probabilidade de erro in procedendo ou in judicando (Instituições de direito processual civil, cit., v. 1, p. 147).
} 
A iniciativa probatória se revela ligada à aproximação de realização do escopo jurídico da jurisdição que, de igual forma que outorga poderes instrutórios ao juiz, deve restar limitada, em obediência à princípios previstos no sistema, tarefa que soa subjetiva e imprecisa de se delimitar, mas cujas premissas, a serem tratadas adiante e no Capítulo 4, venham contribuir para uma definição mais objetiva.

\subsubsection{Elementos de prova legal e interpretação sistemática}

A despeito de imperar no sistema brasileiro o princípio do livre convencimento motivado, há determinados dispositivos que preveem o resultado do exercício intelectivo a ser realizado pelo julgador na valoração da prova. Trata-se de "diretrizes de caráter abstrato que limitam essa liberdade ao prefixar o valor probatório em alguns casos". ${ }^{290}$ Essas diretrizes, embora prevejam certa normatividade em relação à valoração, não podem ser consideradas como provas tarifadas, porquanto se prestam a inserir "alguns poucos critérios racionais ditados pela experiência comum do legislador". ${ }^{291}$

Dentre essas diretrizes de caráter abstrato, Dinamarco cita três denominações ligadas ao que convencionou chamar de elementos de prova legal. Trata-se das presunções relativas que, quando verificadas, dispensam o juiz de examinar a veracidade ou inveracidade da afirmação da partes, salvo quando admitida prova em contrário. Por sua vez, há hipóteses previstas no sistema ligadas à limitação de eficácia probatória, a exemplo do art. 401 do Código de Processo Civil, que estabelece que a prova exclusivamente testemunhal somente será admitida nos contratos cujo valor não exceda o décuplo do salário mínimo vigente no país ao tempo em que foram celebrados, a regra constante no art. 400, I e II, do mesmo Código, ao impor que a prova testemunhal será indeferida quando voltada a provar "fatos já provados por documentos ou confissão da parte" ou "que só por documento ou por exame pericial puderem ser provados", além da regra da distribuição do ônus da prova (art. 333 do CPC), em que o juiz se vê obrigado, a fim de evitar o non liquet, a dar por inexistentes os fatos alegados e não provados, devendo

\footnotetext{
${ }^{290}$ DINAMARCO, Cândido Rangel, Instituições de direito processual civil, v. 3, cit., p. 106.

${ }^{291}$ Ibidem, p. 106.
} 
tal dispositivo ser aplicado como regra de julgamento. ${ }^{292}$ Por fim, a afirmação da eficácia da prova se verifica em situações em que a norma de direito material ou processual prescreve determinada eficácia probatória, a exemplo dos arts. 224 e 1.543 do Código Civil, ao exigir a língua portuguesa para a validade de documento e a certidão do registro civil como prova de casamento. Por sua vez, os arts. 364, 365 e 378 do Código de Processo Civil estabelecem a força probante do documento público: “(...) esclarece-se que as reproduções idôneas de documentos fazem a mesma prova que o original e afirma-se que os livros comerciais fazem prova contra seu autor.",293

Carlos Alberto Alvaro de Oliveira cita outros exemplos presentes no Código de Processo Civil que excluem ou limitam a prova e relativizam a observância do art. 131, como os arts. 302 (que trata, em linhas gerais da presunção de veracidade dos fatos não impugnados pelo réu), 319 (que trata dos efeitos da revelia), 334 (que trata dos fatos que não dependem de prova), 343, parágrafo único (que trata da pena de confissão dos fatos alegados que recai sobre a parte que deixa de comparecer à audiência para prestar depoimento pessoal), 359 (que trata da admissão de serem verdadeiros os fatos que a parte pretendia provar quando a parte contrária se recusa a apresentar documento ou coisa, ou quando a recusa for tida como ilegítima), 364, acima citado, 366 (que estatui que nenhuma outra prova pode suprir a falta do instrumento público quando a lei o exigir como substância do ato), 368 (que trata da presunção de veracidade do documento particular), $370,2^{\mathrm{a}}$ parte (que trata do regime de validade do documento particular em relação a terceiros), 373 (que trata da prova da declaração de vontade contra quem o documento particular não restou impugnado), 376 (que trata do regime valorativo das cartas e registros domésticos como prova), 378 e 379 (que tratam da veracidade dos livros comerciais contra e a favor do seu autor). Outro exemplo é a inadmissibilidade, no processo civil ou penal, da prova obtida por meios ilícitos, determinada pelo art. $5^{\circ}$, inc. LVI, da Constituição Federal. $^{294}$

\footnotetext{
${ }^{292}$ Ibidem, p. 107. Outros exemplos de limitação de eficácia probatória em relação à dispensa de prova são, entre outros: (i) dos fatos confessados (art. 334, II, do CPC); (ii) dos que atribuem à confissão extrajudicial a mesma eficácia da judicial (art. 353); e do dispositivo que dita a indivisibilidade da confissão (art. 354) (Ibidem, p. 107).

293 DINAMARCO, Cândido Rangel, Instituições de direito processual civil, v. 3, cit., p. 106-109. Em igual sentido, José Manoel de Arruda Alvim cita os arts. 215 e 225 do Código Civil, que tratam, como prova plena, da fé pública constante na escritura pública e das reproduções fotográficas, cinematográficas e registros fonográficos em geral, respectivamente (Manual de direito processual civil, cit., v. 2, p. 472).

${ }^{294}$ OLIVEIRA, Carlos Alberto Alvaro de. Do formalismo no processo civil. 3. ed. São Paulo: Saraiva, 2009. p. 186. Semelhantes exemplos também são apontados por João Batista Lopes, que conclui que todas as provas possuem um valor relativo, de sorte a existir determinada hierarquia entre elas, na medida que "o
} 
Essas hipóteses, meramente exemplificativas e jamais exaustivas, se prestam a demonstrar situações que podem dispensar a produção de determinada prova ou prescrevem o critério de sua valoração frente a outras constatações. ${ }^{295}$ São, portanto, preceitos previstos no sistema que podem ser considerados pelo magistrado quando do trabalho valorativo resultante do conjunto probatório, ou que até mesmo justificam a dispensa da produção de determinada prova.

Não pretendemos esgotar o exame de cada um desses dispositivos, o que fugiria à proposta principal deste estudo. Por outro lado, esses artigos não podem passar despercebidos quando do estudo do tema poderes instrutórios, mormente ao se tratar das iniciativas probatórias do juiz em confronto com regras que prescrevem que determinada prova prevalece sobre outra ou pode ser dispensada.

Não se nega que tais dispositivos venham trazer efetividade ao processo e que podem se sobrepor ao valor certeza em decidir, mormente diante da constatação citada no item anterior de que o próprio julgamento do juiz está eivado de um juízo de probabilidade. Portanto, trata-se de situações em que o legislador buscou predefinir determinados preceitos que autorizam o magistrado a julgar apoiado em regras constantes no sistema que venham a servir de fundamento para justificar a dispensa de determinada prova ou a prevalência de uma prova sobre outra. Ainda assim, seria possível afirmar com segurança que tais dispositivos limitam ou relativizam a persuasão racional do magistrado? Poderia, a título de exemplo, a regra prevista no art. 334 do Código de Processo Civil, vedar o juiz de determinar ou indeferir a produção de uma prova acerca de determinado fato, ${ }^{296}$ ou ainda a

acolhimento pelo legislador do critério da persuasão racional significa justamente sujeição às normas jurídicas e de experiência, certo que o juiz, como foi exposto, não goza de liberdade absoluta nesse campo" (A prova no direito processual civil, cit., p. 55-59). Em semelhante sentido, Theotonio Negrão e José Roberto F. Gouvêa entendem que a livre apreciação da prova comporta restrições estabelecidas nos arts. 332 a 334 do Código de Processo Civil, assim como situações que coarctam a liberdade do juiz quanto à apreciação da prova - v.g., arts. 333, 334-IV, 353, 354, 366, 401 e 405, $\S \S 1^{\circ}$ e $3^{\circ}$ (Código de Processo Civil interpretado e legislação processual em vigor. 39. ed. São Paulo: Saraiva, 2007. p. 265).

295 Dos dispositivos retrocitados, excepciona-se a regra de julgamento prevista no art. 333 do Código de Processo Civil que, em verdade deve ser aplicada como último recurso pelo magistrado quando, diante de todo o resultado probatório, ainda persistirem dúvidas sobre como decidir a demanda. Trataremos do tema com maior profundidade no item 3.2.1.

296 “Art. 334 - Não dependem de prova os fatos: I - notórios; II - afirmados por uma parte e confessados pela parte contrária; III - admitidos, no processo, como incontroversos; IV - em cujo favor milita presunção legal de existência ou de veracidade.” 
regra constante no art. $897,{ }^{297}$ relativa à ação de consignação em pagamento, deve ser aplicada irrestritamente?

A resposta é negativa. Isso porque se deve primar por uma interpretação sistemática de todos os dispositivos ligados à formação do livre convencimento motivado do magistrado. Portanto, a aplicação do art. 334 do Código de Processo Civil não é uma regra rígida e estanque que obriga o juiz a se abster de produzir provas sobre determinado fato que a lei reputa notório, confessado, incontroverso ou com presunção legal de existência ou veracidade. Afinal, se o escopo maior do processo é aplicar a vontade concreta da lei, por mais que tais regramentos, num primeiro momento, possam dispensar o juiz de determinar a produção de determinada prova, a aplicação de tais preceitos não se justifica, muito menos se sobrepõe a uma decisão que pode se reputar de injusta.

Milton Paulo de Carvalho, ao tecer comentários acerca dos efeitos da revelia, bem traça as seguintes ponderações:

\begin{abstract}
"É evidente que não se instituiu no art. 319 do CPC, diretamente, nem uma vantagem processual, nem uma vantagem jurídico-material para o autor. Pelo contrário, interessa ao Estado a participação e colaboração efetiva dos litigantes na busca da verdade e consequente atuação da lei. (...) $\mathrm{Na}$ hipótese, entretanto, de estar-se diante de alegações verossímeis que ensejam pedidos plausíveis, a solução há de ser a preconizada pelo texto legal, sem cogitações de que o sistema processual estaria a condenar irremediavelmente o revel., ${ }^{298}$
\end{abstract}

Em igual sentido, Umberto Bara Bresolin acresce que o juiz não deve aplicar os efeitos da revelia quando os fatos alegados pelo autor se reputarem impossíveis, improváveis, contrários a fatos notórios ou a prova eventualmente existente nos autos, de sorte que, para a aplicação da regra do art. 319 do Código de Processo Civil, necessário, no

\footnotetext{
297 “Art. 897 - Não oferecida a contestação, e ocorrentes os efeitos da revelia, o juiz julgará procedente o pedido, declarará extinta a obrigação e condenará o réu nas custas e honorários advocatícios.”

${ }^{298}$ CARVALHO, Milton Paulo de. Efeitos da revelia: exame comparativo do assunto nas legislações processuais civis alemã, italiana, portuguesa e brasileira. Revista de Processo, São Paulo, Revista dos Tribunais, ano 18, n. 69, p. 28, jan./mar. 1993. Em semelhante sentido: BEDAQUE, José Roberto dos Santos, Poderes instrutórios do juiz, cit., p. 155. Dinamarco complementa, ao lembrar o art. 20 da Lei n. 9.099/95 que, a despeito de impor os efeitos da revelia ao réu que não comparece, faz expressa menção a "salvo se o contrário resultar da convicção do juiz" - aliás, semelhante redação também é empregada no art. 277, § $2^{\circ}$, do CPC, ao tratar do procedimento sumário (Instituições de direito processual civil, v. 3, cit., p. 562). A doutrina é majoritária ao entender que sendo o réu revel, a presunção de veracidade dos fatos narrados pelo autor é relativa, valendo citar como exemplos, porém não exaustivos: THEODORO JÚNIOR, Humberto, Curso de direito processual civil, cit., v. 1, p. 393; e BUENO, Cassio Scarpinella, Curso sistematizado de direito processual civil, cit., v. 2, t. 1, p. 90.
} 
mínimo, que as assertivas fáticas do autor sejam prováveis ou merecedoras de credibilidade. $^{299}$ De igual sorte, pondera Antonio Carlos Marcato em relação ao ônus da impugnação específica constante no art. 302, caput, do Código de Processo Civil:

\begin{abstract}
“(...) a não impugnação especificada de todos os fatos declinados na inicial não exclui, prima facie, a livre apreciação, pelo juiz, dos fatos impeditivos, modificativos ou extintivos do alegado direito do autor, acaso provados no processo, independentemente de manifestação do réu, ante o que dispõe o art. 131 do mesmo diploma legal." ${ }^{300}$
\end{abstract}

Do contrário, caso não seja possível delimitar as razões que dão suporte à existência da verossimilhança, não há que se falar em limitação dos poderes instrutórios, porquanto ausente a presença desse conceito jurídico indeterminado. ${ }^{301}$ caberá ao autor (mediante a disponibilidade das provas que pretender produzir) ou ao magistrado (mediante o exercício dos poderes instrutórios) a formação do conjunto probatório suficiente para atender ou rejeitar o pedido.

O que a doutrina convencionou chamar de prova legal ou situações de hierarquia de prova não deve ser visto como regra absoluta e incontrastável. Até porque para um fato que a lei impõe prescindir de prova não necessariamente é vedada a sua produção. ${ }^{302} \mathrm{E}$ essa produção ficaria autorizada não só quando reputada inverossímel ${ }^{303}$ a alegação do autor

\footnotetext{
${ }^{299}$ BRESOLIN, Umberto Bara. Revelia e seus efeitos. São Paulo: Atlas, 2006. p. 199. No mesmo sentido é o posiconamento de José Manoel de Arruda Alvim (Manual de direito processual civil, cit., v. 2, p. 364). Outras exceções que não conduzem à aplicação dos efeitos da revelia estão presentes nos arts. 320 e incs. (pluralidade de réus e um deles contestar a ação, o litígio versar sobre direitos indisponíveis e a petição inicial estiver desacompanhada do instrumento público que a lei considere indispensável à prova do ato), 52, parágrafo único (em que o assistente do réu revel, comparecendo em tempo para responder a demanda e atuando em seu interesse, impugnar os fatos alegados pelo autor), 302, parágrafo único (o ônus da impugnação específica não se aplica ao advogado dativo, ao curador especial e ao órgão do Ministério Público, valendo lembrar que o art. $9^{\circ}$, II, determina que o juiz dará curador especial ao revel citado por edital ou com hora certa), $277, \S 2^{\circ}$ (no procedimento sumário, não reputar-se-ão verdadeiros os fatos alegados na inicial se o contrário resultar da prova nos autos) e o art. 302, III (quando a partir da defesa, em seu conjunto, restar provado o contrário à presunção de veracidade que recai sobre os fatos não impugnados). (Ibidem, p. 115-117).

${ }^{300}$ MARCATO, Antonio Carlos, Procedimentos especiais, cit., p. 31.

${ }^{301}$ Daí porque Dinamarco complementa que, em ocorrendo os efeitos da revelia, sendo os fatos alegados pelo autor impossíveis ou mesmo inverossímeis, ou quando não houver segurança quanto à efetividade da própria citação, ou ainda quando o réu for visivelmente pobre ou despreparado, a revelia não é fator excludente do poder-dever de determinar provas ex officio (Instituições de direito processual civil, v. 3, cit., p. 55-56).

${ }^{302}$ Daí porque Ovídio A. Baptista da Silva, ao discorrer sobre o princípio da oralidade, conclui que o sentido contemporâneo desse princípio exige o abandono de todas as limitações impostas à admissão e avaliação da prova testemunhal, de modo que a prova indiciária constitui mera faculdade de utilização pelo juiz (Curso de processo civil: processo de conhecimento, cit., p. 67).

${ }^{303}$ Afinal, se é o próprio juiz que avalia e analisa quando determinado fato é ou não inverossímel, de sorte a excepcionar a aplicação dos efeitos da revelia, logo tal efeito não é uma limitação aos poderes instrutórios.
} 
(em se tratando da aplicação dos efeitos da revelia), mas também em hipóteses em que se verifica suspeita de colusão entre as partes.

Essa preocupação é registrada por Bento Herculano Duarte, para quem, a fim de evitar a colusão entre os litigantes, o magistrado deve, de ofício, buscar provas, ainda que sobre fatos tidos por confessados ou incontroversos. ${ }^{304}$ E o art. 129 do Código de Processo Civil determina que, constatando que o "autor e réu se serviram do processo para praticar ato simulado ou conseguir fim proibido por lei, o juiz proferirá sentença que obste aos objetivos das partes".

Embora se trate de situações específicas (ausência de verossimilhança e suspeita de colusão), tais hipóteses excepcionam a aplicação irrestrita de comandos definidos por lei destinados a atribuir determinado contorno à atividade de formação do livre convencimento do magistrado. Nada obsta, por exemplo, que uma demanda tenha por objeto o pedido de anulação de uma escritura pública sob o argumento de que ocorreu um vício de consentimento por parte de seu signatário, podendo tais fatos restar provados pelos meios de prova em direito admitidos, a despeito da força probante do documento público que a lei atribui. $^{305}$

Em que pese os elementos de prova legal ou prova tarifada comportarem observância do magistrado quando da valoração de determinada prova ou dispensa de sua produção, isso não significa que tais regras devam ser aplicadas de forma rígida e incontrastável. Caberá ao juiz decidir a aplicação ou não de tais dispositivos, consoante análise sistemática $^{306}$ e teleológica de outros preceitos, notadamente quando o pedido que integra a demanda tiver por objetivo relativizar o efeito legal ou hierárquico de determinada prova. Daí porque Dinamarco pondera:

"Não é porém absoluta a regra da exclusão da prova dos fatos confessados (art. 334, inc. II). Todos os dispositivos que limitam o objeto da prova em razão da incontrovérsia entre as partes, inclusive os que

\footnotetext{
${ }^{304}$ DUARTE, Bento Herculano, Elementos de teoria geral da prova, in Processo civil: aspectos relevantes, cit., p. 20-21.

${ }^{305}$ Arts. 364 e 366 do Código de Processo Civil e 215, caput, do Código Civil.

${ }^{306}$ Severas são as críticas tecidas por Cândido Rangel Dinamarco sobre a equivocada inserção do instituto da prova no Código Civil de 2002 (arts. 212 a 232), porquanto o tema atinente à prova é puramente processual, a envolver definições acerca do objeto da prova, os meios de prova e os critérios de sua valoração (Instituições de direito processual civil, v. 3, cit., p. 45).
} 
fixam presunções relativas (como o efeito da revelia etc.), sujeitam-se necessariamente a uma interpretação sistemática mediante a qual sua eficácia fica sempre condicionada ao livre convencimento do juiz, que é um dos pilares mais sólidos e legítimos do moderno direito probatório (art. 131 - supra, n. 814). Há fatos que integram o objeto da prova e se reputam inexistentes se não vierem a ser provados, mesmo quando revel o réu, mesmo quando ele não os haja impugnado especificamente (arts. 302 e 319) ou ainda que os confesse em vez de impugnar ou depois de havê-los impugnado (supra, nn. 788 e 1.126). Quer se trate de uma incontrovérsia inicial ou sucessiva, cabe sempre ao juiz aceitá-los ou exigir prova, segundo os reclamos de sua racional curiosidade, dando à confissão o valor que no caso concreto seu espírito crítico aceitar". ${ }^{307}$

É o próprio magistrado que subsume o que é um fato notório, incontroverso, que milite presunção legal de existência ou de veracidade ou que seja confessado. ${ }^{308}$ E esse exercício intelectivo é dado ao subjetivismo do julgador, a quem caberá ou não aplicar tais comandos. Gian Antonio Micheli e Michele Taruffo, ao tecerem comentários acerca da prova legal, concluem que a orientação é no sentido de eliminarem ou reduzirem a casos positivamente excepcionais provas que escapam à livre apreciação do juiz, a adotar a tendência de eliminação das normas de "verdade legal" em substituição à plena verdade material dos fatos. ${ }^{309}$

Portanto, na formação do livre convencimento motivado, as provas legais ou hierárquicas podem ser observadas pelo magistrado, mas jamais serem aplicadas de forma rígida e absoluta, senão em consonância com uma observância sistemática dos outros meios de prova que poderão auxiliar o processo cognitivo, de sorte a decidir nos limites objetivos da demanda. A prova legal ou hierárquica é tão somente um elemento adicional para a formação do livre convencimento do magistrado, a ser confrontada diante das

\footnotetext{
${ }^{307}$ DINAMARCO, Cândido Rangel, Instituições de direito processual civil, v. 3, cit., p. 654-655.

${ }^{308}$ Nesse contexto, Luiz Guilherme Marinoni e Sérgio Cruz Arenhart discorrem que se aconfissão goza de eficácia ímpar perante as partes, por outro lado, não gera o mesmo efeito frente à cognição exercida pelo juiz, podendo ele, à luz do princípio da persuasão racional, suplantar o indicativo advindo da confissão ao julgar o mérito (Manual do processo de conhecimento, cit., p. 374-375).

${ }^{309}$ MICHELI, Gian Antonio; TARUFFO, Michele. A prova. Revista de Processo, São Paulo, Revista dos Tribunais, ano 4, n. 16, p. 166, out./dez. 1979. No mesmo sentido, Cassio Scarpinella Bueno discorre que a abrangência do princípio do livre convencimento motivado tem aptidão para que o juiz se valha de outros meios de prova, consoante as circunstâncias do caso concreto, o que relativiza o rigor que decorreria das chamadas provas legais (Curso sistematizado de direito processual civil, cit., v. 2, t. 1, p. 249-250). Por fim, Michele Taruffo aponta: "Es más, en cierto sentido la prueba legal pretende precisamente impedir al juez que use los criterios de la discrecionalidad racional, imponiéndole otros que en mayor o menor medida distinguen al juicio de hecho que se darían según los cánones de la aproximación a la realidad. or esta razón, el sistema de la prueba legal es irracional: más exactamente, es contra-racional porque excluye los critérios racionales de valoración de la prueba." (La prueba de los hechos. Traducción de Jordi Ferrer Beltrán. 2. ed. Madrid: Trotta, 2005. p. 401).
} 
alegações das partes e dos demais meios de prova trazidos aos autos, com a finalidade de integrar um raciocínio lógico e fundamentado para a formação do livre convencimento. ${ }^{310}$

Logo, "o sistema de valoração das provas acolhido pelo direito brasileiro busca uma conjugação necessária entre a disciplina dada pelas normas jurídicas à prova e a convicção do próprio juiz no exame de cada caso concreto". ${ }^{311}$ A prova legal pode servir de fundamento para dispensar a produção de determinada prova, o que não significa tolher a iniciativa probatória do magistrado necessária à formação do livre convencimento motivado, porquanto aquela concorre como justificativa que pode ser aplicada à dispensa da prova, mas não necessariamente obriga o juiz a curvar-se diante dessa dispensa. Nesse sentido são as ponderações de Michele Taruffo:

"Como ya se há mencionado anteriormente, la convicción del juez debe estar libre de vínculos legales - que precluyen la aproximación a la realidad - pero no debe estar libre de los critérios de valoración racionales: es más, éstos son los únicos critérios que permiten establecer si la valoración de la prueba produce elementos aptos para fundar el juicio sobre el hecho.",312

Por outro lado, cumpre tecer breves apontamentos sobre o sistema de presunções e as máximas de experiência, que não constituem necessariamente meios de prova, mas concorrem de igual sorte para a motivação da decisão judicial, de modo a influir nos poderes instrutórios do juiz.

\footnotetext{
${ }^{310}$ Para Humberto Theodoro Júnior: "Sem a rigidez da prova legal, em que o valor de cada prova é previamente fixado na lei, o juiz, atendo-se apenas às provas do processo, formará seu convencimento com liberdade e segundo a consciência formada. Embora seja livre o exame das provas, não há arbitrariedade, porque a conclusão deve ligar-se logicamente à apreciação jurídica daquilo que restou demonstrado nos autos. (...) A convicção fica, pois, condicionada, segundo Amaral Santos: a) aos fatos nos quais se funda a relação jurídica controvertida; $b$ ) às provas desses fatos, colhidas no processo; c) às regras legais e máximas de experiência; d) e o julgamento deverá sempre ser motivado." (Curso de direito processual civil, cit., v. 1, p. 415-416). Por sua vez, Carlos Alberto Alvaro de Oliveira conclui que se mostra evidente o crescente desprestígio do chamado sistema da prova legal em prol da maior liberdade do órgão judicial a respeito (Do formalismo no processo civil, cit., p. 263).

${ }^{311}$ BUENO, Cassio Scarpinella, Curso sistematizado de direito processual civil, cit., v. 2, t. 1, p. 239.

${ }^{312}$ TARUFFO, Michele, La prueba de los hechos, cit., p. 402.
} 


\subsection{Técnicas que podem dispensar a produção da prova: sistema de presunções e máximas de experiência}

As presunções não são consideradas meios de prova, ${ }^{313}$ mas sim métodos de raciocínio ou de convencimento que a lei pode assumir com maior ou menor intensidade em alguns casos para dispensar a produção da prova. Vale dizer, a presunção "é um processo racional do intelecto, pelo qual do conhecimento de um fato infere-se com razoável probabilidade a existência de outro ou o estado de uma pessoa ou coisa".314 Através da presença de indícios, revela-se outro fato, de sorte que as presunções podem ser legais (legis) ou judiciais (hominis, também chamadas presunções simples ou presunções comuns). ${ }^{315}$

As presunções absolutas sempre serão legais e dispensam a constatação de determinado fato, tanto no plano material quanto processual, a exemplo, no primeiro caso, da usucapião, que exige o justo título e boa-fé, se a posse for superior a dez e inferior a quinze anos (art. 1.242, caput e parágrafo único, do CC) ao passo que, na posse superior a quinze anos, tais exigências estão dispensadas (art. 1.238 do CC), porquanto a lei presume a sua existência. De igual sorte, as garantias oferecidas pelo devedor insolvente a um dos credores presumem-se fraudatórias dos direitos dos demais (art. 163 do CC). No âmbito do direito substancial, de igual modo o art. 12, § $3^{\circ}$, do Código de Processo Civil presume autorizado para receber citação o gerente da filial ou agência da pessoa jurídica estrangeira, ao passo que o art. $412, \S 1^{\circ}$, presume a desistência da oitiva da testemunha que não comparece na audiência se a parte que a requereu se comprometeu em levá-la na

\footnotetext{
${ }^{313}$ BUENO, Cassio Scarpinella, Curso sistematizado de direito processual civil, cit., v. 2, t. 1, p. 239. No mesmo sentido: DINAMARCO, Cândido Rangel, Instituições de direito processual civil, v. 3, cit., p. 125126; LOPES, João Batista, A prova no direito processual civil, cit., p. 66; e BARBOSA MOREIRA, José Carlos. As presunções e a prova. In: Temas de direito processual: primeira série. 2. ed. São Paulo: Saraiva, 1988. p. 59). Por sua vez, Humberto Theodoro Júnior perfilha o entendimento de que as presunções são meios "moralmente legítimos" de prova (Curso de direito processual civil, cit., v. 1, p. 425-426), ao passo que Moacyr Amaral Santos classifica as presunções como prova indireta, porquanto o que resta deduzido através de presunção não está provado nos autos (Primeiras linhas de direito processual civil, cit., v. 2, p. 506). A despeito da divergência posta pela doutrina, o Código Civil de 2002 tratou de arrolar a presunção como meio de prova no art. 212, IV. Para os fins perseguidos neste trabalho, mostra-se irrelevante aprofundar o exame de serem ou não as presunções meios de prova, de modo que optaremos pela primeira definição, a complementar o raciocínio apontado no item anterior de que as presunções estão contempladas nos elementos legais de prova.

${ }^{314}$ DINAMARCO, Cândido Rangel, Instituições de direito processual civil, v. 3, cit., p. 113.

${ }^{315}$ BUENO, Cassio Scarpinella, Curso sistematizado de direito processual civil, cit., v. 2, t. 1, p. 239.
} 
audiência. ${ }^{316} \mathrm{Em}$ verdade, as presunções absolutas se aproximam de regras do direito material, ${ }^{317}$ tamanha sua imperatividade em não admitir prova em contrário.

Já as presunções relativas admitem prova em contrário, de modo a servirem como regra de inversão do ônus da prova. ${ }^{318}$ Ou seja, cabe àquele para quem a presunção relativa é favorável tão somente demonstrar a constatação do indício que conduzirá à existência do fato buscado na instrução, independentemente dele restar provado. ${ }^{319}$ Por sua vez, e exatamente por admitir prova em contrário (juris tantum), esse fato que prescinde de demonstração por força da presunção relativa pode restar ilidido por aquele para quem a presunção for desfavorável, uma vez apresentando prova em contrário do fato presumido. $^{320}$

Dentre as presunções relativas legais no plano do direito substancial, alguns exemplos podem ser citados como o disposto no art. 334, IV, do Código de Processo Civil, bem como a presunção de veracidade dos fatos alegados pelo autor, quando incidentes os efeitos da revelia, já comentados no item anterior (art. 319 do CPC e regra de exceção constante no art. 320), ou quando os fatos alegados deixam de ser impugnados de forma específica pelo réu (art. 302 e incs. do CPC. ${ }^{321}$. De igual modo, há presunções relativas no

\footnotetext{
${ }^{316}$ DINAMARCO, Cândido Rangel, Instituições de direito processual civil, v. 3, cit., p. 117-118.

317 Nesse sentido, Barbosa Moreira discorre sobre a frunção normativa da presunção absoluta, na medida que, por não admitir prova em contrário (presunção relativa), acaba por aproximar-se do plano do direito material (As presunções e a prova, in Temas de direito processual: primeira série, cit., p. 63-64). Ao final, conclui que "os fatos legalmente presumidos iuris et de iuri, na verdade, não são apenas fatos que dispensem prova; são fatos irrelevantes já do ponto-de-vista material, isto é, fatos que não precisam ocorrer para que se produza o efeito previsto na lei” (Ibidem, p. 67).

${ }^{318}$ ARRUDA ALVIM, José Manoel de, Manual de direito processual civil, cit., v. 2, p. 480.

${ }^{319}$ YARSHELL, Flávio Luiz, Antecipação de prova sem o requisito da urgência e direito autônomo à prova, cit., p. 134.

${ }^{320}$ Dinamarco elucida com clareza um exemplo de presunção relativa constante no art. 1.253 do Código Civil, que dispõe que "toda construção, ou plantação, existente em um terreno, presume-se feita pelo proprietário e à sua custa, até que se prove o contrário" (Instituições de direito processual civil, v. 3, cit., p. 119). Logo, cabe à parte que milita a presunção tão somente o ônus de demonstrar o domínio sobre o imóvel, ficando o fato probando, relativo ao custeio da plantação, dispensado de prova. Por outro lado, esse fato dispensado de prova pode ser provado em contrário pela parte adversa.

321 “Art. 302 - Cabe também ao réu manifestar-se precisamente sobre os fatos narrados na petição inicial. Presumem-se verdadeiros os fatos não impugnados, salvo: I - se não for admissível, a seu respeito, a confissão; II - se a petição inicial não estiver acompanhada do instrumento público que a lei considerar da substância do ato; III - se estiverem em contradição com a defesa, considerada em seu conjunto. Parágrafo único - Esta regra, quanto ao ônus da impugnação especificada dos fatos, não se aplica ao advogado dativo, ao curador especial e ao órgão do Ministério Público". No que toca à confissão, vale lembrar que ela não é admitida em relação a direitos indisponíveis, consoante dispõe o art. 451 do Código de Processo Civil.
} 
plano do direito material ${ }^{322}$ cuja dispensa de prova de determinado fato pode restar ilidida mediante prova em contrário trazida aos autos.

Por fim, as chamadas máximas de experiência constituem presunções judiciais, ${ }^{323}$ previstas no art. 335 do Código de Processo Civil, ${ }^{324}$ de modo a traduzir "expressão da cultura dos juízes como intérpretes dos valores e da experiência acumulada pela sociedade em que vivem". ${ }^{325}$ São construídas indutivamente, com fundamento na experiência relativa a determinados estados de coisas e representam a experiência da cultura média do homem, ${ }^{326}$ de modo a comporem juízos abstratos decorrentes da observação do que comumente acontece. ${ }^{327}$ Portanto, não se confundem com o conhecimento pessoal do juiz sobre algum fato concreto, mas constotuem percepções em abstrato do que ordinariamente acontece $^{328}$ seja através de experiência comum, seja ainda decorrente de experiência técnica. ${ }^{329}$ E essas percepções se pautam no senso comum, a variar com o tempo e com as sociedades, ${ }^{330}$ valendo transcrever a concepção de Friedrich Stein:

\begin{abstract}
“(...) son definiciones o juicios hipotéticos de contenido general desligados de los hechos concretos que se juzgan en el proceso, precedentes de la experiencia, pero independientes de los casos particulares de cuya observación se han inducido y que, por encima de esos casos, pretenden tener validez para otros nuevos." 331
\end{abstract}

\footnotetext{
${ }^{322}$ Alguns exemplos são trazidos por Dinamarco: “(...) a) a comoriência, que se presume até que uma das partes comprove que as pessoas falecidas no mesmo evento não tiveram mortes rigorosamente simultâneas $\left(\mathrm{CC}\right.$, art. $\left.8^{\circ}\right)$; b) o pagamento de todas as parcelas de uma obrigação anteriores à do vencimento posterior cujo pagamento haja sido provado (CC, art. 322); c) o plantio em terreno de determinada pessoa, que se presume feito por ela (CC, art. 1.253); d) a propriedade de bens móveis, que em caso de casamento sob o regime de comunhão parcial presumem-se adquiridos na constância do casamento (aquestos, art. 1.662 CC); e) a entrega do título da obrigação ao devedor, que firma a presunção do pagamento (CC, art. 324)." (Instituições de direito processual civil, v. 3, cit., p. 120-121).

${ }^{323}$ Ibidem, p. 121 e ss. Entendendo que as máximas de experiência são presunções hominis e, portanto, são classificadas como presunções judiciais: BUENO, Cassio Scarpinella, Curso sistematizado de direito processual civil, cit., v. 2, t. 1, p. 239.

324 “Art. 335 - Em falta de normas jurídicas particulares, o juiz aplicará as regras de experiência comum subministradas pela observação do que ordinariamente acontece e ainda as regras da experiência técnica, ressalvado, quanto a esta, o exame pericial".

${ }^{325}$ DINAMARCO, Cândido Rangel, Instituições de direito processual civil, v. 3, cit., p. 122.

${ }^{326}$ ROSITO, Francisco, Direito probatório: as máximas de experiência em juízo, cit., p. 80.

${ }^{327}$ LOPES, João Batista, A prova no direito processual civil, cit., p. 69.

${ }^{328}$ THEODORO JÚNIOR, Humberto, Curso de direito processual civil, cit., v. 1, p. 416-417.

${ }^{329}$ Em relação à regra de experiência comum, Dinamarco cita como exemplo a presunção de culpa do motorista que abalroou outro veículo por trás: essa culpa deflui que esse modo de colidir é ordinariamente o resultado da desatenção do motorista de trás, má conservação de freios ou pneus, imperícia de deter o veículo a tempo ou excessiva velocidade (Instituições de direito processual civil, v. 3, cit., p. 123). Por sua vez, a regra de experiência técnica se verifica em conhecimentos técnicos ou científicos ao alcance do homo medius, a exemplo da ebulição da água a $100^{\circ} \mathrm{C}$, postulados de matemática ou geometria, etc.

${ }^{330}$ STEIN, Friedrich. El conocimiento privado del juez. Santa Fé de Bogotá: Temis, 1999. p. 32.

${ }^{331}$ Ibidem, p. 27.
} 
Logo, as máximas de experiência valem como elementos a serem confrontados pelo juiz no processo cognitivo, a contribuir e fundamentar a formação da persuasão racional. Tamanha é essa confrontação que o próprio art. 335 do Código de Processo Civil restringe a aplicação dessa presunção tão somente quando ausentes normas jurídicas particulares, sendo vedada "quando a questão de fato que será objeto de sua presunção ou ilação dependa de conhecimento técnico que o magistrado não possua". 332

Assim como a prova legal, as presunções (embora não sejam consideradas meios de prova) não se apoiam no juízo de certeza, mas acabam por confiar razoavelmente na probabilidade de que se mantenha constante a relação entre o fato-base e o presumido, da qual se extrai a constatação da fattispecie para então se subsumir determinado fato. E essa probabilidade se revela em maior grau de acerto nas presunções absolutas (juris et de jure), ao passo em que nas presunções relativas (juris tantum), esse grau é reduzido, mormente por admitirem prova em contrário. ${ }^{333} \mathrm{E}$ exatamente por se tratar de juízo de probabilidade que tais presunções podem servir de apoio ao juiz para fundamentar a dispensa de prova de determinado fato, mas não necessariamente o obrigam a se valer das presunções de forma absoluta, e assim vedar a iniciativa probatória.

Afinal, se as presunções relativas têm utilidade técnica para inverter o ônus da prova em desfavor daquele a quem milita a presunção, ${ }^{334}$ nada impede que o juiz, antes de aplicar essa regra de inversão, utilize iniciativas probatórias com vistas a confirmar a existência ou não do fato presumido. Ainda, sendo a distribuição do ônus da prova entendida como regra de julgamento destinada a evitar o non liquet, de igual sorte a iniciativa probatória do juiz servirá para angariar elementos aos autos necessários à formação do livre convencimento, de modo a evitar-se que o julgamento se baseie num juízo de mera presunção. Vale dizer, em relação às presunções relativas, tendo em vista o caráter de inversão do ônus da prova para aquele a quem a presunção milita

\footnotetext{
${ }^{332}$ JORGE, Flávio Cheim; RODRIGUES, Marcelo Abelha. As máximas de experiência (art. 335, CPC) e a impossibilidade de sua aplicação pelo magistrado quando exige-se conhecimento técnico específico. Revista de Processo, São Paulo, Revista dos Tribunais, ano 32, n. 144, p. 265, fev. de 2007. Para Barbosa Moreira, as máximas de experiência devem ser aplicadas de forma subsidiária à lei, sendo as "regras de experiência" pautadas "ao lado da analogia, dos costumes e dos princípios gerais do direito, irmanados todos pela função comum de complanar as lacunas do texto legal" (As presunções e a prova, in Temas de direito processual: primeira série, cit., p. 69).

${ }^{333}$ DINAMARCO, Cândido Rangel, Instituições de direito processual civil, v. 3, cit., p. 115.

${ }^{334}$ DINAMARCO, Cândido Rangel, Instituições de direito processual civil, v. 3, cit., p. 119. No mesmo sentido: BARBOSA MOREIRA, José Carlos, As presunções e a prova, in Temas de direito processual: primeira série, cit., p. 61.
} 
desfavoravelmente, a distribuição do ônus da prova é regra a ser observada somente na ocasião do julgamento. ${ }^{335}$

De igual sorte, em relação à aplicação de presunções absolutas, conforme exposto acima, elas se aproximam mais de regras de direito material, a tornar desnecessária a investigação sobre fatos que o legislador impôs como presumidos. Daí porque Egas Dirceu Moniz de Aragão entende que as presunções, ainda que absolutas, devem ser confrontadas com as demais provas produzidas nos autos e não limitarem-se a um dogma estanque que impeça a produção de provas requeridas pelas partes. ${ }^{336}$ Parece-nos acertado esse entendimento, porquanto a produção de provas adicionais, ainda que voltadas a confirmar determinada presunção, só irá angariar mais segurança na entrega da tutela jurisdicional, cuja decisão certamente não se limitará a um único fundamento, mas restará mais completa através de dilação probatória mais ampla. ${ }^{337}$

Logo, as presunções não significam uma limitação para a formação do livre convencimento motivado, tampouco uma regra absoluta a ser aplicada pelo julgador, mas, como as provas legais tratadas no item anterior, constituem elementos que podem facilitar o raciocínio lógico-dedutivo quando da formação do livre convencimento, a ponto de dispensarem a produção de determinada prova sobre um fato que a lei reputa presumido.

Ou seja, em que pese o legislador prescrever como verdadeira a existência de determinado fato extraída a partir da presença de outro fato, isso não significa que o juiz jamais deverá deixar de produzir prova para corroborar como verdadeiro o fato presumido, exatamente por conta da presunção relativa admitir prova em contrário e a presunção absoluta, em verdade, aproximar-se mais de regra de direito material que dispensa a prova

\footnotetext{
${ }^{335}$ Voltaremos a tratar desse tema no item 3.2.4.

336 ARAGÃO, Egas Dirceu Moniz de. Regras de prova no Código Civil. Revista de Processo, São Paulo, Revista dos Tribunais, ano 29, n. 116, p. 27, jul./agos. 2004.

${ }^{337}$ Nesse sentido, Bedaque justifica a pertinência da produção de prova determinada pelo magistrado: “(...) quando o juiz determina a realização de alguma prova, não tem condições de saber, de antemão, seu resultado. $\mathrm{O}$ aumento do poder instrutório do julgador, na verdade, não favorece qualquer das partes. Apenas proporciona uma apuração mais completa dos fatos, permitindo que as normas de direito material sejam atuadas corretamente. E tem mais: não seria parcial o juiz que, tendo conhecimento que a produção de determinada prova possibilitará o esclarecimento de um fato obscuro, deixa de fazê-lo e, com tal atitude, acabe beneficiando a parte que não tem razão? Para ele não deve importar que vença o autor ou o réu. Importa, porém, que saia vitorioso aquele que efetivamente tenha razão, ou seja, aquele cuja situação da vida esteja protegida pela norma de direito material, pois somente assim se pode falar que a atividade jurisdicional realizou plenamente sua função." (Poderes instrutórios do juiz, cit., p. 110).
} 
de determinado fato. De igual modo, a aplicação das máximas de experiência não mitiga a formação do livre convencimento, podendo o magistrado exercer "o poder de livre convencimento, no exame da prova do fato-base; depois, quando convencido da ocorrência deste, fará as ilações que o art. 335 lhe determina, sempre com liberdade para raciocinar segundo os ditames de sua cultura e de seu intelecto". 338

Já na presunção absoluta, exatamente por conta da constatação do indício conduzir à existência do fato presumido como se fosse uma regra de direito material, a iniciativa probatória poderá servir para verificar a existência ou não do indício que conduz à ocorrência do fato presumido. ${ }^{339}$ Uma vez existente o indício que conduz à presunção absoluta, dispensa-se, por oportuno, a prova do fato presumido, o que não impede o manejo das iniciativas probatórias voltadas à constatação do indício.

Da mesma forma que restou tratado no item anterior, a constatação da presunção, exatamente por se tratar de um juízo de probabilidade, não reduz a iniciativa probatória do magistrado, mas pode servir como técnica para fundamentar a dispensa de produção de prova de determinado fato, cujo critério de aplicação é restrito ao julgador, tal qual se reveste o juízo subsuntivo em relação ao fato-base, quando da utilização das máximas de experiência. Trata-se, pois, de elementos que facilitam fundamentar a formação do livre convencimento do juiz; os dispositivos relativos a tais presunções podem ser utilizados para fundamentar a dispensa da produção de determinada prova por conta da existência do fato presumido. Por essa razão, soam acertadas as ponderações de Barbosa Moreira:

\footnotetext{
“(...) é intuitivo, em linha de princípio, que um bom julgamento descansa na correta aplicação da norma a fatos reconstituídos com a maior exatidão possível; e julgar bem é preocupação que não pode ser estranha ao órgão judicial. Nessa perspectiva, ao contrário do que insinuam certas fórmulas tradicionais, recusar-lhe a possibilidade de comprovar espontaneamente os fatos parece tão pouco razoável, afinal de contas, quanto negar-lhe a de procurar por si mesmo a norma aplicável: o conhecimento daqueles não lhe é menos necessário que o desta para cumprir sua função essencial de modo satisfatório." 340
}

\footnotetext{
${ }^{338}$ DINAMARCO, Cândido Rangel, Instituições de direito processual civil, v. 3, cit., p. 123.

339 Daí porque Barbosa Moreira complementa: "Não seria inteiramente razoável sequer considerar que, raciocinando a partir de x para chegar a determinada conclusão sobre y, esteja o órgão judicial a valorar a prova. O que ele sem dúvida valorou foi a prova colhida acerca de $x$, para convencer-se de que esse fato realmente ocorrera. Mas a atividade valorativa da prova encerra-se no instante em que o juiz forma tal convencimento." (As presunções e a prova, in Temas de direito processual: primeira série, cit., p. 57).

${ }^{340}$ BARBOSA MOREIRA, José Carlos. Os poderes do juiz na direção e na instrução do processo. In. Temas de direito processual: quarta série. São Paulo: Saraiva, 1989. p. 47.
} 
O que dever ser observado, repita-se, é a observância dos princípios processuais e constitucionais como meio de permitir um mecanismo de controle das decisões judiciais que franqueia às partes a participação em contraditório, mormente quando a iniciativa probatória mostrar-se desnecessária e dispensável.

Traçadas algumas premissas relativas à cognição judicial, seguida de apontamentos acerca da prova, seu objeto, finalidade e, dentro dessa seara, os critérios definidos no sistema para sua valoração em conjunto com os elementos de prova legal e indiciária, cumpre trazer breve conclusão sobre a relação da prova com a cognição judicial.

\subsubsection{Relação da prova com a cognição judicial}

À guisa do que foi objeto de análise acima, pode-se concluir que a cognição judicial revela a atividade de conhecimento exercida pelo juiz voltada à resolução de questões dentro do processo. Essa atividade cognitiva pode apresentar variações no plano vertical (cognição sumária ou exauriente) e no plano horizontal (cognição completa ou limitada), as quais se relacionam com a intensidade na busca da verdade e do esclarecimento convincente e com a área das questões sucetíveis de cognição, respectivamente. ${ }^{341}$

E para realizar a cognição, a prova permite ao juiz maior conhecimento dos fatos, pois seu objeto resume os fatos relevantes para decidir e que portanto necessitam restar $\operatorname{provados}^{342}$, exatamente para se atingir a finalidade de formação do livre convencimento motivado do julgador. Por sua vez, a formação desse livre convencimento deve se aproximar ao máximo de um juízo de certeza que refleta com fidelidade a verdade posta nos autos através do resultado do conjunto probatório.

\footnotetext{
${ }^{341}$ DINAMARCO, Cândido Rangel, Instituições de direito processual civil, v. 3, cit., p. 37. Leciona Kazuo Watanabe que no processo de conhecimento sujeitam-se à cognição um trinômio de questões, consistente nas voltadas à regularidade do processo, as que versam sobre as condições da ação e as questões de mérito (Da cognição no processo civil, cit., p. 71-72). De igual sorte, esse trinômio é válido no processo de execução e no processo cautelar: “(...) evidentemente com as especificações próprias que os diferenciam do processo de conhecimento." (Ibidem, p. 74).

${ }^{342}$ Para Francesco Carnelutti, apenas se fala de prova a propósito de algo que foi afirmado e cuja exatidão necessita ser comprovada (La prueba civil. Traducción de Niceto Alcalá-Zamora y Castillo. Buenos Aires: Depalma, 2000. p. 38).
} 
A necessidade e relevância da produção da prova se impõe como meio destinado a angariar elementos que irão balizar a formação do livre convencimento. Na medida que ao juiz forem apresentados resultados probatórios que tragam maiores informações fáticas relacionadas às questões controvertidas ou inverossímeis, maiores serão os elementos correspondentes à aproximação da verdade e, consequentemente, maior será a probabilidade de acerto para a aplicação de uma decisão justa que reflita a aplicação do direito material. Consoante leciona Barbosa Moreira, "a probabilidade de atingir-se uma decisão justa cresce na razão direta do rendimento dos mecanismos probatórios". 343

De igual modo, as presunções e máximas de experiência, embora não sejam definidas como meios de prova, trazem elementos que podem ser utilizados pelo magistrado para compor a formação do livre convencimento, porquanto o próprio sistema assim define contornos em que a constatação de indícios, por si só, pode ser suficiente para a prova de determinado fato.

Assim, a prova, quando necessária sua produção, constitui elemento fundamental para a formação do convencimento do juiz, de sorte que na cognição será exercida a atividade intelectiva de buscar, examinar e valorar as alegações e as provas produzidas pelas partes, para ao final permitir seja proferida uma decisão fundamentada. Vale dizer, sem o resultado do conjunto probatório carreado aos autos e quando a produção de provas não for compatível com o procedimento, não poderá o juiz decidir a ponto de desvendar qual parte tem razão na demanda. E essa mesma lógica se presta a coroar a máxima chiovendiana de que o processo deve "dare per quanto è possibile praticamente a chi ha um diritto tutto quello e proprio quello ch'egli ha diritto di conseguire". ${ }^{344}$

Portanto, prova e cognição judicial se entrelaçam quando da produção de conhecimento no espírito do juiz, cuja decisão final deve sempre restar fundamentada, a indicar as razões de formação do livre convencimento do julgador. E, sendo o juiz o destinatário da prova, porquanto cabe a ele exclusivamente valorar a prova, até que possa reunir condições de decidir, ganha relevância o manejo dos poderes instrutórios como medida de se propiciar um julgamento que se aproxime com a maior fidelidade da verdade dos fatos.

\footnotetext{
${ }^{343}$ BARBOSA MOREIRA, José Carlos, Alguns problemas atuais da prova civil, cit., p. 122.

${ }^{344}$ CHIOVENDA, Giuseppe, Instituizioni di diritto processuale civile, v. 1, cit., p. 42.
} 
Daí porque, na conjugação entre prova e cognição judicial, os poderes instrutórios estão relacionados com a atividade do juiz voltada à produção de provas e merecem análise mais minuciosa, na tentativa de estabelecer seu conceito, dimensão, momento e limites. Antes, serão traçadas breves considerações acerca das regras de distribuição do ônus da prova previstas no sistema, as quais também podem influenciar a resolução do conflito de interesses apresentado para solução ao Estado-juiz.

\section{2 Ônus da prova, inversão do ônus da prova e carga dinâmica da prova}

Após apontar alguns aspectos ligados à prova, seu objeto, finalidade e relação com a cognição judicial, resta, por fim, traçar breves premissas acerca do ônus probatório e sua relação com as iniciativas probatórias do juiz. Não pretendemos aqui discorrer sobre quem deve provar e o que em juízo, mas sim traçar breve análise da sistemática que abarca a repartição do ônus da prova entre as partes, para ao final verificar se tais regras de distribuição do ônus da prova podem ou não influenciar a iniciativa probatória do juiz.

\subsubsection{O ônus da prova (ônus objetivo e ônus subjetivo)}

A palavra ônus significa "carga", "fardo" "peso", consistente, no que toca ao ônus probatório, em um "dever no sentido de interêsse, de necessidade, interêsse, necessidade de produzir a prova para formar-se a convicção do juiz a respeito dos fatos alegados". ${ }^{345}$ Não se confunde com um dever jurídico, porquanto não há um direito que lhe seja correlato, tampouco qualquer sanção por seu não cumprimento, mas relaciona-se com a necessidade da prática de um ato para a assunção de uma específica posição de vantagem própria ao longo do processo, ao passo que, na hipótese oposta, o que pode ocorrer é um prejuízo para quem não praticou o ato ou o praticou insuficientemente. ${ }^{346}$ Portanto, o ônus de provar não

\footnotetext{
${ }^{345}$ SANTOS, Moacyr Amaral. Prova judiciária no cível e comercial, cit., v. 1, p. 98.

${ }^{346}$ BUENO, Cassio Scarpinella, Curso sistematizado de direito processual civil, cit., v. 2, t. 1, p. 246. Semelhante constatação é feita por Rui Manuel de Freitas Rangel, para quem o ônus corresponde ao exercício de uma faculdade colocada como condição para obter certa vantagem e realizar determinado interesse. Por sua vez, "a inobservância do ónus faz recair sobre a parte que tem esse encargo o risco do silêncio do seu comportamento, que lhe accarretará determinados efeitos negativos e desvantagens; o incumprimento da obrigação ocorre pela possibilidadade que assiste ao sujeito de não cumprir" ( $O$ ônus $d a$ prova no processo civil. 3. ed. Coimbra: Almedina, 2006. p. 93-94).
} 
é um dever, mas é empregado em proveito próprio daquele sobre o qual recai o ônus de provar determinado fato, sob pena de suportar o risco de deixar de lhe ser entregue a tutela jurisdicional na forma pretendida. ${ }^{347}$

Na repartição desse ônus, costuma-se falar em ônus subjetivo e ônus objetivo. $\mathrm{O}$ primeiro está ligado à conduta processual exigida da parte para que a verdade dos fatos por ela arrolados seja admitida pelo juiz, de sorte que o litigante assuma o risco de perder a causa se não provar os fatos alegados, dos quais dependa a existência do direito subjetivo que pretende resguardar através da tutela jurisdicional. ${ }^{348}$ Vale dizer, se a parte deixar de produzir determinada prova cujo ônus lhe incumbia, isso não necessariamente conduz a um julgamento a ela desfavorável, porquanto, conforme visto acima, no ínterim de formação do livre convencimento do magistrado e valoração da prova, é feito o confronto de todas as provas produzidas nos autos, até que possa angariar elementos que fundamentem a decisão em favor de uma das partes. De todo modo, é franqueado à parte fazer prova de seu direito na forma da repartição do ônus probatório; em não o fazendo, assume o risco da demanda lhe ser julgada de forma desfavorável. Alfredo Buzaid conclui:

"O que entre em cogitação é a verdade dos fatos da causa a ser decidida.
Só quando haja incerteza sôbre a questão de fato é que o juiz necessita de
uma indicação, que há de orientar o conteúdo da sentença. Não surge,
pois, o problema do ônus da prova, quando são pacíficas as afirmações
das partes relativas às questões de fato, ou quando o juiz se convence da
verdade ou não das afirmações discutidas, seja porque essa convicção
nasce da prova produzida, seja porque resulta do conjunto dos
debates."

Por outro lado, o ônus objetivo reflete a própria função jurisdicional inerente à atividade do juiz, sendo a ele vedado se abster de julgar (non liquet), sob a premissa de que os fatos trazidos aos autos não restaram comprovados. Consoante leciona João Batista Lopes:

\footnotetext{
${ }^{347}$ Para estudo mais aprofundado do tema, ver: PACÍFICO, Luiz Eduardo Boaventura. Ônus da prova no direito processual civil. 2. tiragem. São Paulo: Revista dos Tribunais, 2001; e MICHELI, Gian Antônio. L'onere della prova. Padova: Cedam, 1966; VERDE, Giovanni. L'onere della prova nel processo civile. Napoli]: Jovene, 1974; e DEVIS ECHANDIA, Hernando, Teoria general de la prueba judicial, cit., v. 1. 348 THEODORO JÚNIOR, Humberto, Curso de direito processual civil, cit., v. 1, p. 420.

${ }^{349}$ BUZAID, Alfredo. Do ônus da prova. Revista de Direito Processual Civil, São Paulo, Saraiva, v. 4, p. 15, 1964.
} 
“(...) há dois aspectos do ônus da prova, bem claros e definidos: a) o ônus subjetivo (a quem incumbe provar); b) o ônus objetivo (encerrada a prova, irrelevante é indagar se houve estrita observância das regras que regem o ônus subjetivo da prova, pois o juiz, destinatário dela, julgará a causa levando em consideração todos os elementos constantes dos autos." 350

Sob essa perspectiva, o que importa é o estabelecimento das bases para a formação da convicção juidicial, de modo que "não é tarefa exclusiva da parte a quem incumbe o ônus da prova; o que interessa é somente o demonstrado, não quem o demonstrou". ${ }^{351} \mathrm{O}$ aspecto objetivo do ônus da prova guarda ligação com o princípio da aquisição processual ou da comunhão nos resultados da prova, ${ }^{352}$ o qual preceitua que pouco importa qual parte tenha trazido a prova aos autos, porquanto ela pertence ao processo e se faz necessária para formar o livre convencimento do juiz.

Por outro lado, seja no aspecto subjetivo, seja no objetivo, a distribuição do ônus da prova tem por finalidade permitir ao juiz que aplique tal regra na ocasião de julgar a demanda, e assim evitar que deixe de julgar com base na falta de prova do direito das partes. Ou seja, é vedado ao juiz não proferir sentença edeixar de entregar a tutela jurisdicional, sob a assertiva de que, pela análise dos elementos probatórios trazidos aos autos, não conseguiu decidir ainda a qual parte assiste razão na demanda. Daí porque as regras de distribuição do ônus da prova guardam utilidade para se evitar o non liquet, porquanto, nessa hipótese, o juiz poderá decidir a demanda fundamentando sua decisão no desatendimento do ônus probatório que recaía sobre o litigante que deixou de produzir a prova acerca de determinado fato necessário para se prover o pedido.

Nesse caso, a decisão, embora fundamentada na falta de prova, será justificada no desatendimento do ônus que cumpria ao litigante comprovar determinado fato, de modo a salvaguardar um julgamento arbitrário. Essas regras de distribuição do ônus probatório

\footnotetext{
${ }^{350}$ LOPES, João Batista, A prova no direito processual civil, cit., p. 46.

${ }^{351}$ BUZAID, Alfredo, Do ônus da prova, cit., p. 17.

352 ARRUDA ALVIM, José Manoel, Manual de direito processual civil, cit., v. 2, p. 481. Pertinentes são as críticas desse autor em relação à infeliz concepção técnica de ônus objetivo, porquanto em verdade não há ônus algum que recaia sobre a conduta do magistrado. Aliás, "se há comunhão nos resultados da prova, num caso concreto, não há que se falar em ônus. Demais disso, o ônus é por natureza, eminentemente subjetivo e relacionado com o agir ou com o não agir bem ou mal sucedido de um litigante" (Ibidem, mesma página). Em semelhante sentido, Dinamarco é taxativo em lecionar que não há ônus processuais ao juiz, mas sim poderes que a lei lhe outorga e que são acompanhados do dever de exercê-los (DINAMARCO, Cândido Rangel, Instituições de direito processual civil, cit., v. 2, p. 213).
} 
devem ser aplicadas somente quando ausentes provas sobre os fatos em que versa a ação, em hipóteses que o juiz não tem outros elementos para reconstruir a realidade, convencerse e proferir uma decisão justa. ${ }^{353}$

Logo, a fim de coroar o escopo jurídico da jurisdição, deve-se evitar o julgamento sem saber quem tem razão e calcado na mera aplicação de regra de distribuição do ônus probatório. A distribuição do ônus da prova prevista no art. 333 do Código de Processo Civil $^{354}$ é vista como uma regra de julgamento, ${ }^{355}$ ou seja, o juiz só deve aplicá-la na ocasião em que proferir sentença, e desde que não tenha elementos suficientes para a formação de seu livre convencimento, e assim decidir de forma justa. ${ }^{356}$ De igual sorte, a

${ }^{353}$ CAMBI, Eduardo. A prova civil: admissibilidade e relevância. São Paulo: Revista dos Tribunais, 2006. p. 316.

${ }^{354}$ Ao autor cabe provar o fato constitutivo de seu direito, ao passo que ao réu incumbe demonstrar a existência de fato impeditivo, modificativo ou extintivo do direito do autor. Em linhas gerais, consoante leciona Bedaque, fato constitutivo é aquele que dá vida a uma vontade concreta da lei, que tem essa função e normalmente produz efeito. O fato extintivo faz cessar essa vontade, ao passo que o fato impeditivo é a inexistência do fato que deve concorrer com o constitutivo para que ele produza efeitos; o fato constitutivo é causa eficiente, ao passo que o fato impeditivo é a ausência de uma causa concorrente (Poderes instrutórios do juiz, cit., p. 117).

${ }^{355}$ Vale lembrar que a regra constante no art. 333 do Código de Processo Civil não é a única em relação à distribuição do ônus da prova. Conforme pondera Dinamarco, há inúmeras situações regidas pelo direito processual e pelo direito material que distribuem o ônus da prova, a exemplo do art. 389, I, do Código de Processo Civil, ao impor o ônus de demonstrar a falsidade do documento que compete à parte que houver arguido, assim como o inc. II, que determina que na impugnação sobre a assinatura do documento, deve ser demonstrada a autenticidade da parte daquele que o assina. Outros exemplos também se encontram previstos no Código Civil, cabendo ao depositário o ônus de provar o caso fortuito ou a força maior, sempre que os alegue como fundamento para não respoder pelos danos sofridos pela coisa depositada (art. 642); àquele que pagou de forma indevida, incumbe o ônus de provar tê-lo feito por erro (art. 877); quem paga o incapaz e vindo a obrigação a ser anulada por isso, tem o ônus de provar que o pagamento reverteu em proveito dele, para assim obter a restituição do valor pago (arts. 181 e 310). Por sua vez, cabe ao fabricante, produtor, construtor ou importador o ônus de comprovar a alegação de não haver colocado o produto no mercado, ou de que ele não é defeituoso, ou que o dano decorreu de culpa exclusiva do consumidor (art. 12, $\S 3^{\circ}$, incs. I a III, do CDC - Lei n. 8.078/90), ao passo que a Lei do Inquilinato (Lei n. 8.245/91) prevê o ônus do locatário de provar a causa dirimente (caso fortuito ou de força-maior - art. 23, III, V e XI), a fim de exonerar-se da responsabilidade pelo incêndio do prédio locado (Instituições de direito processual civil, v. 3, cit., p. 73-75).

${ }^{356}$ Nesse sentido: THEODORO JÚNIOR, Humberto. Prova - princípio da verdade real - poderes do juiz ônus da prova e sua eventual inversão - provas ilícitas - prova e coisa julgada nas ações relativas à paternidade (DNA). Revista brasileira de direito de família, Porto Alegre, Síntese, v. 1, n. 3, p. 13, out./dez. 1999; LOPES, João Batista, A prova no direito processual civil, cit., p. 50; BRAGA, Sidney da Silva. Iniciativa probatória do juiz no processo civil. São Paulo: Saraiva, 2004. p. 131; NERY JUNIOR, Nelson; NERY, Rosa Maria de Andrade. Código de Processo Civil comentado e legislação extravagante. São Paulo: Revista dos Tribunais, 2002. p. 479; DALL'AGNOL JUNIOR, Antônio Janyr. Comentários ao Código de Processo Civil: arts. 102-242. Coordenação de Ovídio A. Baptista da Silva. São Paulo: Revista dos Tribunais, 2000. v. 2, p. 132-133; MATTOS, Sérgio Luís Wetzel de. Da iniciativa probatória do juiz no processo civil. Rio de Janeiro: Forense, 2001. p. 103-104; CAMPANELLI, Luciana Amicucci. Poderes instrutórios do juiz e a isonomia processual. São Paulo: Juarez de Oliveira, 2006. p. 93; DIDIER JR., Fredie. Sobre a fundamentação da decisão judicial. In: CARVALHO, Milton Paulo de (Coord.). Direito processual civil. São Paulo: Quartier Latin, 2007. p. 260; MARINONI, Luiz Guilherme; ARENHART, Sérgio Cruz, Manual do processo de conhecimento, cit., p. 316; DINAMARCO, Cândido Rangel, Instituições de direito processual civil, cit., v. 3, p. 81-82; e BEDAQUE, José Roberto dos Santos, Poderes instrutórios do juiz, cit., p. 124 e ss. 
regra de julgamento também se aplica à inversão do ônus da prova, assim como na distribuição dinâmica do ônus da prova, porém com algumas ressalvas, conforme se verificará adiante.

\subsubsection{A inversão do ônus da prova}

Não obstante a regra geral de distribuição do ônus da prova prevista no art. 333 do Código de Processo Civil, há situações que definem a inversão do ônus da prova de determinado fato controvertido entre as partes, que consistem em "alterações de regras legais sobre a distribuição deste, impostas ou autorizadas por lei”. ${ }^{357}$ Portanto, trata-se de hipóteses que excepcionam a regra geral prevista no art. 333 do Código de Processo Civil, para assim inverterem o ônus probatório sobre determinado fato que cumpria a quem alega comprovar. Em síntese, essas regras de inversão do ônus da prova se resumem às presunções relativas, à convenção sobre a prova e à regra de inversão do ônus da prova prevista no Código de Defesa do Consumidor (Lei n. 8.078/90).

Conforme já tratado nos itens 3.1.2.2 e 3.1.2.2.1, as presunções relativas, exatamente em razão da característica que guardam em admitir prova em contrário a respeito da existência do fato presumido, acabam por impor que o ônus da prova recaia sobre aquele que milita em desfavor à presunção. Ou seja, cabe a este o ônus de apresentar prova em contrário a respeito do fato presumido.

Por sua vez, a inversão convencional do ônus da prova prevista no art. 333, parágrafo único, do Código de Processo Civil ${ }^{358}$ comporta determinadas limitações arroladas no próprio parágrafo desse dispositivo, tais como o óbice à convenção versar sobre direitos indisponível, ${ }^{359}$ ou quando tornar excessivamente difícil o encargo de provar pela parte que convenciona a inversão.

\footnotetext{
${ }^{357}$ DINAMARCO, Cândido Rangel, Instituições de direito processual civil, cit., v. 3, p.75.

358 "Parágrafo único - É nula a convenção que distribui de maneira diversa o ônus da prova quando: I - recair sobre direito indisponível da parte; II - tornar excessivamente difícil a uma parte o exercício do direito."

${ }^{359}$ Embora não tenha natureza de direito indisponível, o Código de Defesa do Consumidor (Lei n. 8.078/90) veda no art. 51, VI, a existência de cláusulas que determinem o ônus da prova em prejuízo do consumidor.
} 
Por fim, a inversão do ônus da prova prevista no art. $6^{\circ}$, III, do Código de Defesa do Consumidor (Lei n. 8.078/90) teve por escopo equacionar situação vista como desigual dentro em processo, para viabilizar aos litigantes a paridade de armas em dada pretensão resistida. Vale dizer, ao consumidor, na maior parte das vezes, nem sempre lhe será possível a produção de determinada prova nos autos, dada sua hipossuficiência técnica ou econômica, cabendo ao juiz, surgindo o estado de dúvida, e quando presentes os requisitos para a inversão, aplicar a regra da inversão do ônus da prova. Vale dizer, é necessário que seja verossímil a alegação do autor ${ }^{360}$ ou que haja hipossuficiência econômica, técnica ou informativa, consoante as regras de experiência. Por sua vez, a inversão se limitará aos fatos diretamente relacionados com a hipossuficiência do consumidor. ${ }^{361}$

Em relação a esses três últimos aspectos, a hipossuficiência econômica reflete a ausência de condições financeiras do consumidor poder arcar com o custo de determinada prova, de modo a comprometer o acesso à justiça e prestação da tutela jurisdicional mais efetiva $^{362}$ de sorte que a inversão, no caso da hipossuficiência econômica, não implica necessariamente que a parte sobre a qual recai a inversão arque com os custos de determinada prova requerida pela parte favorecida, mas sim que os efeitos da inversão, por si só, já implicam no ônus de produzir determinada prova, sob pena de presumirem-se

\footnotetext{
360 “Art. $6^{\text {o }}$ - São direitos básicos do consumidor: (...) VIII - a facilitação da defesa de seus direitos, inclusive com a inversão do ônus da prova, a seu favor, no processo civil, quando, a critério do juiz, for verossímil a alegação ou quando for ele hipossuficiente, segundo as regras ordinárias de experiências". Segundo Eduardo Cambi: "Alegação verossímil é aquela que, mesmo não sendo apoiada em elementos probatórios, tem a aparência de ser verdadeira. Opera-se, pois, com indícios ou sérias suspeitas que o fato tenha realmente ocorrido, embora, para se chegar a essa convicção, não se exija nem mesmo um início de prova." (Inversão do ônus da prova e tutela dos direitos transindividuais: Alcance exegético do art 6, VIII, do CDC. Revista de Processo, São Paulo, Revista dos Tribunais, ano 30, n. 127, p. 102, set. 2005). Semelhante constatação é feita por Antonio Gidi, para quem a mera probabilidade do fato alegado pelo consumidor não autoriza o magistrado a decidir em seu favor, mas apenas a inverter o ônus da prova (Aspectos da inversão do ônus da prova no código do consumidor. Revista de Direito do Consumidor, São Paulo, Revista dos Tribunais, n. 13, p. 35, jan./mar. 1995).

${ }^{361}$ CARVALHO FILHO, Milton Paulo de. Ainda a inversão do ônus da prova no Código de Defesa do Consumidor. Revista dos Tribunais, São Paulo, ano 92, n. 807, p. 66, jan. 2003.

${ }^{362}$ Essa inviabilidade econômica não pode ser óbice à tutela dos direitos do consumidor em juízo, porquanto o parágrafo único do art. $2^{\circ}$ da Lei n. 10.60/50, sem prejuízo do inc. LXXIV do art. $5^{\circ}$ da Constituição Federal, já garantem o acesso à justiça aos que comprovarem a insuficiência de recursos (art. $2^{\circ}$ da Lei n. 1.060/50: "Gozarão dos benefícios desta Lei os nacionais ou estrangeiros residentes no País que necessitarem recorrer à justiça penal, civil, militar ou do trabalho. Parágrafo único - Considera-se necessitado, para os fins legais, todo aquele cuja situação econômica não lhe permita pagar as custas do processo e os honorários de advogado, sem prejuízo do sustento próprio ou da família"). Por sua vez, a redação do art. $5^{\circ}$, I, do Código de Defesa do Consumidor, ao tratar da Política Nacional das Relações de Consumo, deixa clara a "manutenção de assistência jurídica, integral e gratuita, para o consumidor carente".
} 
verdadeiros os fatos por ele narrados. ${ }^{363}$ Por conta desse risco (presunção de veracidade por conta da inversão do ônus da prova), a parte sobre a qual recai a regra de inversão se vê em situação de arcar com os custos da prova requerida pela outra parte, podendo ao final da demanda, caso seja julgada improcedente, exigir a cobrança de tais despesas.

A hipossuficiência técnica, por sua vez, repousa na vulnerabilidade, na inaptidão técnica do consumidor frente ao fornecedor do produto/prestador do serviço que coloca em circulação. Significa dizer a disparidade entre o consumidor, cidadão médio, e aquele que é dotado de maior conhecimento técnico do produto/serviço por ele fornecido ou prestado. ${ }^{364}$ Inverte-se o ônus da prova em favor do consumidor porque ao fornecedor, detentor do conhecimento tecnológico, é mais fácil fazê-lo (e, em muitos casos, somente a ele é possível a produção da prova). Logo, se está correto que a hiposuficiência do consumidor está relacionada com a falta de conhecimentos técnicos e específicos da atividade desenvolvida pelo fornecedor/prestador de serviço, afigura-se de clareza meridiana que somente em relação a tais conhecimentos é legítima a inversão do ônus da prova. ${ }^{365}$

Por fim, a hipossuficiência informativa está relacionada aos dados e informações de detenção exclusiva do fornecedor do produto/prestador do serviço. Ou seja, a prova sobre determinado fato restará produzida por conta de uma diligência que verse sobre o levantamento de dados de posse exclusiva do fornecedor/prestador do serviço, inerente a determinada relação de consumo entre as partes litigantes. ${ }^{366}$

\footnotetext{
363 “Recurso Especial - Código de Defesa do Consumidor. Inversão do ônus da prova. A inversão do ônus da prova não tem o efeito de obrigar a parte contrária a arcar dom as despesas da prova requerida pelo consumidor. A transferência é apenas da obrigação de provar o seu direito para elidir a presunção que vige em favor do consumidor. (REsp n. 435.155). Precedentes. Recurso especial não conhecido.” (STJ - REsp


de 06.03.2006). No mesmo sentido: STJ - REsp n. 639.534/MT, rel. Min. Carlos Alberto Menezes Direito, v.u., DJU, de 13.02.2006; STJ - AgR AI n. 88407/SP, rel. Min. Aldir Passarinho Júnior, v.u., DJU, de 05.11.2007.

${ }^{364}$ José Geraldo Brito Filomeno cita o exemplo da vítima de acidente automobilístico em decorrência de roda com grave defeito, decorrente de processo inadequado de fundição. A vítima poderá ser tanto o proprietário de um veículo importado de primeira linha (logo, não há hipossuficiência econômica), quanto o de um modesto veículo "popular", situação em que a hipossuficiência para ambos assemelha-se quanto à ausência de conhecimento técnico apto a demonstrar a existência do dano por conta do processo inadequado de fundição. Nesse caso, a inversão do ônus da prova recai sobre o fornecedor do produto, a fim de comprovar a ausência de nexo causal entre o dano e eventual processo inadequado de fundição da roda (Código Brasileiro de Defesa do Consumidor comentado pelos autores do anteprojeto. 8. ed. Rio de Janeiro: Forense, 2005. p. 148).

${ }^{365}$ GIDI, Antonio, Aspectos da inversão do ônus da prova no Código do Consumidor, cit., p. 37.

${ }^{366}$ Embora não aponte distinção entre hipossuficiência técnica e informativa, Heitor Vitor Mendoça Sica ilustra um exemplo que deixa clara a cautela necessária quanto aos critérios da inversão: "Pense-se em demanda indenizatória ajuizada contra determinada companhia que fabrica cigarros, alegando o autor ter
} 
Embora seja um mecanismo de facilitação da prova por parte do consumidor, tal regramento ope judicis deve ser aplicado pelo magistrado somente na ocasião de sentenciar, ausentes elementos nos autos necessários para decidir, e desde que tal inversão não reflita em prova diabólica, ${ }^{367}$ que inviabilize o exercício da ampla defesa pelo prestador de serviço/fornecedor do produto.

No que toca ao momento para a inversão do ônus da prova previsto no Código de Defesa do Consumidor, a doutrina diverge entre a inversão ocorrer na ocasião do julgamento ou no início da instrução processual. Para os que advogam a primeira

contraído câncer nos pulmões em decorrência do consumo prolongado desse produto, sem advertências do fornecedor acerca dos riscos do tabagismo causar dependência química e diversos males à saúde. Para que a pretensão do consumidor seja acolhida, é necessário que fiquem devidamente demonstrados, pelo menos, os seguintes fatos: a) que o consumidor efetivamente adquiria e consumia continuadamente os cigarros fabricados pela empresa demandada; b) que o consumidor desenvolveu câncer; c) que o câncer foi contraído em decorrência do tabagismo; d) que a publicidade veiculada pelo fornecedor não alertou o consumidor acerca dos riscos advindos do consumo de cigarro. O consumidor não é hipossuficiente para prova dos fatos a e b, acima enunciado. (...) Mas é natural que haja hipossuficiência do consumidor para prova do nexo entre tabagismo e câncer (fato c), bem como da inexistência de propaganda adequada que alerte dos riscos do produto para a saúde (fato d). Quanto ao primeiro fato, é natural que o fornecedor detenha de conhecimentos técnicos muito mais vastos e profundos em relação ao consumidor, o que lhe permitiria ter subsídios infinitamente mais ricos para produzir prova que quebrasse o alegado nexo causal. Isso poderia se dar, por exemplo, mediante pesquisas médicas que atestassem que o consumidor de uma quantidade reduzida de tabaco, durante um intervalo breve de tempo, tem as mesmas chances de contrair câncer que um paciente que jamais tenha fumado, especialmente se morador de uma grande metrópole castigada pela poluição atmosférica, ou mesmo demonstrado que o tabaco empregado em seus produtos passa por processos de alteração genética e química que eliminam substâncias potencialmente cancerígenas. No segundo caso (d), a empresa demandada teria possibilidades muito mais evidentes de provar que se desincumbiu do dever de alertar adequadamente acerca dos riscos à saúde, do que teria o consumidor de demonstrar o contrário. Afinal, é ela quem sabe quais anúncios publicitários veiculou e quando isso ocorreu." (Questões velhas e novas sobre a inversão do ônus da prova. Revista de Processo, São Paulo, Revista dos Tribunais, ano 32, n. 146, p. 53-54, abr. 2007).

367 A advertência é feita por Antonio Gidi, ao asseverar que deve haver uma correlação racional entre a diferença existente entre o consumidor e fornecedor e o efetivo benefício concedido pelo ordenamento mediante a regra da inversão do ônus probatório, sob pena de afrontar o princípio da igualdade entre as partes. Um exemplo pode ilustrar o problema da prova diabólica em situação em que o consumidor teve o filme destruído em processo de revelação: "No entanto, se o consumidor, ao pleitear a indenização, alegar que as fotografias latentes na película destruída foram tiradas com o objetivo de instruir prova em processo judicial e que a sua perda implicou prejuízo de um milhão de dólares, repugna o bom senso que o magistrado inverta o ônus da prova para que o laboratório prove que tais fotos não estavam no filme, e sim fotografias banais de família, sem qualquer repercussão financeira imediata. A inversão nesse caso está vedada não por faltar verossimilhança à alegação, pois isso dependeria exclusivamente do exame do caso concreto realizado pelo magistrado. O que torna a inversão ilegítima é que a dificuldade de produção dessa prova é inerente à própria situação fática configurada, independentemente da hipossuficiência específica do consumidor na relação de consumo. Qualquer autor, em qualquer processo semelhante, experimentaria a mesma angústia de estar impossibilitado de provar as suas alegações: não há nada de peculiarmente mais difícil para o consumidor, por se tratar de uma relação de consumo. Assim postas as coisas, no amplo espectro de fatos jurídicos que exigem prova por parte do consumidor-autor, como a existência do dano, o montante do prejuízo, o nexo de causalidade, a culpa (nos caso de responsabilidade subjetiva), e mesmo a efetiva ocorrência do fato ilícito, nem todos poderão ser objeto de inversão do ônus da prova. Somente aqueles fatos diretamente relacionados com a hipossuficiência do consumidor ensejam a inversão legítima do ônus da prova." (Aspectos da inversão do ônus da prova no Código do Consumidor, cit., p. 37). 
assertiva, ${ }^{368}$ sustenta-se que a inversão é regra de julgamento, de sorte que o referido preceito somente deverá ser aplicado de forma subsidiária, uma vez esgotada a instrução processual, e desde que, uma vez presentes os requisitos necessários para a aplicação da regra de inversão, o juiz ainda não esteja provido de elementos suficientes para decidir.

Por outro lado, há entendimentos de que a regra de inversão do ônus da prova prevista na legislação consumerista deverá ocorrer antes de iniciada instrução do processo, em momento entre o despacho da petição inicial e o saneamento do processo, podendo, excepcionalmente, conforme a análise da prova, inverter-se o ônus em desfavor do réu, desde que lhe seja assegurada a produção da prova sobre a alegação que milita a inversão. ${ }^{369} \mathrm{O}$ principal fundamento utilizado para revestir o contraponto supracitado é que se a inversão do ônus da prova restar declarada na sentença, dificilmente será assegurado ao réu a produção de prova apta a ilidir o ônus que lhe compete. Ou seja, sendo o ônus da prova invertido na sentença, não lhe será assegurada oportunidade de fazer prova em contrário além dos fatos alegados pelo autor, ou seja, de que eles sequer ocorreram, de modo a violar, portanto, o princípio constitucional do contraditório.

Outra crítica contrária à inversão do ônus na sentença é a de que, invertendo-se o ônus da prova como regra de julgamento, fatalmente a ação será procedente ao autor, independentemente do processo estar ou não em condições de julgamento. Uma vez exaurida a instrução probatória, permanecendo ainda o estado de dúvida sobre como decidir, o magistrado inverte o ônus da prova e assim julga a demanda desfavoravelmente ao réu. Assim, ao réu, a quem antes cabia provar a existência de fato impeditivo, modificativo ou extintivo do direito do autor (art. 333 do CPC), invertido o ônus na sentença, ainda será necessário provar a ausência de fato constitutivo do direito do autor (calcado em mera verossimilhança), ou seja, ilidir a verossimilhança das alegações trazidas na inicial. Invertido o ônus na sentença, não haverá oportunidade para exercer esse ônus adicional.

\footnotetext{
368 MATOS, Cecília. O ônus da prova no Código de Defesa do Consumidor. Revista de Direito do Consumidor, São Paulo, Revista dos Tribunais, n. 11, p. 167, jul./set. 1994); NERY JUNIOR, Nelson. Aspectos do processo civil no Código de Defesa do Consumidor. Revista de Direito do Consumidor, São Paulo, Instituto Brasileiro de Política e Direito do Consumidor, v. 1, p. 217-218.

${ }^{369}$ GIDI, Antonio, Aspectos da inversão do ônus da prova no Código do Consumidor, cit., p. 39.
} 
Daí porque parece correto o entendimento ${ }^{370}$ de que antes de se inverter o ônus da prova, deverá ser assegurado ao réu oportunidade para a produção de novas provas, ${ }^{371}$ porquanto a ele competirá o ônus de fazer prova em contrário sobre fatos cuja demonstração antes cabia ao autor. Se invertido o ônus da prova na sentença, essa oportunidade jamais restará garantida, e assim estaria violado o princípio constitucional do contraditório. Assim, parece adequada a proposta de Ada Pellegrini Grinover e Kazuo Watanabe, no sentido do magistrado alertar as partes, no despacho saneador, de que poderá ser invertido o ônus da prova. ${ }^{372}$

Tal distinção parece resolver a questão ligada a eventual cerceamento de defesa quando a inversão do ônus da prova é feita somente na sentença. Em assim o fazendo, o magistrado já deixará assente para as partes de que não dispõe de elementos aptos para decidir a demanda, o que implicará em eventual inversão do ônus desfavorável a uma das partes. Assim, cada litigante já estará ciente de que não basta fazer prova de seu direito

\footnotetext{
370 "Processo Civil - Recurso especial. Consumidor. Inversão do ônus da prova. Momento oportuno. Instância de origem que concretizou a inversão, no momento da sentença. Pretendida reforma. Acolhimento. Recurso especial conhecido em parte e, nessa extensão, provido. A inversão do ônus da prova, prevista no art. $6^{\circ}$, inc. VIII, do Código de Defesa do Consumidor, como exceção à regra do art. 333 do Código de Processo Civil, sempre deve vir acompanhada de decisão devidamente fundamentada, e o momento apropriado para tal reconhecimento se dá antes do término da instrução processual, inadmitida a aplicação da regra só quando da sentença proferida. O recurso deve ser parcialmente acolhido, anulando-se o processo desde o julgado de primeiro grau, a fim de que retornem os autos à origem, para retomada da fase probatória, com o magistrado, se reconhecer que é o caso de inversão do ônus, avalie a necessidade de novas provas e, se for o caso, defira as provas requeridas pelas partes. Recurso especial conhecido em parte e, na extensão, provido." (STJ - REsp n. 881.651/BA, 4ª Turma, rel. Min. Hélio Quaglia Barbosa, DJ, de 21.05.2007, p. 592). "Recurso Especial - CDC. Aplicabilidade às instituições financeiras. Enunciado $n$. 297 da Súmula do STJ. Inversão do ônus da prova (art. $6^{\circ}$, inc. VIII, do CDC). Momento processual. Fase instrutória. Possibilidade. 1. Há muito se consolidou nesta Corte Superior o entendimento quanto à aplicabilidade do Código de Defesa do Consumidor às instituições financeiras (enunciado n. 297 da Súmula do STJ) e, por conseguinte, da possibilidade de inversão do ônus da prova, nos termos do inc. VIII do art. $6^{\circ}$ da Lei Consumerista. 2. O Tribunal de origem determinou, porém, que a inversão fosse apreciada somente na sentença, porquanto consubstanciaria verdadeira 'regra de julgamento'. 3. Mesmo que controverso o tema, dúvida não há quanto ao cabimento da inversão do ônus da prova ainda na fase instrutória - momento, aliás, logicamente mais adequado do que na sentença, na medida que não impõe qualquer surpresa às partes litigantes -, posicionamento que vem sendo adotado por este Superior Tribunal, conforme precedentes. 4. Recurso especial parcialmente conhecido e, no ponto, provido." (STJ - REsp n. 662.608/SP, $4^{\mathrm{a}}$ Turma, rel. Min Hélio Quaglia Barbosa, DJ, de 05.02.2007, p. 242).

${ }^{371}$ Nesse sentido: BUENO, Cassio Scarpinella, Curso sistematizado de direito processual civil, cit., v. 2, t. 1, p. 247-248.

${ }^{372}$ GRINOVER, Ada Pellegrini et al. Código Brasileiro de Defesa do consumidor comentado pelos autores do anteprojeto. 8. ed. Rio de Janeiro: Forense, 2005. p. 796-797. José Roberto dos Santos Bedaque também perfilha semelhante entendimento: "Como se trata de exceção, para não violar o devido processo legal e a igualdade das partes no processo, parece conveniente que o juiz, antes do encerramento da fase postulatória, indique qual dos critérios vai seguir, ante eventual deficiência no conjunto probatório." (Direito e processo: influência do direito material sobre o processo, cit., p. 48). Dinamarco pondera que, a despeito da inversão do ônus da prova ocorrer na ocasião do julgamento, o juiz deve advertir as partes sobre a possibilidade da inversão logo na audiência preliminar (Instituições de direito processual civil, v. 3, cit., p. 83).
} 
consoante a regra do art. 333 do Código de Processo Civil, mas poderá ainda ser invertido o ônus probatório, para fazer prova em contrário acerca do que caberia à outra parte demonstrar.

Embora a questão seja polêmica na doutrina, filiamo-nos ao entendimento de que o magistrado deverá alertar as partes sobre a possibilidade da inversão, o que implica numa dilação probatória mais densa e garantidora da defesa de ambas as partes litigantes na demanda. Aliás, sob esse enfoque, assegurar aos litigantes a produção das provas que se fizerem necessárias (principalmente ao réu, já ciente da possibilidade da inversão), com certeza conduzirá a um julgamento mais seguro e equânime, na medida que cada parte produzirá a prova que entender necessária e estará ciente do ônus que lhe compete, deixando, portanto, de se surpreender com a regra da inversão de imediato na sentença.

\subsubsection{A carga dinâmica da prova}

A regra de distribuição do ônus da prova prevista no art. 333 do Código de Processo Civil pode por vezes ser insuficiente para auxiliar o juiz no descobrimento da verdade ou sua aproximação necessária para decidir a demanda. A despeito do próprio dispositivo retrocitado servir como fundamento para que o juiz decida a demanda sem saber qual parte tenha razão, ganhou espaço na doutrina a teoria da chamada carga ou distribuição dinâmica do ônus da prova. Em síntese, por ser diâmica a distribuição do ônus probatório, cabe ao juiz, verificando qual parte teria melhores condições de produzir determinada prova necessária para o julgamento da demanda (conhecimentos técnicos, informações específicas e relevantes para o julgamento ou até mesmo melhor facilidade na demonstração de determinado fato), impor que uma das partes o faça, a fim de facilitar o conhecimento de um fato necessário para o julgamento. ${ }^{373}$

\footnotetext{
${ }^{373}$ THEODORO JÚNIOR, Humberto, Curso de direito processual civil, cit., v. 1, p. 422. No mesmo sentido, CARVALHO FILHO, Milton Paulo de, Ainda a inversão do ônus da prova no código de defesa do consumidor, cit., p. 62. Consoante leciona Antônio Janyr Dall'Agnol Junior, "deve provar quem tem melhores condições para tal. É logicamente insustentável que aquele dotado de melhores condições de demonstrar os fatos deixe de fazê-lo, agarrando-se em formais distribuições do ônus de demonstração. O processo moderno não se compactua com táticas ou espertezas procedimentais e busca, cada vez mais, a verdade" (Distribuição dinâmica dos ônus probatórios. Revista dos Tribunais, São Paulo, ano 90, n. 788, p. 102, jun. 2001). Para maiores aprofundamentos sobre o tema, ver: CREMASCO, Suzana Santi. A distribuição dinâmica do ônus da prova. Rio de Janeiro: GZ Editora, 2009; MARINONI, Luiz Guilherme.
} 
Os principais fundamentos dessa teoria residem no princípio da comunhão da prova já comentado neste trabalho (art. 131 do CPC), em que pouco importa qual parte trouxe aos autos determinada prova, mas sim a ideia de que a prova produzida pertence aos autos e, portanto, se presta a auxiliar na formação do livre convencimento do magistrado. Paralelamente, o princípio da boa-fé e da cooperação, notadamente a redação dos arts. 125 , I, e 339 do Código de Processo Civil, assim como a aplicação analógica dos arts. 355 e 359 do mesmo diploma, serve de fundamento para impor a distribuição dinâmica do ônus probatório. ${ }^{374}$ Por sua vez, não se trata de negar as regras existentes sobre distribuição do ônus probatório, mas é um meio adicional para que a inversão dinâmica se imponha, quando verificada a maior facilidade de produção de uma prova por um dos litigantes. ${ }^{375}$

Em contrapartida, consoante leciona Humberto Theodoro Júnior, a distribuição dinâmica deve ocorrer com parcimônia, em situações em que: (i) reputam-se verossímeis os fatos alegados por uma das partes; (ii) seja possível aferir a maior facilidade de produção da prova pela parte sobre a qual recai a distribuição dinâmica do ônus; (iii) a prova redirecionada seja possível e não constitua prova diabólica a ser suportada pela parte sobre a qual recai a distribuição dinâmica, (iv) a redistribuição não cause surpresa, franqueando-se oportunidade de produção de prova apta à parte que desincumbir-se do encargo, permitindo-se, portanto, o contraditório; e, por fim:

Formação da convicção e inversão do ônus da prova segundo as peculiaridades do caso concreto. Revista dos Tribunais, São Paulo, ano 96, n. 862, p. 11-21, ago. 2007; PEYRANO, Jorge W. Nuevos lineamientos de las cargas probatórias dinâmicas. In. PEYRANO, Jorge W.; WHITE, Inês Lépori (Coords.). Cargas probatórias dinâmicas. Santa Fé: Rubinzal-Culzoni, 2004. p. 19-24; e KNIJNIK, Danilo. As (perigosíssimas) doutrinas do 'ônus dinâmico da prova' e da 'situação de senso comum' como instrumentos para assegurar o acesso à justiça e superar a probatio diabólica. In: FUX, Luiz et al (org.). Processo e Constituição: estudos em homenagem ao prof. José Carlos Barbosa Moreira. São Paulo: Revista dos Tribunais, 2006. p. 942-952.

374 “Art. 339 - Ninguém se exime do dever de colaborar com o Poder Judiciário para o descobrimento da verdade. (...) Art. 355 - O juiz pode ordenar que a parte exiba documento ou coisa, que se ache em seu poder. (...) Art. 359 - Ao decidir o pedido, o juiz admitirá como verdadeiros os fatos que, por meio do documento ou da coisa, a parte pretendia provar: I - se o requerido não efetuar a exibição, nem fizer qualquer declaração no prazo do art. 357; II - se a recusa for havida por ilegítima."

${ }^{375}$ Para Suzana Santi Cremasco, outros fundamentos abarcam a distribuição dinâmica do ônus da prova, tais como: (i) a busca pela verdade real no processo e a obtenção de um resultado justo, a evitar a aplicação da regra de distribuição do ônus probatório em decisão em que o juiz decida desprovido de conhecer qual parte tinha razão na demanda; (ii) os poderes instrutórios do juiz, a evitar a postura de um juiz indiferente que se veja forçado a julgar consoante a disponibilidade exclusiva das partes na produção da prova e ao final decida sem saber a qual parte assistia razão; (iii) as mesmas doutrinas publicistas que servem de fundamento para o exercício dos poderes instrutórios (A distribuição dinâmica do ônus da prova, cit., p. 79 e ss). Por sua vez, a ideia da carga dinâmica do ônus da prova constitui uma extensão mais ampla da exibição de documento ou coisa estatuída nos arts. 355 e 363 do Código de Processo Civil, porquanto não se limita apenas à exibição de coisa ou documento, mas comporta abrangência em relação à parte que tiver melhor condição de produzir a prova, de modo a não se restringir, portanto, somente ao "requerido" ou "terceiro", tal qual previsto nos arts. 357 e seguintes do Código de Processo Civil. 
“(...) a parte que suporta o redirecionamento não fica encarregada de provar o fato constitutivo do direito do adversário; sua missão é a de esclarecer o fato controvertido apontado pelo juiz, o qual já deve acharse parcial ou indiciariamente demonstrado nos autos, de modo que a diligência ordenada tanto pode confirmar a tese de um como de outro dos litigantes; mas se o novo encarregado do ônus da prova não se desempenhar a contento da tarefa esclarecedora, sairá vitorioso aquele que foi aliviado, pelo juiz, da prova completa do fato controvertido., ${ }^{376}$

Na jurisprudência, o Superior Tribunal de Justiça já reconheceu a aplicação da teoria dinâmica, conforme se depreende de voto da lavra do Ministro Ruy Rosado de Aguiar, ao reconhecer que, em ação de adquirente de cartela de "telebingo" que alega haver sido contemplado, caberia à organizadora do certame provar que os números sorteados não correspondem à cartela adquirida pelo autor:

"A teoria da dinâmica da prova transfere o ônus para a parte que
melhores condições tenha de demonstrar os fatos e esclarecer o juízo
sobre as circunstâncias da causa. Na hipótese dos autos, encontramos um
bom exemplo para a aplicação dessa regra probatória, pois apenas a
organizadora do certame televisionado poderia fornecer os elementos
esclarecedores do ato que promoveu, porquanto não seria razoável exigir
que o concorrente gravasse o programa a fim de eventualmente produzir
prova em juízo. Não lhe cabe fazer essa demonstração apenas com os
recursos do telemática, mas também com a simples juntada do registro
constante da ata exigida na legislação pertinente. O argumento de que a ré
encaminhou o feito para o julgamento antecipado não pode ser acolhido
porque com aquela manifestação não estava ela renunciando a algum
direito seu; significou apenas que, sem a prova dos fatos alegados pelo
réu, poderia o feito ser julgado a favor da requerente, não contra.",377

No âmbito legislativo, há expressa previsão da chamada carga dinâmica da prova tanto no Projeto de Lei da Nova Lei da Ação Civil Pública (PL n. 5.139/2009, ${ }^{378}$ quanto no Projeto de Lei n. 3.015/2008, de autoria do deputado Manoel Junior. ${ }^{379}$ No que toca ao

376 THEODORO JÚNIOR, Humberto, Curso de direito processual civil, cit., v. 1, p. 422-423.

377 STJ - REsp n. 316.316/PR, 3 ${ }^{\text {a }}$ Turma, rel. Min. Ruy Rosado de Aguiar, DJU, de 12.11.2001, p. 156. Outros precedentes também já acolheram o entendimento da aplicação da carga dinâmica da prova: STJ REsp n. 69.309/SC, $4^{\text {a }}$ Turma, rel. Min. Ruy Rosado de Aguiar, DJU, de 26.08.1996, p. 2; TJRS - AC n. 597083534, $1^{a}$ Câmara Cível, rel. Des. Armínio José Abreu Lima da Rosa, j. 03.12.1997; TJMG - AI n. 1.0702.06.289.424-2/002, $18^{\text {a }}$ Câmara Cível, rel. Des. Fábio Maia Viani, DJMG, de 20.07.2007; TJRJ AC n. 2008.001.08926, 9a Câmara Cível, rel. Des. Carlos Santos de Oliveira, j. 07.03.2008; TRF 2a Região - REO n. 326.858 (1997.51.01.000967-7/RJ), 6 $6^{\text {a }}$ Turma, rel. Juiz André Fontes, j. 20.08.2003, DJU, de 16.04.2004.

${ }^{378}$ Disponível em: <http://www.camara.gov.br/sileg/integras/651669.pdf>. Acesso em: 30 nov. 2009.

${ }^{379}$ Disponível em: <http://www.camara.gov.br/sileg/integras/544501.pdf>. Acesso em: 05 dez. 2009.

Ao que consta em informações obtidas no site da Câmara dos Deputados, os projetos citados aguardam manifestação da Comissão de Constituição, Justiça e Cidadania. 
objetivo desta dissertação, o primeiro projeto prevê, no art. 20, incs. IV a VIII, procedimento semelhante ao da carga dinâmica da prova, ${ }^{380}$ e o segundo propõe acréscimo de um parágrafo ao art. 333 do Código de Processo Civil: “§ $2^{\circ}$ - É facultado ao juiz, diante da complexidade do caso, estabelecer a incumbência do ônus da prova de acordo com o caso concreto". Embora não seja objeto deste estudo o exame mais aprofundado da carga dinâmica do ônus da prova, não pode passar despercebido que este tema pode dar margem a uma tendência no sistema processual brasileiro, o que reflete, sem dúvida, no aumento dos poderes do juiz e reclama, em contrapartida, observância à garantia dos princípios constitucionais e processuais.

Parece-nos que a regra da distribuição dinâmica do ônus da prova se aproxima da inversão do ônus no Código de Defesa do Consumidor tratada no intem anterior, com a ressalva de que para a aplicação dinâmica pelo magistrado, prescinde-se que haja uma relação de consumo entre os litigantes, ${ }^{381}$ sendo suficientes, portanto, os requisitos citados neste tópico.

Feito breve exame das principais regras de distribuição do ônus probatório, cumpre analisar a projeção de cada um desses regramentos nos poderes instrutórios do juiz.

\footnotetext{
380 “Art. 20 - Não obtida a conciliação ou quando, por qualquer motivo, não for utilizado outro meio de solução do conflito, o juiz, fundamentadamente: I - decidirá se o processo tem condições de prosseguir na forma coletiva; II - poderá separar os pedidos em ações coletivas distintas, voltadas à tutela dos interesses ou direitos difusos e coletivos, de um lado, e dos individuais homogêneos, do outro, desde que a separação represente economia processual ou facilite a condução do processo; III - fixará os pontos controvertidos, decidirá as questões processuais pendentes e determinará as provas a serem produzidas; IV - distribuirá a responsabilidade pela produção da prova, levando em conta os conhecimentos técnicos ou informações específicas sobre os fatos detidos pelas partes ou segundo a maior facilidade em sua demonstração; V poderá ainda distribuir essa responsabilidade segundo os critérios previamente ajustados pelas partes, desde que esse acordo não torne excessivamente difícil a defesa do direito de uma delas; VI - poderá, a todo momento, rever o critério de distribuição da responsabilidade da produção da prova, diante de fatos novos, observado o contraditório e a ampla defesa; VII - esclarecerá as partes sobre a distribuição do ônus da prova; e VIII - poderá determinar de ofício a produção de provas, observado o contraditório.’

${ }^{381}$ Nesse sentido, Bento Herculano Duarte sustenta que o magistrado pode ter ampla liverdade para inverter a regra central do onus probandi, de modo a não restringir essa hipótese apenas à citada no art. $6^{\circ}$, VIII, do Código de Defesa do Consumidor (Elementos de teoria geral da prova, in Processo civil: aspectos relevantes, cit., p. 30).
} 


\subsubsection{A distribuição do ônus da prova: reflexos nos poderes instrutórios}

Após breve análise das regras de distribuição do ônus probatório, cumpre verificar em que medida tais regras influenciam ou não os poderes instrutórios. No que toca à inversão legal do ônus da prova por força das presunções relativas previstas em lei, de igual sorte quando ocorre a inversão do ônus da prova com base no art. $6^{\circ}$, VIII, do Código de Defesa do Consumidor, recomenda-se que a parte sobre a qual recai a inversão do ônus seja advertida acerca da possibilidade de inversão, a fim de lhe franquear a produção de prova em contrário, o que transcende o ônus inicial que cabia a cada um dos litigantes no início da demanda.

Por outro lado, a chamada carga dinâmica da prova, quando devida sua aplicação, e ao retirar o ônus estático previsto no art. 333 do Código de Processo Civil e atribuir tal sujeição à parte que tenha melhores condições de produzir determinada prova, de igual modo, deve ser previamente informada, permitindo ao litigante a produção da prova desejada pelo magistrado, tudo isso a fim de guardar observância ao princípio constitucional do contraditório.

E tais regramentos, a despeito de serem estáticos (art. 333 do CPC), facilitarem a produção da prova ao consumidor (art. $6^{\circ}$, VIII, do CDC), ou até mesmo se revestirem de distribuição dinâmica, consoante a maior facilidade da parte em produzir determinada prova (carga dinâmica), devem ser entendidos como regras de julgamento. ${ }^{382}$

Vale dizer, os poderes instrutórios do juiz não se limitam, tampouco ficam aumentados, quaisquer que seja as regras de distribuição do ônus da prova, porquanto somente serão aplicadas como condição necessária a evitar-se o non liquet e de sorte a serem entendidas como regras de julgamento. A ressalva, em verdade, não guarda ligação com os poderes instrutórios, mas sim com a premissa de que, sobrevindo a inversão por força do Código de Defesa do Consumidor ou aplicando-se a inversão dinâmica, deve ser

\footnotetext{
${ }^{382}$ Sobre o maciço entendimento da doutrina no sentido da distribuição do ônus da prova perfilhar regra de julgamento, ver o item 3.2.1.
} 
franqueada à parte a oportunidade de produção da prova necessária para a inversão do próprio ônus que sobre ela recai.

Assim, pouco importa a quem pertence o ônus de produzir determinada prova (ainda que por conta da inversão do ônus probatório, qualquer que seja a regra de inversão a ser aplicada), porquanto a distribuição do ônus probatório somente ocorrerá quando do julgamento, em nada tolhendo, portanto, as iniciativas probatórias. Daí porque, para Barbosa Moreira:

"O valor normativo das disposições pertinentes à distribuição do ônus probandi assume real importância na ausência de prova: em semelhante hipótese é que o juiz há de indagar a qual dos litigantes competia o ônus, para imputar-lhe as consequências desfavoráveis da lacuna existente no material probatório. E isso se aplica, sem sombra de dúvida, às normas que consagram presunções relativas, como normas, que na verdade são, de atribuição do onus probandi. Bem se concebe, v.g., que os elementos probatórios capazes de afastar a presunção sejam trazidos aos autos, quiçá inadvertidamente, pela própria parte a quem ela favorecia; o resultado prático será o mesmo que ocorreria se trazidos fossem tais elementos pela parte adversa". 383

Ainda sobre o tema, discorre o autor:

"Julgar segundo as regras de distribuição do ônus não é atitude que
tranquilize de todo o juiz consciente de sua responsabilidade: ele atira no
escuro; pode acertar o alvo, mas pode igualmente errar, e sua sentença,
injusta, produzirá na vida dos litigantes efeitos diversos dos queridos pelo
ordenamento, quando não diametralmente opostos. Não será preferível
que ele procure fazer jorrar alguma luz sobre os desvãos escuros da causa
-e, se possível, baseie o julgamento uma ciência mais exata e completa
do que realmente aconteceu?."”84

Esse pensar deixa mais nítida a finalidade pública da jurisdição em aproximar a aplicação da vontade concreta da lei, porquanto não é a relação de direito material que justifica o ativismo judicial no âmbito dos poderes instrutórios. Afinal, a desejada decisão justa, para ser de fato justa, deve ser proporcionada a todo o jurisdicionado de forma

\footnotetext{
${ }^{383}$ BARBOSA MOREIRA, José Carlos, As presunções e a prova, in Temas de direito processual: primeira série, cit., p. 61-62.

${ }^{384}$ BARBOSA MOREIRA, José Carlos, O neoprivatismo no processo civil, cit., p. 1. Em semelhante sentido são as conclusões de Luiz Guilherme Marinoni e Sérgio Cruz Arenhart: "Com efeito, se o juiz tem o dever de esclarecer a situação fática, julgando o mais próximo possível daquilo que realmente ocoreu, não há como se negar a possibilidade dele determinar prova de ofício, somente após ter julgado com o apoio na referida regra do ônus da prova." (Manual do processo de conhecimento, cit., p. 322).
} 
indistinta, desprezando-se qualquer influência projetada pela relação jurídica de direito material. $^{385}$

Portanto, os poderes instrutórios não se subordiam às regras sobre ônus da prova, de sorte que a incidência delas apenas se verifica em situações de insuficiência de prova, aplicáveis de forma excepcional, como última saída para o juiz. ${ }^{386}$ Por essa razão parece correto admitir que as iniciativas probatórias podem materializar-se no curso da instrução e ainda quando advertida uma das partes para que venha a produzir determinada prova. Afinal, o que se busca com a prova é amealhar elementos necessários para que o juiz venha decidir, o que não se confunde, tampouco se aproxima, a eventual imparcialidade, porquanto o resultado da prova ainda será desconhecido, tema que voltaremos a tratar no item 4.2.4. Por outro lado, quanto mais o juiz participar na formação do conjunto probatório, menos terá de recorrer à regra de distribuição do ônus da prova, porquanto já haverá nos autos elementos que se aproximam mais de um juízo de certeza do que um juízo apenas destinado a evitar o non liquet.

Estabelecidas premissas acerca da prova e sua relação com a cognição judicial, seguida de breve análise das regras de inversão do ônus da prova, cumpre examinar, por fim, e aliado às conclusões traçadas até o momento, o tema poderes instrutórios.

\subsection{Os poderes do juiz}

Os poderes instrutórios são espécie do gênero poderes do juiz, ${ }^{387}$ que não deixam de ser poderes-deveres. Sendo o juiz o agente em que o Estado deposita poderes que o

\footnotetext{
${ }^{385}$ Voltaremos a tratar desse tema no item 4.1.3.

${ }^{386}$ BEDAQUE, José Roberto dos Santos, Poderes instrutórios do juiz, cit., p. 122.

${ }^{387}$ Segundo Sidnei Amendoeira Junior, um esboço da classificação dos poderes do juiz se encontra presente, em síntese, no Livro I, Título IV, Capítulo IV do Código de Processo Civil, fazendo remissão aos arts. 125 (direção do processo e solução rápida para o litígio, combatendo atos atentatórios à dignidade da Justiça), 126 (vedação do non liquet) e 130 e 131 (poderes instrutórios). Ao final, conclui que as principais atividades do juiz no processo são: I - dirigir o processo; II - determinar (ou indeferir) a produção de provas, participação de sua colheita e apreciá-las; III - combater a má-fé processual; IV - decidir as questões que lhe forem postas (enfrentando, assim, o que lhe propõe o objeto do processo); V - impor o quanto decidido; e VI - evitar que a tutela entregue não seja justa (preservação das garantias constitucionais do processo), efetiva (do próprio bem da vida pleiteado, evitando paliativos) e tempestiva (entregue a tempo). Ao final, conclui: "Essas atividades serão refletidas, portanto, na classificação dos poderes-deveres do juiz que será aqui adotada: poder decisório (controle), poder ético (fiscalização) e poder ordinatório (movimentação e direção em geral). Como, porém, não basta o juiz declarar a vontade concreta da lei,
} 
legitimam a realização de seus atos, eles são exercidos como um dever perante as partes, inerente à garantia constitucional do controle jurisdicional (art. 5 $\mathrm{XXXV}$, da CF), uma vez que a realização da justiça não é um favor do Estado, mas a garantia solene de promessa constitucional (acesso à justiça). ${ }^{388}$

A classificação dos poderes do juiz não é pacífica na doutrina e seria tarefa que foge das premissas centrais deste estudo tentar pontuar qual a categorização mais adequada, diante de tantas variações que, em verdade, deixam de agregar contribuições práticas no que toca às diferenças destacadas por cada autor. Portanto, apontaremos tão somente alguns estudos relativos à classificação dos poderes do juiz para, no item seguinte, traçar a localização metodológica dos poderes instrutórios.

Na concepção de Odilon de Andrade, ${ }^{389}$ os poderes instrutórios estão divididos entre os poderes de promoção e os poderes de inspeção. Isso porque, para esse autor, os poderes do juiz dividem-se em poderes de inspeção (v.g., o poder de apontar às partes as nulidades e irregularidades sanáveis que encontrar no processo; o poder de indeferir diligências inúteis ou meramente protelatórias), poderes de promoção (v.g., o poder de determinar de ofício as diligências necessárias à instrução do processo; o poder de determinar a reunião de ações conexas) e poderes de repressão (v.g., o poder de aplicar

\footnotetext{
decidindo a questão de mérito (poder decisório), fazendo-se necessário, ainda, atuar essa declaração, se não cumprida espontaneamente por quem de direito, os poderes executivos devem estar presentes. (...) Por fim, existiria, ainda, um poder geral de cautela ligado à ideia de que o juiz deve possuir poderes suficientes e conceder tutelas de urgência, mediante cognição sumária e que envolveria as tutelas antecipadas e cautelares. Assim, e em conclusão, podem ser divididos e classificados os poderes-deveres jurisdicionais do juiz em: ordinários, instrutórios, decisórios, éticos, executivos e geral de cautela." (Poderes do juiz e tutela jurisdicional, cit., p. 36-37). Sobre o tema, ver ainda: MIRANDA, Vicente. Poderes do juiz no processo civil brasileiro. São Paulo: Saraiva, 1993. p. 118-126, SOUZA, Carlos Aurélio Mota de. Poderes éticos do juiz: a igaldade das partes e a repressão ao abuso do processo. Porto Alegre: Sergio Antonio Fabris, 1987. p. 73-89; DINAMARCO, Cândido Rangel, Instituições de direito processual civil, cit., v. 2, p. 234-247; GOMES, Sérgio Alves. Os poderes do juiz na direção e instrução do processo civil. Rio de Janeiro: Forense, 1997. p. 47-49; e MARQUES, José Frederico. Instituições de direito processual civil, cit., v. 2, p. 155-159.

${ }^{388}$ É o que leciona José Manoel de Arruda Alvim, ao discorrer acerca do aspecto dúplice dos poderesdeveres. Ou seja, a todo dever corresponde, no plano do direito público, um poder. Logo, poder-dever constituem um binômio que se concretiza através da atividade pública judicante (Código de Processo Civil comentado. São Paulo: Revista dos Tribunais, 1979. v. 5, p. 20-21). Em entendimento semelhante, Dinamarco acresce que os poderes do juiz, que em si mesmos seriam situações jurídico-processuais ativas, têm em contrapartida situação passiva representada pelo dever de cumpri-los (Instituições de direito processual civil, cit., v. 2, p. 211-212). Por sua vez, Moacyr Amaral Santos conclui que "dever do juiz é usar dos seus poderes, movimentando a relação processual e, desde que regular, decidir da ação e do mérito" (Primeiras linhas de direito processual civil, cit., v. 1, p. 331). De forma mais específica, em relação aos poderes-deveres instrutórios, ver o item 3.3.1.

389 ANDRADE, Odilon de. Os poderes do juiz no processo civil. Revista Forense, Rio de Janeiro, v. 37, n. 84, p. 3-14, out. 1940 .
} 
pena ao litigante de má-fé; o poder de obstar que as partes se sirvam do processo para realizar ato simulado ou conseguir fim proibido em lei).

Para Carlos Aurélio Mota de Souza, ${ }^{390}$ o juiz exerce poderes-atividades, fragmentados em poderes jurisdicionais, poderes processuais e poderes administrativos. Dentre os poderes atividades, os poderes jurisdicionais dizem respeito ao poder do juiz exercido no momento processual em que lhe compete dizer o direito em concreto e em definitivo, ao passo que os poderes processuais estão ligados à direção formal e material da causa, consistindo em atividades que o juiz exerce para prolatar a sentença. Já os poderes administrativos tratam dos atos do juiz de direção e fiscalização dos serviços judiciários, como órgão corregedor permanente, aí incluídos todos os processos sob a competência do magistrado.

Barbosa Moreira classifica os poderes instrutórios dentre os chamados poderesmeio (que precedem os poderes-fim ligados à atividade decisória), de feição instrumental, aí compreendidos também os poderes de direção do processo e os poderes de coerção. ${ }^{391}$ Por sua vez, Cintra, Grinover e Dinamarco classificam os poderes do juiz em poderes administrativos ou de polícia, destinados a evitar a perturbação do processo e assegurar a ordem e o decoro daqueles que devem envolvê-lo (arts. 445 e 446 do CPC) e poderes jurisdicionais, que se desenvolvem no processo e dividem-se em poderes-meio (daí envolvendo os ordinatórios, ligados ao simples andamento do processo e os instrutórios, voltados à formação do convencimento do juiz) e poderes-fim (daí compreendidos os decisórios e os de execução). ${ }^{392}$

\footnotetext{
${ }^{390}$ SOUZA, Carlos Aurélio Mota de, Poderes éticos do juiz: a igualdade das partes e a repressão ao abuso do processo, cit., p. 78-80.

${ }^{391}$ BARBOSA MOREIRA, José Carlos. Reformas processuais e poderes do juiz. In: Temas de direito processual: oitava série. São Paulo: Saraiva, 2004. p. 55.

392 CINTRA, Antonio Carlos de Araújo; GRINOVER, Ada Pellegrini; DINAMARCO, Cândido Rangel, Teoria geral do processo, cit., p. 315. Semelhante é a classificação de Moacyr Amaral Santos, com a ressalva de que os poderes jurisdicionais, além de dividirem-se em ordinatórios e instrutórios, têm ainda uma terceira divisão, qual seja, os poderes finais, os quais englobam os poderes decisórios, ligados às decisões proferidas e os poderes satisfativos ou executórios, voltados ao processo de execução (Primeiras linhas de direito processual civil, cit., v. 1., p. 326 e ss.). Parecida também é classificação de José Frederico Marques, com a ressalva de que os poderes administrativos contemplam os poderes de polícia processual, exercidos "em torno do processo". Por sua vez, os poderes jurisdicionais, exercidos dentro do processo, se dividem em instrumentais ou ordinários, destinados a resolver questões incidentes, mas que, ao serem decididas, propiciam a movimentação processual, e poder decisório ou vinculação final, voltado a declarar e realizar o direito, ou seja, é o poder judicial para proferir a decisão que soluciona a lide e fazê-la cumprir de maneira coercitiva, quando necessário (Instituições de direito processual civil, cit., v. 2, p. 153 e ss.). Por fim, classificação parecida é a de José Manoel de Arruda Alvim, que concebe os poderes do juiz entre poderes jurisdicionais, compreendendo todos os atos, desde a formação da relação jurídica processual até a
} 
Por fim, Vicente Miranda ${ }^{393}$ atribui aos poderes instrutórios uma classe própria (espécie de poderes do juiz), ligada também a um poder oficial (poder que o juiz tem de agir no processo independente de provocação das partes).

Assim, vê-se que os poderes instrutórios foram alocados nas mais variadas classes pela doutrina; essas divergências não têm relevância prática, mas sim a constatação de que se trata de poderes-deveres. A seguir, apontaremos brevemente uma tentativa de classificação dos poderes instrutórios diante das concepções doutrinárias retrocitadas, para em seguida, traçar algumas premissas ligadas à dimensão, conceito e limites desses poderes.

\subsubsection{Os poderes instrutórios na classificação dos poderes do juiz: panorama no Código de Processo Civil}

Consoante restou exposto no item anterior, a classificação dos poderes do juiz está ligada com a finalidade do ato emanado do magistrado. Desse modo, os poderes instrutórios guardam finalidade específica (tema que será melhor abordado nos itens 3.3.1.1 e seguintes), de sorte que sua alocação como espécie do gênero poderes do juiz também se aproxima das muitas classificações doutrinárias apontadas no item anterior. Assim, adotando-se a a classificação de Odilon de Andrade, tais diligências estão alocadas dentre os chamados poderes de promoção (v.g., poder de determinar de ofício as diligências necessárias à instrução do processo).

Mediante definição concebida por Cintra, Grinover e Dinamarco, os poderes instrutórios inserem-se na classificação dos poderes-meio, notadamente na subdivisão poderes ordinatórios (voltados à formação do convencimento do juiz), porquanto para Carlos Aurélio Mota de Souza, os poderes instrutórios estão contemplados nos poderes processuais, na medida que refletem a atividade do juiz voltada a assegurar o correto andamento de cada processo, dirigindo formal e materialmente a causa. Por fim, na

\footnotetext{
sentença, e poderes de polícia, assim entendidos os poderes exercidos pelo juiz como autoridade, a exemplo dos art. 445 e 446 do Código de Processo Civil (Manual de direito processual civil, cit., v. 2, p. 30).

${ }^{393}$ MIRANDA, Vicente, Poderes do juiz no processo civil brasileiro, cit., p. 119, 122 e 123.
} 
concepção retrocitada de Vicente Miranda, a classe própria dos poderes instrutórios como espécie de poderes do juiz se aproxima do chamado poder oficial (que, por sua vez, confere ao magistrado o poder de agir no processo independente de provocação das partes).

Através de breve análise das classificações supracitadas, embora com poucas divergências, pode-se extrair que os poderes instrutórios caracterizam-se por diligências determinadas de ofício pelo juiz, cuja finalidade se presta à instrução do processo, com vistas à formação do convencimento do magistrado mediante direção formal e material da causa. Nesse contexto, leciona Pontes de Miranda que a direção formal consiste no juiz ordenar o processo em sua marcha externa através de atos relativos à fixação de prazos, abertura e encerramento de audiências, oitiva de testemunhas, etc. Por sua vez, a direção material trata-se da atuação do juiz para viabilizar que o material do processo se articule de modo que melhor se colha a verdade, esclareçam-se as argumentações das partes e assim se obtenha uma visão conjunta de tais elementos, a exemplo do que determina o art. 125 do Código de Processo Civil. ${ }^{394}$

Tais diligências (poderes instrutórios) se encontram expressamente previstas em muitas passagens do Código de Processo Civil, cujas hipóteses são meramente exemplificativas. Isso porque ao Estado-juiz cabe o papel de prestar a tutela jurisdicional. Sendo o juiz mero agente estatal, a ele são conferidos poderes que se alinham a poderesdeveres, porquanto são exercidos com a finalidade de se realizar a função pública da jurisdição. Logo, os poderes do juiz defluem da própria investidura do cargo exercido pelo magistrado como agente estatal e, portanto, correspondem a deveres destinados a atender aos escopos da jurisdição, mediante atuação do Estado-juiz. ${ }^{395}$ Significa dizer que a atuação jurisdicional do magistrado ocorre no processo, dentro do espaço delimitado pelas normas e princípios processuais. Sidnei Amendoeira Junior acresce, ainda, que esse dever decorre da própria garantia destinada a preservar o equilíbrio do sistema:

\footnotetext{
${ }^{394}$ PONTES DE MIRANDA, Francisco Cavalcanti. Comentários ao Código de Processo Civil. 3. ed. Rio de Janeiro: Forense, 1995. v. 2, p. 367.

${ }^{395}$ Nessa linha de raciocínio, José Carlos Baptista Puoli bem assevera que sem o aumento dos poderes do juiz, não há como atingir-se a instrumentalidade, cuja premissa central é a visão do processo como um instrumento público, de sorte que, a fim de acomodar-se essa visão teleológica, necessária a relativização de alguns princípios do processo: "Esta tendência encontra sua justificação no fato de ser crítico que não adianta exigir do juiz uma postura interessada no atendimento dos escopos do processo se não lhe for dado o instrumental legal e os demais meios necessários para o bom desempenho dessa função." (Os Os poderes do juiz e as reformas do processo civil, cit., p. 53).
} 
"O juiz é titular de situações jurídicas integradas, que não são verdadeiramente dativas ou passivas, aquilo que o juiz pode fazer, também deve fazê-lo; poder no sentido de que ao ato as partes se submeterão e dever no sentido de garantir o equilíbrio do sistema e obter os resultados desejados. Enquanto for observado o equilíbrio nessas situações jurídicas integradas, estará o magistrado exercendo, legitimamente, o poder estatal, ou seja, exercendo esses poderes/deveres de forma equilibrada, estará o magistrado preparando legitimamente o ato final do processo." 396

De igual sorte, Nelson Juliano Schaefer Martins aponta os poderes instrutórios como poderes-deveres, porquanto a tendência de buscar a verdade dos fatos, face à publicização do processo, necessita da intensificação das atividades instrutórias do juiz, sem a qual não é possível esclarecer as questões referentes à demanda, ${ }^{397}$ entendimento também perfilhado por Carlos Aurélio Mota de Souza, para quem “os poderes que incumbem ao juiz são intrinsecamente deveres, sem os quais não poderia exercer plenamente o comando jurisdicional que o Estado lhe outorgou". 398

Por sua vez, o art. 130 do Código de Processo Civil determina que "caberá ao juiz, de ofício ou a requerimento da parte, determinar as provas necessárias à instrução do processo, indeferindo as diligências inúteis ou meramente protelatórias". A conjugação do verbo "caberá" no futuro do indicativo dá a conotação de um dever, ao passo que a expressão "de ofício"399 revela um poder conferido ao juiz que, em verdade, "deve" ser exercido pelo julgador e prescinde de requerimento das partes. Vale dizer, por ser uma diligência de ofício, ela deve ser determinada independentemente de pleito das partes, pois a sua realização se impõe como medida de ofício, incondicionada, portanto à discricionariedade do juízo.

\footnotetext{
${ }^{396}$ AMENDOEIRA JUNIOR, Sidnei, Poderes do juiz e tutela jurisdicional, cit., p. 21.

${ }^{397}$ MARTINS, Nelson Juliano Schaefer. Poderes do juiz no processo civil. São Paulo: Dialética, 2004. p. 192-193.

${ }^{398}$ SOUZA, Carlos Aurélio Mota de, Poderes éticos do juiz: a igualdade das partes e a repressão ao abuso do processo, cit., p 77.

${ }^{399}$ Não pretendemos neste trabalho esgotar todas as premissas que circundam as matérias e diligências de ofício, suas hipóteses e limitações, tarefa envolta em terreno pantanoso que não se presta à finalidade central desta dissertação. Utilizaremos da expressão "de oficio" tão somente como referência a diligências que devem ser implementadas pelo magistrado (dever de ofício) e prescindem requerimento das partes.
} 
De igual modo, cabe ao juiz determinar, sem necessidade de provocação, a realização de perícia (art. $331, \S 2^{\circ}$, do CPC), ${ }^{400}$ ordenar o comparecimento pessoal das partes, para "interrogá-las sobre os fatos da causa" (art. 342 do CPC), determinar a exibição de documento ou coisa, em poder de terceiro ou do litigante, assim como a exibição de livros comercias e documentos (arts. 355, 360 e 382 do CPC), requisitar a repartições públicas, em qualquer tempo ou grau de jurisdição, "certidões necessárias à prova das alegações das partes" ou "procedimentos administrativos nas causas em que for interessado a União, o Estado, o Município ou respectivas entidades da administração indireta" (art. 399 do CPC), proceder à inspeção de pessoas ou coisas (art. 440 do CPC), inquirir como testemunhas as pessoas referidas em depoimentos ou declarações, assim como determinar a "acareação de duas ou mais testemunhas, ou de algumas delas com a parte, quando sobre fato determinado, que possa influir na decisão da causa, divergirem as suas alegações" (art. 418 do CPC), determinar a produção de nova perícia (art. 437 do CPC), bem como ouvir como declarantes as testemunhas impedidas ou suspeitas (art. 405, $\S 4^{\circ}$, do CPC). Esses são meros exemplos de iniciativas probatórias do magistrado previstos no Código de Processo Civil, cujo rol não é restritivo, mas sim exemplificativo, conforme discorrido nos parágrafos anteriores. Ademais, a literal redação do art. 130 do Código de Processo Civil é clara em prever que caberá ao juiz, de ofício ou a requerimento da parte, "determinar as provas necessárias à instrução do processo", o que não limita, por oportuno, a um rol taxativo que restrinja as iniciativas probatórias do juiz. Portanto, são diligências cujo limite é a própria formação do convencimento do magistrado. Todavia, o

\footnotetext{
${ }^{400}$ A redação inicial do art. 331, I do Código de Processo Civil de 1973 previa: "Se não se verificar nenhuma das hipóteses previstas nas secções precedentes, o juiz, ao declarar saneado o processo: I - deferirá a realização de exame pericial, nomeando o perito e facultando às partes a indicação dos respectivos assistentes técnicos". Ainda no período de vacatio legis do Código Buzaid, a Lei n. 5.925 conferiu nova redação ao art. 331, cuja alteração modesta desobrigou o magistrado de determinar a produção de prova pericial, ao substituiu o termo "deferirá" por "decidirá": "Se não se verificar nenhuma das hipóteses previstas nas seções procedentes, o juiz, ao declarar saneado o processo: I - decidirá sobre a realização de exame pericial, nomeando o perito e facultando às partes a indicação dos respectivos assistentes técnicos". Passados dez anos de vigência do Código de Processo Civil de 1973, a Lei n. 8.952/94 alterou novamente a redação do art. 331, condicionando a produção da prova apenas após exaurida a tentativa de conciliação das partes: "Se não se verificar qualquer das hipóteses previstas nas seções precedentes e a causa versar sobre direitos disponíveis, o juiz designará audiência de conciliação, a realizar-se no prazo máximo de 30 (trinta) dias, à qual deverão comparecer as partes ou seus procuradores, habilitados a transigir. $\S 1^{\circ}$ - Obtida a conciliação, será reduzida a termo e homologada por sentença. $\S 2^{\circ}-\mathrm{Se}$, por qualquer motivo, não for obtida a conciliação, o juiz fixará os pontos controvertidos, decidirá as questões processuais pendentes e determinará as provas a serem produzidas, designando audiência de instrução e julgamento, se necessário". A despeito das reformas supracitadas modificarem em parte a redação do art. 331, é certo que tais modificações legislativas não retiraram, tampouco reduziram, o poder-dever do juiz em determinar as provas que julgar necessárias, o que remete, inclusive, à redação do próprio art. 130.
} 
exercício dos poderes instrutórios encontra balizas que serão comentadas adiante, mormente a observância das garantias constitucionais.

Estabelecida uma tentativa de alocação dos poderes instrutórios que se aproxime das diversas classificações dos poderes do juiz difundidas pela doutrina, seguida de breves apontamentos no Código de Processo Civil, passemos a definir dimensão, conceito e momento de exercício desses poderes.

\subsubsection{Dimensão, conceito e momento das iniciativas probatórias}

Antes da tentativa de conceituar poderes instrutórios, necessário breve exame da amplitude de tais poderes dentro do processo e das fases do procedimento, ou seja, em que fase do processo, se existente alguma limitação, são permitidos os poderes instrutórios, o que doravante denominaremos dimensão.

O vocábulo "instrutório" advém da palavra "instruir", cujo significado pode ser concebido como "transmitir ou adquirir conhecimento", "dar notícia, comunicar, informar", "ensinar a fazer (algo), adestrar, habilitar, iniciar, dar ou obter esclarecimento, informação sobre algo, informar-se, esclarecer-se, orientar-se". 401 Já o termo "instrução" deriva do latim instructio (ordem, disposição, ensino), cuja terminologia forense é empregada para "exprimir, a soma de atos e diligências que, na forma das regras legais estabelecidas, devem ou podem ser praticados, no curso do processo, para que se esclareçam as questões ou fatos, que constituem o objeto da demanda ou do litígio. A instrução, pois, dispondo os elementos na ordem regulamentar, vem ministrar os esclarecimentos ou trazer elucidação aos fatos, que se precisam saber (...). Tudo, pois, que se faça ou promova no processo, com a intenção de provar, mostrar, esclarecer, documentar, é instrução". 402

\footnotetext{
401 HOUAISS, Antônio; VILlAR, Mauro de Salles. Dicionário Houaiss da língua portuguesa. Rio de Janeiro: Objetiva, 2001. p. 1.627, verbete instruir. Semelhante definição também pode ser encontrada em outros dicionarios: "Ato ou efeito de instruir-se, ensino, conhecimentos adquiridos, cultura, saber, erudição, explicação dada para um determinado fim, esclarecimento ou ordem dada a pessoa encarregada de alguma negociação ou empreendimento" (FERREIRA, Aurélio Buarque de Holanda. Novo dicionário da língua portuguesa. 2. ed., 13. impr. Rio de Janeiro: Nova Fronteira, 1986. p. 953).

${ }^{402}$ DE PLÁCIDO E SILVA, Oscar José. Instrução. In: Vocabulário jurídico. 24. ed. Rio de Janeiro: Forense, 2004. p. 752-753. E também: "E, assim sendo, instrução mostra-se em sentido equivalente a esclarecimento, elucidação, pois que, mesmo no sentido processual, não é outro o objetivo, que se colima, quando é posta em função" (Ibidem, p. 753).
} 
Partindo da premissa mais ampla de que os poderes instrutórios compreendem os atos do juiz destinados a trazer elementos e provas aos autos necessários à realização da cognição para se decidir um pedido (que não implique necessariamente em sentença), não se limitando, portanto, à chamada fase instrutória, soa lógica a conclusão de Dinamarco: “Instrução não é sinônimo de prova nem fase instrutória se confunde com fase probatória. Provas e alegações unificam-se no conceito de instrução, porque ambas são teleologicamente unidas pelo objetivo de produzir conhecimento no espírito do juiz". 403

Assim, a dimensão dos poderes instrutórios se estende em amealhar elementos, informações e constatações necessários à construção do campo probatório destinado à formação do convencimento do magistrado. A dimensão desses poderes-deveres não se limita, portanto, à chamada fase instrutória inserta no processo de conhecimento, mas inclui todo ato do juiz que esteja ligado à cognição, ${ }^{404}$ seja a cognição sumária ou decisões proferidas em processo de execução.

Portanto, estando a atividade cognitiva ligada aos poderes instrutórios, é certo que a dimensão desses poderes não se restringe apenas à fase de conhecimento, tampouco em atos do juiz que precedam a sentença, podendo tais poderes serem exercidos em toda situação que demande a busca de elementos pelo magistrado necessários para decidir e fundamentar uma decisão. Essa é a dimensão dos poderes instrutórios que, em verdade, podem ser exercidos pelo juiz sempre que necessários para a formação de seu convencimento e quando compatível a produção da prova com o procedimento. ${ }^{405} \mathrm{O}$ que se discute e será melhor debatido adiante são as limitações do exercício desses poderes como forma de compatibilizarem com os princípios existentes no sistema.

Estabelecidas premissas ligadas à classificação doutrinária e dimensão dos poderes instrutórios, seu conceito reside na manifestação do juiz exercida de ofício para determinar

\footnotetext{
403 DINAMARCO, Cândido Rangel, Instituições de direito processual civil, cit., v. 3, p. 34. Em igual sentido: "Instruir não é sinônimo de provar e prova não é sinônimo de instrução" (Vocabulário do processo civil. São Paulo: Malheiros, 2009, p. 163).

${ }^{404}$ Dinamarco complementa: “A instrução é pois o gênero próximo e a prova, uma de suas espécies. Tanto quanto a cognição, a instrução incide sobre todos os pontos de fato e de direito relevantes para decidir (...). Em uma conceituação ainda mais ampla, instrução é 'preparação' e instruir é 'preparar'." (Vocabulário do processo civil. São Paulo: Malheiros, 2009. p. 163).

${ }^{405}$ Dinamarco assevera ser o mandado de segurança o procedimento mais angustioso, em que praticamente inexiste momento predisposto a provas ou alegações, que em verdade são produzidas pelas partes quando da impetração e das informações, por parte do impetrante e impetrado, respectivamente (Instituições de direito processual civil, cit., v. 3, p. 35).
} 
a produção das provas, quando julgar necessárias. ${ }^{406} \mathrm{Em}$ resumo, são os atos do juiz ligados à própria instrução que, por sua vez, leva a um conceito mais amplo, relativo a toda situação no processo em que seja necessário produzir conhecimento no espírito do julgador, mediante direção formal e material da causa, que se aperfeiçoa de ofício.

Por outro lado, os atos ligados à produção da prova defluem da própria iniciativa probatória do juiz ou deferimento das provas requeridas pelas partes. Portanto, tais atos somente se materializam quando da produção da prova, ao passo que a admissibilidade ou indeferimento da colheita de tal prova se aperfeiçoa na oportunidade em que é franqueado o exercício da especificação de provas aos litigantes, ${ }^{407}$ de sorte a constituir-se um expediente de participação recíproca entre o juiz e os litigantes. Nesse sentido, discorre Moacyr Amaral Santos:

\begin{abstract}
"Dá-se, assim, no processo probatório, uma perfeita interdependência de atribuições das partes e do juiz. Apenas aquelas não podem ter ingerência na função específica deste, de emitir provimentos relativos a qualquer dos atos probatórios e de avaliar a estimar as provas, porque, então, seria transformarem-se em juízes das próprias alegações. Por sua vez, o juiz não pode, a não ser dentro do critério legal e com o propósito de esclarecer a verdade, objeto de ordem pública, assumir o ônus de provar fatos não alegados ou de ordenar provas quando as partes delas descuidam ou negligenciam. ${ }^{408}$
\end{abstract}

Portanto, os atos do juiz ligados ao deferimento/indeferimento de determinada prova ou meio de sua produção relacionam-se com os poderes do juiz voltados à produção da prova, sendo os poderes instrutórios (iniciativas probatórias) uma espécie do gênero desses atos.

\footnotetext{
${ }^{406}$ Para Moacyr Amaral Santos, a prova possui momentos distintos, consistentes na proposição (ato da parte e do juiz na especificação dos meios de prova ou determinação dos fatos por provar, respectivamente) admissão (momento da avaliação preventiva de sua utilidade, exercido pelo juiz) e produção ou execução (reprodução do fato afirmado) (Prova judiciária no cível e comercial, cit., v. 1. p. 242, 254-255 e 260). Para José Roberto dos Santos Bedaque, os poderes do juiz relacionados à produção da prova não se restringem apenas à produção de provas ex officio, mas também estão ligados ao indeferimento de diligências inúteis ou desnecessárias (Código de processo civil interpretado, in MARCATO, Antonio Carlos (Coord.), Código de processo civil interpretado, cit., p. 385-386).

${ }^{407}$ Conforme leciona Dinamarco, cada meio de prova é uma técnica procedimental específica, composta de atividades disciplinadas em lei ou divididas em fases ou momentos da prova. Estes, por sua vez, se dividem na propositura pela parte, admissão pelo juiz, realização mediante participação de todos os sujeitos processuais e a valoração, atividade exclusiva que compete ao magistrado (Instituições de direito processual civil, cit., v. 3, p. 88-89).

${ }^{408}$ SANTOS, Moacyr Amaral, Prova judiciária no cível e comercial, cit., v. 1, p. 238.
} 
Resta verificar em que momento o juiz deve assumir postura mais ativa quanto à iniciativa probatória.

A a prova tem por finalidade, ${ }^{409}$ em linhas gerais, trazer elementos de influência necessários à convicção do julgador, de sorte que seu objeto reside na investigação dos fatos relevantes ou pertinentes que devem ser examinados pelo juiz como necessários para decidir. Daí o magistrado se valer dos meios de prova para investigar o objeto, mediante a produção das provas que, por sua vez, classificam-se quanto ao sujeito, à forma e ao momento. No que importa à investigação deste trabalho, em relação ao momento do meio de prova, "eles podem ser apresentados dentro ou fora da 'fase instrutória' dos mais diversos procedimentos". 410

Através das principais contribuições da doutrina já abordadas no item 3.1.2 (sem, contudo, confrontar todos os aspectos ligados à teoria geral da prova e algumas variações difundidas por outros autores), pode-se concluir que a produção da prova pretende convencer o juiz acerca de uma premissa em aproximação da verdade, dentre as demais alegações controvertidas entre as partes, ou entre aquelas que, apesar de não controvertidas, dependam de comprovação. ${ }^{411}$ Por outro lado e conforme já tratamos naquele mesmo item, o juiz é o destinatário da prova, porquanto cabe a ele decidir e, nas situações que demandam a produção de provas, a decisão se fundamentará no resultado probatório. ${ }^{412}$ Destarte, havendo necessidade de dilação probatória, a construção desse campo se impõe para que o juiz identifique elementos necessários para a formação de seu livre convencimento. E, sendo a dimensão dos poderes instrutórios estendida a toda a situação que exija a busca de elementos para a formação do convencimento do juiz, necessários a decidir e fundamentar sua decisão, e quando compatível a produção da prova com o procedimento, de igual sorte o momento de exercício da iniciativa probatória do

\footnotetext{
${ }^{409}$ Ver item 3.1.2.

${ }^{410}$ BUENO, Cassio Scarpinella, Curso sistematizado de direito processual civil, cit., v. 2, t. 1, cit., p. 234.

411 É o que aponta Dinamarco, ao tratar das situações em que não se presumem verdadeiros os fatos que deixaram de ser impugnados pelo réu (art. 302 do CPC), bem como nas hipóteses em que os efeitos da revelia deixam de ser aplicados (art. 320 do CPC) (Instituições de direito processual civil, cit., v. 3, p. 6263).

${ }^{412}$ Embora soe repetitivo a todo momento o emprego da palavra "prova", ela não se confunde com "evidência", conforme leciona Dinamarco: "É uma profanação ao vernáculo e às tradições vocabulares ligadas ao linguajar jurídico romano o emprego do vocábulo 'evidência' em lugar de 'prova'. Esse péssimo uso é obra de maus tradutores que, iludidos por um falso cognato (pitfall), não se apercebem de que 'evidence' significa 'prova' e não evidência.” (Instituições de direito processual civil, cit., v. 3, p. 42).
} 
magistrado pode ocorrer sempre que preceder uma decisão, quando relevante a produção da prova. ${ }^{413}$

Contudo, cabe verificar se esse momento de iniciativa probatória é supletivo à oportunidade dada às partes para requererem as provas que pretendem produzir, ou se o juiz, ab initio, já fica autorizado a investigar e determinar de ofício as provas que entender necessárias para o julgamento da lide. Na doutrina, Moacyr Amaral Santos, ${ }^{414}$ Cândido Rangel Dinamarco, ${ }^{415}$ João Batista Lopes, ${ }^{416}$ Humberto Theodoro Júnior ${ }^{417}$ e José Manoel de Arruda Alvim ${ }^{418}$ sustentam que as iniciativas probatórias do juiz devem ser utilizadas supletivamente às provas já produzidas nos autos pelas partes, e desde que persista dúvida no convencimento do magistrado sobre como decidir.

Embora a conclusão seja convergente, os fundamentos difundidos por esse segmento da doutrina variam e não são unânimes entre os autores. Dentre as principais assertivas, tem-se que o juiz que determina a produção de provas de ofício substitui o ônus dos litigantes, mormente a regra de ônus da prova prevista no art. 333 do Código de Processo Civil. ${ }^{419}$ Por essa razão, as iniciativas probatórias do juiz somente devem se aperfeiçoar após a produção das provas requeridas pelas partes. Superada essa etapa, o juiz somente deverá ter a iniciativa probatória se restar dúvida sobre como decidir, ou seja, se ainda carecer elementos no campo probatório que o impeçam de formar o seu livre convencimento. Do contrário, estaria subsidiando uma das partes e, em consequência,

\footnotetext{
${ }^{413} \mathrm{Na}$ definição de Dinamarco, "procedimento é somente uma série ordenada de atos destinados à realização de algum objetivo" (Instituições de direito processual civil, cit., v. 3, p. 337). A partir daí se extraem os diversos procedimentos adequados à tutela jurisdicional pretendida. Em relação à profundidade da cognição e instrução, na medida que no procedimento ordinário a fase instrutória é bastante ampla e especializada em lei (arts. 332 e seguintes do CPC), no procedimento sumário, embora inexista uma fase instrutória propriamente dita (por ter uma vocação a ser concentrado para poder ser mais rápido), há oportunidade plena para alegar e provar em audiência ou mediante perícia (arts. 278, § 2º , e 276 do CPC). (Ibidem, p. $35)$.

${ }^{414}$ SANTOS, Moacyr Amaral, Primeiras linhas de direito processual civil, cit., v. 2, p. 77.

${ }^{415}$ DINAMARCO, Cândido Rangel, Instituições de direito processual civil, cit., v. 3, p. 55.

${ }^{416}$ LOPES, João Batista. Iniciativas probatórias do juiz e os arts 130 e e 333 do CPC. Revista dos Tribunais, São Paulo, ano 84, n. 716, p. 46, jun. 1995. Esse autor, embora reconheça a tendência de fortalecimento das iniciativas probatórias do juiz (A prova no direito processual civil, cit., p. 199), conclui que, não se afigura adequado, "permitir que o juiz substitua as partes na tarefa que lhes é atribuída, peremiando sua omissão e descaso. (Ibidem, p. 199). Mas também não se deve subestimar a força do preceito, que se insere nas modernas tendências do processo civil, presentes a função social do processo e os ideais de justiça". ( $A$ prova no direito processual civil, cit., p. 76).

${ }^{417}$ THEODORO JÚNIOR, Humberto, Curso de direito processual civil, cit., v. 1, p. 419.

${ }^{418}$ ARRUDA ALVIM, José Manoel de, Manual de direito processual civil, cit., v. 2, p. 484.

419 “Art. 333 - O ônus da prova incumbe: I - ao autor, quanto ao fato constitutivo do seu direito; II - ao réu, quanto à existência de fato impeditivo, modificativo ou extintivo do direito do autor."
} 
desequilibrando o contraditório. Logo, o juiz atuaria mais no sentido de complementar a prova do que ter ampla iniciativa independente da manifestação das partes.

Por outro lado, parece isolada a posição de José Roberto dos Santos Bedaque, ${ }^{420}$ posteriormente acompanhada por Antonio Janyr Dall'Agnol Junior, ${ }^{421}$ Sérgio Alves Gomes, ${ }^{422}$ Sérgio Luís Wetzel de Matos ${ }^{423}$ e Sidney da Silva Braga, ${ }^{424}$ cujas premissas também nos convenceram. Em primeiro lugar, deve-se pontuar que a iniciativa probatória do juiz se destina a resolver o processo e atender ou não ao pedido do autor ou do réu. A produção de determinada prova não se destina, portanto, a beneficiar ou substituir a falha de uma das partes no campo probatório, mas sim tem o condão de trazer subsídios necessários para o juiz decidir, decisão essa voltada a atingir os escopos sociais e jurídico da jurisdição. Portanto, a prova determinada de ofício não revela benefício a uma das partes, até porque não é conhecido de plano o seu resultado.

Ademais, conforme já exposto nos itens 3.2.1 e seguintes, a distribuição do ônus da prova é regra de julgamento. Vale dizer, o art. 333, I e II, do Código de Processo Civil tem aplicação tão somente quando o magistrado profere sentença, e desde que os fatos sobre os quais demandem produção de provas deixarem de restar comprovados, embora já exaurida a instrução probatória. ${ }^{425}$ Daí porque se mostra irrelevante verificar qual parte produziu determinada prova. ${ }^{426} \mathrm{O}$ que importa, sob a perspectiva de um processo instrumental, é

${ }^{420}$ BEDAQUE, José Roberto dos Santos, Poderes instrutórios do juiz, cit., p. 117 e ss.

${ }^{421}$ São os comentários ao art. 130 do Código de Processo Civil (DALL'AGNOL JUNIOR, Antônio Janyr. Comentários ao Código de Processo Civil: arts. 102-242. Coordenação de Ovídio A. Baptista da Silva. São Paulo: Revista dos Tribunais, 2000. v. 2, p. 132-133), de sorte que no processo civil moderno, o que se objetiva, fundamentalmente, é alcançar a verdade, o que justifica não só a iniciativa probatória da parte, mas do próprio juiz.

${ }^{422}$ GOMES, Sérgio Alves, Os poderes do juiz na direção e instrução do processo civil, cit., p. 255, 257 e 261.

${ }^{423}$ MATTOS, Sérgio Luís Wetzel, Da iniciativa probatória do juiz no processo civil, cit., p. 83.

${ }^{424}$ BRAGA, Sidney da Silva, Iniciativa probatória do juiz no processo civil, cit., p. 130-131.

${ }^{425}$ É o que assevera Bedaque, ao concluir que os princípios estabelecidos no art. 333 do Código de Processo Civil só devem ser aplicados após esgotarem-se todos os meios necessários a obtenção da prova sobre os fatos. Daí porque soa irrelevante refletir quem trouxe a prova sobre determinado fato, devendo a regra da inversão ser aplicada somente quando insuficiente a prova (Poderes instrutórios do juiz, cit., p. 120-121).

${ }^{426}$ É o que se verifica no trecho de ementa de um julgado do Superior Tribunal de Justiça, do qual se pode extrair a conclusão de que, por ser irrelevante a constatação de qual parte produziu determinada prova, de rigor que é ela importe para a formação do convencimento do julgador. Logo, tendo a prova sido produzida de ofício, o que se busca é angariar elementos para tornar palatável a formação do livre convencimento do magistrado, o que não se confunde com imparcialidade: “(...) III - Ao juiz, frente à moderna sistemática processual, incumbe analisar o conjunto probatório em sua globalidade, sem perquerir a quem competiria o onus probandi. Constando dos autos a prova, ainda que desfavorável a quem a tenha produzido, é dever do julgador tomá-la em consideração na formação de seu convencimento." (STJ - REsp n. 11.468-0/RS, $4^{\text {a }}$ Turma, rel. Min. Sálvio de Figueiredo, j. 01.04.1992, v.u., DJU, de 11.05.1992, p. 6.437). Cintra, Grinover 
pacificar conflitos com justiça e, para tanto, cabe ao magistrado angariar elementos (seja por iniciativa das partes, seja por sua própria determinação de ofício) necessários à formação de sua livre convicção, para assim preferir uma decisão justa que se aproxime de um juízo de certeza. ${ }^{427}$ É esse resultado do processo que importa ao Estado-juiz. Portanto, as iniciativas probatórias do juiz não se confundem com a regra de ônus da prova, tampouco são violação à imparcialidade ou a princípios constitucionais e do processo civil, conforme o que será melhor analisado no capítulo seguinte.

Sem embargo do quanto aqui esposado, é certo que impera o princípio do livre convencimento motivado (art. 131 do CPC). Portanto, se cabe ao magistrado apreciar livremente a prova, de modo a reunir condições que conduzam à formação de seu livre convencimento, de igual modo, ausentes tais elementos probatórios, nada impede que o magistrado determine diligências com vistas a angariar provas que lhe propiciem ter condições necessárias para decidir.

Portanto, parece-nos que a iniciativa probatória do magistrado não se limita ao momento posterior às provas produzidas pelas partes nos autos, mas pode o juiz deter tal iniciativa na mesma ocasião em que decide sobre a produção de provas, a exemplo do que ocorre no procedimento ordinário (art. 331, § $2^{\circ}$ do CPC). Isso porque a literal redação do art. 130 do Código de Processo Civil em nenhum momento restringe a iniciativa probatória do juiz a situações apartadas no curso do processo, ${ }^{428}$ razão pela qual entendemos que o poder instrutório pode ser exercido quando cabível e oportuna a produção de provas. ${ }^{429}$

\footnotetext{
e Dinamarco, embora admitam que “(...) uma vez produzida a prova, torna-se irrelevante indagar quem a produziu, sendo importante apenas verificar se os fatos relevantes foram cumpridamente provados (princípio da aquisição)", não conseguem desvincular o ônus da prova com a iniciativa probatória do juiz: "Os poderes de iniciativa do juiz com relação à prova dos fatos controvertidos, seja no processo penal, como visto acima, seja no processo civil (CPC, art. 130), têm importante reflexo na relevância da distribuição do ônus da prova. Em um imaginário sistema puramente inquisitório, em que o Estado chamaria a si toda a função de investigar a verdade dos fatos, perderia todo sentido a disciplina legal do ônus da prova." (Teoria geral do processo, cit., p. 376).

${ }^{427}$ Oportuno lembrar os ensinamentos de Cintra, Grinover e Dinamarco de que o juiz deve julgar secundum allegada et probata partium, e não secundum propriam suam conscientiam, de onde se extrai o princípio da persuasão racional ou livre convencimento motivado, que trataremos no item 4.2.3. (Teoria geral do processo, cit., p. 375).

${ }^{428}$ A chamada conversão do julgamento em diligência, trazida pela Lei n. 11.276/2006, que introduziu a redação do $\S 4^{\circ}$ ao art. 515 do Código de Processo Civil, sem prejuízo da redação do art. 560, parágrafo único, embora voltadas à correção de "nulidade sanável" ou "preliminar sobre nulidade suprível", tais dispositivos tem sido aplicados de forma mais ampla, no sentido do próprio tribunal determinar a realização de diligências probatórias para depois julgar. É o que se depreende do seguinte julgado: "Investigação de paternidade - Procedência da ação com fulcro na Súmula n. 301 do STJ, diante da ausência de comparecimento do réu para a realização do exame de DNA. Inconformismo no sentido de que o não comparecimento se deu por justo motivo. Requerimento de produção da prova médico-legal. Primazia do
} 
Ainda, dentre as hipóteses que de alguma forma conferem as iniciativas probatórias ao magistrado, para citar alguns exemplos arrolados no Código de Processo Civil (arts. 342, comparecimento pessoal das partes; 355, 360 e 382, exibição de documentos ou coisa; e 437, determinação de nova perícia), em nenhum momento o legislador restringiu a iniciativa probatória do juiz somente após exaurimento da produção das provas pretendidas pelas partes. Do contrário, soa mais lógico que a produção dessas provas ocorra concomitantemente ao meio de prova então produzido (v.g., se restar designada audiência de instrução para colheita da oitiva das testemunhas, por economia processual, poderia o magistrado, caso entenda relevante colher o depoimento pessoal das partes, nesse mesmo ato preparatório à audiência, intimá-las para colheita dos depoimentos pessoais). Ou seja, na medida que é conferida ao juiz a iniciativa probatória, de rigor que os meios de prova determinados ex officio sejam produzidos concomitantemente ao mesmo meio de prova já deferido em relação às partes. Pensar de modo diverso afronta os princípios da economia processual e da instrumentalidade das formas, porquanto haverá a realização de um ato que poderia ter se consumado na mesma oportunidade que outro semelhante.

Portantanto, entendemos que o momento para a iniciativa probatória de ofício pode ocorrer sempre que o juiz precisar amealhar elementos para decidir ou instruir o processo, ${ }^{430}$ pautado nas regras atinentes a cada procedimento, ou na mesma medida que se

princípio da amplitude da defesa. Conversão do julgamento em diligência, nos termos do $\S 4^{\circ}$ do art. 515 do CPC, sem anulação da $\mathrm{r}$. sentença. (...) Nessa ordem de ideias, considerando-se sempre a primazia do princípio da amplitude de defesa, é de se deferir ao apelante mais uma oportunidade para a realização da perícia médica legal, com base direta e analógica no $\S 4^{\circ}$ do art. 515 do Código de Processo Civil." (TJSP AC c/Revisão n. 616.386-4/1-00, 6a Câmara de Direito Privado, j. 19.03.2009). Essa recente decisão revela uma visão instrumentalista do processo, no sentido de relativizar em parte a rigidez do sistema de preclusões em prol da busca da verdade real no processo. Tal medida, embora louvável, deve ser vista com parcimônia e em estrita consonância com as garantias constitucionais processuais que trataremos no Capítulo seguinte, sob pena de revestir decisões arbitrárias e teratológicas.

429 Aqui vale transcrever dois dispositivos previstos no Código de Processo Civil que talvez transmitam ideias contraditórias. Ao passo que, no procedimento ordinário, o art. 456 determina que "encerrado o debate ou oferecidos memoriais, o juiz proferirá a sentença desde logo ou no prazo de 10 (dez) dias", o parágrafo único do art. 132 reza que "em qualquer hipótese, o juiz que proferir a sentença, se entender necessário, poderá mandar repetir as provas já produzidas." Embora o art. 456 esteja inserido no Livro I, Título VIII, Capítulo VII, Seção III, ao tratar da instrução e julgamento no procedimento ordinário, o art. 132, previsto no Livro I, Título IV, Capítulo IV, Seção I, versa exclusivamente sobre o juiz, notadamente no campo que abrange seus poderes, deveres e responsabilidades (Seção I), o que permite concluir que a atividade exercida pelo Estado-juiz no que toca à iniciativa probatória, a princípio não encontra restrições temporais, mas deve ser fundamentada e permitir o exercício do contraditório e ampla defesa às partes, sem prejuízo de atender a todas as garantias processuais constitucionais.

${ }^{430}$ Para Flávio Luiz Yarshell, o ato de instruir não se restringe a meio de preparar o julgamento estatal, mas se presta também como "meio de esclarecimento e de convencimento das partes para eventualmente se evitar o processo declaratório e a decisão estatal imperativa" (Antecipação de prova sem o requisito da urgência e direito autônomi à prova, cit., p. 147). 
der oportunidade às partes de se manifestarem sobre as provas que pretendem produzir. Nesse contexto, desnecessário lembrar que a iniciativa probatória do magistrado deve guardar estrita observância com os princípios constitucionais e processuais, tema que será melhor debatido no Capítulo 4. Antes, e para encerramento deste capítulo, discorreremos acerca dos limites dos poderes instrutórios, bem como faremos breves apontamentos relativos à previsão desses poderes nos sistemas estrangeiros, seguidos de sua evolução legislativa no ordenamento brasileiro.

\subsubsection{Limites}

O balizamento dos poderes instrutórios encontra esteio nos princípios processuais e constitucionais. Pretendemos neste tópico fazer breve menção às principais limitações, cujo desenvolvimento se dará no capítulo seguinte.

Iniciaremos pelo princípio da demanda, objeto do processo e de conhecimento do juiz (o qual trataremos no item 4.2.1. em sua similitude com o princípio dispositivo), em que as partes limitam a atividade e os poderes, principalmente os decisórios do juiz, mediante a fixação do objeto do processo. ${ }^{431}$ Da mesma forma que o juiz está adstrito a julgar nos limites dos pedidos do autor ou em resposta do réu, de sorte a guardar correlação entre a parte dispositiva da sentença e acolhimento da procedência ou não dos pedidos, ${ }^{432}$ a instrução probatória deve voltar-se à colheita de elementos necessários para decidir tais pedidos, e nada mais. Sendo o objeto do processo o pedido, as provas a serem produzidas devem guardar ligação com a investigação deste objeto, ${ }^{433}$ a fim de se atender ou não a pretensão da parte que o pleiteia.

\footnotetext{
${ }^{431}$ AMENDOEIRA JUNIOR, Sidnei. Poderes do juiz e tutela jurisdicional, cit., p. 74. Mário Guimarães trata das limitações aos poderes do juiz em três aspectos: a proibição de iniciativa da propositura da ação, ne procedat judex de officio, a vedação de conceder coisa diversa, a menos ou a mais do que houver sido pedido, e a limitação quanto a mudar a causa pretendi ( $O$ juiz e a função jurisdicional. Rio de Janeiro: Forense, 1958. p. 274-275).

${ }^{432}$ Aqui entenda-se pedido em sua acepção ampla, referindo-se tanto ao pedido do autor, quanto ao do réu.

433 Consoante leciona Milton Paulo de Carvalho, a estabilização do processo ocorre após a citação válida do réu, oportunidade em que o autor não poderá mais modificar o pedido ou a causa de pedir sem o consentimento do réu, ex vi do que dispõe o art. 264, caput, do Código de Processo Civil, cujo parágrafo único veda em definitivo a alteração do pedido ou da causa de pedir após o saneamento do processo (Do pedido no processo civil. Porto Alegre: Sergio Antonio Fabris, 1992. p. 121-123). Por sua vez, a estabilização do processo apresenta fundamento dúplice: a primeira, consistente "na realização prática do
} 
Logo, o exercício dos poderes instrutórios deverá destinar-se tão somente à busca de provas necessárias à formação do livre convencimento do magistrado, para que ao final se possa decidir o pedido, ou seja, os poderes instrutórios devem guardar ligação com os limites da matéria relacionada ao objeto litigioso. Tal limitação também compreende a causa de pedir, ${ }^{434}$ no que toca aos fatos trazidos para conhecimento do julgador, devendo a investigação probatória relacionar-se com pontos ligados a tais fatos. ${ }^{435}$ Nesse contexto, bem assevera Barbosa Moreira:

\begin{abstract}
"Em matéria de instrução, prevalece igualmente nas leis contemporâneas a tendência a confiar papel ativo ao juiz, deferindo-lhe ampla iniciativa na verificação dos fatos relevantes para a solução do litígio, tal como submetido à sua cognição, isto é, nos limites do pedido e da causa de pedir." ${ }^{436}$
\end{abstract}

Portanto, a primeira limitação ao exercício dos poderes instrutórios diz respeito à produção de provas pertinentes para se decidir o pedido e consoante os fatos que o

princípio da lealdade processual, o qual não consiste apenas na fidelidade à verdade, mas compreende a colocação clara e precisa dos fatos e dos fundamentos jurídicos por ambas as partes, de sorte que quem se defenda conheça integralmente a violação de direito que lhe é atribuída e os meios de prova para confirmar tal violação, e o que acuse conheça os meios articulados pela defesa, bem assim a prova respectiva, de modo a não se surpreender, nem um, nem outro, com alegações novas de fatos ou indicação de provas imprevistas" (Ibidem, p. 122). O segundo fundamento reside no interesse público da boa administração da Justiça, de sorte que o juiz decide sobre o que foi pedido e como foi pedido.

${ }^{434}$ A causa de pedir (causa petendi) está preconizada no art. 282 III do Código de Processo Civil e reflete os fatos e fundamentos jurídicos do pedido. Por sua vez, os fatos e fundamentos jurídicos do pedido são classificados pela doutrina em causa de pedir próxima e causa de pedir remota. Embora seja controvertida na doutrina a relação dos fatos constitutivos e fundamentos jurídicos do pedido com causa de pedir próxima ou causa de pedir remota, para a finalidade deste trabalho, adotaremos a definição de causa de pedir remota como os fundamentos jurídicos do pedido, ao passo que a causa de pedir próxima consiste nos fatos constitutivos (MARCATO, Antonio Carlos, Procedimentos especiais, cit., p. 20). Em nosso sistema processual, adotou-se a teoria da substanciação, ligada aos aforismos da mihi factum, dabo tibi jus e iura novit curia, de sorte que a qualificação jurídica dada pela parte é irrelevante para a subsunção pelo juiz dos fatos narrados à norma a ser aplicada para se atender ou não ao pedido. Logo, o magistrado não está ligado às consequências jurídicas narradas na petição inicial, podendo atender ao pedido com base em fundamentação diversa da postulada pelo autor.

${ }^{435}$ Isso não significa que os poderes-deveres instrutórios se restrinjam à iniciativa do magistrado. Pode ocorrer que a produção de determinada prova conduza à verificação de outra que repute relevante e necessária ao julgamento do feito. É o que constata Dinamarco, ao aduzir que o juiz tem o mesmo dever de investigação quando o resultado de determinada prova evidenciar ou insinuar a existência de outros meios de prova inexplorados pelas partes, porém relevantes para o julgamento da causa, o que se materiliza de forma alinhada ao art. 130 do Código de Processo Civil (Instituições de direito processual civil, cit., v. 3, p. 53-54). Por sua vez, nos termos do art. 131 do Código de Processo Civil, o juiz apreciará livremente a prova, atendendo aos fatos e circunstâncias constantes nos autos, "ainda que não alegados pelas partes". Logo, é o juiz quem amealha elementos necessários a formar seu livre convencimento e ao final decidir o pedido, de sorte que os fatos alegados pelas partes constituem, num primeiro momento, direcionamento para a instrução probatória poder concluir pela procedência ou não do pedido. Assim, os fatos trazidos pelo resultado de determinada prova podem ser conhecidos pelo juiz e o levarem à produção de outra prova, desde que destinada a colher elementos necessários para se atender ao pedido.

${ }^{436}$ BARBOSA MOREIRA, José Carlos, Os poderes do juiz na direção e na instrução do processo, in Temas de direito processual: quarta série, cit., p. 47. 
constituem (causa de pedir), à luz do princípio dispositivo, princípio da correlação ou adstrição. $^{437}$

Dessa premissa nasce a necessidade do dever de motivação das decisões judiciais erigido ao status de princípio constitucional (arts. 93, IV, da CF e 131, 458, II e 165 do CPC), o que reflete a segunda limitação ao exercício dos poderes instrutórios. Vale dizer, toda decisão judicial, seja admitindo a produção de determinada prova, seja a indeferindo por entendê-la desnecessária ou impertinente ao deslinde do feito, seja, ainda determinando a produção de dada prova por iniciativa do próprio juiz, deverá revestir-se de ampla fundamentação, delineando não só os motivos que revestem esse comando judicial, mas também a linha de raciocínio empregada pelo magistrado e o motivo que o levou a tal convencimento. E os reflexos dessa providência permitem não só imprimir transparência à atividade desempenhada pelo Estado-juiz no exercício dos poderes instrutórios, mas também se prestam a regular a legitimidade da decisão, porquanto serão conhecidas as razões que conduziram o magistrado a decidir de tal maneira, permitindo-se, portanto, o controle do pronunciamento judicial pelas partes e pela sociedade. ${ }^{438}$

Em verdade, a observância dessa garantia constitucional tem o condão de evitar decisões arbitrárias e desprovidas de fundamentação, o que se aproxima, portanto, de uma condição de legitimidade e validade da decisão frente aos princípios processuais

\footnotetext{
${ }^{437}$ O princípio calcado nos arts. 128 e 459 e 460 do Código de Processo Civil possui inúmeras designações que variam na concepção doutrinária: princípio da correlação ou adstrição (BEDAQUE, José Roberto dos Santos, Poderes instrutórios do juiz, cit., p. 154); princípio da ação (CINTRA, Antonio Carlos de Araújo; GRINOVER, Ada Pellegrini; DINAMARCO, Cândido Rangel, Teoria geral do processo, cit., p. 66); princípio dispositivo (LOPES, João Batista, A prova no direito processual civil, cit., p. 195 e 199); José Frederico Marques, Manual de direito processual civil, cit., v. 1, p. 605; BURGARELLI, Aclibes, Tratado das provas cíveis, cit., p. 29; e PORTANOVA, Rui. Os princípios do processo civil. Porto Alegre: Livraria do Advogado, 1995. p. 121; esse último, concebe como expressões sinônimas princípio dispositivo, princípio da congruência ou princípio dispositivo em sentido material; e princípio dispositivo em sentido material (CAPPELLETTI, Mauro. La testimonianza della parte nel sistema dell'oralità: contributo alla teoria della utilizzazione probatoria del sapere delle parti nel processo civile. Milano: Giufrè, 1962. p. 358). Por mera opção metodológica e conforme será analisado no item 4.2.1, utilizaremos o princípio baseado nos arts. 128, 459 e 460 do Código de Processo Civil como princípio dispositivo. O que importa e ganha relevância prática, a nosso ver, não é a investigação sobre a melhor rotulação desse princípio, mas sim aprofundar os limites em que o juiz pode decidir diante do que restou pedido pelas partes, mormente diante os poderes instrutórios.

${ }^{438}$ Em igual sentido, Sidney da Silva Braga discorre que a fundamentação deve fazer menção ao objeto do processo, à relevância da prova e, principalmente, à sua necessidade. Desse modo: "Obrigando-se o juiz a fundamentar a iniciativa probatória oficial, elimina-se, pela via do controle pelas próprias partes, através dos recursos, e pela sociedade, ante a natureza pública do processo, o risco de ofensa aos princípios basilares da igualdade entre as partes e da imparcialidade do julgador, além de se possibilitar pronta averiguação sobre estar ou não sendo indevidamente ampliado o objeto do processo, tal qual delimitado pelas partes." (Iniciativa probatória do juiz no processo civil, cit., p. 138).
} 
constitucionais e garantia aos litigantes asseguradas na Constituição Federal. Todavia, uma decisão que desrespeita garantias constitucionais comporta reforma à luz do ordenamento jurídico processual, o que significa dizer que aquela atividade exercida pelo magistrado deixa de ser admitida. Logo, o respeito aos princípios constitucionais de motivação das decisões judiciais, do contraditório e da ampla defesa (o que será tratado no parágrafo seguinte) reputa limitação aos poderes instrutórios, porquanto a decisão judicial deficiente na obediência dessas garantias ofende a própria Constituição Federal e, portanto, é passível de anulação. ${ }^{439}$

Destarte, o exercício dos poderes instrutórios deve manter ampla observância ao princípio do contraditório e ampla defesa previsto no art. $5^{\circ}, \mathrm{LV}$, da Constituição Federal. Significa dizer que para toda determinação judicial relativa ao deferimento ou indeferimento da produção de dada prova ou sua produção de ofício deve ser assegurada aos litigantes a oportunidade de ciência e reação a tal decisão. Ademais, aos litigantes deve ser garantido o direito de participarem amplamente na produção da prova, bem como de se manifestarem sobre o seu resultado, podendo as partes ainda a complementar. Somente assim será garantida às partes participação plena e efetiva na atividade instrutória, o que elimina qualquer hipótese de gravame, porquanto mediante a oportunidade de ciência, participação e reação, cada litigante poderá contribuir com a produção da prova e seus reflexos na formação do convencimento do juiz, mormente insurgir-se contra a decisão.

Outra limitação diz respeito à vedação de admissibilidade de provas ilícitas ou produzidas por meios ilícitos. Conforme será melhor analisado no item 4.1.7, o princípio constitucional que veda a admissibilidade das provas tidas por ilícitas pelo ordenamento ou cujo meio de produção reputa ilícito comporta certa relativização em situações isoladas e excepcionais, nas quais pode ser aplicado prudentemente o princípio da proporcionalidade. Todavia, conforme se verificará abaixo, essa aplicação do princípio da proporcionalide se restringe ao poder instrutório do juiz ligado à admissibilidade da prova produzida por meio ilícito e em situações apartadas, deixando de compreender, portanto, qualquer iniciativa do

\footnotetext{
439 "É nulo o acórdão não fundamentado." (STJ - REsp n.12.445/AL, $1^{\text {a }}$ Turma, rel. Min. Gomes de Barros, $D J U$, de 25.11.1991, p. 17.043). "O indeferimento imotivado de prova testemunhal importa cerceamento de defesa (RTJ 79/640, RSTJ 13/306) e acarreta nulidade da decisão (RT 620/144). O mesmo ocorre com o indeferimento, sem qualquer justificação, de requisição de certidão necessária à prova de alegação da parte (RTJ 84/547)." (NEGRÃO, Theotonio; GOUVÊA, José Roberto F. Código de processo civil interpretado e legislação processual em vigor, cit., p. 290.
} 
magistrado voltada à produção de prova cujo meio é considerado ilícito e repelido pelo ordenamento.

Há na doutrina ainda quem sustente serem limite dos poderes instrutórios os efeitos da revelia, quando considerados verossímeis e incontroversos os fatos deduzidos pelo autor. $^{440}$ Embora o tema relativo à revelia restou analisado no item 3.1.2.2, o que se concluiu, em síntese, é que essa limitação parece fazer sentido se e desde que esteja presente a verossimilhança dos fatos narrados na petição inicial. Vale dizer, para que sejam aplicados os arts. 319 e 334, III do Código de Processo Civil, necessário que haja nos autos elementos mínimos (seja por conta das alegações do autor, seja em razão da existência de provas) que conduzam à proximidade de verossimilhança necessária à procedência do pedido. Daí porque a decisão que aplica essa regra deve apontar e fundamentar os elementos em que o julgador se pautou para subsumir a verossimilhança, de sorte a guardar logicidade com o provimento do pedido. Por outro lado, ausente a constatação da verossimilhança, inexiste limitação ao exercício do poder instrutório.

Portanto, tal qual todo e qualquer poder possui regras de contenção destinadas a evitar arbitrariedades e teratologias, de igual sorte o exercício dos poderes instrutórios comporta algumas limitações que, em linhas gerais, compreendem: (i) a investigação probatória restrita a angariar elementos necessários a atender ou rejeitar o pedido das partes, em observância aos princípios da ação, da demanda, da correlação, congruência ou adstrição, dispositivo ou dispositivo em sentido material (todas essas variações conceituais concebidas pela doutrina, embora destinadas, com pequenas oscilações e no que interessa a este trabalho, ao mesmo predicado ligado ao julgamento da causa, nos termos do que foi

\footnotetext{
${ }^{440}$ É o que leciona com propriedade José Roberto dos Santos Bedaque, em referência a julgado de sua lavra, ( ${ }^{\circ}$ TACSP - Ap. n. 771.669/São Paulo, 12 Câm., j. 04.05.1999: “(...) lícito afirmar ser inadmissível a determinação oficial para que o autor demonstre a veracidade dos fatos constitutivos de seu direito, verossímeis e incontroversos. O legislador, nesse caso, optou claramente pelo valor efetividade, preferindo tutela rápida, concedida mediante cognição sumária. Em princípio, não há razão para o julgador determinar a produção de provas. Estamos diante de limite técnico e legítimo à iniciativa probatória oficial. Por isso, já concluí em diversas oportunidades pela incidência do disposto nos arts. 319 e 334, III, do Código de Processo Civil, por se tratar de fatos verossímeis e incontroversos. O sistema não aceita outra alternativa, senão o acolhimento da pretensão inicial. Eventual ausência de prova não impede essa conclusão, pois as regras legais indicam para a possibilidade da tutela final ser concedida sem cognição exauriente, bastando a versão verossímil da autora. Nem seria legítima a iniciativa probatória oficial (CPC, art. 130), pois o legislador, em casos como o dos autos, optou pelo valor efetividade, em detrimento da segurança jurídica." (Poderes instrutórios do juiz, cit., p. 156).
} 
pedido pelas partes), ${ }^{441}$ em decisão que seja (ii) motivada, apontando as razões que o conduziram a tomar a iniciativa de determinar a produção de dada prova, de modo a (iii) assegurar às partes a plena oportunidade ao contraditório e ampla defesa, calcada no trinômio ciência, participação e reação. Ainda (iv) é vedado ao magistrado determinar a produção de provas por meios ilícitos ou vedados pelo ordenamento, conquanto a admissibilidade da prova produzida sob essas circunstâncias venha a ser aceita em alguns casos excepcionais, mediante a aplicação da técnica da proporcionalidade. Destarte, (v) em relação à aplicação dos efeitos da revelia, presente a verossimilhança do direito postulado pelo autor, deverá o magistrado evitar o prosseguimento de qualquer iniciativa probatória.

Essas são, em linhas gerais, as principais limitações ao exercício dos poderes instrutórios, apontadas por mera organização metodológica. Elas não são limitações isoladas e estanques, mas são argumentos de principal relevância. Assim, a atividade do Estado-juiz deve pautar-se, sobretudo, à observância dos princípios constitucionais do processo civil (tema que será tratado no Capítulo 4).

\subsubsection{Legislação estrangeira: breves comentários}

Os poderes instrutórios guardam peculiares características, se analisados sob a ótica do direito processual vigente na legislação alienígena. Embora haja variações, trata-se de uma tendência a ampliação dos poderes do juiz nos sistemas processuais modernos,

\footnotetext{
${ }^{441}$ Conforme será melhor delineado no Capítulo 4, diversas são as variações para a extenção do princípio dispositivo (disponibilidade pelas partes das provas a serem produzidas), que para alguns doutrinadores compreendem também o que outros diferenciam por chamar de princípio da demanda (disponibilidade quanto à delimitação do objeto litigioso). No que toca à limitação a um "pedido" formulado pelas partes, Cassio Scarpinella Bueno bem delineia que na "execução" está compreendida tanto a tutela jurisdicional executiva - o resultado -, quanto a atividade jurisdicional executiva - meios para alcançá-los (Curso sistematizado de direito processual civil, cit., v. 1, p. 7). Portanto, o exercício das iniciativas probatórias no processo de execução está ligado a decidir questões ou pontos para propiciar a satisfação da tutela jurisdicional executiva (resultado do bem da vida ali pretendido), bem como municiar o magistrado de elementos para fundamentar a própria atividade jurisdicional executiva (meios para alcançá-los). Nesse contexto que se materializa o exercício dos poderes instrutórios no processo de execução (título executivo extrajudicial) ou na fase cumprimento de sentença (título executivo judicial), a trazer elementos para a formação do livre convencimento do magistrado para decidir um pedido formulado por uma das partes ou até mesmo quando o sistema lhe permite tomar providências de ofício, a exemplo das chamadas medidas de apoio, tema ao qual voltaremos nos itens 5.5 e seguintes.
} 
conforme pondera Cappelletti. ${ }^{442}$ Incrementando-se os poderes do juiz, de igual sorte ampliam-se os poderes instrutórios, notadamente as iniciativas probatórias. E essa tendência de modo algum beira o autoritarismo, porquanto concebidos tais poderes sob a égide de regimes democráticos em que se franqueia ao juiz e às partes a disponibilidade de produção da prova, conforme anota Taruffo:

"Come si è visto più sopra, i vari ordinamenti processuali hanno usato
tecniche normative diverse e si sono spinti più o meno avanti nella
direzione dell'estensione dei poteri instruttori del giudice: um dato
constante che emerge dall'indagine comparatistica è comunque che
nessun ordinamento processuale moderno rinuncia ad orientarsi verso la
ricerca della verità dei fatti, e nessun ordinamento processuale moderno
fa affidamento esclusivo sull'iniziativa delle parti per conseguire questo
obbiettivo. Sarà anche utile notare che su nessuno di questi ordinamenti
incombe l'obra di Torquemada, e in nessuno di essi affiora Il fantasma
del giudice come longa manus di Hitler, di Mussolini o di Stalin. Emerge
piuttosto la figura, assai più modesta e ragionevole, de um giudice che
assiste al "gioco delle parti" ed interviene quando si avvede che questo
gioco rischia di portare a decisioni ingiuste perché fondate su un
accertamento inadeguato dei fatti, in quanto le parti non hanno prodotto
in giudizio tutte le prove disponibili.",

Vale dizer, não há relação alguma entre o aumento dos poderes do juiz, concessão de poderes instrutórios e eventual influência do regime político vigente. Regimes autoritários não necessariamente correspondem a sistemas que outorgam amplos poderes ao juiz, ao passo que há regimes democráticos cuja limitação de iniciativa probatória do juiz é mais evidente, a exemplo do sistema norte-americano. ${ }^{444}$

Como proposta metodológica, faremos breves comentários sobre os poderes instrutórios em três grupos de ordenamento: os que vedam ou proíbem poderes

\footnotetext{
442 "Pero lo que importa aquí de manera predominante es señalar que excepciones igualmente amplias, a menudo tambiém mayores, se hayan ido manifestando, especialmente en el curso de los últimos años o decenios, también en muchos otros paises, hasta el punto de que puede hablarse hoy en día de una bien clara y definida tendencia evolutiva de todos los ordenamientos procesales modernos." (CAPPELLETTI, Mauro. La oralidad y las pruebas em el proceso civil. Traducción de Santiago Sentis Melendo, Buenos Aires: EJEA, 1972, p. 119). Mais adiante, apontaremos os reflexos dessa tendência nos principais ordenamentos da Europa.

${ }^{443}$ TARUFFO, Michele, Poteri probatori delle parti e del giudice in Europa, cit., p. 262.

444 CÂMARA, Alexandre Freitas. Poderes instrutórios do juiz e processo civil democrático. Revista de Processo, São Paulo, Revista dos Tribunais, ano 32, 153, p. 35, nov. 2007.
} 
instrutórios, os que permitem a iniciativa probatória em situações específicas e, por fim, os sistemas que conferem ampla investigação probatória do juiz. ${ }^{445}$

O que delimita e diferencia esses três grupos é a dimensão e influência do princípio dispositivo (que trataremos mais adiante), cujo reflexo define um sistema com maior ou menor iniciativa probatória do magistrado. ${ }^{446}$

Nesse contexto, o sistema que mais restringe os poderes instrutórios do juiz é o espanhol, de forte influência de um princípio dispositivo mais rígido, cuja direção do processo em sua maior parte é conferido à vontade dos litigantes, restando ao magistrado a postura passiva de mero espectador, diante da formação do campo probatório. ${ }^{447}$ É o que se verifica da análise conjunta dos arts. 434, 435 e 436 da Lei de Enjuinciamiento Civil, de 7

\footnotetext{
${ }^{445}$ Maria Elizabeth de Castro Lopes enuncia a evolução dos poderes do juiz no sistema romano, mediante sua participação no processo em três fases: na primeira, conhecida por período das legis actiones (754 a.C. até 149 a.C.), ao juiz cabia receber a ação e, caso aceita, fixava o objeto litigioso, transferindo a um particular (o iudex ou arbiter) a incumbência de ouvir as partes, colher provas, receber os debates e até mesmo sentenciar. A segunda fase, conhecida como per formulas, é marcada pela figura do pretor peregrino (149 a.C até 209 d.C.). Essa etapa dividia-se em in iure (apresentação da pretensão ao magistrado e verificação da presença dos requisitos de admissibilidade do processo) e in iudicio ou apud iudicem (em que o magistrado indicava um particular - iudex - para prosseguir na ação até proferir sentença através da litiscontestatio). Ao final, ao pretor cabia a tarefa de fazer cumprir o julgado. Por fim, na cognitio extraordinária (209 até o fim do Império Romano), houve a unificação em uma única etapa da in iure e da in judicio, de sorte que a função do magistrado iniciava-se com o recebimento da pretensão do autor, prosseguindo esse mesmo juiz com a direção do processo e proferimento de sentença, seguindo-se até a execução ( $O$ juiz e o princípio dispositivo. São Paulo: Revista dos Tribunais, 2006. p. 83). Por sua vez, Sidnei Amendoeira Junior discorre que, após as invasões bárbaras e a queda de Roma, teve início o processo germânico, exercendo o juiz função extremamente formal, restando às partes a produção probatória, sendo a sentença proferida por uma assembleia cuja decisão cabia ao juiz apenas declarar e, ao final, a execução de sentença era realizada pelas partes. No processo canônico, a decisão dos que detinham poder jurisdicional (bispos, arcebispos, metropolitanos, patriarcas e pontífices) estava condicionada ao resultado das ordálias (ou juízos de Deus) e, somente a partir do século XI, com a divisão do processo em fases (postulatória e probatória, separadas pela litiscontestatio), o juiz passou a exercer certos poderes (conciliação), além de deter mais autonomia quanto à apreciação e valoração da prova (princípio da prova racional), restando contudo ao alvedrio das partes a incumbência de produzir provas. O juiz tinha poderes decisórios plenos para julgar, segundo seu convencimento, podendo inclusive recusar-se a proferir decisão por insuficiência de provas. Através da Clementina Saepe, expedida pelo Papa Clemente V, em 1306, instituiu-se o procedimento sumário, em que o magistrado passou a ter o poder de encerrar a instrução do processo quando entendesse adequado, dispensando provas que reputasse desnecessárias, além da concentração, em uma só audiência, de todas as manifestações das partes, o que fortaleceu os poderes do magistrado em relação à direção do processo (Poderes do juiz e tutela jurisdicional, cit., p. 40 e ss.).

${ }^{446}$ Essas são as conclusões de Sidnei Amendoeira Junior, para quem: “(...) nos ordenamentos de tipo dispositivo puro, a verdade processual se aproxima minimamente à real, nos ordenamentos de tipo inquisitório, essa aproximação é máxima." (Poderes do juiz e tutela jurisdicional, cit., p. 52).

${ }^{447}$ MARTIN OSTOS, José dos Santos. Las diligencias para mejor proveer em el proceso civil. Madrid: Montecarvo S. A., 1981. p. 20. Leciona Eduardo J. Couture que "son diligencias para mejor proveer, aquellas medidas probatorias que el Juez puede disponer por propia iniciativa, destinadas a mejorar las condiciones de información requeridas por la sentencia, de cuya génesis lógica forman parte" (Teoria de las diligencias para mejor proveer. Montevideo: Casa A. Barreiro Ramos, 1932. p. 63).
} 
de janeiro de 2000, com vigência a partir de 8 de janeiro de $2001,{ }^{448}$ os quais deixam claro que as chamadas providencias para mejor prover (com vistas a esclarecer dúvidas antes do julgamento) só podem ser realizadas após a fase normal de instrução probatória, por iniciativa exclusiva das partes, sendo vedada a produção de provas que poderiam ter sido por elas propostas no tempo normal, o que atribui determinada eficácia preclusiva, salvo a existência de fatos supervenientes ou provas que não poderiam ter sido produzidas pelos litigantes na ocasião oportuna. A única exceção ao que se aproximaria de uma iniciativa probatória do juiz diz respeito à renovação da prova sobre fatos relevantes, e desde que as provas produzidas não tenham atingido o resultado esperado, por circunstâncias alheias à vontade das partes; e ainda se exige que haja fundadas razões para crer que nessa segunda oportunidade tais provas tragam resultado diverso e destinado a esclarecer a verdade sobre os fatos. É o que se verifica em parte no art. 429 , que trata da admissibilidade da prova. ${ }^{449}$ Portanto, o sistema espanhol apresenta feições rígidas e limitadoras da iniciativa de ofício do magistrado de produção de provas, restritas tão somente à renovação de provas já propostas, e por iniciativa das partes.

\footnotetext{
448 “Art. 434 - Sentencia. 1. La sentencia se dictará dentro de los veinte días siguientes a la terminación del juicio. 2. Si, dentro del plazo para dictar sentencia y conforme a lo prevenido en los artículos siguientes, se acordasen diligencias finales, quedará en suspenso el plazo para dictar aquélla. Art. 435 - Diligencias finales. Procedencia. 1. Sólo a instancia de parte podrá el tribunal acordar, mediante auto, como diligencias finales, la práctica de actuaciones de prueba, conforme a las siguientes reglas: $1^{o}$ - No se practicarán como diligencias finales las pruebas que hubieran podido proponerse en tiempo y forma por las partes, incluidas las que hubieran podido proponerse tras la manifestación del tribunal a que se refiere el apartado 1 del art. 429. $2^{\circ}$ - Cuando, por causas ajenas a la parte que la hubiese propuesto, no se hubiese practicado alguna de las pruebas admitidas. $3^{\circ}$ - También se admitirán y practicarán las pruebas pertinentes y útiles, que se refieran a hechos nuevos o de nueva noticia, previstos en el art. 286. 2. Excepcionalmente, el tribunal podrá acordar, de oficio o a instancia de parte, que se practiquen de nuevo pruebas sobre hechos relevantes, oportunamente alegados, si los actos de prueba anteriores no hubieran resultado conducentes a causa de circunstancias ya desaparecidas e independientes de la voluntad y diligencia de las partes, siempre que existan motivos fundados para creer que las nuevas actuaciones permitirán adquirir certeza sobre aquellos hechos. En este caso, en el auto en que se acuerde la práctica de las diligencias habrán de expresarse detalladamente aquellas circunstancias y motivos. Artículo 436 Plazo para la práctica de las diligencias finales. Sentencia posterior. 1. Las diligencias que se acuerden según lo dispuesto en los artículos anteriores se llevarán a cabo, dentro del plazo de veinte días, en la forma establecida en esta Ley para las pruebas de su clase. Una vez practicadas, las partes podrán, dentro del quinto día, presentar escrito en que resuman y valoren el resultado. 2. El plazo de veinte días para dictar sentencia volverá a computarse cuando transcurra el otorgado a las partes para presentar el escrito a que se refiere el apartado anterior."

449 "Art. 429 - Proposición y admisión de la prueba. Señalamiento del juicio. 1. Si no hubiese acuerdo de las partes para finalizar el litigio ni existiera conformidad sobre los hechos, la audiencia proseguirá para la proposición y admisión de la prueba. Cuando el tribunal considere que las pruebas propuestas por las partes pudieran resultar insuficientes para el esclarecimiento de los hechos controvertidos lo pondrá de manifiesto a las partes indicando el hecho o hechos que, a su juicio, podrían verse afectados por la insuficiencia probatoria. Al efectuar esta manifestación, el tribunal, ciñéndose a los elementos probatorios cuya existencia resulte de los autos, podrá señalar también la prueba o pruebas cuya práctica considere
} 
Semelhante passividade se verifica no adversary system, típico dos países de common law, no qual o juiz não tem iniciativa probatória, conforme leciona Michele Taruffo. ${ }^{450}$ Sidnei Amendoeira Jr. também deixa claro que nesse sistema o juiz inglês fala e age pouco, sendo-lhe vedado afrontar o príncípio da soberania do júri e substituir uma atividade exclusiva das partes, como o é a produção de provas, cabendo-lhe o mister de dirigir a audiência e garantir a lealdade processual durante o trial, ${ }^{451} \mathrm{com}$ o que Barbosa Moreira conclui que o adversarial system se contrapõe ao sistema inquisitorial. ${ }^{452}$ Embora o sistema inglês esteja pautado nessas premissas, há uma tendência de ampliar os poderes instrutórios do juiz, pois os juízes têm tido cada vez mais acesso a certos documentos arrazoados e preparados pelas partes (contendo as questões fáticas e de direito e um resumo das provas colhidas na discovery) antes mesmo do trial. ${ }^{453}$ Ademais, o Rules of Civil Procedure, promulgado em 26 de abril de 1999, ${ }^{454}$ contém diversos dispositivos destinados a conceder poderes instrutórios ao juiz inglês, tais como o dever de fixar as questões que carecem de demonstração, a natureza da prova a ser produzida em relação a esses pontos fixados, podendo excluir certas provas e seu modo de apresentá-las na trial. Ainda compete ao juiz valer-se da witness summonses, a fim de instar terceiros a

conveniente. En el caso a que se refiere el párrafo anterior, las partes podrán completar o modificar sus proposiciones de prueba a la vista de lo manifestado por el tribunal."

450 “(...) non abbia poteri instruttori autonomi da esercitare al fine di integrare lê attività di pare onde pervenire ad um accertamento completo della veritá. Si ritiene anzi che poteri di questo genere colpirebbero quelláspetto essenziale della fairness del trial che consiste nela più assoluta parità formale delle parti." (TARUFFO, Michele. Il processo civile “adversary” nellésperienza amaricana. Pádova: Cedam, 1979. p. 20-21).

451 AMENDOEIRA JUNIOR, Sidnei, Poderes do juiz e tutela jurisdicional, cit., p. 54-55. Sobre o papel do juiz na instrução do processo no adversary system, John Anthony Jolowicz deixa claro a postura passiva do juiz e justificativas empregadas naquele sistema para vedar a iniciativa probatória de ofício pelo magistrado: "Decerto o juiz preside o trial e, uma vez ouvidos os advogados das partes, dá ao júri as instruções necessárias quanto às regras de direito aplicáveis à espécie. Mas não toma parte alguma nas deliberações do júri. Mais: a ingerência do juiz antes do trial, seja a propósito da redação dos pleadings, e por conseguinte da determinação das questões que o júri terá de resolver, seja no tocante à instrução do feito, equivaleria a restringir a soberania do júri. Inevitável, assim que o papel do juiz deve ser passivo e toda atividade processual, inclusive a instrução do processo, seja deixada exclusivamente às partes. Tocalhes determinar não só o objeto do litígico, mas igualmente as próprias questões discutidas. Também sendo necessariamente passivo o papel do júri, juiz de fato, o processo não pode deixar de reconhecer que predomina o papel das partes. Segundo a opinião tradicional, considera-se até bom, e não apenas inevitável, que o júri - ou o juiz singular - entre na sala de audiência sem prévio conhecimento do litígio que lhe será submetido." (A reforma do processo civil inglês: uma derrogação do adversary system. Tradução de José Carlos Barbosa Moreira [baseado no mesmo artigo publicado na Common Law d'um siécle à l'autre, ed. Por Legrand, Ed. Blais, Cowansville, Quebec Canadá]. Revista de Processo, São Paulo, Revista dos Tribunais, ano 19, n. 75, p. 66, fev. 1994).

452 BARBOSA MOREIRA, José Carlos. Notas sobre alguns aspectos do processo (civil e penal) nos países anglo-saxônicos. Revista de Processo, São Paulo, Revista dos Tribunais, ano 23, n. 92, p. 90, out./dez. 1998.

${ }^{453}$ AMENDOEIRA JUNIOR, Sidnei, Poderes do juiz e tutela jurisdicional, cit., p. 56.

${ }^{454}$ Esse diploma tomou feição de um código de processo civil inglês, ao passo em que antes a disciplina anterior era regulada pelo Civil Procedure Act, datado de 1997, e de legislação esparsa. 
testemunhar em juízo ou a apresentar documentos, sob pena de que uma ordem seja emitida em caso de descumprimento, podendo ainda o magistrado impor multa a terceiro, visando à consecução da ordem. ${ }^{455}$ Vê-se, portanto, uma crescente tendência do direito inglês no fortalecimento dos poderes instutórios, embora mantida a estrutura contida do adversary system. Em contrapartida, no processo civil norte-americano (regulado pela Federal Rules of Civil Procedure), a tendência a um aumento dos poderes instrutórios do juiz, por ora, se restinge às muitas manifestações doutrinárias nesse sentido, que se afeiçoam mais ao campo ideológico, ${ }^{456}$ permanecendo, por ora, as regras contidas do adversary system.

Por sua vez, o ordenamento italiano confere às partes a iniciativa probatória, ${ }^{457} \mathrm{de}$ sorte a atribuir caráter excepcional aos poderes instrutórios de ofício do magistrado, conforme se depreende da redação do art. 281-ter, acrescentado ao Códice di Procedura Civile de 1988: “Il giudice può disporre d'ufficio la prova testimoniale formulandone $i$ capitoli quando le parti neslla esposizione dei fatti si sono riferite a persone che appaiono in grado di conoscere la verità". Outras iniciativas probatórias também se verificam nos arts. 61 (consulta técnica), 118 (inspeção de pessoas e coisas), 213 (requisição, de ofício, de informações e documentos da Administração pública) e 257 (oitiva, também de ofício, de pessoas referidas na oitiva de testemunhas). ${ }^{458}$ Conforme discorre Bedaque, embora a

\footnotetext{
455 AMENDOEIRA JUNIOR, Sidnei, ob. cit., p. 58.

${ }^{456}$ Nesse sentido, discorre Vittorio Denti: "Finalmente, la tendencia a racionalizar el procedimiento probatorio va acompañada por la ya señalada de atenuar el tradicional adversary system y de acentuar los poderes de control y dirección del juez sobre la marcha del trial." (Estudios de derecho probatorio. Traducción de Santiago Sentis Melendo; Tomás A. Banzhaf. Buenos Aires: EJEA, 1974, p. 132). Em semelhante sentido: DÍAZ CABIALE, José Antonio. Principios de aportación de parte y acusatorio: la imparcialidade del juez. Granada: Comares, 1996. p. 288-290 e AMENDOEIRA JUNIOR, Sidnei, Poderes do juiz e tutela jurisdicional, cit., p. 60-61.

${ }^{457}$ É o que se verifica no art. 115 do Codice di Procedura Civile: "Art. 115 - Salvi i casi previsti dalla legge, il giudice deve porre a fondamento della decisione le prove proposte dalle parti o dal pubblico minitero. Puó tuttavia, senza bisogno di prova, porre a fondamento della decisione le nozioni di fatto che rientrano nella comune esperienza."

458 “Art. 61 - Quando é necessario, il giudice puó farsi assistere, per il compimento di singoli atti o per tutto il processo, da uno o piu consulenti di particolare competenza tecnica. La scelta dei consulenti tecnici deve essere normalmente fatta tra le persone iscritte in albi speciali formati a norma delle disposizione di attuazione al presente codice. Art. 118 - Il giudice può ordinare alle parti e ai terzi di consentire sulla loro persona o sulle cose in loro possesso le ispezioni che appaiano indispensabili per conoscere $i$ fatti della causa, purché ció possa compiersi senza grave danno per la parte o per il terzo, e senza costringerli a violare uno dei segreti previsti negli articoli 351 e 352 del codice di procedura penale. Se la parte rifiuta di eseguire tale ordine senza giusto motivo, il giudice può da questo rifiuto desumere argomenti di prova a norma dell' articolo 116, secondo comma. Se rifiuta il terzo, il giudice lo condanna a uma pena pecuniaria non superiore a lire ottomila. Art. 213 - Fuori dei casi previsti negli articoli 210 e 211, il giudice può richiedere d'ufficio alla pubblica amministrazione le informazioni scritte relative ad atti e documenti dell'amministrazione stessa, che è necessario acquisire al processo. Art. 257 - Se alcuno dei testimoni si
} 
maioria da doutrina italiana afirme a existência dos poderes instrutórios restrita a dispositivos esparsos, como os citados acima, cuja interpretação traduz-se não só na iniciativa probatória das partes, mas também na presença do impulso oficial no campo probatório, há vozes em sentido contrário, que defendem a presença do princípio dispositivo e iniciativa exclusiva das partes, restringindo, portanto, a ação oficial a situações específicas previstas em lei. Em contrapartida, no processo trabalhista italiano, o poder de iniciativa do juiz de produção de provas é amplo. ${ }^{459}$

Vê-se, portanto, que os poderes instrutórios do juiz na Itália é tema de intenso debate doutrinário. Optamos pela moderna corrente difundida por Luigi Paolo Comoglio, Conrado Ferri e Michele Taruffo, que sustentam a existência do poder do juiz de direção material do processo, consistente em postura mais inquisitória, com vistas a realizar o direito material no caso concreto, o que se materializa mediante o órgão jurisdicional valerse de todos os meios de prova destinados a esse mister, independentemente de requisiçao das partes, no campo probatório. ${ }^{460}$ Semelhante entendimento é asseverado por Mauro Cappelletti, para quem o juiz, além de diretor formal, também exerce papel de diretor material do processo, na medida que assume poderes referentes ao objeto deduzido em juízo, permanecendo as partes com o poder de disposição e de exceção e ao juiz um poder de "auxílio" às partes (em sentido de colaboração), destinado ao fortalecimento do campo

riferisce, per la conoscenza dei fatti, ad altre persone, il giudice instruttore può disporre d'ufficio che esse siano chiamate a deporre. Il giudice può anche disporre che siano sentiti i testimoni dei quali há ritenuto l'audizione superflua a norma dell'articolo 245 o dei quali há consentito la rinuncia; e del pari può disporre che siano nuovamente esaminati i testimoni già interrogati, al fine di chiarire la loro deposizione o di correggere irregolarità avveratesi nel precedente esame."

${ }^{459}$ BEDAQUE, José Roberto dos Santos, Poderes instrutórios do juiz, cit., p. 154, p. 81-83. Bedaque aponta na doutrina italiana aqueles que restringem os poderes instrutórios às hipóteses previstas em lei (VERDE, Giovanni. Profili del processo civil: parte generale. Napoli: Jovene, 1978. p. 84-85; MADRIOLI, Crisanto. Corso di diritto processuale civile. Torino: Giappiacchelli, 1978. v. 1, p. 85-86; e ZANZUCCHI, Marco Tulio. Diritto processuale civile. Milano: Giuffrè, 1964. v. 1, p. 367-371) e os processualistas que sustentam a exclusividade das partes quanto à iniciativa probatória, entendendo que a iniciativa do juiz no campo da prova deve ser limitada ao máximo (LA CHINA, Sérgio. L'esibizione delle prove nel processo civile. Milano: Giuffrè, 1960. p. 75; TARZIA, Giuseppe. Lineamenti del nuovo processo di cognizione. Milano: Giuffrè, 1991. p. 114; e CALAMANDREI, Piero. Instituzioni di diritto processuale civile. Napoli: Morano, 1970. v. 4, p. 222-223. Esse último, embora admita um aumento dos poderes instrutórios através das últimas reformas, mantém seu entendimento de que o princípio dispositivo, por conferir a disposição do direito material colocado em litígio, consequentemente se projeta para a disponibilidade no campo do processo, mediante vontade das partes.

460 "Meritano un discorso a parte, beninteso, data la loro penetrante incisività, I poteri di direzione materiale che caratterizzano il ruolo 'forte' (e addirittura la posizione dominante) del giudice nei processi di stampo inquisitorio, ove l'iniziativa d'ufficio nell'acertamento di fatti e nell'istruzione probatoria non è piu l'eccezione, ma diventa la regola, consentendo all'organo giudicanti di disporre sua sponte, senza riguardo alle istanze di parte, qualsiasi mezzo di prova ritenuto utile ai fini del giudizio." (COMOGLIO, Luigi Paolo; FERRI, Conrado; TARUFFO, Michele, Lezioni sul proceso civile, cit., p. 210. 
probatório necessário para o julgamento do pedido. ${ }^{461}$ Portanto, o que se verifica no direito italiano é a busca de um equilíbrio, de um lado tendendo ao processo inquisitório lastreado em poderes instrutórios de ofício do magistrado, e, de outro, evitando exageros, cabendo ao juiz o papel de regular o ideal, diante de cada caso concreto. ${ }^{462}$

Por sua vez, a legislação alemã confere iniciativas probatórias amplas ao magistrado, restringindo, em contrapartida, a produção de prova testemunhal mediante requerimento das partes. ${ }^{463}$ Semelhante definição é constatada na legislação colombiana (Código de Procedimiento Civil), cujos arts. 179 e $180^{464}$ preveem os poderes instrutórios, de sorte que o art. 37, n. 4, reza que tais poderes devem ser utilizados sempre que conveniente para verificar os direitos alegados pelas partes, e com vistas a evitar nulidades. ${ }^{465} \mathrm{Na}$ legislação argentina, o art. 36 do Código Procesal Civil y Comercial de La Nación (Ley 17.454, publicada no Boletín Oficial de 07.11.1967, com modificações introduzidas pela Ley 25.488, publicada em Boletín Oficial de 22.11.2001) prevê inúmeros deveres e faculdades assegurados à parte, ao juiz e ao tribunal, dentre elas as que apresentam contornos de poderes instrutórios. ${ }^{466} \mathrm{O}$ ordenamento português, embora atento

461 "No se llega todavía a la conclusión extrema de desvincular al uez del poder dispositivo y exclusivo de las partes en materia de acción y de excepción (y de determinación de los elementos constitutivos de la acción y de la excepción, entre ellos el elemento causal); pero se atribuye, sin embargo, al juez un poder de intervención, de solicitación, de estímulo; él puede hacer presente a la parte la irregularidad no solamente formal de la acción propuesta, lo incompleto o lo impreciso de las alegaciones o de las peticiones, la possibilidad de cambiar, de ampliar, de corregir la propia posición. (...) en suma, un proceso en el cual el juez tiene el poder, no ya de sustituir a la de las partes su propia voluntad en la determinación de la res judicanda, sino de aconsejar y de asistir a las partes en sua también siempre libre y soberana determinación de aquella res." (CAPPELLETTI, Mauro, La oralidad y las pruebas em el proceso civil. cit., p. 125).

${ }^{462}$ AMENDOEIRA JUNIOR, Sidnei, Poderes do juiz e tutela jurisdicional, cit., p. 52.

463 “ $\$ \$ 142$ e 272 (prova documental); 144 (inspeção e consulta técnica); 448 (interrogatório); 282, 'b', apartado II, n. 2 (pedido de informações à administração pública).” (BEDAQUE, José Roberto dos Santos, Poderes instrutórios do juiz, cit., p. 80). Fritz Baur comenta acerca do sistema alemão que "de acordo com a regulamentação atualmente em vigor, o juiz se acha nessa hipótese em uma posição mais livre: ele pode servir-se de ofício de todos os meios de prova (por conseguinte, sem pedido das partes), com exceção da prova testemunhal" (O papel ativo do juiz, cit., p. 192).

464 "Art. 179 - Las pruebas pueden ser decretadas a petición de parte, o de oficio cuando el magistrado o juez las considere útiles para la verificación de los hechos relacionados com las alegaciones de las partes. Art. 180 - Podrán decretarse pruebas de oficio, en los términos probatorios de las instancias y de los incidentes, y posteriormente, antes de fallar. Cuando no sea posible practicar estas pruebas dentro de las oportunidades de que disponen las partes, el juez señalará para tal fin una audiencia o un término que no podrá exceder del que se adiciona, según fuere el caso."

465 “Art. 37 - Son deberes del juez: (...) 4. Emplear los poderes que este Código le concede en materia de pruebas, siempre que lo considere conveniente para verificar los hechos alegados por las partes y evitar nulidades y providencias inhibitorias."

466 “Art. 36 - Aún sin requerimiento de parte, los jueces y tribunales deberán: 1) Tomar medidas tendientes a evitar la paralización del proceso. A tal efecto, vencido un plazo, se haya ejercido o no la facultad que corresponda, se pasará a la etapa siguiente en el desarrollo procesal, disponiendo de oficio las medidas necesarias. 2) Intentar una conciliación total o parcial del conflicto o incidente procesal, pudiendo proponer y promover que las partes deriven el litigio a otros medios alternativos de resolución de conflictos. En cualquier momento podrá disponer la comparecencia personal de las partes para intentar 
ao princípio dispositivo, confere poderes amplos de direção e instrução voltados a fatos lícitos de conhecer, conforme se verifica no arts. 264 e 265, n. 3, do Código de Processo Civil lusitano, ${ }^{467}$ sem prejuízo de inúmeras situações apartadas que conferem o poder de instrução oficial, tais como a convocação, a qualquer momento, para depoimento pessoal das partes (art. 552, 1), bem como a sua convocação, seus representantes ou mandatários, para prestarem esclarecimentos sobre matéria de fato ou de direito pertinente à causa (art. 266, 2), além do poder de determinar de ofício a inspeção de coisas ou pessoas (art. 612), a oitiva de testemunha não arrolada pelas partes, ainda que não referida em outro depoimento (art. 645) e a produção de prova pericial (art. 579).

A investigação oficial do magistrado é a mais ampla possível no direito francês, ${ }^{468}$ conforme Sidnei da Silva Braga ${ }^{469}$ bem assevera, em relação aos arts. 10, 143 e 144 do

una conciliación. 3) Proponer a las partes fórmulas para simplificar y disminuir las cuestiones litigiosas surgidas en el proceso o respecto de la actividad probatoria. En todos los casos la mera proposición de fórmulas conciliatorias no importará prejuzgamiento. 4) Ordenar las diligencias necesarias para esclarecer la verdad de los hechos controvertidos, respetando el derecho de defensa de las partes. A ese efecto, podrán: a) Disponer, en cualquier momento, la comparecencia personal de las partes para requerir las explicaciones que estimen necesarias al objeto del pleito; b) Decidir en cualquier estado de la causa la comparecencia de testigos con arreglo a lo que dispone el artículo 452, peritos y consultores técnicos, para interrogarlos acerca de lo que creyeren necesario; c) Mandar, con las formalidades prescriptas en este Código, que se agreguen documentos existentes en poder de las partes o de terceros, en los términos de los artículos 387 a 389. 5) Impulsar de oficio el trámite, cuando existan fondos inactivos de menores o incapaces, a fin de que los representantes legales de éstos o, en su caso, el Asesor de Menores, efectúen las propuestas que estimen más convenientes en interés del menor o incapaz, sin perjuicio de los deberes propios de dicho funcionario con igual objeto. 6) Corregir, en la oportunidad establecida en el artículo 166, inc. 1) y 2), errores materiales, aclarar conceptos oscuros, o suplir cualquier omisión de la sentencia acerca de las pretensiones discutidas en el litigio, siempre que la enmienda, aclaración o agregado no altere lo sustancial de la decisión."

467 "Art. 264" (Princípio dispositivo) 1. Às partes cabe alegar os factos que integram a causa de pedir e aqueles em que se baseiam as excepções. 2. O juiz só pode fundar a decisão nos factos alegados pelas partes, sem prejuízo do disposto nos arts. $514^{\circ}$ e $665^{\circ}$ e da consideração, mesmo oficiosa, dos factos instrumentais que resultem da instrução e discussão da causa. 3. Serão ainda considerados na decisão os factos essenciais à procedência das pretensões formuladas ou das excepções deduzidas que sejam complemento ou concretização de outros que as partes hajam oportunamente alegado e resultem da instrução e discussão da causa, desde que a parte interessada manifeste vontade de deles se aproveitar e à parte contrária tenha sido facultado o exercício do contraditório. Art. $265^{\circ}$ (Poder de direcção do processo e princípio do inquisitório) 1. Iniciada a instância, cumpre ao juiz, sem prejuízo do ónus de impulso especialmente imposto pela lei às partes, providenciar pelo andamento regular e célere do processo, promovendo oficiosamente as diligências necessárias ao normal prosseguimento da acção e recusando o que for impertinente ou meramente dilatório. 2. O juiz providenciará mesmo oficiosamente, pelo suprimento da falta de pressupostos processuais susceptíveis de sanação, determinando a realização dos actos necessários à regularização da instância ou, quando estiver em causa alguma modificação subjectiva da instância, convidando as partes a praticá-los. 3. Incumbe ao juiz realizar ou ordenar, mesmo oficiosamente, todas as diligências necessárias ao apuramento da verdade e à justa composição do litígio, quanto aos factos de que lhe é lícito conhecer."

${ }^{468}$ Na França, vigoram dois códigos processuais: o Ancien Code de Procédure Civile, de 1806, e o Nouveau Code de Procédure Civile, de 1976.

${ }^{469}$ BRAGA, Sidney da Silva, Iniciativa probatória do juiz no processo civil, cit., p. 74-75. 
Noveau Code de Procedure Civile ${ }^{470}$ assim como a legislação austríaca, datada de 1895 , em que é admitida amplamente a investigação oficial, revelando um caráter altamente publicista, ${ }^{471}$ a chilena, com referência ao art. 15 da Lei 18.101, que dispõe sobre a locação de prédios urbanos, ${ }^{472}$ a uruguaia, calcada no art. 24, 4, do Código General del Processo (aprovado pela Ley 15.982, de 18.10.1988), ${ }^{473}$ a peruana (art. 194 do Código Procesal Civil, de $1993^{474}$ ) e a venezuelana (art. 401 do Código de Procedimiento Civil, de 1985). ${ }^{475}$

470 “Art. 10 - Le juge a le pouvoir dórdonner d'office toutes les mesures d'instruction, légalement admissibles. Art. 143 - Les faits dont dépend la solution du litige peuvent, à la demande des parties ou d'office, être l'objet de toute mesure d'instruction légalement admissible. Art. 144 - Les mesures d'instruction peuvent être ordonnées en tout état de cause, dès lors que le juge ne dispose pas d'éléments suffisants pour statuer."

${ }^{471}$ PROTO PISANI, Anrea. Appunti sulla giustezia civile. Bari: Caccuci, 1982, p. 26, apud BEDAQUE, José Roberto dos Santos, Poderes instrutórios do juiz, cit., p. 85. Semelhante constatação é feita por Mauro Cappelletti, ao definir o sistema austríaco como "social", sendo o exercício dos poderes instrutórios meramente auxiliar à dispositividade das partes em relação as provas: "El principio dispositivo y de la demanda rige hasta en lo que tal vez aún hoy puede considerarse el más acentuadamente 'social' entre los procesos civiles de la Europa occidental: me refiero al proceso civil austríaco, regulado por la Zivilprozessordnung de 1895, que há sido el primer código de procedimiento civil declarada y abiertamente inspirado - como lo dijo muchas veces su insigne redactor, Franz Klein - em uma concepción 'social'. Este código há aumentado profundamente los poderes del juez respecto de la asunción y de la valoración de las pruebas; há abolido pácticamente las pruebas legales; há impuesto a las partes deberes de clarificación, de completud y de veridicidad (verdad) que están netamente em función de uma 'moralización' y socialización' de la conducta de las partes em el proceso; há atribuido al juez todos los poderes y deberes estimados necesarios para hacer así que la igualdad de las partes em el proceso se no solo formal y aparente sino efectiva; y valga por ende no menos para el pobre, para el ignorante, para el que está mal defendido, que para el rico o para el docto. (...) La intervención del juez tiene, em resumidas cuentas, em el proceso austríaco com em el suizo, em el alemán (occidental) como em el sueco y los de otros países, carácter meramente auxiliar; nunca carácter sustitutivo de las partes y de su voluntad em la determinación de los merita causae y em la determinación, por ende, del thema decidendum." (Proceso, ideologias, sociedad, cit., p. 17-19 - grifos nossos).

${ }^{472}$ PAILLAS, Enrique. El principio oficial y el principio dispositivo em el proceso civil moderno. Revista de Derecho Procesal, Santiago do Chile, Departamento de Derecho Procesal, Facultad de Derecho, Universidade de Chile, n. 17, p. 111, 1992, apud BEDAQUE, José Roberto dos Santos, Poderes instrutórios do juiz, cit., p. 81.

473 “Art. 24. Facultades del Tribunal - El Tribunal está facultado: 1) Para rechazar in límine la demanda cuando fuere manifiestamente improponible, cuando carezca de los requisitos formales exigidos por la ley o cuando se ejercite una pretensión especialmente sujeta a término de caducidad y este haya vencido; 2) Para relevar de oficio las excepciones que este Código le faculta. 3) Para dar al proceso el trámite que legalmente corresponda cuando el requerido aparezca equivocado; 4) Para ordenar las diligencias necesarias al esclarecimiento de la verdad de los hechos controvertidos, respetando el derecho de defensa de las partes; 5) Para disponer en cualquier momento la presencia de los testigos, de los peritos y de las partes, para requerirles las explicaciones que estime necesarias al objeto del pleito; 6) Para rechazar las pruebas inadmisibles, así como las manifiestamente inconducentes e impertinentes". Assim como no sistema brasileiro, há também previsão de situações específicas que avultam os poderes instrutórios no direito uruguaio, a exemplo do que se verifica nos arts. 177.2 (renovação da prova pericial), 186 (inspeção judicial de pessoas, lugares ou coisas) e 149.1 (determinação de interrogatório das partes), todos do Código General del Processo.

474 “Art. 194 - Pruebas de oficio - Cuando los medios probatorios ofrecidos por las partes sean insuficientes para formar convicción, el Juez, en decisión motivada e inimpugnable, puede ordenar la actuación de los medios probatorios adicionales que considere convenientes. Excepcionalmente, el Juez puede ordenar la comparecencia de un menor de edad con discernimiento a la audiencia de pruebas o a una especial."

475“Art. 401 - Concluido el lapso probatorio, el Juez podrá de oficio ordenar la práctica de las siguientes diligencias: $1^{\circ}$ - Hacer comparecer a cualquiera de los litigantes para interrogarlos libremente, sin juramento, sobre algún hecho que aparezca dudoso u obscuro. $2^{\circ}$ - Exigir la presentación de algún 
Não por outra razão que, diante dos sistemas latino-americanos preverem, em sua maioria, a iniciativa probatória de ofício pelo magistrado, se cristalizou, no art. $33,4^{\circ}$, do Anteproyecto de Código Procesal Civil Modelo para Iberoamerica, de 1988, o poder irrestrito do juiz de "ordenar las diligencias necesarias para esclarecer la verdad de los hechos controvertidos, respetando el derecho de defensa de las partes", ao passo que os art. $12, \S 3^{\circ}$, do Código Modelo de Processos Coletivos para a Ibero-América determina que "o juiz poderá determinar de ofício a produção de provas, observado o contraditório", ${ }^{476}$ ou seja, a preocupação maior do legislador quanto a essas culturas jurídicas foi preservar o princípio do contraditório na produção da prova, o que, assim o fazendo, não impede o exercício de ofício dos poderes instrutórios.

Por fim, nos países de regime socialista, os poderes instrutórios eram irrestritos, de sorte a importar a proteção da ordem socialista comum, e não o interesse dos litigantes. Vale dizer, o que releva os poderes instrutórios amplos do magistrado em países desse regime é a defesa do Estado, o que desvia por completo a finalidade da jurisdição de pacificar conflitos com justiça. ${ }^{477}$ Conforme leciona Bedaque, "amplíssimos são os poderes instrutórios do juiz na Hungria (Código de Procedimento Civil de 1911), Polônia (Código de Procedimento Civil de 1933, modificado em 1950, art. 236) e Checoslováquia (Código de Procedimento Civil de 1963, art. 120, $\S 1^{0} \%{ }^{478}$ Com a queda dos regimes socialistas em 1989, todavia, a iniciativa probatória do magistrado nesses países passou a sofrer restrições, o que, como alerta Luigi Paolo Comoglio, destina a reformas desses sistemas o

\footnotetext{
instrumento de cuya existencia haya algún dato en el proceso y que se juzgue necesario. $3^{\circ}$ - La comparecencia de algún testigo que habiendo sido promovido por alguna de las partes, sin embargo, no rindió oportunamente su declaración, o la de cualquier otro que sin haber sido promovido por las partes, aparezca mencionado en alguna prueba o en cualquier acto procesal de las partes. $4^{\circ}$ - Que se practique inspección judicial en algún lugar, y se forme un croquis sobre los puntos que se determinen; o bien se tenga a la vista un proceso que exista en algún archivo público y se haga certificación de algunas actas, siempre que en el pleito de que se trate haya alguna mención de tal proceso y tengan relación el uno con el otro. $5^{\circ}$ - Que se practique alguna experticia sobre los puntos que determine el Tribunal, o se amplíe o aclare la que existiere en autos. El auto en que se ordenen estas diligencias, fijará el término para cumplirlas y contra él no se oirá recurso de apelación. Cumplidas las diligencias, se oirán las observaciones de las partes en el acto de informes."

${ }^{476}$ A última versão do Código Modelo de Processos Coletivos para a Ibero-América foi elaborada e aprovada pelo Instituto Ibero-americano de Direito Processual em outubro de 2004, durante as XIX Jornadas Iberoamericanas de Direito Processual, em Caracas (Venezuela). Como o próprio nome diz, o código modelo se presta a servir não só como repositório de princípios, mas também como modelo concreto para inspirar reformas em países de cultura jurídica comum, a ser adaptado às peculiaridades locais, levadas em consideração na atividade legislativa de cada país, de sorte a revestir um modelo plenamente operativo. Recentemente, está em trâmite na Câmara dos Deputados o Projeto de Lei da Nova Lei da Ação Civil Pública (PL n. 5.139/2009). Disponível em: 〈http://www.camara.gov.br/sileg/integras/651669.pdf〉, que voltaremos a comentar no item seguinte.

${ }^{477}$ BRAGA, Sidney da Silva, Iniciativa probatória do juiz no processo civil, cit., p. 81-82.

${ }^{478}$ BEDAQUE, José Roberto dos Santos, Poderes instrutórios do juiz, cit., p. 85.
} 
mister de eliminar os excessos dos poderes instrutórios antes vigorantes e, ao mesmo tempo, preservar o que for aproveitável e útil para os ordenamentos. ${ }^{479}$

Portanto, diante de breve análise de diversos sistemas processuais, é indubitável a existência de poderes instrutórios nos mais variados graus, sendo a iniciativa probatória ampla dominante na maioria dos ordenamentos, mormente nos sistemas romanogermânicos do civil law, ${ }^{480}$ com a tendência de conferir poderes instrutórios irrestritos ao magistrado, uma vez preservado o princípio do contraditório. A seguir, serão apontados os principais diplomas no ordenamento brasileiro que conduziram à evolução da iniciativa probatória do juiz, até o advendo do Código de Processo Civil de 1973 e a legislação nacional em vigor.

\subsubsection{Histórico do sistema brasileiro e da legislação contemporânea}

Antes de atingir a atual concepção dos poderes instrutórios de forma ampla e traçada no Código de Processo Civil de 1939, a legislação brasileira percorreu um iter arraigado em diversas etapas. Após a proclamação da independência ${ }^{481}$ de Portugal, em 1822, por força do Decreto de 20 de outubro de 1823, o Brasil herdou as normas processuais contidas nas Ordenações Filipinas (precedidas pelas Ordenações Manuelinas, de 1521, e Afonsinas, 1456, cujas fontes principais foram o direito romano e o direito canônico), promulgadas em 1603 por D. Felipe II da Espanha e I de Portugal, e suas modificações posteriores. ${ }^{482}$

Em relação aos poderes instrutórios, Sidnei Amendoeira Jr. discorre que as Ordenações Manuelinas e Filipinas adotaram a mesma estrutura inserta nas Ordenações Afonsinas, em que a iniciativa probatória do juiz se aproximava mais de fiscalização do

${ }^{479}$ COMOGLIO, Luigi Paolo. Sttato di diritto e crisi dei modelli processuali nei sistemi di democracia socialista. Revista de Derecho Procesal, Padova, Cedam, 1992, p. 272-273, apud BEDAQUE, José Roberto dos Santos, Poderes instrutórios do juiz, cit., p. 86.

${ }^{480}$ São essas as conclusões de José dos Santos Martin Ostos, ao aduzir que o Brasil é apontado pela doutrina estrangeira, juntamente com o México, Itália, Alemanha, Áustria, Rússia e Argentina como um país em que a tendência moderna dos poderes instrutórios do juiz encontra-se consagrada (Las diligencias para mejor proveer em el proceso civil, cit., p. 94).

${ }^{481}$ Com a independência do Brasil, instaurou-se o Império (1822-1829), seguido da República, a partir de 15 de novembro de 1889. Antes do Império, o Brasil viveu o período colonial (1500-1822), sujeito, portanto, aos ordenamentos lusitanos.

482 CINTRA, Antonio Carlos de Araújo; GRINOVER, Ada Pellegrini; DINAMARCO, Cândido Rangel, Teoria geral do processo, cit., p. 111. 
que propriamente de participação na solução do conflito, ficando esse adstrito ao quanto provado nos autos pelas partes (Livro III, Título 66, PR. Das Ordenações Filipinas). ${ }^{483}$ Semelhante constatação é realizada por Bedaque, ao aduzir que:

\begin{abstract}
"A iniciativa oficial era meramente supletiva das partes, ou seja, dependia preponderantemente destas, podendo o magistrado apenas diligenciar no sentido de esclarecer alguns pontos obscuros." 484
\end{abstract}

Por sua vez, o Código de Processo Criminal de 1832, com a chamada "disposição provisória acerca da administração da justiça civil”, trouxe inovações no processo civil, mantendo, contudo, a vigência das Ordenações Filipinas. Após a sanção do Código Comercial de 1850 pelo governo imperial, teve esteio o primeiro código processual elaborado no Brasil, o chamado Regulamento 737, ${ }^{485}$ desse mesmo ano, sobrevindo, em 28 de dezembro de 1876, a consolidação, num único diploma, de todas as normas que regulavam o processo civil (Consolidação das Leis do Processo Civil). ${ }^{486}$ Nesse ínterim, o Regulamento 737 teve contornos altamente privados e rígidos no campo probatório (arrolando as chamadas provas plenas e absolutas - arts. 140 a 144), ${ }^{487}$ deixando à ${ }^{483}$ AMENDOEIRA JUNIOR, Sidnei, Poderes do juiz e tutela jurisdicional, cit., p. 44.
${ }^{484}$ BEDAQUE, José Roberto dos Santos, Poderes instrutórios do juiz, cit., p. 74.
${ }^{485}$ COSTA, Moacyr Lobo. Breve notícia histórica do direito processual civil brasileiro e de sua literatura.
São Paulo: Revista dos Tribunais, 1970. p. 29. Retrata o autor que "um dos maiores méritos do Regulamento n. 737 foi o de propiciar a floração de estudos e trabalhos doutrinários sobre o processo civil, com o que se iniciou a 'formação de uma consciência processual brasileira'. Embora o processo civil permanecesse sob a regência das velhas normas do Livro III das Ordenações, com as alterações introduzidas pela Disposição Provisória e legislação posterior, até o advento do Decreto n. 763, de 1890, que mandou observar no processo cível o Regulamento n. 737, o certo é que Paula Batista e Ramalho, os dois maiores processualistas da época, escreveram seus famosos livros de processo tendo presentes, sempre, os dispositivos do Regulamento, que a todo passo citavam como assento das proposições doutrinárias que o enunciavam" (Ibidem, p. 51).

${ }^{486}$ CINTRA, Antonio Carlos de Araújo; GRINOVER, Ada Pellegrini; DINAMARCO, Cândido Rangel, Teoria geral do processo, cit., p. 113. Como assevera Maria Elizabeth de Castro Lopes, a Consolidação das Leis do Processo Civil de 1876, conhecida também como Consolidação Ribas, também teve forte influência do princípio dispositivo (art. 334), restando ao juiz o papel de tentar a conciliação e dirigir o processo, sendo-lhe vedado interferir na produção das provas, prevalecendo, quanto a elas, a dispositividade das partes (O juiz e o princípio dispositivo. cit., p. 83-84).

${ }^{487}$ Vale lembrar que a denominação prova plena e absoluta empregada no Regulamento 737 não se confunde com a concepção de presunção relativa ou absoluta, porquanto ambas as espécies de prova citadas no regulamento admitem prova em contrário. É o que se verifica no art. 142 do Regulamento: “Art. 142. A prova plena absoluta ou relativa admitte prova em contrario." Em verdade, a distinção traçada no Regulamento diz respeito à extenção da presunção que emana de cada uma destas provas: "Art. 143 - A presumpção que a prova plena absoluta induz é extensiva aos terceiros, quanto á existencia do contrato, e dos factos e actos certificados no instrumento pelo Official publico, por se haverem passado na presença delle e das testemunhas. Art. 144 - A presumpção que a prova plena relativa induz é restricta ás partes contratantes e seus herdeiros, e comprehende não só a existencia do contrato, e dos actos e factos certificados no instrumento pelo Official publico, por se haverem passado na presença delle e das testemunhas, mas tambem os actos e factos referidos, narrados ou enunciados, si elles têm relação directa com o contrato." 
exclusiva disponibilidade das partes requererem as provas a serem produzidas (arts. 66, § $4^{\circ}, 102$ e $237, \S 3^{\circ}$ ), inexistindo, regra geral, previsão acerca da produção de provas de ofício.

As únicas exceções estão limitadas à vistoria (arts. $209^{488}$ e 214), ao arbitramento $(\operatorname{art.~191)~})^{489}$ e à hipótese de, antes da sentença, determinar a realização de diligências que julgasse necessária (art. 230). ${ }^{490}$ No que toca a essa última providência, embora se mostrasse uma iniciativa tímida, por condicionar o ativismo judicial no campo probatório somente após as alegações finais (porém inovadora, na medida que traçava novos contornos de iniciativa do juiz na produção de provas mediante a realização de diligências), é certo que o art. 230 do Regulamento 737 serviu de lenitivo para um novo pensar acerca da produção de provas ex officio. O que restava, portanto, era uma mudança na quebra de paradigma de um juiz passivo diante da disponibilidade da prova pelas partes, porquanto o próprio ordenamento já conferia ao magistrado a iniciativa probatória, ainda que ao final do processo.

Por sua vez, o Decreto n. 763, de 11 de setembro de 1890, determinou que, salvo algumas exceções, fosse aplicado o Regulamento 737 ao processo civil, ${ }^{491}$ situação que permaneceu até a promulgação da primeira Constituição republicana do Brasil em 24 de fevereiro de 1891, ocasião em que se instaurou a dualidade de competências para legislar sobre processo civil, cabendo à União editar normas processuais de competência da Justiça Federal $^{492}$ e a cada Estado editar seu próprio código relativo aos processos de competência

488 “Art. 209 - A vistoria tem logar ou sendo requerida pelas partes, como no arbitramento (art. 190), ou ex officio, ou nos casos prescriptos no Codigo. Art. 214 - O Juiz, além das testemunhas do acto, chamará ou ex officio ou a requerimento da parte as testemunhas do facto, ou informadoras."

489 “Art. 191 - Proceder-se-ha ao arbitramento na dilação probatoria, sendo anteriormente requerido pelas partes, ou nos casos em que o Codigo o exige: terá porém logar afinal quando for decretado pelo Juiz ou ex officio, ou a requerimento das parte."

490 "Art. 230 - Si examinados os autos o Juiz entender necessaria para julgar afinal alguma diligencia, ainda que lhe não tenha sido requerida nas allegações finaes, a poderá ordenar, marcando para isso o prazo conveniente."

491 “Art. $1^{\circ}$ - São applicaveis ao processo, julgamento e execução das causas civeis em geral as disposições do Regulamento n. 737 de 25 de novembro de 1850 , excepto as que se conteem no titulo $1^{\circ}$, no capitulo $1^{\circ}$ do titulo $2^{\circ}$, nos capitulos $4^{\circ}$ e $5^{\circ}$ do titulo $4^{\circ}$, nos capitulos $2^{\circ}, 3^{\circ}$ e $4^{\circ}$ e secções $1^{\mathrm{a}}$ e $2^{\mathrm{a}}$ do capitulo $5^{\circ}$ do titulo $7^{\circ}$, e no titulo $8^{\circ}$ da primeira parte. Paragrapho unico - Continuam em vigor as disposições legaes que regulam os processos especiaes, não comprehendidos no referido regulamento."

492 A Justiça Federal restou instituída e organizada através do Decreto n. 848, de 11.11.1890, adotando-se o mesmo modelo do Regulamento n. 737 para as regras do processo relativas às causas de competência daquela Justiça. 
da Justiça Estadual. ${ }^{493}$ Assim, teve início a edição dos códigos estaduais que, em sua maioria, pautaram-se em semelhante redação do Regulamento 737, senão idêntica, conforme assevera Moacyr Lobo da Costa:

"Nos Códigos estaduais foi mantida, em suas linhas mestras, a contextura
do velho Regulamento, que lhes serviu não só de modêlo, como de fonte
de seus dispositivos (...) o Regulamento foi a espinha dorsal de todos os
organismos processuais dos Estados, eixo de cristalização para a pouca
matéria nova que eles trouxeram, sendo, por isso mesmo, parecidos uns
com os outros como gotas d'água da mesma fonte. Na elaboração desses
Códigos, os legisladores estaduais acharam mais fácil copiar do que
inovar." 994

É o que se verifica, no que interessa a este trabalho, nos arts. 182 do Código de Processo Civil do Distrito Federal (Dec. n. 16.752, de 31.12.1924) ${ }^{495}$ e semelhante redação em outros códigos de processo estaduais (art. 245 - Pernambuco; art. 262 - São Paulo; art. 1.226 - Rio de Janeiro; art. 686 - Santa Catarina; art. 126 - Bahia), todos voltados a conferir exclusivamente às partes a disponibilidade da prova. No que toca à produção de provas por parte do magistrado, algumas ressalvas merecem ser feitas, tais como os arts. 238 do Código de Processo Civil do Distrito Federal e 310 do Código de Processo Civil e Comercial Paulista (Lei n. 2.421, de 14.01.1930), os quais permitiam a produção de prova pericial de ofício pelo juiz. Em relação ao art. 310, Antônio Luiz da Câmara Leal complementa que esse dispositivo tratava de prova pericial ex officio, não se tratando de produção de prova judicial subsidiária. ${ }^{496}$ De concluir-se, portanto, que nesses diplomas as iniciativas probatórias do juiz estavam limitadas a provas específicas, notadamente a prova pericial.

Diferente foi a redação do Código de Processo Civil do Estado da Bahia (Lei n. 1.121, de 21.08.1915), cujo art. 127 estabelecia que "o juiz pode ordenar ex officio as diligências que julgar necessárias para apurar a verdade dos factos allegados, depois de realizadas as que forem requeridas pelas partes". Sem dúvida referido dispositivo tem semelhante redação ao art. 230 do Regulamento 737 retrocomentado, com a inovação de

\footnotetext{
493 CINTRA, Antonio Carlos de Araújo; GRINOVER, Ada Pellegrini; DINAMARCO, Cândido Rangel, Teoria geral do processo, cit., p. 114.

${ }^{494}$ COSTA, Moacyr Lobo, Breve notícia histórica do direito processual civil brasileiro e de sua literatura, cit., p. 63.

495 “Compete, em regra, a cada uma das partes fornecer os elementos de prova das allegações que fizer."

496 LEAL, Antônio Luiz da Câmara. Código de Processo Civil e Commercial do Estado de São Paulo: arts. 262 a 449. São Paulo: Saraiva, 1930. v. 2, p. 172-174.
} 
que o dispositivo baiano prescindia o exaurimento das alegações finais para que o juiz atuasse de ofício, o que levou Eduardo Espinola a tecer fortes elogios ao Projeto do Código baiano, considerado um avanço alinhado aos ordenamentos mais modernos, à época, no que toca aos poderes instrutórios do juiz. ${ }^{497}$

A fase dos códigos estaduais restou superada com a promulgação da Constituição Federal de 1934, que extinguiu a dualidade de competência legislativa ligada a matéria processual, concentrando-se na União a competência para editar normas sobre processo, o que desaguou na edição do Código de Processo Civil de 1939 (Dec.-Lei n. 1.608, de 18.09.1939), a partir do projeto apresentado por Pedro Batista Martins, revisado por Francisco Campos, Guilherme Estelitta e Abgar Renault. ${ }^{498}$ O Código de 1939, inspirado em paradigmas calcados nos Códigos da Áustria, da Alemanha e de Portugal, trouxe inédita inovação legislativa no que toca aos poderes instrutórios, mediante a novel redação do art. 117, ao determinar que: "A requerimento, ou ex officio, o juiz poderá, em despacho motivado, ordenar as diligências necessárias à instrução do processo e indeferir as inúteis em relação a seu objeto, ou requeridas com propósitos manifestamente protelatórios.”

Portanto, o Código de Processo Civil de 1939 eliminou qualquer barreira que nos diplomas anteriores limitavam o exercício dos poderes instrutórios somente a determinadas provas ou condicionavam a iniciativa do magistrado só após a produção dos elementos de formação do campo probatório requeridos pelas partes. Pelo contrário, esse diploma de abrangência nacional deu amplo e irrestrito poder ao magistrado para determinar a realização de toda e qualquer prova que julgasse necessária para a instrução da causa, o que restou corroborado pelo próprio ministro Francisco Campos, ao redigir a Exposição de Motivos do Código de 1939:

\footnotetext{
497 "Este artigo, como outros do Projecto, procura pôr o processo no foro bahiano na mesma altura a que chegaram os códigos mais perfeitos da Europa. É de notar que a doutrina, naquelles proprios paises que não conseguiram uma reforma processual que banisse de todo o gasto e anacrônico principio da inércia do juiz, não cessa de louvar os códigos que se inspiram no princípio oposto. (...) O art. 183 do Código de Processo austríaco é a mais solemne consagração do novo principio, egualmente admittido em toda a sua amplitude pelo Codigo de Processo civil húngaro, art. 288. É verdade que o Codigo de Processo civil allemão só em poucos casos admitiu a iniciativa do juiz quanto á produção das provas; mas a doutrina, criticando a parcimonia da lei, não cessa de reclamar uma reforma radical. Assim é que o grande jurisconsulto Köhler, em artigo, a que já me referi, não cessa de apregoar a superioridade da lei austríaca e especialmente da húngara que elle considera 'a mais significativa creação de processualística civil dos tempos modernos'." (ESPINOLA, Eduardo. Código do Processo do Estado da Bahia: Constituição da Bahia: Lei de Reorganização Judiciária e Código Do Processo Civil e Commercial (processo ordinário). Salvador: Typ. Bahiana, 1916. v. 1, p. 499 e 501).

${ }^{498}$ CINTRA, Antonio Carlos de Araújo; GRINOVER, Ada Pellegrini; DINAMARCO, Cândido Rangel, Teoria geral do processo, cit., p. 115.
} 
"Quer na direção do processo, quer na formação do material submetido a julgamento, a regra que prevalece, embora temperada e compensada como manda a prudência, é a de que o juiz ordenará quanto for necessário ao conhecimento da verdade. Prevaleceu-se o Código, nesse ponto, dos benefícios que trouxe ao moderno direito processual a chamada concepção publicística do processo. Foi o mérito dessa doutrina, a propósito da qual deve ser lembrado o nome de Giuseppe Chiovenda, o ter destacado com nitidez a finalidade do processo, que é a atuação da vontade da lei num caso determinado."

Vê-se, portanto, que a intenção do legislador foi de realmente permitir maior participação do magistrado na formação do campo probatório, o que viabilizou a materialização de um processo civil mais justo, porquanto voltado à realização da vontade concreta da lei, e não ao exclusivo interesse das partes e entrega da tutela jurisdicional mediante a manipulação por elas da formação do campo probatório. ${ }^{499}$

O Código de Processo Civil de 1973 (Lei n. 5.869/73), embora editado por necessidade de novas adaptações a aspectos práticos decorrentes de sua aplicação que atendessem aos novos anseios da sociedade, preservou redação semelhante à do Código de 1939, no que toca aos podereis instrutórios, conforme se verifica no art. 130 do Código de Processo em vigor: "Caberá ao juiz, de ofício ou a requerimento da parte, determinar as provas necessárias à instrução do processo, indeferindo as diligências inúteis ou meramente protelatórias". Logo, restou mantida a ideologia que evoliu por séculos, destinada a imprimir postura mais ativa ao magistrado na formação do campo probatório. Conforme já comentado, o art. 130 já outorga poder instrutório amplo ao magistrado, sendo as situações previstas nos arts. 342 (depoimento pessoal), 355 (exibição de documentos ou coisas pelas partes), 399 (requisição de documentos às repartições públicas), 437 (determinação de nova perícia) e 440 (inspeção judicial), dentre outras, hipóteses meramente exemplificativas.

\footnotetext{
499 É o que se depreende na continuação da Exposição de Motivos retrocitada: “O juiz é o Estado administrando a justiça; não é um registro passivo e mecânico dos fatos, em relação aos quais não o anima nenhum interesse de natureza vital. Não lhe pode ser indiferente o interesse da justiça. Este é o interesse da comunidade, do povo, do Estado, e é no juiz que um tal interesse se representa e personifica."
} 
Por sua vez, a Lei n. 9.099/95 dispôs de forma mais acentuada e esclarecida as iniciativas probatórias do juiz. É o que se verifica na redação dos arts. $5^{\circ}$ e 33 e $35,{ }^{500}$ que conferem ao magistrado de forma expressa, no âmbito dos Juizados Especiais, ${ }^{501}$ o poder de dirigir o processo "com liberdade para determinar as provas a serem produzidas". Segundo Dinamarco, o procedimento probatório nos juizados é deformalizado, porquanto é autorizada a produção, em audiência, mesmo de provas que não hajam sido previamente requeridas. $^{502}$

Por fim, no âmbito das iniciativas legislativas, não pode passar despercebido o Projeto de Lei n. 5.139/2009, em trâmite na Câmara dos Deputados, que se presta a dar novos contornos ao que o legislador intitula de "nova Lei da Ação Civil Pública". ${ }^{503}$ A ideia desse projeto é centralizar num único diploma mecanismos de tutela dos chamados direitos difusos, coletivos e individuais homogêneos, revogando, portanto, os dispositivos de tutela desses direitos espalhados pela legislação específica. ${ }^{504} \mathrm{Sem}$ prejuízo das

\footnotetext{
500 “Art. $5^{\circ}$ - O Juiz dirigirá o processo com liberdade para determinar as provas a serem produzidas, para apreciá-las e para dar especial valor às regras de experiência comum ou técnica. Art. 35. Quando a prova do fato exigir, o Juiz poderá inquirir técnicos de sua confiança, permitida às partes a apresentação de parecer técnico. Parágrafo único - No curso da audiência, poderá o Juiz, de ofício ou a requerimento das partes, realizar inspeção em pessoas ou coisas, ou determinar que o faça pessoa de sua confiança, que lhe relatará informalmente o verificado. Art. 33 - Todas as provas serão produzidas na audiência de instrução e julgamento, ainda que não requeridas previamente, podendo o Juiz limitar ou excluir as que considerar excessivas, impertinentes ou protelatórias."

${ }^{501}$ A Lei n. 10.259, de 16.07.2001, dispõe sobre os Juizados Especiais no âmbito da Justiça Federal, de sorte que os juizados federais e seus processos são subsidiariamente regidos e, na medida do que for compatível com a lei especial, pela Lei n. 9.099/95.

${ }^{502}$ Dinamarco Instituições de direito processual civil, cit., v. 3, p. 805. É cediço que a ideia embrionária de criação dos juizados especiais, além de maximizar a garantia do acesso à justiça ao público de baixa renda, também está pautada na rápida resolução de litígios de menor complexidade, de sorte a permitir regras menos rígidas através de um procedimento menos formal, calcado na simplicidade dos atos, na tentativa mais enérgica de conciliação através da presença de conciliadores e diálogos com os litigantes, de sorte a proporcionar um procedimento muito mais célere e acessível a um número maior de cidadãos. Ou seja, o que se buscou foi a implantação de um procedimento com ênfase mais acentuada nos princípios da oralidade, simplicidade, informalidade, economia processual e celeridade, sem prejuízo da busca incessante da conciliação ou transação.

${ }^{503}$ Disponível em: <http://www.camara.gov.br/sileg/integras/651669.pdf>. Os trabalhos de redação do projeto encerraram-se no final de março de 2009; seguiu-se o envio do texto para a Casa Civil quee, após alterações, remetido ao Congresso Nacional em 27 de março, recebendo o número 5.139/2009, sob a relatoria do deputado federal Antonio Carlos Biscaia; atualmente aguarda manifestação da Comissão de Constituição e Justiça e de Cidadania. Os comentários iniciais acerca das principais inovações desse projeto podem ser encontrados em: GOMES JUNIOR, Luiz Manoel; FAVRETO, Rogério. Anotações sobre o projeto da nova lei da ação civil pública: principais inovações. Revista de Processo, São Paulo, Revista dos Tribunais, ano 34, n. 176, p. 174-194, out. 2009.

${ }^{504} \mathrm{O}$ projeto de lei em tela pretende revogar, dentre outros dispositivos, a Lei n. 7.347/85 (Lei da Ação Civil Pública), os arts. $3^{\circ}$ a $7^{\circ}$ da Lei n. 7.853/89 (Lei da Pessoa Portadora de Deficiência), o art. $3^{\circ}$ da Lei $n$. 7.913/89 (Lei dos Investidores do Mercado de Valores Mobiliários), os arts. 209 a 213 e 215 a 224 da Lei n. 8.069/90 (Estatuto da Criança e do Adolescente), os arts. 81 a 84, 87, 90 a 95, 97 a 100, 103 e 104 da Lei n. 8.078/90 (Código de Defesa do Consumidor) e o art. 88 da Lei n. 8.884/94 (Lei de Prevenção e Repressão às Infrações contra a Ordem Econômica - Antitruste).
} 
inovações tratadas nesse projeto, no que toca ao objetivo desta dissertação, os incs. IV a VIII do art. 20 dispõem sobre procedimento semelhante ao da carga dinâmica da prova tratada no item 3.2.3.

Por sua vez, o caput do art. 20 e incs. III e VIII são claros ao preverem que após exaurida a tentativa de conciliação, o juiz "determinará as provas a serem produzidas" e ainda "poderá determinar de ofício a produção de provas, observado o contraditório". 505 Vale dizer, a seguir a evolução que reclama um ativismo judicial, é cada vez mais assente a perspectiva de um processo arraigado de contornos publicistas, de sorte que os poderes instrutórios reputam uma realidade cuja tendência é manter-se no âmbito das futuras legislações.

É por meio da observância das garantias constitucionais e princípios previstos no sistema que se atinge o balizamento ideal dos poderes instrutórios do juiz. Ou seja, é a conduta do magistrado alinhada aos princípios que norteiam a sua participação em dado caso concreto, de modo a tornar o sistema harmônico e assim evitar arbitrariedades. Passemos agora à análise mais aprofundada do confronto das iniciativas probatórias do magistrado com os princípios processuais e constitucionais.

\footnotetext{
505 “Art. 20 - Não obtida a conciliação ou quando, por qualquer motivo, não for utilizado outro meio de solução do conflito, o juiz, fundamentadamente: (...) III - fixará os pontos controvertidos, decidirá as questões processuais pendentes e determinará as provas a serem produzidas; (...) VIII - poderá determinar de ofício a produção de provas, observado o contraditório."
} 


\section{CONFRONTO DAS INICIATIVAS PROBATÓRIAS DO JUIZ COM OS PRINCÍPIOS PROCESSUAIS CONSTITUCIONAIS E INFRACONSTITUCIONAIS}

Os princípios são diretrizes valorativas ou deveres de otimização. ${ }^{506}$ Como define Umberto Ávila, "princípios são normas imediatamente finalísticas, primariamente prospectivas e com pretensão de complementaridade e de parcialidade, para cuja aplicação se demanda uma avaliação da correlação entre o estado de coisas a ser promovido e os efeitos decorrentes da conduta havida como necessária à sua promoção". 507 Ou seja, os princípios se prestam à finalidade de fixar preceitos fundamentais que dão forma e caráter aos sistemas processuais, a fixar um aspecto de ordenação, coerência e logicidade. Situamse, portanto e conforme o conteúdo do princípio, entre a epistemologia (ciência do direito positivo, à qual pertence a dogmática jurídica, que estuda o direito como ordem normativa) e a deontologia (estudo dos valores éticos), entre a norma e o valor ético, no limiar de ambos. $^{508}$

Para Celso Antonio Bandeira de Mello:

“(...) princípio é, por definição, mandamento nuclear de um sistema, verdadeiro alicerce dele, disposição fundamental que irradia sobre diferentes normas compondo-lhes o espírito e servindo de critérios para sua exata compreensão e inteligência, exatamente por definir a lógica e a racionalidade do sistema normativo, no que lhe confere a tônica e lhe dá sentido harmônico (...).,509

\footnotetext{
506 Para Robert Alexy, os princípios são "normas de otimização", posto que seu caráter de abstração e generalidade intrínsecos permitem aplicação indistinta. De igual sorte, as normas são o gênero e os princípios e regras espécies (Teoria de los derechos fundamentales. Traducción de Ernesto Garzón Valdés. Madrid: Centro de Estúdios Políticos y Constitucionales, 2001. p. 86).

507 ÁVILA, Humberto. Teoria dos princípios: da definição à aplicação dos princípios jurídicos. 3. ed. São Paulo: Malheiros, 2004. p. 71. De igual sorte, Humberto Ávila diferencia os princípios de regras, ao definilas como "normas imediatamente descritivas, primariamente restrospectivas e com pretensão de decidibilidade e abrangência, para cuja aplicação se exige a avaliação da correspondência, sempre centrada na finalidade que lhes dá suporte ou nos princípios que lhes são axiologicamente sobrejacentes, entre a construção conceitual da descrição normativa e a construção conceitual dos fatos” (Ibidem, p. 72). Para Luciana Amicucci Campanelli, princípios diferem das regras, na medida que os primeiros são abstratos e genéricos, de sorte que na colisão de princípios, eles se harmonizam e convivem por intermédio de concessões recíprocas, ao passo que as regras contêm comando direto e objetivo, além de sua incompatibilidade resultar na invalidade de uma delas. (Poderes instrutórios do juiz e a isonomia processual, cit., p. 18).

${ }^{508}$ CINTRA, Antonio Carlos de Araújo; GRINOVER, Ada Pellegrini; DINAMARCO, Cândido Rangel, Teoria geral do processo, cit., p. 56.

509 BANDEIRA DE MELLO, Celso Antonio. Elementos de direito administrativo. 5. tiragem. São Paulo: Revista dos Tribunais, 1986. p. 230.
} 
Embora não seja escopo deste estudo analisar com mais profundidade aspectos ligados à melhor definição dos princípios e diferenças entre eles e as regras, ${ }^{510}$ não pode passar despercebida a importância do papel dos princípios no sistema que se verifica através de síntese comparativa traçada por José Joaquim Gomes Canotilho ${ }^{511}$ : (i) natureza: as regras devem ser explícitas e expressas, ao passo em que os princípios, por constituírem a ratio das regras, o seu fundamento, podem existir de forma implícita no sistema jurídico; (ii) essencialidade para o direito: as regras se encontram abaixo dos princípios na "chamada pirâmide normativa", conquanto os princípios ocupam espaço mais relevante; (iii) proximidade da ideia do direito: as regras, por vezes, tipificam uma situação especial, com conteúdo meramente formal, ao passo que os princípios são aplicáveis em situações indeterminadas; (iv) abstração: as regras possuem abstração reduzida e os princípios elevado grau de abstração; e (v) determinabilidade de aplicação ao caso concreto: as regras são aplicáveis diretamente ao caso concreto e os princípios, por conta de sua abstração, demandam atividade interpretativa. ${ }^{512}$

Os princípios exercem papel de relevante importância no ordenamento, ${ }^{513}$ reconhecidos inclusive como princípios gerais e fontes do direito. ${ }^{514}$ Daí porque o juiz não apenas subsume as peculiaridades do caso concreto para aplicar a norma, mas também deve interpretar o conteúdo e aplicabilidade dela "à luz de um conceito do princípio que, igualmente, será por ele plasmado no momento da tomada da decisão". ${ }^{515}$ Grinover, Cintra e Dinamarco discorrem haver distinção na doutrina entre os princípios gerais do direito processual e as normas ideais, que representam uma aspiração de melhoria no aparelho

\footnotetext{
${ }^{510}$ Sobre o tema, ver: DWORKIN, Ronald. Taking rights seriously. Cambridge: Harvard University Press, 2001 e ALEXY, Robert, Teoría de los derechos fundamentales, cit. Adotaremos a síntese das conclusões de Alexy, para quem as normas jurídicas são o gênero, do qual os princípios e regras são espécies.

511 CANOTILHO, José Joaquim Gomes. Direito constitucional e teoria da constituição. 2. ed. Coimbra: Almedina, 1998. p. 1.034.

512 Sobre essa colocação e em relação à característica "proximidade da ideia de direito" ousamos apontar algumas ressalvas ligadas aos conceitos jurídicos indeterminados que, embora previstos na norma, a vagueza e subsunção do conceito é conferida ao juiz em situações abstratas.

513 Daí porque Paulo Bonavides cita como uma das características da importância vital dos princípios no ordenamento as suas funções e presença no texto das Constituições contemporâneas como pontos axiológicos fundamentais na hermenêutica dos tribunais e fixação de preceitos de ordem constitucional (Curso de direito constitucional, cit., p. 260).

${ }^{514}$ Art. $4^{\circ}$ do Decreto-Lei n. 4.657/42: "Quando a lei for omissa, o juiz decidirá o caso de acordo com a analogia, os costumes e os princípios gerais de direito. Art. 126 do Código de Processo Civil: “O juiz não se exime de sentenciar ou despachar alegando lacuna ou obscuridade da lei. No julgamento da lide caberlhe-á aplicar as normas legais; não as havendo, recorrerá à analogia, aos costumes e aos princípios gerais de direito."

${ }^{515}$ PUOLI, José Carlos Baptista, Os poderes do juiz e as reformas do processo civil, cit., p. 63.
} 
processual, calcadas nos chamados "princípios informativos ${ }^{516}$ do processo" a saber: a) o princípio lógico ${ }^{517}$ (seleção dos meios mais eficazes e rápidos de procurar e descobrir a verdade e de evitar o erro); b) o princípio jurídico (igualdade no processo e justiça na decisão); c) o princípio político (o máximo de garantia social, com o mínimo de sacrifício individual da liberdade e d) o princípio econômico (processo acessível a todos, com vista ao seu custo e à sua duração. ${ }^{518}$

A premissa metodológica mais adequada a este trabalho é a separação proposta por Cassio Scarpinella Bueno ${ }^{519}$ em princípios constitucionais do processo civil e princípios infraconstitucionais do processo civil. Procuraremos neste capítulo extrair do significado de alguns princípios constitucionais e infraconstitucionais os conteúdos que influenciam a atividade do juiz, quando no exercício dos poderes instrutórios, de modo a evidenciar o

\footnotetext{
${ }^{516}$ Paulo Bonavides acrescenta aos princípios informativos os princípios “abertos", tais como a dignidade da pessoa humana, a liberdade, a igualdade, o Estado de Direito, o Estado social, a democracia e a separação de poderes (Curso de direito constitucional, cit., p. 242). Para Antonio Jorge Pereira Junior, "a dignidade humana pode ser descrita como valor ético-jurídico fundamental, fonte de notas características irredutíveis e perduráveis da pessoa humana, apreendidas ao longo da história, cujo reconhecimento e proteção são necessários para a vida em sociedade" (Limites constitucionais à liberdade de expressão e os deveres da televisão em face do telespectador infanto-juvenil. In: MARTINS, Ives Gandra; RESEK, Francisco (Coords.). Constituição Federal: avanços, contribuições e modificações no processo democrático brasileiro. São Paulo: Revista dos Tribunais, 2008. p. 799).

${ }^{517}$ No que toca ao presente trabalho, o princípio lógico se presta a orientar o juiz na busca da verdade mediante meios técnicos e eficazes necessários à entrega da devida tutela jurisdicional. Afinal, o valor justiça não coaduna com a omissão ou falsidade, porquanto impõe a existência da verdade para sua correta aplicação.
}

${ }^{518}$ CINTRA, Antonio Carlos de Araújo; GRINOVER, Ada Pellegrini; DINAMARCO, Cândido Rangel, Teoria geral do processo, cit., p. 57. Semelhante concepção pode ser encontrada em: CHIOVENDA, Giuseppe. Principios de derecho procesal civil. Traducción de José Casais y Santaló. Madrid: Reus, 1922. v. 1.

519 BUENO, Cassio Scarpinella, Curso sistematizado de direito processual civil, cit., v. 1, p. 471-475. A escolha de tal classificação apenas se prende a aspectos práticos voltados ao desenvolvimento deste trabalho, de sorte a relacionar os poderes do juiz à luz de princípios previstos na Constituição Federal e àqueles específicos à seara do processo civil. Aclibes Burgarelli, por sua vez, define princípios gerais e amplos, ditados em um ordenamento jurídico amplo (v.g., a Constituição Federal), princípios inerentes ao plano infraconstitucional, que se dividem em princípios gerais, menos amplos, mas comuns em diversas matérias - v.g., princípios gerais do processo - e princípios específicos e que guardam peculiaridade a dada disciplina - v.g., princípios do direito processual civil, princípios do direito do trabalho, etc. (Tratado das provas cíveis, cit., p. 14). Paulo Bonavides perfilha entendimento peculiar, ao sustentar que os princípios se sobrepõem às normas, elevando-se a status constitucional e localizados no ápice da pirâmide normativa, classificando-os como "norma das normas", "fonte das fontes" (Curso de direito constitucional, cit., p. 261-265). Por fim, Grinover, Cintra e Dinamarco, ainda acrescem breve menção à doutrina de Gomes Canotilho, que classifica os princípios em a) estruturantes, consistentes nas ideias diretivas básicas do processo, de índole constitucional (juiz natural, imparcialidade, igualdade, contraditório, publicidade, processo em tempo razoável, etc.); b) fundamentais, que seriam aqueles mesmos princípios, quando aplicados ou citados pelos estatutos processuais em suas peculiaridades; e, c) instrumentais, que se prestam como garantia destinada ao atingimento dos princípios fundamentais, como o são o princípio da demanda, o do impulso oficial, o da persuasão racional do juiz, o da oralidade, etc. (Teoria geral do processo, cit., p. 57). 
correto uso dos poderes que lhe são dados, com vistas a atuar harmonicamente com o sistema e os princípios que o regem.

\subsection{Princípios constitucionais do processo civil e influência da constitucionalização no processo}

A Constituição Federal de 1988 consagrou princípios cuja aplicação está plasmada no processo civil. Tais princípios fornecem diretrizes mínimas, porém fundamentais, ao comportamento do próprio Estado-juiz, de sorte a balizar o "modelo constitucional do processo civil". ${ }^{520}$ Vale dizer, a partir da Constituição Federal é que se originam os nortes para um "modo de ser" do processo, e portanto necessária, na dinâmica do processo, a observância das garantias processuais asseguradas pela Carta Magna. Por essa razão, Dinamarco assevera:

"A Constituição age sobre o processo, garantindo-lhe os princípios básicos, para que o processo possa, depois, atuar convenientemente os preceitos e garantias que ela própria contém e que projeta sobre todo o ordenamento jurídico. A bipolaridade dessas influências associa-se, naturalmente, ao reconhecimento do poder que os juízes exercem, como guardas da Constituição e responsáveis pela sua interpretação fiel e cumprimento estrito." 521

Nos dizeres de Cassio Scarpinella Bueno: "É correto, portanto, tratar os princípios constitucionais do processo civil como significativos de um modelo mínimo, mas indispensável, mas vinculante, mas impositivo, para a atuação do Estado-juiz". ${ }^{522}$ Portanto,

\footnotetext{
${ }^{520}$ BUENO, Cassio Scarpinella, Curso sistematizado de direito processual civil, cit., v. 1, p. 92. Em verdade, o modelo constitucional do processo civil contempla não só os princípios constitucionais processuais, mas todo o desenho estruturado na Constituição Federal relativo ao direito processual, daí compreendendo, portanto, o direito processual constitucional (remédios constitucionais previstos na Constituição), os dispositivos relativos à organização da Justiça (v.g., organização do Poder Judiciário) e aqueles voltados a disciplinar as funções essenciais à justiça, a exemplo da magistratura, do Ministério Público, da advocacia e da Defensoria Pública. Por sua vez, Dinamarco sintetiza o modelo constitucional do processo civil não só como um modelo garantístico (tutela constitucional do processo e jurisdição constitucional das liberdades), mas também ao qual se assomam outros elementos essenciais, "no qual ao Poder Judiciário compete todo o controle jurisdicional - inclusive em relação a todas as causas envolvendo a Administração Pública e à constitucionalidade das leis - podendo o controle de constitucionalidade ser difuso ou coletivo, dispondo o Supremo Tribunal Federal de competência para rejulgar as causas em grau de recurso extraordinário sem se limitar à mera cassação e sendo públicos os julgamentos feitos pela própria Corte Suprema e por todos os órgãos jurisdicionais em todas as Justiças existentes no Brasil” (Instituições de direito processual civil, cit., v. 1, p. 185-188).

${ }^{521}$ DINAMARCO, Cândido Rangel, A instrumentalidade do processo, cit., p. 46.

${ }^{522}$ BUENO, Cassio Scarpinella, Curso sistematizado de direito processual civil, cit., v. 1, p. 93.
} 
os princípios constitucionais do processo civil veiculam direitos fundamentais que devem ser observados na dinâmica processual, de sorte a imprimir um "modo de ser" do processo atento às diretrizes que devem ser observadas pelo Estado, notadamente quando exerce a função de jurisdição.

Vale citar como garantias processuais previstas na Constituição Federal o direito de ação (art. 5, XXXV), a facilitação do acesso à justiça, através da legitimação do Ministério Público e corpos intermediários (sindicatos, associações, partidos políticos) voltados à tutela de interesses difusos e coletivos (arts. $5^{\circ}$, XXI e LXX, $8^{\circ}$, III, 129, III e $\S$ $1^{\circ}$ e 232), a previsão constitucional dos juizados de pequenas causas (art. 98, I) a organização da carreira jurídica dos defensores públicos (art. $5^{\circ}$, LXXIV c.c. o art. 134, § $2^{\circ}$, com redação dada pela EC n. 45/2004), o devido processo legal (art. $5^{\circ}$ LIV) que, por sua vez, é corolário de inúmeras garantias como o contraditório e a ampla defesa (art. $5^{\circ}$, LV), a publicidade e o dever de motivar as decisões judiciárias (arts. 5 , LX e 93, IX), a inadmissibilidade das provas obtidas em meio ilícito (art. $5^{\circ}, \mathrm{LVI}$ ) e a garantia à duração razoável do processo e meios que garantam a celeridade de sua tramitação (art. $5^{\circ}$, LXXVIII), dentre outras, insertas também na seara infraconstitucional do direito processual civil.

Dinamarco assevera que a tutela constitucional do processo (em síntese, a observância de garantias processuais constitucionais), com vistas a materializar a realização de um processo justo e équo, e a jurisdição constitucional das liberdades (resumida ao exercício dos chamados remédios constitucionais - mandado de segurança individual ou coletivo, mandado de injunção, habeas corpus, habeas data, ação popular, ação civil pública, ação direta de inconstitucionalidade $)^{523}$ conduzem à conclusão de que

\footnotetext{
523 Acresça-se, ainda, que a reclamação constitucional tem sido admitida como integrante da jurisdição constitucional, conforme se depreende de recente decisão liminar da lavra do Ministro Gilmar Ferreira Mendes, em 29.01.2009, nos autos da Rcl n. 6.200-MC/RN: “(...) a tendência hodierna é de que a reclamação assuma cada vez mais o papel de ação constitucional voltada à proteção da ordem constitucional como um todo. Os vários óbices à aceitação da reclamação em sede de controle concentrado de constitucionalidade, inclusive, já foram superados, estando o Supremo Tribunal Federal em condições de ampliar o uso desse importante e singular instrumento da jurisdição constitucional brasileira. A ordem constitucional necessita de proteção por mecanismos processuais céleres e eficazes. Esse é o mandamento constitucional, que fica bastante claro quando se observa o elenco de ações constitucionais voltadas a esse mister, como o habeas corpus, o mandado de segurança, a ação popular, o habeas data, o mandado de injunção, a ação civil pública, a ação direta de inconstitucionalidade, a ação declaratória de constitucionalidade e a ação de descumprimento de preceito fundamental. A reclamação constitucional sua própria evolução o demonstra - não mais se destina apenas a assegurar a competência e a autoridade de
} 
"o modelo constitucional do processo civil brasileiro é acentuadamente garantístico, no duplo sentido de que toda a vida do processo civil deve necessariamente ser permeada da mais estrita fidelidade aos princípios ditados na Constituição Federal". 524

Por essa razão que ganha relevo a influência da constitucionalização no processo, de sorte que ele, como instrumento de realização do direito material, deve necessariamente pautar-se nos princípios, valores e diretrizes que derivam da Constituição Federal. Trataremos, pois, de fazer breve análise das garantias processuais previstas na Constituição, a iniciar pelo princípio do devido processo legal, princípio síntese de todas as garantias, conforme será demonstrado a seguir.

\subsubsection{Princípio do devido processo legal}

O devido processo legal, ${ }^{525}$ em verdade, é uma série de garantias previstas na Constituição Federal de 1988 e que podem ser extraídas da cláusula pétrea prevista no art.

decisões específicas e bem delimitadas do Supremo Tribunal Federal, mas também constitui-se como ação voltada à proteção da ordem constitucional como um todo."

${ }^{524}$ DINAMARCO, Cândido Rangel, Instituições de direito processual civil, cit., v. 1, p. 186. Dinamarco ainda discorre sobre a evolução das preocupações de processualistas em agregar ligação entre o direito processual civil e o plano constitucional: "Já no século XIX, João Mendes Júnior propunha o exame do processo em correlação com a preservação dos direitos individuais. Nos anos cinquenta do século XX, José Frederico Marques conceituou a 'condensação metodológica dos princípios introdutórios do processo em geral' como uma série de manifestações de interesse pelos fundamentos constitucionais do processo, afirmando a existência de um direito processual constitucional. Nos anos setenta em diante, sobrevieram inúmeras obras preocupadas em desenvolver e aprofundar o tema processual-constitucional, de sorte a colocar em evidência temas ligados à garantia da ação, inafastabilidade da tutela jurisdicional, à cláusula due process of law e à questão ética das provas obtidas por meio ilícito. Essas reflexões desaguaram em novas preocupações, dessa feita ligadas às propostas da escola instrumentalista e às ondas renovatórias, o que repercutiu no estudo de temas relativos ao atendimento aos portadores de pretensões de baixo valor econômico, à tutela coletiva, ao meio ambiente, aos consumidores ou comunidades integradas em grupos associativos, tudo isso, alinhado a fazer a efetividade da tutela jurisdicional atingir os escopos sociais do processo, a proporcionar o acesso à justiça como um valor a ser a todo custo postulado pela ordem processual e, finalmente pela implantação de um sistema de processo justo e équo. Boa parte destas inovações restaram inseridas no texto constitucional de 1988, de sorte que não há como o processualista moderno pensar o processo civil sem estar apegado aos preceitos e garantias sedimentadas na Constituição Federal." (Ibidem, p. 288-289).

525 Como reporta Nelson Nery Junior, foi a Magna Charta, de João Sem Terra (1215), o primeiro ordenamento a fazer menção ao que inicialmente foi chamado de law of the land e posteriormente se aproximaria ao due process of law, cuja terminologia foi expressamente utilizada na lei inglesa de 1354, baixada no reinado de Eduardo III, conhecida como Statute of Westminster of the Liberties of London. A despeito de inicialmente essa carta se destinar apenas a proteger os direitos da nobreza em face dos abusos da Coroa inglesa, foi a primeira aparição de institutos eficazes que serviram de garantias que se fortaleceram ao longo da evolução do direito constitucional. Em síntese, o devido processo legal pode ter diversos sentidos: a) o devido processo legal em sentido genérico, consistente no trinômio vida-liberdade propriedade; b) o devido processo legal em sentido material (substantive due process), atuando no que respeita ao direito material e, de outro lado, a tutela desses direitos por meio do processo judicial ou 
5', LIV: "Ninguém será privado da liberdade ou de seus bens sem o devido processo legal". A partir dessa cláusula, deriva uma série de garantias processuais asseguradas aos litigantes. É o gênero do qual todos os demais princípios constitucionais do processo são espécie. $^{526}$

Grinover, Cintra e Dinamarco sustentam que o conteúdo da cláusula do devido processo legal, por sua vez, se desdobra em váriasas garantias: (i) a dúplice garantia do juiz natural, assim compreendida a proibição de juízos ou tribunais de exceção e a dimensão do juiz competente (art. 5 XXXVII e LIII); e (ii) uma série de garantias estendidas ao processo civil e compreendidas no ordenamento constitucional, daí contemplando o contraditório e ampla defesa (art. $5^{\circ}, \mathrm{LV}$, da $\mathrm{CF}$ ), a isonomia processual, transmudando-se a partir daí o princípio dinâmico da par conditio ou igualdade de armas (art. $5^{\circ}$, I, da CF), a publicidade e o dever de motivar as decisões judiciárias (arts. $5^{\circ}, \mathrm{LV}$ e 93, IX da CF), a inadmissibilidade de provas obtidas por meios ilícitos (art. $5^{\circ}$, LVI da CF), dentre outras. Ao final, concluem que a garantia do acesso à justiça, materializada no plano constitucional mediante o exercício do direito de ação e do direito de defesa (direito à prestação jurisdicional e à adequada resistência à prestação jurisdicional, respectivamente), tem como conteúdo o direito ao processo, com observância às garantias do devido processo legal. Logo, “o procedimento há de realizar-se em contraditório, cercando-se de todas as garantias necessárias para que as partes possam sustentar suas razões, produzir provas, influir sobre a formação do convencimento do juiz. E mais: para que esse procedimento, garantido pelo devido processo legal, legitime o exercício da função jurisdicional", 527

O acesso à justiça (exercício do direito de ação e do direito de defesa) e ao devido processo legal são as vertentes principiológicas para que flua o direito à ordem jurídica justa, lembrando que o rol supracitado é meramente elucidativo, de sorte a comportar

\footnotetext{
administrativo, de sorte a se observar o princípio da proporcionalidade; e, por fim, c) o devido processo legal em sentido processual, daí contemplando várias garantias, dentre elas: "a) direito à citação e ao conhecimento do teor da acusação; b) direito a um rápido e público julgamento; c) direito ao arrolamento de testemunhas e à sua notificação para comparecimento aos tribunais; d) direito ao procedimento contraditório; e) direito de não ser processado, julgado ou condenado por alegada infração às leis ex post facto; f) direito à plena igualdade entre acusação e defesa; g) direito contra medidas ilegais de busca e apreensão; h) direito de não ser acusado nem condenado com base em provas ilegalmente obtidas; i) direito à assistência judiciária, inclusive gratuita; $\mathrm{j}$ ) privilégio contra a autoincriminação (Princípios do processo civil na Constituição Federal, cit., p. 78-79).

${ }_{526}^{526}$ NERY JUNIOR, Nelson, Princípios do processo civil na Constituição Federal, cit., p. 77.

${ }^{527}$ CINTRA, Antonio Carlos de Araújo; GRINOVER, Ada Pellegrini; DINAMARCO, Cândido Rangel, Teoria geral do processo, cit., p. 88-90.
} 
inúmeros desdobramentos. ${ }^{528}$ No que toca ao direito à prova, integra a garantia do devido processo legal, como corolário do contraditório e da ampla defesa. ${ }^{529}$

Nesse liame, oportuna a observação de Nelson Nery Junior de que "bastaria a Constituição Federal de 1988 ter anunciado o princípio do devido processo legal, e o caput e os inc.s do art. 5\%, em sua grande maioria, seriam absolutamente despiciendos". ${ }^{530} \mathrm{~A}$ partir da menção expressa à clausula do devido processo legal, derivaria uma série de garantias destinadas a permitir o acesso à ordem justiça mediante um processo que observe preceitos voltados a coroar a ordem jurídica justa. Todavia, o rol de garantias insertas no art. $5^{\circ}$ da Carta Magna, ainda que não seja exaustivo quanto aos desdobramentos do devido processo legal, por si só já se presta a consignar expressamente o mínimo das garantias que devem ser observadas, inclusive consagradas como cláusulas pétreas (art. 60, § $4^{\circ}$, IV, da $\mathrm{CF}$ ).

De igual modo, para que se propicie o efetivo acesso à ordem jurídica justa, necessário que a função exercida pelo Estado-juiz seja desempenhada sob as margens de um modelo garantístico previsto na Constituição Federal. Esse modelo, como é cediço,

\footnotetext{
${ }^{528}$ Outro exemplo é o princípio do duplo grau de jurisdição, cuja discussão na doutrina pontua se o direito ao reexame de decisões judiciais se trata de mero princípio ligado à ciência processual ou diz respeito à garantia constitucional. Sobre o tema, ver: MARCATO, Ana Cândida Menezes. Princípio do duplo grau de jurisdição e a reforma do código de processo civil. São Paulo: Atlas, 2007; LIMA, Carolina Alves de Souza. O princípio constitucional do duplo grau de jurisdição. São Paulo: Manole, 2004; e LASPRO, Oreste Nestor de Souza. Duplo grau de jurisdição no direito processual civil. São Paulo: Revista dos Tribunais, 2005. Dinamarco acresce como garantia constitucional, ainda que explícita, mas dada sua relevância institucional e sociopolítica, o acesso à justiça, na medida que constitui a síntese e razão de ser de todas as garantias - inclusive a do devido processo legal -, porquanto nela reside a promessa constitucional de que os serviços jurisdicionais devem ser realizados com vistas postas no resultado final do processo (Instituições de direito processual civil, cit., v. 1, p. 186-187). Portanto, assegurar acesso à justiça é assegurar justiça.

529 CINTRA, Antonio Carlos de Araújo; GRINOVER, Ada Pellegrini; DINAMARCO, Cândido Rangel, Teoria geral do processo, cit., p. 91. Daí porque sustentam que, a partir dos princípios constitucionais do acesso à justiça e do devido processo legal, defluem outros postulados necessários a assegurar o direito à ordem jurídica justa, assim preservando a fórmula norte-americana dos direitos implícitos, ao advertir no $\S$ $2^{\circ}$ do art. $5^{\circ}$ da Constituição Federal que "os direitos e garantias expressos nesta Constituição não excluem outros decorrentes do regime e dos princípios por ela adotados, ou dos tratados internacionais em que a República Federativa do Brasil seja parte”. Portanto, pode-se concluir que a chamada ordem jurídica justa contém contornos flutuantes que se adaptam aos anseios dinâmicos de dada sociedade. No que toca aos tratados internacionais, vale lembrar o teor da Emenda Constitucional n. 45/2004, que conferiu nova redação ao art. $5^{\circ}$ do Texto Magno, para acrescer o $\S 3^{\circ}$, que elevou ao status de emenda constitucional "os tratados e convenções internacionais sobre direitos humanos que forem aprovados, em cada Casa do Congresso Nacional, em dois turnos, por três quintos dos votos dos respectivos membros".

530 NERY JUNIOR, Nelson, Princípios do processo civil na Constituição Federal, cit., p. 85. Em igual sentido, Cassio Scarpinella Bueno, que ainda complementa que o rol enumerado na Constituição não deixa de ter seu valor como forma de enfatizar garantias norteadoras da Administração Pública, do Poder Legislativo e do Poder Judiciário. (Curso sistematizado de direito processual civil, cit., v. 1, p. 93).
} 
propõe uma série de garantias de índole democráticas, o que se extrai da própria síntese da consagração do princípio do devido processo legal como cláusula pétrea. Daí porque não faz sentido dizer que o aumento dos poderes do juiz, notadamente os poderes instrutórios, venha causar temor, a ponto de beirar o autoritarismo, ou que possa dar vazão ao exercício de condutas arbitrárias e teratológicas. Isso porque o próprio sistema, na Constituição Federal, consagra uma série de princípios que devem ser observados e obedecidos rigidamente pelo magistrado, e esses postulados nortes darão o mínimo de segurança para que se materialize um processo civil de índole democrática e regulado sob o manto de proteção de garantias fundamentais que se projetam no plano processual. Portanto, eventuais exageros ou arbitrariedades cometidas pelo juiz sujeitam-se ao controle jurisdicional, cuja ofensa, por si só, viola as garantias processuais constitucionais.

Serão examinados a seguir os princípios constitucionais (decorrentes ou não do devido processo legal) que melhor exprimem os poderes do juiz, notadamente a utilização dos poderes instrutórios, de sorte a se encontrar um balizamento que caminhe em consonância com esses princípios.

\subsubsection{Princípio do contraditório (princípio da cooperação) e ampla defesa}

O princípio do contraditório e da ampla defesa restou delineado de forma ampla na Constituição Federal de 1988 (art. 5, LV), de sorte a garantir que "aos litigantes, em processo judicial ou administrativo, e aos acusados em geral são assegurados o contraditório e a ampla defesa, com os meios e recursos a ela inerentes”. Diz-se forma ampla, pois o texto constitucional anterior (art. 153, $\S 6^{\circ}$, da CF de 1969) restringia a previsão expressa da garantia do contraditório apenas para o processo penal, a despeito da doutrina defender ${ }^{531}$ que o dispositivo também se estendia ao processo civil e ao administrativo. Em verdade, o contraditório e a ampla defesa denotam dois significados que, embora conexos, revelam certa distinção.

\footnotetext{
${ }^{531}$ Nesse sentido, ver: GRINOVER, Ada Pellegrini. O princípio da ampla defesa no processo civil, penal e administrativo. In: O processo em sua unidade II. Rio de Janeiro: Forense, 1984. p. 60 e ss e e OLIVEIRA, Régis Fernandes de. Infrações e sanções administrativas. São Paulo: Revista dos Tribunais, 1985. p. 66.
} 
A ampla defesa reside na garantia constitucional de exercício abrangente, extenso e ostensivo do direito de defesa. Não significa o exercício da ampla defesa apenas interno no processo, mas reputa a garantia de que o Estado viabilize meios concretos para a realização desse princípio, tais como a previsão do sistema de assistência jurídica integral gratuita (art. 5, LXXIV, da CF) e a instituição de defensorias públicas (art. 134 da CF). Nesse contexto, Cassio Scarpinella Bueno complementa que, na ampla defesa, "não basta se defender mas também faz-se necessário criar condições de se exercer adequadamente esta defesa" ${ }^{532}$ Portanto, a ampla defesa está ligada à garantia de acesso à justiça não só ao autor, mas também ao réu, de sorte que deficiências econômicas não sejam um óbice para a obtenção da tutela jurisdicional por aquele que se defende em juízo.

Por outro lado, o contraditório integra o binômio "ciência e resistência" ou "informação e reação", de sorte que o primeiro elemento desse binômio seja indispensável, ao passo em que o segundo eventual ou possível. ${ }^{533}$ Significa dizer que, entre os litigantes, para todo ato jurisdicional em sua acepção ampla, há de ser preservada a devida ciência, bem como assegurados meios de se exercer reação. Portanto, o juiz, colocando-se entre as partes, ouvindo uma, não pode deixar de ouvir a outra, para assim lhes assegurar igual possibilidade de exporem suas razões, de apresentar provas e paritariamente lhes dar oportunidade para influírem em seu livre convencimento, de sorte a, mediante a soma da parcialidade das partes (uma representando a tese, a outra a antítese), o juiz venha corporificar a síntese, em um processo dialético. ${ }^{534}$ Tem-se, portanto, além da observância da "ciência ou informação" e "resistência ou reação", a possibilidade de exercer "participação", das partes cooperarem para o julgamento, ${ }^{535}$ de contribuírem para a formação do livre convencimento. ${ }^{536}$

\footnotetext{
${ }^{532}$ BUENO, Cassio Scarpinella, Curso sistematizado de direito processual civil, cit., v. 1, p. 114.

${ }^{533}$ Ibidem, p. 107.

534 CINTRA, Antonio Carlos de Araújo; GRINOVER, Ada Pellegrini; DINAMARCO, Cândido Rangel, Teoria geral do processo, cit., p. 61. Exemplificando o raciocínio, tem-se os atos de citação (ato de ciência a alguém da instauração de um processo, chamando-o a participar da relação processual - art. 213 do CPC) e de intimação (ato de ciência a alguém dos atos do processo - art. 234 do CPC).

535 Para Dinamarco, a participação contempla "participar pedindo, participar alegando e participar provando" (Instituições de direito processual civil, cit., v. 1, p. 221).

536 A "ciência ou informação" está relativizada em dadas situações processuais, em que, para evitar o perecimento do direito pela demora (periculum in mora), o juiz provê medidas sem o consentimento da parte contrária (inaudita altera parte), a exemplo das medidas cautelares (arts. 813 do CPC) e liminares nas ações possessórias (v.g., arts. 929, 932 e 937 do CPC). Nessas situações em que a própria natureza jurídica do direito material reclama provimento jurisdicional de urgência, é assegurado o contraditório, embora $a$ posteriori. Igual situação de urgência se verifica no instituto da antecipação de tutela (art. 273 do CPC), ao passo que, conforme sustenta Nelson Nery Junior, "em certas ocasiões a ciência dos atos processuais à parte adversa e mesmo a demora na efetivação da medida solicitada poderiam resultar em ineficácia da atividade jurisdicional" (Princípios do processo civil na Constituição Federal, cit., p. 237).
} 
Logo, a garantia constitucional estatuída no art. $5^{\circ}, \mathrm{LV}$, da Constituição Federal reproduz não só a possibilidade de assegurar aos litigantes a "ciência, reação e participação" (contraditório), mas também a existência de mecanismos destinados a assegurar ao litigante o exercício de defesa amplo e de qualidade. Nesse sentido é a síntese das conclusões de Luigi Paolo Comoglio, Corrado Ferri e Michele Taruffo, ${ }^{537}$ ao discorrerem sobre o que denominam conteúdo mínimo do contraditório: a) direito a adequada informação dos atos processuais; b) possibilidade de defesa técnica, mediante assistência de defensor profissionalmente qualificado; c) adequação qualitativa das possibilidades de alegação e produção de provas capaz de influenciar a formação do convencimento do juiz; d) igualdade das partes, não apenas em sentido formal, mas também substancial; e) direito a motivação das decisões, etc.

As iniciativas probatórias do magistrado em nada colidem com o significado deste princípio, desde que observadas as quatro características retrocitadas. Em verdade, conforme leciona Dinamarco, a garantia constitucional do contraditório também está endereçada ao juiz, como imperativo de sua função no processo, e não mera faculdade, constituindo, portanto, dever e poder ligado a atos de direção, de prova e de diálogo. Relativamente à iniciativa probatória por parte do juiz:

“(..) embora possam as partes ter a disponibilidade das situações de
direito material pela qual litigam, não pode o Estado-juiz permanecer
inteiramente à disposição do que elas fizerem ou omitirem no processo,
sem condições de cumprir adequadamente sua função. O processo não é
um negócio, ou mesmo um jogo entre os litigantes, mas uma instituição
estatal. (...) O juiz mudo tem também algo de Pilatos e, por temor ou
vaidade, afasta-se do compromisso de fazer justiça."

Ou seja, a iniciativa do magistrado quanto à determinação de produção de dada prova, ainda que não requerida pelas partes, não guarda ligação alguma com suposta violação ao princípio do contraditório e da ampla defesa. Basta, contudo, que a produção da prova ocorra com ampla participação dos litigantes, além de lhes serem assegurada a possibilidade de informação quanto ao resultado da prova, garantindo a cada uma das partes a oportunidade de ouvir o que a outra tem a dizer quanto ao seu resultado.

\footnotetext{
${ }^{537}$ COMOGLIO, Luigi Paolo; FERRI, Conrado; TARUFFO, Michele, Lezioni sul proceso civile, cit., p. 72 73.

${ }^{538}$ DINAMARCO, Cândido Rangel, Instituições de direito processual civil, cit., v. 1, p. 227 e 230.
} 
Afinal, a prova, como já dito, é o instrumento destinado à formação do campo probatório que influenciará o convencimento motivado do juízo. Sem a sua produção, não haverá julgamento revestido de fundamentação necessária para alicerçar uma decisão justa. E exatamente para que a decisão não esteja eivada de arbitrariedade é que se impõe a ampla participação dos litigantes na produção da prova, até mesmo para que cada uma das partes possa em tempo expor suas razões acerca da valoração da prova produzida de ofício pelo magistrado. Esse pensar deflui de outro princípio que deriva do contraditório, que é o “princípio da cooperação”, sobre o qual leciona Cassio Scarpinella Bueno:

“(...) o princípio da 'cooperação' pode ser entendido como o princípio do contraditório, inserido no ambiente dos direitos fundamentais, que hipertrofia a tradicional concepção dos princípios jurídicos como meras garantias dos particulares contra eventuais abusos do Estado na sua atuação concreta. E por isto mesmo é que ele convida a uma renovada reflexão do princípio do contraditório." 539

O juiz atento à cooperação das partes traduz abrangência dupla ao princípio do contraditório: a instituição de meios para a participação dos litigantes no processo (direitos das partes) e o seu dever em franquear-lhes os meios para exercerem o mister de participar da preparação e desenvolvimento na formação do campo probatório para, ao final, julgar o feito. ${ }^{540}$ Portanto, em que pese cada um dos litigantes tentar revelar ao juiz a versão dos fatos que melhor lhe convenha, o princípio da cooperação se impõe como quebra dessa ideia privatista, porquanto sendo o processo instrumento público, a todos interessa a obtenção de um resultado que seja justo e reflita a proximidade da norma de direito material.

Através da cooperação entre os litigantes (pouco importando quem trouxe determinada prova aos autos, mas sim a ideia de que tal prova pertence ao processo princípio da comunhão da prova - e será necessária para um bom julgamento), aproximase da obtenção de uma decisão justa, cuja participação e controle é extensiva às partes:

\footnotetext{
${ }^{539}$ BUENO, Cassio Scarpinella, Curso sistematizado de direito processual civil, cit., v. 1, p. 109. Ao final, Cassio Scarpinella Bueno conclui: “O princípio da cooperação, assim, deve ser entendido como diálogo, no sentido de troca de informações, de municiar o magistrado com todas as informações possíveis e necessárias para melhor decidir.” (Ibidem, p. 110).

${ }^{540}$ Ibidem, p. 109.
} 


\begin{abstract}
"A presença ativa e participante das partes servirá como forma de controle dos amplos poderes do juiz na tradução jurídica do fato social, limitando o arbítrio, favorecendo o processo dialógico, que é a garantia de objetividade da maior abertura na decisão. A parte passa a ter efetiva possibilidade de atuar sobre o desenvolvimento e sobre o êxito da controvérsia, tendo importância não só o resultado a ser obtido mas a forma como o mesmo o será, no que podemos vislumbrar até mesmo uma função legitimadora do princípio da cooperação intersubetiva no processo civil moderno, inclusive no brasileiro., ${ }^{, 41}$
\end{abstract}

Aliás, o princípio da cooperação não se limita à garantia das partes de ampla participação na produção da prova, mas revela um dever delas contribuirem e municiarem o magistrado para o descobrimento da verdade. É o que, no âmbito infraconstitucional, reza o art. 339 do Código de Processo Civil, ao impor que "ninguém se exime do dever de colaborar com o Poder Judiciário para o descobrimento da verdade." Semelhante ideia de busca da verdade se depreende no campo probatório, na medida que o art. 332 do Código de Processo Civil reza que "todos os meios legais, bem como os moralmente legítimos, ainda que não especificados neste Código, são hábeis para provar a verdade dos fatos, em que se funda a ação ou a defesa”. Por fim, o dever de expor a verdade dos fatos pelos litigantes (art. 14, I), caso desrespeitado, de sorte a se materializar sua alteração indevida, constitui litigância de má-fé (arts. 17, II, e 18), o que deixa nítido que o intuito do legislador certamente foi o de preservar a busca do valor justiça nos autos e condenar veementemente a parte que não contribui ou tenta dificultar o encontro da verdade.

Dessa feita, no processo, os reflexos do princípio constitucional do contraditório e da ampla defesa repercutem (i) na garantia fundamental de oportunidade de "informação, participação e reação" às partes, bem como (ii) no direito/dever assegurado aos litigantes em cooperar (contraditório) com toda a dinâmica na formação do campo probatório e, (iii) ao juiz, o poder-dever de direção e de diálogo entre as partes. Portanto, a fiel observância do princípio do contraditório e ampla defesa, aliada ao dever de cooperação das partes, contribui para municiar o juízo de elementos que se aproximem de um juízo de certeza, revestidos de subsídios que fortalecem e facilitam a entrega de uma tutela jurisdicional mais justa e adequada. Serão analisadas a seguir outras garantias constitucionais amplamente entrelaçadas com o princípio tratado neste item.

${ }^{541}$ GOUVEIA, Lúcio Grassi. A função legitimadora do princípio da cooperação intersubjetiva no processo civil brasileiro. Revista de Processo, São Paulo, Revista dos Tribunais, ano 34, n. 172, p. 52, jun. 2009. 


\subsubsection{Princípio da isonomia}

O princípio da isonomia, decorrente de vasta evolução e conquista histórica, constitui um dos pilares fundamentais do Estado Democrático de Direito. ${ }^{542}$ Previsto no art. $5^{\circ}$, caput, da Constituição Federal, traduz-se em diretriz voltada ao tratamento paritário e indiscriminado de qualquer natureza. Semelhante ideia, para citar alguns exemplos, também está calcada na igualdade entre os desiguais prevista nos incs. LXXIV e LXXVI dos art. $5^{\circ}$ e $6^{\circ}$, assim como a vedação da instituição de tratamento desigual entre os contribuintes que se encontrem em situações equivalentes, proibindo a distinção em razão da ocupação profissional ou função, independentemente da denominação jurídica dos rendimentos, títulos ou direitos (art. 150, II). No âmbito processual, essa igualdade se estende às partes e procuradores, o que denota a regra do art. 125, I, do Código de Processo Civil como um dever do juiz em assegurar a eles igualdade de tratamento.

\footnotetext{
${ }^{542}$ MIRANDA, Jorge. Manual de direito constitucional. Coimbra: Coimbra Editora, 1996. v. 4, p. 205. Em síntese, o panorama histórico de afirmação do princípio da isonomia está ligado à desenvoltura e consagração dos direitos fundamentais, cujos marcos na história remontam aos ideais proclamados pela Revolução Francesa e pela Declaração dos Direitos do Homem e do Cidadão (1789), merecendo igual importância a Declaração de Independência dos Estados Unidos (1776). Conforme leciona José Afonso da Silva, os princípios constantes na Declaração dos Direitos do Homem e do Cidadão influenciaram as Constituições brasileiras anteriores à de 1988, sendo a Constituição de 1824 a primeira a prever os direitos do homem, dando-lhes efetiva concreção jurídica, incluindo, a partir daí, o próprio direito à igualdade (art. 179, VII). Seguiu-se a Constituição Federal de 1891, ao afirmar categoricamente em seu art. 72, § 21, serem todos iguais perante a lei, ao passo em que a Carta constitucional de 1934, além de dispor no art. 113, I, semelhante isonomia, recriminou a existência de privilégios e distinções por motivo de nascimento, sexo, raça, profissões próprias ou dos pais, classe social, riqueza, crenças religiosas ou ideias políticas. Por sua vez, a Constituição de 1937, embora tendo estabelecido no art. 122, incs. I e II, serem todos iguais perante a lei, gozando os brasileiros do direito de livre circulação em todo o território nacional, não deixou de ceder ao autoritarismo de Getúlio Vargas, cujo governo ditatorial tornou letra morta muitos dispositivos dessa Carta (Curso de direito constitucional positivo. 18. ed. São Paulo: Malheiros, 2000. p. 174). E conclui José Afonso da Silva: “(...) não se realizou; não foi respeitada; quase toda nem sequer existiu, prevalecendo, apenas, a ossatura ditatorial” (Ibidem, p. 281). A igualdade voltou a ser concretamente respeitada na Carta de 1946 (art. 141, § 1º), reforçando-se tal ideia na Constituição de 1967 (Capítulo IV, art. $150, \S 1^{\circ}$ ), com o acréscimo da igualdade perante a lei aplicar-se "sem distinção, de sexo, raça, trabalho, credo religioso e convicções políticas". O Ato Institucional n. 5/68, embora não vetasse expressamente a previsão legal da igualdade, suspendeu a garantia de habeas corpus em casos de crimes políticos contra a segurança nacional, a ordem econômica e social e a economia popular (art. 10), além de, na prática, também tolher a garantia da isonomia. Por fim, a Carta Magna de 1988 consagrou no caput do art. $5^{\circ}$ o princípio isonômico de forma ampla, o que, nos dizeres de Ives Gandra da Silva Martins e Celso Ribeiro Bastos, ao não especificar quais os critérios vedados, deixou certo não repousar a discriminação tão somente no critério escolhido, mas na ausência de correlação lógica entre ele e a finalidade pretendida (Comentários à Constituição do Brasil. 2. ed. São Paulo: Saraiva, 2001. v. 2, p. 14).
} 
Significa dizer não só tratar igualmente os iguais, mas também desigualmente os desiguais, do que deflui a concepção da isonomia substancial. ${ }^{543}$ Necessária, portanto, a nivelação de tratamento aos substancialmente iguais, ou seja, àqueles em igual paridade de situações concretas. Essa percepção é visível no processo civil, para se atingir a paridade de $\operatorname{armas}^{544}$ entre os litigantes, sempre que alguma causa ou circunstância exterior ao processo ponha uma delas em condições de superioridade ou inferioridade em face da outra. ${ }^{545}$ É o que se verifica em muitos dispositivos do Código de Processo Civil que, em verdade, se aplicam mais aos interesses públicos sob a premissa de que supostas dificuldades extraordinárias para a defesa em juízo justificariam a implantação de verdadeiros privilégios no processo civil. ${ }^{546}$ Afora premissas de diferenciação em prol dos interesses da Fazenda Pública, outro exemplo de igualdade substancial se verifica na prioridade de tramitação de todos os atos e diligências em que figure como parte pessoa com idade igual ou superior a sessenta e cinco anos (art. 1.211-A do CPC). ${ }^{547}$

Barbosa Moreira afirma que uma medida eficaz para se evitar o desequilíbrio substancial entre os litigantes e apurar a verdade dos fatos é o reforço do poder instrutório

\footnotetext{
${ }^{543}$ Conforme define Luciana Amicucci Campanelli, a igualdade substancial reputa a incidência da isonomia com a observância de dadas circunstâncias que reclamam tratamento diferenciado. (Poderes instrutórios do juiz e a isonomia processual, cit., p. 44). Essas circunstâncias constituem um discrímem que deve guardar consonância lógica e fática com o motivo que a ocasionou, o que evita que o intérprete ou aplicador da norma crie diferenciações arbitrárias. A regra de julgamento denominada inversão do ônus da prova, prevista no art. $6^{\circ}$, VIII, do Código de Defesa do Consumidor (Lei n. 8.078/90), também reflete situação em que, para que se possa atingir isonomia real entre o consumidor e o fornecedor, necessária a adoção de mecanismos como a inversão do ônus da prova, porquanto, em tese, o consumidor é a parte mais frágil na relação de consumo (art. $4^{\circ}$, I, do CDC). Sobre o tema, ver os itens 3.2.1 e seguintes.

${ }^{544}$ Como leciona Nelson Nery Junior, a igualdade de armas não significa paridade absoluta, mas sim na medida que as partes estiverem diante da mesma realidade em igualdade de situações processuais (Princípios do processo civil na Constituição Federal, cit., p. 239-240).

${ }^{545}$ CINTRA, Antonio Carlos de Araújo; GRINOVER, Ada Pellegrini; DINAMARCO, Cândido Rangel, Teoria geral do processo, cit., p. 60.

${ }^{546}$ Essa é a crítica sustentada por Grinover, Cintra e Dinamarco: "O interesse público e supostas dificuldades extraordinárias para a defesa em juízo são as razões ordinariamente invocadas para a implantação de verdadeiros privilégios no processo civil, como a) os prazos em quádruplo e em dobro, em benefício da Fazenda e do Ministério Público (CPC, art. 188); b) a necessária remessa do processo ao tribunal competente para a apelação, mesmo que nenhuma das partes haja recorrido, em caso de sentenças proferidas contra a Fazenda Pública (cfr. art. $475, \S \S 2^{\circ}$ e $3^{\circ}$, que timidamente atenuaram esse indesejável privilégio fazendário); c) o tratamento generoso dedicado a esta quando sai vencida no processo e paga honorários do vencedor em percentual inferior ao que pagaria uma parte comum (art. 20, $\S 4^{\circ}$ ). Outras prerrogativas, que se justificam pela idoneidade financeira e pelo interesse público, são a procrastinação do pagamento das despesas processuais (dispensa de preparo) e a concessão da medida cautelar independentemente de justificação prévia e de caução (CPC, arts. 27, 511 e 816, I)." (Teoria geral do processo, cit., p. 60).

${ }^{547}$ Em verdade, o beneplácito deve ser estendido a pessoas com idade igual ou superior a sessenta anos, a rigor do que dispõe a lei especial (art. 71 do Estatuto do Idoso - Lei n. 10.741/2003).
} 
oficial, que deflui do poder-dever dado ao julgador em diversos dispositivos do Código de Processo Civil. ${ }^{548}$ Afrânio Silva Jardim perfilha semelhante entendimento, ao aduzir que:

“(...) muitas vezes, a parte deixa de exercitar uma faculdade processual ou desincumbir-se de um ônus mais em razão de sua debilidade econômica ou cultural do que em razão de aceitação de uma situação que lhe é adversa, ou seja, não quer ela dispor de seu direito, nem reconhecer o da parte contrária, deixando de agir por circunstâncias outras." $" 549$

Mais uma vez, as iniciativas probatórias do juiz surgem como ponto de questionamento diante dos princípios constitucionais do processo civil, de modo a convidar ao debate acerca da iniciativa probatória compatibilizar-se ou não com o princípio da isonomia. Em que pesem as vozes da doutrina voltadas a justificar a iniciativa probatória como forma de nivelação entre os litigantes (isonomia substancial), ousamos discordar em parte desse posicionamento.

Em verdade, a iniciativa probatória se justifica como necessidade do magistrado de buscar elementos necessários à formação de seu livre convencimento. Pouco importa a relação jurídica de direito material que rege o objeto litigioso, mas a preocupação maior deve voltar-se à consecução de elementos suficientes para o juiz decidir a demanda com segurança, cabendo-lhe a sapiência e gestão dos recursos destinados à formação do campo probatório. Se a parte deixa de requerer determinada prova, por carecer-lhe capacidade técnica suficiente para reconhecer que aquele meio de prova eventualmente o beneficiaria, não soa razoável que o juiz, por essa exclusiva razão, se obrigue a determinar a produção daquela prova. O que impera, conforme será melhor analisado no item 4.2.3, é a formação do livre convencimento do julgador. Enquanto não estiver convencido o suficiente para decidir a demanda, necessária e oportuna a iniciativa probatória, ainda que de ofício.

Até porque, conforme bem pontua José Roberto dos Santos Bedaque, "enquanto a solução permanecer nas mãos do Estado, não pode o juiz se contentar apenas com a atividade das partes. A visão do 'Estado-social' não admite essa posição passiva, conformista, pautada por princípios essencialmente individualistas". 550

\footnotetext{
${ }^{548}$ BARBOSA MOREIRA, José Carlos. A função social do processo civil moderno e o papel do juiz e das partes na direção e na instrução do processo, cit., p. 146.

${ }^{549}$ JARDIM, Afrânio Silva. Da publicização no processo civil. Rio de Janeiro: Liber Juris, 1982. p. 107-108.

${ }^{550}$ BEDAQUE, José Roberto dos Santos, Poderes instrutórios do juiz, cit., p. 99.
} 
Sob essa premissa se justifica a iniciativa probatória do juiz, razão pela qual ousamos discordar do fundamento ligado a uma nivelação relativa à hipossuficiência de um dos litigantes. Afinal, se a iniciativa probatória se justifica exclusivamente como ato voltado a equacionar eventuais deficiências técnicas entre as partes, significa admitir que em parte a imparcialidade resta suprimida ou excepcionada, porquanto a hipossuficiência permitiria ao magistrado, em tese, beneficiar uma das partes, embora ainda não se saiba o resultado da prova. Em outras palavras, àquele que seja hipossuficiente é franqueado um ativismo judicial no campo probatório, ao passo que, inexistindo essa condição, deve o juiz limitar-se às provas apresentadas pelos litigantes. Ou seja, a quem é hipossuficiente, o Estado-juiz tenta compensar mediante uma decisão mais justa e próxima da verdade. Essa premissa, por si só, caminha em direção oposta ao próprio escopo social do processo, que reza a pacificação de conflitos com justiça.

Logo, a determinação da produção de determinada prova de oficio pelo juiz, sob a exclusiva premissa de que uma das partes é deficiente tecnicamente para conhecer a possibilidade de produção daquela prova (e, portanto, deve equacionar tal deficiência), não coaduna com o princípio da imparcialidade, porquanto essa justificativa deixa a impressão da parte hipossuficiente carecer melhor assistência no campo probatório, embora, repita-se, o resultado da prova sequer é conhecido. Aliás, para aqueles que sustentam, dentre inúmeras assertivas já definidas neste estudo, que as iniciativas instrutórias do juiz não esbarram na imparcialidade, por não se saber o resultado da prova, deve-se admitir, em contrapartida, que a prova de oficio, determinada sob a premissa exclusiva de "nivelar" eventual desigualdade entre os litigantes, por si só revela certa parcialidade ou regra de exceção, porquanto essa justificativa já deixaria claro que a prova em si beneficiaria a parte hiposuficiente.

Em síntese, é um contra-senso aduzir que a iniciativa probatória do juiz não fere a imparcialidade por não se saber o resultado da prova e, ao mesmo tempo, sustentar que em dadas situações a prova determinada pelo juiz se faz necessária para compensar eventual disparidade técnica, informativa ou econômica entre os litigantes. De igual modo dos que sustentam que a relação jurídica de direito material não pode influir na disponibilidade da prova, ${ }^{551}$ mostrar-se-ia contraditório defender que a hipossuficiência sirva como lenitivo

${ }^{551}$ Trataremos do princípio dispositivo e respectivos desdobramentos nos itens 4.2.1 e 4.2.2. 
para justificar uma postura mais ativa do juiz quanto às iniciativas probatórias. Por essa razão, soa adequada a síntese de Sidnei da Silva Braga de que "condicionar a iniciativa probatória do juiz à existência de acentuada diferença socioeconômica entre as partes equivale a desrespeitar o pricípio constitucional da igualdade processual". ${ }^{552}$ No mesmo sentido, leciona Milton Paulo de Carvalho:

\begin{abstract}
"Tal sistema concebe um juiz ativo, com poderes instrutórios caracterizados pela objetividade na perquirição dos fatos, juiz voltado para a obtenção da verdade que alicerçará o seu julgamento, sem necessidade de atendimento à situação econômica ou à qualificação social das partes. Fixado o objetivo do alcance da verdade, não haverá risco da parcialidade assistencial por inferioridade econômica, deficiência técnica do procurador ou por qualquer outro motivo." ${ }^{, 53}$
\end{abstract}

Daí porque a iniciativa probatória deve voltar-se ao estado de dúvida sobre como decidir, à carência e deficiência de elementos para a formação do livre convencimento necessário à entrega da tutela jurisdicional justa, o que, nesse caso, não guarda margem de aproximação com a igualdade substancial. Portanto, "a pacificação que se visa a alcançar com o processo, que corresponde ao seu escopo social mais relevante, depende da correspondência entre o resultado do processo e a vontade do direito substancial", 554

Logo, não se nega a necessidade de prevalecer a igualdade substancial entre as partes no processo, cabendo ao juiz sua melhor direção (art. 125 do CPC), conforme a situação jurídica posta em litígio. O que não se consegue vislumbrar, conforme exposto

\footnotetext{
${ }^{552}$ BRAGA, Sidney da Silva, Iniciativa probatória do juiz no processo civil, cit., p. 102. Dando continuidade a esse raciocínio, Braga alerta que: "Limitar a iniciativa oficial a esses casos não é tratar igualmente os iguais e desigualmente os desiguais: é, ao contrário, implantar odiosa discriminação na distribuição da justiça, pois equivale a dizer que o Estado, representado no processo pelo juiz, somente deve preocupar-se em envidar esforços na busca do resultado, o mais justo possível, quando houver sensível desnível socioeconômico entre os litigantes, significando que, quando ambos forem ricos ou ambos forem pobres, o Estado, em última análsie, não se interessa pelo grau de justiça alcançado pelo processo." (Ibidem, p. 102).

${ }^{553}$ CARVALHO, Milton Paulo de. Aplicação e reforma da lei processual. In: MEDINA, José Miguel Garcia; CRUZ, Luana Pedrosa de Figueiredo; CERQUEIRA, Luís Otávio Sequeira de; GOMES JUNIOR, Luiz Manoel (Coords.). Os poderes do juiz e o controle das decisões judiciais: estudos em homenagem à professora Teresa Arruda Alvim Wambier. São Paulo: Revista dos Tribunais, 2008. p. 1.126-1.127.

${ }^{554}$ BEDAQUE, José Roberto dos Santos, Poderes instrutórios do juiz, cit., p. 104. Dando continuidade ao raciocínio, Bedaque sustenta que "considerando que a parte mais fraca não tem as mesmas possibilidades que a mais forte, de trazer para os autos as provas necessárias à demonstração de seu direito, a ausência de iniciativa probatória pelo juiz corresponde a alguém assistir passivamente a um duelo entre o lobo e o cordeiro. Evidentemente, não estará atendido o princípio da igualdade substancial que, segundo a moderna ciência processual, deve prevalecer sobre o da mera igualdade formal. E, em razão dessa passividade do julgador, provavelmente se chegará a um resultado diverso daquele desejado pelo direito material”. Em que pesem essas sábias ponderações, ousamos discordar da premissa ligada ao fundamento da igualdade substancial (como acima exposto) e convergir as ideias para as demais premissas que justificam as iniciativas probatórias do magistrado.
} 
acima, é justificar o manejo das iniciativas probatórias do juiz sob a premissa de fazer jus a esse princípio constitucional, notadamente a isonomia substancial. Em síntese: a iniciativa probatória do magistrado se presta a atender ao objeto do processo, a angariar elementos necessários ao julgamento, o que não se confunde com a influência que a relação jurídica de direito material possa projetar sobre o ativismo judicial no campo probatório. A seguir, passaremos a discorrer acerca do princípio constitucional da publicidade, cuja importância é fundamental para a realização do princípio do contraditório e da ampla defesa.

\subsubsection{Princípio da publicidade}

O princípio da publicidade está previsto de forma ampla nos arts. $5^{\circ}$, LX e 93, IX da da Constituição Federal de 1988, ao determinarem que "a lei só poderá restringir a publicidade dos atos processuais quando a defesa da intimidade ou o interesse social o exigirem" e que "a preservação do direito à intimidade do interessado no sigilo não projudique o interesse público à informação", respectivamente. A publicidade consagrada na Carta Magna impõe garantia de acesso ao público da atividade dos órgãos jurisdicionais como regra geral, de sorte a imprimir transparência e clareza nas atividades de jurisdição estatal. Atua, portanto, como mecanismo de fiscalização popular sobre a obra dos magistrados, promotores públicos e advogados. ${ }^{555}$

Por sua vez, o inc. IX do art. 93 da Carta Magna, além de revestir o princípio da fundamentação das decisões judiciais, é claro ao outorgar ao legislador a possibilidade da "lei limitar a presença, em determinados atos, às próprias partes e a seus advogados, ou somente a estes, em casos nos quais a preservação do direito à intimidade do interessado no sigilo não prejudique o interesse público à informação".

No plano infraconstitucional, no que toca ao direito processual civil, o art. 444 do Código de Processo Civil prevê que as audiências são públicas, salvo as hipóteses previstas no art. 155, que compreendem determinadas limitações, ao restringir o acesso aos autos somente às partes e respectivos procuradores nas ações em que o interesso público o exigir ou que digam respeito a casamento, separação, conversão dela em divórcio, filiação,

\footnotetext{
555 CINTRA, Antonio Carlos de Araújo; GRINOVER, Ada Pellegrini; DINAMARCO, Cândido Rangel, Teoria geral do processo, cit., p. 75.
} 
alimentos e guarda de menores, cabendo ao terceiro somente o direito de pedir certidões do dispositivo da sentença e de inventário e partilhas resultantes de separação judicial ou divórcio, ou, ainda, somente quando amparado por interesse jurídico. ${ }^{556}$

A publicidade, na medida que atua como garantia política destinada ao controle da opinião pública nos serviços da Justiça, em dadas circunstâncias, se excessiva e desmesurada, pode violar a intimidades dos litigantes. É o que bem observam Grinover, Cintra e Dinamarco, ao sustentarem que a publicidade "não pode ser confundida com o sensacionalismo que afronta a dignidade humana. Cabe à técnica legislativa encontrar o justo equilíbrio e dar ao problema a solução mais consentânea em face da experiência e dos costumes de cada povo". ${ }^{557}$ Deve-se, portanto, sopesar princípios diametralmente opostos: de um lado, "o direito público à informação" e, de outro, "o sigilo da informação nociva ao interesse social"'.

Embora essa constatação convide a maiores debates, seria tarefa árdua e inserta em terreno pantanoso a tentativa de aprofundar esse tema, o que fugiria ao propósito deste trabalho. Trataremos, pois, de aspectos ligados à chamada publicidade interna ou restrita, ou seja, a publicidade relacionada com o acesso público aos autos do processo. ${ }^{558}$

\footnotetext{
${ }^{556}$ Para Grinover, Cintra e Dinamarco a previsão constitucional, por restringir a publicidade somente à "defesa da intimidade" ou do "interesse social", conceitos jurídicos abertos ou indeterminados, convidam a novas reavaliações sobre a Carta Magna de 1988 ter recepcionado a restrição alusiva no Código de Processo Civil de 1973 (Teoria geral do processo, cit., 76). Para Nelson Nery Junior, a Constituição Federal de 1988 recepcionou o art. 155 do Código de Processo Civil. (Princípios do processo civil na Constituição Federal, cit., p. 279). Parece-nos que, em verdade, a definição restritiva consagrada na Carta Magna é mais ampla, contudo ligada aos conceitos abertos retrocitados, de sorte que, embora se exija a proteção desses conceitos (defesa da intimidade ou interesse social), eles podem ser relativizados, diante do interesse público à informação (art. 93, IX, da CF). Tarefa árdua, que foge ao objeto deste trabalho, é a tentativa de mensurar o conflito entre a prevalência do interesse público e a proteção à privacidade (art. $5^{\circ}$, $\mathrm{X}$, da CF). Essa ponderação de princípios quiçá possa ser resolvida mediante o princípio da proporcionalidade, que será melhor tratado no item 4.1.6.

557 CINTRA, Antonio Carlos de Araújo; GRINOVER, Ada Pellegrini; DINAMARCO, Cândido Rangel, Teoria geral do processo, cit., p. 77.

558 A publicidade interna ou restrita opõe-se à publicidade externa ou ampla. Esta diz respeito aos "julgamentos", que devem ser "públicos", assim como as audiências realizadas pelos juízes de primeiro grau. Sobre o tema, ver: SICA, Heitor Vitor Mendonça. Panorama atual da garantia de publicidade no processo civil brasileiro. (art. inédito que integrará a obra coletiva Direito Processual Civil II, a ser publicada pela editora Quartier Latin, 2010); e ABDO, Helena Najjar. Observância da regra da objetividade na publicidade do processo realizada pelos meios de comunicação social. Tese (Doutorado) Faculdade de Direito da Universidade de São Paulo, 2006.
} 
A publicidade interna ou restrita se presta a viabilizar a concretização da garantia processual fundamental do princípio do contraditório já tratado neste estudo. Isso porque, se não houver acesso aos autos pela parte, o que viabiliza oportunidade do exercício de informação, participação e reação, não há como vislumbrar a abrangência completa dessa garantia fundamental.

No que tange às iniciativas probatórias, a publicidade se impõe no aspecto informação, mediante ciência às partes da decisão que determina a produção de prova de ofício, de sorte que, se eventualmente um dos litigantes entender ter havido gravame que o prejudique, poderá, diante dessa decisão, insurgir-se, através do recurso cabível. De igual sorte, a participação se evidencia mediante a publicidade da decisão do juiz que convoca as partes a contribuírem com a produção de determinada prova (atendendo-se, portanto, ao princípio da cooperação), ao passo que a reação está materializada nos atos das partes que compõem toda a dinâmica de produção da prova. Se não houver publicidade para ligar a comunicação entre as partes e o juiz, certamente elas não terão conhecimento da dada decisão, tampouco lhes serão assegurada oportunidade de participação e reação, o que viola o princípio do contraditório. ${ }^{559}$ Logo, as principais funções da observância do princípio da publicidade se prestam a (i) proteger as partes contra juízos arbitrários e secretos, como corolário integrante da garantia do devido processo legal e (ii) possibilitar a fiscalização da sociedade sobre o exercício da atividade jurisdicional. ${ }^{560}$

Portanto, a garantia constitucional da publicidade também se evidencia em todos os atos ligados aos poderes instrutórios, mormente para a concretização de outra garantia processual fundamental, qual seja, o princípio do contraditório e ampla defesa.

\footnotetext{
${ }^{559}$ Deve-se pontuar que, assim como em dadas situações processuais o contraditório não se aperfeiçoa de imediato, a exemplo das medidas cautelares inaudita altera pars e outros provimentos jurisdicionais de urgência, de igual sorte, e sob as mesmas premissas, em dadas situações, a publicidade se materializa $a$ posteriori, a exemplo da penhora on-line (arts. 655, I e 655-A do CPC), em que, por vezes, o prévio conhecimento ao devedor contumaz, mediante publicação no Diário Oficial, viabiliza atos que acabam por frustrar a constrição patrimonial, ao levantar todos os valores em conta-corrente antes da tentativa de penhora on-line. Nessa situação, soa mais lógico que a publicidade do despacho ocorra tão somente após a tentativa de bloqueio on-line.

${ }^{560}$ ABDO, Helena Najjar. A publicidade do processo. In: CARVALHO, Milton Paulo de (Coord.). Direito processual civil. São Paulo: Quartier Latin, 2007. p. 97.
} 


\title{
4.1.5 Princípio da motivação das decisões judiciais
}

O princípio da motivação ou da fundamentação das decisões judiciais está previsto no art. 93, IX, da Constituição Federal. A motivação consagra uma das principais garantias dentro do processo, que é a necessidade do juiz fundamentar todas suas decisões, de fato e de direito, apontando as razões que o levaram a decidir de determinada maneira. Conforme leciona Nelson Nery Junior, a fundamentação tem implicação substancial e não meramente formal. Logo, “não se consideram 'substancialmente' fundamentadas as decisões que afirmam que 'segundo os documentos e testemunhas ouvidas no processo, o autor tem razão, motivo porque julgou procedente o pedido'. Essa decisão é nula porque lhe falta fundamentação". 561

Além de imprimir transparência da atividade jurisdicional de modo objetivo, se presta a viabilizar o controle das decisões judiciais, mediante o conhecimento ao jurisdicionado da razão de decidir que influenciou a tomada de dada decisão no caso concreto, constituindo manifesta exigência inerente ao Estado Democrático de Direito. ${ }^{562}$

Para Cassio Scarpinella Bueno, a motivação deve ser entendida como algo imanente à prestação da tutela jurisdicional:

\begin{abstract}
"É uma forma do juiz 'prestar contas do exercício de sua função jurisdicional' ao jurisdicionado, aos demais juízes, a todos os participantes do processo e, mais amplamente - e como consequência inafastável - a toda a sociedade (...). O princípio da motivação, à luz deste novo paradigma da norma jurídica, destarte, assume inegáveis foros de mecanismos de justificativa e de controle do exercício da função jurisdicional. Sua importância para o estudo do direito processual civil como um todo, pois, é inegável."
\end{abstract}

\footnotetext{
${ }^{561}$ NERY JUNIOR, Nelson, Princípios do processo civil na Constituição Federal, cit., p. 170.

562 Esse é o recente entendimento do Supremo Tribunal Federal: "Recurso Extraordinário. Garantia constitucional de fundamentação das decisões judiciais. Art. 118, § $3^{\circ}$, do Regimento Interno do Superior Tribunal Militar. 1. A garantia constitucional estatuída no art. 93, inc. IX, da Constituição Federal, segundo a qual todas as decisões judiciais devem ser fundamentadas, é exigência inerente ao Estado Democrático de Direito e, por outro, é instrumento para viabilizar o controle das decisões judiciais e assegurar o exercício do direito de defesa. 2. A decisão judicial não é um ato autoritário, um ato que nasce do arbítrio do julgador, daí a necessidade da sua apropriada fundamentação. 3. A lavratura do acórdão dá consequência à garantia constitucional da motivação dos julgados. 4. Recurso extraordinário conhecido e provido." (STF RE n. 540.995-3/RJ, $1^{\text {a }}$ Turma, rel. Min. Menezes Direito, j. 19.02.2008,).

${ }^{563}$ BUENO, Cassio Scarpinella, Curso sistematizado de direito processual civil, cit., v. 1, p. 132-133.
} 
Conforme leciona Michele Taruffo, a garantia constitucional da motivação (racionalidade, amplitude e contrabilidade) gera consequências destinadas ao controle dos fundamentos e validade da decisão. ${ }^{564}$ Entendimento semelhante é asseverado por Grinover, Cintra e Dinamarco, ao sustentarem que a função política da motivação das decisões judiciais se destina não só às partes e ao juiz, mas se presta também a aferir a imparcialidade do julgador e legalidade da justiça da decisão. ${ }^{565}$

Este princípio está amplamente relacionado com outros princípios existentes no ordenamento, como o da publicidade, de sorte que a motivação e seu aspecto ligado ao dever do juiz expor suas razões de decidir pressupõe que as decisões sejam públicas e acessíveis a todos em geral. Se a decisão apenas determinar e for omissa quanto à sua fundamentação, certamente a publicidade restará tolhida, no que toca à transparência da razão de decidir da decisão. Não se saberá o fundamento de dada decisão e, portanto, haverá a supressão parcial da publicidade.

De igual modo, a decisão que determina uma dada providência, mas não esclarece o motivo, viola o princípio do contraditório, a exemplo da decisão do magistrado que determina a produção de prova pericial, mas, por outro lado, é omissa em mencionar por qual razão e a qual finalidade se prestará a prova. Nessa hipótese, a formulação de quesitos pelas partes será deficiente ou de pouca abrangência, porquanto desconhecida a razão específica ou o motivo da prova. Logo, restará prejudicada a participação das partes na

\footnotetext{
564 "La garantia constituzionale della motivazione produce conseguenze, oltre che sul contenuto della motivazione, anche sulla struttura che essa deve avere in quanto mezzo per il controllo sulla fondatezza e validità della decisione. Tali conseguenze possono essere riassunte in ter caratteri necessari della motivazione: razionalità, completezza e controllabilità." (TARUFFO, Michele. Il significato constituzionale dell'obbligo di motivazione. In: DINAMARCO, Cândido Rangel; GRINOVER, Ada Pelegrini; WATANABE, Kazuo (Coords.). Participação e processo. São Paulo: Revista dos Tribunais, 1988. p. 47).

565 CINTRA, Antonio Carlos de Araújo; GRINOVER, Ada Pellegrini; DINAMARCO, Cândido Rangel, Teoria geral do processo, cit., p. 74. Para Nelson Nery Junior, a motivação compreende não só a necessidade de comunicação judicial, mas também a exposição do exercício da atividade lógica e intelectual subsumida pelo magistrado quando decide, o que reflete "consequentemente a exigência da imparcialidade do juiz, a publicidade das decisões judiciais, a legalidade da mesma decisão, passando pelo princípio constitucional da independência jurídica do magistrado, que pode decidir de acordo com sua livre convicção, desde que motive as razões de seu convencimento (princípio do livre convencimento motivado)" (Princípios do processo civil na Constituição Federal, cit., p. 285-286). Sobre o tema, ver ainda: BARBOSA MOREIRA, José Carlos. A motivação das decisões judiciais como garantia inerente ao estado de direito. In. Temas de direito processual: segunda série. 2. ed. São Paulo: Saraiva, 1988. p. 83-95; TUCCI, Rogério Lauria; TUCCI, José Rogério Cruz e. Constituição de 1988 e processo: regramentos e garantias constitucionais do processo. São Paulo: Saraiva, 1989.
} 
produção da prova, porquanto a formulação dos quesitos será pouco abrangente, inclusive o próprio objeto de investigação da perícia.

De igual modo, a motivação também se faz necessária quando da avaliação da prova produzida nos autos e apresentação dos motivos que conduziram à formação do livre convencimento do juiz. Barbosa Moreira assevera que:

\begin{abstract}
“(...) não bastará, p. ex., dizer que as declarações da testemunha $X$ pareceram mais dignas de crédito que as da testemunha $\mathrm{Y}$, mas será mister esclarecer o asserto pelo confronto das características pessoais dos depoentes, pelo exame da forma como se expressaram, da coerência interna dos depoimentos, e da respectiva concordância ou discordância com outras peças de informação."
\end{abstract}

O Código de Processo Civil também impõe a motivação como requisito da sentença (art. 458, II), ao exigir sejam delineados "os fundamentos, em que o juiz analisará as questões de fato e de direito". De igual sorte, o art. 131 determina que o juiz "deverá indicar, na sentença, os motivos que lhe formaram o convencimento", ao passo que o art. 165 exige que as demais decisões sejam fundamentadas, ainda que de modo conciso. Essa fundamentação concisa (que também pode ser observada no art. 459, no que toca às sentenças terminativas) revela um mínimo de exposição das razões de decidir, até porque se o dispositivo de lei dispensasse nessas hipóteses a fundamentação, não haveria razão para se dizer "concisa". Por sua vez, na exigência de fundamentação no âmbito do Juizado Especial Cível (Lei n. 9.099/95, art. 38), basta a indicação dos elementos de convicção, assim como os acórdãos do colégio recursal terão fundamentação sucinta (art. 46), porém "autorizar a fundamentação concisa ou sucinta não significa dispensar a motivação ou sua inteireza, pois isso viria de encontro à Constituição Federal" 567

Em verdade, o grau de fundamentação da decisão deve ser exigido conforme a natureza do que restou determinado ${ }^{568}$, ainda que em decisão interlocutória. ${ }^{569}$ Se o juiz

\footnotetext{
${ }^{566}$ BARBOSA MOREIRA, José Carlos, Alguns problemas atuais da prova civil, cit., p. 130.

${ }^{567}$ DINAMARCO, Cândido Rangel, Instituições de direito processual civil, cit., v. 1, p. 250.

${ }^{568}$ Deve-se lembrar que meros despachos sem conteúdo decisório dispensam a fundamentação (art. 162, $\S 3^{\circ}$, do CPC).

${ }^{569}$ Tarefa difícil é encontrar o grau certo que deva incidir a fundamentação. O que é conciso para o juiz talvez não o seja para a parte, assim como pode soar precária a indicação dos elementos de convicção. Novamente invocamos os ensinamentos de Dinamarco, para quem a motivação deve ser completa, sem omitir pontos cuja solução pudesse conduzir o juiz a concluir diferentemente, mormente quando a sentença estiver dividida em capítulos correlacionada com diversos pedidos. Ainda, "o essencial é motivar no
} 
decide de modo a trazer gravame a uma das partes, naturalmente sua decisão deve ser bem fundamentada, delimitando com clareza as razões de decidir, bem como deve analisar todos os argumentos trazidos pelas partes. Se a decisão realiza subsunção de um conceito jurídico indeterminado, impõe-se ampla fundamentação que deixe clara a subsunção e constatações do magistrado suficientes a entender a presença do conceito jurídico. Se o juiz determina a produção de prova que não foi requerida pelas partes, impõe-se a fundamentação que justifique o porquê da necessidade de tal prova, bem como a que se destina esclarecer a prova, lembrando que a fundamentação deve ser substancial, e não meramente formal. De igual modo, se o juiz indefere a produção de uma prova postulada pela parte, deve fundamentar as razões que conduzem à irrelevância e desnecessidade de sua produção. Ainda, se o juiz determina de ofício a produção de uma prova antes mesmo de permitir que as partes o façam, maior será a relevância necessária a justificar a produção prematura da prova.

Portanto, as iniciativas probatórias do magistrado, desde que fundamentadas, não se mostram incompatíveis com o "modelo constitucional do processo civil". Aliás, é exatamente a fundamentação que trará transparência às razões de decidir, mormente a determinação de prova que eventualmente possa trazer gravame a uma das partes. Até quando o juiz impõe que uma das partes deve produzir tal prova (carga dinâmica da prova) ${ }^{570}$ essa decisão se reveste de legitimidade se devidamente fundamentada. Daí porque a importância da fundamentação das decisões judiciais, mormente quando das iniciativas probatórias do magistrado. Somente assim se permitirá um mecanismo de transparência e controle da decisão judicial ${ }^{571}$ que impeça a existência de teratologias ou arbitrariedades.

\footnotetext{
tocante aos pontos relevantes e essenciais, de modo que a motivação lançada em sentença mostre que o juiz tomou determinada decisão porque assumiu determinados fundamentos com que esta guarda coerência. A regra de equilíbrio é esta: motiva-se no essencial e relevante, dispensa-se relativamente a motivação no periférico e circunstancial" (Instituições de direito processual civil, cit., v. 1, p. 248-249).

${ }^{570}$ Ver o item 3.2.3.

${ }^{571}$ Daí porque Carlos Alberto Alvaro de Oliveira conclui: “O princípio compreende não só o enunciado das escolhas do juiz em relação à individuação das normas aplicáveis ao caso concreto e às correspondentes consequências jurídicas, como os nexos de implicação e coerências entre esses enunciados, com vistas a possibilitar o controle do pronunciamento judicial pelas partes e pela sociedade." (Do formalismo no processo civil, cit., p. 106).
} 
Na medida que o juiz fundamenta sua decisão, mormente as iniciativas probatórias de ofício, ${ }^{572}$ a parte que eventualmente entender ter sido prejudicada terá com certeza elementos suficientes para requerer o reexame da decisão pelo tribunal, ${ }^{573}$ porquanto será de conhecimento da corte as razões que motivaram o magistrado a tomar tal medida, bem como aferir se a decisão tomada é a mais correta, à luz do caso concreto.

\subsubsection{Princípio da proporcionalidade}

Em determinados casos concretos, é comum que o juiz para decidir tenha que optar pela aplicação de um princípio em detrimento de outro. Vale dizer, a despeito do sistema prever a observância de diretrizes que devam ser respeitadas, em dadas situações essas diretrizes ou princípios podem colidir, de sorte que a decisão deve fundar-se na interpretação de aplicação de um princípio que prevalecerá sobre outro. ${ }^{574}$ Para essa colisão de princípios, doutrina e jurisprudência têm admitido a aplicação do chamado princípio da proporcionalidade. ${ }^{575}$ Como leciona Canotilho, o princípio da

572 Alinhado ao entendimento perfilhado por Ada Pellegrini Grinover, a motivação das decisões judiciais constitui um dos limites para a iniciativa probatória do juiz: “(...) a atuação do juiz na atividade instrutória não é ilimitada. Existem balizas intransponíveis à iniciativa oficial, que se desdobram em três parâmetros: a rigorosa observância do contraditório, a obrigatoriedade de motivação, os limites impostos pela licitude (material) e legitimidade (processual) das provas." (A iniciativa instrutória do juiz no processo penal acusatório. Revista Forense, Rio de Janeiro, v. 95, n. 347, p. 3, jul./set. 1999). Semelhante é o entendimento perfilhado por Bedaque sobre a necessidade de fundamentação da decisão judicial ligada à iniciativa probatória do juiz. Deve o magistrado apresentar os motivos que o levaram a aplicar a regra do art. 130 do Código de Processo Civil, tal qual se faze necessária a fundamentação em qualquer ato decisório para que, na eventualidade de sobrevir recurso, "as partes possam apresentar razões de impugnação e o órgão superior tenha condições de examinar os argumentos favoráveis e contrários à conclusão impugnada" (Poderes instrutórios do juiz, cit., p. 154).

${ }^{573}$ Deve-se entender nessa assertiva as situações comuns no processo que seguramente admitem o acesso à instância recursal, excepcionando-se as hipóteses em que o ordenamento não admite o reexame de determinadas decisões, a exemplo das ações declaratórias de constitucionalidade e ações diretas de inconstitucionalidade, cuja decisão final não é passível de reexame por um órgão superior.

${ }^{574}$ No que tange à antinomia de normas, os $\$ \S 1^{\circ}$ a $3^{\circ}$ do art. $2^{\circ}$ da Lei de Introdução ao Código Civil (Dec.Lei n. 4.657/42) cuidou de estabelecer dois critérios objetivamente constatáveis, de sorte a prevalecer a norma mais específica (princípio da especialidade) ou mais recente: “Art. $2^{\circ}$ - Não se destinando à vigência temporária, a lei terá vigor até que outra a modifique ou revogue. $\S 1^{\circ}$ - A lei posterior revoga a anterior quando expressamente o declare, quando seja com ela incompatível ou quando regule inteiramente a matéria de que tratava a lei anterior. $\S 2^{\circ}$ - A lei nova, que estabeleça disposições gerais ou especiais a par das já existentes, não revoga nem modifica a lei anterior."

${ }^{575}$ Para Cassio Scarpinella Bueno, diz-se "regra da proporcionalidade" e não princípio, porquanto não admite qualquer hesitação, quanto à sua aplicação, em termos de preponderância valorativa. (Curso sistematizado de direito processual civil, cit., v. 1, p. 99). Por sua vez, João Batista Lopes defende que a proporcionalidade é um princípio, pois uma regra não tem o condão de resolver colisão entre princípios. Prossegue aduzindo que a proporcionalidade é um princípio constitucional, corolário do próprio Estado de Direito, que veda o excesso e o abuso, pelo qual os direitos ou interesses em jogo devem ser avaliados para dar prevalência aos valores que informam a ordem jurídica e, por fim, sua aplicação deve ser criteriosa, 
proporcionalidade aplica-se a todas as espécies de atos dos poderes públicos, de modo que vincula o legislador, a Administração pública e o Poder Judiciário. ${ }^{576}$

O princípio da proporcionalidade não se confunde com o princípio da razoabilidade, porquanto o primeiro é de origem germânica, ao passo que o segundo fundase no direito anglo-saxão. O princípio da razoabilidade, por sua vez, tem uma função negativa, pois sua desobediência significa "ultrapassar irremediavelmente os limites do que as pessoas em geral, de plano, consideram aceitáveis em termos jurídicos”. Já o O princípio da proporcionalidade tem uma função positiva, "na medida que pretende demarcar aqueles limites, indicando como nos mantermos dentro deles". 577

De todo modo, como sustenta Marcelo José Magalhães Bonicio, os dois princípios estão inseridos no conceito de standard, ou seja, termos fluidos que servem de sustentação jurídica para hipóteses em que não há regra específica para regular determinada situação. Ambos estão consubstanciados na garantia existente na regra do due process of law, ao passo que, quando se trata do controle da razoabilidade das leis, é comumente utilizada a expressão aplicada nos países de common law, ou seja, devido processo legal em sentido substantivo ou material (substantive due process of law). ${ }^{578}$ Daí porque essa aproximação da proporcionalidade com a razoabilidade. Embora se trate de princípios com peculiares

para evitar que o subjetivismo comprometa o resultado alcançado (Efetividade da tutela jurisdicional à luz da constitucionalização do processo civil. Revista de processo, São Paulo, Revista dos Tribunais, ano 29, n. 116, p. 70, jul./ago. 2004). Embora não guarde ligação com o objetivo deste trabalho decidir entre princípio ou regra da proporcionalidade, tomaremos partido pela primeira opção, por ser essa a expressão comumente utilizada, mormente em decisões do Supremo Tribunal Federal, a exemplo da manifestada na ADI n. 958 (rel. Min.. Marco Aurélio, DJ, de 16.05.1994), conforme sustenta Gilmar Ferreira Mendes (Jurisdição constitucional: o controle abstrato de normas no Brasil e na Alemanha. 4. ed. São Paulo: Saraiva, 2004. p. 208).

${ }^{576}$ CANOTILHO, José Joaquim Gomes, Direito constitucional e teoria da Constituição, cit., p. 264. Outro não é o entendimento do Min. Celso Bastos que, ao analisar a aplicação e incidência do princípio da proporcionalidade, atesta que "o princípio da proporcionalidade se qualifica enquanto coeficiente de aferição da razoabilidade dos atos estatais como postulado básico de contenção dos excessos do Poder Público (...) essa é a razão pela qual a doutrina, após destacar a ampla incidência desse postulado sobre os múltiplos aspectos em que se desenvolve a atuação do Estado - inclusive sobre a atividade estatal de produção normativa -, adverte que o princípio da proporcionalidade, essencial à racionalidade do Estado Democrático de Direito e imprescindível à tutela das liberdades fundamentais, proíbe o excesso e veda o arbítrio do poder" (MC ADI n. 1.407-2/DF, j. 07.03.1996, DJ, de 24.11.2000).

${ }^{577}$ GUERRA FILHO, Willis Santiago. Direitos fundamentais, processo e princípio da proporcionalidade. In. Dos direitos humanos aos direitos fundamentais. Porto Alegre: Livraria do advogado, 2007. p. 25.

578 BONICIO, Marcelo José Magalhães. Proporcionalidade e processo: a garantia constitucional da proporcionalidade, a legitimação do processo civil e o controle das decisões judiciais. São Paulo: Atlas, 2006. p. 33-34. 
distinções, o fundamento da proporcionalidade engloba o da razoabilidade que, por sua vez, contempla o devido processo legal substancial. ${ }^{579}$

Basicamente, a aplicação do princípio da proporcionalide está balizada em três critérios distintos: adequação, necessidade e proporcionalidade em sentido estrito. A adequação deve primar pela correspondência lógica entre os meios e fins a serem alcançados, de modo que o meio determinado seja razoável e proporcional com a finalidade pretendida. ${ }^{580}$ A necessidade se pauta no princípio da menor ingerência possível, ou seja, deve-se suprimir na menor fração possível determinado princípio em detrimento de outro, de sorte a definir a opção menos gravosa, dentre outras existentes. Por fim, a proporcionalidade em sentido estrito reflete conjugação da adequação com necessidade, ocasião em que o juiz irá ponderar a menor ingerência possível com a correspondência lógica da medida adotada no caso concreto, para assim concluir qual valor deve prevalecer, fundamentando sua decisão. ${ }^{581}$

\footnotetext{
${ }^{579}$ Sobre o devido processo legal substancial, ver: DINAMARCO, Cândido Rangel, Instituições de direito processual civil, cit., v. 1, p. 250 e ss.; NERY JUNIOR, Nelson, Princípios do processo civil na Constituição Federal, cit., p. 81 e ss. Embora não façam alusão expressa ao princípio da razoabilidade, tem-se o significado do devido processo legal em sentido material (substantive due process of law) como uma obrigação negativa, consistente no respeito às garantias do devido processo legal que, em verdade, não se restringem às garantias processuais previstas na Constituição Federal de 1988. Daí porque Dinamarco resume a definição substancial da cláusula due process of law como "amorfa e enigmática, que mais se colhe pelos sentimentos e intuição do que pelos métodos puramente racionais da inteligência" (Instituições de direito processual civil, cit., v. 1, p. 253).

${ }^{580}$ Nesse sentido, Carlos Alberto Alvaro de Oliveira bem assevera que a adequação se desdobra na análise de três aspectos: o quantitativo - intensidade com que o meio pode promover menos, igualmente ou mais o fim do que outro meio; o qualitativo - qualidade do meio que pode promover pior, igual ou melhor o fim do que outro meio; e probabilístico - probabilidade de certeza e acerto que o meio eleito pode promover, em relação a outro meio (Os direitos fundamentais à efetividade e à segurança em perspectiva dinâmica, in As grandes transformações do processo civil brasileiro: homenagem ao professor Kazuo Watanabe, cit., p. 45).

${ }^{581}$ É o que ensina Paulo Bonavides: "O princípio da proporcionalidade (Verhältnismässigkeit) pretende, por conseguinte, instituir como acentua Gentz, a relação entre fim e meio, confrontando o fim e o fundamento de uma intervenção com os efeitos desta para que se torne possível um controle do excesso (eine Übermasskontrolle). O segundo elemento ou subprincípio da proporcionalidade é a necessidade, ao qual também alguns autores costumam dar tratamento autônomo e não raro identificá-lo como a proporcionalidade propriamente dita. Pelo princípio ou subprincípio da necessidade, a medida não há de exceder os limites indispensáveis à conservação do fim legítimo que se almeja, ou uma medida para ser admissível deve ser necessária." (Curso de direito constitucional, cit., p. 357). Semelhante definição é dada por Gilmar Ferreira Mendes: "O subprincípio da adequação (Geeignetheit) exige que as medidas interventivas adotadas mostrem-se aptas a atingir os objetivos pretendidos. O subprincípio da necessidade (Notwendigkeit oder Erforderlichkeit) significa que nenhum meio menos gravoso para o indivíduo revelarse-ia igualmente eficaz na consecução dos objetivos pretendidos (...). Um juízo definitivo sobre a proporcionalidade da medida há de resultar da rigorosa ponderação e do possível equilíbrio entre o significado da intervenção para o atingido e os objetivos perseguidos pelo legislador (proporcionalidade em sentido estrito)." (O princípio da proporcionalidade na jurisprudência do Supremo Tribunal Federal: novas leituras. Revista Diálogo Jurídico, Salvador, Centro de Atualização Jurídica, ano 1, v. 1, n. 5, p. 4, ago. 2001).
} 
$\mathrm{Na}$ aplicação do princípio da proporcionalide, por tratar-se de mecanismo de ponderação e, por vezes, a supressão de um princípio ou valor em detrimento de outro, necessário que a decisão esteja vastamente fundamentada. Isso porque a aplicação da proporcionalidade guarda ligação exclusiva com as peculiaridades do caso concreto e exatamente por essa característica de abstração que se impõe a fundamentação da decisão judicial, sob pena de violação a outros princípios constitucionais. Assim, quanto maior o grau de intervenção em determinado direito, maiores deverão ser os motivos justificadores, porquanto os critérios de valoração da proporcionalidade se pautuam nas peculiaridades do caso concreto.

De igual modo, o exercício das iniciativas probatórias pelo magistrado deve se dar com observância ao princípio da proporcionalidade. Significa dizer que a prova determinada de ofício pelo juiz deve guardar relevância para o resultado e influenciar o julgamento do pedido, de sorte que a pertinência dessa prova se evidencie diante da carência do campo probatório até então formado nos autos. Por outro lado, deve-se ponderar se tal diligência não estenderá demais o curso do processo, porquanto a demora na entrega da tutela jurisdicional pode prejudicar os litigantes. Para essa ponderação, impõe-se a observância do princípio da proporcionalidade, em situações em que a iniciativa probatória e o tempo necessário para a produção de determinada prova (seja para permitir um julgamento com maior proximidade da certeza de acerto, seja para, em última análise, determinar a produção de dada prova que porventura possa resolver o conflito) entra em confronto com o fator celeridade do processo e entrega da tutela jurisdicional em tempo razoável. Nesse caso, há de prevalecer uma única escolha, cuja decisão implique em sacrifício ou supressão da outra.

Conforme leciona Dinamarco, o juiz que busca a certeza muito elevada para julgar acaba por esconder uma tendência burocrática e comodista que deve ser repelida. Portanto, deve o magistrado pontuar-se em conduta que "aja como a pessoa comum ao formar sua convicção, concluindo pela existência do fato quando a sua consciência tiver por bem mais provável a existência do que a inexistência e sem se chegar a extremos de exigência". ${ }^{52}$

${ }_{582}$ DINAMARCO, Cândido Rangel, A instrumentalidade do processo, cit., p. 300. 
A proporcionalidade também exerce importante papel quando da aplicação das máximas de experiência, "no caso de existir dúvidas quanto à existência ou inexistência de um fato, sem contar a notoriedade de certos fatos e as regras jurídicas que permitem que o juiz utilize determinadas modalidades de presunções para chegar a um resultado qualquer". ${ }^{583}$ Por se tratar de juízo de probabilidade, a aplicação das máximas de experiência devem ser ponderadas, a ponto de se chegar a um denominador comum entre o excesso de exigir um grau muito elevado de certeza para entrega da tutela jurisdicional e, de outro lado, o julgamento baseado em meras probabilidades, desprezando provas que pudessem conduzir a entendimento em contrário.

O princípio da proporcionalidade também deve ponderar a análise do estabelecimento do ônus atribuído a cada um dos litigantes para a produção da prova. Deve-se evitar um ônus excessivo de provar, porquanto toda e qualquer decisão é amparada por um juízo de probabilidade, por mais que se almeje a obtenção de absoluta certeza. Em que pese a regra estatuída no art. 333 do Código de Processo Civil, é certo que na ocasião em que o magistrado aplica a regra de julgamento do ônus da prova, ${ }^{584}$ deve cuidar que seja proporcional e não atribua excessivamente tal ônus a uma das partes. Nesse caso, conforme propõe Marcelo José Magalhães Bonicio, a aplicação da inversão do ônus da prova deve ser noticiada no início da instrução do processo, o que permitirá à parte sobre a qual recai tal ônus municiar-se de todos os meios de prova para que se defenda da maneira mais ampla possível, ${ }^{585}$ mormente para demonstrar de que modo transcende a regra geral de distribuição do ônus da prova (art. 333 do CPC), como quando aplicada a carga dinâmica da prova já tratada no item 3.2.3.

Ainda no que toca à regra de inversão do ônus da prova, a proporcionalidade deverá balizar entre a simples aplicação dessa regra de julgamento e, por outro lado, as iniciativas probatórias do magistrado cujos resultados eventualmente sejam suficientes para a formação do livre convencimento. Ou seja, ao invés de onerar uma das partes com a regra de inversão e, em determinados casos, obter resultados duvidosos e injustos, poderia a lide ser resolvida mediante a produção de prova de ofício por parte do juiz, cujo resultado

\footnotetext{
${ }^{583}$ BONICIO, Marcelo José Magalhães, Proporcionalidade e processo..., cit., p. 83.

${ }^{584}$ Ver item 3.2.1.

${ }^{585}$ BONICIO, Marcelo José Magalhães, ob. cit., p. 89.
} 
atingisse a proximidade de certeza. ${ }^{586}$ Por sua vez, o princípio da proporcionalidade também guarda utilidade, com as ressalvas que serão tratadas no item seguinte, quando da admissibilidade da prova produzida por meio ilícito, se ela for o único elemento de prova hábil a ser carreado aos autos: pondera-se o benefício trazido por força da prova, em cotejo com o princípio da vedação das provas obtidas por meio ilícito.

Portanto, a proporcionalidade se presta a equacionar situações em que o juiz, notadamente no que toca às iniciativas probatórias, deve ponderar um valor em detrimento de outro. ${ }^{587}$ Conforme visto neste item, algumas vezes será necessário confrontar a "celeridade" com a "aproximação da certeza ao decidir". Por vezes, também se confrontará o "juízo de aproximação de certeza” com o "juízo de probabilidade ao aplicar as máximas de experiência" e, em dadas situações, o magistrado deverá ponderar entre "mera inversão do ônus da prova excessiva a uma das partes" e "iniciativa probatória destinada a tentar desvendar a qual parte assiste razão na demanda", assim como "o benefício da prova" e "a vedação de sua admissibilidade em juízo". Para tanto, tendo em vista que a proporcionalidade é aplicada casuisticamente, necessária a máxima atenção ao princípio da motivação das decisões judiciais já comentado, a fim de permitir o controle ${ }^{588}$ de decisão judicial pautada em elementos abertos e circunstanciais às peculiaridades do caso concreto.

\subsubsection{Princípio da vedação das provas ilícitas ou obtidas por meios ilícitos}

O princípio da vedação das provas ilícitas ou obtidas por meios ilícitos está previsto no art. $5^{\circ}$, LVI, da Constituição Federal. ${ }^{589}$ Inicialmente, cumpre salientar que as provas

\footnotetext{
586 A correta ponderação do princípio da proporcionalidade também se torna mais assente quando da aplicação da chamada "carga dinâmica da prova", tema analisado nos itens 3.2.3 e seguintes.

${ }^{587}$ Carlos Alberto Alvaro de Oliveira, ao aduzir acerca da colisão entre os valores efetividade e segurança jurídica, conclui que caberá ao julgador a adequada ponderação, observadas as peculiaridades do caso concreto, à luz do princípio da proporcionalidade (Os direitos fundamentais à efetividade e à segurança em perspectiva dinâmica, in As grandes transformações do processo civil brasileiro: homenagem ao professor Kazuo Watanabe, cit., p. 45 e ss.).

${ }^{588}$ Fritz Baur, ao discorrer acerca do Stuttgarter Modell como solução para a longa duração do processo, conclui que embora se reclame por uma postura mais ativa do juiz, essa atividade sempre estará sujeita a limitações e garantias previstas em lei: "Para evitar mal-entendidos, se deve ressaltar que o alargamento do campo das atividades do juiz não significa querer-se transformar o processo em um todo de atos carentes de forma, entregue total e completamente à apreciação do juiz. Se cada juiz montasse o processo de acordo com a sua vontade, isto significaria ter-se posto em perigo a paridade de tratamento e a igualdade jurídica, garantidas pelo direito material. Então, o papel do juiz realmente precisa de nítidos contornos legislativos.” (O papel ativo do juiz, cit., p. 191).

589 “Art. $5^{\circ}$ - (...) LVI - são inadmissíveis, no processo, as provas obtidas por meios ilícitos.”
} 
ilícitas não se confundem com as provas obtidas por meios ilícitos, ${ }^{590}$ que são vedadas pelo ordenamento quanto à sua forma de obtenção, constituição e formação, ao passo que aquelas por si só já ferem o próprio ordenamento. ${ }^{591}$ Não pretendemos, todavia, aprofundar a questão da vedação das provas ilícitas ou obtidas por meios ilícitos e aspectos ligados ao debate, tema complexo e controvertido, que demanda estudo próprio e exclusivo, fugindo dos escopos deste trabalho. No que toca ao cerne desta dissertação, trataremos restritivamente das provas obtidas por meios ilícitos, porquanto são elas que comportam certa relativização quanto à sua admissibilidade diante das iniciativas probatórias do magistrado, como analisaremos adiante.

A prova obtida de forma ilícita é aquela que o magistrado deixou ser produzida ${ }^{592} \mathrm{e}$ cuja admissibilidade em juízo viola princípios constitucionais. Como exemplo, uma gravação de conversa telefônica por um dos interlocutores ou por mera interceptação que, a despeito do art. $5^{\circ}$, XII, da Constituição Federal ${ }^{593}$ excepcionar a violação do sigilo das comunicações telefônicas somente para fins de investigação criminal ou instrução processual penal, ${ }^{594}$ fosse admitida em outras hipóteses, constituiria manifesta violação à intimidade e à vida privada (art. $5^{\circ}, \mathrm{X}$, da $\mathrm{CF}$ ). Ademais, a produção de dada prova mediante gravação de conversa por um interlocutor, e desprezada a ciência do outro, torna mais provável a possibilidade de manipulação da conversa para produzir o conteúdo da prova almejado unilateralmente.

\footnotetext{
${ }^{590}$ Trataremos como sinônimas as expressões prova obtida por meio ilícito (CINTRA, Antonio Carlos de Araújo; GRINOVER, Ada Pellegrini; DINAMARCO, Cândido Rangel, Teoria geral do processo, cit., p. 89); e prova obtida de forma ilícita (BUENO, Cassio Scarpinella, Curso sistematizado de direito processual civil, cit., v. 1, p. 136).

${ }^{591}$ BUENO, Cassio Scarpinella, Curso sistematizado de direito processual civil, cit., v. 1, cit., p. 136. Por sua vez, Suzana Henriques da Costa afirma que as provas ilícitas propriamente ditas são as colhidas com infração a normas ou princípios de direito material, de direito constitucional, de direito penal, civil ou administrativo, cuja violação é anterior ou concomitante ao processo, mas ocorre fora dele, quando da colheita da prova, ao passo em que as provas ilegítimas são aquelas cuja colheita fere normas de direito processual, sendo a ilegalidade cometida dentro do processo, no momento da introdução da prova (Os poderes do juiz na admissibilidade das provas ilícitas. Revista de Processo, São Paulo, Revista dos Tribunais, ano 31, n. 140, p. 86, mar. 2006). A vedação das provas ilícitas ou obtidas por meios ilícitos será aqui encarada na qualidade de princípio, porquanto elevada ao status de garantia fundamental (Título II, Capítulo I da CF de 1988). Para Cintra, Grinover e Dinamarco, a vedação às provas obtidas por meios ilícitos é garantia que deriva do devido processo legal. (Teoria geral do processo, cit., p. 89).

${ }^{592}$ BUENO, Cassio Scarpinella, Curso sistematizado de direito processual civil, cit., v. 1, cit., p. 136.

593 “Art. $5^{\circ}$ (...) XII - é inviolável o sigilo da correspondência e das comunicações telegráficas, de dados e das comunicações telefônicas, salvo, no último caso, por ordem judicial, nas hipóteses e na forma que a lei estabelecer para fins de investigação criminal ou instrução processual penal."

${ }^{594}$ Em linhas gerais, a Lei n. 9.296/96 disciplina as condições em que o juiz penal, para fins de instrução criminal, pode determinar a quebra dos sigilos telefônicos e de outras fontes do acusado.
} 
Há, contudo, situações excepcionais em que a prova obtida de forma ilícita vem sendo admitida. De se frisar que tais hipóteses variam conforme as peculiaridades do caso concreto, podendo ser traçadas algumas premissas que justificam certa mitigação da vedação de admissibilidade de tais provas. Por um lado, a admissão de prova obtida de forma ilícita viola princípios constitucionais. De outro lado, deve-se ponderar essa violação diante de outro princípio de carga e valoração maior que deixará de ser atendido caso a prova em questão não seja admitida, aliada à circunstância de que essa prova é a única que poderia ter sido produzida nos autos. ${ }^{595}$ Por vezes, o valor vida poderá se sobrepor ao princípio da vedação das provas ilícitas, como em dada situação, exaurida a instrução probatória, apenas uma única prova, embora produzida por meios ilícitos, é suficiente para absolver o acusado e assim evitar o cumprimento indevido de uma pena.

E, havendo ponderação de princípios, deve-se utilizar o critério do princípio da proporcionalidade, para se alcançar a solução mais razoável possível. Deve-se, num primeiro momento, questionar, em relação a prova ilícita apresentada, 596 "se a infração gerou dano superior ao benefício trazido à instrução do processo". ${ }^{597}$ Dando continuidade a esse pensar, deve-se questionar se o benefício se lastreia em um princípio fundamental suficiente para a se sobrepor ao princípio da vedação das provas obtidas por meios ilícitos, para, a partir de então, caso a resposta nesse exame preliminar for positiva, seguir-se a aplicação do princípio da proporcionalidade pelos critérios da adequação, necessidade e da proporcionalidade em sentido estrito, já tratado no item 4.1.6, supra.

\footnotetext{
595 É o que exemplifica Cassio Scarpinella Bueno, ao aduzir que, em determinadas situações, a prova lícita obtida de forma ilícita pode ser utilizada válida e eficazmente se for o único meio de provar fato que diga respeitos a interesses maiores, "à segurança pública, por exemplo, ou se ela puder beneficiar o acusado. Trata-se, uma vez mais, da aplicação do 'princípio da proporcionalidade', assunto ao qual se volta o n. 2.1, supra. A prova ilícita, contudo, não deve tolerar qualquer gradação ou qualquer temperamento" (Curso sistematizado de direito processual civil, cit., v. 1, p. 136-137). Para Bedaque, deve-se encontrar o equilíbrio entre valores contrapostos: “(...) a tutela da norma violada com a obtenção da prova ilícita e a utilização dos meios necessários ao alcance do escopo da atividade jurisdicional." (Poderes instrutórios do juiz, cit., p. 141). Em igual sentido: COSTA, Suzana Henriques da, Os poderes do juiz na admissibilidade das provas ilícitas, cit., p. 98.

${ }^{596}$ Cassio Scarpinella Bueno acresce a mitigação do princípio da vedação das provas ilícitas ou obtidas por meios ilícitos mediante aplicação do princípio da proporcionalidade nas situações de prova por derivação. Ou seja, uma prova lícita é produzida a partir do conteúdo de uma prova ilícita ou obtida de forma ilícita, de sorte que aquela só foi produzida em razão do conhecimento do resultado da segunda. (Curso sistematizado de direito processual civil, cit., v. 1, p. 137).

${ }^{597}$ BARBOSA MOREIRA, José Carlos. A Constituição e as provas ilicitamente obtidas. In. Temas de direito processual: sexta série. São Paulo: Saraiva, 1997. p. 110.
} 
Outra questão que merece comentários diz respeito à admissibilidade de prova emprestada tomada de uma prova produzida no juízo penal para fins de investigação criminal e cuja produção inicial fosse inadmitida no juízo civil. Ou seja, poderia eventual escuta telefônica ${ }^{598}$ produzida no juízo penal e mediante autorização do juiz para fins de instrução criminal (portanto, uma regra de exceção à vedação da produção de prova por meio ilícito) ser utilizada como prova emprestada no processo civil? A doutrina tem se manifestado no sentido de admitir como prova emprestada a produzida no processo criminal, ${ }^{599}$ considerada portanto uma prova atípica (art. 332 do CPC). ${ }^{600}$ De todo modo, entendemos que a admissibilidade dessa mesma prova emprestada, se originariamente considerada como prova produzida por meio ilícito no juízo cível, ficaria condicionada às exceções sustentadas nos parágrafos anteriores (ponderação de princípios), de sorte que à parte contra quem é produzida a prova deverá ser assegurado o contraditório e demais garantias processuais constitucionais.

Até o momento, discorremos sobre os poderes instrutórios do juiz no que toca à admissibilidade em juízo da prova obtida por meio ilícito. Resta, portanto, a tentativa de solucionar se, sob a ótica dos poderes instrutórios, poderia o juiz cível ter a iniciativa probatória de produção de prova cujo meio é considerado ilícito pelo ordenamento. Para esse questionamento, dispensa-se, de plano, maiores aprofundamentos. Isso porque, não obstante as raízes e fundamentos que sustentam a iniciativa probatória do juiz para descobrimento da verdade, ou maior sua aproximação necessária a proporcionar julgamento o mais justo possível, há regras no sistema que devem ser rigidamente observadas.

\footnotetext{
${ }^{598}$ A escuta telefônica é a feita por terceiro, com o conhecimento de um dos interlocutores, podendo ter sido produzida por interesse e iniciativa deste. Por sua vez, a interceptação telefônica é realizada por um terceiro, desprovida da ciência dos interlocutores.

599 Nesse sentido, Cassio Scarpinella Bueno (Curso sistematizado de direito processual civil, cit., v. 1, p. 138) e Nelson Nery Junior, para quem a natureza da causa civil é irrelevante para a admissão da prova emprestada obtida no juízo penal para investigação criminal ou instrução processual penal: "Desde que a escuta tenha sido determinada para servir de prova direta na esfera criminal, pode essa prova ser emprestada ao processo civil." (Princípios do processo civil na Constituição Federal, cit., p. 268). Todavia, a admissibilidade da prova emprestada fica condicionada à participação da parte contra quem é produzida a prova, na ocasião em que se apresenta a prova a ser emprestada, efetivando-se assim o contraditório.

${ }^{600}$ Para João Batista Lopes, a prova emprestada constitui espécie de prova atípica (A prova no direito processual civil, cit., p. 176). Todavia, a sua valoração não se vincula ao entendimento do juízo do qual se tomou emprestada a prova, ficando reservado o critério da persuasão racional ao juiz que a toma emprestada (Ibidem, p. 65).
} 
Nesse contexto, o preceito tratado no art. $5^{\circ}$, LVI, da Constituição Federal soa como uma regra rígida e limitativa da iniciativa do magistrado de produzir provas por meio considerado ilícito. Não fosse assim, o legislador constitucional não teria restringido como exceção à regra as hipóteses de investigação ou instrução criminal. Inexistiria, por conseguinte, norma infraconstitucional regulamentando essas exceções. ${ }^{601}$ Vale dizer, a mera iniciativa da produção da prova, por si só, já é considerada ilícita pelo ordenamento. Ademais, na medida que excepcionalmente a prova produzida por meios ilícitos tem sido admitida, à luz da importância do conteúdo e relevância de seu resultado em detrimento de um princípio que restaria suprimido, torna-se difícil aplicar esse mesmo raciocínio à iniciativa probatória cujo meio de plano já é vedado pelo ordenamento, e cujo resultado o magistrado sequer sabe.

Ou seja, o juiz já cometeria uma ilegalidade ao determinar a produção de prova cujo meio é vedado pelo sistema, sem sequer ter conhecimento do resultado da prova (logo, exaure-se por completo qualquer regra que relevaria o resultado da prova e sua repercussão diante da admissibilidade da prova ilicitamente produzida) e, caso tivesse conhecimento antecipado desse resultado, manifesta seria sua imparcialidade, porquanto teria a iniciativa probatória de prova cujo resultado já era esperado e conhecido pelo próprio julgador. ${ }^{602}$ Por sua vez, tal qual exposto nesse capítulo, de igual modo que (i) a prova ilícita por derivação ou (ii) a prova produzida no juízo penal como exceção à vedação do princípio (v.g., interceptação telefônica autorizada pelo juízo criminal) podem ser admitidas como prova emprestadas (observadas as restrições acima expostas), nada impede que o magistrado, tendo conhecimento da possibilidade da produção dessas provas, venha ter a iniciativa probatória para trazer tais elementos aos autos. Afinal, de igual modo

\footnotetext{
${ }^{601}$ A exemplo da já citada Lei n. 9.296/96, que disciplina as condições em que o juiz penal, para fins de instrução criminal, pode determinar a quebra dos sigilos telefônicos e de outras fontes do acusado.

${ }^{602}$ Bedaque apresenta um exemplo isolado, em que se poderia cogitar a iniciativa probatória na produção de uma prova por meio ilícito: "Daí a seguinte sugestão: não teria a parte interessada na prova, e que para consegui-la comportou-se de maneira ilícita, o direito de exigir a sua apresentação? Caberia ao magistrado, exclusivamente, ponderar sobre a necessidade e conveniência da produção. Se a conclusão for afirmativa, determinaria ele, ex officio, a vinda para os autos da prova obtida ilicitamente. Evidentemente, o julgador somente poderia utilizar-se desse poder em caráter excepcional, isto é, apenas quando a produção da prova lhe pareça absolutamente imprescindível para que o escopo do processo seja alcançado. E após rigorosa ponderação dos valores que se contrpõe. Assim, apresentando-se essa situação excepcional, o julgador, ao tomar conhecimento da existência de uma prova, determinaria sua produção, ainda que obtida por meio ilegal. A eventual ilicitude não pode afastar por completo o poder instrutório do juiz. No caso em tela, esse poder seria ainda maior, visto que não importaria a parte interessada pretender trazê-la aos autos. Aqui, a iniciativa probatória seria exclusiva do magistrado." (Poderes instrutórios do juiz, cit., p. 146-147).
} 
que se sustenta a admissibilidade dessas provas em hipóteses excepcionais, seria um contra-senso vedar a iniciativa probatória.

Logo, a admissibilidade de prova obtida por meio ilícito deve obedecer a condições excepcionais, pautadas na aplicação do princípio da proporcionalidade, ao passo que a iniciativa probatória do juiz na produção de prova cujo meio é ilícito não parece ser uma das medidas mais adequadas para atingir os escopos do processo, sem que se infrinja o direito processual constitucional, buscando uma prova cujo resultado ab initio sequer se conhece.

\subsubsection{Princípio da duração razoável do processo}

A Emenda Constitucional n. 45/2004, acresceu, dentre outras providências, o inc. LVIII ao art. $5^{\circ}$ da Constituição Federal de 1988, para tornar cláusula pétrea e garantia fundamental a duração razoável do processo e os meios que garantam a celeridade de sua tramitação. Esse princípio apresenta feição dúplice, consistente não só no tempo do processo até o seu trânsito em julgado, mas também implica a adoção de meios alternativos de solução de conflitos, de sorte a aliviar a carga de trabalho da Justiça ordinária e assim abreviar a duração média do processo. ${ }^{603}$

Para traçar melhores contornos ao conteúdo do que é entendido por duração razoável do processo, importa definir alguns critérios a serem observados para permitir delimitar o grau de tempo de duração entendido por razoável para um processo: a) a natureza do processo e a complexidade da causa; b) o comportamento das partes e de seus procuradores; c) a atividade e o comportamento das autoridades judiciárias e

\footnotetext{
${ }^{603}$ NERY JUNIOR, Nelson, Princípios do processo civil na Constituição Federal, cit., p. 314. Segundo José Rogério Cruz e Tucci, para detectar a ocorrência de indevida dilação processual deve-se proceder ao exame: a) da complexidade do assunto; b) do comportamento dos litigantes e de seus procuradores ou da acusação e da defesa no processo penal; e, c) da atuação do órgão jurisdicional (Tempo e processo. São Paulo: Revista dos Tribunais, 1997. p. 145)
} 
administrativas competentes; e, d) a fixação legal de prazos para a prática de atos processuais que assegurem efetivamente o direito ao contraditório e ampla defesa. ${ }^{604}$

Embora tais critérios objetivem dar parâmetros ao conceito jurídico indeterminado “duração razoável”, deve-se ponderar se a busca do valor celeridade necessariamente conduz a uma decisão que prime pela justiça e efetividade. Diante da expressa adoção desse princípio no sistema brasileiro, questiona-se até que ponto seria possível dar efetividade ao processo e ao mesmo tempo preservar o respeito às demais garantias processuais e constitucionais. Em verdade, a morosidade da Justiça não se resolve através da mera consagração de um princípio, senão após identificados e combatidos os reais problemas que engessam a celeridade do processo. ${ }^{605}$ Afinal, "se uma Justiça lenta demais é decerto uma Justiça má, daí não se segue que uma Justiça muito rápida seja necessariamente uma Justiça boa" ${ }^{606}$

Portanto, o novel princípio deve ser observado com parcimônia, para se evitar a hipertrofia do valor celeridade, o que ao mesmo tempo pode comprometer a qualidade da justiça das decisões. Até porque outros fatores concorrem para a morosidade da Justiça,

\footnotetext{
${ }^{604}$ Nelson Nery Junior relata que os critérios objetivos "a", "b" e "c" restaram fixados no âmbito da União Europeia em diversas decisões do Tribunal Europeu de Direitos Humanos (Acórdãos Manzoni, de 19.02.1991, A 195-B, p. 29, § 7º Kemache, de 27.11.1991, A 218, p. 27, § 60; Doustaly, de 23.04.1998, R 98, § 39), critérios esses também adotados pela Legge Pinto (L 89, de 24.03.2001) para compelir o Poder Público italiano a indenizar os danos morais e patrimoniais causados pela duração exagerada do processo (Princípios do processo civil na Constituição Federal, cit., p. 315).

${ }^{605}$ Leciona Antonio Carlos Marcato que o custo e a duração do processo constituem os obstáculos mais angustiantes que se antepõem ao destinatário final da atividade exercida no processo ( $O$ processo monitório brasileiro. 2. ed. São Paulo: Malheiros, 2001. p. 20).

${ }^{606}$ As advertências são feitas por Barbosa Moreira, que discorre sobre inúmeros mitos difundidos para se aperfeiçoar a Justiça (O futuro da Justiça: alguns mitos. In: Temas de direito processual: oitava série. São Paulo: Saraiva, 2004. p. 5). No que toca à breve análise do princípio da duração razoável do processo, vale lembrar do mito intitulado por esse autor como "a rapidez acima de tudo (ou quanto mais depressa, melhor)", que está dividido em quatro submitos aqui resumidos: a) submito n. 1: a crença de que a morosidade da Justiça é problema exclusivamente brasileiro, que, em verdade, tem escala mundial, a exemplo do levantamento de dados apresentandos na Itália (entre 1991 e 1997, um processo durava em média quatro anos, apenas em primeiro grau de jurisdição), no Japão (a duração média de um decênio consumida por um processo que se arrasta da primeira instância até a decisão da Corte Suprema) e nos Estados Unidos (onde se constatou que um processo chega a durar em média na primeira instância de três a cinco anos), dentre outros países; b) submito n. 2: a ideia de que todos os jurisdicionados clamam por uma rápida solução do litígio, o que na verdade caminha em direção oposta, porquanto o desejo de pelo menos um dos litigantes é o de que o feito se prolongue tanto quanto possível e os advogados se valham de todos os meios para procrastinar o desfecho do processo; c) submito n. 3: consistente na crença de que cabe aos defeitos da legislação processual a maior responsabilidade pela duração excessiva dos pleitos, quando na verdade, o foco deve ser concentrado na falta de aparelhamento estatal e deficiência do número de juízes para atender a todos os jurisdicionados; d) submito n. 4: o superdimensionamento do valor celeridade, de sorte que tal fator será a panaceia para todos os males, o que põe em risco a própria qualidade das decisões judiciais.
} 
tais como a escassez de tempo e o volume de serviços, a falta de aparelhamento estatal e até mesmo o ímpeto do litigante sucumbente de sempre, ou na maioria das vezes, desejar recorrer até a última oportunidade que lhe seja franqueada.

Não pretendemos aqui aprofundar a discussão acerca da melhor definição que interprete o significado da "duração razoável do processo" ou buscar meios de se atender à efetividade dessa garantia, tema esse que refoge a esta proposta. Todavia, entendemos que a observância da duração razoável não pode servir como lenitivo a um juiz que deixe de produzir determinada prova ou que julgue o processo de forma deficiente no campo probatório para, de um lado, atender à essta garantia constitucional e, de outro, deixar de entregar a tutela jurísdicional justa. Em verdade, o problema da morosidade da Justiça está ligado a muitos fatores que não se restringem a atividade do juiz. É o que aponta Fritz Baur, ao discorrer acerca de parecida problemática vivenciada na Alemanha, e que se assemelha à realidade brasileira:

\begin{abstract}
"As causas são variadas: a sobrecarga dos Tribunais decorrente do crescimento do número de processos, insuficiência do equipamento dos Tribunais, no que diz respeito quer a recursos técnicos, quer a recursos humanos, mas também, e não em último lugar, em decorrência de uma exploração insuficiente dos meios de aceleração fornecidos pela lei." ${ }^{607}$
\end{abstract}

Portanto, a despeito de louvável a ideologia calcada nesta garantia constitucional, entendemos que a duração razoável não deve tolher a atividade do magistrado ligada à colheita de provas necessárias à formação de seu livre convencimento, de modo a não se aproximar de uma regra de limitação ao exercício dos poderes instrutórios. ${ }^{608}$ Afinal, mais

${ }^{607}$ BAUR, Fritz, O papel ativo do juiz, cit., p. 191.

${ }^{608}$ Sidney da Silva Braga acresce como limitação aos poderes instrutórios o respeito ao direito que as partes têm de obter uma prestação jurisdicional em tempo e mediante custo razoáveis. Para tanto, afirma que a verdade absoluta é inatingível no processo, de sorte que as decisões judiciais devem se contentar com determinado grau de probabilidade, maior ou menor, alcançado com as técnicas de cognição sumária ou exauriente, conforme sejam decisões liminares e provisórias ou finais e aptas a se tornarem definitivas pelo instituto da coisa julgada. (Iniciativa probatória do juiz no processo civil, cit., p. 140-141). Assim discorre: “(...) considerando a equação quase inexorável segundo a qual quanto mais se aprofunda ainvestigação probatória, mais o processo se torna moroso e custoso, deve o juiz ter redobrada cautela e apurado bom senso ao utilizar seus poderes instrutórios (...) se o processo não é do interesse exclusivo das partes, também não o é do Estado, cujo representante é o juiz, que não pode estender a cognição, por sua iniciativa exclusiva, a limites que configurem verdadeira negação da prestação jurisdicional em tempo razoável. Apresenta-se, também aqui, neste tema específico, o velho dilema que insiste em desafiar os processualistas de todos os tempos e lugares: a contraposição da segurança jurídica à celeridade processual”. Ao final, conclui que deve o juiz comparar os eventuais benefícios que a prova poderá trazer ao alcance da justiça processual possível naquele caso com os prováveis inconvenientes decorrentes do aumento estimado da duração e o custo do processo para as partes. 
vale uma sentença que seja justa e pacifique um conflito de modo équo do que uma decisão proferida às pressas e desprovida de conhecimento sobre qual parte tinha razão na demanda. Até porque essa "falsa celeridade" ao final pode revelar "extrema morosidade", considerando que uma decisão injusta seja passível de inconformismo e inevitavelmente consumirá mais tempo até efetivar-se a sua reforma.

Logo, cumpre esclarecer que as ideias constantes neste trabalho se aproximam mais do campo ideológico para traçar fundamentos que permitam e também não deixem de restringir o exercício dos poderes instrutórios, acompanhadas de sugestões práticas que serão apresentadas no capítulo seguinte. Em contrapartida, são constantes as reticências voltadas a perquerir ser manifestamente impossível que o juiz venha se valer de seus poderes instrutórios com a finalidade de realizar a concreta vontada de lei, dentre elas as assertivas de elevado volume de trabalho, a desproporção entre o número de juízes e os que buscam o Poder Judiciário, a necessidade que se vê imbuído o magistrado para decidir provimentos de urgência de forma rápida ${ }^{609}$ e um sem-número de fatores que em verdade estão mais ligados à deficiência de aparelhamento estatal do Poder Judiciário. Parece-nos que tais escusas reclamam melhores reflexões voltadas a suprir o problema da carência de aparelhamento material e pessoal para servir o Poder Judiciário, o que não se confunde com os fundamentos para que o juiz tenha iniciativas probatórias e busque proporcionar um julgamento mais próximo da certeza ao decidir. Embora tais problemas estejam ligados, não é piorando a qualidade da justiça em busca de um julgamento mais célere que se resolverá o problema da morosidade. Conforme já mencionado no parágrafo anterior, supera-se um obstáculo para, ao final, criar outro. Por essa razão, o que se deve ter como premissa é a concentração do foco para combater a morosidade da Justiça, conforme apontada Antonio Carlos Marcato:

"A preocupação vem centrada, portanto, na observância do tempo programado para a obtenção do resultado prático esperado do processo, em atenção à promessa do direito material. Essa é a mola mestra que impulsiona as reformas constitucionais e processuais nos dias que

\footnotetext{
${ }^{609}$ Os tribunais e associações, sob a coordenação do Conselho Nacional de Justiça, criaram em 2009 a campanha "Meta 2: bater recordes é garantir direitos". Trata-se de "um desafio que o Judiciário deve superar e um serviço que a sociedade merece receber" (Metas de nivelamento - Meta 2). Ela consiste em "identificar os processos judiciais mais antigos e adotar medidas concretas para o julgamento de todos os distribuídos até 31.12.2005 (em $1^{\circ}, 2^{\circ}$ grau ou tribunais superiores)". Disponível em: <http://www.cnj.jus.br/index.php?option=com_content\&view=article\&id=7909\&Itemid=963>. Acesso em: 10 dez. 2009.
} 
correm, tendo por foco a busca de decisões justas, obtidas em prazo razoável e a custo suportável pelas partes. Busca utópica, talvez, mas indispensável à manutenção da crença da justiça."

Nesse contexto, Italo Andolina pondera:

“'Tempo del processo' e 'processo nel tempo' si coniugano ed intreciano in obbedienza a regole differenziate ma egualmente (ciascuna nel suo âmbito di operatività) funzionali. L'uma (il tempo del processo), operando all 'interno del processo quale elemento organizzatorio di esso, si prefigge di garantirne la ragionevole durata, e di assicurare quindi la 'tempestività-effettività' della tutela giurisdizionale; l'altra (il processo nel tempo), volgendo lo sguardo ai rapporti tra processo e realtà ad esso esterna, si propone di garantir ela coerenza del prodotto giustiziale ai fatti in perenne divenire: che è quanto dire, la sua verità."611

Por fim, a garantia em tela não deve ser esquecida, mas sua aplicação implica na regra de proporcionalidade necessária a ponderar a conjugação de valores assim definidos: “celeridade (duração razoável) x julgamento justo mediante aproximação de um juízo de certeza (poderes instrutórios)". ${ }^{612}$ Sidney da Silva Braga conclui que "não há como fixar uma regra objetiva, que seja aplicável a todas as hipóteses. Sem querermos adotar solução que fuja do debate pelo caminho mais fácil, a verdade é que, aqui, vale uma repetida máxima do direito: cada caso é um caso". ${ }^{613}$

São aspectos subjetivos que devem ser observaados quando adotada postura mais participativa do magistrado, em colaboração com as partes, na produção da prova produzida em contraditório. Afinal, o resultado da prova não é conhecido pelo juiz, de modo a angariar mais elementos para se alcançar uma decisão mais justa e que ao mesmo

\footnotetext{
${ }^{610}$ MARCATO, Antonio Carlos. Crise da justiça e influência dos precedentes judiciais no direito processual civil brasileiro. Tese (Professor Titular) - Faculdade de Direito da Universidade de São Paulo São Paulo, 2009. p. 14.

${ }^{611}$ ANDOLINA, Italo. Il tempo e il processo. Revista de Processo, São Paulo, Revista dos Tribunais, ano 34, n. 176, p. 259-274, out. 2009.

${ }^{612}$ Nesse sentido, Dinamarco bem adverte que: "Processo efetivo não é apenas o que rigorosamente atue a vontade concreta do direito, mas o que seja capaz de cumprir bem os escopos do sistema, vistos em conjunto e compensadas certas deficiências por outras vantagens. O processo que chegue ao ideal de segurança jurídica com razoável celeridade, eliminando o conflito, é eficaz e legitimado pela utilidade social, ainda que falho do ponto de vista jurídico." (A instrumentalidade do processo, cit., p. 328).

${ }^{613}$ BRAGA, Sidney da Silva, Iniciativa probatória do juiz no processo civil, cit., p. 141. Em semelhante sentido, Carlos Alberto Alvaro de Oliveira bem adverte que a postura de uma corte jacobina, uma busca frenética da verdade, pode prejudicar os bons resultados do exercício da jurisdição, o que remete ao conflito entre celeridade e ponderação, traduzível também na possível dissonância entre justiça e pacificação (Do formalismo no processo civil, cit., p. 177).
} 
tempo não dilate excessivamente a razoável duração do processo, cuja problemática, em verdade, não se restringe ao ativismo judicial em relação às iniciativas probatórias.

\subsection{Iniciativas probatórias do juiz e os princípios infraconstitucionais do processo civil}

As iniciativas probatórias do magistrado guardam ligação com alguns princípios do processo civil norteadores da atividade do magistrado. Por opção metodológica, pretendemos confrontar as iniciativas probatórias de ofício com esses princípios civis. ${ }^{614}$

\subsubsection{Princípio dispositivo}

Um dos princípios mais utilizados como justificativa para tolher os poderes instrutórios do juiz é o princípio dispositivo. ${ }^{615}$ Exatamente por estar ligado à instrução da causa, esse princípio reza, em linhas gerais, que o juiz depende da iniciativa das partes quanto às provas e às alegações em que se fundamentará a decisão (judex secundum allegata et probata partium iudicare debet). ${ }^{616}$ Pontes de Miranda define o princípio dispositivo como:

\footnotetext{
${ }^{614}$.Outros princípios guardam importância para a dinâmica das iniciativas probatórias, como o princípio da oralidade. Para uma leitura mais aprofundada desse tema, ver: MORAES, José Rubens de. Princípio da oralidade: visão comparativa das suas mútliplas manifestações nos sistemas common law e "europeu continental"... In:. CARVALHO, Milton Paulo de (Coord.). Direito processual civil. São Paulo: Quartier Latin, 2007. p. 101-163.

${ }^{615}$ Cassio Scarpinella Bueno define o "princípio da vinculação do juiz ao pedido" ou sinônimos empregados pela doutrina como "princípio da imutabilidade do libelo", "princípio da adstrição do juiz ao pedido", "princípio da congruência", "princípio da adstrição da correlação entre provimento e demanda" e, finalmente, "princípio dispositivo" como a veiculação da tutela jurisdicional "limitada ao que o autor, qualitativa e quantitativamente, requereu quando rompeu a inércia da jurisdição" (Curso sistematizado de direito processual civil, cit., v. 1, p. 495-496). Sobre maiores aprofundamentos acerca do princípio dispositivo, ver: ESTEVES, Carolina Bonadiman. (In)disponibilidade do direito processual civil: uma análise do seu reflexo sobre a atividade do juiz e das partes à luz dos princípios fundamentais. Dissertação (Mestrado em Processo Civil) - Faculdade de Direito da Universidade de São Paulo, São Paulo, 2002.

${ }^{616}$ SANTOS, Moacyr Amaral, Primeiras linhas de direito processual civil, cit., v. 2, p. 76. Para Moacyr Amaral Santos, cabe ao juiz, na instrução da causa, conhecer apenas dos fatos em que se funda o pedido, ficando restrito às alegações das partes, ao passo que para a apuração de tais fatos, é permitida ampla iniciativa probatória pelo magistrado. Ousamos discordar dssa segunda assertiva, na medida que, nos termos do art. 131 do Código de Processo Civil, o juiz apreciará livremente a prova, atendendo aos fatos e circunstâncias constantes nos autos, "ainda que não alegados pelas partes". Portanto, é o juiz quem amealha elementos necessários a formar seu livre convencimento e, ao final, decidir o pedido, conforme será melhor elucidado no item 4.2.3.
} 
“(...) aquele segundo o qual, entre outras vedações, o juiz não pode levar em conta, na sua apreciação do feito, a qualquer momento, fatos que não foram alegados pelas partes, nem formar a sua conviç̧ão com os meios que, propostos pelos litigantes, não se produziram com observância das regras legais." ${ }^{\circ 17}$

Por sua vez, João Batista Lopes, ${ }^{618}$ Humberto Theodoro Júnior, ${ }^{619}$ José Frederico Marques $^{620}$ e Aclibes Burgarelli ${ }^{621}$ vão mais além e definem o princípio dispositivo associado não só com a ideia de iniciativa das partes quanto à produção de provas, mas compreendendo também as alegações e os pedidos formulados (arts. $2^{\circ}, 128$ e 460 do CPC). Logo, é vedado ao juiz decidir a demanda além, de sorte a dar mais do que restou pedido pelo autor (ultra petita), aquém, para assim conceder pedido de natureza ou objeto diverso do requerido (extra petita), ou ainda deixar de apreciar e decidir um dos pedidos ou o pedido formulado pelo autor (infra citra petita). ${ }^{622}$

Em linhas gerais, o princípio dispositivo é aquele segundo o qual a vontade relevante e decisiva no processo é a das partes: consiste no poder das partes de dispor do processo civil, determinando com a sua atuação o início, o objeto, o desenvolvimento e o término do processo. ${ }^{623}$ Não são pacíficos na doutrina a dimensão do princípio dispositivo e seu conteúdo.

${ }^{617}$ PONTES DE MIRANDA, Francisco Cavalcanti. Comentários ao Código de Processo Civil, cit., p. 406. Em igual sentido: SILVA, Ovídio A. Baptista da, Curso de processo civil: processo de conhecimento, cit., p. 59.

${ }^{618}$ LOPES, João Batista, A prova no direito processual civil, cit., 195 e 199. No que toca à disponibilidade da prova, referido doutrinador sustenta que o princípio dispositivo opõe-se ao princípio inquisitório (ou inquisitivo) em que a iniciativa é conferida ao juiz.

${ }^{619}$ THEODORO JÚNIOR, Humberto, Curso de direito processual civil, cit., v. 1, p. 27.

${ }^{620}$ MARQUES, José Frederico, Manual de direito processual civil, cit., v. 2, p. 338.

${ }^{621}$ BURGARELLI, Aclibes, Tratado das provas cíveis, cit., p. 29.

${ }^{622}$ A regra do juiz decidir a demanda nos termos pleiteados pelo autor comporta algumas exceções: na condenação em prestações periódicas (art. 290 do CPC), na condenação ao pagamento de honorários advocatícios (art. 20 do CPC), na inclusão de juros moratórios (art. 293 do CPC e Súmula n. 254 do STF) e incidência de correção monetária (art. $1^{\circ}$, da Lei n. 6.899/81). Outras exceções se verificam quanto ao conceito jurídico indeterminado "resultado prático equivalente" presente no art. 461, § $1^{\circ}$, do Código de Processo Civil, que trataremos no Capítulo 5, e, consoante lembra Bedaque, quando o juiz fixa multa diária ao réu para cumprimento de obrigação de fazer ou de não fazer em ação de conhecimento ( $\operatorname{art}$. 461 , $\S 4^{\circ}$, do CPC), assim como na execução de título executivo extrajudicial (art. 645 do CPC) (Poderes instrutórios do juiz, cit., p. 96).

${ }^{623}$ ESTEVES, Carolina Bonadiman, (In)disponibilidade do direito processual civil..., cit., p. 104. Semelhante constatação é traçada por Milton Paulo de Carvalho: "Consiste esse princípio em poder a parte deduzir ou não sua pretensão em juízo, bem como deduzi-la como lhe aprouver, não se permitindo a nenhum juiz desencadear o procedimento ou alterar por sua conta a postulação ou a defesa sem provocação do interessado quando e como permitido pela lei." (Os princípios e um novo Código de Processo Civil. In. CARNEIRO, Athos Gusmão; CALMON, Petrônio (Orgs.). Bases científicas para um renovado direito processual. Brasília: Instituto Brasileiro de Direito Processual, 2008. v. 1, p. 208). 
Grinover, Cintra e Dinamarco relacionam a vedação do juiz ir além do pedido com o "princípio da ação", 224 ao passo que José Manoel de Arruda Alvim trata do princípio dispositivo como a vinculação do juiz às provas produzidas e aos fatos alegados, de modo que não pode ir além do tema probatório, ou seja, "da lide ou do objeto litigioso, nem infringir o princípio do ônus (subjetivo) da prova". ${ }^{625}$ Por sua vez, Niceto Alcalá-Zamorra y Castillo ${ }^{626}$ pondera que as partes podem convencionar sobre objetos cujo reflexo repercuta no direito processual e interfiram na área do julgador, a exemplo da eleição de comum acordo para dirimir eventual conflito, desde que a natureza do direito material em litígio não esbarre em norma cogente de competência absoluta.

Carolina Bonadiman Esteves, após discorrer acerca da discussão doutrinária entre o chamado princípio da demanda e o princípio dispositivo, opta por dividir o princípio dispositivo lato sensu em princípio da disponibilidade do início do processo, do objeto, do desenvolvimento e do termo do processo. A disponibilidade do início do processo ou da demanda está ligada ao brocardo nemo judex sine actore, ne procedat judex ex officio, ubi non est actio, ibi non est jurisdictio, de sorte a traduzir a vedação ao juiz, regra geral, de iniciar o processo. A disponibilidade do objeto e dos limites do processo traduz-se na disponibilidade do pedido e da respectiva causa de pedir, daí extraindo-se o princípio da adstrição ou da congruência, segundo o qual o juiz está limitado às alegações de fato e ao pedido formulado pelas partes. ${ }^{627}$ Por sua vez, a disponibilidade do desenvolvimento do

${ }^{624}$ CINTRA, Antonio Carlos de Araújo; GRINOVER, Ada Pellegrini; DINAMARCO, Cândido Rangel, Teoria geral do processo, cit., p. 66. O princípio da ação está amplamente ligado ao princípio da inércia da jurisdição (art. $5^{\circ}, \mathrm{XXXV}$, da $\mathrm{CF}$ ) e, para esses autores, possui três acepções: a primeira consiste na iniciativa de provocar a movimentação do aparelho jurisdicional; a segunda reflete a pretensão do réu contra o autor (reconvenção); e a terceira traduz-se na limitação imposta ao juiz para não decidir além dos limites do pedido (ne eat iudex ultra petita partium). Sem prejuízo quanto à eventual discussão ligada à inserção dessa terceira acepção junto ao princípio da ação ser a melhor opção doutrinária (o que não guarda relevância com o cerne deste trabalho), ousamos acrescer a essa terceira acepção a vedação ao julgamento além (ultra petita) e inferior (citra ou infra petita) ao pedido, o que, para a maioria da doutrina, reflete o princípio dispositivo.

${ }_{625}$ ARRUDA ALVIM, José Manoel de, Manual de direito processual civil, cit., v. 2, p. 484.

626 "Cuando la faculdad de disposición de las partes, en vez de ejercitarse respecto de la cuestión litigiosa o de fondo - en cuyo caso se trataría de parte juzgadora (supra, num. 44) -, trasciende al desarrolo de proceso y sirve, verbigracia, para alterar el régimen de la competencia o para cambiar la marcha del procedimiento, com derogación del principio de formalismo y de la noción de orden público que sobre las normas procesales se proyectan, entonces habremos de considerar tales mutaciones, sean obra de una sola de las partes o de ambas, como incursiones de éstas por los domínios del juzgador, lícitas desde el momento en que las consiente la ley, pero que no por ello se detienen ante su estricta cualidad de sujetos que piden, sino que los impulsan hasta erigirlas en sujetos que deciden (cfr. Supra, num. 4)." (ALCALÁZAMORA Y CASTILLO, Niceto. Estúdios de teoria general e historia del proceso (1945-1972). México: Universidade Nacional Autônoma de México, 1974. v. 1, p. 292-293.

${ }^{627}$ Para Rui Portanova, princípio dispositivo, princípio da congruência e princípio dispositivo em sentido material são expressões sinônimas (Os princípios do processo civil, cit., p. 121). 
processo consiste na liberdade conferida às partes quanto aos atos de impulso e andamento do processo, aí se inserindo os atos de instrução probatória. Ao final, a disponibilidade do termo do processo reflete a possibilidade das partes disporem sobre o objeto litigioso do processo mediante renúncia, reconhecimento do pedido, transação ou qualquer outro ato processual que implique no direito subjetivo das partes. ${ }^{628}$

Por fim, Bedaque bem adverte sobre a dificuldade de se definirem dimensão e conteúdo do princípio dispositivo, baseando-se em dois fenômenos apontados pela doutrina alemã relativos aos poderes do magistrado e suas limitações: um relativo à propositura da demanda (Dispositionsmaxime) e o outro ligado à estrutura interna do processo (Verhandlungsmaxime), ${ }^{629}$ optando, ao final, por reservá-lo tão somente aos reflexos que a relação de direito material disponível possa produzir no processo:

\footnotetext{
${ }^{628}$ ESTEVES, Carolina Bonadiman, (In)disponibilidade do direito processual civil..., cit., p. 107-108.

${ }^{629}$ BEDAQUE, José Roberto dos Santos, Poderes instrutórios do juiz, cit., p. 87-89. "Fala-se, por exemplo, que tal princípio significa, em sentido amplo, deixar para as partes os ônus de iniciação, determinação do objeto, impulso do processo e produção de provas (...). Outros preferem a expressão 'princípio da demanda' para referir-se ao primeiro fenômeno, enquanto 'princípio dispositivo' representaria apenas o segundo. Até sobre o conteúdo de cada um há controvérsia. Uns acham que a dedução dos fatos, da causa de pedir, integra o Dispositionsmaxime, pois, se em consequência da natureza privada do direito subjetivo, a parte tem o monopólio sobre a propositura da demanda, evidentemente que, nesse poder, inclui-se a sua identificação, ou seja, a limitação imposta ao juiz de decidir apenas a respeito dos fatos narrados. Outros sustentam que a dedução dos fatos apenas pelas partes integra o Verhandlungsmaxime." (Ibidem, p. 89-90). Barbosa Moreira aponta as inúmeras variações na doutrina alemã no começo do século XIX relativas à disponibilidade de direitos no processo, nomenclaturas adotadas e reflexos nos poderes do juiz. A Verhandlungsmaxime consiste na "máxima (ou princípio) do debate" possível a indicar a limitação do material utilizável no julgamento àquilo que os litigantes tragam à discussão. Algumas décadas mais tarde foi proposta a Verhandlungmaxime-Untersuchungsmaxime, ligada com o modo de funcionar do mecanismo processual no tocante aos fatos e à prova deles (disponibilidade própria ou material, poder de introduzir no processo a matéria de fato, de decidir sobre a necessidade da respectiva verificação e de tomar a iniciativa desta) e a Dispositionsmaxime, relacionada com a liberdade do titular do direito de utilizar ou não o instrumento do processo para a respectiva vindicação (disponibilidade imprópria ou processual, poder de decidir sobre a instauração do processo, sobre a respectiva subsistência e sobre a delimitação do litígio e disposição do objeto do processo pela parte), fragmentada por alguns autores na Parteibetrieb, consistente na iniciativa da parte de instaurar o processo e mantê-lo em movimento - impulso processual. (O problema da divisão de trabalho entre o juiz e as partes. Revista de Processo, São Paulo, Revista dos Tribunais, ano 11, n. 41, p. 9-10, jan./mar. 1986). Para Bedaque, o Dispositionsmaxime, por estar relacionado, conforme variação na doutrina, ao princípio da demanda ou princípio dispositivo, não decorre da disponibilidade do direito substancial. Por sua vez, o Verhandlungsmaxime, que reflete a verdadeira feição do princípio dispositivo, porquanto diz respeito à estrutura interna do processo mantida sob o domínio das partes, também deve ser repelida pela ciência processual, por estar ligada a contornos privatistas e plena disponibilidade das relações jurídico-processuais, hoje ultrapassadas. (Poderes instrutórios do juiz, cit., p. 93). Semelhante é a definição dada por Fritz Baur, ao aduzir que o Dispositionsmaxime diz respeito à prerrogativa das partes de disporem do objeto do litígio, ao passo que o Verhandlungsmaxime ou "máxima dos debates" trata da introdução no processo, oralmente ou por escrito, dos fatos alegados (O papel ativo do juiz, p. 188 e 191).
} 
"Assim, tratando-se de direito disponível, as partes têm ampla liberdade
para dele dispor, através de atos processuais (renúncia, desistência,
reconhecimento do pedido). E não pode o juiz opor-se à prática de tais
atos, exatamente em virtude da natureza do direito material em questão.
Essa sim corresponde à verdadeira e adequada manifestação do princípio
dispositivo. Trata-se de um princípio relativo à relação material, não à
processual. ${ }^{630}$

Daí porque, em relação ao conhecimento do objeto litigioso e aos atos de instrução necessários à efetiva entrega da tutela jurisdicional, o juiz não fica adstrito à vontade dos litigantes, pois na relação processual o interesse sempre será indisponível e sendo essa relação jurídica pública, caberá ao Estado-juiz realizar a concreta vontade da lei. Vale dizer, uma vez submetido o litígio à decisão do órgão estatal, caberá a ele amealhar todos os elementos necessários, na tentativa de proporcionar a pacificação social e a ordem jurídica justa. Logo, não cabe exclusivamente às partes dispor sobre as provas que serão produzidas para a entrega da tutela jurisdicional, mas ao magistrado deve angariar todos os elementos necessários à formação de seu livre convencimento para, ao final, decidir a lide nos termos do pedido. Ou seja, o interesse pela pacificação social pertence ao Estado-juiz, e não às partes. De igual modo, cabe a ele a melhor condução do processo, com vistas a entregar a tutela jurisdicional que seja a mais justa possível.

Nesse contexto, soa mais adequada a definição de Mauro Cappelletti, pela qual o princípio dispositivo em sentido material ou próprio consiste no poder exclusivo da parte, na exigência da tutela jurisdicional, de fixar o objeto litigioso, cabendo só a ela a disponibilidade de tais direitos (salvo os direitos indisponíveis), ao passo que o princípio dispositivo em sentido processual ou impróprio denota a vinculação do juiz à iniciativa das partes quanto ao desenvolvimento do processo e dos instrumentos para a formação do convencimento judicial, sendo que no princípio dispositivo em sentido processual, caberá ao magistrado ir além do proposto pelas partes quando necessário à investigação dos fatos e provas necessários a decidir o pedido. ${ }^{631}$

Com vistas a melhor compreender os limites do princípio dispositivo e seus reflexos diante das iniciativas probatórias do juiz, optamos pela concepção ampla, de sorte a compreender não só os atos que dependam de iniciativa das partes e relativos à

\footnotetext{
${ }^{630}$ BEDAQUE, José Roberto dos Santos, Poderes instrutórios do juiz, cit., p. 90.

${ }^{631}$ CAPPELLETTI, Mauro, La testimonianza della parte nel sistema dell'oralità: contributo alla teoria della utilizzazione probatoria del sapere delle parti nel processo civile, cit., p. 358, nota 432.
} 
disposição do objeto litigioso e das prerrogativas processuais, mas também à regra de conhecimento da decisão da demanda nos limites do que foi pedido. ${ }^{632}$ Assim, trataremos do princípio dispositivo naquilo que pertine ao balizamento da iniciativa do juiz e das partes quanto à produção das provas no processo. No que toca ao princípio dispositivo, não há como deixar de discorrer acerca do princípio da disponibilidade que, em verdade e diante das inúmeras posições doutrinárias retrocitadas, corresponde a um desdobramento do princípio dispositivo. ${ }^{633}$

\subsubsection{Princípio da disponibilidade e da indisponibilidade}

O princípio da disponibilidade e da indisponibilidade está ligado com a disponibilidade que as partes têm ou não em exercer seus direitos. No que toca à disponibilidade, esse sentido compreende não só a faculdade conferida às partes de pleitear ou não a tutela jurisdicional, mas também o exercício de prerrogativas endoprocessuais. ${ }^{634}$ Como premissa metodológica deste estudo, trataremos do princípio da disponibilidade e indisponibilidade ligado aos atos das partes exercidos dentro do processo.

\footnotetext{
${ }^{632}$ Conclui Barbosa Moreira: “A rigor, a denominação poderia reputar-se adequada a um único tópico: o dos atos de disposição que as partes pratiquem no curso do processo. Com efeito, afigura-se lógico referir à disponibilidade da relação litigiosa, no particular, a vinculação do órgão judicial, que sem dúvida aprecia a matéria pelo prisma da validade - verificando, justamente, se o direito era mesmo disponível -, mas não pode pronunciar-se sobre o conteúdo do ato praticado, sob pena de indevido cerceamento da autonomia da vontade dos litigantes Aí está, na verdade, fenômeno que faz sentido ligar a um princípio chamado 'dispositivo'. Quanto aos outros que se costumam mencionar neste contexto, parece-nos altamente duvidosa, para dizer o menos, a propriedade da correlação." (O problema da divisão de trabalho entre o juiz e as partes, cit., p. 11).

633 Outra não deixa de ser a conclusão de Dinamarco quanto à aproximação do princípio dispositivo ao princípio da disponibilidade: “O princípio dispositivo é a matriz das regras e sistemas pelos quais ao juiz não competem iniciativas probatórias. Associa-se ao princípio da demanda, que fada o juiz à inércia inicial e só admite a instauração do processo por iniciativa da parte (supra, n. 398-399) e ambos têm fundamento na disponibilidade dos direitos e do próprio poder de ação. A similitude vocabular é grande e gera alguma confusão, não sendo a doutrina unânime nem constante nessas distinções terminológicas. Em síntese, (a) o veto à iniciativa do processo pelo juiz é inerente ao princípio da demanda (arts. $2^{\circ}$ e 262 CPC); b) a proibição de fazer-se ativo na busca de elementos de convicção, agora já no processo instaurado e pendente, é a expressão do princípio dispositivo." (Instituições de direito processual civil, cit., v. 3, p. 52).

${ }^{634}$ Nesse sentido, ver: PUOLI, José Carlos Baptista, Os poderes do juiz e as reformas do processo civil, cit., p. 25-26. Como elucidado no item anterior quanto à dificuldade da doutrina convergir em uma definição acerca do princípio dispositivo, Rui Portanova define como sinônimos o princípio da ação, princípio da disponibilidade, princípio do pedido, princípio da liberdade do direito de ação, princípio da iniciativa da parte, princípio monopolístico do cidadão de movimentar o Poder Judiciário e princípio da promoção do processo, nemo iudex sine actore. (Os princípios do processo civil, cit., p. 114). Como proposta metodológica, trataremos do princípio da disponibilidade em seu aspecto endoprocessual.
} 
Exemplos de disponibilidade dentro do processo se evidenciam em atos como a renúncia (arts. 269, V, e 794, III, do CPC), a desistência (arts. 267, VIII, c.c. 501, § $4^{\circ}$, $412, \S 1^{\circ}$ e 569 do CPC), o reconhecimento jurídico do pedido (art. 269, II, do CPC) e a transação (arts. 269, III, e 794, II, do CPC), ou seja, atos que reflitam a disponibilidade da relação jurídica de direito material.

Por outro lado, Cassio Scarpinella Bueno lembra alguns exemplos de atos de indisponibilidade (que prescindem, portanto, de requerimento das partes), como o sistema das cláusulas abusivas elencadas no Código de Defesa do Consumidor (arts. $1^{\circ}$ e 51 ), o sistema de nulidades estatuído no Código Civil (art. 168, parágrafo único) e a possibilidade de reconhecimento de ofício da prescrição (art. $\left.219, \S 5^{\circ}\right) .{ }^{635}$ Portanto, a delimitação de um direito que seja ou não indisponível dentro do processo está mais relacionada à influência da ordem pública ${ }^{636}$ (art. 303, II, do CPC) que tutela determinado direito.

Em contrapartida, a disponibilidade ligada ao exercício do direito de ação não é supressora do princípio da inércia da jurisdição. A jurisdição é inerte, independentemente da relação jurídica de direito material. ${ }^{637}$

${ }^{635}$ BUENO, Cassio Scarpinella, Curso sistematizado de direito processual civil, cit., v. 1, p. 500-501. Ao final, conclui: "Em contrapartida, o princípio inquisitorial faz-se presente em situações bastante próximas justamente em função do grau de indisponibilidade que caracteriza o direito controvertido em dado processo - para impedir que se presuma a verdade de fatos alegados por uma das partes mesmo quando não haja contraposição (art. 320, II e III); para submeter determinadas decisões a reexame perante as instâncias superiores mesmo que o interessado não interponha recurso (art. 475); para impor a participação processual do Ministério Público em determinados casos (art. 82), apenas para mencionar alguns exemplos." (Ibidem, p. 501) Em suma, são muitas as situações que exemplificam a indisponibilidade do direito, de sorte que a limitação da disponibilidade das partes, em tese, é a existência de norma cogente.

${ }^{636}$ A ordem pública não necessariamente está ligada a todo pronunciamento de ofício do juiz, conforme alerta Tereza Arruda Alvim Wambier (Nulidades do processo e da sentença. 6. ed. São Paulo: Revista dos Tribunais, 2007. p. 164). No âmbito processual, muitos dispositivos do Código de Processo Civil apontam matérias que o juiz conhecerá de ofício: art. 301 (inexistência ou nulidade da citação, incompetência absoluta, inépcia da petição inicial, perempção, litispendência, coisa julgada, conexão, incapacidade da parte, defeito de representação ou falta de autorização, carência de ação, falta de caução ou de outra prestação, que a lei exige como preliminar; a exceção a esse dispositivo é a necessidade de arguição de competência relativa e da existência de compromisso arbitral - art. 301, § $4^{\circ}$ e 114); art. 267, § $3^{\circ}$ (ausência de pressupostos de constituição e desenvolvimento válido e regular do processo, acolhimento da alegação de perempção, litispendência e coisa julgada e ausência de condições da ação), assim como outras determinações: art. 19, $\S 2^{\circ}$ (determinação pelo juiz de riscar expressões injuriosas), art. 18 (aplicação da multa ao litigante de má-fé), art. 33 (determinação de ofício da prova pericial e respectivo ônus do autor quanto ao pagamento dos honorários do perito), art. 112, parágrafo único (declaração de nulidade de ofício de cláusula de eleição de foro em contrato de adesão) e art. 118 (suscitar conflito de competência), dentre outras providências.

${ }^{637}$ Conforme adverte Bedaque: "Não é, portanto, a natureza da relação jurídica de direito material que determina a impossibilidade de o magistrado dar início ao processo. A regra prevalece, mesmo quando for indisponível o direito; e algumas exceções referem-se a direitos eminentemente disponíveis." (Poderes instrutórios do juiz, cit., p. 93). Como exemplo dessas conclusões, nas ações penais públicas, a jurisdição permanece inerte. O que ocorre é a indisponibilidade do direito da vítima, por conta da prevalência do 
Assim, nos parece que a disponibilidade das provas apresenta ampla aproximação com o princípio dispositivo, porquanto, na medida ela diz respeito a atos volitivos a serem exercidos pelas partes voltados à produção das provas que pretendem produzir, o princípio dispositivo é a limitação do plano investigatório desses atos, ou seja, a materialização da disponibilidade pelas partes relativa ao campo probatório fica limitada à investigação do objeto litigioso (causa de pedir e pedido). ${ }^{638}$

De igual sorte que a perspectiva individualista do processo restou paulatinamente mitigada, conforme já tratado no Capítulo 2, a disponibilidade das provas a serem produzidas consoante vontade exclusiva das partes também guarda novos contornos. Isso porque a perspectiva publicista do processo não mais permite que os elementos a serem trazidos aos autos fiquem limitados à vontade das partes, no que toca à produção de provas. ${ }^{639}$ Vale dizer, o que se preserva no processo é o interesse do Estado-juiz em pacificar conflitos com justiça, e não condicionar a entrega da tutela jurisdicional mediante disponibilidade das provas conforme vontade das partes. Esse repúdio em limitar a instrução probatória ao monopólio das partes se torna claro na medida que cada litigante não está preocupado em presenciar a justiça sendo feita nos autos, mas sim em satisfazer seus próprios interesses, mediante a obtenção de tutela jurisdicional que lhe seja favorável. Para tanto, por óbvio que nenhuma parte terá interesse na produção de prova cujo resultado possa colocar em risco sua vitória na demanda.

Portanto, a disponibilidade da prova pelas partes guarda limitações ditadas pelo instituto da preclusão, que será melhor tratado no Capítulo 5, ao passo que para o juiz, a disponibilidade da prova está ligada a dois aspectos: (i) a formação de seu livre convencimento; e (ii) os limites da matéria relacionada ao pedido que o magistrado deve

interesse do Estado (ius puniendi), cuja legitimidade acaba por ser exercida pelo Ministério Público. Embora público o interesse em litígio, o Estado continua inerte. Por outro lado, no que toca aos direitos disponíveis, a exceção ao princípio da inércia da jurisdição é a abertura ex officio de inventário (art. 989 do CPC). Em igual sentido, ver: BARBOSA MOREIRA, José Carlos, O problema da divisão de trabalho entre o juiz e as partes, cit., p. 8.

${ }^{638}$ Ver o item 3.3.1.2.

${ }^{639}$ Grinover, Cintra e Dinamarco, ao discorrerem sobre a influência da publicização do processo, acentuada a partir do século XIX, não deixam de trazer hipóteses acerca do aumento dos poderes do juiz, citando como exemplos o poder não só de impulsionar o andamento da causa, mas também determinar provas: “(...) conhecer ex officio de circunstâncias que até então dependiam da alegação das partes, dialogar com elas, reprimir-lhes eventuais condutas irregulares etc. Dentro desses princípios, elaboraram-se os códigos processuais civis da Alemanha, da Itália e da Áustria, bem como os nossos, a partir de 1939." (Teoria geral do processo, cit., p. 70). 
conhecer para a formação do livre convencimento. Ou seja, o magistrado deve voltar a instrução probatória para os fatos ligados à causa de pedir e ao pedido que compõe a demanda, de modo a, baseado no resultado da prova, encontrar condições suficientes para decidir.

Nesse contexto, a iniciativa probatória do magistrado há de ser interrompida quando já estão presentes nos autos elementos suficientes para decidir os pedidos. Vale dizer, cabe ao magistrado coordenar no processo o desenvolvimento da formação do campo probatório, de sorte que possa decidir a demanda conscientemente e convicto da aproximação de certeza sobre a correta entrega da tutela jurisdicional. ${ }^{640}$

Ainda, diante da discussão que gravita em torno da limitação da disponibilidade e indisponibilidade da prova pelas partes e consequente reflexo quanto à dosimetria de incidência dos poderes instrutórios do juiz, também não deve ser esquecida qual ideia de busca da verdade prevalece no processo civil, diante dos reflexos da doutrina publicista: a verdade formal (consistente na busca da verdade condicionada às provas trazidas aos autos) ou a verdade real ${ }^{641}$ (ou material, ligada ao dever do juiz em atender a qualquer custo o descobrimento da verdade no processo)? Embora já se tenha chegado à conclusão neste trabalho de que a verdade real, embora desejável, não possui um grau de certeza absoluta e condizente com a verdade, as discussões acerca das limitações do princípio dispositivo acabam por abarcar esses conceitos que, na verdade, estão mais ligados à premissa do juiz ter ou não iniciativas probatórias. ${ }^{642}$

Assim, há inúmeras vozes na doutrina que alimentam a polêmica acerca do alcance e limitações do princípio dispositivo (nessa hipótese, sem fazer distinção com o princípio da disponibilidade) e opção entre o princípio da verdade formal ou real, de sorte a evitar a postura de um juiz imparcial e autoritário quanto à produção da prova. Nesse contexto, há quem sustente que somente a indisponibilidade da natureza do direito material justificaria a

\footnotetext{
${ }^{640}$ Trataremos melhor do tema no item 4.2.3, ao discorrermos sobre o princípio da persuasão racional.

${ }^{641}$ Assim como a prova no processo penal é em maior parte indisponível, a observância da verdade real é uma diretriz necessária e obrigatória, porquanto o interesse repressivo do Estado no juízo penal deve prevalecer em consonância com o descobrimento da verdade, para se evitarem condenações injustas e erros do Estado no exercício do ius puniendi. Há, contudo, exceções, quando o juiz não dispuser de meios para assegurar a verdade real, de sorte que fique prejudicada a real certeza sobre a existência do crime, conforme preceitua o art. 386, II e VI, do Código de Processo Penal.

${ }^{642}$ Ver o item 3.1.2.1.
} 
intervenção do juiz para a produção de determinada prova, ao passo que outros defendem a necessidade de intervenção do Ministério Público nas ações cuja função seria procurar a "verdade real", ${ }^{643}$ para assim limitar eventual imparcialidade do julgador. José Frederico Marques perfilha o entendimento de que embora presentes os poderes instrutórios, o intuito do legislador foi afastar o juiz o máximo possível dessa atividade. ${ }^{644}$

Liebman, a despeito de pensar ser indiferente a distinção entre disponibilidade e indisponibilidade da relação jurídica de direito material servir como parâmetro quanto à iniciativa probatória do juiz, ${ }^{645}$ defende que o exercício dos poderes instrutórios deve ser exercido por outro órgão público, sob pena de haver uma aproximação entre a função jurisdicional e a administrativa. Portanto, sustenta o total afastamento do juiz da atividade instrutória: "L'imparzialità del giudice è il bene prezioso che deve essere preservato in ogni caso, anche col sacrifício dei poteri d'iniziativa instruttoria del giudice (sebbene possano talvolta da altri punti di vista, apparire utili e convenienti).

Por sua vez, Grinover, Cintra e Dinamarco discorrem que:

“(...) embora o juiz hoje não mais se limite a assistir inerte à produção das provas, pois em princípio pode e deve assumir a iniciativa destas (CPC; arts. 130, 342 etc.), na maioria dos casos (direitos disponíveis) pode satisfazer-se com a verdade formal, limitando-se a acolher o que as partes levam ao processo e eventualmente rejeitando a demanda ou a defesa por falta de elementos probatórios (...). Impera, portanto, tanto no campo processual penal como no campo processual civil, o princípio da livre investigação das provas, embora com doses maiores de dispositividade no

${ }^{643}$ SILVA, Carlos Manuel Ferreira da. Poderes do juiz e poderes das partes. Separata da Revista da Ordem dos Advogados, Lisboa, p. 209, abr. 1980, apud BEDAQUE, José Roberto dos Santos, Poderes instrutórios do juiz, cit., p. 108. Semelhante advertência é feita por Grinover, Cintra e Dinamarco ao sustentarem que "quando a causa não penal versa sobre relações jurídicas em que o interesse público prevalece sobre o privado, não há concessões à verdade formal. Nas causas versando direito de família ou infortunística, de longa data se faz presente o órgão do Ministério Público e o juiz não está vinculado ao impulso das partes" (Teoria geral do processo, cit., p. 71).

${ }^{644}$ MARQUES, José Frederico, Manual de direito processual civil, cit., v. 2, p. 339.

${ }^{645}$ LIEBMAN, Enrico Tullio. Fondamento del principio dispositivo. In: Problemi del processo civile. Milano: Morano, 1962. p. 16. Semelhante indiferença entre ser ou não o direito disponível determinante para limitar a iniciativa probatória pelo juiz é ponderada por Sidnei Amendoeira Junior: "Afirmações como estas, apesar de parecerem bastante ultrapassadas, continuam sendo usadas para tolher a atividade oficiosa do juiz no processo. (...) seria importante fazer a seguinte pergunta: por que, quando estivermos diante de direitos indisponíveis, os mesmos doutrinadores que se colocam contrários à atuação ex officio do juiz admitem que isso ocorra? De duas uma: ou estão a afirmar que nas causas que versem sobre direitos indisponíveis o juiz pode ser parcial, ou, na realidade, que a atuação ex officio nada tem a ver com imparcialidade, tratando-se apenas de uma questão de política judiciária. Sem sombra de dúvidas, correta é a segunda opção." (Poderes do juiz e tutela jurisdicional, cit., p. 70).

${ }^{646}$ LIEBMAN, Enrico Tullio, Fondamento del principio dispositivo, in Problemi del processo civile, cit., p. 17. 
processo civil (...). O sistema adotado representa uma conciliação do princípio dispositivo com o da livre investigação judicial." ${ }^{, 647}$

Já Moacyr Amaral Santos defende que ao juiz cabe dirigir a instrução do processo (art. 125 do CPC), deixando de estar circunscrito às provas propostas pelas partes, podendo não admiti-las quando entendê-las protelatórias e, por outro lado, determinar a produção de ofício das provas que considerar necessárias (art. 130 do CPC), de sorte que essa iniciativa judicial seja supletiva à disponibilidade das partes e, ainda, seja utilizada em casos em que "houver necessidade de melhor esclarecimento da verdade, sem o que não seria possível ao juiz, de consciência tranquila, proferir sentença". ${ }^{648}$ Conclui, ao final, que a regra ${ }^{649}$ é que as provas sejam propostas pelas partes e excepcionalmente, o juiz poderá, de ofício, ordenar diligências necessárias à instrução da causa, cuja decisão deverá ser motivada.

Por fim, Mauro Cappelletti propõe manifesta revisitação do princípio dispositivo (tratado como princípio da dispositividade da prova), para defender a "direção material do processo" em substituição à "direção formal do processo", cujas premissas fundamentais são: (i) não cabe às partes a iniciativa probatória, ficando reservado ao juiz determinar as diligências necessárias à integral apuração dos fatos; (ii) a moderna concepção do princípio dispositivo diz respeito tão somente à iniciativa das alegações e dos pedidos, ambos reservados às partes; e (iii) ao juiz, sendo o diretor formal do processo, cabe exercer um poder de solicitação, de intervenção e de estímulo destinado a permitir que as partes

${ }^{647}$ CINTRA, Antonio Carlos de Araújo; GRINOVER, Ada Pellegrini; DINAMARCO, Cândido Rangel, Teoria geral do processo, cit., p. 71-72. Justificam a afirmação por ser uma tendência universal, citando como exemplos a prevalência do sistema da livre investigação em Estados liberais (v.g. Áustria, Suíça, França e Inglaterra), além do próprio Brasil já ter instituído semelhante sistema, quando existente o então Código Estadual da Bahia de 1915. Ao final, concluem que: "Essa marcha para o denominado processo civil autoritário é consequência da colocação publicista, correspondendo àquilo que se convencionou denominar 'socialização do direito'. Mas o poder discricionário do juiz está contido no âmbito da lei, não se confundindo com arbítrio: o juiz age, na direção do processo, solutus partibus, mas não solutus lege."

${ }^{648}$ SANTOS, Moacyr Amaral, Primeiras linhas de direito processual civil, cit., v. 2, p. 360. João Batista Lopes também entende que a regra do art. 130 do Código de Processo Civil deve ser vista com certa parcimônia, de sorte que a figura do "juiz investigador", mormente em se tratando de direitos disponíveis, não deve prevalecer, não cabendo a ele, em ocorrendo a omissão das partes quanto à disponibilidade probatória, substituir a vontade dos litigantes (A prova no direito processual civil, cit., p. 75-76). Todavia essa restrição resta relativizada, no que toca ao interrogatório informal (já que há oficiosidade do juiz prevista no art. 342 do $\mathrm{CPC}$ ), bem como em relação à produção da prova pericial, quando só com a sua produção puderem ser esclarecidos pontos da lide.

${ }^{649}$ Para Moacyr Amaral Santos, essa regra também comporta algumas exceções nas situações em que a res in iudicium deducta não se subordina apenas ao interesse das partes, de modo a sofrer interferência do interesse público, a exemplo dos litígios que versem sobre direito de família e questões de Estados em que intervém o Ministério Público. (Primeiras linhas de direito processual civil, cit., v. 2, p. 77). 
esclareçam suas alegações e petições, de modo a assegurar a igualdade substancial entre elas. $^{650}$

Como reflexo de um processo civil sob influências publicista, ${ }^{651}$ os ensinamentos de Cappelletti soam mais adequados, mormente para uma perspectiva instrumentalista do processo. Se o juiz é o destinatário da prova, a ele compete conhecer dos fatos e de igual sorte proferir a tutela jurisdicional, independentemente da relação jurídica de direito material ser disponível ou não. Para ser atingida a pacificação social mediante realização concreta do direito material, urge que os elementos que formam a convicção do juízo sejam bem delineados na sentença ou decisão que o convencença ${ }^{652}$. Essa atividade não implica um juízo imparcial, até porque, conforme já frisado, não se sabe o resultado da prova. $^{653}$

No que tange à natureza da relação jurídica material atuar como fator limitante à iniciativa probatória do juiz, ousamos discordar, pois essa não parece ser a conclusão mais acertada, ao passo que a criação desse discrímen acaba por violar o próprio princípio da isonomia. Vale dizer, se a natureza do bem em litígio for disponível, será dado exclusivamente às partes a opção de influenciarem o julgador, que ficará limitado em decidir conforme as provas por elas produzidas, até porque, como já dito, a elas só importa

${ }^{650}$ CAPPELLETTI, Mauro, La oralidad y las pruebas en el proceso civil, cit., p. 122 e ss.

${ }^{651}$ É o que corroboram as lições de Dinamarco, ao criticar o papel do juiz no chamado princípio dispositivo clássico, em que ao juiz é imposto um comportamento estático e receptivo: "Essa concepção radical tende no entanto a ser superada, mitigando-se gradualmente a lógica do raciocínio privatista que lhe está à base, seja porque nem só de direitos 'disponíveis' o processo civil trata, seja porque ao juiz de hoje cabe um comportamento dinâmico no processo (ativismo judicial: supra, n. 88). Não há mais clima para tanto predomínio do princípio dispositivo, que exclui os comportamentos inquisitivos do juiz no processo e na sua instrução. Aquela ideia radical é espelho das premissas privatistas do processo civil, que hoje é reconhecidamente informado pela natureza de instituto de direito público." (Instituições de direito processual civil, cit., v. 3, p. 51-52).

${ }^{652}$ Ensina Milton Paulo de Carvalho: “O sistema do Código de 1973 concernente à prova deixa nítida a diferença, aliás não dele derivada mas apenas por ele acolhida, entre a possível e indiscutível disponibilidade dos direito (falamos de direitos disponíveis, é claro) e a indisponibilidade da prova, o que permite demonstrar a diferença antecedente, de categorias jurídicas, entre a disponibilidade do direito modo de exercício do direito subjetivo, área do direito material - e o ônus de provar, situado entre as atividades atinentes à jurisdição, no campo do direito público, especificamente aquela destinada a definir a vontade concreta do direito objetivo que resolve o litígio emergente. De sorte que não há falar em dispositividade da prova na mesma medida da disponibilidade do direito subjetivo, no mais das vezes de natureza substancial; aquela interessa ao Estado para dar razão a quem a tem, envolve os três sujeitos da relação processual e sua natureza é jurídico-pública." (Aplicação e reforma da lei processual, in Os poderes do juiz e o controle das decisões judiciais: estudos em homenagem à professora Teresa Arruda Alvim Wambier, cit., p. 1.126).

${ }^{653}$ Nesse sentido, ver: PICÓ I JUNOY, Joan. El derecho a la prueba em el proceso civil. Barcelona: Bosch, 1996. p. 242. 
o interesse de vencer a demanda, seja pacificando conflitos com justiça ou não. Portanto, cada parte tem em mente definir a melhor estratégia dentro do processo que satisfaça unicamente ao seu interesse, o que afasta por completo do escopo magno da jurisdição. Por outro lado, sendo o direito em litígio de natureza indisponível, por haver a influência de norma cogente, aos litigantes é assegurada a resolução do litígio mediante atuação de juiz mais ativo e participativo no processo e, somente nesse caso, a função da jurisdição de pacificar conflitos com justiça atuaria de forma efetiva. Em síntese, sendo o direito indisponível, o Estado-juiz envidará esforços para atingir uma decisão justa e que reflita a aproximação de certeza em decidir; sendo o direito disponível, o Estado-juiz se vê obrigado a decidir consoante o monopólio das provas trazidas pelas partes. Daí porque soa razoável sustentar que:

\footnotetext{
"O direito material em litígio não tem nada a ver com a participação do juiz, pois esta é necessária, de forma intensa, para que o processo, que é instrumento do Estado, seja justo e coerente, pouco importando a disponibilidade ou não do direito material. Entender que no caso de direitos disponíveis o juiz pode se limitar a acolher o que as partes levaram ao processo é o mesmo que concluir que o Estado não está muito preocupado com o que se passa com os direitos disponíveis, ou que o processo que trata de direitos disponíveis não é o mesmo processo que é instrumento público destinado a cumprir os fins do Estado."
}

Logo, pensar desse modo significa limitar a busca de mecanismos destinados à obtenção da aproximação da certeza (exercício dos poderes instrutórios) quanto à plena realização do direito material, o que, salvo melhor juízo, não coaduna com os escopos da jurisdição. Até porque o Código de Processo Civil não confere tratamento diferenciado ao ativismo do juiz no campo das provas por conta do direito em litígio ser disponível ou não. Através de simples análise dos arts. 130, 342, 355, 382, 418 e 440, ou qualquer outro dispositivo que faça menção aos poderes instrutórios, não se verificará, em momento algum, situação em que a disponibilidade ou indisponibilidade do direito material influencie em maior ou menor grau a iniciativa probatória do magistrado ou aprofundamento no conhecimento dos fatos. ${ }^{655}$

\footnotetext{
${ }^{654}$ MARINONI, Luiz Guilherme, Novas linhas do processo civil, cit., p. 63.

${ }^{655}$ Esse argumento é bem lembrado por Barbosa Moreira, que sustenta que a natureza jurídica da relação de direito material não pode influenciar no grau de manuseio dos poderes instrutórios (O problema da divisão de trabalho entre o juiz e as partes, cit., p. 9).
} 
Conforme leciona Barbosa Moreira, ${ }^{656}$ o processo deve:

\begin{abstract}
“(...) assegurar condições propícias à exata e completa reconstituição dos fatos relevantes, a fim de que o convencimento do julgador corresponda, tanto quanto puder à realidade; d) em toda a extensão da possibilidade prática, o resultado há de ser tal que assegure à parte vitoriosa o gozo pleno da específica utilidade a que faz jus segundo o ordenamento; e) cumpre que se possa atingir semelhante resultado com o mínimo dispêndio de tempo e energias."
\end{abstract}

Verifica-se, portanto, que a efetividade do processo a ser atingida necessita utilizar instrumentos adequados de tutela que reproduzam fielmente os fatos necessários à formação do convencimento do magistrado, o que denota maior participação do juiz e, por outro lado, colaboração das partes na instrução probatória para o deslinde desse mister. Aliás, não é outra a redação do art. 339 do Código de Processo Civil já citado neste trabalho. Semelhante ideia é tratada nos arts. 340 e 341 do Código de Processo Civil, ao impor às partes, o dever de "comparecer em juízo, respondendo ao que lhe foi interrogado, submeter-se à inspeção judicial" e, ao terceiro, o dever de "informar ao juiz os fatos e as circunstâncias, de que tenha conhecimento, exibir coisa ou documento, que esteja em seu poder". Essa acepção ampla é clara, ao definir um "dever"657 que abrange não só os litigantes, mas qualquer órgão, repartição, pessoas, enfim todos aqueles que de alguma forma (seja mediante esclarecimentos prestados em respostas a ofícios, seja através da colheita de depoimento pessoal, oitiva de testemunhas ou, ainda, por meio da realização de perícia) possam trazer elementos de esclarecimentos para a busca da aproximação da verdade.

\footnotetext{
${ }^{656}$ BARBOSA MOREIRA, José Carlos. Notas sobre o problema da efetividade do processo. In: Temas de direito processual: terceira série. São Paulo: Saraiva, 1984. p. 27-28. Ainda na mesma página, outras conclusões são ponderadas por Barbosa Moreira, no que toca à efetividade do processo: "O processo deve dispor de instrumentos de tutela adequados, na medida do possível, a todos os direitos (e outras disposições jurídicas de vantagem) contemplados no ordenamento, que resultam de expressa previsão normativa que se possam inferir no sistema; b) esses instrumentos devem ser praticamente utilizáveis, ao menos em princípio, sejam quais forem os supostos titulares dos direitos (e das outras posições jurídicas de vantagem) de cuja preservação ou reintegração se cogita, inclusive quando indeterminado ou indeterminável o círculo dos eventuais sujeitos (...)". Dinamarco também sustenta o repúdio ao juiz Pilatos, inerte e preso à vontade das partes. Para tanto, necessário que o juiz abandone postura de indiferença e, percebendo a possibilidade de alguma prova que as partes não requereram, tome a iniciativa que elas não tomaram e mande que a prova se produza (Instituições de direito processual civil, cit., v. 1, cit., p. 228-229).

${ }^{657}$ Importante lembrar o que já tratamos no item 4.1.2, ao discorrer sobre o princípio da cooperação, sobre o dever das partes de "expor os fatos em juízo conforme a verdade"; se violado, como a tentativa de "alterar a veracidade dos fatos”, impõe condenação em multa por litigância de má-fé (arts. 14, I, 17, II e 18 do CPC).
} 
A conjugação de todas essas assertivas denota com singular clareza a postura do magistrado que prima pela verdade real ${ }^{658}$ que, como pudemos concluir no item 3.1.2.1, não é absoluta. Todavia, não é razoável que seja dado ao juiz o poder de exaustivamente transformar-se em mero órgão inquisitivo que a todo custo tente obter a clareza da verdade mediante desmesurada investigação probatória. Daí porque torna-se tarefa árdua o exercício dessa parcimônia, de sorte a equacionar a entrega da tutela jurisdicional com justiça e, por outro lado, evitar exageros que venham permear a parcialidade ou alongar excessivamente a instrução do processo. Esse mister revela aspectos subjetivos que, em parte, podem ser contornados se adotada postura mais participativa do magistrado e das partes na instrução probatória.

Partindo da premissa de que o magistrado ainda não formou seu livre convencimento e, portanto, não está apto a decidir a demanda, a primeira postura participativa ocorre na oportunidade de conceder às partes a oportunidade de requererem a produção das provas que entenderem necessárias (art. $331, \S 2^{\circ}$, do $\mathrm{CPC}^{659}$ ), cabendo ao juiz dirigir a instrução do processo e inclusive indeferir tais provas quando entendê-las serem protelatórias e, por outro lado, determinar a produção de ofício das provas que entender necessárias (arts. 125 e 130 do CPC). Essa decisão relativa à admissibilidade do tipo de prova a ser produzida, seja sob a ótica do autor, seja sob a ótica do réu, pode implicar em gravame a alguma das partes, de sorte que o próprio modelo constitucional do processo civil já assegura o controle dessa decisão mediante acesso ao duplo grau de jurisdição. Deverá, no entanto, ser a decisão vastamente fundamentada, assunto que restou tratado no item 4.1.5.

Essa fundamentação por si só confere legitimidade ao exercício do poder instrutório do magistrado, que não resvala em arbitrariedade, parcialidade ou excessiva inquisitoriedade, porquanto a premissa maior que justifica tal exercício diante do direito subjetivo será delinear a utilidade da diligência como necessária para melhor

\footnotetext{
${ }^{658}$ Cassio Scarpinella Bueno prima pelo abandono da verdade material no processo civil, de sorte a conspirar com os objetivos a serem atingidos pelo Estado, quando da prestação da tutela jurisdicional. Ainda, a manutenção da verdade material se contrapõe ao próprio "modelo constitucional do direito processual civil", conquanto a busca da verdade real corresponde ao que realmente aconteceu no plano exterior ao processo e, por ter acontecido, acabou por motivar a necessidade da atuação do Estado-juiz de prestar tutela jurisdicional (Curso sistematizado de direito processual civil, cit., v. 2, t.1, p. 236).

${ }^{659}$ Em linhas gerais, esse é o momento em que o juiz deve determinar as provas de ofício. Há exceções que defluem da amplitude da própria atividade cognitiva exercida pelo magistrado e que reclamam o exercício dos poderes instrutórios, conforme já tratado no Capítulo 3.
} 
esclarecimento da verdade, mormente quando o juízo ainda não dispuser de elementos necessários para a formação de seu livre convencimento, e assim puder decidir de modo tranquilo e próximo à realização do direito material.

O que releva e importa quando da iniciativa do juiz no campo probatório é a preservação das garantias constitucionais calcadas no devido processo legal, cujos desdobramentos refletem a observância do contraditório e ampla defesa, assim como a fundamentação da decisão que imponha a produção de provas de ofício. Observada essa premissa, o sistema torna-se bem mais lógico e adequado a atingir o escopo da jurisdição, o que inclusive reflete na pacificação dos conflitos com justiça.

Portanto, o princípio dispositivo, em sua concepção moderna, jamais limita a iniciativa probatória do magistrado necessária a dispor de elementos suficientes para a formação do livre convencimento do juiz. Esse pensar se alinha a uma tendência de busca da verdade real no processo, ainda que não seja absoluta. Tal assertiva deriva de uma simples dedução lógica: se ao juiz é dado decidir conforme a formação de seu livre convencimento, de igual sorte a ele é outorgado o poder de amealhar provas necessárias para se convencer e depois decidir. E a atividade de busca dessas provas, alinhada à tendência de pacificar conflitos com justiça, deve primar pela busca da verdade real ${ }^{660}$ que, como já tratamos no item 3.1.2.1, tão somente se aproxima com a maior fidelidade possível da verdade.

Por outro lado, a disponibilidade das provas pelas partes está sujeita ao crivo do magistrado para que julgue a pertinência, necessidade e relevância da produção de

\footnotetext{
660 Sustentam que o processo civil contemporâneo deve primar pela verdade real: BUENO, Cassio Scarpinella, Curso sistematizado de direito processual civil, cit., v. 1, p. 481-482; BEDAQUE, José Roberto dos Santos, Poderes instrutórios do juiz, cit., p. 95-96 e 107; CINTRA, Antonio Carlos de Araújo; GRINOVER, Ada Pellegrini; DINAMARCO, Cândido Rangel. Teoria geral do processo, cit., p. 72; AMENDOEIRA JUNIOR, Sidnei, Poderes do juiz e tutela jurisdicional, cit., p. 70. O Superior Tribunal de Justiça já se manifestou a respeito do tema, ao mitigar o princípio da persuasão racional em ação investigatória de paternidade, cuja decisão de primeiro grau de improcedência restou reformada pelo tribunal, dando-se prevalência à prova testemunhal e documental, em detrimento da prova pericial que concluía pela existência de dúvidas sobre a suposta paternidade. No fundamento de seu voto, o Ministro Menezes Direito, ao examinar o critério de apreciação das provas, assim concluiu: "Sem dúvida alguma, a independência do juiz na apreciação da prova produzida nos autos, ou seja, aquela prova que forma o seu convencimento da verdade formal, que pode ser, também, a verdade real, subordina-se ao interesse maior de prestar a jurisdição com o máximo de confiabilidade humana, ou seja, com a utilização de todos os meios disponíveis para buscar a verdade real." (STJ -REsp n. 97.148/MG, 3a Turma, rel. Min. Menezes Direito, DJU, de 08.09.1997, p. 492).
} 
determinada prova, de sorte que a persuasão racional do magistrado desenhará a adequada dosimetria entre repelir a produção de provas protelatórias ou determinar a produção de provas, ainda que não requeridas.

\subsubsection{Princípio da persuasão racional do juiz ou livre convencimento motivado}

Ao juiz é assegurado formar livremente sua convicção (persuasão racional), desde que suas razões de convencimento estejam vastamente motivadas (livre convencimento motivado). Logo, o juiz pode apreciar as provas produzidas nos autos para assim formar seu livre convencimento, que deve ser motivado.

Esse princípio se contrapõe a outros sistemas jurídicos simpatizantes da chamada prova legal ou tarifada, em que os elementos probatórios possuem valor prefixado, cabendo ao magistrado somar tais valores conforme o resultado da prova favoreça a uma das partes, para ao final decidir em favor da parte com soma mais acentuada. ${ }^{661}$

Pontes de Miranda discorre que nesse sistema “(...) a lei fixava regra sobre quais as provas admissíveis, sobre o valor probante de cada meio probatório, sobre a quantidade mesma de força probatória", de modo que os pontos positivos e negativos desse sistema consistiam, em síntese, na vantagem que cada um dos litigantes teria previamente em conhecer das provas a seu favor e respectivo valor delas em relação às provas do adversário. Em contrapartida, o juiz, nesse sistema, ficaria limitado em julgar consoante as provas produzidas pelas partes, cabendo a ele o limitado mister de calcular o valor de cada

\footnotetext{
${ }^{661}$ Conforme discorre Francisco Rosito, o sistema das provas legais teve origem no processo bárbaro, inserido no direito germânico, que se dividia em três meios de prova: o duelo, o juramento e o juízo de Deus. Esse último, conhecido também por ordálio, caracterizava-se pela ignorância das relações de causa e efeito nos fenômenos da natureza e na superstição de que tudo dependia da vonta de divina, v.g., sacar uma pedra ou um anel de uma caldeira com água fervendo, a imersão no iudicium aquae, o indicium ferri candentis, o iudicium panis adiurati etc. Aquele que sobrevivesse ao ordálio ou que não se ferisse não transgredira a paz e, por essa razão, refletia a razão de Deus. (Direito probatório: as máximas de experiência em juízo, cit., p. 41).
} 
prova e, ao final, decidir em favor daquele que angariasse melhor pontuação. ${ }^{662}$ Não cabia ao magistrado, portanto, valorar a prova segundo critérios subjetivos de convencimento. ${ }^{663}$

Por sua vez, no sistema do julgamento secundum conscientiam ou sistema da livre apreciação da prova, com origem do direito romano ${ }^{664}$, o juiz estava autorizado a decidir de acordo com as suas impressões pessoais, de acordo com a prova dos autos, fora da prova dos autos e inclusive contra a prova dos autos, ${ }^{665}$ dispensando-se, por consequinte, a própria motivação da decisão que, por vezes, pode resumir-se à convicção íntima do julgador. Não havia limitação quanto aos meios de prova de que o juiz se pudesse valer, tampouco restrições especiais quanto à origem ou qualidade de certas provas, em manifesta oposição ao sistema da prova legal. ${ }^{666}$ Esse sistema convida à formulação de arbitrariedades, porquanto o magistrado, além de puder decidir conforme sua convicção pessoal, pode valorar a prova da forma que melhor lhe convier e, ainda, fica dispensado de qualquer motivação. ${ }^{667}$

Por fim, no sistema da persuasão racional ou livre convencimento motivado, ao magistrado é dada a liberdade de formação de seu convencimento, contudo, vinculado a extrair sua convicção através das provas produzidas, aos fatos estabelecidos, às regras jurídicas e às regras da lógica e da experiência. ${ }^{668}$ No sistema brasileiro não há tarifação da prova, mas sim a liberdade dada ao juiz para decidir conforme as provas que melhor o convencem.

Todavia, o convencimento há de firmar-se em fatos que foram trazidos ao processo pelos meios probatórios regulares, consagração à máxima quod non est in actis non est in

${ }^{662}$ PONTES DE MIRANDA, Francisco Cavalcanti, Comentários ao Código de Processo Civil, v. 2, cit., p. 379-380.

${ }^{663}$ SILVA, Ovídio A. Baptista da, Curso de processo civil: processo de conhecimento, cit., p. 348-349.

${ }^{664}$ Em verdade, conforme leciona Moacyr Amaral Santos, o sistema da convicção secundum conscientiam não prevaleceu em sua integralidade no direito romano, de sorte que na fase imperial ocorreram as primeiras restrições quanto à livre apreciação da prova, sob a novel influência do direito canônico (Prova judiciária no cível e comercial, cit., v. 1, p. 356-357).

${ }^{665}$ COUTURE, Eduardo J., Fundamentos del derecho procesal civil, cit., p. 274.

${ }^{666}$ SILVA, Ovídio A. Baptista da, Curso de processo civil: processo de conhecimento, cit., p. 350.

${ }^{667}$ DALL'AGNOL JUNIOR, Antônio Janyr, Comentários ao Código de Processo Civil, cit., v. 2, p. 137.

668 ROSITO, Francisco, Direito probatório: as máximas de experiência em juízo, cit., p. 43. Consoante leciona Ovídio A. Baptista da Silva, o sistema da persuasão racional é o que inspira maior grau de confiança da sociedade nos juízes e credibilidade da instrituição no Poder Judiciário, exatamente por conferir ampla liberdade na valoração da prova. (Curso de processo civil: processo de conhecimento, cit., p. 352). 
mundo, de sorte que, nos termos o art. 131 do Código de Processo Civil, o juiz aprecie livremente a prova "atendendo aos fatos e circunstâncias constantes dos autos, ainda que não alegados pelas partes”. Portanto, a iniciativa probatória do magistrado não está limitada em perquirir as alegações das partes, mas o julgador deve dirigir a instrução nos limites necessários para decidir o pedido. Afinal, o que importa na demanda é o julgamento do pedido. ${ }^{669}$

Por outro lado, o exercício dos poderes instrutórios se presta a angariar elementos nos autos aptos a formar o livre convencimento do magistrado necessário para julgar o pedido. Esse pensar caminha de acordo com as definições de Grinover, Dinamarco e Cintra sobre o princípio da persuasão racional:

\begin{abstract}
"O Brasil também adota o princípio da persuasão racional: o juiz não é desvinculado da prova e dos elementos existentes nos autos (quod non est in actis non est in mundo), mas a sua apreciação não depende de critérios legais determinados a priori. O juiz só decide com base nos elementos existentes no processo, mas os avalia segundo critérios críticos e racionais (CPC, arts. 131 e 436; CPP, arts. 157 e 182)." ${ }^{, 670}$
\end{abstract}

Sendo o juiz o destinatário da prova, a ele cabe o papel de coordenar e tomar iniciativas para a formação do campo probatório. Essa coordenação reflete a dinâmica dos poderes instrutórios no que toca à iniciativa probatória e indeferimento de diligências inúteis ou meramente protelatórias (art. 130 do CPC), cujo objetivo é angariar elementos suficientes para a formação de seu livre convencimento, com o objetivo de julgar o pedido. $\mathrm{Na}$ medida que se permite o livre convencimento, ele deve se apresentar amplamente motivado (livre convencimento motivado), o que inclusive caminha em consonância com o preceito do arts. 93, IX, da Constituição Federal e 131 e 458, II, do Código de Processo Civil. $^{671}$ Deve o magistrado, portanto, indicar os motivos e as circunstãncias que o

\footnotetext{
${ }^{669}$ Essa assertiva convida à reflexão sobre a melhor interpretação do art. 332 do Código de Processo Civil, que reza que "todos os meios legais, bem como os moralmente legítimos, ainda que não especificados neste Código, são hábeis para provar a verdade dos fatos, em que se funda a ação ou a defesa". A expressão "em que se funda a ação ou a defesa" deve ser interpretada de forma mais ampla, compreendendo o pedido do autor e do réu e não as alegações empregadas pelas partes.

${ }^{670}$ CINTRA, Antonio Carlos de Araújo; GRINOVER, Ada Pellegrini; DINAMARCO, Cândido Rangel, Teoria geral do processo, cit., p. 73-74. Esses autores não estabelecem diferença entre o princípio da persuasão racional e o princípio do livre convencimento do magistrado. Para eles, esse princípio começou a delinear-se a partir do século XVI, consolidando-se com a Revolução Francesa e veio a ser acolhido implicitamente no Código Napoleônico, seguindo os estatutos processuais da Alemanha e Áustria.

671 "A livre apreciação da prova, desde que a decisão seja fundamentada, considerada a lei e os elementos existentes nos autos, é um dos cânones do nosso sistema processual." (STJ - REsp n. 7.870/SP, $4^{a}$ Turma., rel. Min. Sávio de Figueiredo, j. 03.12.1991, provimento parcial, v.u., DJU, de 03.02.1992, p. 469).
} 
conduziram a admitir a veracidade dos fatos em que baseaou a decisão, apontando os elementos de prova com que restou convencido, de modo a apresentar conclusão sentencial que guarde coerência lógica com a prova constante nos autos. ${ }^{672}$

De igual sorte, a decisão interlocutória que determina a produção de provas de ofício também deve revestir-se de fundamentação, o que legitima o exercício do poder instrutório. Aliás, a fundamentação também se presta a justificar a independência do magistrado na formação de seu livre convencimento. Ou seja, o livre convencimento deve ser respeitado, conquanto que estejam fundamentadas as razões de decidir e guardem dedução lógica com as provas carreadas nos autos. ${ }^{673} \mathrm{E}$, conforme tratado no item 3.1.2 supra, se o juiz deve formar sua convicção livremente, adstrito apenas a motivar sua decisão e consoante critérios lógicos de raciocínio, cabe a ele trazer para o processo os elementos de prova de que necessite para julgar o pedido, ainda que as partes não tenham proposto a produção de tais provas.

Nesse contexto, a iniciativa probatória do magistrado se mantém até a formação do livre convencimento necessário à entrega da tutela jurisdicional. Daí porque soa um contrasenso uma decisão que, ao mesmo tempo que julga antecipadamente a lide (art. 330 do CPC), a sentença de improcedência se fundamenta na falta de provas do direito do autor, assunto que voltaremos a tratar no Capítulo 5.

\footnotetext{
${ }^{672}$ SILVA, Ovídio A. Baptista da, Curso de processo civil: processo de conhecimento, cit., p. 350-351.

${ }^{673}$ Nesse contexto, transcrevemos parte do voto do Ministro. Menezes Direito proferido em julgamento já citado, cujo teor também se aplica neste tópico, ao perfilhar o entendimento de que a persuasão racional do magistrado deva ser respeitada, mas, em contrapartida, a fundamentação da decisão deve guardar identidade com os elementos probatórios trazidos aos autos: “A falibilidade humana não pode justificar o desprezo pela afirmação científica, estando mais a liberdade de apreciação da prova que o sistema defere ao juiz, como responsável pela prestação jurisdicional, sendo o perito mero auxiliar, em cercar-se de todas as garantias necessárias para que a sua decisão não seja calcada em sentimento contrário à verdade científica. O critério da imperfeição como sinal axiológico na consideração das provas oferece um flanco ainda mais perigoso do que o temperamento da liberdade agasalhada nos arts. 131 e 436 do Código de Processo Civil. O juiz forma o seu livre convencimento explicitando os motivos que apoiaram a sua conclusão. E tais motivos devem estar compatíveis com a realidade dos autos, não sendo possível desqualificar esta ou aquela prova sem o devido lastro para tanto. Ou seja, o próprio art. 131 exige que haja motivos explicitados para a formação de seu convencimento, o que significa que sob tal comando, independentemente do exame da prova, o que se deve discutir é a compatibilidade dos motivos apresentados com a realidade existente, ou se se preferir, com a verdade formal revelada pelos autos. Quando os motivos apresentados não estão

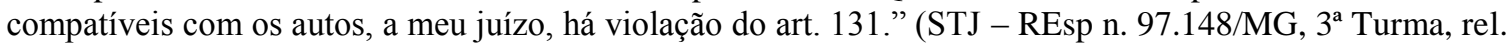
min. Menezes Direito, DJU, de 8.9.97, p. 492).
} 


\subsubsection{Princípio da imparcialidade}

A imparcialidade do magistrado pressupõe a equidistância que o juiz deve manter das partes, cujas alegações e provas que pretendem trazer aos autos dizem respeito única e exclusivamente à tutela de seus direitos. Vale dizer, o juiz, e não o juízo, deve portar-se indiferente em relação ao litígio, às partes e ao objeto do processo, deixando, portanto, de imprimir afeições pessoais a esses elementos. ${ }^{674} \mathrm{~A}$ garantia da imparcialidade está amplamente ligada às hipóteses de impedimento ou de suspeição arroladas nos arts. $134 \mathrm{e}$ 135 do Código de Processo Civil ${ }^{675}$ respectivamente, ${ }^{676}$ cujos óbices também guardam relação com as vedações previstas no parágrafo único do art. 95 da Constituição Federal.

${ }^{674}$ Cassio Scarpinella Bueno acrescenta que o juiz deve portar-se, em relação ao litígio, como "um terceiro, totalmente estranho, totalmente indiferente à sorte do julgamento e ao destino de todos aqueles que, direta ou indiretamente, estejam envolvidos nele" (Curso sistematizado de direito processual civil, cit., v. 1, p. 118).

${ }^{675}$ Código de Processo Civil: “Art. 134 - É defeso ao juiz exercer as suas funções no processo contencioso ou voluntário: I - de que for parte; II - em que interveio como mandatário da parte, oficiou como perito, funcionou como órgão do Ministério Público, ou prestou depoimento como testemunha; III - que conheceu em primeiro grau de jurisdição, tendo-lhe proferido sentença ou decisão; IV - quando nele estiver postulando, como advogado da parte, o seu cônjuge ou qualquer parente seu, consanguíneo ou afim, em linha reta; ou na linha colateral até o segundo grau; V - quando cônjuge, parente, consanguíneo ou afim, de alguma das partes, em linha reta ou, na colateral, até o terceiro grau; VI - quando for órgão de direção ou de administração de pessoa jurídica, parte na causa. Parágrafo único - No caso do n. IV, o impedimento só se verifica quando o advogado já estava exercendo o patrocínio da causa; é, porém, vedado ao advogado pleitear no processo, a fim de criar o impedimento do juiz. Art. 135 - Reputa-se fundada a suspeição de parcialidade do juiz, quando: I - amigo íntimo ou inimigo capital de qualquer das partes; II - alguma das partes for credora ou devedora do juiz, de seu cônjuge ou de parentes destes, em linha reta ou na colateral até o terceiro grau; III - herdeiro presuntivo, donatário ou empregador de alguma das partes; IV - receber dádivas antes ou depois de iniciado o processo; aconselhar alguma das partes acerca do objeto da causa, ou subministrar meios para atender às despesas do litígio; V - interessado no julgamento da causa em favor de uma das partes. Parágrafo único - Poderá ainda o juiz declarar-se suspeito por motivo íntimo". Constituição Federal: “Art. 95 - Os juízes gozam das seguintes garantias: (...) Parágrafo único - Aos juízes é vedado: I exercer, ainda que em disponibilidade, outro cargo ou função, salvo uma de magistério; II - receber, a qualquer título ou pretexto, custas ou participação em processo; III - dedicar-se à atividade políticopartidária. IV - receber, a qualquer título ou pretexto, auxílios ou contribuições de pessoas físicas, entidades públicas ou privadas, ressalvadas as exceções previstas em lei; V - exercer a advocacia no juízo ou tribunal do qual se afastou, antes de decorridos três anos do afastamento do cargo por aposentadoria ou exoneração."

${ }^{676}$ Conforme preceitua o art. 245 do Código de Processo Civil, não há preclusão para as hipóteses de impedimento, devendo, inclusive, o juiz declarar-se impedido de ofício. A exceção de impedimento pode ser alegada a qualquer tempo e constitui inclusive fundamento para cabimento da ação rescisória (art. 485, II, do CPC). 
Para Grinover, Cintra e Dinamarco, a imparcialidade constitui caráter inseparável do próprio órgão jurisdicional (subjetivamente capaz) e atua como pressuposto para que a relação processual se instaure validamente. ${ }^{677}$

Portanto, a imparcialidade do magistrado é garantia das partes de que tenham a atuação da jurisdição equidistante de seus interesses nas causas que são submetidas para decisão pelo Estado-juiz. Sua função presta a conferir legitimidade à prestação da tutela jurisdicional, de sorte que o juiz, como agente público do Estado, deve:

“(...) deter a isenção indispensável para escutar as partes na apresentação
de suas versões de fato e de direito e, uma vez percorrido o iter
procedimental legalmente previsto para aquele tipo de demanda, proferir
julgamento contendo a atuação da vontade concreta do direito material ao
caso." 678

De outra banda, imparcialidade diferencia de neutralidade. A primeira se destina a evitar que o juiz julgue causas de seu próprio interesse (que não seja parte e juiz ao mesmo tempo), ao passo que a segunda resulta na:

“(...) consciência do magistrado de sua posição de agente político que deve fazer um acompanhamento constante dos fatos e das realidades sociais e políticas que lhe são trazidas pelos mais variados canais, tais como os meios de comunicação de massa, o produto dos estudos formulados no âmbito de outras ciências (...) entre várias outras fontes que serão indispensáveis para que o juiz esteja situado e atento aos acontecimentos do mundo que o rodeia.,

677 CINTRA, Antonio Carlos de Araújo; GRINOVER, Ada Pellegrini; DINAMARCO, Cândido Rangel, Teoria geral do processo, cit., p. 58. Semelhante conclusão é ponderada por Rui Portanova: "A imparcialidade é condição primordial para que um juiz atue. É questão inseparável e inerente ao juiz não tomar partido, não favorecer qualquer parte, enfim, não ser parte. Em verdade, a expressão juiz imparcial é redundância e seria quase desnecessário falar em imparcialidade, tal é a imanência existente entre juiz e imparcialidade." (Os princípios do processo civil, cit., 1995, p. 79).

${ }^{678}$ PUOLI, José Carlos Baptista, Os poderes do juiz e as reformas do processo civil, cit., p. 38.

679 PUOLI, José Carlos Baptista, Os poderes do juiz e as reformas do processo civil, cit., p. 44. Rui Portanova acresce que "juiz imparcial é aquele que não tem interesse no julgamento, de sorte que a imparcialidade busca ressalvar o juiz do comprometimento com a parte (atitude omissiva), ao passo que a neutralidade reflete dado subjetivo que liga o juiz cidadão social à sua visão geral do mundo, no concerto de sua consciência, de sorte a imprimir comportamento comprometido" (Os princípios do processo civil, cit., p. 78). Por sua vez, Sérgio Alves Gomes assevera: "Juiz imparcial não é aquele que deixa de determinar a produção de prova não requerida pela parte. A imparcialidade há de ser entendida como a predisposição da qual o magistrado se sente imbuído a dar razão a quem merece, segundo o direito vigente. Ser imparcial não significa ser neutro." (Os poderes do juiz na direção e instrução do processo civil, cit., p. 256). Por fim, João Batista Lopes assevera que o juiz imparcial não favorece indevidamente uma das partes, de sorte que a "imparcialidade não significa neutralidade, isto é, o juiz deve ser um homem do seu tempo, sensível à realidade social e não mero árbitro do litígio" (A prova no direito processual civil, cit., p. 201). 
Todavia, é certo que parcialidade não se confunde com uma postura mais ativa do magistrado, notadamente no que diz respeito às iniciativas probatórias objeto deste estudo. Significa dizer que o engessamento do juiz em relação às iniciativas probatórias resultaria deixar a sorte do processo, principalmente a decisão, ao alvedrio da atividade ou inércia probatória das partes. Novamente, esse pensar certamente viola os próprios escopos da jurisdição, de sorte que um juiz inerte quanto aos poderes instrutórios obrigatoriamente terá que julgar a lide no estado em que se encontra, porquanto é vedado o non liquet. Nesse contexto, se considerada a hipótese de que o juiz deve ficar limitado à sorte das partes no que toca às iniciativas probatórias, em ocorrendo uma instrução mal feita ou insuficiente, fatalmente nele recairia a infeliz incumbência de decidir a demanda, independente de haver formado um juízo de certeza ou probabilidade ${ }^{680}$ acerca da convicção quanto à procedência ou não do pedido e, principalmente, exatidão quanto à aplicação do direito material.

Portanto, os poderes instrutórios se prestam a alcançar a ordem jurídica justa, o que em momento algum se confunde com imparcialidade do juízo. Aliás, sendo vedado o non liquet, outro fundamento que pode ser empregado quanto à legitimidade da iniciativa probatória reside exatamente nessa busca de elementos destinados à formação do livre convencimento, cujo princípio já restou analisado neste trabalho.

Ademais, conforme já exposto no Capítulo 3, o juiz é o destinatário da prova, de sorte que sendo ela insuficiente para a formação de seu livre convencimento, a ele cabe o poder de complementar o campo probatório até então presente nos autos, mediante o exercício dos poderes instrutórios. Ou seja, para a correta aplicação da lei ao caso concreto (escopo jurídico) e atuação da pacificação social, ${ }^{681}$ necessário, portanto, que o juiz tenha

\footnotetext{
${ }^{680}$ Ver item 3.1.2.1.

${ }^{681}$ Dinamarco, após analisar todos os ângulos que norteiam a postura do juiz mais ativo, principalmente alguns aspectos negativos, ao final conclui que a imparcialidade somente ocorrerá quando deixar de haver indiferenças ligadas aos aspectos sociológicos-políticos do juiz: “(...) a realidade da vida que chega ao juiz, no drama de cada processo, é muito mais complexa e intrincada, solicitando dele uma sensibilidade muito grande para a identificação dos fatos e enquadramento em categorias jurídicas, para a descoberta da própria verdade quanto à alegações de fato feitas pelos litigantes e sobretudo para a determinação do preciso e atual significado das palavras, contidas na lei. Examinar as provas, intuir o correto enquadramento jurídico e interpretar de modo correto os textos legais à luz dos grandes princípios e das existências sociais do tempo - eis a grande tarefa do juiz, ao sentenciar." (A instrumentalidade do processo, cit., p. 231). Esse pensar soa correto, pois o que reveste uma postura mais ativa do juiz é o interesse público estatal na realização do direito material (escopo jurídico), e não o tratamento desigual entre as partes por convicções pessoais ligadas a aspectos de índole política e social inerentes à pessoa do juiz. Em igual sentido, ver: PUOLI, José Carlos Baptista, Os poderes do juiz e as reformas do processo civil, cit., p. 45.
} 
elementos suficientes para inclusive motivar os fundamentos que revestirão o decisum. Mais uma vez as vertentes publicistas do processo e sua finalidade de atender ao interesse estatal de pacificar conflitos com justiça se impõe. ${ }^{682}$ Nessa linha de raciocínio, sustenta Bedaque:

"A participação do juiz na formação do conjunto probatório,
determinando a realização das provas que entender necessárias ao
esclarecimento dos fatos deduzidos pelas partes, de forma alguma afeta
sua imparcialidade. Agindo assim, demonstra o magistrado estar atento
aos fins sociais do processo. A visão publicista deste exige um juiz
comprometido com a efetivação do direito material. Isto é, o juiz pode, a
qualquer momento e de ofício determinar sejam produzidas provas
necessárias ao seu convencimento. Trata-se de atitude não apenas
admitida pelo ordenamento, mas desejada por quem concebe o processo
como instrumento efetivo de acesso à ordem jurídica justa. Não se deve
confundir imparcialidade com passividade do julgador durante o
desenvolvimento do processo. Principalmente quando se trata do
exercício dos poderes que a lei lhe confere de maneira inequívoca."

Acresça-se, ainda, que mediante iniciativa probatória, o magistrado sequer conhece o resultado da prova que determinar a produção. Ela pode beneficiar tanto uma parte quanto a outra, ou até mesmo deixar de trazer uma solução para a formação do livre convencimento do juiz. Por isso que a iniciativa probatória jamais esbarra ou viola o princípio da imparcialidade, porquanto não se sabe o resultado da prova. ${ }^{684}$

\footnotetext{
${ }^{682}$ José Carlos Baptista Puoli ainda complementa esse pensar com um paralelo com a doutrina administrativa e suas justificativas voltadas a explicar a prevalência do interesse público sobre o privado. Nesse contexto, sustenta que a postura instrumentalista do processo convida à abertura de outras ciências e/ou ramos do direito que venham contribuir para o aperfeiçoamento da resposta jurisdicional. Ademais, tanto o direito administrativo quanto o direito processual civil são afetos ao direito público, constituindo, portanto e em sua acepção ampla, à convergência de objetivos, de sorte que "os escopos do processo e do direito administrativo são comuns e intercambiáveis, sob uma rubrica comum de regras de direito público destinadas a conscientizar o agente público e dele cobrar uma atuação tendente a fazer com que haja uma prevalência do interesse púbico sobre o interesse particular. Por esses motivos é que se tem reconhecido que o princípio da imparcialidade não pode servir de escudo para impedir que o juiz detenha uma posição mais ativa no decorrer da demanda" (Os poderes do juiz e as reformas do processo civil, cit., p. 41).

${ }^{683}$ BEDAQUE, José Roberto dos Santos, Poderes instrutórios do juiz, cit., p. 110-111.

${ }^{684}$ Mais uma vez se faz necessário invocar os ensinamentos de Bedaque, que sustenta que o aumento do poder instrutório do julgador não favorece qualquer das partes, mas tão somente proporciona a apuração mais completa dos fatos, de modo a permitir a correta aplicação das normas de direito material. Ao final, conclui que para o juiz "não deve importar que vença o autor ou o réu. Importa, porém, que saia vitorioso aquele que efetivamente tenha razão, ou seja, aquele cuja situação da vida esteja protegida pela norma de direito material, pois somente assim se pode falar que a atividade jurisdicional realizou plenamente sua função" (Poderes instrutórios do juiz, cit., p. 109-110).
} 
Ainda, qualquer diligência determinada pelo magistrado com vistas a instruir o campo probatório se destina a complementar e angariar mais elementos para se obter um juízo de certeza quanto ao acolhimento ou não do pedido ou pleito da parte. Mais vale um juízo de certeza ou com maiores probabilidades de acerto ${ }^{685}$ do que uma decisão mal fundamentada ou revestida de poucas provas. A consequência dessa postura mais ativa do juiz só traz repercussões positivas: a decisão calcada nas provas trazidas aos autos, mormente as diligências determinadas de ofício pelo magistrado, certamente deixará de causar gravame à parte que eventualmente sucumbiria e recorreria suscitando nulidade da sentença por lhe faltar oportunidade para a produção de determinada prova, por vezes já determinada pelo juiz. Quiçá o próprio resultado da prova que restou determinada pelo juiz já esvaziaria a própria pretensão recursal. Por outro lado, quanto maior for a quantidade de provas trazidas ao processo, menores serão as possibilidades da parte sucumbente recorrer, na medida que uma decisão bem fundamentada e lastreada em diversos pontos integrantes do conjunto probatório será manifesta quanto à sua pacificação social, ou seja, essa decisão calcada em diversos fundamentos servirá como consolação para o próprio convencimento da parte sucumbente de desistir de recorrer e dar-se por conformada, conforme leciona Dinamarco:

"Não se busca o consenso em torno das decisões estatais, mas a
imunização delas contra os ataques dos contrariados; e indispensável,
para cumprimento da função pacificadora exercida pelo Estado legislando
ou sub specie jurisdictionis, é a eliminação do conflito como tal, por
meios que sejam reconhecidamente idôneos. O que importa, afinal, é
'tornar inevitáveis e prováveis decepções em decepções difusas: apesar
de descontentes, as partes aceitam a decisão'. Elas sabem que, exauridos
os escalões de julgamento, esperança alguma de solução melhor seria
humanamente realizável; além disso, ainda que inconscientemente, sabem
também que necessitam da proteção do Estado e não convém à
tranquilidade de ninguém a destruição dos mecanismos estatais de
proteção mediante a sistemática desobediência.(...) Entra aqui a
relevância do valor justiça. Eliminar conflitos mediante critérios justos -
eis o mais elevado escopo social das atividades jurídicas do Estado."

${ }^{685}$ Em semelhante sentido, José Carlos Barbosa Moreira complementa que embora o exercício do poder instrutório não permita o alcance da verdade completa, inequivocamente auxiliará no encontro de parte dela, ainda que reduzida: “(...) antes buscar essa, do que não buscar nenhuma.” (O juiz e a prova. Revista de Processo, São Paulo, Revista dos Tribunais, ano 9, n. 35, p. 178, ju./set. 1984).

${ }^{686}$ DINAMARCO, Cândido Rangel, A instrumentalidade do processo, cit., p. 190. 
Por fim, o exercício dos poderes instrutórios decorre de expressa previsão estatuída na lei adjetiva, valendo lembrar novamente a redação do art. 130 do Código de Processo Civil, cuja literal redação consagra o juiz como destinatário da prova pois a ele cabe dirigir o processo (art. 125 do CPC); dentre essas atividades, lhe é assegurado o poder de indeferir as provas desnecessárias ou inúteis, assim como determinar a produção daquelas que forem fundamentais ou possam angariar elementos para a formação de seu livre convencimento. Não obstante, o exercício desses poderes há de se materializar em consonância com as exigências garantidas pelas Constituição Federal retrocitadas, tal como o dever de fundamentação das decisões (ainda que interlocutórias) e de proporcionar a oportunidade de conhecimento, participação e reação dessa decisão (garantia do contraditório e ampla defesa), de sorte que, ainda que se cogite em eventual margem à teratologia ou arbitrariedade, é certo que a parte que se sentir vítima de eventual gravame serão asseguradas as garantias do devido processo legal previstas na Carta Magna, os meios de acesso à instância recursal e mecanismos de controle das decisões judiciais que coroam o exercício do duplo grau de jurisdição, sem prejuízo dos meios de impugnação ${ }^{687}$ dessas mesmas decisões.

Bedaque alerta para os efeitos danosos de uma postura passiva do magistrado receoso de utilizar os poderes instrutórios:

"Suponha-se que o juiz esteja convencido, pelo exame dos elementos dos
autos, que poderia chegar à verdade, bastando suprir alguma omissão da
parte no tocante à prova. Evidentemente, decidirá contra a sua
consciência, se não determinasse o esclarecimento do fato. Esse temor de
perder a imparcialidade tem contribuído de maneira decisiva para que
nossos magistrados, infelizmente, deixem de utilizar dos poderes
instrutórios que lhes são conferidos pelo legislador processual. Criou-se
uma tradição do juiz passivo, espectador, temeroso que qualquer
iniciativa sua possa torná-lo parcial. A escassez de iniciativas probatórias
oficiais, mesmo quando manifesta a sua conveniência, tem sido apontada
como um das causas do mau funcionamento do mecanismo judiciário.
(...) Juiz imparcial é aquele que aplica a norma de direito material a fatos
efetivamente verificados, sem que se deixe influenciar por outros fatores
que não seus conhecimentos jurídicos. Para manter sua imparcialidade,
basta que o magistrado se limite ao exame objetivo dos fatos, cuja
reprodução nos autos se faz mediante provas. Não importa que as
traga.".688

${ }^{687}$ A exemplo do mandado de segurança e da ação rescisórias, nas hipóteses cabíveis.

${ }^{688}$ BEDAQUE, José Roberto dos Santos, Poderes instrutórios do juiz, cit., p. 111-112. 
Portanto, sob todas as óticas, indubitável que o exercício dos poderes instrutórios sequer resvala no princípio da imparcialidade e que a iniciativa probatória de ofício não se confunde com o dever de preservação de uma postura equidistante ao interesse das partes no processo, valendo lembrar que a toda decisão judicial, a Constituição Federal impõe a submissão ao princípio do contraditório e o dever de motivação, garantias essas que se prestam ao controle da decisão judicial. ${ }^{689}$

689 “(...) a concessão de poderes instrutórios ao juiz encontra seu limite natural no contraditório, que impede a transformação da arbitragem em arbitrariedade, da discricionariedade em depotismo." (BEDAQUE, José Roberto dos Santos, Poderes instrutórios do juiz, cit., p. 115). 


\section{IMPACTOS DAS INICIATIVAS PROBATÓRIAS DO JUIZ NO SISTEMA - BREVES CONTRIBUIÇÕES PRÁTICAS}

Diante do quanto restou exposto, apresentaremos neste capítulo sugestões práticas de iniciativas probatórias do juiz de utilidade no processo civil, com vistas a acarretar uma decisão que se aproxime de um juízo de certeza em decidir e que prime pela efetividade do processo.

Trata-se de um ensaio acerca do proveito a ser extraído das iniciativas probatórias, com análise de situações específicas em que elas são de maior utilidade. Não pretendemos examinar em profundidade os institutos e demais questões que circundam as hipóteses, mas sim demonstrar como as iniciativas probatórias do juiz são úteis em dadas situações concretas, algumas já decididas pela jurisprudência. ${ }^{690}$

\subsection{Julgamento antecipado da lide fundamentado na ausência de provas do direito da parte}

O julgamento antecipado da lide constitui técnica que autoriza o juiz a proferir sentença antes mesmo de iniciar a instrução probatória, nas hipóteses elencadas nos incs. I e II do art. 330 do Código de Processo Civil. ${ }^{691}$ Como já discorremos no item 3.1.2.2, a revelia (art. 330, inc. II) não implica no automático julgamento antecipado da lide, tampoucou de forma favorável ao pedido do autor. Por sua vez, a hipótese tratada no inciso I do art. 330 autoriza que o juiz decida a lide antecipadamente, se a questão for unicamente de direito ou, sendo de direito e de fato, restar dispensada a necessidade de dilação probatória.

\footnotetext{
690 Como premissa metodológica, nos concentraremos na pesquisa de julgados emanados das cortes excepcionais - Superior Tribunal de Justiça e Supremo Tribunal Federal - para seguir a tendência das últimas reformas operadas no Código de Processo Civil, destinadas a consolidar a obediência das instâncias ordinárias ao entendimento prevalecente nas instâncias de superposição, a exemplo da súmula impeditiva de recursos (art. 518 do CPC), do julgamento monocrático pelo relator quando o recurso se encontrar em confronto com súmula ou com jurisprudência dominante do respectivo tribunal, do Supremo Tribunal Federal ou de Tribunal Superior (art. 557 do CPC) e outros mecanismos condicionantes de acesso àquelas cortes (repercussão geral - art. 543-A, § $3^{\circ}$ ).

691 “Art. 330 - O juiz conhecerá diretamente do pedido, proferindo sentença: I - quando a questão de mérito for unicamente de direito, ou sendo de direito e de fato, não houver necessidade de produzir prova me audiência; II - quando ocorrer a revelia (art. 319)".
} 
Vale dizer, o termômetro para aplicação desse dispositivo é a formação do livre convencimento motivado do magistrado. Presentes elementos que irão sustentar uma decisão fundamentada de conhecimento do pedido, autoriza-se o julgamento antecipado.

É muito comum a aplicação desse dispositivo em situações em que a decisão é fundamentada na falta de provas do direito que recaia a uma das partes comprovar. ${ }^{692} \mathrm{Em}$ que pese nesse ínterim processual ser aplicada a regra de distribuição do ônus probatório na sentença, o magistrado julga a lide antecipadamente sem saber qual parte tinha razão na demanda, pois o fundamento da sentença é a própria falta de provas do direito que assistia à parte sucumbente comprovar. Por outro lado, nessas situações, a instrução processual sequer é iniciada. O que importa frisar nesta hipótese de julgamento antecipado é que o juiz decide a demanda antecipadamente sem saber a qual parte assiste razão.

Ou seja, julga a demanda antecipadamente, dispensa a dilação probatória e fundamenta a decisão na falta de provas que cabia a uma das partes comprovar, notadamente a parte sucumbente. Essa contradição, embora pareça ser evidente, tem sido motivo de anulação de inúmeras sentenças, a ponto de chegar a conhecimento e julgamento pelo Superior Tribunal de Justiça e transcender qualquer óbice que esbarraria na aplicação da Súmula n. 7 por reexame fático-probatório ${ }^{693}$ dessa corte:

\footnotetext{
"Recurso especial. Alegada violação do art. 535 do Código de Processo Civil. Não ocorrência. Arts. 130 e 330, I, do Código de Processo Civil. Julgamento antecipado da lide. Cerceamento de defesa. Ocorrência. Retorno dos autos à origem.

No tocante à alegada violação do art. 535 do Código de Processo Civil, o recurso não logra perspectiva de êxito, uma vez que não há nos autos qualquer omissão, contradição ou obscuridade, pois o egrégio Tribunal $a$ quo apreciou toda a matéria recursal devolvida.

'Ainda que as partes não tenham requerido produção de provas, mas sim o julgamento antecipado da lide, se esta não estiver suficientemente instruída, de sorte a permitir tal julgamento, cabe ao juiz, de ofício, determinar as provas necessárias à instrução do processo (RT 664/91)' (Theotônio Negrão, com colaboração de José Roberto Ferreira Gouvêa, Código de Processo Civil e legislação processual em vigor, 35. ed. São Paulo: Saraiva, 2003, p. 410).'
}

\footnotetext{
${ }^{692}$ Nesse sentido, Antonio Carlos Marcato bem adverte que constitui cerceamento de defesa o julgamento antecipado do pedido quando, havendo controvérsia a respeito da matéria de fato relevante, o juiz impedir a produção de provas necessárias à sua elucidação. Por sua vez, o julgamento antecipado, nos termos do art. 330 do Código de Processo Civil, sempre será julgamento de mérito, porquanto o caput do referido dispositivo é claro ao aduzir que o juiz "conhecerá diretamente do pedido" (MARCATO, Antonio Carlos (Coord.). Código de processo civil interpretado. 3. ed. São Paulo: Atlas, 2008. p. 1.040).

${ }^{693}$ Súmula n. 7 do STJ: "A pretensão de simples reexame de prova não enseja recurso especial".
} 
In casu, emerge dos autos que o r. juiz de primeiro grau houve por bem julgar antecipadamente a lide, mas concluiu que não havia provas suficientes nos autos a demonstrar satisfatoriamente que a autora era credora da ré. Dessa forma, deveria ter determinado a produção de outras provas, nos termos do art. 130 do Código de Processo Civil. Com efeito, mesmo que a parte tenha requerido o julgamento antecipado da lide, por entender que as provas constantes dos autos seriam suficientes para demonstrar o alegado na inicial, cabe ao juiz, de ofício, determinar as provas necessárias à instrução do processo, caso entenda pela deficiência das provas dos autos. A hipótese vertente não trata de matéria puramente de fato. Em verdade, cuida-se de qualificação jurídica dos fatos, que não se confunde com matéria de fato. Recurso especial provido, para que os autos retornem à origem e o r. magistrado de primeiro grau prossiga a instrução probatória". ${ }^{64}$ (grifos nossos).

Consoante exposto nessa decisão, a violação da norma infraconstitucional nessa hipótese é do próprio art. 130 do Código de Processo Civil, que, como abordado em muitas passagens deste trabalho, permite as iniciativas probatórias ao juiz. Aliás, da interpretação desse julgado, fica claro que tais iniciativas constituem mais um dever do que uma faculdade dada o magistrado, porquanto a própria parte que recorreu já havia postulado pelo julgamento antecipado da lide, confiante de que ele lhe seria favorável. Todavia, o Superior Tribunal de Justiça entendeu que esse ato de disponibilidade da prova não seria suficiente para que o magistrado decidisse sem saber a quem assistia razão na demanda, tampouco fundamentar a decisão na falta de provas de uma das partes, ainda que ela tenha expressamente propugnado pelo julgamento antecipado. Portanto, seria dever do juiz a iniciativa probatória, com vistas a angariar elementos para a formação do livre convencimento.

Outro entendimento do Superior Tribunal de Justiça deixa clara a contradição existente entre uma sentença que julga antecipadamente a lide e a motiva com base na falta de provas do direito que cabia à parte sucumbente demonstrar:

"Processo civil. Agravo regimental. Agravo de instrumento. Embargos à
execução fiscal. Julgamento antecipado da lide. Cerceamento de defesa.
I - Resta configurada a violação ao art. 330 , I, do Código de Processo
Civil, uma vez que, ao mesmo tempo que o acórdão recorrido entendeu
que a lide resumia-se a questão de direito e que os fatos encontravam-se
documentalmente comprovados, podendo ter seu julgamento antecipado
sem produção de provas, entendeu, no mérito, que os embargos à

${ }^{694}$ STJ - REsp n. 288.400/PB, 2 ${ }^{\text {a }}$ Turma, rel. Min. Franciulli Netto, j. 01.04.2004, v.u., DJ, de 27.09.2004, p. 289. 
execução não poderiam ser acolhidos por falta de prova segura de que o depósito efetivado seria referente aos mesmos valores agora discutidos.

II - Inexistência de violação à Súmula n. 7 do STJ.

III - Agravo regimental improvido". 995

Por fim, outro julgado da corte excepcional serve para demonstrar que o requerimento de provas pela parte deve ser atendido se a fundamentação da sentença residir na própria falta de demonstração do direito que se pretendia restar provado:

\begin{abstract}
"Processual Civil. Recurso especial. Instrução probatória. Requerimento da parte na petição inicial. Falta de indicação das provas a produzir no momento processual oportuno. Reconhecimento da necessidade da prova na sentença pelo magistrado. Poder instrutório do juiz. Cerceamento de defesa.

Ao julgador é lícita a determinação de produção de provas ex officio sempre que o conjunto probatório mostrar-se contraditório, confuso ou incompleto e puder a prova a ser produzida influir na formação de sua convicção.

Resta configurado o cerceamento de defesa quando há prévia e expressa manifestação pela produção de provas na petição inicial e o d. Juízo $a$ $q u o$, embora na sentença reconheça a sua imprescindibilidade, julga antecipadamente improcedente o pedido formulado pelo autor sob o fundamento de falta de provas". ${ }^{696}$
\end{abstract}

Em sentido semelhante, o mesmo raciocínio pode ser empregado quando o tribunal aplica indevidamente o art. 515, $\S 3^{\circ}$, do Código de Processo Civil:

\begin{abstract}
"Processual civil. Requerimento de prova pericial e julgamento antecipado da lide. Anulação da sentença em sede de apelação. Teoria da causa madura. Pedido indeferido por falta de provas. Cerceamento de defesa. Matéria exclusivamente de direito.

I - Na linha dos precedentes desta Corte, não é admissível antecipar o julgamento da lide, indeferindo a produção de prova pericial, para, posteriormente, desprover a pretensão com fundamento na ausência de prova cuja a produção não foi permitida.

II - Essa conclusão se impõe ainda que o julgamento antecipado tenha ocorrido pelo próprio Tribunal, em grau de apelação, mediante a aplicação da teoria da causa madura prevista no art. $515, \S 3^{\circ}$, do Código de Processo Civil.
\end{abstract}

\footnotetext{
${ }^{695}$ STJ - AgR AgR AI n. 376.686/SP, $1^{\text {a }}$ Turma, rel. Min. Francisco Falcão, j. 06.08.2002, v.u., DJ, de 30.09.2002, p. 183. Em idêntico sentido: STJ - AgR AgR AI n. 298.190/SP, $1^{\text {a }}$ Turma, rel. Min. Francisco Falcão, j. 16.05.2002, v.u., DJ, de 09.09./2002, p. 163; STJ - AgR REsp n. 175.561/SP, $1^{\text {a }}$ Turma, rel. Min. Francisco Falcão, j. 02.05.2002, v.u., DJ, de 09/09/2002, p. 162.

${ }^{696}$ STJ - REsp 406.862/MG, $3^{\mathrm{a}}$ Turma, rel. Min. Nancy Andrighi, j. 08.11.2002, v.m., DJ, de 07.04.2003, p. 281. No mesmo sentido: STJ - REsp n. 106.6409/RS, 2a Turma, rel. Min. Eliana Calmon, j. 09.09.2008, v.u., DJe, de 30.09.2008; STJ - REsp n. 623.479/RJ, $3^{\text {a } T u r m a, ~ r e l . ~ M i n . ~ C a r l o s ~ A l b e r t o ~ M e n e z e s ~ D i r e i t o, ~ j . ~}$ 04.08.2005, v.u., DJ, de 07.11.2005, p. 265; STJ - REsp n. 783.185/RJ, $1^{\text {a }}$ Turma, rel. Min. Luis Fux, j. 24.04.2007, v.u., DJ, de 13.12.2007, com menção a inúmeros julgados no mesmo sentido.
} 
III - Recurso especial provido, para anular o aresto recorrido e determinar o retorno dos autos ao primeiro grau de jurisdição". 697

Portanto, a jurisprudência parece haver pacificado o entendimento de que julgamento antecipado da lide e fundamentação na falta de provas do direito da parte são premissas que não compatibilizam na mesma sentença ou acórdão, razão pela qual ganham relevância as iniciativas probatórias do magistrado nessa situação concreta, mormente se a parte (i) requereu a produção de determinada prova, ou (ii) postulou pelo julgamento antecipado da lide. Novamente, o que se preserva é evitar que o juiz seja passivo e julgue a demanda sem saber qual parte tem razão, sem sequer ter o trabalho de verificar que elementos de prova poderiam ser úteis para a formação do livre convencimento.

\subsection{Preclusão da prova - preclusão da parte e preclusão do juízo}

No que diz respeito aos atos de produção de provas, o instituto da preclusão ${ }^{698}$ pode suscitar dúvidas acerca de eventual limitação das iniciativas probatórias do juiz, a entender que o magistrado estaria impedido de determinar a produção de uma prova preteritamente indeferida no curso do processo. A projeção da preclusão em relação às partes também poderia impedir o magistrado de determinar a produção de uma prova que deixou de ser requerida no momento oportuno? Ainda, se a parte não deseja que uma prova seja produzida, poderia o juiz, ainda assim, insistir na sua produção? Na resposta a essas questões, e alinhados às premissas já defendidas, pretendemos nos apoiar em posicionamentos da jurisprudência, em especial do Superior Tribunal de Justiça.

No que toca à preclusão em relação às partes, seus efeitos somente teriam relevância se, através de outros elementos de provas trazidos aos autos, o juiz pudesse formar o livre convencimento necessário a decidir. Nesse caso, o instituto da preclusão como sistema de freios e contrapesos deve ser observado, porquanto uma vez presentes as condições para decidir o pedido e conhecer qual parte tem razão na demanda, não se deve

\footnotetext{
${ }^{697}$ STJ - REsp n. 948.289/RJ, 3 3 Turma, rel. Min. Sidnei Beneti, j. 09.12.2008, v.u., DJe, de 03.02.2009, p. 308.

698 Sobre uma análise em profundidade do instituto da preclusão, ver: SICA, Heitor Vitor Mendonça. Preclusão processual civil. 2. ed. São Paulo: Atlas, 2008; NEVES, Daniel Amorim Assumpção. Preclusões para o juiz: preclusão pro iudicato e preclusão judicial no processo civil. São Paulo: Método, 2004; FERREIRA FILHO, Manoel Caetano. A preclusão no direito processual civil. Curitiba: Juruá, 1991.
} 
retornar a marcha processual para franquear novamente a oportunidade de produção de provas pela parte cujo comportamento implicou preclusão lógica, temporal ou consumativa. ${ }^{699}$ Por outro lado, uma vez operada a preclusão em relação às partes, s o juiz ainda não dispuser de elementos suficientes à formação de seu livre convencimento, ${ }^{700}$ é perfeitamente admissível a iniciativa probatória de ofício. Nesse sentido:

"Previdenciário e processual civil. Violação ao art. 535 do Código de Processo Civil não configurada. Iniciativa probatória do magistrado. Possibilidade.

1. Embora tenha o julgado deixado de fazer menção expressa ao art. 333, I, do Código de Processo Civil, não há que se falar em omissão, já que a questão jurídica de que trata o citado dispositivo foi devidamente analisada, tendo o magistrado a quo emitido juízo de valor acerca da controvérsia.

2. Em que pese o art. 333, I do Código de Processo Civil determinar que compete ao autor o ônus da prova, quanto ao fato constitutivo do seu direito, o art. 130 do Código de Processo Civil possibilita também ao juiz a iniciativa probatória, mesmo quando a parte tenha tido a oportunidade de requerer a produção da prova e, no entanto, quedou-se inerte.

3. De acordo com a prestigiada doutrina processualística contemporânea, admite-se uma atuação protagonista do julgador que, ao invés de mero fiscal da aplicação das leis, passa a agir intensivamente para a maior efetividade do processo, especialmente quando se tratar de relação processual desproporcional, a exemplo das demandas previdenciárias.

4. Recurso especial do INSS improvido". ${ }^{701}$ (grifos nossos).

Portanto, ainda que a parte não tenha requerido a produção de determinada prova (preclusão temporal), caso ela se faça necessária para angariar elementos necessários à formação do livre convencimento, em que pese operar a preclusão da prova em relação à parte, seus efeitos não se projetam a ponto de impedir que o juiz se valha das iniciativas probatórias destinadas a melhor instruir os autos com elementos que lhe permitam decidir o pedido. Esse mesmo raciocínio também se aplica à preclusão lógica, quando a parte postula pelo julgamento antecipado e, ainda assim, o magistrado entende necessária a produção de determinada prova:

\footnotetext{
699 Em síntese, a preclusão que se projeta na atividade das partes dentro do processo conduz à extinção de uma facultade e comporta três denominações: a preclusão temporal, que se opera quando determinado ato processual deixa de ser realizado no prazo estabelecido para sua prática (art. 183 do CPC); a preclusão lógica, que decorre da incompatibilidade entre o ato praticado e outro que se queria praticar; e a preclusão consumativa, em que a realização do ato por si só já exaure a possibilidade dele se repetir novamente (art. 473 do CPC).

${ }^{700}$ Para Bedaque, a preclusão não pode prevalecer sobre o poder-dever do juiz de tentar esclarecer os fatos para aproximar-se o quanto possível da verdade e cumprir a missão de pacificar com justiça (Poderes instrutórios do juiz, cit., p. 19 e ss.).

${ }^{701}$ STJ - REsp n. 964.649/RS, $5^{\text {a }}$ Turma, rel. Min. Napoleão Nunes Maia Filho, j. 23.08.2007, v.u., DJ, de 10.09.2007, p. 308 .
} 
"Processual civil. Benefício acidentário. Perícia médica. Determinação ex officio pelo juiz. Possibilidade. Em se tratando de ação para a concessão de benefício acidentário, é possível ao juiz determinar ex officio a realização de perícia médica, tendo em vista a sua importância para a solução da lide, ainda que o segurado, motivado pelo deferimento do benefício no âmbito administrativo, tenha requerido o julgamento conforme o estado do processo, por entender desnecessária a prova técnica. Recurso não conhecido" ${ }^{702}$ (grifos nossos).

Inexiste preclusão da prova em relação às partes quando o juiz entender necessária a produção de determinada prova; de igual modo, não há preclusão pro judicato temporal, ${ }^{703}$ muito menos lógica, se o juiz indefere a produção de uma prova e, mais adiante, entende relevante sua produção, ou o próprio tribunal assim o determina:

\footnotetext{
"Processual civil. Prova testemunhal. Indeferimento. Agravo de instrumento e agravo retido. Preclusão consumativa. Inexistência.

1 - Não há preclusão para o juiz em matéria probatória, razão pela qual não viola o art. 473 do Código de Processo Civil o julgado do mesmo Tribunal que, ao julgar apelação, conhece e dá provimento a agravo retido, para anular a sentença e determinar a produção de prova testemunhal requerida pelo autor desde a inicial, ainda que, em momento anterior, tenha negado agravo de instrumento sobre o assunto.

2 - Interpretação teleológica do art. 130 do Código de Processo Civil corroborada pela efetiva e peremptória intenção do autor em produzir a prova.

3 - Recurso especial não conhecido". ${ }^{704}$

“(...)
}

${ }^{702}$ STJ - REsp n. 285.872/PR, 5 Turma, rel. Min. Felix Fischer, j. 20.03.2001, v.u., DJ, de 09.04.2001, p. 378.

${ }^{703}$ Humberto Theodoro Júnior leciona que a preclusão temporal não se aplica ao magistrado, porquanto os prazos para a prática de atos do juiz são impróprios, podendo ser ordenada a produção de prova a qualquer tempo, embora as partes já tenham incorrido em preclusão a respeito (Curso de direito processual civil, cit., v. 1, p. 533).

${ }^{704}$ STJ - REsp n. 418.971/MG, 4a Turma, rel. Min. Fernando Gonçalves, j. 11.10.2005, v.u., DJ, de 07.11.2005, p. 288. No mesmo sentido, julgado cujo voto do relator remete a inúmeras decisões pacificadas quanto à ausência de preclusão pro judicato em matéria probatória: "Em matéria relacionada com a instrução probatória, não há falar-se em preclusão para o juiz. Tal é a orientação de há muito traçada pelo STJ (REsp ns. 12.223/BA, 61.107/PR e 431.941/DF, todos de minha relatoria). Num dos primeiros recursos apreciados por este órgão fracionário, assentara-se que 'a norma do art. 473 do Código de Processo Civil, alusiva à preclusão das 'questões já decididas', dirige-se às partes, não ao juiz, máxime em matéria probatória, e sob o amparo inclusive do art. 130 do mesmo Código' (REsp n. 13/SP, rel. designado Min. Athos Carneiro). Assim se decidiu, por igual, quando do julgamento do REsp n. 222.445/PR, rel. Min. Sálvio de Figueiredo Teixeira." (STJ - REsp n. 262.978/MG, 4 ${ }^{\mathrm{a}}$ Turma, rel. Min. Barros Monteiro, j. 06.02.2003, v.u., $D J$, de 30.06.2003, p. 251). Ainda, em julgado relatado pelo Min. Francisco Falcão: “(...) II - Noutras palavras, ainda que tenha havido o anterior indeferimento da produção de prova pericial pelo juízo de primeiro grau, ainda assim pode o Tribunal de apelação, de ofício, determinar tal produção, se entender pela sua indispensabilidade. IV - Precedentes citados: AgR REsp n. 738.576/DF, rel. Min. Nancy Andrighi, $D J$, de 12.09.2005; ED AI n. 646.486/MT, rel. Min. Barros Monteiro, DJ, de 29.08.2005; AgR AI n. 655.888/MG, rel. Min. Arnaldo Esteves de Lima, $D J$, de 22.08.2005; REsp n. 406.862/MG, rel. Min. Carlos Alberto Menezes Direito, DJ, de 07.04.2003 (...).” (STJ - REsp n. 896.072/DF, $1^{\text {a }}$ Turma, rel. Min. Francisco Falcão, j. 15.04.2008, v.u., DJe, de 05.05.2008). 
II - Além das questões concernentes às condições da ação e aos pressupostos processuais, a cujo respeito há expressa imunização legal (CPC, art. 267, $\S 3^{\circ}$ ), a preclusão não alcança o juiz, em se cuidando de instrução probatória.

III - Diante do cada vez maior sentido publicista que se tem atribuído ao processo contemporâneo, o juiz deixou de ser mero espectador inerte da batalha judicial, passando a assumir uma posição ativa, que lhe permite, dentre outras prerrogativas, determinar a produção de provas, desde que $\mathrm{o}$ faça com imparcialidade e resguardando o princípio do contraditório". ${ }^{705}$

“(..)

A iniciativa probatória do magistrado, em busca da verdade real, com realização de provas de ofício, não se sujeita à preclusão temporal, porque é feita no interesse público de efetividade da justiça". ${ }^{706}$

Portanto, são manifestas as decisões a concluir que não há preclusão pro judicato no que toca às iniciativas probatórias e, em dadas hipóteses, os efeitos da preclusão operada em relação às partes também comportam mitigação. $\mathrm{O}$ critério para relativizar a preclusão das partes em matéria probatória é a formação do livre convencimento do magistrado, ${ }^{707}$ de sorte que ausentes elementos necessários para decidir, reputa-se possível a produção de prova de ofício.

\subsection{Conversão do julgamento em diligência}

A conversão do julgamento em diligência é outro campo fértil que aproveita o exercício das iniciativas probatórias, ainda que em segundo grau de jurisdição. Com o advento da Lei n. 11.276/2006, restou introduzido na redação do art. 515 do Código de Processo Civil o $\S 4^{\circ}$, cujo teor merece interpretação conjunta com o parágrafo único do art. 560 do mesmo diploma. ${ }^{708}$ Embora esses dispositivos tratem especificamente de

\footnotetext{
${ }^{705}$ STJ - REsp n. 222.245/PR, $4^{\mathrm{a}}$ Turma, rel. Min. Sálvio de Figueiredo Teixeira, j. 07.03.2002, v.u., DJ, de 29.04.2008, p. 246 No mesmo sentido, sustentando que a mesma imunização legal (CPC, art. 267, $\S 3^{\circ}$ do CPC) se aplica à instrução probatória: REsp n. 140.665/MG, 4ª Turma, rel. Min. Sálvio de Figueiredo Teixeira, j. 17.09.1998, DJ, de 03.11.1998, p. 147.

${ }^{706}$ REsp n. 345.436/SP, $3^{\text {a }}$ Turma, rel. Min. Nancy Andrighi, j. 07.03.2002, DJ, de 13.05.2002, p. 208.

${ }^{707}$ Nesse sentido: BEDAQUE, José Roberto dos Santos, Poderes instrutórios do juiz, cit., p. 19.

708 MACHADO, Antonio Cláudio da Costa. Código de processo civil interpretado: artigo por artigo, parágrafo por parágrafo. 8. ed. São Paulo: Manole, 2009. p. 649. Na linha dos dispositivos citados: “Art. 515 - A apelação devolverá ao tribunal o conhecimento da matéria impugnada. (...) $\S 4^{\circ}$ - Constatando a ocorrência de nulidade sanável, o tribunal poderá determinar a realização ou renovação do ato processual, intimadas as partes; cumprida a diligência, sempre que possível prosseguirá o julgamento da apelação. Art. 560 - Qualquer questão preliminar suscitada no julgamento será decidida antes do mérito, deste não se conhecendo se incompatível com a decisão daquela. Parágrafo único - Versando a preliminar sobre nulidade suprível, o tribunal, havendo necessidade, converterá o julgamento em diligência, ordenando a remessa dos autos ao juiz, a fim de ser sanado o vício."
} 
"nulidade sanável", a ser intimada a parte para cumprimento da diligência, ou "nulidade suprimível”, a ser sanada mediante a conversão do julgamento em diligência, ordenando-se a remessa dos autos ao juiz, os tribunais tem aplicado esses dispositivos também como fundamento a autorizar a iniciativa probatória do juiz ou do tribunal no âmbito recursal. Por sua vez, através da interpretação sistemática do parágrafo único do art. 560, em conjunto com o $\S 4^{\circ}$ posteriormente introduzido no art. 515, tem-se a possibilidade do próprio tribunal determinar seja a nulidade sanada, dispensando-se, por oportuno, a remessa dos autos à primeira instância. ${ }^{709}$

Outras discussões podem advir da interpretação conjunta desses dispositivos: se compete monocraticamente ao juiz (relator) ou tribunal (turma julgadora) aplicar essa norma; se eles podem determinar a realização da prova de ofício ou se a eles compete simplesmente determinar a anulação da sentença, para que a prova seja produzida pelo juízo de primeiro grau. São questões que embora suscitem dúvidas, não impedem o aproveitamento da técnica processual, desde que a utilização harmônica desses dispositivos não viole os princípios da teoria geral dos recursos ${ }^{710}$ e os princípios que regem o sistema, notadamente que se preserve o contraditório.

Apresentaremos a seguir julgados que evidenciam a possibilidade do manejo da iniciativa probatória em instância recursal, ${ }^{711}$ independentemente da conversão do julgamento em diligência ou da postulação de pedido de anulação da sentença pela parte, a demonstrar o manejo das iniciativas probatórias no âmbito recursal Nesse sentido, o Superior Tribunal de Justiça já decidiu que:

"Civil e processual. Ação investigatória de paternidade post mortem. Sentença que julgou procedente a ação. Acórdão que de ofício anula a sentença e determina nova instrução processual com oportunidade para

\footnotetext{
709 BUENO, Cassio Scarpinella. Curso sistematizado de direito processual civil: recursos, processos e incidentes nos tribunais: sucedâneos recursais, técnicas de controle das decisões judiciais. São Paulo: Saraiva, 2008. v. 5. p. 103

${ }^{710}$ Sobre o tema, ver: APRIGLIANO, Ricardo de Carvalho. A apelação e seus efeitos. 2. ed. São Paulo: Atlas, 2007; JORGE, Flávio Cheim. Teoria geral dos recursos cíveis. 4. ed. São Paulo: Revista dos Tribunais, 2009; CARVALHO, Fabiano. Os poderes do relator nos recursos: art 557 do CPC. São Paulo: Saraiva, 2008.

${ }^{711}$ Há farto entendimento consolidado no Superior Tribunal de Justiça de que o art. $515, \S 4^{\circ}$, do Código de Processo Civil não se aplica nas instâncias extraordinárias: STJ - AgR EREsp n. 932.702/AL, Corte Especial, rel. Min. Francisco Falcão, j. 16.09.2009, v.u., DJe, de 19.10.2009; STJ - AgR EREsp n. 107.8837/PE, 6 ${ }^{\mathrm{a}}$ Turma, rel. Min. Og Fernandes, j. 17.02.2009, v.u., DJe, de 16.03.2009; STJ - REsp 104.8954/PR, 2a Turma, rel. Min. Mauro Campbell Marques, j. 18.09.2008, , v.u., DJe, de 29.10.2008.
} 
realização do exame de DNA. Possibilidade. Ação de estado. Busca da verdade real. Preclusão. Inocorrência. Art. 131 do Código de Processo Civil e precedentes. Reformatio in pejus. Afastamento.

I. Tem o julgador de segunda instância a iniciativa probatória, mormente quando se trata de causa que tem por objeto direito indisponível (ações de estado).

II. Mitigação do princípio dispositivo em razão da busca da verdade real.

III. Em questões probatórias não há preclusão para o magistrado.

IV. Anulada decisão desfavorável à recorrente, não há que se falar em reformatio in pejus.

V. Recurso especial não conhecido". ${ }^{712}$ (grifos nossos).

Embora o julgado em tela evidencie a possibilidade de iniciativa probatória em segundo grau de jurisdição, a relação jurídica de direito material, em se tratando de direito indisponível, é apenas um plus a justificar tal iniciativa, em nada restringindo, tampouco condicionando que tal hipótese só se materialize sob essas circunstâncias. Essa premissa fica mais clara através da leitura da ementa abaixo, cujo teor é claro, ao deixar de condicionar a relação jurídica de direito material para permitir as iniciativas probatórias:

\begin{abstract}
“(...)
III. Pelo nosso sistema jurídico, é perfeitamente possivel a produção de prova em instância recursal ordinária.

IV. No campo probatório, a grande evolução jurídica em nosso século continua sendo, em termos processuais, a busca da verdade real.

V. Diante do cada vez maior sentido publicista que se tem atribuído ao processo contemporâneo, o juiz deixou de ser mero espectador inerte da batalha judicial, passando a assumir posição ativa, que lhe permite, dentre outras prerrogativas, determinar a produção de provas, desde que o faça com imparcialidade e resguardando o princípio do contraditório". ${ }^{713}$ (grifos nossos).
\end{abstract}

Portanto, é perfeitamente admissível que o traibunal exerça iniciativas probatórias, quando necessário angariar melhores elementos para decidir. De todo modo, a técnica processual e interpretação teleológica do art. 560, $\S 4^{\circ}$, permite subsumir que a prova seja produzida diretamente em segundo grau de jurisdição, o que encurta o iter procedimental $^{714}$, ao invés de, em contrapartida, determinar a anulação da sentença para a

\footnotetext{
712 STJ - REsp n. 101.0559/RN, 4ª Turma, rel. Min. Aldir Passarinho Junior, j. 16.10.2008, v.u., DJe, de 03.11.2008.

${ }^{713}$ STJ - REsp n. 192.681/PR, 4 a Turma, rel. Min. Sálvio de Figueiredo Teixeira, j. 02.03.2000, v.m., DJ, de 24.03.2003, p. 233. No mesmo sentido: STJ - REsp n. 985.077/SC, $3^{\text {a }}$ Turma, rel. Min. Humberto Gomes de Barros, j. 18.10.2000, , v.u., DJ, de 06.11.2007, p. 170.

${ }^{714}$ Soa correta a ponderação de José Roberto dos Santos Bedaque, ao asseverar que a aplicação do art. 515, § $4^{\circ}$, do Código de Processo Civil não implica em supressão de instância, "pois o juiz já examinou o mérito, considerando suficiente para tanto o conjunto probatório até então existente. Por considerar necessára a produção de outras provas para melhor compreensão da matéria fática, nada obsta ao tribunal determiná-la" (Poderes instrutórios do juiz, cit., p. 22).
} 
produção da prova em primeiro grau de jurisdição, nova decisão, sujeita portanto a novo recurso de apelação, o que certamente consumirá mais tempo, até atingir-se a tutela jurisdicional definitiva. $^{715}$

\subsection{Iniciativas probatórias para obtenção do resultado prático equivalente}

Após a reforma traçada pela Lei n. 8.952/94, o caput do art. 461 do Código de Processo Civil passou a contar com nova redação para permitir, nas ações que tenham por objeto o cumprimento de obrigação de fazer ou não fazer, que o juiz conceda tutela específica ou, se procedente o pedido, determine providências que "assegurem o resultado prático equivalente ao do adimplemento". ${ }^{716}$ Por sua vez, o $\S 1^{\circ}$ desse dispositivo prevê que a obrigação somente se converterá em perdas e danos se o autor o requerer ou se impossível a tutela específica ou a obtenção do resultado prático correspondente. ${ }^{717}$ Leciona Cassio Scarpinella Bueno:

"Pelo texto do dispositivo, não há como negar que objeto de proteção
legal é o resultado da obrigação, entendendo-se que o 'resultado prático
equivalente' repousa inegavelmente na variação da forma de obtenção
daquilo que deveria decorrer do adimplemento da obrigação por ato do
próprio réu. (...) É correta, pois, a interpretação de que a diferença entre a
tutela específica e o resultado prático equivalente ao do adimplemento
repousa inequivocadamente nos mecanismos a serem empregados
jurisdicionalmente para obtenção do cumprimento da obrigação (pedido
imediato), isto é, para perseguimento do bem da vida pretendido pelo
autor (pedido imediato). (...) São diferentes espécies porque representam
mecanismos variados ou técnicas diversas para obtenção do resultado que
deveria decorrer do cumprimento espontâneo da obrigação no plano do

715 Essa preocupação é registrada por Trícia Navarro Xavier, ao asseverar que a hipótese de anulação da sentença para a produção de provas em verdade deveria tratar de reforma da decisão para que o próprio tribunal produzisse a prova que entendesse necessária, porquanto se o magistrado de primeiro grau já formou o livre convencimento ao sentenciar e baseado nas provas coligidas nos autos, eventual anulação dessa decisão por parte do tribunal, para determinar a produção de nova prova, dificilmente irá alterar o teor da nova sentença a ser proferida. Mais coerente seria o tribunal diretamente determinar a produção da prova que entender necessária e depois proferir o acórdão (O "ativismo" do juiz em tema de prova. Revista de Processo, São Paulo, Revista dos Tribunais, ano 33, n. 159, p. 172-197, maio 2008. p. 194-195).

${ }^{716} \mathrm{O}$ intuito do legislador na nova redação do caput desse dispositivo foi simplesmente reproduzir a redação que já se encontrava expressa no art. 84 do Código de Defesa do Consumidor (Lei n. 8.078/90).

717 “Art. 461 - Na ação que tenha por objeto o cumprimento de obrigação de fazer ou não fazer, o juiz concederá a tutela específica da obrigação ou, se procedente o pedido, determinará providências que assegurem o resultado prático equivalente ao do adimplemento. $\S 1^{\circ}$ - A obrigação somente se converterá em perdas e danos se o autor o requerer ou se impossível a tutela específica ou a obtenção do resultado prático correspondente." 
direito material. São, em última análise, diferentes formas de tutela jurisdicional (pedido imediato) para alcançar, da maneira mais eficaz possível, um mesmo bem da vida (pedido mediato) violado ou ameaçado por ato do devedor. Justamente por isso é que elas podem até ser combinadas pelo magistrado, preocupado em conceder ao autor o mesmo resultado que decorreria do cumprimento da obrigação no plano do direito material". 718

Esse conceito jurídico indeterminado é sem dúvida um aumento dos poderes do juiz, reflexo da tendência das últimas reformas havidas no sistema. No que importa às premissas constantes neste estudo, cumpre verificar se o magistrado poderia exercer iniciativas probatórias destinadas a alcançar o resultado prático equivalente para assegurar o adimplemento de determinada obrigação, cuja técnica também se estende às obrigações de entrega de coisa, ex vi do quanto disposto no $\S 3^{\circ}$ do art. 461-A do Código de Processo Civil. ${ }^{719}$ A resposta é positiva.

Diante das premissas já sedimentadas nos itens 3.3 e seguintes, as iniciativas probatórias se prestam a angariar elementos necessários à formação do livre convencimento do juízo para decidir. Portanto, se o legislador estatuiu como técnica processual conferida ao magistrado o manejo de providências que assegurem o resultado prático equivalente ao adimplemento de determinada obrigação, exatamente por conta da problemática que representa delimitar o "resultado prático equivalente" mais adequado a dado caso concreto, as iniciativas probatórias do juiz certamente instrumentalizam a vinda de elementos necessários a se aproximar de uma decisão de qualidade para alcançar o resultado prático.

Vale dizer, o sistema permite ao juiz conceder tutela jurisdicional através de uma decisão que deve ser determinada, mas a lei lhe confere liberdade para subsumi-la ao conceito jurídico indeterminado "resultado prático equivalente"; nada impede que para atingir esse objetivo, sejam angariados elementos suficientes para formar a convicção necessária para a entrega da tutela mais precisa e acertada a delimitar a subsunção que se extrai desse conceito vago em relação a dado caso concreto. Em síntese, para atingir o "resultado prático equivalente", o juiz deve se valer de suas iniciativas probatórias, com

\footnotetext{
${ }^{718}$ MARCATO, Antonio Carlos (Coord.), Código de processo civil interpretado, cit., p. 1.463 e 1.468.

${ }^{719}$ Em verdade, a aplicação do regime previsto no art. 461 é subsidiária nas ações que tenham por objeto a entrega de coisa (art. 461-A), como pondera Dinamarco, advertindo que, na hipótese de impossibilidade de entrega de coisa certa, a conversão em perdas e danos é automática (Instituições de direito processual civil. 3. ed. São Paulo: Malheiros, 2009. v. 4. p. 527).
} 
vistas a se convencer, para conceder um pedido, para dar contornos que adaptem a necessidade do caso concreto a uma tutela aberta permitida pelo sistema.

Embora não se enquadre exatamente à ideia desenvolvida acima, mormente por conta da vedação de exame de matéria fático-probatória que representa o óbice da Súmula n. 7 do Superior Tribunal de Justiça, essa corte excepcional já decidiu pela ampla aplicação do resultado prático equivalente, quando impossível a tutela específica, baixando-se os autos para ultimar essa providência:

"Administrativo e processual civil. Ensino superior. Pós-graduação. Residência médica. Oferecimento de alojamento e alimentação pelo Poder Público durante o período da residência (auxílio in natura). Lei n. 6.932/81. Direito à tutela jurisdicional que envolve a adequação dos provimentos judiciais. Tutela específica. Impossibilidade. Art. 461, § $1^{\circ}$, do Código de Processo Civil. Conversão em medida que garanta resultado prático equivalente. Auxílio em pecúnia.

1. Trata-se de recurso especial em que se discute se a Secretaria de Saúde do Estado do Rio Grande do Sul tem o dever legal de oferecer alojamento e alimentação aos residentes de medicina e, em não o fazendo, se é cabível a conversão da obrigação em pecúnia.

2. É a seguinte a redação do art. $4^{\circ}, \S 4^{\circ}$, da Lei n. 6.932/81: 'As instituições de saúde responsáveis por programas de residência médica oferecerão aos residentes alimentação e moradia no decorrer do período de residência'.

3. Há limites para a discricionariedade administrativa, especialmente quando o dispositivo legal é peremptório a respeito da obrigatoriedade no fornecimento de alojamento e alimentação.

4. Se o Poder Público insiste em desconsiderar a norma, fazendo dessa previsão letra morta, caberá controle e intervenção do Judiciário, uma vez que, nestes casos, deixa-se o critério da razoabilidade para adentrar-se a seara da arbitrariedade, fato que, em último grau, caracteriza a omissão como ilegal.

5. A partir do momento em que opta pela inércia não autorizada legalmente, a Administração Pública se sujeita ao controle do Judiciário da mesma forma que estão sujeitas todas as demais omissões ilegais do Poder Público, tais como aquelas que dizem respeito à consecução de políticas públicas (v., p. ex.: STF - AgR RE n. 410.715/SP, 2 ${ }^{\mathrm{a}}$ Turma, rel. Min. Celso de Mello, DJU, de 03.02.2006).

6. É óbvio que o Judiciário não tem o condão de determinar que a Secretaria de Estado competente forneça pontualmente moradia e alimentação (i.e., de forçar que este órgão crie um mecanismo bastante para atender a um residente específico), pois isso seria contrariar uma premissa pragmática inafastável, qual seja, a de que o magistrado, no exercício de sua função, não possui condições para avaliar, no nível macro, as condições financeiro-econômicas de certo Estado membro para viabilizar tal e qual política de assistência.

7. Contudo, a simples inexistência de previsão legal para conversão de auxílios que deveriam ser fornecidos in natura em pecúnia não é suficiente para obstaculizar o pleito recursal, pois é evidente que se insere 
dentro do direito constitucional individual à tutela jurisdicional (art. $5^{\circ}$, inc. XXXV, da Constituição da República vigente) a necessidade de que a prestação jurisdicional seja adequada.

8. É por isso que o Código de Processo Civil, em seu art. 461, $\S 1^{\circ}$, dispõe que, na impossibilidade de tutela específica, é dado ao Poder Judiciário determinar medidas que garantam um resultado prático equivalente - ou mesmo se que converta a obrigação em perdas e danos.

9. Na inicial, a recorrente pede que os magistrados fixem um percentual sobre a bolsa de estudos em substituição ao dever estatal de prestação de alojamento e alimentação. Nada obstante, esta instância especial não tem poderes para analisar questões fático-probatórias para auxiliar a fixação desses valores, sob pena de violação à Súmula n. 7 desta Corte Superior.

10. Recurso especial provido, determinando o retorno dos autos à origem a fim de que lá seja determinado um valor razoável que garanta um resultado prático equivalente ao que determina o art. $4^{\circ}, \S 4^{\circ}$, da Lei $n$. $6.932 / 81 " 720$

Em que pese o julgado acima não tratar expressamente das iniciativas probatórias, conclusão inafastável é a de que, ao baixarem os autos à origem para que seja determinado um valor razoável, que garanta um resultado prático equivalente ao pleito do autor, necessáriamente haverá nova cognição para essa providência, seguida de contraditório, e, ao final, uma decisão do juiz para atender ao comando consignado pela corte excepcional. ${ }^{721} \mathrm{O}$ que se pretende sustentar diante desse julgado admitindo a aplicação do art. 461, § $1^{\circ}$, do Código de Processo Civil é que durante a instrução, ou quando evidente a impossibilidade ou frustração de cumprimento da tutela específica, nada impede que o juiz se valha de suas iniciativas probatórias para delimitar o melhor contorno para conceder o "resultado prático equivalente" ao pedido postulado pelo autor.

Portanto, pode o juiz, para alcançar o "resultado prático equivalente", valer-se de suas iniciativas probatórias, para trazer elementos aos autos suficientes a propiciar a correta aplicação dessa técnica processual. Até mesmo em situações em que não exista um

\footnotetext{
${ }^{720}$ STJ - REsp n. 813.408/RS, $2^{\text {a }}$ Turma, rel. Min. Mauro Campbell Marques, j. 02.06.2009, v.u., RSTJ v. 15 , p. 311

${ }^{721}$ Outras dúvidas podem ser extraídas quando aplicado o $\S 1^{\circ}$ do art. 461 do Código de Processo Civil: em sendo pedida apenas a tutela específica e ao final concedido o "resultado prático equivalente", como equacionar a repartição da verba sucumbencial, na medida que o pedido do autor não foi atendido na forma que foi postulada, mas sim através de "resultado prático equivalente"? A possibilidade do autor recorrer, sustentando que "resultado prático equivalente" proporcionado pelo juiz não é o mais adequado, etc. Há discussão também acerca da correta classificação da eficácia da sentença proferida na hipótese do art. 461. Para nos mantermos alinhados à premissa central deste trabalho, não pretendemos esgotar o debate que gravita sobre essas questões paralelas (o que convidaria a um exame mais aprofundado desss temas), mas apenas tentar deixar claro que as iniciativas probatórias do juiz são possíveis para se atingir o "resultado prático equivalente", medida que, haja vista o exercício de um poder ex officio conferido ao magistrado, recomendável a ampla participação e oportunidade de reação das partes e atenção aos princípios processuais e constitucionais que regem o sistema.
} 
pedido subsidiário de aplicação do art. 461, $\S 1^{\circ}$, o sistema permite que o magistrado aplique a técnica processual destinada a não atender o pedido do autor quando impossível ou frustrado o adimplemento, mas conceder o "resultado prático equivalente". ${ }^{722}$ Logo, de igual modo que é permitido ao juiz valer-se das iniciativas probatórias quando necessário decidir ou verificar a viabilidade de um pedido, nada impede que essas providências sejam utilizadas para a concessão de uma tutela autorizada e batizada pelo sistema como "resultado prático equivalente".

Aliás, a aplicação dessa técnica também não viola o princípio dispositivo, mas pode ser considerada uma mitigação desse princípio. ${ }^{723}$ De toda sorte, tendo em vista tratar-se de um conceito jurídico indeterminado, cuja aplicação refletirá diretamente na vida dos litigantes, de bom alvitre que o juiz abra vistas em contraditório para as partes se manifestarem sobre uma proposta de aplicação do "resultado prático equivalente", e que a utilização desse dispositivo seja fundamentada e proporcional às circunstâncias do caso concreto.

\subsection{Aplicação de "medidas de apoio" e revisão da astreinte}

Da mesma forma que a Lei n. 8.952/1994 tornou expressa a possibilidade do juiz conceder providências que assegurem o "resultado prático equivalente" ao adimplemento das obrigações de fazer ou não fazer e de dar coisa, já tratados no item anterior como o

\footnotetext{
${ }^{722}$ Como leciona Cassio Scarpinella Bueno, frustrada ou impossível a obtenção da tutela específica, cabe ao juiz, ainda que não haja pedido, buscar o "resultado prático equivalente". Portanto, a conversão da tutela específica em perdas e danos somente ocorrerá se a parte requerer diretamente na petição inicial como pedido subsidiário ou esgotada a sistemática de frustração da "tutela específica", "resultado prático equivalente", seguida de conversão em "perdas e danos" - art. 461, § 1º do Código de Processo Civil (Código de Processo Civil interpretado. In: MARCATO, Antonio Carlos (Coord.). Código de Processo Civil interpretado. 3. ed. São Paulo: Atlas, 2008. p. 1.463). No mesmo sentido ver: DINAMARCO, Cândido Rangel, Instituições de direito processual civil, cit., v. 4, p. 471.

${ }^{723}$ Nesse contexto, são os comentários tecidos por Cassio Scarpinella Bueno, ao deixar claro que a permissão legal da conversão da tutela específica em "resultado prático equivalente" não viola o art. 460 do Código de Processo Civil (Código de processo civil interpretado, in MARCATO, Antonio Carlos (Coord.), Código de processo civil interpretado, cit., p. 1.457). Paulo Henrique dos Santos Lucon cita o "resultado prático equivalente" como medida de apoio para cumprimento de uma obrigação, de modo a não afrontar os arts. 128, 460 e 463 do Código de Processo Civil (Código de Processo Civil interpretado. In: MARCATO, Antonio Carlos (Coord.). Código de Processo Civil interpretado. 3. ed. São Paulo: Atlas, 2008. p. 2.093). No mesmo sentido, Dinamarco assevera que essa regra é exceção ao postulado da correlação entre a sentença e a demanda (arts. 128 e 460 do CPC), porquanto "a medida de resultado prático equivalente já não será a mesma pedida na inicial e concedida em sentença, que se mostrou ineficaz a proporcionar tal resultado" (Instituições de direito processual civil, cit., v. 3, p. 250).
} 
próprio pedido ali concedido, o legislador preocupou-se também em outorgar poderes ao juiz para, de ofício, se valer de mecanismos destinados a viabilizar o cumprimento da tutela específica ou obtenção do resultado prático equivalente.

Trata-se da multa prevista nos $\S \S 4^{\circ}$ e $6^{\circ}$ do art. 461 do Código de Processo Civil, denominada astreinte, ou das chamadas medidas de apoio elencadas no $\S 5^{\circ}$ do mesmo dispositivo. ${ }^{724} \mathrm{~A}$ ideia desses mecanismos é intimidar o devedor a satisfazer a obrigação que está sendo compelido a adimplir, com mero caráter coercitivo (astreintes) ou determinando medidas de apoio destinadas à "efetivação da tutela específica" ou "obtenção do resultado prático equivalente". De todo modo, são medidas de pressão psicológica para que "o juiz faça de tudo para persuadir o executado a cumprir especificamente a obrigação". 725

Tais técnicas se destinam a assegurar a efetividade do adimplemento da obrigação de fazer, de não fazer ou de dar coisa, através de decisões cuja iniciativa o juiz pode ter de ofício, seja para a fixação ou revisão da multa (astreinte), seja para determinar as medidas de apoio previstas no $\S 5^{\circ}$ do art. 461 do Código de Processo Civil, cujo rol ali elencado é meramente exemplificativo. ${ }^{726}$ Portanto, visam a dar efetividade ao cumprimento de um comando (i) concedido em antecipação de tutela $-\S 3^{\circ}$ do art. 461 e $\S 3^{\circ}$ do art. 273 -, (ii) apreciado e decidido em sentença $-\S 4^{\circ}$ do art. 461 -, ou (iii) de ofício, como medida para a "efetivação da tutela específica" ou a "obtenção do resultado prático equivalente" $-\S 5^{\circ}$ do art. 461, todos do Código de Processo Civil.

\footnotetext{
724 “Art. 461 - (...) $§ 3^{\text {o }}$ - Sendo relevante o fundamento da demanda e havendo justificado receio de ineficácia do provimento final, é lícito ao juiz conceder a tutela liminarmente ou mediante justificação prévia, citado o réu. A medida liminar poderá ser revogada ou modificada, a qualquer tempo, em decisão fundamentada. $\S 4^{\circ}$ - O juiz poderá, na hipótese do parágrafo anterior ou na sentença, impor multa diária ao réu, independentemente de pedido do autor, se for suficiente ou compatível com a obrigação, fixando-lhe prazo razoável para o cumprimento do preceito. $\S 5^{\circ}$ - Para a efetivação da tutela específica ou a obtenção do resultado prático equivalente, poderá o juiz, de ofício ou a requerimento, determinar as medidas necessárias, tais como a imposição de multa por tempo de atraso, busca e apreensão, remoção de pessoas e coisas, desfazimento de obras e impedimento de atividade nociva, se necessário com requisição de força policial. (redação dada pela Lei n. 10.444/2002). § $6^{\circ}$ - O juiz poderá, de ofício, modificar o valor ou a periodicidade da multa, caso verifique que se tornou insuficiente ou excessiva".

${ }^{725}$ DINAMARCO, Cândido Rangel, Instituições de direito processual civil, cit., v. 4, p. 471.

726 Nesse sentido: BUENO, Cassio Scarpinella, Código de processo civil interpretado, in MARCATO, Antonio Carlos (Coord.), Código de processo civil interpretado, cit., p. 1.477; DINAMARCO, Cândido Rangel, Instituições de direito processual civil, cit., v. 4, p. 53.
} 
No que aproveita ao objeto deste trabalho, é importante ressaltar que tais providências podem ser determinadas de ofício pelo juiz, o que se aplica tanto para as astreintes, quanto para as medidas de apoio, ex vi do quanto disposto no art. $461, \S 5^{\circ}$ do Código de Processo Civil. ${ }^{727}$ Aliás, o Superior Tribunal de Justiça já decidiu nesse sentido, e quanto a esse ponto não pairam dúvidas:

"Administrativo e processual civil. Art. 535, II, do Código de Processo Civil. Omissão. Inexistência. Custeio de tratamento médico. Moléstia grave. Bloqueio de valores em contas públicas. Possibilidade. Art. 461, caput e $\S 5^{\circ}$ do Código de Processo Civil.

1. A verificação, no âmbito desta Corte, de eventual omissão pelo Tribunal a quo na análise de matéria constitucional importaria na usurpação da competência reservada ao Supremo Tribunal Federal.

2. Além de prever a possibilidade de concessão da tutela específica e da tutela pelo equivalente, o Código de Processo Civil armou o julgador com uma série de medidas coercitivas, chamadas na lei de 'medidas necessárias', que têm como escopo o de viabilizar o quanto possivel o cumprimento daquelas tutelas.

3. As medidas previstas no $\S 5^{\circ}$ do art. 461 do Código de Processo Civil foram antecedidas da expressão 'tais como', o que denota o caráter não exauriente da enumeração. Assim, o legislador deixou ao prudente arbitrio do magistrado a escolha das medidas que melhor se harmonizem às peculiaridades de cada caso concreto.

4. Submeter os provimentos deferidos em antecipação dos efeitos da tutela ao regime de precatórios seria o mesmo que negar a possibilidade de tutela antecipada contra a Fazenda Pública, quando o próprio Pretório Excelso já decidiu que não se proíbe a antecipação de modo geral, mas apenas para resguardar as exceções do art. $1^{\circ}$ da Lei n. 9.494/97.

5. O disposto no caput do art. 100 da Constituição Federal de 1988 não se aplica aos pagamentos de obrigações definidas em lei como de pequeno valor, de modo que, ainda que se tratasse de sentença de mérito transitada em julgado, não haveria submissão do pagamento ao regime de precatórios.

6. Em casos como o dos autos, em que a efetivação da tutela concedida está relacionada à preservação da saúde do indivíduo, a ponderação das normas constitucionais deve privilegiar a proteção do bem maior que é a vida.

7. Precedentes de ambas as Turmas que compõem a Primeira Seção.

8. Recurso especial improvido". ${ }^{728}$ (grifos nossos).

${ }^{727}$ Dinamarco afirma que tanto as multas como as outras medidas necessárias têm o condão de abrir o caminho para a satisfação do credor e preservar a autoridade das decisões judiciárias, sendo medida a ser tomada pelo juiz, portanto, de ofício (Instituições de direito processual civil, cit., v. 4, p. 539). Novamente cabe aqui tecer a ressalva de que, para a finalidade deste trabalho, o que cumpre deixar claro neste item é que as medidas previstas no art. 461, $\S 5^{\circ}$, do Código de Processo Civil podem ser aplicadas de ofício e convidam à investigação acerca da possibilidade do juiz exercer iniciativas probatórias antes de aplicar esse dispositivo. Portanto, não trataremos de outras questões correlatas ao instituto, tais como a discussão acerca do termo a quo de incidência e exigibilidade de astreinte, limitação de seu valor, etc.

${ }^{728}$ STJ - REsp n. 853.880/RS, 2 ${ }^{\text {a }}$ Turma, rel. Min. Castro Meira, j. 19.06.2006, v.u., DJ, de 28.09.2006. No mesmo sentido: STJ - REsp n. 776.922/SP, 2 ${ }^{\text {a }}$ Turma, rel. Min. Eliana Calmon, j. 27.03.2007, DJ, de 13.04.2007, p. 364; STJ - REsp. n. 853.880/RS, $2^{\text {a }}$ Turma, rel. Min. Castro Meira, j. 19.06.2006, v.u., DJ, de 28.09.2006; STJ - AgR REsp n. 947.892/RS, 2a Turma, rel. Min. Mauro Campbell Marques, j. 
E é exatamente no exercício desse poder de ofício conferido pelo sistema ao magistrado que surge a seguinte dúvida: pode o juiz valer-se de suas iniciativas probatórias antes de decidir pontos relacionadas às astreintes ou à determinação das medidas de apoio? A resposta é afirmativa.

Se o que importa é satisfazer a obrigação reclamada pela parte e determinado o cumprimento pelo juiz, em que pesem as medidas de apoio não angariarem elementos ao conhecimento do juiz para ao final decidir um pedido, trata-se de medidas voltadas a forçar a própria satisfação da tutela jurisdicional, consistente no adimplemento de uma obrigação específica ou obtenção de seu resultado equivalente. E para a correta e acertada aplicação dessas medidas, a decisão do magistrado pode necessitar buscar elementos, provas e constatações fáticas que sejam suficientes a embasar a correta e razoável aplicação do instituto. Até porque a decisão deverá ser fundamentada e guardar observância com os princípios processuais e constitucionais que integram o sistema.

Portanto, as iniciativas probatórias guardam utilidade prática na determinação das medidas de apoio, a preceder a formação do livre convencimento do magistrado, quando, de ofício, decidir pela aplicação do instituto. A título de exemplo, a decisão que impõe, majora ou reduz a fixação da astreinte deve não apenas ser motivada, mas apontar todos os elementos a justificar a imposição desse mecanismo de coerção, mormente diante dos efeitos que essa decisão causará às partes. ${ }^{729}$ De igual modo, se uma diligência determinada pelo juiz, voltada à "efetivação da tutela específica ou à obtenção do resultado prático equivalente" se mostrar insuficiente para esse mister, nada impede que o juiz tenha iniciativas probatórias com vistas a determinar outro meio que seja mais eficiente a garantir o adimplemento de dada obrigação. Trata-se, portanto, da dinâmica com que o juiz dirigirá o processo, visando a forçar o devedor ao adimplemento de uma obrigação positiva ou negativa, e até mesmo de dar coisa certa, dinâmica que irá variar consoante os impactos da medida inicialmente determinada e os efeitos práticos decorrentes.

06.08.2009, v.u., DJe, de 06.08.2009; STJ - AgR AI n. 1.040.411/RS, $2^{\mathrm{a}}$ Turma, rel. Min. Herman Benjamim, j. 02.10.2008, v.u., DJe, de 19.12.2008; STJ - AgR REsp n. 100.2335/RS, $1^{\text {a }}$ Turma, rel. Min. Luiz Fux, j. 21.08.2008, v.u., DJe, de 22.09.2008.

${ }^{729}$ Marcelo José Magalhães Bonicio bem adverte sobre o critério da proporcionalidade que reclama a revisão da multa prevista no art. 461 do Código de Processo Civil. De um lado, deve-se evitar que seja fixado um valor irrisório, a ponto de não trazer estímulo algum ao devedor para cumprir a obrigação. Em contrapartida, as multas não devem atingir um valor excessivo, de sorte a constituir verdadeira "pensão vitalícia” a ser almejada pelo credor (Proporcionalidade e processo..., cit., p. 131). 
Ou seja, se a ideia traçada pelo legislador em relação às chamadas medidas de apoio é exatamente forçar o devedor a adimplir uma dada obrigação, sendo franqueado ao juiz inclusive poderes para, de ofício, regular a melhor maneira de imposição dessas medidas. Consoante as circunstâncias fáticas de cada caso concreto, a contribuição materializada pelas iniciativas probatórias se presta tão somente a trazer melhores elementos para apurar uma decisão mais razoável possível e adequada ao emprego de tais medidas.

Por outro lado, quando da determinação ou revisão da aplicação das medidas de apoio, as inciativas probatórias devem ser exercidas pelo magistrado somente se houver dúvidas para atingir um denominador comum a aquilatar a utilização da melhor medida, o que constitui inclusive um dos limites das iniciativas probatórias, já tratado no itens 3.3 e seguintes. O que se pretende defender neste item é a possibilidade do juiz exercer iniciativas probatórias antes de aplicar o disposto no $\S 5^{\circ}$ do art. 461 do Código de Processo Civil, o que somente será um dever nas situações em que carecer de elementos de prova para uma decisão, quando aplicará as medidas de apoio para cumprimento de uma obrigação específica ou obtenção de seu resultado prático equivalente.

\subsection{Atualização do valor do bem penhorado e apresentação de novo quantum debeatur}

As iniciativas probatórias do magistrado também devem ser exercidas para a satisfação da tutela executiva, a qual deve se alinhar aos princípios que regem o processo de execução, ${ }^{730}$ de modo a proporcionar uma tutela que, não obstante se ocupe de entregar o bem da vida postulado pelo credor, ainda assim deve ser justa.

Por sua vez, os atos de expropriação patrimonial do devedor e todo o iter que acompanha a avaliação do bem penhorado na execução de título judicial ou cumprimento de sentença (lastreado no pedido de pagamento de quantia) até a efetiva expropriação, de

\footnotetext{
${ }^{730}$ Como leciona Cassio Scarpinella Bueno, regem a tutela jurisdicional executiva os seguintes princípios: da autonomia ou do sincretismo; do título executivo; da patrimonialidade; da disponibilidade; da adequação; da tipicidade dos atos executivos; do resultado e da menor gravidade ao executado; e da lealdade (BUENO, Cassio Scarpinella, Curso sistematizado de direito processual civil, cit., v. 3, p. 14 a 30).
} 
igual sorte, devem primar pela observância dos princípios que guarnecem o sistema. $\mathrm{O}$ Superior Tribunal de Justiça já decidiu que a iniciativa probatória do juiz com vistas a determinar a realização de nova avaliação do bem penhorado não constitui violação a nenhum dispositivo de lei:

"Processual civil. Execução fiscal. Bem penhorado. Nova avaliação. Art. $13, \S 1^{\circ}$, da Lei n. $6.830 / 80$.

1. A regra insculpida no art. $13, \S 1^{\circ}$, da Lei de Execuções Fiscais tem por escopo assegurar a possibilidade de qualquer das partes impugnar o laudo de avaliação e, se impugnação houver, descreve o procedimento para que o juiz proceda a nova avaliação dos bens penhorados. No entanto, daí não se deve defluir esteja o juiz impedido de determinar, de ofício, tal providência, propugnando, dessa forma, para que 'a execução se faça pelo modo menos gravoso para o devedor' princípio da economicidade Código de Processo Civil, art. 620, in fine.

2. Dentre os poderes que o Código de Processo - arts. 125, I; 130, ambos c.c. o art. 598 - confere ao juiz na direção do processo de execução, subsume-se o de determinar atos instrutórios necessários para que a execução se processe de forma calibrada, justa, de modo a não impor desnecessários sacrifícios ao devedor. Daí a necessidade de se instruir corretamente o processo para que a alienação do bem penhorado alcance preço tanto quanto possível mais próximo do valor de mercado.

3. Dentre as razões que fizeram o legislador avultar os poderes de comando do juiz no processo de execução, está a de não permitir que na realização da praça se aceite o oferecimento de preço vil (CPC, art. 692). Quer o legislador, em última análise, que a execução se ultime sempre de forma justa.

4. Se o processo de conhecimento é instruído com o escopo de permitir que o juiz o encerre com a formulação da regra aplicável ao caso concreto, ou seja, profira a sentença; o processo de execução, na modalidade por quantia certa, é instruído de modo a possibilitar a satisfação do direito do credor, o que se consegue com a alienação do patrimônio contristado, mas, frise-se, sempre pelo preço justo.

5. No processo de execução, em face da incidência do princípio da responsabilidade patrimonial agasalhado pelo art. 591 do Código de Processo Civil, cabe ao juiz a tarefa indeclinável de adequar o débito à responsabilidade do executado, visto ser a execução nos dias atuais parcial, vale dizer, limita-se ao necessário e suficiente para satisfazer a obrigação. Razão por que o valor do bem penhorado deve ser sempre corretamente aferido.

6. Recurso especial a que se nega provimento". ${ }^{731}$ (grifos nossos)

A peculiaridade que se depreende desse julgado é que não obstante o executado deixar de apresentar impugnação à avaliação do bem penhorado no prazo legal, ainda

731 STJ - REsp. n. 719.60/SP, 2a Turma, rel. Min. João Otávio de Noronha, j. 25.03.2003, v.u., DJ, de 14.04.2003, p. 206 No mesmo sentido: STJ - REsp. n. 299.120/MS, $3^{\text {a }}$ Turma, rel. Min. Humberto Gomes de Barros, j. 12.04.2005, v.u., DJ, de 09.05.2005, p. 388; STJ - REsp. n. 82.068/SP, Corte Especial, rel. Min. José Dantas, j. 18.02.1998, , v.u., DJ, de 09.03.1998, p. 3. 
assim o magistrado entendeu pela necessidade de se proceder a uma nova avaliação, com vistas a proporcionar a atualização do valor do bem que fosse adequada e correspondente com o seu valor de mercado na ocasião em que se realizaria o leilão. Por sua vez, os fundamentos empregados nessa decisão perfilham as iniciativas probatórias do juiz como decorrência dos poderes de direção do processo conferidos no art. 125, I, do Código de Processo Civil. Ou seja, para se garantir uma isonomia que refletisse no correto valor de mercado do bem diante do leilão se que aproximava, o juiz determinou a realização de nova avaliação. Assim, estar-se-ia preservando o interesse do credor e, por outro lado, o princípio da economicidade constante no art. 620 do Código de Processo Civil, para que a execução se fizesse pelo meio menos gravoso possível ao devedor. Nesse contexto, ao discorrer acerca da extenção dos poderes do juiz no ato executivo, Araken de Assis bem assevera que:

“(..) uma vez proposta a demanda, nenhum estímulo externo do
exequente se requer para a emanação e a prática de qualquer ato, sejam
quais forem o alcance e a consequência do provimento do juiz. Desejando
trancá-lo, o credor dele pode desistir explicitamente, como lhe assegura o
art. 569 do Código de Processo Civil. Se, porém, o credor almeja
modificá-lo, na hipótese em que a lei não estipulou forma rígida, porque
inconveniente e difícil a conformação prévia, basta invocar a faculdade
prevista no art. 615 , I. A inércia do credor põe o juiz à vontade para
prover segundo sua sensibilidade. Exatamente, nesse ponto, avultam os
poderes de direção do juiz, que, em largueza e profundidade, conhecem
poucos limites. (...) Esses poderes avantajados remarcam, salvo engano, a
indispensabilidade do controle judicial no curso do ato executivo". ${ }^{732}$

Em recente decisão, o Superior Tribunal de Justiça decidiu acerca da possibilidade do juiz determinar de ofício a apresentação de novo cálculo pelo credor, a despeito da lei imputar ao devedor o ônus de comprovar eventual inexatidão:

"Processual civil. Embargos do devedor à execução fundada em título
judicial. Ônus da prova. Iniciativa probatória do julgador.
Admissibilidade.
- Os juízos de $1^{\circ}$ e $2^{\text {o }}$ graus de jurisdição, sem violação ao princípio da
demanda, podem determinar as provas que lhes aprouverem, a fím de
firmar seu juízo de livre convicção motivado, diante do que expõe o art.
130 do Código de Processo Civil.
- A iniciativa probatória do juiz, em busca da verdade real, com
realização de provas de ofício, é amplíssima, porque é feita no interesse
público de efetividade da justiça.

${ }^{732}$ ASSIS, Araken de. Manual da execução. 11. ed. São Paulo: Revista dos Tribunais, 2007. p. 93. 
- Embora recaia sobre o devedor embargante o ônus de demonstrar a inexatidão dos cálculos apresentados pelo credor exequente, deve-se admitir a iniciativa probatória do julgador, feita com equilíbrio e razoabilidade, para aferir a exatidão de cálculos que aparentem ser inconsistentes ou inverossímeis, pois assim se prestigia a efetividade, celeridade e equidade da prestação jurisdicional.

Recurso especial improvido". 733

Esses julgados são meramente exemplificativos, a demonstrar a admissibilidade das iniciativas probatórias do juiz com vistas a preservar outro dever seu, consistente em determinar que a execução se processe do modo menos gravoso para o devedor. ${ }^{734}$ Esse pensar reflete uma dinâmica mais acentuada para justificar as iniciativas probatórias do magistrado, consistente em aproximar decisões que atinjam um julgamento justo, a evitar, em dadas circunstâncias de inércia do devedor, que a avaliação do bem penhorado se materialize de forma inadequada e deixe de refletir o valor de mercado no ato de sua expropriação (primeiro julgado), ao passo que os cálculos aparentemente inconsistentes ou inverossímeis podem ser questionados pelo magistrado, a provocar iniciativas probatórias para melhor esclarecimento (segundo julgado).

Em que pesem os brilhantes fundamentos constantes no primeiro acórdão acima citado, ousamos discordar apenas de uma dessas premissas. Acertado o entendimento de que a iniciativa probatória do juiz deva produzir resultados justos dentro da dinâmica que circunda os atos de penhora, avaliação e expropriação de bens no processo de execução. Todavia, tais iniciativas não correspondem inexoravelmente a preservar o princípio da execução se operar do modo menos gravoso ao devedor, até porque não se sabe o resultado da prova que determina uma nova avaliação, sem prejuízo de que o resultado pode inclusive refletir uma avaliação deficitária do bem (a considerar depreciações em razão do tempo e desgaste de tal bem, por exemplo) que conduza à redução do valor apontado em levantamento anterior.

\footnotetext{
${ }^{733}$ STJ - REsp n. 101.2306/PR, $3^{\text {a }}$ Turma, rel. Min. Nancy Andrighi, j. 28.04.2009, v.u., DJe, de 07.05.2009.

${ }^{734}$ Parte do voto do Ministro João Otávio de Noronha, constante no julgado em comento, é o seguinte: "No entanto, daí não se deve defluir esteja o juiz impedido de determinar, de ofício, tal providência, propugnando, dessa forma, para que 'a execução se faça pelo modo menos gravoso para o devedor' princípio da economicidade - conforme estabelece o art. 620, in fine, Código de Processo Civil. Até porque - na atenta observação de Pontes de Miranda - 'na aplicação do art. 620, o juiz não tem o arbítrio, mas sim o dever de escolher o modo menos gravoso para o devedor' (Comentários ao CPC, v. 10, p. 43). Dentre os poderes que o Código de Processo - arts. 125, I; 130, c.c. o art. 598 - confere ao juiz na direção do processo de execução, subsume-se o de determinar atos instrutórios necessários para que a execução se processe de forma calibrada, justa, de modo a não impor desnecessários sacrifícios ao devedor. Daí a necessidade de se instruir corretamente o processo, para que a alienação do bem penhorado alcance preço tanto quanto possível mais próximo do seu valor de mercado".
} 
De todo modo, a premissa que se coloca neste item é a de que as iniciativas probatórias do magistrado devem ser observadas, com vistas a refletir maior aproximação da realidade nos atos que albergam a tutela executiva, notadamente no que tange à determinação de ofício de nova avaliação do bem penhorado e de refazimento dos cálculos, quando eles se mostrarem inconsistentes ou inverossímeis. Ou seja, o que se preserva é a aproximação da verdade em relação ao interesse do credor (exatidão dos cálculos que corresponda ao quanto tipificado no título executivo) e nos atos de expropriação do patrimônio do devedor (valor do bem atualizado próximo ao ato de expropriação).

\subsection{Determinação da prova a ser produzida pela parte e inversão dinâmica do ônus da prova}

Consoante já restou sedimentado no Capítulo 3, a iniciativa probatória do juiz não encontra limitações em relação ao sujeito sobre o qual é requerida a produção de determinada prova. Ou seja, por simples interpretação teleológica dos arts. 130 e 339 do Código de Processo Civil, o juiz poderá de ofício "determinar as provas necessárias à instrução do processo", porquanto o sistema impõe que "ninguém se exime do dever de colaborar com o Poder Judiciário para o descobrimento da verdade.” Portanto, ainda que o resultado da prova possa parecer favorável ao autor e o juiz determine que ela seja produzida pelo réu, essa circunstância não esvazia a iniciativa probatória do juiz, tampouco dá margem a qualquer cogitação de imparcialidade. Nesse sentido já decidiu o Superior Tribunal de Justiça:

"Processo civil. Ausência de omissão, contradição ou falta de motivação
no acórdão a quo. Embargos à execução. Crédito decorrente de diferença
de correção monetária sobre cruzados novos. Extratos das contas em
poder do Bacen. Exibição de documento. Art. 844, II, do Código de
Processo Civil. Precedentes.
1. Recurso especial contra acórdão segundo o qual 'evidenciando-se a
ausência de documentos necessários à instrução do processo, documentos
esses que se encontram em poder da parte contrária, é de todo salutar que
o juiz, mediante provocação da parte interessada ou de ofício, os requisite
de quem os possuir'.
2. Decisão a quo clara e nítida, sem omissões, obscuridades, contradições
ou ausência de motivação. O não acatamento das teses do recurso não
implica cerceamento de defesa. Ao juiz cabe apreciar a questão de acordo
com o que entender atinente à lide. Não está obrigado a julgá-la conforme
o pleiteado pelas partes, mas sim com seu livre convencimento (CPC, art. 
131), usando fatos, provas, jurisprudência, aspectos atinentes ao tema e legislação que entender aplicáveis ao caso. Não obstante a oposição de embargos declaratórios, não são eles mero expediente para forçar o ingresso na instância especial, se não há vício para suprir. Não há ofensa ao art. 535, I, do Código de Processo Civil quando a matéria é abordada no aresto a quo.

3. O direito processual civil contemporâneo está a exigir uma participação mais ativa do juiz na formação e no desenvolvimento da relação jurídico-processual, especialmente quando uma das partes é hipossuficiente economicamente.

4. Evidenciando-se ausência de documentos necessários à instrução do processo, documentos esses que se encontram em poder da parte contrária, é de todo salutar que o juiz, mediante provocação da parte interessada ou de ofício, os requisite de quem os possuir.

5. O art. 844, II, do Código de Processo Civil estatui que 'tem lugar, como procedimento preparatório, a exibição judicial de documento próprio ou comum, em poder de cointeressado, sócio, condômino, credor ou devedor; ou em poder de terceiro que o tenha em sua guarda, como inventariante, testamenteiro, depositário ou administrador de bens alheios'.

6. 'Em tema de terceiro e exibição, cumpre lembrar a parte final do inciso II, do art. 844, ora em exame. Mesmo que o documento não seja próprio ou comum, o terceiro tem o dever de exibi-lo se sob sua custódia ou guarda. A enumeração da lei a esse respeito (com menção a inventariante, testamenteiro, depositário ou administrador de bens alheios) exibe, não há dúvida, natureza meramente exemplificativa' (Carlos Alberto Álvaro de Oliveira, Comentários ao Código de Processo Civil, 3. ed., Rio de Janeiro: Forense, v. 8, t. 2, p. 220).

7. Precedentes desta Corte Superior.

8. Recurso não provido". ${ }^{735}$

Embora parte da fundamentação empregada no acórdão supracitado faça menção analógica à medida cautelar de exibição de documentos, o que importa para este estudo é a constatação de que em ação de conhecimento o juiz pode determinar que uma das partes produza determinada prova que se encontra em seu poder, providência que se alinha às primissas já traçadas em relação às iniciativas probatórias. Por outro lado, se a parte se nega a produzir a prova, poderia o juiz aplicar a regra de inversão dinâmica do ônus probatório? A resposta soa afirmativa, a remeter às conclusões traçadas no item 3.2.3, relativas à chamada carga dinâmica da prova.

\footnotetext{
${ }^{735}$ STJ - REsp. n. 829.716/SC, $1^{\text {a }}$ Turma, rel. Min. José Delgado, j. 23.05.2006, v.u., DJ, de 08.06.2006, p. 153, No mesmo sentido: STJ - REsp. n. 827.326/MG, $1^{\text {a }}$ Turma, rel. Min. José Delgado, j. 18.05.2006, DJ, de 08.06.2006, p. 152.Em semelhante sentido, em relação à legitimidade do síndico para responder a ação cautelar de exibição de documentos ajuizada pelo condomínio: STJ - REsp. n. 557.379/DF, 4a Turma, rel. Min. Barros Monteiro, j. 05.02.2004, DJ, de 03.05.2006, p. 178.
} 
Para a aplicação da carga dinâmica, é necessário ponderar algumas ressalvas já traçadas no item supracitado, no sentido de que: (i) reputem-se verossímeis os fatos alegados por uma das partes; (ii) seja possível aferir que haverá maior facilidade de produção da prova pela parte sobre a qual recai a distribuição dinâmica do ônus; (iii) a prova redirecionada deve ser possível e não deve constituir prova diabólica a ser suportada por aquele sobre o qual recai a distribuição dinâmica; (iv) a redistribuição não pode causar surpresa para a parte, sendo-lhe franqueada a oportunidade de produção de prova apta a desincumbir-se do cargo, permitindo-se, portanto, o contraditório; e, por fim, (v) o ônus invertido para a parte seja o de esclarecer o fato controvertido apontado pelo juiz.

Deve ainda restar superada nos autos a questão de que a parte se encontra melhor habilitada para a produção de determinada prova exigida pelo juiz, de modo a permitir a aplicação do regramento e inclusive a distribuição dinâmica. Portanto, o que se busca preservar com essa medida é tão somente agregar elementos de prova para conhecimento do magistrado que sejam necessários e relevantes para decidir. E a aplicação da carga dinâmica da prova soa adequada nessa hipótese, porquanto se a parte simplesmente se nega a produzir determinada prova em que já restou superada a questão de que ela teria melhores condições de fazê-lo, tal fato não coaduna com os escopos do processo, restando ao juiz, pura e simplesmente, aplicar a regra estática de julgamento de distribuição do ônus probatório, caso esse seja o único meio de prova acessível para permitir a formação do livre convencimento.

\subsection{Indisponibilidade das partes em arcar com o custo da produção da prova determinada pelo juiz}

$\mathrm{Na}$ dinâmica que envolve as iniciativas probatórias do juiz, pode ocorrer que a produção da prova determinada de ofício não seja desejada pelos litigantes, principalmente por aquele sobre o qual recai o ônus econômico necessário para custeá-la. Nessa hipótese, tem-se um problema de ordem econômica, cujos reflexos, caso se mostre infrutífera a tentativa de produção da prova determinada pelo juiz, fatalmente conduzirá à aplicação da 
regra de distribuição do ônus probatório, ocasião em que o magistrado se verá obrigado a decidir sem ter conhecimento suficiente que lhe permita aferir qual parte tinha razão na demanda. $^{736}$

O juiz determina de ofício a produção de dada prova, cujo custo em princípio deve ser arcado pelo autor $\left(\operatorname{art} .19, \S 2^{\circ} \text {, do } \mathrm{CPC}\right)^{737}$. Diz-se em princípio, pois o Superior Tribunal de Justiça já consolidou o entendimento de que, sobrevindo a aplicação da regra de inversão do ônus da prova, caberá à parte sobre a qual recai o ônus ser advertida da possibilidade de inversão, sendo de bom alvitre, portanto, que ela arque com o ônus econômico, sob pena de, na ocasião do julgamento, ser aplicada a regra de inversão, e assim presumirem-se verdadeiros os fatos alegados pela parte beneficiada pela inversão:

\footnotetext{
"Processual civil. Inversão do ônus da prova. Extensão. Honorários periciais. Pagamento. Perícia determinada de ofício. Autor beneficiário da justiça gratuita.

1. Cinge-se a controvérsia em saber se a questão de inversão do ônus da prova acarreta a transferência ao réu do dever de antecipar as despesas que o autor não pôde suportar.

2. A inversão do ônus da prova, nos termos de precedentes desta Corte, não implica impor à parte contrária a responsabilidade de arcar com os custos da perícia solicitada pelo consumidor, mas meramente estabelecer que, do ponto de vista processual, o consumidor não tem o ônus de produzir essa prova.

3. No entanto, o posicionamento assente nesta Corte é no sentido de que a parte ré, neste caso, a concessionária, não está obrigada a antecipar os honorários do perito, mas se não o fizer, presumir-se-ão verdadeiros os fatos afirmados pelo autor (REsp n. 466.604/RJ, rel. Min. Ari Pargendler e REsp n. 433.208/RJ, rel. Min. José Delgado).
}

\footnotetext{
${ }^{736}$ Ver o item 3.2.4.

737، “Art. 19 - Salvo as disposições concernentes à justiça gratuita, cabe às partes prover as despesas dos atos que realizam ou requerem no processo, antecipando-lhes o pagamento desde o início até sentença final; e bem ainda, na execução, até a plena satisfação do direito declarado pela sentença. $\S 1^{\circ}$ - O pagamento de que trata este artigo será feito por ocasião de cada ato processual. $\S 2^{\circ}$ - Compete ao autor adiantar as despesas relativas a atos, cuja realização o juiz determinar de ofício ou a requerimento do Ministério Público". Vale lembrar que se a prova pericial for requerida exclusivamente pelo réu, caberá a ele o custeio da prova, conforme se depreende do art. 33 do Código de Processo Civil: "Art. 33 - Cada parte pagará a remuneração do assistente técnico que houver indicado; a do perito será paga pela parte que houver requerido o exame, ou pelo autor, quando requerido por ambas as partes ou determinado de ofício pelo juiz".
} 
4. Por fim, prejudicado o pedido de antecipação de tutela, em vista da não obrigatoriedade de pagamento, pela concessionária, dos honorários periciais." 738

Ou seja, o entendimento consolidado no Superior Tribunal de Justiça caminha no sentido de que "a inversão do ônus da prova não implica a transferência, ao demandado, da obrigação pelo pagamento ou adiantamento das despesas do processo", porquanto "não se pode confundir inversão do ônus da prova ( = ônus processual de demonstrar a existência de um fato), com inversão do ônus financeiro de adiantar as despesas decorrentes da realização de atos processuais".

Esse mesmo raciocínio pode ser empregado nas situações em que o juiz determina a produção de uma prova cujo custo as partes não desejam arcar, ainda que, em princípio, caiba ao autor arcar com os custos da prova cuja produção foi determinada pelo juiz. Ou seja, restando frustrada a tentativa de produção da prova pelo juiz, em razão de óbices financeiros, não lhe restará outro caminho senão decidir consoante aplicação da regra de distribuição do ônus da prova na ocasião do julgamento. Nesse contexto, leciona José Roberto dos Santos Bedaque:

"Haverá situações em que, não obstante entenda o juiz ser imprescindível
a realização da prova, óbices intransponíveis impeçam a produção.
Imagine-se, por exemplo, que o autor se recuse a antecipar os honorários
do perito judicial (art. 33 do CPC), por entender absolutamente
desnecessária a prova técnica, ou por não ter condições econômicas de
arcar com a despesa. Nesse caso, se também o réu não concordar com o
pagamento e o conjunto probatório for insuficiente para a formação de
seu convencimento, não terá o julgador outra alternativa senão recorrer às
regras de distribuição previstas no art. 333 (......"

Essa conclusão fatalmente conduzirá a um julgamento em que o juiz aplica a regra de distribuição do ônus probatório sem ter conhecimento a qual parte assistia razão na

\footnotetext{
${ }^{738}$ STJ - AgR REsp n. 104.2919/SP, 2 ${ }^{\text {a }}$ Turma, rel. Min. Humberto Martins, j. 05.03.2009, v.m., DJe, de 31.03.2009. No mesmo sentido: STJ - ED REsp n. 843.963/RJ, $1^{\mathrm{a}}$ Turma, rel. Min. José Delgado, j. 12.12.2006, v.u., DJ, de 01.02.2007, p. 432; STJ - REsp n. 871.350/RJ, $2^{\mathrm{a}}$ Turma, rel. Min. Eliana Calmon, j. 13.05.2008, v.u., DJe, de 26.05.2008; STJ - AgR AI n. 979.525/SP, $3^{\mathrm{a}}$ Turma, rel. Min. Sidnei Beneti, j. 28.08.2008, DJe, de 28.08.2008; STJ - REsp n. 635.885/SP, $3^{\text {a }}$ Turma, rel. Min. Carlos Alberto Menezes Direito, j. 29.11.2006, v.u., DJ, de 02.04.2007, p. 263, v.u.; STJ - REsp n. 845.601/SP, $4^{\text {a }}$ Turma, rel. Min. Hélio Quaglia Barbosa, j. 06.03.2007, v.u., DJ, de 02/04/2007, p. 290; STJ - REsp n. 661.149/SP, $3^{\text {a }}$ Turma, rel. Min. Nancy Andrighi, j. 17.08.2006, v.u., DJ, de 04.09.2006, p. 261; STJ - REsp n. 466.604/RJ, $3^{\mathrm{a}}$ Turma, rel. Min. Ari Pargendler, j. 07.04.2003, v.u., DJ, de 02.06.2003.

${ }^{739}$ BEDAQUE, José Roberto dos Santos, Poderes instrutórios do juiz, cit., p. 126.
} 
demanda. Trata-se de uma consequência inevitável, que se encontra prevista no sistema e que pode revelar-se mais acintosa em comarcas onde não obstante uma parte, ou ambos os litigantes, serem beneficiários da assistência gratuita, há deficiência de aparelhamento (falta de convêncios entre o Poder Judiciário e órgãos especializados na produção de prova pericial, por exemplo) apto a garantir a benesse estatuída no art. $3^{\circ}$ da Lei n. 1.060/50, o que sem dúvida é um óbice ao amplo acesso à justiça. ${ }^{740}$

Aliás, em recente julgado, o Superior Tribunal de Justiça relativizou o quanto disposto no art. 18 da Lei da Ação Civil Pública (Lei n. 7.347/85), para determinar que o Ministério Público, na qualidade de autor da ação, adiantasse o pagamento dos honorários periciais, ${ }^{741}$ oportunidade em que a Ministra Eliana Calmon deixou assente a seguinte premissa: “(...) não se pode impor ao profissional que realiza a prova técnica trabalho gratuito em prol da Justiça, como também não se pode impor ao réu o ônus de uma vultosa prova, de elevado custo, contra ele próprio. Ademais, se a parte ré não dispuser de recursos para financiar a prova, como fica a demanda?"

De todo modo, para a conclusão deste item, cumpre asseverar que as iniciativas probatórias do juiz, quando dependerem de prévio pagamento para a produção da prova, podem encontrar óbices e resistência das partes em arcar com o seu custo, a conduzir, inevitavelmente (caso seja a única prova necessária à formação do livre convencimento), à aplicação da regra de distribuição do ônus probatório.

\footnotetext{
${ }^{740}$ Vale lembrar que essa garantia emana de status constitucional consagrado como cláusula pétrea no art. $5^{\circ}$, incs. LXXIV e LXXVII da Constituição Federal.

741 "Processo civil. Ação civil pública. Honorários periciais. Ministério Público. Art. 18 da Lei 7.347/85. 1. $\mathrm{Na}$ ação civil pública, a questão do adiantamento dos honorários periciais, como estabelecido nas normas próprias da Lei n. 7.347/85, com a redação dada ao art. 18 da Lei n. 8.078/90, foge inteiramente das regras gerais do Código de Processo Civil. 2. Posiciona-se o Superior Tribunal de Justiça no sentido de não impor ao Ministério Público condenação em honorários advocatícios, seguindo a regra de que na ação civil pública somente há condenação em honorários quando o autor for considerado litigante de má-fé. 3. Em relação ao adiantamento das despesas com a prova pericial, a isenção inicial do Ministério Público não é aceita pela jurisprudência de ambas as turmas, diante da dificuldade gerada pela adoção da tese. 4. Abandono da interpretação literal para impor ao parquet a obrigação de antecipar honorários de perito, quando figure como autor na ação civil pública. Precedentes. 5. Recurso especial não provido.” (REsp n. 891.743/SP, $2^{\text {a }}$ Turma, rel. Min. Eliana Calmon, j. 13.10.2009, v.u., DJe, de 04.11.2009). Em relação à Fazenda Pública, no mesmo esteio do quanto decidido nesse julgado, a Súmula n. 232 do STJ sedimentou o entendimento de que: "A Fazenda Pública, quando parte no processo, fica sujeita à exigência do depósito prévio dos honorários do perito".
} 


\subsection{Outros julgados que podem servir de fundamento para o emprego das iniciativas probatórias do juiz}

À luz do quanto restou exposto neste trabalho, inúmeras são as premissas a justificar uma postura mais ativa do juiz no processo que reflita no manejo das iniciativas probatórias. Não obstante as situações específicas versadas neste capítulo, os julgados a seguir aproveitam não só aqueles casos concretos, mas podem servir de subsídio a fundamentar a iniciativa probatória do juiz nas mais variadas situações. Trata-se de decisões fundamentadas em assertivas mais amplas, já aqui discutidas, das quais se podem extrair justificativas aptas a comprovar a aceitação das iniciativas probatórias do juiz sedimentada pela jurisprudência. Portanto, são decisões cujos fundamentos poderão ser empregados em outros casos concretos, além dos demais já citados neste capítulo, sempre observadas as limitações apontadas no item 3.2.1.2 e no Capítulo 4.

Nesse contexto, um dos fundamentos empregados para permitir a iniciativa probatória reside na ideia de que o juiz deve buscar a verdade real nos autos, consoante já se manifestou o Superior Tribunal de Justiça:

\footnotetext{
"Processo Civil. Agravo no recurso especial. Iniciativa probatória do juiz. Perícia determinada de ofício. Possibilidade. Mitigação do princípio da demanda. Precedentes.

- Os juízos de primeiro e segundo graus de jurisdição, sem violação ao princípio da demanda, podem determinar as provas que lhes aprouverem, a fim de firmar seu juízo de livre convicção motivado, diante do que expõe o art. 130 do Código de Processo Civil.

- A iniciativa probatória do magistrado, em busca da verdade real, com realização de provas de ofício, é amplíssima, porque é feita no interesse público de efetividade da Justiça.

Agravo no recurso especial improvido.",742
}

Outro fundamento que pode guardar utilidade em muitos casos concretos consiste na assertiva de que o manejo das iniciativas probatórias pode se materializar a qualquer tempo durante o processo:

\footnotetext{
742 STJ - AgR REsp n. 738.576/DF, 33 Turma, rel. Min. Nancy Andrighi, j. 18.08.2005, v.u., DJ, de 12.09.2005, p. 330. No mesmo sentido: STJ - REsp n. 101.2306/PR, $3^{\mathrm{a}}$ Turma, rel. Min. Nancy Andrighi, j. 28.04.2009, v.u., DJe, de 07.05.2009; STJ - REsp n. 101.0559/RN, 4 ${ }^{\mathrm{a}}$ Turma, rel. Min. Aldir Passarinho Junior, j. 16.10.2008, v.u., DJe, de 03.11.2008.
} 
"Processo Civil. Recurso especial. Realização de provas por iniciativa do juiz. Art. 130 do Código de Processo Civil. Possibilidade. Precedentes do Superior Tribunal de Justiça e Supremo Tribunal Federal.

- O juiz tem o poder de iniciativa probatória, inclusive para determinar a produção das provas que julgar necessárias à solução da lide. Esta prerrogativa pode ser utilizada em qualquer fase do processo.

- Recurso especial conhecido e provido". ${ }^{743}$

Mediante simples interpretação desse julgado, a dimensão dos poderes instrutórios não se limita somente à denominada fase instrutória prevista no procedimento ordinário, sendo perfeitamente possível sua utilização em segundo grau de jurisdição, ou até no processo de execução, conforme visto acima. ${ }^{744}$ Por fim, as iniciativas probatórias do juiz também não comprometem a imparcialidade do julgador, mas constituem um "ativismo judicial sadio":

"Recurso Especial. Processo civil. Iniciativa probatória do juiz.
Determinação ex officio. Possibilidade. Art. 130 do Código de Processo
Civil. Recurso não conhecido.
1. No caso dos autos, determinou o Tribunal a quo o retorno dos autos à
primeira instância, cassando, por conseguinte, a sentença de
improcedência prolatada, na medida que, tendo admitido expressamente o
magistrado singular que as provas colacionadas aos autos não seriam
suficientes para verificação da alegada violação de cláusulas contratuais,
deveria ter determinado, ex officio, sua realização.
2. 'A experiência mostra que a imparcialidade não resulta comprometida
quando, com serenidade e consciência da necessidade de instruir-se para
melhor julgar, o juiz supre com iniciativas próprias as deficiências
probatórias das partes. Os males de possíveis e excepcionais
comportamentos passionais de algum juiz não devem impressionar o
sentido de fechar a todos os juízes, de modo absoluto, as portas de um
sadio ativismo' (Instituições de direito processual civil, 2. ed. São Paulo:
Malheiros, 2002, v. 3, p. 52-54).
3. Recurso especial não conhecido." 745

E, como síntese dos julgados, o Tribunal Pleno do Supremo Tribunal Federal já decidiu que as iniciativas probatórias podem ser exercidas a qualquer tempo, inexistindo preclusão para o juiz, de sorte que a formação do livre convencimento consiste no principal aspecto a ser observado quando das iniciativas probatórias:

\footnotetext{
${ }^{743}$ STJ - REsp n. 382.742/PR, 2 ${ }^{\text {a }}$ Turma, rel. Min. Francisco Peçanha Martins, j. 16.02.2006, v.u., DJ, de 26.04.2006, p. 198. No mesmo sentido: STJ - REsp n467.789/RJ, 2 ${ }^{\mathrm{a}}$ Turma, rel. Min. Castro Meira, j. 15.02.2005, v.u., DJ, de 02.05.2005, p. 254.

${ }^{744}$ Ver itens 3.3.1.1 e 5.4 a 5.6.

745 STJ - REsp n. 629.312/DF, 4ª Turma, rel. Min. Hélio Quaglia Barbosa, j. 27.03.2007, v.u., DJ de 23/04/2007, p. 271.
} 
“Agravo regimental em agravo regimental na ação rescisória. Despacho saneador. Realização de provas por iniciativa do juiz. Art. 130 do Código de Processo Civil. Preclusão. Inexistência.

1. A preclusão é instituto processual que importa em sanção à parte, não alcançando o magistrado que, em qualquer estágio do procedimento, de ofício, pode ordenar a realização das provas que entender imprescindíveis à formação de sua convicção.

2. Código de Processo Civil, art. 130. Aplicação do princípio do livre convencimento do juiz, a quem cabe a direção do processo, determinando, inclusive, as diligências necessárias à solução da lide. Instrução probatória. Preclusão pro judicato. Inexistência. Agravo regimental não provido." ${ }^{, 76}$

Os julgados trancritos guardam aproveitamento para diversos casos concretos, porquanto as iniciativas probatórias do juiz podem ser exercidas sempre que carecer de elementos para a formação do seu livre convencimento e presumir que o resultado da prova lhe traga novo subsídio suficiente para decidir.

${ }^{746}$ STF - AgR AgR AR n. 1.538-1/MG, Tribunal Pleno, rel. Maurício Corrêa, j. 04.10.2001, v.u., DJ, de 08.02.2002, p. 261. 


\section{CONCLUSÕES}

À vista de todo o exposto, podem ser extraídas as seguintes conclusões:

1. A evolução dos conceitos de jurisdição, defesa, ação e processo converge numa aproximação da visão publicista do direito processual civil, a impor maior participação do juiz, no ensejo de tentar ao máximo aproximar-se da entrega da tutela jurisdicional justa e efetiva.

Sendo o escopo jurídico da jurisdição a realização da vontade concreta da lei, de onde deflui a realização dos escopos sociais e políticos, o interesse do Estado se sobrepõe ao interesse dos litigantes, com a finalidade de fazer atuar o direito objetivo. Logo, a capacidade do Estado de dirimir os conflitos que envolvem as pessoas deve primar por decidir as pretensões apresentadas e impor decisões que reflitam a realização da vontade concreta da lei, oportunidade em que se extrai o proveito do manejo dos poderes instrutórios do juiz, voltados a se apurar um juízo mais próximo da certeza dos fatos, para propiciar melhor acerto na entrega da tutela jurisdicional de forma justa. Sob esse enfoque metodológico, também se denota uma visão instrumentalista da jurisdição.

O processo é uma relação jurídica que serve como instrumento através do qual se visa a um provimento justo. Na relação jurídica processual havida entre autor e réu, sendo a eles asseguradas as garantias constitucionalmente previstas para o exercício do direito de ação, do contraditório e da ampla defesa, desenvolve-se a atuação do magistrado, para dirigir o processo de modo a se atingir o escopo jurídico da jurisdição. Há a necessidade de satisfação do interesse público, na obediência à ordem jurídica estabelecida quando da entrega da tutela jurisdicional, razão por que os poderes instrutórios se manifestam, com vistas a trazer elementos para verificar qual parte tem razão na demanda, cujo desenvolvimento se processa em contraditório franqueado para ambas as partes.

Os institutos fundamentais do direito processual civil guardam ampla ligação com o exercício dos poderes instrutórios. A concepção moderna desses institutos se encontra entrelaçada ao ativismo judicial, notadamente para atender à ordem jurídica justa. Esse pensar deflui da chamada publicização do processo civil, tema cujos contornos estão 
assentados não só por força da evolução de garantias constitucionais, mas também da própria escala de estudo da ciência processual.

2. O fenômeno da publicização do processo consiste no desapego do sincretismo do direito privado para assim tornar o processo civil ramo do direito público. O interesse do Estado-juiz passa, de mero espectador passivo do acompanhamento do exercício de faculdades, ônus e prerrogativas das partes dentro do processo, a assumir feição mais ativa, destinada a realizar um bem maior, calcado na aproximação de certeza dos fatos necessária à aplicação concreta da lei, com vistas a propiciar a pacificação social. Tem-se, portanto, a necessidade de uma participação mais ativa do juiz, destinada a obter o resultado desejado pelo instrumento, que reside, em síntese, na realização da vontade concreta da lei.

A publicização está relacionada à instrumentalidade do processo, no sentido do sistema processual dever ser examinado sob uma ótica ampla, mediante sua inserção na ordem jurídica, política e social, e assim propiciar resultados justos e efetivos que conduzam à realização dos escopos da jurisdição. Assim, a relação do duplo sentido da instrumentalidade com os poderes instrutórios se acentua na medida em que ao Estado-juiz não cabe seguir as regras processuais de modo rígido e incontrastável. A despeito da existência de ônus, deveres e sujeições conferidas às partes dentro do processo, por vezes a função pública do processo (mormente por ser o juiz o destinatário da prova) reclama a relativização de formalismos (aspecto negativo), para assim se obter a tutela jurisdicional justa (aspecto positivo).

O ativismo judicial como reflexo da publicização do processo também guarda fundamentos na própria evolução das gerações de direitos fundamentais e das ondas renovatórias de acesso à justiça traçadas por Mauro Cappelletti. Na evolução dos direitos fundamentais, o reclamo por um Estado mais ativo, participativo e solidarista dá margem, no plano da jurisdição, para que as decisões emanadas do Estado-juiz se preocupem em decidir de forma justa, aplicando a vontade concreta da lei, ao passo que a visão calcada na terceira onda renovatória exprime o mesmo ideal de efetividade do processo, para que a tutela jurisdicional seja entregue de forma équa.

Tem-se, como consequência da evolução do processo como ciência (fase instrumentalista), das gerações de direitos fundamentais e das ondas renovatórias 
idealizadas por Mauro Cappelletti, o aumento dos poderes do juiz, notadamente o exercício dos poderes instrutórios como premissa para se evitar uma postura passiva do magistrado, diante do monopólio das partes sobre as provas que são coligidas no processo, obrigandoo, por vezes, a decidir sem ter conhecimento a qual parte assiste razão na demanda.

A jurisdição estatal é um serviço público. A partir do momento em que as partes a ela submetem a resolução de seus litígios, sujeitam-se à decisão do órgão jurisdicional, cujos contornos metodológicos impõem o dever do Estado-juiz de assegurar o seu bom funcionamento, com a finalidade de obter a aproximação de verdade e trazer efetividade e justiça às decisões.

3. O exercício dos poderes instrutórios não implica em condutas arbitrárias, teratológicas ou que se aproximem do autoritarismo. Em verdade, não se trata de debate entre "ideologia liberal" e "ideologia autoritária", mas sim a discussão acerca de qual ideologia é empregada em cada sistema, a definir a respectiva finalidade a que se presta o processo.

Um sistema que preserva o monopólio das partes na determinação das provas a serem produzidas obriga o juiz a curvar-se diante da análise das provas trazidas sob o exclusivo interesse dos litigantes, vendo-se compelido a decidir, ainda que não tenha elementos suficientes para verificar qual parte tem razão na demanda, o que compromete a própria qualidade da decisão: de um lado, preserva-se a exclusividade das partes na produção da prova e, em contrapartida, corre-se o risco de haver uma decisão deficiente na análise dos fatos e fadada a desacertos, despreocupada com a justiça da decisão. Busca-se tão somente legitimar uma decisão judicial com a aparência de ser um resultado correto e acertado, quando, por vezes, sequer restaram trazidos aos autos elementos de prova necessários a concluir qual parte tinha razão, de modo que desempenha função marginal e simbólica.

Por outro lado, soa mais correta a concepção metodológica do processo como instrumento que esteja sensível para a realização concreta da lei e, de igual modo, os poderes instrutórios se prestam a atingir essa finalidade, destinada à obtenção da tutela jurisdicional justa, por meio de decisões que exprimam melhor fidelidade aos fatos, para permitir a acertada aplicação do direito. Notadamente em relação ao sistema brasileiro, 
forçoso cogitar que as iniciativas probatórias do juiz reflitam condutas autoritárias, ilegais ou arbitrárias, porquanto a Constituição Federal de 1988 assegura garantias aos litigantes, que permitem amplo controle das decisões judiciais.

4. A cognição, seja no plano vertical, seja no plano horizontal, é exercível em qualquer fase do processo e integra atividade intelectiva do magistrado que, por sua vez, pode valer-se de seus poderes instrutórios na busca de elementos necessários a decidir. Cabe ao magistrado, no processo de conhecimento, fixar os pontos controvertidos na demanda e determinar sobre quais questões recairá a produção de provas, ao passo que a iniciativa probatória também poderá ser exercida quando relevantes e necessários outros elementos de prova, cuja finalidade se presta à formação do livre convencimento.

5. A ideia de busca da verdade absoluta e irrefutável soa algo intangível e de difícil constatação relativa à própria certeza. Há limites do próprio saber humano que impedem uma visão completa da realidade. O juiz, ao ter a iniciativa probatória, deve ter a cautela de tornar-se um juiz inquisidor que tente a todo custo obter a certeza absoluta como condição necessária a decidir a demanda. Afinal, a verdade não é um fim para o processo, mas um meio para atingir outros fins, dentre eles o escopo jurídico e social da jurisdição.

6. A valoração da prova pelo juiz não o vincula aos elementos de prova legal, tampouco limita o exercício dos poderes instrutórios, mas tais elementos podem servir de fundamento a dispensar a produção de provas, até porque é o subjetivismo do julgador que definirá se determinados fatos se subsumem às hipóteses de prova legal. Mais uma vez, é a formação do livre convencimento motivado que indicará a relevância da produção de determinada prova de ofício. A prova legal ou hierárquica representa tão somente um elemento adicional para exame do magistrado, a ser confrontada diante das alegações das partes e dos demais meios de prova trazidos aos autos, com a finalidade de integrar um raciocínio lógico e fundamentado para a formação do livre convencimento.

As presunções não significam uma limitação ao conhecimento do juiz, tampouco uma regra absoluta a ser aplicada pelo julgador, mas assim como as provas legais, constituem elementos que podem facilitar o raciocínio lógico-dedutivo, quando da formação do livre convencimento, a ponto de dispensarem a produção de determinada prova sobre um fato que a lei reputa presumido. A presunção, exatamente por se tratar de 
um juízo de probabilidade extraído a partir da constatação de um indício, não reduz a iniciativa probatória do magistrado, mas pode servir como técnica para fundamentar a dispensa de produção de prova sobre o fato presumido, cujo critério de aplicação é restrito ao julgador, como no juízo subsuntivo em relação ao fato-base, quando da utilização das máximas de experiência. Trata-se, pois, de elementos de facilitação para fundamentar a formação do livre convencimento do juiz, cujos dispositivos podem ser utilizados para justificar a dispensa da produção de determinada prova, por conta da existência do fato presumido, mas que não tolhem as iniciativas probatórias.

7. Na cognição, será exercida a atividade intelectiva de buscar, examinar e valorar as alegações e as provas produzidas pelas partes e determinada a produção pelo juiz, cuja necessidade constitui elemento fundamental para a formação do convencimento para, ao final, permitir que seja proferida uma decisão fundamentada. Sendo relevante a prova e quando sua produção for compatível com o procedimento, não poderá o juiz decidir a ponto de desvendar qual parte tem razão na demanda, sem antes verificar o resultado do conjunto probatório carreado aos autos.

8. A distribuição do ônus da prova prevista no art. 333 do Código de Processo Civil é regra de julgamento, assim como a inversão do ônus e a chamada carga dinâmica da prova. Os poderes instrutórios do juiz não se limitam, tampouco ficam aumentados, qualquer que seja a regra de distribuição do ônus da prova, porquanto ela somente será aplicada como condição necessária a se evitar o non liquet, de sorte a perfilhar regra de julgamento. A ressalva, em verdade, não guarda ligação com os poderes instrutórios, mas sim na premissa de que, sobrevindo a possibilidade de inversão por força do Código de Defesa do Consumidor, ou aplicando a inversão dinâmica, deve ser franqueada à parte a oportunidade de produção da prova necessária para a inversão do próprio ônus que poderá sobre ela recair.

Pouco importa a quem pertence o ônus de produzir determinada prova (ainda que por conta da inversão do ônus probatório, qualquer que seja a regra de inversão a ser aplicada), porquanto a distribuição do ônus probatório somente ocorrerá quando do julgamento, em nada tolhendo as iniciativas probatórias. 
9. Através de breve análise das classificações acerca dos poderes do juiz, embora com poucas divergências, pode-se extrair que os poderes instrutórios caracterizam-se por revelar diligências determinadas de ofício, cuja finalidade se presta à instrução do processo, com vistas à formação do convencimento do magistrado.

$\mathrm{O}$ art. 130 do Código de Processo Civil dispõe de forma ampla sobre o poder-dever de iniciativa probatória do juiz, porquanto as hipóteses ventiladas nos arts. 331, § $2^{\circ}, 342$, $355,360,382,399,440,418,437,405, \S 4^{\text {o }}$, tratam de situações meramente exemplificativas, em nada restringindo o quanto disposto no caput do art. 130 retrocitado, cuja redação é clara, ao prever que caberá ao juiz, de ofício ou a requerimento da parte, “determinar as provas necessárias à instrução do processo".

Estando a atividade cognitiva ligada aos poderes instrutórios, a dimensão desses poderes não se restringe apenas à fase de conhecimento, tampouco a atos do juiz que precedam a sentença, podendo ser exercidos em toda situação que demande a busca, pelo magistrado, de elementos necessários para decidir e fundamentar uma decisão. Essa é a dimensão dos poderes instrutórios que, em verdade, podem ser exercidos pelo juiz sempre que necessários para a formação de seu convencimento e quando compatível a produção da prova com o procedimento.

10. Uma tentativa de definição do conceito dos poderes instrutórios reside na manifestação do juiz exercida de ofício para determinar a produção das provas que julgar necessárias. Seriam os atos do juiz ligados à própria instrução que, por sua vez, reputa um conceito mais amplo, relativo a toda situação no processo em que seja necessário produzir conhecimento no espírito do julgador, mediante direção formal e material da causa.

11. O momento de exercício dos poderes instrutórios não é subsidiário à produção de provas pelas partes, mas, por economia processual, pode ocorrer sempre que preceder uma decisão, quando relevante à produção da prova para decidir ou instruir o processo, pautado nas regras atinentes a cada procedimento, ou na mesma medida que se possibilitar às partes se manifestarem sobre as provas que pretendem produzir.

12. Os poderes instrutórios comportam algumas limitações que, em linhas gerais, compreendem: (i) a investigação probatória restrita a angariar elementos necessários a 
atender ou rejeitar o pedido das partes, em decisão que seja (ii) motivada, apontando os motivos que o conduziram a tomar a iniciativa de determinar a produção de dada prova, de modo a (iii) assegurar às partes a plena oportunidade ao contraditório e ampla defesa, calcada no trinômio ciência, participação e reação. Ainda, (iv) é vedado ao magistrado determinar a produção de provas por meios ilícitos ou vedados pelo ordenamento, conquanto a admissibilidade da prova produzida sob essas circunstâncias venha a ser aceita em alguns casos excepcionais, mediante a aplicação da técnica da proporcionalidade. Destarte, (v) em relação à aplicação dos efeitos da revelia, presente a verossimilhança do direito postulado pelo autor, deverá o magistrado evitar o prosseguimento de qualquer iniciativa probatória.

13. A influência dos poderes instrutórios está projetada nos mais variados sistemas estrangeiros, cujo grau de aceitação pode ser dividido em três grupos de ordenamentos: os que vedam ou proíbem os poderes instrutórios, os que permitem a iniciativa probatória em situações específicas, e, por fim, os sistemas que conferem ampla atuação ao juiz, quanto à investigação probatória, restando, no sistema brasileiro, a interpretação teleológica, que se exprime da leitura do art. 130 do Código de Processo Civil.

14. A Constituição Federal consagra uma série de princípios que devem ser observados e obedecidos rigidamente pelo magistrado, dos quais se extraem postulados que possibilitam o mínimo de segurança para que se materialize um processo civil de índole democrática e regulado sob o manto de proteção de garantias fundamentais, que se projetam no plano processual. Eventuais exageros ou arbitrariedades cometidos pelo juiz sujeitam-se ao controle jurisdicional, cuja literal ofensa, por si só, viola as garantias processuais constitucionais. Portanto, a observância dos princípios processuais constitucionais e infraconstitucionais dá contornos de equilíbrio e parcimônia para o exercício das iniciativas probatórias do magistrado, podendo ser traçadas as sínteses que seguem:

Os reflexos do princípio constitucional do contraditório e da ampla defesa repercutem (i) na garantia fundamental de oportunidade de "informação, participação e reação" às partes, bem como (ii) no direito/dever assegurado aos litigantes de cooperar (contraditório) com toda a dinâmica na formação do campo probatório e (iii) ao juiz, o poder-dever de direção e de diálogo entre as partes. Então, a fiel observância do princípio 
do contraditório e ampla defesa, aliada ao dever de cooperação das partes, contribui para municiar o juízo de elementos que se aproximem de um juízo de certeza, revestidos de subsídios que fortalecem e facilitam a entrega de uma tutela jurisdicional mais justa e adequada. Logo, é curial que essa garantia constitucional seja observada quando restar determinada a produção de ofício da prova.

A iniciativa probatória se justifica como necessidade do magistrado voltada a buscar elementos necessários à formação de seu livre convencimento. Pouco importa a relação jurídica de direito material que rege o objeto litigioso, mas a preocupação maior deve voltar-se à consecução de elementos suficientes para o juiz decidir a demanda com segurança, cabendo-lhe a sapiência e gestão dos recursos destinados à formação do campo probatório. Dessa forma, a iniciativa probatória do juiz está dissociada da isonomia substancial.

A garantia constitucional da publicidade também se evidencia em todos os atos ligados aos poderes instrutórios, mormente para a concretização de outra garantia processual fundamental, qual seja, o princípio do contraditório e ampla defesa. Tem o condão de ligar a comunicação entre as partes e o juiz, de modo a (i) protegê-las contra juízos arbitrários e secretos, como corolário integrante da garantia do devido processo legal e (ii) possibilitar a fiscalização da sociedade sobre o exercício da atividade jurisdicional.

Na medida que o juiz fundamenta sua decisão e inclui transparência em suas razões de decidir, mormente as iniciativas probatórias de ofício, a parte que eventualmente entender ter sido prejudicada seguramente terá elementos suficientes para requerer o reexame daquela decisão perante o tribunal, porquanto serão de conhecimento da corte as razões que motivaram o magistrado a tomar tal medida, que terá condições de aferir se a decisão tomada é a mais correta, à luz do caso concreto.

A proporcionalidade se presta a equacionar situações em que o juiz, notadamente no que toca às iniciativas probatórias, deve ponderar um valor em detrimento de outro. Algumas vezes, será necessário confrontar a "celeridade" com a "aproximação da certeza ao decidir". Por vezes, também se confronta o "juízo de aproximação de certeza” com o “juízo de probabilidade ao aplicar as máximas de experiência”, e, em dadas situações, o magistrado deve ponderar entre "mera inversão do ônus da prova excessiva a uma das 
partes" e "iniciativa probatória destinada a tentar desvendar a qual parte assiste razão na demanda", assim como "o benefício da prova" e "a vedação de sua admissibilidade em juízo". Para tanto, tendo em vista que a proporcionalidade é aplicada casuisticamente, necessária a máxima atenção ao princípio da motivação das decisões judiciais já comentado, a fim de permitir o controle de decisão judicial pautada em elementos abertos e circunstanciais às peculiaridades do caso concreto.

A admissibilidade de prova obtida por meio ilícito deve obedecer a situações excepcionais, pautadas na aplicação do princípio da proporcionalidade, ao passo que a iniciativa probatória do juiz na produção de prova cujo meio é ilícito não parece ser uma das medidas mais adequadas para atingir os escopos do processo, sem que se infrinja o direito processual constitucional, na busca de uma prova que ab initio sequer se conhece o resultado. Por sua vez, em caráter excepcional, é admissível a iniciativa probatória destinada a se valer de prova emprestada que foi produzida no juízo penal e cujo resultado já é conhecido, como exceção ao princípio da vedação das provas obtidas por meios lícitos.

O princípio da duração razoável do processo deve ser observado, a evitar que seja dado ao juiz o poder de exaustivamente transformar-se em mero órgão inquisidor e que a todo custo tente obter a clareza da verdade mediante desmesurada investigação probatória. Torna-se, portanto, tarefa árdua o exercício dessa parcimônia, de sorte a equacionar a entrega da tutela jurisdicional com justiça e, por outro lado, evitar exageros que venham a comprometer a parcialidade ou dilatar excessivamente a instrução do processo.

O princípio dispositivo está relacionado com a relação jurídica de direito material (princípio dispositivo em sentido material ou próprio), e não processual. Não cabe exclusivamente às partes disporem sobre as provas que serão produzidas para a entrega da tutela jurisdicional, mas ao magistrado é devido angariar todos os elementos necessários à formação de seu livre convencimento, para ao final decidir a lide nos termos do pedido. $\mathrm{Ou}$ seja, o interesse à pacificação social pertence ao Estado-juiz, e não às partes. De igual modo, cabe a ele a melhor condução do processo, com vistas a entregar tutela jurisdicional que seja mais justa possível e nos limites do que foi pedido.

O princípio da disponibilidade, como desdobramento do princípio dispositivo, outorga às partes a disponibilidade do objeto litigioso submetido para resolução do conflito 
pelo Estado-juiz. A disponibilidade da prova em relação às partes guarda limitações com o instituto da preclusão, ao passo que, para o juiz, a disponibilidade da prova está ligada a dois aspectos: (i) a formação de seu livre convencimento e, (ii) os limites da matéria relacionada ao pedido que o magistrado deve conhecer para a formação do livre convencimento. O magistrado deverá voltar a instrução probatória para os fatos ligados à causa de pedir e ao pedido que compõe a demanda, de modo a, baseado no resultado da prova, encontrar condições suficientes para decidir.

Cabe ao juiz a direção material do processo, na dinâmica que se faz necessária à produção de provas, valendo-se dos poderes instrutórios para angariar elementos que lhe permitam aferir a qual parte assiste razão na demanda. Afinal, se é o juiz que julga a demanda e o sistema impõe que haja a formação do livre convencimento motivado, cabe a ele a iniciativa probatória, quando necessário for angariar provas para formar a livre convicção, que inclusive deve ser motivada, por vezes, com base nas provas coligidas aos autos.

Portanto, é o juiz o principal destinatário da prova e as iniciativas probatórias não afrontam o princípio da imparcialidade, na medida que não é conhecido o resultado da prova que será produzida. Em verdade, uma decisão apoiada em diversos fundamentos (dentre eles o resultado de uma prova) guarda melhor probabilidade de acerto na entrega da tutela jurisdicional. Mais vale conhecer em profundidade os fatos a refletir numa decisão de qualidade do que decidir na incerteza, sem saber a qual parte assistia razão.

E as iniciativas probatórias devem ser exercidas independentemente da relação jurídica de direito material posta em juízo, pois o interesse do Estado em pacificar conflitos com justiça constitui um dos escopos da jurisdição, o que transcende qualquer característica do direito material existente entre os litigantes. 


\section{REFERÊNCIAS}

ABDO, Helena Najjar. Observância da regra da objetividade na publicidade do processo realizada pelos meios de comunicação social. 2006. 300 p. Tese (Doutorado) - Faculdade de Direito da Universidade de São Paulo, 2006.

. A publicidade do processo. In: CARVALHO, Milton Paulo de (Coord.). Direito processual civil. São Paulo: Quartier Latin, 2007.

ALCALÁ-ZAMORA Y CASTILLO, Niceto. Estúdios de teoria general e historia del proceso (1945-1972). México: Universidade Nacional Autônoma de México, 1974. v. 1.

ALEXY, Robert. Teoría de los derechos fundamentales. Traducción de Ernesto Garzón Valdés. Madrid: Centro de Estúdios Políticos y Constitucionales, 2001.

ALLORIO, Enrico. Comentario del Codice di Procedura Civile: art. 1-68. Torino: Torinese, 1973.

ALVES, Cleber Francisco. Justiça para todos!: assistência jurídica gratuita nos Estados Unidos, na França e no Brasil. Rio de Janeiro: Lumen Juris, 2006.

AMENDOEIRA JUNIOR, Sidnei. Poderes do juiz e tutela jurisdicional. São Paulo: Atlas, 2006.

ANDOLINA, Italo. Il tempo e il processo. Revista de Processo, São Paulo, Revista dos Tribunais, ano 34, n. 176, p. 259-274, out. 2009.

ANDRADE, Odilon de. Os poderes do juiz no processo civil. Revista Forense, Rio de Janeiro, v. 37, n. 84, p. 3-14, out. 1940.

APRIGLIANO, Ricardo de Carvalho. A apelação e seus efeitos. 2. ed. São Paulo: Atlas, 2007. 
ARAGÃO, Egas Dirceu Moniz de. Regras de prova no Código Civil. Revista de Processo, São Paulo, Revista dos Tribunais, ano 29, n. 116, p. 11-28, jul./ago. 2004.

ARRUDA ALVIM, José Manoel de. Manual de direito processual civil. 12. ed. São Paulo: Revista dos Tribunais, 2008. v. 1-2.

Código de Processo Civil comentado: arts. 125-133. São Paulo: Revista dos Tribunais, 1979. v. 5.

ASSIS, Araken de. Manual da execução. 11. ed. São Paulo: Revista dos Tribunais, 2007.

ÁVILA, Humberto. Teoria dos princípios: da definição à aplicação dos princípios jurídicos. 3. ed. São Paulo: Malheiros, 2004.

BANDEIRA DE MELLO, Celso Antonio. Elementos de direito administrativo. 5. tiragem. São Paulo: Revista dos Tribunais, 1986.

BARBI, Celso Agrícola. Ação declaratória principal e incidente. Rio de Janeiro: Forense, 1977.

BARBOSA MOREIRA, José Carlos. Alguns problemas atuais da prova civil. Revista de Processo, São Paulo, Revista dos Tribunais, ano 14, n. 53, p. 122-133, jan./mar. 1989.

Breves reflexiones sobre la iniciativa oficial en materia de prueba. In: Temas de direito processual: terceira série. São Paulo: Saraiva, 1984. p. 79-86.

A Constituição e as provas ilicitamente obtidas. In: Temas de direito processual: sexta série. São Paulo: Saraiva, 1997.

A função social do processo civil moderno e o papel do juiz e das partes na direção e na instrução do processo. Revista de Processo, São Paulo, Revista dos Tribunais, ano 10, n. 37, p. 140-150, jan./mar. 1985.

. O futuro da Justiça: alguns mitos. In: Temas de direito processual: oitava série. São Paulo: Saraiva, 2004. p. 1-15.

. O juiz e a prova. Revista de Processo, São Paulo, Revista dos Tribunais, ano 9, n. 35, p. 178-184, jul./set. 1984.

. A motivação das decisões judiciais como garantia inerente ao estado de direito. In: Temas de direito processual: segunda série. 2. ed. São Paulo: Saraiva, 1988. p. 83-95. 
O neoprivatismo no processo civil. Revista de Processo, São Paulo, Revista dos Tribunais, ano 30, n. 122, p. 9-21, abr. 2005.

- Notas sobre alguns aspectos do processo (civil e penal) nos países anglosaxônicos. Revista de Processo, São Paulo, Revista dos Tribunais, ano 23. n. 92, p. 87-104, out./dez. 1998.

- Notas sobre o problema da efetividade do processo. In: Temas de direito processual: terceira série. São Paulo: Saraiva, 1984. p. 27-42.

. Os novos rumos do processo civil brasileiro. In: Temas de direito processual: sexta série. São Paulo: Saraiva, 1997.

. Os poderes do juiz na direção e na instrução do processo. In: Temas de direito processual: quarta série. São Paulo: Saraiva, 1989. p. 45-52.

. As presunções e a prova. In: Temas de direito processual: primeira série. 2. ed. São Paulo: Saraiva, 1988. p. 55-71.

O problema da divisão de trabalho entre o juiz e as partes. Revista de Processo, São Paulo, Revista dos Tribunais, ano 11, n. 41, p. 7-14, jan./mar. 1986.

. O processo, as partes e a sociedade. In: Temas de direito processual: oitava série. São Paulo: Saraiva, 2004. p. 29 e ss.

. Reformas processuais e poderes do juiz. In: Temas de direito processual: oitava série. São Paulo: Saraiva, 2004. p. 53-68.

BAUR, Fritz. O papel ativo do juiz. Revista de Processo, São Paulo, Revista dos Tribunais, ano 7, n. 27, p. 186-199, jul./set. 1982.

BEDAQUE, José Roberto dos Santos. Código de Processo Civil interpretado. Coordenação de Antonio Carlos Marcato. 3. ed. São Paulo: Atlas, 2008.

. Direito e processo: influência do direito material sobre o processo. 4. ed. rev. e ampl. São Paulo: Malheiros, 2006.

. Efetividade do processo e técnica processual. São Paulo: Malheiros, 2006.

Poderes instrutórios do juiz. 4. ed. rev., atual. e ampl. São Paulo: Revista dos Tribunais, 2009.

BERMUDES, Sergio. Introdução ao processo civil. 2. ed. Rio de Janeiro: Forense, 1996. 
BONAVIDES, Paulo. Curso de direito constitucional. 7. ed. rev., atual. e ampl. São Paulo: Malheiros, 1997.

BONICIO. Marcelo José Magalhães. Proporcionalidade e processo: a garantia constitucional da proporcionalidade, a legitimação do processo civil e o controle das decisões judiciais. São Paulo: Atlas, 2006.

BRAGA, Sidney da Silva. Iniciativa probatória do juiz no processo civil. São Paulo: Saraiva, 2004.

BRESOLIN, Umberto Bara. Revelia e seus efeitos. São Paulo: Atlas, 2006.

BUENO, Cassio Scarpinella. Código de Processo Civil interpretado. In: MARCATO, Antonio Carlos (Coord.). Código de Processo Civil interpretado. 3. ed. São Paulo: Atlas, 2008.

. Curso sistematizado de direito processual civil: teoria geral do direito processual civil. São Paulo: Saraiva, 2007. v. 1.

. Curso sistematizado de direito processual civil: procedimento comum, ordinário e sumário. São Paulo: Saraiva, 2007. v. 2, t. 1.

Curso sistematizado de direito processual civil: tutela jurisdicional executiva. São Paulo: Saraiva, 2007. v. 3.

. Curso sistematizado de direito processual civil: recursos, processos e incidentes nos tribunais: sucedâneos recursais, técnicas de controle das decisões judiciais. São Paulo: Saraiva, 2008. v. 5.

BURGARELLI, Aclibes. Tratado das provas cíveis. São Paulo: Juarez de Oliveira, 2000.

BÜLOW, Oskar Von. La teoria de las excepciones procesales y los presupuestos procesales. Traducción de Miguel Angel Rosas Lichtschein. Buenos Aires: EJEA, 1964. Título original: Die lehre von den Prozesseinreden und die prozessvoraussetzungen (Gissen, Ed. Roth, 1868). 
BUZAID, Alfredo. A ação declaratória no direito brasileiro. 2. ed. rev. e ampl. São Paulo: Saraiva, 1986.

. Do ônus da prova. Revista de Direito Processual Civil, São Paulo, Saraiva, v. 4, p. 5-24, 1961.

CALAMANDREI, Piero. Direito processual civil. Tradução de Luiz Abezia e Sandra Drina Fernandez Barbery. Campinas: Bookseller, 1999. v. 3.

. Eles, os juízes, vistos por um advogado. Tradução de Eduardo Brandão. São Paulo: Martins Fontes, 1998.

. Estudios sobre el proceso civil. Traducción de Santiago Sentis Melendo. Buenos Aires: EJEA, 1962. Instituzioni di diritto processuale civile. Napoli: Morano, 1970. v. 4. . La relatività del concetto d'azione. In: . Studi sul processo civile. Padova:

Cedam, 1947. v. 5.

CALMON DE PASSOS. José Joaquim. A ação no direito processual civil brasileiro. Salvador: Progresso, 1959. . Comentários ao código de processo civil. 8. ed. Rio de Janeiro: Forense, 1998. v. 3.

CÂMARA, Alexandre Freitas. O objeto da cognição no processo civil. Rio de Janeiro: Instituto de Estudos Jurídicos, (IEP), 1995. p. 207-225. (Livro de Estudos Jurídicos, n. 11). . Poderes instrutórios do juiz e processo civil democrático. Revista de Processo, São Paulo, Revista dos Tribunais, ano 32, 153, p. 35-46, nov. 2007.

CAMBI, Eduardo. Inversão do ônus da prova e tutela dos direitos transindividuais: alcance exegético do art. $6^{\circ}$, VIII, do CDC. Revista de Processo, São Paulo, Revista dos Tribunais, ano 30, n. 127, p. 101-105, set. 2005.

A prova civil: admissibilidade e relevância. São Paulo: Revista dos Tribunais, 2006.

CAMPANELLI, Luciana Amicucci. Poderes instrutórios do juiz e a isonomia processual. São Paulo: Juarez de Oliveira, 2006. 
CAMPILONGO, Celso Fernandes. Política, sistema jurídico e decisão judicial. São Paulo: Max Limonad, 2002

CANOTILHO, José Joaquim. Direito constitucional. 6. ed. Coimbra: Almedina, 1993. . Direito constitucional e teoria da Constituição. 4. ed. Coimbra: Almedina, 2000. . Direito constitucional e teoria da Constituição. 2. ed. Coimbra: Almedina, 1998.

CAPPELlETTI, Mauro. Juizes legisladores. Tradução de Carlos Alberto Alvaro de Oliveira. Reimpr. Porto Alegre: Sergio Antonio Fabris, 1999.

. La oralidad y las pruebas em el proceso civil. Traducción de Santiago Sentis Melendo, Buenos Aires: EJEA, 1972. . Proceso, ideologias, sociedad. Traducción de Santiago Sentis Melendo e Tomás A. Banzhaf. Buenos Aires; EJEA, 1974.

O processo civil no direito comparado. Tradução de Hiltomar Martins de Oliveira. Belo Horizonte: Líder, 2001. . La testimonianza della parte nel sistema dell'oralità: contributo alla teoria della utilizzazione probatoria del sapere delle parti nel processo civile. Milano: Giufrè, 1962.

CAPPELLETTI, Mauro; Garth, Bryant. Acesso à justiça. Tradução de Ellen Gracie Northfleet. Porto Alegre: Sergio Antonio Fabris, 1988.

CARMONA, Carlos Alberto. Arbitragem e processo: um comentário à Lei n. 9.307/96. São Paulo: Atlas, 2004.

CARNEIRO, Athos Gusmão. Jurisdição e competência. 8. ed. São Paulo: Saraiva, 1997.

CARNELUTTI, Francesco. Derecho y proceso. Traducción de Santiago Sentis Melendo. Buenos Aires: EJEA, 1971. . Instituciones del proceso civil. Traducción de Santiago Sentis Melendo. Buenos Aires: El Foro, 1997. v. 1. La prueba civil. Traducción de Niceto Alcalá-Zamora y Castillo. Buenos Aires: Depalma, 2000. . Sistema di diritto processuale civile. Padova: Cedam, 1936. . Trattato del processo civile. 2. ed. Napoli: Morano, 1958. 
CARVALHO, Fabiano. Poderes do relator nos recursos: art. 557 do CPC. São Paulo: Saraiva, 2008.

CARVALHO, Milton Paulo de. Aplicação e reforma da lei processual. In: MEDINA, José Miguel Garcia; CRUZ, Luana Pedrosa de Figueiredo; CERQUEIRA, Luís Otávio Sequeira de; GOMES JUNIOR, Luiz Manoel (Coords.). Os poderes do juiz e o controle das decisões judiciais: estudos em homenagem à professora Teresa Arruda Alvim Wambier. São Paulo: Revista dos Tribunais, 2008. p. 1.125-1.131.

Efeitos da revelia: exame comparativo do assunto nas legislações processuais civis alemã, italiana, portuguesa e brasileira. Revista de Processo, São Paulo, Revista dos Tribunais, ano 18, n. 69, p. 21-30, jan./mar. 1993.

. Do pedido no processo civil. Porto Alegre: Sergio Antonio Fabris, 1992.

. Os princípios e um novo Código de Processo Civil. In. CARNEIRO, Athos Gusmão; CALMON, Petrônio (Orgs.). Bases científicas para um renovado direito processual. Brasília: Instituto Brasileiro de Direito Processual, 2008. v. 1, p. 199-239.

CARVALHO, Milton Paulo de (Coord.). Direito processual civil. São Paulo: Quartier Latin, 2007.

CARVALHO FILHO, Milton Paulo de. Ainda a inversão do ônus da prova no Código de defesa do consumidor. Revista dos Tribunais, São Paulo, ano 92, n. 807, p. 56-81, jan. 2003.

CHIOVENDA, Giuseppe. L'azione nel sistema dei diritti (1903). In: Saggi di diritto processuale civile. 2. ed. Roma: Foro Italiano, 1930. v. 1, p. 3-100.

. Dell’azione nascente dal contratto preliminare. In. - Saggi di diritto processuale civile. 2. ed. Roma: Foro Italiano, 1930. v. 1. p. 101-120. . Istituizione di diritto processuale civile. 2. ed. Napoli: Jovene, 1935. v. 1-2. . Principios de derecho procesal civil. Traducción de José Casais y Santaló. Madrid: Reus, 1922. v. 1.

CINTRA, Antonio Carlos de Araújo; GRINOVER, Ada Pellegrini; DINAMARCO, Cândido Rangel. Teoria geral do processo. 24. ed. São Paulo: Malheiros, 2008. 
COMOGLIO, Luigi Paolo; FERRI, Corrado; TARUFFO, Michele. Lezioni sul processo civile. 2. ed. Bologna: Il Mulino, 1998.

COSTA, Moacyr Lobo da. Breve notícia histórica do direito processual civil brasileiro e de sua literatura. São Paulo: Revista dos Tribunais, 1970.

COSTA, Suzana Henriques da. Os Poderes do juiz na admissibilidade das provas ilícitas. Revista de Processo, São Paulo, Revista dos Tribunais, ano 31, n. 133, p. 85-120, mar. 2006.

COUTURE, Eduardo Juan. Fundamentos del derecho procesal civil. 2. ed. Buenos Aires: Depalma, 1951. . Teoria de las diligencias para mejor proveer. Montevideo: Casa A. Barreiro Ramos, 1932.

CREMASCO, Suzana Santi. A distribuição dinâmica do ônus da prova. Rio de Janeiro: GZ Editora, 2009.

CRESCI SOBRINHO, Élcio de. Dever de veracidade das partes no processo civil. Porto Alegre: Sérgio Antônio Fabris, 1988.

DALL'AGNOL JUNIOR, Antônio Janyr. Comentários ao Código de Processo Civil: do processo de conhecimento: arts. 102 a 242. Coordenação de Ovídio A. Baptista da Silva. São Paulo: Revista dos Tribunais, 2000. v. 2. . Distribuição dinâmica dos ônus probatórios. Revista dos Tribunais, São Paulo, ano 90, n. 788, p. 92-107, jun. 2001.

DALLARI, Dalmo de Abreu. Elementos de teoria geral do estado. 20. ed. São Paulo: Saraiva, 1998.

DE PLÁCIDO E SILVA, Oscar José. Vocabulário jurídico. 24. ed. Rio de Janeiro: Forense, 2004. v. 2. 
DENTI, Vittorio. Estudios de derecho probatorio. Traducción de Santiago Sentis Melendo e Tomás A. Banzhaf. Buenos Aires: EJEA, 1974.

DEVIS ECHANDIA, Hernando. Teoria general de la prueba judicial. 5. ed. Buenos Aires: Víctor P. de Zavalía, 1981. v. 1.

DIAS, Jean Carlos. Curso crítico do processo de conhecimento. Curitiba: Juruá, 2005.

DÍAZ CABIALE, José Antonio. Principios de aportación de parte y acusatorio: la imparcialidade del juez. Granada: Comares, 1996.

DIDIER JR., Fredie. Regras processuais no novo Código Civil: aspectos da influência do Código Civil de 2002 na legislação processual. 2. ed. São Paulo: Saraiva, 2004.

. Sobre a fundamentação da decisão judicial. In: CARVALHO, Milton Paulo de (Coord.). Direito processual civil. São Paulo: Quartier Latin, 2007. p. 251-272.

DINAMARCO, Cândido Rangel. Fundamentos do processo civil moderno. 5. ed. São Paulo: Malheiros, 2002. v. 1. . Instituições de direito processual civil. 6. ed. São Paulo: Malheiros, 2009. v. 1-3. . Instituições de direito processual civil. 3. ed. São Paulo: Malheiros, 2009. v. 4. . A instrumentalidade do processo. 13. ed. rev. e atual. São Paulo: Malheiros, 2008. . O princípio do contraditório e sua dupla destinação. In: . Fundamentos do

processo civil moderno. 5. ed. São Paulo: Malheiros, 2002. v. 1, p. 124-135. . Vocabulário do processo civil. São Paulo: Malheiros, 2009.

DUARTE, Bento Herculano. Elementos de teoria geral da prova. In: DUARTE, Bento Herculano; DUARTE, Ronnie Preuss (Coords.). Processo civil: aspectos relevantes. São Paulo: Método, 2006. p. 16-39.

DWORKIN, Ronald. Taking rights seriously. Cambridge: Harvard University Press, 2001.

ESPINOLA, Eduardo. Código do Processo do Estado da Bahia: Constituição da Bahia, Lei de Reorganização Judiciária e Código Do Processo Civil e Commercial (processo ordinário). Salvador: Typografia. Bahiana, 1916. v. 1. 
ESTEVES, Carolina Bonadiman. (In)disponibilidade do direito processual civil: uma análise do seu reflexo sobre a atividade do juiz e das partes à luz dos princípios fundamentais. 2002. 227 p. Dissertação (Mestrado em Processo Civil) - Faculdade de Direito da Universidade de São Paulo, 2002.

FAZZALARI, Elio. Processo (Teoria generale). In. NOVISSIMO digesto italiano. Turim: UTET, 1966. v. 13, p. 1.067-1.076.

FERREIRA, Aurélio Buarque de Holanda. Novo dicionário da língua portuguesa. 2. ed., 13. impr. Rio de Janeiro: Nova Fronteira, 1986.

FERREIRA FILHO, Manoel Caetano. A preclusão no direito processual civil. Curitiba: Juruá, 1991.

FILOMENO, José Geraldo de Brito et al. Código Brasileiro de Defesa do Consumidor comentado pelos autores do anteprojeto. 8. ed. Rio de Janeiro: Forense Universitária, 2005.

FISS, Owen. Contra o acordo. In: . Um novo processo civil: estudos norte-americanos sobre jurisdição, constituição e sociedade. Tradução de Carlos Alberto de Salles, Coordenador; Daniel Porto Godinho da Silva; Melina de Medeiros Rós. São Paulo: Revista dos Tribunais, 2004. p. 139-142.

GARTH, Bryant. Delay and settlement in civil litigation: notes toward a comparative and sociological perspective. In: STUDI in onore di Vittorio Denti: storia e metodologia garanzie e principi generali. Milano: Cedam, 1994, v. 1.

GIDI, Antonio. Aspectos da inversão do ônus da prova no Código do Consumidor. Revista de Direito do Consumidor, São Paulo, Revista dos Tribunais, n. 13, p. 33-41, jan./mar. 1995.

GOLDSCHMIDT, James. Teoria general del processo. Tradução de Leonardo Prieto Castro. Barcelona: Labor, 1936. 
GOMES JUNIOR, Luiz Manoel; FAVRETO, Rogério. Anotações sobre o projeto da nova lei da ação civil pública: principais inovações. Revista de Processo, São Paulo, Revista dos Tribunais, ano 34, n. 176, p. 174-194, out. 2009.

GOMES, Sérgio Alves. Os poderes do juiz na direção e instrução do processo civil. Rio de janeiro: Forense, 1997.

GOUVEIA, Lúcio Grassi. A função legitimadora do princípio da cooperação intersubjetiva no processo civil brasileiro. Revista de Processo, São Paulo, Revista dos Tribunais, ano 34, n. 172 , p. 32-53, jun. 2009.

GRAU, Eros Roberto. Direito posto e direito pressuposto. 6. ed. São Paulo: Malheiros, 2005.

GRECO, Leonardo. O conceito de prova. In: Estudos de direito processual. Campos dos Goytacazes, RJ: Editora da Faculdade de Direito de Campos, 2005. p. 423-470.

Publicismo e privatismo no processo civil. Revista de Processo, São Paulo, Revista dos Tribunais, ano 33, n. 164, p. 29-56, out. 2008.

GRINOVER, Ada Pellegrini. Ação (direito de) - II. In. ENCICLOPÉDIA Saraiva do direito. São Paulo: Saraiva, 1977. v. 2, p. 170-180.

. A iniciativa instrutória do juiz no processo penal acusatório. Revista Forense, Rio de janeiro, v. 95, n. 347, p. 3-10, jul./set. 1999.

Processo em evolução. Rio de Janeiro: Forense, 1996.

O princípio da ampla defesa no processo civil, penal e administrativo. In:

O processo em sua unidade II. Rio de Janeiro: Forense, 1984.

GRINOVER, Ada Pellegrini et al. Código Brasileiro de Defesa do Consumidor comentado pelos autores do anteprojeto. 8. ed. Rio de Janeiro: Forense Universitária, 2005.

GUERRA FILHO, Willis Santiago. Direitos fundamentais, processo e princípio da proporcionalidade. In: GUERRA FILHO, Willis Santiago (Org.). Dos direitos humanos aos direitos fundamentais. Porto Alegre: Livraria do advogado, 1997. p. 11-29. 
GUIMARÃES, Mário. O juiz e a função jurisdicional. Rio de Janeiro: Forense, 1958.

HOUAISS, Antônio; VILLAR, Mauro de Salles. Dicionário Houaiss da língua portuguesa. Rio de Janeiro: Objetiva, 2001.

JARDIM, Afrânio Silva. Da publicização no processo civil. Rio de Janeiro: Liber Juris, 1982.

JOLOWICZ, John Anthony. A reforma do processo civil inglês: uma derrogação do adversary system. Tradução de José Carlos Barbosa Moreira. Revista de Processo, São Paulo, Revista dos Tribunais, ano 19, n. 75, p. 64-75, jul./set. 1994.

JORGE, Flávio Cheim. Teoria geral dos recursos cíveis. 4. ed. São Paulo: Revista dos Tribunais, 2009.

JORGE, Flávio Cheim; RODRIGUES, Marcelo Abelha. As máximas de experiência (art. 335, CPC) e a impossibilidade de sua aplicação pelo Magistrado quando exige-se conhecimento técnico específico. Revista de Processo, São Paulo, Revista dos Tribunais, ano 32, n. 144, p. 257-274, fev. 2007.

KNIJNIK, Danilo. As (perigosíssimas) doutrinas do "ônus dinâmico da prova" e da "situação de senso comum" como instrumentos para assegurar o acesso à justiça e superar a probatio diabólica. In: FUX, Luiz; NERY JUNIOR, Nelson; WAMBIER, Teresa Arruda Alvim (Coords.). Processo e constituição: estudos em homenagem ao professor José Carlos Barbosa Moreira. São Paulo: Revista dos Tribunais, 2006. p. 942-951. . A prova nos juízos cível, penal e tributário. Rio de Janeiro: Forense, 2007.

LA CHINA, Sérgio. L'esibizione delle prove nel processo civile. Milano: Giuffrè, 1960.

LASPRO, Oreste Nestor de Souza. Duplo grau de jurisdição no direito processual civil. São Paulo: Revista dos Tribunais, 2005. 
LEAL, Antônio Luiz da Câmara. Código de Processo Civil e Commercial do Estado de São Paulo: arts. 262 a 449. São Paulo: Saraiva, 1930. v. 2.

LIEBMAN, Enrico Tullio. Fondamento del principio dispositivo. In: Problemi Del processo civile. Milano: Morano, 1962. p. 3-17.

. Manual de direito processual civil. Tradução e notas de Cândido Rangel Dinamarco. 3. ed. São Paulo: Método, 2005. v. 1.

LIMA, Carolina Alves de Souza. O princípio constitucional do duplo grau de jurisdição. São Paulo: Manole, 2004.

LOPES, João Batista. Efetividade da tutela jurisdicional à luz da constitucionalização do processo civil. Revista de Processo, São Paulo, Revista dos Tribunais, ano 29, n. 116, , p. 29-93, jul./ago. 2004.

. Iniciativas probatórias do juiz e os arts 130 e e 333 do CPC. Revista dos Tribunais, São Paulo, ano 84, n. 716, p. 41-47, jun. 1995. . A prova no direito processual civil. 3. ed. São Paulo: Revista dos Tribunais, 2007. . Tutela antecipada no processo civil brasileiro. São Paulo: Saraiva, 2001.

LOPES, Maria Elizabeth de Castro. O juiz e o princípio dispositivo. São Paulo: Revista dos Tribunais, 2006.

LUCON, Paulo Henrique dos Santos. Código de Processo Civil interpretado. In: MARCATO, Antonio Carlos (Coord.). Código de Processo Civil interpretado. 3. ed. São Paulo: Atlas, 2008.

LUISO, Francesco P. Presente e futuro della conciliazione in Itália. In. YARSHELL, Flávio Luiz; MORAES, Maurício Zanoite de (Coords.). Estudos em homenagem à Professora Ada Pellegrini Grinover. São Paulo: DPJ, 2005. p. 575-576.

MACHADO, Antonio Cláudio da Costa. Código de Processo Civil interpretado: artigo por artigo, parágrafo por parágrafo. 8. ed. São Paulo: Manole, 2009. 
MANCUSO, Rodolfo de Camargo. Ação popular, proteção do patrimônio público, da moralidade administrativa e do meio ambiente. 5. ed. São Paulo: Revista dos Tribunais, 2003 .

MADRIOLI, Crisanto. Corso di diritto processuale civile. Torino: Giappiacchelli, 1978.

MARCATO, Antonio Carlos. Crise da justiça e influência dos precedentes judiciais no direito processual civil brasileiro. Tese (Professor Titular) - Faculdade de Direito da Universidade de São Paulo São Paulo, 2009.

. Procedimentos especiais. 12. ed. São Paulo: Atlas, 2006.

. O processo monitório brasileiro. 2. ed. São Paulo: Malheiros, 2001.

MARCATO, Antonio Carlos (Coord.). Código de Processo Civil interpretado. 3. ed. São Paulo: Atlas, 2008.

MARCATO, Ana Cândida Menezes. Princípio do duplo grau de jurisdição e a reforma do Código de Processo Civil. São Paulo: Atlas, 2007.

MARINONI, Luiz Guilherme. Formação da convicção e inversão do ônus da prova segundo as peculiaridades do caso concreto. Revista dos Tribunais, São Paulo, ano 96, n. 862, p. 11-21, ago. 2007.

. Novas linhas do processo civil. 4. ed. São Paulo: Malheiros, 2000.

MARINONI, Luiz Guilherme; ARENHART, Sérgio Cruz. Manual do processo de conhecimento. 3. ed. São Paulo: Revista dos Tribunais, 2004.

MARQUES, Cláudia Lima. Contratos no Código de Defesa do Consumidor. São Paulo: Revista dos Tribunais, 1995.

MARQUES, José Frederico. Instituições de direito processual civil. 2. ed. Rio de Janeiro: Forense, 1968. v. 2. . Manual de direito processual civil. 2. ed. rev. e atual. por Vilson Rodrigues Alves. Campinas: Millennium, 2000. v. 1-2. 
MARTINS, Ives Gandra da Silva; BASTOS, Celso Ribeiro. Comentários à Constituição do Brasil. 2. ed. São Paulo: Saraiva, 2001. 2 v.

MARTINS, Nelson Juliano Schaefer. Poderes do juiz no processo civil. São Paulo: Dialética, 2004.

MARTIN OSTOS, José dos Santos. Las diligencias para mejor proveer em el proceso civil. Madrid: Montecarvo, 1981.

MATOS, Cecília. O ônus da prova no Código de Defesa do Consumidor. Revista de Direito do Consumidor, São Paulo, Revista dos Tribunais, n. 11, p. 161-169, jul./set. 1994.

MATTOS, Sérgio Luís Wetzel de. Da iniciativa probatória do juiz no processo civil. Rio de Janeiro: Forense, 2001.

MENDES, Gilmar Ferreira. Jurisdição constitucional: o controle abstrato de normas no Brasil e na Alemanha. 4. ed. São Paulo: Saraiva, 2004.

. O princípio da proporcionalidade na jurisprudência do Supremo Tribunal Federal: novas leituras. Revista Diálogo Jurídico, Salvador, Centro de Atualização Jurídica, ano 1, v. 1, n. 5, ago. 2001.

MENDES, Gilmar Ferreira; COELHO, Inocêncio Mártires; BRANCO, Paulo Gustavo Gonet. Curso de direito constitucional. São Paulo: Saraiva, 2007.

MESQUITA, José Ignácio Botelho de. Da ação civil. In: Teses estudos e pareceres de processo civil: direito de ação, partes e terceiros, processo e política. São Paulo: Revista dos Tribunais, 2005. v. 1, p. 33-128.

. Da ação civil. São Paulo: Revista dos Tribunais, 1975.

. Coisa julgada. Rio de Janeiro: Forense, 2004.

MICHELI, Gian Antônio. L'onere della prova. Padova, Cedam, 1966.

MICHELI, Gian Antonio; TARUFFO, Michele. A prova. Revista de Processo, São Paulo, Revista dos Tribunais, ano 4, n. 16, p. 155-168, out. 1979. 
MIRANDA, Jorge. Manual de direito constitucional. Coimbra: Coimbra Editora, 1996. v. 4.

MIRANDA, Vicente. Poderes do juiz no processo civil brasileiro. São Paulo: Saraiva, 1993.

MONTEIRO, João. Teoria do processo civil. 6. ed. atual. por J. M. Carvalho Santos. Rio de Janeiro: Borsoi, 1956, v. 1.

MONTERO AROCA, Juan. El derecho procesal em el siglo XX. Valencia: Tirant lo Blanch, 2000.

MONTERO AROUCA, Juan (Coord.). Proceso civil e ideología: un prefacio, una sentencia, dos cartas y quince ensayos. Valencia: Tirant Lo Blanch, 2006.

MONTORO, André Frnaco. Introdução à ciência do direito. 24. ed. São Paulo: Revista dos Tribunais, 1997.

MORAES, José Rubens de. Princípio da oralidade: visão comparativa das suas mútliplas manifestações nos sistemas common law e "europeu continental"... In:. CARVALHO, Milton Paulo de (Coord.). Direito processual civil. São Paulo: Quartier Latin, 2007. p. 101-163.

MORELLO, Augusto Mario. La prueba: tendencias modernas. Buenos Aires: PlatenseAbeledo Perrot, 1991.

NEGRÃO, Theotonio; GOUVÊA, José Roberto F. Código de Processo Civil interpretado e legislação processual em vigor. 39. ed. São Paulo: Saraiva, 2007.

NERY JUNIOR, Nelson. Aspectos do processo civil no código de defesa do consumidor. Revista de direito do consumidor, São Paulo, Instituto Brasileiro de Política e Direito do Consumidor, v. 1, p. 200-221. . Princípios do processo civil na Constituição Federal. 9. ed. São Paulo: Revista dos Tribunais, 2009. 
NERY JUNIOR, Nelson; NERY, Rosa Maria de Andrade. Código de Processo Civil comentado e legislação extravagante. São Paulo: Revista dos Tribunais, 2002.

NEVES, Celso. Estrutura fundamental do processo civil. 2. ed., 2. tiragem. Rio de Janeiro: Forense, 1997.

NEVES, Daniel Amorim Assumpção. Preclusões para o juiz: preclusão pro iudicato e preclusão judicial no processo civil. São Paulo: Método, 2004.

OLIVEIRA, Carlos Alberto Alvaro de. Os direitos fundamentais à efetividade e à segurança em perspectiva dinâmica. In: SALLES, Carlos Alberto de (Coord.). As grandes transformações do processo civil brasileiro: homenagem ao professor Kazuo Watanabe. São Paulo: Quartier Latin, 2009. p. 31-48. . Do formalismo no processo civil. 3. ed. São Paulo: Saraiva, 2009.

OLIVEIRA, Régis Fernandes de. Infrações e sanções administrativas. São Paulo: Revista dos Tribunais, 1985.

ORESTANO, Ricardo, Azione, diritti soggesttivi, persone giuridiche. Bolonha: Il Mulino, 1978.

PACÍFICO, Luiz Eduardo Boaventura. Ônus da prova no direito processual civil. 2. tiragem. São Paulo: Revista dos Tribunais, 2001.

PAULA JUNIOR, Aloysio Libano de. A experiência probatória no direito americano e no brasileiro. 2008. Dissertação (Mestrado em Direito Processual) - Faculdade de Direito da Universidade do Estado do Rio de Janeiro (UERJ), 2008.

PEYRANO, Jorge W. Nuevos lineamientos de las cargas probatórias dinâmicas. In. PEYRANO, Jorge W.; WHITE, Inês Lépori (Coords.). Cargas probatórias dinâmicas. Santa Fé: Rubinzal-Culzoni, 2004. p. 19-24.

PEYRANO, Jorge W.; CHIAPINI, Julio O. Doctrina de las cargas probatorias dinámicas: procedimento civil y comercial. Rosario: Juris, 1991. 
PEREIRA JUNIOR, Antonio Jorge. Limites constitucionais à liberdade de expressão e os deveres da televisão em face do telespectador infanto-juvenil. In: MARTINS, Ives Gandra; RESEK, Francisco (Coords.). Constituição Federal: avanços, contribuições e modificações no processo democrático brasileiro. São Paulo: Revista dos Tribunais, 2008. p. 790-809.

PICÓ I JUNOY, Joan. El derecho a la prueba em el proceso civil. Barcelona: Bosch, 1996. El derecho procesal entre el garantismo y la eficacia: un debate mal planteado. In: MONTERO AROUCA (Coord.). Proceso civil e ideología: un prefacio, una sentencia, dos cartas y quince ensayos. Valencia: Tirant Lo Blanch, 2006. p. 102-126.

PONTES DE MIRANDA, Francisco Cavalcanti. Comentários ao Código de Processo Civil. 3. ed. Rio de Janeiro: Forense, 1995. v. 2.

PORTANOVA, Rui. Os princípios do processo civil. Porto Alegre: Livraria do Advogado, 1995.

PUOLI, José Carlos Baptista. Os poderes do juiz e as reformas do processo civil. São Paulo: Juarez de Oliveira, 2002.

RAMOS, Elival da Silva. Parâmetros dogmáticos do ativismo judicial em matéria constitucional. 2009. 289 p. Tese (Professor Titular) - Faculdade de Direito da Universidade de São Paulo, São Paulo, 2009.

RANGEL. Rui Manuel de Freitas. O ônus da prova no processo civil. 3. ed. Coimbra: Almedina, 2006.

ROCCO, Alfredo. La sentencia civil. Traducción de Mariano Ovejero. Buenos Aires: El Foro, 2003.

ROCCO, Ugo. Trattato di diritto processuale civile. Torino: UTET, 1957. v. 1.

RODRIGUES, Marcelo Abelha. A distribuição do ônus da prova no anteprojeto do Código Brasileiro de Processos Coletivos. In. GRINOVER, Ada Pellegrini; MENDES, Aluisio 
Gonçalves de Castro; WATANABE, Kazuo. (Coord.). Direito processual coletivo e o anteprojeto de Código Brasileiro de Processos Coletivos. São Paulo: Revista dos Tribunais, 2007. p. 245-253.

ROSEMBERG, Leo. La carga de la prueba. Buenos Aires: EJEA, 1956.

ROSITO, Francisco. Direito probatório: as máximas de experiência em juízo. Porto Alegre: Livraria do Advogado, 2007.

SALLES, Carlos Alberto de (Coord.). As grandes transformações do processo civil brasileiro: homenagem ao professor Kazuo Watanabe. São Paulo: Quartier Latin, 2009.

SANTOS, Moacyr Amaral. Primeiras linhas de direito processual civil. 17. ed. São Paulo: Saraiva, 1994. v. 1.

. Primeiras linhas de direito processual civil. 23. ed. rev. e atual. São Paulo: Saraiva, 2004. v. 2.

. Prova judiciária no cível e comercial. São Paulo: Max Limonad, 1949. v. 1.

SICA, Heitor Victor Mendonça. Direito de defesa e tutela jurisdicional: estudo sobre a posição do réu no processo civil brasileiro. 2009. 350 p. Tese (Doutorado) - Faculdade de Direito da Universidade de São Paulo, 2009.

. Panorama atual da garantia de publicidade no processo civil brasileiro (artigo inédito que integrará a obra coletiva Direito Processual Civil II, São Paulo: Quartier Latin, 2010).

_. Preclusão processual civil. 2. ed. São Paulo: Atlas, 2008.

. Questões velhas e novas sobre a inversão do ônus da prova: CDC, art. 6 , VIII. Revista de Processo, São Paulo, Revista dos Tribunais, ano 32, n. 146, p. 49-68, abr. 2007.

SILVA, José Afonso da. Curso de direito constitucional positivo. 18. ed. São Paulo: Malheiros, 2000.

SILVA, Ovídio A. Baptista da. Curso de processo civil: processo de conhecimento.4. ed. São Paulo: Revista dos Tribunais, 1998. 
Verdade e significado. Revista Magister de Direito Civil e Processual Civil, Porto Alegre: Magister, v. 1, n. 5, p. 76-97, mar./abr. 2005.

SILVA, Ovídio A. Baptista e GOMES, Fábio Luiz, Teoria geral do processo civil. 4. ed. São Paulo: Revista dos Tribunais, 2006.

SOUZA, Carlos Aurélio Mota de. Poderes éticos do juiz: a igualdade das partes e a repressão ao abuso do processo. Porto Alegre: Sérgio Antonio Fabris, 1987.

STEIN, Friedrich. El conocimiento privado del juez. Santa Fé de Bogotá: Temis, 1999.

TARUFFO, Michele. Poteri probatori delle parti e del giudice in Europa. Revista de Processo, São Paulo, Revista dos Tribunais, ano 31, n. 133, p. 239-266, mar. 2006.

. Il processo civile "adversary” nell ésperienza amaricana. Pádova: Cedam, 1979. . La prueba científica en el proceso civil. In: FERRER BELTRÁN, Jordi et al. Estudios sobre la prueba. México: Universidad Nacional Autónoma de México, 2006. p. 135-186.

. La prueba de los hechos. Traducção de Jordi Ferrer Beltrán. 2. ed. Madrid: Trotta, 2005 .

. Il significato constituzionale dell'obbligo di motivazione. In. DINAMARCO, Cândido Rangel; GRINOVER, Ada Pelegrini; WATANABE, Kazuo (Coords.). Participação e processo. São Paulo: Revista dos Tribunais, 1988. p. 37-50.

Verità e probabilità nella prova dei fatti. Revista de Processo, São Paulo, Revista dos Tribunais, ano 32, n. 154, p. 207-222, dez. 2007.

TARZIA, Giuseppe. Lineamenti del nuovo processo di cognizione. Milano: Giuffrè, 1991.

THEODORO JÚNIOR, Humberto. Curso de direito processual civil. 50. ed. Rio de janeiro: Forense, 2009. v. 1.

. Prova - incípio da verdade real - poderes do juiz - ônus da prova e sua eventual inversão - provas ilícitas - prova e coisa julgada nas ações relativas à paternidade (DNA). Revista Brasileira de Direito de Família, Porto Alegre, Síntese, 1999. v. 1 , n. 3, p. 5-23, out./dez. 1999. 
TUCCI, José Rogério Cruz e. Tempo e processo. São Paulo: Revista dos Tribunais, 1997.

TUCCI, Rogério Lauria. Curso de direito processual civil. São Paulo: Saraiva, 1989. v. 2.

TUCCI, Rogério Lauria; TUCCI, José Rogério Cruz e; Constituição de 1988 e processo: regramentos e garantias constitucionais do processo. São Paulo: Saraiva, 1989.

VÁZQUEZ SOTELO, José Luis. Iniciativas probatorias del juez en el proceso civil. Revista de Processo, São Paulo, Revista dos Tribunais, ano 34, n. 177, p. 94-152, nov. 2009.

VERDE, Giovanni. Las ideologías del proceso en un reciente ensayo. In: MONTERO AROUCA (Coord.). Proceso civil e ideología: un prefacio, una sentencia, dos cartas y quince ensayos. Valencia: Tirant Lo Blanch, 2006. p. 67-80.

L'onere della prova nel processo civile. [Napoli]: Jovene, 1974. (Pubblicazione della Scuela di Perfezionamento in Diritto Civile dell’Università di Camerino, 6). . Profili del processo civil: parte generale. Napoli: Jovene, 1978.

WACH, Adolf. Pretensióon de declaración. Traducción de Juan M. Semon. Buenos Aires: EJEA, 1962.

WAMBIER, Tereza Alvim Wambier. Nulidades do processo e da sentença. 6. ed. São Paulo: Revista dos Tribunauis, 2007.

WATANABE, Kazuo. Cultura da sentença e cultura da pacificação. In: YARSHELL, Flávio Luiz; MORAES, Maurício Zanoite de (Coords.). Estudos em homenagem à Professora Ada Pellegrini Grinover. São Paulo: DPJ, 2005. p. 684-690.

Da cognição no processo civil. 2. ed. São Paulo: Central de Publicações Jurídicas; Centro Brasileiro de Estudos e Pesquisas Judiciais, 1999.

WATANABE, Kazuo et al. Código Brasileiro de Defesa do Consumidor comentado pelos autores do anteprojeto. 9. ed. Rio de Janeiro: Forense Universitária, 2007. 
WINDSCHEID, Bernhard; MUTHER, Theodor. Polêmica sobre la "actio”. Traducción de Tomás A. Banzhaf. Buenos Aires: EJEA, 1974.

XAVIER, Trícia Navarro. O "ativismo" do juiz em tema de prova. Revista de Processo, São Paulo, Revista dos Tribunais, ano 33, n. 159, p. 172-197, maio 2008.

YARSHELL, Flávio Luiz. Antecipação de prova sem o requisito da urgência e direito autônomo à prova. São Paulo: Malheiros, 2009.

. Tutela jurisdicional específica nas ações de declaração de vontade. São Paulo: Malheiros, 1993.

ZANZUCCHI, Marco Tulio. Diritto processuale civile. Milano: Giuffrè, 1964. v. 1. 